\title{
$7^{\text {EOTOOPA }}$
}

\section{DESAFIOS DAEDUCAÇÃ̃ \\ NACONTEMPORANEIDADE \\ DISCURSOS EMERGENTES \\ E CONCEPÇÕES DE ENSINO}

\section{ORGANIIADORES}

Jessica Kelly Sousa Ferreira LeonardoPereira Tavares 


\section{TEDITORA \\ LAMPLLA}

\section{DESAFIOS DAEDUCAÇÃ̃}

NACONTEMPORANEIDADE

DISCURSOS EMERGENTES

E CONCEPÇÕES DE ENSINO

ORGANIZADORES

Jessica Kelly Sousa Ferreira

LeonardoPereira Tavares 


\section{ZIMAPLLA}

2020 - Editora Amplla

Copyright @ Editora Amplla

Editor Chefe: Leonardo Pereira Tavares

Design da Capa: Editora Amplla

Projeto Gráfico e Editoração: Higor Costa de Brito

Desafios da educação na contemporaneidade: discursos emergentes e concepções de ensino está licenciado sob CC BY 4.0.

cc (i) Esta licença exige que as reutilizações deem crédito ao criador. Ele permite que os reutilizadores distribuam, remixem, adaptem e construam o material em qualquer meio ou formato, mesmo para fins comerciais.

O conteúdo da obra e seus dados em sua forma, correção e confiabilidade são de responsabilidade exclusiva dos autores, não representando a posição oficial da Editora Amplla. É permitido o download da obra e o compartilhamento desde que sejam atribuídos créditos aos autores. Todos os direitos para esta edição foram cedidos à Editora Amplla.

ISBN: 978-65-88332-13-9

Editora Amplla

Campina Grande - PB - Brasil

contato@ampllaeditora.com.br www.ampllaeditora.com.br 
Bergson Rodrigo Siqueira de Melo - Universidade Estadual do Ceará Carla Caroline Alves Carvalho - Universidade Federal de Campina Grande Cícero Batista do Nascimento Filho - Universidade Federal do Ceará Clécio Danilo Dias da Silva - Universidade Federal do Rio Grande do Norte Daniela de Freitas Lima - Universidade Federal de Campina Grande Denise Barguil Nepomuceno - Universidade Federal de Minas Gerais Dylan Ávila Alves - Instituto Federal Goiano Érica Rios de Carvalho - Universidade Católica do Salvador Gilberto de Melo Junior - Universidade Federal de Goiás Higor Costa de Brito - Universidade Federal de Campina Grande Italan Carneiro Bezerra - Instituto Federal da Paraíba Ivo Batista Conde - Universidade Estadual do Ceará João Henriques de Sousa Júnior - Universidade Federal de Santa Catarina Joilson Silva de Sousa - Instituto Federal do Rio Grande do Norte José Cândido Rodrigues Neto - Universidade Estadual da Paraíba Jose Henrique de Lacerda Furtado - Instituto Federal do Rio de Janeiro Josenita Luiz da Silva - Faculdade Frassinetti do Recife Luís Paulo Souza e Souza - Universidade Federal do Amazonas Luiza Catarina Sobreira de Souza - Faculdade de Ciências Humanas do Sertão Central Manoel Mariano Neto da Silva - Universidade Federal de Campina Grande Marcus Vinicius Peralva Santos - Universidade Federal da Bahia Marina Magalhães de Morais - Universidade Federal de Campina Grande Natan Galves Santana - Universidade Paranaense Nathalia Bezerra da Silva Ferreira - Universidade do Estado do Rio Grande do Norte Neide Kazue Sakugawa Shinohara - Universidade Federal Rural de Pernambuco Sabrynna Brito Oliveira - Universidade Federal de Minas Gerais Samuel Miranda Mattos - Universidade Estadual do Ceará Tatiana Paschoalette Rodrigues Bachur - Universidade Estadual do Ceará Telma Regina Stroparo - Universidade Estadual do Centro-Oeste Virginia Tomaz Machado - Faculdade Santa Maria de Cajazeiras Walmir Fernandes Pereira - Miami University of Science and Technology Wanessa Dunga de Assis - Universidade Federal de Campina Grande Wellington Alves Silva - Universidade Estadual de Roraima Yáscara Maia Araújo de Brito - Universidade Federal de Campina Grande Yuciara Barbosa Costa Ferreira - Universidade Federal de Campina Grande 


\section{ПGAMPLLA}

2020 - Editora Amplla

Copyright @ Editora Amplla

Editor Chefe: Leonardo Pereira Tavares

Design da Capa: Editora Amplla

Projeto Gráfico e Editoração: Higor Costa de Brito

Dados Internacionais de Catalogação na Publicação (CIP)

Sueli Costa CRB-8/5213

Ferreira, Jessica Kelly Sousa Ferreira

Desafios da educação na contemporaneidade: discursos

emergentes e concepções de ensino [livro eletrônico] / Jessica Kelly Sousa Ferreira, Leonardo Pereira Tavares. Campina Grande : Editora Amplla, 2020 .

$433 \mathrm{p}$.

Formato: PDF

ISBN : $978-65-88332-13-9$

1. Educação 2. Desafios (Educação) 3. Discursos (Educação)

4. Ensin I. Tavares, Leonardo Pereira II. Título

CDD -370

\section{Índice para catálogo sistemático:}

1. Educação 370

\section{Editora Amplla}

Campina Grande - PB - Brasil contato@ampllaeditora.com.br www.ampllaeditora.com.br 


\section{PREFÁCIO}

Pensar a Educação no século XXI é um desafio intrigante. Já se fala em Educação 4.0, nomenclatura proveniente do desenvolvimento rápido e contínuo das tecnologias da informação e comunicação (TICs) e da internet que tem, cada vez mais, invadido o cotidiano das escolas e das salas de aula. Enquanto se teoriza uma Educação que, supostamente, é 4.0 e tem acompanhado as tendências digitais, ousamos problematizar que os problemas e desafios que envolvem os espaços educativos ainda são da geração 1.0 .

O termo Educação 1.0, do final do século XVIII, conceitua um enfoque tradicional de educação, o professor é o protagonista e o processo de ensino e aprendizagem individualizado, reservado as elites. A educação 2.0 surgiu com o intuito de preparar o homem para trabalhar nas fábricas durante o século XIX, os processos eram pautados na repetição e memorização. Em meados do século XX, a partir da $3^{\circ}$ Revolução Industrial, surgiu a educação 3.0 que, de maneira inovadora, incorporou as novas tecnologias aos processos de ensino e aprendizagem, tratando os alunos como protagonistas da sua aprendizagem, democratização do saber. Já a educação 4.0 aparece como consequência da quarta revolução industrial, buscando atender as supostas emergências e necessidades do século, informações mais acessíveis, digitalização dos processos e diversas possibilidades de inovação ${ }^{1}$.

A obra "Desafios da educação na contemporaneidade: discursos emergentes e concepções de ensino" contém artigos que levam a pensar nesses desafios, compreendendo que eles envolvem as tecnologias digitais, mas vão bem além delas. Há desafios emergentes nos processos de ensino e aprendizagem que por ora são silenciados em detrimento de outros. Esta obra é uma das aberturas das cortinas das escolas e salas de aula visando trazer à tona temáticas que, na maioria das vezes, ainda são invisibilizadas.

Tais temáticas, abordadas ao longo dos capítulos, enfocam desafios das mais diversas ordens, tais como: Formação de professores, prática docente, educação e diretos humanos, projeto político pedagógico, educação e tecnologias, educação na

\footnotetext{
${ }^{1}$ LENGEL, J. G. A evolução da educação: 1-2-3. In: Carvalho, M. T. (Org.). Educação 3.0: novas perspectivas para o ensino. Unisinos. São Leopoldo, RS: 2017.
} 
pandemia, ensino remoto, educação a distância, educação e cultura, relações étnicoraciais, educação inclusiva, estágio docente, dentre outras.

A partir das temáticas abordadas pelos autores e pelas autoras, percebemos que ao falar dos desafios da educação na contemporaneidade e ao analisar esses desafios visando desnudar o chão dos espaços educativos, as discussões têm como objetivo central o encontro de possíveis caminhos que colaborem e motivem não apenas os profissionais da educação, mas também seus alunos e alunas. Enquanto os desafios se desenham como vielas aparentemente sem saída, caminhos bifurcados ou como o tão conhecido fundo do poço, o debate sobre eles aqui proposto tendem por ressignificálos à medida que transformam os desafios em molas propulsoras de esperança e de novas possibilidades.

Problematizar e refletir sobre a educação contemporânea e seus desafios é uma forma de ser sensível ao que vivem os profissionais da educação espalhados por esse país em seu trabalho cotidiano com os alunos e as alunas. Essa sensibilidade é ainda mais urgente quando, além dos já conhecidos inúmeros desafios que assolam a educação brasileira, passamos a viver, de repente, um contexto de pandemia, a saber, a pandemia do novo coronavírus (COVID 19).

Nesse contexto, as questões discutidas pelos autores, de maneira envolvente e interdisciplinar a partir de abordagens teórico-metodológicas, funcionam ainda como materiais de apoio, de colaboração e de esperança para os profissionais da educação. Falar sobre os desafios não significa esbarrar neles e estagnar. É preciso fazer, sem romantizar, o que os profissionais da educação desse país sabem fazer de melhor: Ousar, criar, redesenhar, esperançar, amar... Mesmo diante do caos. Que os desafios aqui discutidos sejam possibilidades de pensar além.

Jessica Kelly Sousa Ferreira Pós-graduada em Educação - Práticas Pedagógicas Interdisciplinares - UEPB Mestre em Formação de Professores - UEPB Doutoranda em Educação - UFPB 


\section{SUMÁRIO}

CAPÍTULO I - AS POLÍTICAS PÚBLICAS DE FORMAÇÃO DE PROFESSORES PARA A EDUCAÇÃO BÁSICA BRASILEIRA: CONQUISTAS E DESAFIOS. 10

CAPÍTULO II - ALFABETIZAÇÃO E LETRAMENTO: REFLEXÕES SOBRE A PRÁTICA DOCENTE NA FORMAÇÃO LETRADA DOS ESTUDANTES DA EDUCAÇ̃̃O BÁSICA 25

CAPÍTULO III - A FORMAÇÃO DE PROFESSORES NUMA PERSPECTIVA CRÍTICO - DIALÉTICA NA ABORDAGEM DA PEDAGOGIA HISTÓRICO - CRÍTICA

CAPÍTULO IV - CONSTRUINDO UMA IDENTIDADE DOCENTE INCLUSIVA NO PROCESSO DE FORMAÇ̃̃ DE PROFESSORES 61

CAPÍTULO V - O PAPEL DO COORDENADOR PEDAGÓGICO EM INSTITUIÇÕES DE ENSINO BÁSICO E SUPERIOR...........71 CAPÍTULO VI - A EDUCAÇÃO PERMANENTE COMO ESTRATÉGIA PARA ORGANIZAÇ̃̃O DO PROCESSO DE TRABALHO DA EQUIPE NO CENTRO DE REFERÊNCIA EM ASSISTÊNCIA SOCIAL- CRAS ARACAPÉ-CE .84

CAPÍTULO VII - CONSTRUÇÃO COLETIVA DO PROJETO POLÍTICO PEDAGÓGICO NA EDUCAÇÃO DO CAMPO 100

CAPÍtULO VIII - INOVAÇÃo CURRICULAR BASEADA EM PROJETOS: DESENVOLVENDO COMPETÊNCIAS COM APRENDIZAGEM ATIVA. .117

CAPÍTULO IX - PROJETOS PEDAGÓGICOS PARA A EDUCAÇÃO INFANTIL: PRINCIPAIS DESAFIOS EM SUA FORMULAÇÃO NO SISTEMA EDUCACIONAL BRASILEIRO .129

CAPÍTULO X - EDUCAÇÃO POSTURAL NA INFÂNCIA E ADOLESCÊNCIA: UM FATOR ESSENCIAL NOS TEMPOS ATUAIS143 CAPÍTULO XI - A PANDEMIA DE COVID-19 E A DISSEMINAÇÃO DE FAKE NEWS: CONSIDERAÇ̃̃ES PARA UM LETRAMENTO MIDIÁTICO. .153

CAPÍTULO XII - ENSAIO SOBRE OS DESAFIOS DA EDUCAÇÃO NA CONTEMPORANEIDADE: REFLEXÕES SOBRE A EDUCAÇÃO NO BRASIL 161

CAPÍTULO XIII - FILOSOFIA DA CIÊNCIA E DA MODERNIDADE: BREVE ANÁLISE DE JAMAIS FOMOS MODERNOS, DE BRUNO LATOUR. . .182

CAPÍTULO XIV - A RELAÇÃO ENTRE DISCURSO E PODER: UMA BREVE CONVERSA ENTRE MARX E FOUCAULT .......201

CAPÍTULO XV - EDUCAÇÃO EM DIREITOS HUMANOS: CONQUISTAS, AVANÇOS E DESAFIOS ............................. 209

CAPÍTULO XVI - TECNOLOGIAS COMO PRÁTICAS DE UMA EDUCAÇ̃̃O INOVADORA NO SÉCULO XXI .221 
CAPÍTULO XVII - UTILIZAÇÃO DE MÍDIAS SOCIAS COMO INSTRUMENTOS DE DIVULGAÇ̃̃O CIENTÍFICA, INSTITUCIONAL E DE CONSTRUÇÃO DO CONHECIMENTO POR ALUNOS DOS CURSOS DE SAÚDE DE UMA FACULDADE PARTICULAR DO MUNICÍPIO DE LAURO DE FREITAS - BAHIA 229

CAPÍTULO XVIII - ENSINO REMOTO EMERGENCIAL UMA NOVA REALIDADE PARA EDUCAÇÃO SUPERIOR. 247

CAPÍTULO XIX - ENSINO REMOTO EMERGENCIAL: DESAFIOS EDUCACIONAIS EM TEMPOS DE COVID-19 259

CAPÍTULO XX - EDUCAÇ̃̃O NO CONTEXTO DA PANDEMIA DE COVID-19: UMA ANÁLISE DO PROCESSO ENSINOAPRENDIZAGEM NA UFERSA-CMPF. 268

CAPITULO XXI - EDUCAÇÃO A DISTÂNCIA: QUAL O PAPEL DO TUTOR NESSE CENÁRIO? .282

CAPÍTULO XXII - E-LEARNING E MOODLE: CONTRIBUIÇÕES PARA O PROCESSO DE ENSINO E APRENDIZAGEM ..... 289

CAPÍtULO XXIII - MULTICULTURALISMO PEDAGÓgICO NA ESCOLA: RE-SIGNIFICAÇÃO PARA UMA NÃO HOMOGENEIZAÇ̃̃O 296

CAPÍTULO XXIV - O PAPEL LIBERTADOR DA EDUCAÇ̃̃O FRENTE A CRIMINALIZAÇÃO DA CULTURA PERIFÉRICA ... 306 CAPÍTULO XXV - A EDUCAÇÃO DAS RELAÇÕES ÉTNICO-RACIAIS NA SEGUNDA VERSÃO DA BASE NACIONAL COMUM CURRICULAR .319

CAPÍTULO XXVI - AS “MANEIRAS DE FAZER” DO PRÉ-UNIVERSITÁRIO PARA AFRODESCENDENTES EM ITABUNA-BAHIA 333

CAPÍTULO XXVII - AFRICANOS DE ONDE? A NEO-COLONIZAÇÃO INGLESA E O IMPERIALISMO NA ÁFRICA EM CHIMAMANDA NGOZIE ADICHIE 352

CAPÍTULO XXVIII - A APRENDIZAGEM DO SURDOCEGO PÓS-LINGUÍSTICO: AÇ̃̃ES PEDAGÓGICAS PARA O ATENDIMENTO EDUCACIONAL ESPECIALIZADO 369

CAPÍTULO XXIX - A IMPORTÂNCIA DO INCENTIVO AO ENSINO DA MATEMÁtICA PARA OS ALUNOS SURDOS DA EDUCAÇÃO BÁSICA. .391

CAPÍTULO XXX - USO DE RECURSOS DIDÁTICOS ALTERNATIVOS PARA O ENSINO DE ASTRONOMIA. 407 CAPITULL XXXI - ESTÁGIO DOCENTE EM HISTÓRIA: RELATO DE EXPERIÊNCIA NO ENSINO MÉDIO E CONSIDERAÇÕES SOBRE SUAS NOVAS DEMANDAS .418 


\title{
CAPÍTULO I
}

\section{AS POLÍTICAS PÚBLICAS DE FORMAÇÃO DE PROFESSORES PARA A EDUCAÇÃO BÁSICA BRASILEIRA: CONQUISTAS E DESAFIOS}

\author{
Queila Pahim da Silva ${ }^{1}$ \\ Maria Cristina Mesquita da Silva ${ }^{2}$
}

\begin{abstract}
${ }^{1}$ Doutoranda em Educação pela Universidade Católica de Brasília (UCB). Professora do Instituto Federal de Educação, Ciência e Tecnologia de Brasília (IFB).

2 Mestranda em Educação pela Universidade Católica de Brasília (UCB). Analista em Ciência e Tecnologia na CAPES/MEC. Professora da Secretaria de Educação do Distrito Federal (SEEDF).
\end{abstract}

\section{RESUMO}

O presente artigo tem por objetivo analisar os principais normativos legais brasileiros que versam sobre a formação de professores da educação básica no país, no intuito de refletir sobre a importância e conquistas dessa formação e a descontinuidade das políticas educacionais, conforme apontado por diversos estudiosos da área. Trata-se de uma pesquisa documental e bibliográfica, que utilizou como fonte de pesquisa a base de dados Scientific Eletronic Library Online (SciELO) e normativos legais brasileiros que tratam da temática. Os resultados indicam uma evolução normativa rumo à flexibilização das políticas públicas e a coexistência de diversos programas voltados à formação docente. Esses programas são, contudo, ainda desconexos entre si, e por vezes, insuficientes frente à demanda de formação existente.

Palavras-chave: Políticas Públicas. Formação de Professores. Educação Básica Brasileira.

\section{INTRODUÇÃO}

A formação dos professores que atuam na educação básica brasileira tem sido amplamente debatida ao longo dos anos, não só na academia, como nas associações científicas e em demais segmentos sociais interessados na educação. No entanto, apesar de apresentar conquistas, possui desafios no que tange às lacunas dos normativos legais que a regulamentam devido a descontinuidade dos mesmos.

Nesse contexto, no intuito de melhor compreender esta temática, foi desenvolvida esta pesquisa que aborda a instituição e operacionalização das principais políticas públicas da formação de professores para a educação básica no Brasil, com recorte temporal de 1996 a 2019.

O marco inicial da pesquisa é a Lei de Diretrizes e Bases da Educação Brasileira (LDB) de 1996, escolhida devido sua relevância para a educação do país, ao ponto de ser 
chamada por Saviani (1998) de "Lei Magna da Educação Brasileira". O limite temporal do estudo foi o ano de 2019 a fim de apresentar os mais novos trabalhos e normativos publicados. O objetivo desse recorte de normativos legais é fomentar o debate e reflexão sobre a dificuldade em se estabelecer uma consistente e alinhada política para formação de professores no Brasil.

Os programas aqui abordados foram escolhidos pois seus escopos de atuação atendem à orientação da LDB de 1996 e do Plano Nacional de Educação (PNE) de 2014, referentes à necessidade de ampliar a oferta do ensino superior e principalmente da formação e valorização dos professores.

Este trabalho constitui-se em introdução; marco teórico com os tópicos: educação e formação de professores, formação de professores no Brasil: principais normativos legais, principais programas públicos para a formação de professores no Brasil; metodologia, discussão dos resultados com as considerações finais e referências consultadas.

\subsection{Educação e formação de professores}

Dado o papel essencial atribuído à educação para a transformação de nossas vidas e seu entendimento como um bem público e um direito humano fundamental, que é o pilar para a efetivação de outros direitos, faz-se necessário o empenho dos governos em prol da construção e atualização de políticas educativas. Pensando nisso, vários países, inclusive o Brasil, assumiram os compromissos expressos no Marco de Ação de Dakar ${ }^{1}$ e na Agenda $2030^{2}$, que devido à importância de seus 17 Objetivos para o Desenvolvimento Sustentável (ODS) adotados em todos os continentes, está apresentada na Figura 1 que segue:

${ }^{1}$ Compromisso coletivo firmado durante o Fórum Mundial da Educação em Dakar, em 2000, representando um esforço da comunidade internacional em avançar na realização do direito à educação no mundo, através de um conjunto de metas que vigoraram entre 2000 e 2015 . Foi feito com base nos preceitos da Declaração Universal de Direitos Humanos (1948), da Convenção sobre os Direitos da Criança (1989) e da Declaração Mundial de Educação Para Todos (Jomtien, 1990).

2 Plano de ação global para promover o desenvolvimento sustentável composta por 17 Objetivos, com vigência entre 2015 e 2030. Disponível em: http://www.agenda2030.org.br/sobre/. Acesso em 24 jan. 2020. 
Figura 1. Objetivos globais para o Desenvolvimento Sustentável da Agenda 2030

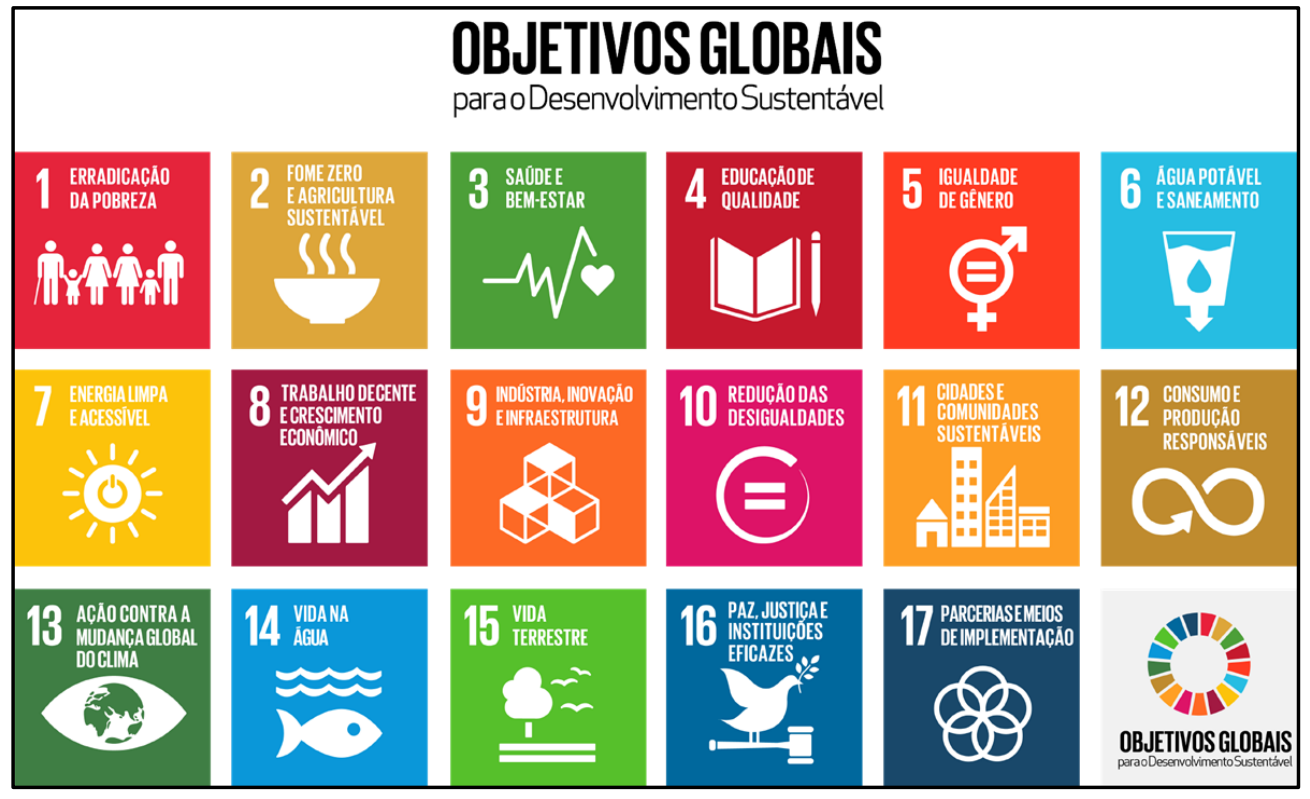

Fonte: Plataforma Agenda 2030 (ONU, 2020.

O ODS 4 da Agenda 2030 está diretamente voltado para o tema da educação: "Assegurar a educação inclusiva e equitativa de qualidade, e promover oportunidades de aprendizagem ao longo da vida para todos" (ONU, 2015) e é composto por 7 metas de resultado e 3 de insumo, como a última, que se refere à qualificação dos professores.

Assim como apresentado por Marlova Noleto, diretora e representante da UNESCO no Brasil em 2019, no prefácio de Gatti et al. (2019), para o alcance da qualidade educativa proposta pelo ODS 4, é necessário professores bem formados e valorizados e construção de sistemas educativos de qualidade, equitativos e inclusivos. Isso passa necessariamente pela efetivação de políticas docentes que promovam atratividade à carreira, formação inicial e continuada consistente, reconhecimento e possibilidade de desenvolvimento profissional, remuneração e condições de trabalho adequadas.

Diferentes estudiosos e pesquisadores do campo da educação têm concentrado esforços para instigar interlocuções epistemológicas e metodológicas em torno de uma temática abrangente e multidisciplinar, com uma centralidade comum: a formação docente. Eles também analisam as tensões (BRZEZINSKI, 2018), conflitos, fragilidades (GATTI, 1997), embates (BARRETO, 2015), contradições e descontinuidade (SAVIANI, 2016) das leis e comandos legais que instituem e fomentam essa formação de 
profissionais para a educação básica brasileira. Parte dos resultados desses esforços tem se transformado em aportes teórico-explicativos que expressam uma reflexão mais apropriada sobre o ideal e necessário para uma formação de qualidade em nosso país e a realidade.

Para Oliveira e Leiro (2019), ela tem sido tomada como área estratégica de intervenção, a fim de alcançar as transformações desejáveis na educação, constituindose em um cenário de inquietudes e disputas políticas e ao considerar que as políticas públicas podem ser compreendidas como um entrelaçado de normas formuladas a partir dos direitos da população, e que permeia todas suas fases ou ciclos (COUTINHO, 2013). Por isso, torna-se relevante entendê-las e estudá-las, já que representam ou ao menos deveriam, nossos direitos, e por isso, será apresentado os principais normativos legais brasileiros que versam sobre a formação de professores para a educação básica, no tópico seguinte.

\subsection{Formação de professores no Brasil: principais normativos legais}

Várias são as políticas educacionais relacionadas à formação de professores no Brasil, por isso e com o propósito de analisá-las, foi realizado o levantamento do ordenamento legal de instituição das mesmas desde 1996 até 2019, incluindo algumas das leis, decretos e planos de desenvolvimento da educação oficializados pelo Ministério da Educação (MEC), que regulamentam esta temática.

A Lei de Diretrizes e Bases da Educação Brasileira (LDB), sancionada em 20 de dezembro de 1996 (Lei no 9.394/1996), define e regulariza a organização da educação brasileira com base nos princípios presentes na Constituição Nacional de 1988 e constitui-se como marco nas transformações ocorridas desde então na formação de professores do Brasil, permitindo a discussão e consolidação de medidas que ampliaram o acesso e melhoraram o financiamento do ensino em nosso país, tendo passado por diversas modificações, decorrentes das 39 leis aprovadas entre 1997 e 2015 (SAVIANI, 2016).

No ano de 2001 foi sancionada a Lei № 10.172, de 9 de janeiro de 2001, que aprovou o Plano Nacional de Educação (PNE), com diretrizes e metas para os dez anos seguintes. Ele foi criado em sintonia com a Declaração Mundial sobre Educação para todos, de 1990, como sugere o $\S 1$ 으, do art. 87 da LDB de 1996. As diretrizes para 
formação de professores do referido PNE colocam a implementação de políticas públicas neste campo como condição e meio para o avanço científico e tecnológico do país (OLIVEIRA; LEIRO, 2019).

Uma das metas propostas pelo PNE de 2001 para a formação de professores da educação básica, foi que, em até cinco anos, todos os professores da educação infantil tivessem o nível médio e que, em dez anos pelo menos, 70\% deles tivessem formação em nível superior. Para e educação fundamental, a meta era de que em até cinco anos todos tivessem o nível superior concluído (BRASIL, 2001). Outra determinação foi o estabelecimento do prazo de um ano para a constituição de diretrizes e parâmetros curriculares para os cursos superiores de formação de professores e demais profissionais da educação.

O Plano de Desenvolvimento da Educação (PDE), lançado em abril de 2007, teve o objetivo de melhoria da educação e redução de desigualdades relativas às oportunidades educacionais e um de seus principais pontos, foi a formação de professores e a valorização dos profissionais da educação básica (BRASIL, 2008). Apesar de ter sido descontinuado, uma de suas iniciativas perdurou: a expansão e interiorização da oferta de cursos de educação superior através da Universidade Aberta do Brasil (UAB).

Ainda em 2007, através da Lei no 11.502, de 11 de julho de 2007, a Capes passou a ter a finalidade de induzir e fomentar a formação inicial e continuada de professores da educação básica, em regime de colaboração com os Estados, os Municípios e o Distrito Federal e somente através de convênios com as instituições de ensino superior públicas e privadas (BRASIL, 2007).

No ano de 2009, por meio da publicação do Decreto № 6.755, de 29 de janeiro de $2009^{1}$, foi instituída a Política Nacional de Formação de Profissionais do Magistério da Educação Básica, cuja finalidade era organizar, em regime de colaboração entre a União, os Estados, o Distrito Federal e os Municípios, a formação inicial e continuada dos profissionais do magistério para as redes públicas da educação básica (BRASIL, 2009).

\footnotetext{
${ }^{1}$ O Decreto no 6.755/2009 foi revogado pelo Decreto n. 8.752 de 09 de maio de 2016.
} 
Em 2014, houve a publicação do Plano Nacional de Educação (PNE) 2014-2024, sancionado pela Lei no 13.005, em 25 de junho de 2014. Com vigência de dez anos, constitui-se como uma referência central para os entes federativos em relação às políticas educacionais a serem implantadas por meio das 10 diretrizes, 20 metas e 254 estratégias, definindo os objetivos para a educação a serem alcançados até 2024.

Especificamente em relação à formação dos profissionais da educação, a que se referem às metas 15 e 16 do PNE 2014-2024 e a ligação com o ODS 4.c da Agenda 2030, a porcentagem de docentes nos anos finais do ensino fundamental com formação superior na área em que lecionam foi de apenas 45,9\%, em 2015 (SIQUEIRA, 2017). A Meta 15 deste PNE planeja que 100\% dos docentes da educação básica, tenham formação na área em que lecionam até 2024 (BRASIL, 2014).

No referido Plano, há também outras metas que fazem referência a formação de professores para a educação básica, como a Meta 1, que trata da Educação Infantil e a Meta 3, que trata do ensino médio e aumento da taxa de matrícula neste nível de ensino, prevendo como primeira estratégia, uma renovação curricular e do ensino, indicando a necessidade de uma formação continuada de professores.

Na Resolução CNE/CP no 2/2015, que “Define as Diretrizes Curriculares Nacionais para a formação inicial em nível superior (cursos de licenciatura, cursos de formação pedagógica para graduados e cursos de segunda licenciatura) e para a formação continuada" (Brasil, 2015), percebe-se pressa na formação dos profissionais já em exercício, como previsto nos artigos 14 e 15. Em ambos os casos, determina-se carga horária reduzida, variando conforme a situação a ser atendida, e, no caso do curso para segunda licenciatura, os portadores de diploma de licenciatura com exercício comprovado no magistério da educação básica, poderão ter redução de até $100 \mathrm{~h}$ da carga horária do estágio curricular supervisionado (BRASIL, 2015).

Em dezembro de 2019, uma nova Resolução do Conselho Nacional de Educação (CNE) foi promulgada tratando da definição de Diretrizes Curriculares Nacionais para a Formação Inicial de Professores para a educação básica e também da instituição da Base Nacional Comum para a Formação Inicial de Professores da Educação Básica (BNCFormação), trata-se da Resolução CNE/CP no 2, de 20 de dezembro de 2019.

No que tange à carga horária dos cursos, quando cotejada com a Resolução no 02/2015, há, entre outras flexibilizações, a diminuição da carga horária dos cursos de 
formação pedagógica (de 1400 a 1000 horas para 760 horas) e nova classificação dos cursos de segunda licenciatura, as quais terão durações variadas, a depender do agrupamento em que se enquadram.

\subsection{Principais programas públicos para a formação de professores no Brasil}

Assim como variadas são as políticas educacionais relacionadas à formação de professores no Brasil, também os são os programas públicos destinados a esse fim. Abaixo destacam-se aqueles considerados mais representativos e que seguem vigentes no âmbito da administração pública federal.

O Sistema UAB foi instituído pelo Decreto no 5.800, de 08 de junho de 2006, para o desenvolvimento da modalidade de educação a distância (EaD), com o objetivo de expandir e interiorizar a oferta de cursos e programas de educação superior no Brasil. De acordo com Branco e Peixoto (2018), o sistema UAB materializa-se como uma grande rede de cooperação entre entes federados com o objetivo de implementar um modelo de EaD no setor público.

Já para Gatti e Barreto (2009), essa medida legal assentou-se no pressuposto de que a EaD constituía a iniciativa de maior alcance para enfrentar as novas demandas do número de egressos do ensino médio e de formação docente.

Barreto (2015) discute sobre a necessidade de revisar os projetos de formação desses cursos ofertados à distância, já que carecem, assim como os presenciais, de reflexões mais profundas sobre o perfil profissional que se pretende formar. Pondera, ainda que é necessário refletir se essa expansão da oferta de formação estaria acompanhada da qualidade que lhe é necessária ou seria apenas uma tentativa de resolver os impasses da formação de professores no Brasil, tornando-a ainda mais frágil.

A despeito das posições reticentes ou mesmo contrárias a essa política pública, no ano de 2020 a UAB está completando 14 anos de existência. Trata-se de um programa longevo e amplamente interiorizado. Conforme o Sistema de Gestão da UAB (SisUAB) participam da UAB 135 Instituições Públicas de Ensino Superior (IPES), as quais podem ofertar cursos em 848 polos aptos em todos os estados do Brasil. Os dados da Diretoria de Educação a Distância (DED/Capes), revelam que em maio de 2020 a UAB já contava com 273.938 formados, dos quais 188.724 formados em cursos relacionados à formação de professores (licenciaturas e especializações). 
A UAB representa numericamente o programa público de maior capilaridade para formação docente da atualidade. Para Arruda (2018), a UAB se constitui no primeiro grande programa de EaD em nível nacional, responsável por um movimento promotor da democratização do ensino superior no interior do Brasil, mas por outro lado, em sua longevidade, o Sistema contribui para o pouco desenvolvimento institucional da EaD nas universidades públicas, posto que reduz o funcionamento da modalidade ao fomento de um programa em específico.

O Programa Institucional de Bolsa de Iniciação à Docência (PIBID) foi regulamentado primeiro por meio da Portaria do MEC no 38, de 12 de dezembro de 2007 e mais tarde ampliado por meio do Decreto no 7.219, de 24 de junho de 2010. 0 programa tem como objetivo proporcionar aos licenciandos da primeira metade do curso atividades de iniciação à docência, através de propostas como criação de objetos educacionais, oficinas e projetos acadêmicos, entre outros. São oferecidas bolsas para os licenciandos, professores das escolas e equipe de docentes do programa na Instituição de Ensino Superior.

De acordo com os dados da Diretoria de Formação de professores da Educação Básica da Capes (DEB/Capes), em suas nove edições concluídas, o PIBID beneficiou 258.706 estudantes de iniciação à docência. Durante o primeiro semestre de 2020 foram conduzidos os processos seletivos referentes à 10aㅡ edição do programa, com a oferta de cerca de 30.000 bolsas de iniciação à docência ${ }^{1}$.

Outro programa que merece destaque, o Plano Nacional de Formação de Professores da Educação Básica (PARFOR), foi constituído por meio da portaria normativa MEC no 09 de 30 de junho de 2009, com o objetivo de estabelecer ações e metas para a qualificação profissionais do magistério que ainda não possuem a formação requerida para o exercício da docência em regime de colaboração com as Secretarias de Educação dos Estados, do Distrito Federal e dos Municípios e com as Instituições de Ensino Superior, no âmbito do PDE - Plano de Metas Compromisso Todos pela Educação.

O objetivo principal do programa é garantir que os professores em exercício na rede pública de educação básica obtenham a formação exigida pela LDB, por meio de

\footnotetext{
${ }^{1}$ http://www.capes.gov.br/educacao-basica/capespibid/editais-e-selecoes
} 
cursos superiores públicos, gratuitos e de qualidade. As modalidades de cursos oferecidas contemplam primeira, segunda ou terceira licenciatura para docentes em exercício (BRASIL, 2009).

Consoante às informações da DEB/Capes, até dezembro de 2019, o PARFOR contava com 354 turmas em andamento, e mais de 11.000 professores da educação básica matriculados. Ao longo de sua existência, o PARFOR formou cerca de 54 mil professores (DEB/Capes, 2019).

No ano de 2018, um outro programa voltado à formação dos estudantes de licenciatura foi lançado pela Capes/MEC, o Residência Pedagógica. Instituído pela Portaria Capes no 38/2018, o programa tem o objetivo de propiciar e intensificar a formação prática nas licenciaturas, por meio da imersão do licenciando na escola de educação básica a partir da segunda metade do curso. A exemplo do PIBID, no Residência Pedagógica são oferecidas bolsas para os licenciandos, professores das escolas e equipe de docentes do programa/IES. Em entrevista à Revista Nova Escola, Mello (2018) destacou a relevância de programas de residência pedagógica, para favorecer a compreensão, por parte dos licenciandos, da dimensão prática da profissão docente. Segundo a estudiosa, a residência pedagógica poderia ser um primeiro passo para corrigir a ausência e/ou insuficiência da formação prática dos estudantes, embora a iniciativa governamental ainda se revele pequena para o número de futuros professores que se formarão nos próximos anos.

\section{METODOLOGIA}

Este trabalho constitui-se de pesquisa documental e bibliográfica, abordando o tema de formação de professores para educação básica no Brasil. A pesquisa documental consiste na análise dos normativos legais brasileiros que tratam dessa capacitação, informações institucionais constantes do site da Capes, do sistema de gestão da UAB, do SisUAB e da Plataforma Capes de Educação Básica.

Como fonte de busca para a pesquisa bibliográfica, utilizou-se autores como Gatti e Barreto (2009), Gatti et al. (2019), Saviani (1997, 1998 e 2016), Brzezinski (2018) e artigos publicados em revistas científicas de educação e na base de dados Scientific Eletronic Library Online (SciELO). 
A busca nessa base de dados foi feita em outubro de 2019 e o uso se justifica pela sua abrangência e por incluir publicações relevantes na área de Educação, conforme o sistema Qualis-Periódicos ${ }^{1}$ da CAPES.

\section{DISCUSSÃO DOS RESULTADOS E CONSIDERAÇÕES FINAIS}

Ao analisarmos os normativos legais que orientam para a formação de professores da educação básica brasileira desde a LDB de 1996, vemos que sua maior contribuição conforme apontado por Gatti et al. (2019) foi a proposição dessa formação em nível superior. No entanto, em 2013, voltou-se a admitir, sem restrições, a formação de docentes para a educação infantil e primeiros anos do ensino fundamental na modalidade normal em nível médio (BRASIL, 2013).

A UAB, constituída em 2006, é um marco de interiorização da formação inicial e continuada desses profissionais, expandindo o ensino superior dos grandes centros para os municípios menores e mais distantes. Representa também uma política pública de amplo alcance do ponto de vista do número de matrículas e de formados, posto que atua por meio da modalidade EaD. Vários autores reconhecem o papel democratizante da UAB e sua atuação frente ao cumprimento das Metas do PNE. Há, contudo, a preocupação com a qualidade dos cursos (GATTI et al, 2019) e até mesmo com a possibilidade de retração de outras iniciativas em EaD nas Instituições, por conta do modelo de gestão e fomento do Programa (ARRUDA, 2018).

O PIBID, instituído em 2007, de acordo com o estudo realizado por Gatti et al. (2014), trouxe várias contribuições para as licenciaturas e contribui para a valorização da profissão de professor, constituindo-se em rara política de atenção à formação inicial dos professores para a educação básica. É ainda um programa que desacomoda as licenciaturas e mobiliza escolas e por suas contribuições deve ser institucionalizada e tornada perene como política de Estado (GATTI et al., 2014).

Mas desde 2015, tem tido cortes orçamentários, frutos da retração dos investimentos planejados para a Capes, o que reflete na diminuição no número de

${ }^{1}$ Ferramenta usada para classificar a produção científica dos programas de pós-graduação no que se refere aos artigos publicados em periódicos científicos. A classificação é realizada pelos comitês de consultores de cada área de avaliação seguindo critérios previamente definidos pela área e procuram refletir a importância relativa dos diferentes periódicos para uma determinada área (BRASIL, 2018). 
bolsas. Esse fato faz do PIBID um exemplo de ação pública que, apesar de ter trazido inúmeras contribuições para o campo educacional, está sendo prejudicada pela diminuição de investimentos para sua execução (PANIAGO; SARMENTO; ROCHA, 2018). O Residência Pedagógica, embora tenha sido implementado apenas em 2018, alinha-se estritamente com o PIBID, pois também está direcionado à melhoria da formação inicial dos professores, assim como à valorização e fortalecimento dos cursos de licenciatura. Trata-se, da forma como atualmente se estrutura, de um programa complementar, pois a diferenciação prática entre os mesmos é tão somente o momento dos cursos para os quais são direcionados (PIBID, para a primeira metade e Residência Pedagógica, para a segunda metade das licenciaturas). A primeira edição do Residência Pedagógica ofertou 45.000 vagas. A segunda edição, que está em fase de seleção, ofertou cerca de 30.000 vagas. Para Mello (2018) trata-se de uma oferta ainda insuficiente, considerando o grande número de licenciandos do país.

O PARFOR (2009) tem cumprido o objetivo para o qual foi criado, o de qualificação dos profissionais da educação que estão em atividade e não possuem licenciatura, mas, na percepção de Brezezinski (2014), foi uma de tantas outras alternativas emergenciais do governo brasileiro, para suprir a necessidade de formação adequada aos docentes, tendo dificuldade de sua efetivação na prática, pois os professores não têm substitutos para ministrarem as suas aulas enquanto estudam, e, por isso, acabam por abandonar os cursos de formação.

Os PNEs de 2001 e 2014 abrangem em suas metas a questão da formação inicial e continuada dos professores, contemplando estratégias para todas as etapas da educação básica. Observam-se, contudo, em ambos, proposições não factíveis dentro dos prazos estabelecidos. Isso claramente se deu com o primeiro PNE (2001-2010), no qual se observa que as estratégias estabelecidas ficaram longe de serem cumpridas. Para Iulianelli (2016, p. 139), este PNE "teria se tornado uma mera carta de intenções. Sua baixa efetividade foi tão intensa que se teve que elaborar um Plano do Desenvolvimento da Educação". Muito provavelmente o descompasso entre o previsto e o executado venha a se repetir em muitas das Metas previstas no atual PNE (20142024). Nesse âmbito, revela-se a importância e a necessidade de que o planejamento das políticas públicas esteja articulado às reais condições de execução das mesmas, ou seja, da operacionalização dos programas. 
No PNE de 2014, no que tange às metas relacionadas à formação de professores, podem ser identificadas estratégias relacionadas aos programas em andamento abordados nesta pesquisa, como por exemplo, a estratégia 15.9 que se relaciona com o PARFOR e com a UAB, a 15.3 que está atrelada ao PIBID e Residência Pedagógica e a 12.2 que trata da UAB.

Apesar de ser necessária a formação de professores em exercício e de novos professores, as determinações legais verificadas revelam um traço persistente e problemático em nossa história de formação para o magistério, em que situações inadequadas e impróprias nas escolas públicas, como formação profissional inadequada e desmotivação, justificam ações aligeiradas e provisórias na preparação dos docentes da educação básica no país (GATTI, et al., 2019).

Por fim, importa destacar que a lógica e dinâmica das políticas em nosso país, sobretudo na área educacional, não apresenta a linearidade e articulação necessárias ao cumprimento adequado das metas e estratégias estabelecidos normativamente. Tratam-se ainda de programas fragmentados e de caráter emergencial. É o que Brzezinski (2018) chama de "descompasso/compasso entre a proposição, a execução e os resultados (BRZEZINSKI, 2018, p. 8).

Ela ainda sustenta que a dinâmica das políticas no sentido de constantes reformas, planos de ação, mudanças e alterações de rotas, são fruto de um cenário fortemente pautado na internacionalização, financeirização e pelo movimento de diversificação e diferenciação institucional, o que altera e complexifica ainda mais os processos de gestão, financiamento e organização da educação nacional, incluindo a democratização do acesso e permanência com qualidade social (BRZEZINSKI, 2018).

Cabe aqui, ressaltar que, o intuito do histórico dos normativos legais e programas públicos federais relacionados à formação de professores para a educação básica, foi de desenvolver reflexões sobre as políticas educacionais no país desde 1996 a fim de relacioná-la com a realidade que vivenciamos como docentes e pesquisadoras da área.

\section{REFERÊNCIAS}

ARRUDA, E. P. Reflexões sobre a política nacional de formação de professores a distância e o enfraquecimento da EaD pública pela Universidade Aberta do Brasil (UAB). Revista Educação (UFSM), Santa Maria. Vol. 43, n. 4, p. 823-842, out./dez. 2018. 
BARRETO, E. S. S. Políticas de formação docente para a educação no Brasil: embates contemporâneos. Revista Brasileira de Educação, v. 20, n. 62 jul.-set. 2015. Disponível em: http://www.scielo.br/pdf/rbedu/v20n62/1413-2478-rbedu-2062-0679.pdf. Acesso em: 05 nov. 2019.

BRANCO, J. C.; PEIXOTO, M. C. Universidade Aberta do Brasil. In: MILL. D. (Org.) Dicionário Crítico de Educação e Tecnologias de Educação a Distância. Campinas. SP. Papirus. 2018.

BRASIL. Decreto no 5.800, de 8 de junho de 2006. Dispõe sobre o Sistema Universidade Aberta do Brasil - UAB. Brasília, 2006. Disponível em: http://www.planalto.gov.br/ccivil_03/_Ato20042006/2006/Decreto/D5800.htm. Acesso em: 8 jun. 2020.

BRASIL. Lei no 11.502, de 11 de julho 2007. Modifica as competências e a estrutura organizacional da fundação Coordenação de Aperfeiçoamento de Pessoal de Nível Superior -CAPES de que trata a Lei $n^{\circ} 8.405$, de 9 de janeiro de 1992; e altera as Leis $\mathrm{n}^{\text {os }}$ 8.405, de 9 de janeiro de 1992, e 11.273, de 6 de fevereiro de 2006, que autoriza a concessão de bolsas de estudo e de pesquisa a participantes de programas de formação inicial e continuada de professores para a educação básica. Brasília, $2007 . \quad$ Disponível em: http://www.planalto.gov.br/ccivil_03/_Ato2007-2010/2007/Lei/L11502.htm. Acesso em: 08 jun. 2020.

BRASIL. Lei no 10.172, de 9 de janeiro de 2001. Plano Nacional de Educação. Brasília, 2001. http://www.planalto.gov.br/ccivil_03/leis/leis_2001/I10172.htm. Acesso em: 01 dez. 2019.

BRASIL. Lei no 13.005, de 25 de junho de 2014. Aprova o Plano Nacional de Educação (PNE) e dá outras providências. Brasília. Brasília, 2014. Disponível: http://www. observatoriodopne.org.br/uploads/reference/file/439/documentoreferencia.p df. Acesso em: 11 dez. 2019.

BRASIL. Ministério da Educação. Conselho Nacional de Educação. Resolução CNE/CP no 02, de 10 de Julho de 2015. Define as Diretrizes Curriculares Nacionais para a Formação Inicial de Professores para a Educação Básica Disponível em: <http://portal.mec.gov.br/index.php?option=com_docman\&view=download\&a lias=17719-res-cne-cp-002-03072015\&category_slug=julho-2015pdf\&Itemid=30192> Acesso em: 08 jun. 2020.

BRZEZINSKI, I (Org.). LDB/1996 vinte anos depois: projetos educacionais em disputa. 1. ed. São Paulo: Cortez, 2018.

CAPES. Coordenação de Aperfeiçoamento de Pessoal de Nível Superior. Portaria № 38, de 28 de Fevereiro de 2018. Institui o Programa de Residência Pedagógica. Disponível em: <http://www.capes.gov.br/images/stories/download/legislacao/28022018Portaria_n_38-Institui_RP.pdf> Acesso em: 08 jun. 2020 
COUTINHO, D. R. O direito nas políticas públicas. In: MARQUES, E.; FARIA, C. A. P. de (orgs.). A política pública como campo multidisciplinar. São Paulo: Ed. UNESP; Rio de Janeiro: Ed. Fiocruz, 2013. p. 181-200.

GATTI, B. A. et al. Professores do Brasil: novos cenários de formação. Brasília: UNESCO, 2019.

GATTI, B. A. et al. Um estudo avaliativo do Programa Institucional de Bolsa de Iniciação à Docência. Fundação Carlos Chagas. São Paulo, 2014. Disponível em: http://publicacoes.fcc.org.br/ojs/index.php/textosfcc/issue/view/298. Acesso em 8 jun. 2020.

MEC. Ministério da Educação. Conselho Nacional de Educação. Resolução CNE/CP no 02, de 20 de Dezembro de 2019. Define as Diretrizes Curriculares Nacionais para a Formação Inicial de Professores para a Educação Básica e institui a Base Nacional Comum para a Formação Inicial de Professores da Educação Básica (BNC-Formação). Disponível em: $<$ http://portal.mec.gov.br/index.php?option=com_docman\&view=download\&a lias=135951-rcp002-19\&category_slug=dezembro-2019-pdf\&ltemid=30192> Acesso em: 08 jun. 2020.

MEC, Ministério da Educação. Conselho Nacional de Educação. Portaria Normativa no 09 de 30 de junho de 2009. Institui o Plano Nacional de Formação de Professores da Educação Básica no âmbito do MEC. Disponível em: http://portal.mec.gov.br/dmdocuments/port_normt_09_300609.pdf. Acesso em 09 jun. 2020.

MILL, D. A Universidade Aberta do Brasil. In: LITTO, M. F. FORMIGA, M. Educação a Distância: O Estado da Arte 2. São Paulo. Pearson Education do Brasil, 2012.

MELLO, G. N. A formação precisa deixar de ser problema e virar solução [Entrevista concedida a] Lais Semis. Revista Nova Escola. 2018. Disponível em: <https://novaescola.org.br/conteudo/11751/a-formacao-precisa-deixar-de-serproblema-e-virar-solucao> Acesso em: 09 jun. 2020.

PANIAGO, R. N.; SARMENTO, T.; ROCHA, S. A. O PIBID e a inserção à docência: experiências, possibilidades e dilemas. Educ. rev., Belo Horizonte, v. 34, 2018. Disponível em <http://www.scielo.br/scielo.php?script=sci_arttext\&pid=S0102$46982018000100176 \&$ lng=pt\&nrm=iso>. Acesso em 09 jun. 2020.

OLIVEIRA, H. L. G. O.; LEIRO, A. C. R. Políticas de formação de professores no Brasil: referenciais legais em foco. Pro-Posições, v.30. Campinas: SP, 2019.

ONU. 17 Objetivos para transformar o mundo. Nova York: ONU, 2015. Disponível em: https://nacoesunidas.org/pos2015/. Acesso em: 24 jan. 2020.

SAVIANI, D. A Lei da Educação (LDB): Trajetória, limites e perspectivas. 13. ed., revista, atualizada e ampliada com um novo capítulo. Campinas: Autores Associados, 2016. 
SAVIANI, D. Formação de professores: aspectos históricos e teóricos do problema no contexto brasileiro. 2009.

SAVIANI, D. A nova lei da educação: trajetória, limites e perspectivas. 4. ed. Campinas: Autores Associados, 1998.

SIQUEIRA, F. A implementação dos Objetivos de Desenvolvimento Sustentável no Brasil e os desafios das metas em educação. Ação Educativa, 2017. Disponível em:

http://acaoeducativa.org.br/wpcontent/uploads/2017/02/implementa\%C3\%A7 \%C3\%A3o_ODS_Brasil.pdf. Acesso em 01 jun. 2020. 


\section{CAPÍTULO II}

\section{ALFABETIZAÇÃO E LETRAMENTO: REFLEXÕES SOBRE A PRÁTICA DOCENTE NA FORMAÇÃO LETRADA DOS ESTUDANTES DA EDUCAÇÃO BÁSICA}

Priscila Alves de Paula Belo ${ }^{1}$

Scarlett O'hara Costa Carvalho ${ }^{2}$

\footnotetext{
${ }^{1}$ Mestra em Educação. Programa de Pós Graduação em Educação da Universidade Federal do Ceará - UFC.

${ }^{2}$ Doutoranda em Educação. Programa de Pós Graduação em Educação da Universidade Estadual do Ceará - UECE.
}

\section{RESUMO}

Esta produção tem por objetivo explicitar as concepções de letramento e alfabetização, refletindo acerca da prática docente no ensino da língua portuguesa. Os estudos realizados, a partir das discussões levantadas por autores como Vygotsky, Ferreiro, Kleiman e Soares, e das orientações apresentadas na Base Nacional Comum Curricular (BNCC) e nos Parâmetros Curriculares Nacionais ( PCN) de Língua Portuguesa, possibilitaram o entendimento em relação à aquisição da leitura e escrita e a diferenciação entre alfabetização e letramento, considerando que esse processo de aquisição, dentro da escola, necessita estar inserido em um contexto social para que seja apreendido significativamente pela criança. Quanto à prática docente, percebeu-se o papel fundamental do educador no percurso desse processo de aprendizagem, visto que a sua prática pedagógica no ensino da leitura e escrita, quando contextualizada, poderá influenciar e contribuir, ou não, para formação de sujeitos letrados e aptos a se comunicarem efetivamente na sociedade.

Palavras-chave: Alfabetização. Letramento. Prática Docente.

\section{INTRODUÇÃO}

Durante o processo de aquisição da escrita, a criança passa a utilizar símbolos, desenhos, imagens, rabiscos, textos ou qualquer outra forma que ela encontre para expressar o mundo ao seu redor. De acordo com Vygotsky (1989), a aquisição da escrita resulta de um longo processo de desenvolvimento das funções superiores do comportamento infantil que o autor chama de pré-história da linguagem escrita, esta que por sua vez constitui a história das formas de expressão da criança. Contudo, a escolarização da escrita tem limitado essas expressões transformando este processo em algo mecânico e sistematizado, impedindo-os assim de perceber a utilização racional e social deste sistema e até a própria livre expressão. 
Este é um processo bastante complexo, que acontece de forma particular e em tempos diferentes para cada indivíduo, portanto necessita de uma maior atenção por parte do educador, que precisa estar atento não somente para o processo isolado de conhecimento das letras e formação de palavras, mas também para a realidade social em que estão inseridos, já que o contexto da aprendizagem pode ser fator contribuinte para o desenvolvimento dos alunos (FERREIRO, 1995).

A aprendizagem da escrita, por muito tempo, tomou uma visão simplista, perdendo a sua especificação e caracterizando-se pelo conhecimento dos códigos linguísticos e da sua formação de palavras, frases etc. Desse modo, muitas crianças tornavam-se apenas codificadores, ou seja, capazes de transcrever de acordo com as regras e sistemas da grafia, porém sem conseguir fazer uma real interpretação do mundo, sem a habilidade de produzir bons textos e construir uma escrita reflexiva. Conforme Mello (2005, p. 29) explica, “o problema é que, ao tornar o processo mais simples buscando ensinar primeiro as letras para então chegar aos processos de comunicação e expressão, se perdeu de vista a função social da escrita [...]", ou seja, a finalidade pela qual a escrita foi criada foi colocada em segundo plano.

Pesquisas apontam que cerca de $30 \%$ da população brasileira, com faixa etária entre 15 e 64 anos, são considerados analfabetos funcionais. Isso significa dizer que "A cada 10 brasileiros, três não conseguem resolver operações básicas que envolvam, por exemplo, o total de uma compra, o cálculo do troco ou valor de prestações sem juros quando vão ao supermercado" (CAMPOS JÚNIOR, 2018, p.1). Ou seja, esses indivíduos sofrem ao resolver tarefas simples do cotidiano devido aos obstáculos gerados pela dificuldade na interpretação de textos ou situações que surgem constantemente, o que prejudica, em sua maioria, a formação de cidadãos autônomos e com uma visão de mundo crítica.

Os estudos do Indicador de Analfabetismo Funcional (INAF), datados entre 2001 e 2018, ainda revelam que, embora tenha aumentado para a taxa de escolaridade de crianças entre seis e 14 anos, desse mesmo público, "7 em cada 10 ainda são analfabetos funcionais e apenas 1\% pode ser considerado proficiente" (CAMPOS JÚNIOR, 2018, p.1).

Necessita-se, portanto, repensar sobre a importância do processo de alfabetização, buscando ter como foco o aprendiz em formação, um ser social, que precisa desenvolver uma visão crítica a respeito do mundo em que vive, sabendo 
expressar sua opinião nas demais formas de representação da linguagem, inclusive a escrita. É fundamental levar em consideração o olhar do aprendiz e a partir daí buscar meios e estratégias que proporcionem o interesse pela escrita, a fim de que ele possa aprender não somente a escrever o seu nome ou textos simples, mas também a expressar a sua opinião por meio da língua escrita, construindo textos críticos, poéticos, artísticos, questionadores e reais.

Sendo assim, temos como objetivo explicitar as concepções de letramento e alfabetização, refletindo acerca da prática docente no ensino da língua portuguesa. Pois, considera-se fundamental a reflexão sobre esse processo de aquisição da linguagem desenvolvido no ambiente escolar, analisando as lacunas que contribuem para o fracasso no contexto social. Assim como afirma Kleiman (1995, p.47): “As falhas, acredito, são mais profundas, pois são decorrentes dos próprios pressupostos que subjazem ao modelo de letramento escolar".

Com efeito, este artigo traz uma discussão sobre a prática docente na formação letrada dos estudantes da educação básica. Para isso, foi realizada uma pesquisa bibliográfica, de natureza qualitativa, buscando adquirir conhecimento por intermédio das principais fontes relacionadas à temática abordada (PRESTES, 2008).

\section{EDUCAR PARA LETRAR}

A criança por si só é constituída por um mundo de imaginação e criatividade, é observadora, tem opinião sobre as coisas e é capaz de produzir magníficos trabalhos. Para isso, elas exploram o meio ao seu redor travando problemas abstratos e complexos em busca de construir o seu conhecimento de mundo, dentre eles, o conhecimento relacionado ao processo de escrita (FERREIRO, 1995). Por isso, é preciso estar atento a esse processo considerando seu contexto social, bem como para as práticas educativas, de modo que possam contribuir para o afloramento dessa criatividade em relação às produções escritas e proporcionem oportunidades em que os discentes se expressem e desenvolvam suas habilidades.

\subsection{Alfabetização e Letramento}

Entender a aquisição da linguagem escrita requer a compreensão dos processos entre os quais o aprendiz perpassa em seu desenvolvimento. Segundo Mello (2005) a 
apropriação da linguagem escrita pela criança precisa ocorrer de modo natural por meio de uma vivência social numa comunidade que lê e escreve constantemente. Os estudos a respeito desse processo de aquisição apresentam dois termos intrínsecos e interligados, são eles: alfabetização e letramento, dos quais discutiremos a seguir.

Soares (1995) traz uma diferenciação entre estes termos de maneira concisa e nos proporciona um melhor esclarecimento a respeito do assunto. Ela ressalta que conforme as mudanças que foram ocorrendo ao longo do tempo surgiram à necessidade de novas definições quanto à aprendizagem da língua escrita. A autora explica que o termo letramento surgiu a partir de novas demandas na sociedade quanto ao uso da leitura e escrita.

Conforme Soares (1995) a palavra letramento foi introduzida na biblioteca educacional brasileira baseando-se na palavra Literacy (palavra inglesa que se refere ao estado ou condição que assume aquele que aprende a ler e escrever). Implicitamente neste conceito está o papel social da escrita, pois letramento não se refere somente aquele a quem domina a regras gramaticais e consegue escrever uma palavra, mas sim àquele que sabe usá-la efetivamente nos grupos sociais a que está inserido, ocasionando assim consequências sociais, culturais, políticas, econômicas, cognitivas e linguísticas.

Quanto à alfabetização, Soares (2009) expõe as concepções a partir do dicionário Aurélio da Língua Portuguesa, que define como "a ação de alfabetizar, de ensinar a ler e escrever", ou seja, o ato de ensinar as letras, formação de palavras, frases e dentre outras coisas.

Percebe-se aqui a principal diferenciação entre estes termos. Enquanto a alfabetização propicia apenas o ensino rudimentar da escrita, o letramento propõe o uso social da escrita, o seu domínio para a comunicação no cotidiano.

Definir o conceito de letramento, e em seguida diferenciá-lo do conceito de alfabetização é uma tarefa bastante complicada, já que estão diretamente ligados entre si e no que diz respeito às definições existe ainda uma grande confusão de ideias. Quanto a isso Soares ressalta:

Dissociar alfabetização e letramento é um equívoco porque, no quadro das atuais concepções psicológicas, lingüísticas e psicolingüísticas de leitura e escrita, a entrada da criança (e também do adulto analfabeto) no mundo da escrita se dá simultaneamente por esses dois processos: pela aquisição do sistema convencional de escrita - a alfabetização, e pelo desenvolvimento de habilidades de uso desse sistema em 
atividades de leitura e escrita, nas práticas sociais que envolvem a língua escrita - o letramento. Não são processos independentes, mas interdependentes, e indissociáveis: a alfabetização se desenvolve no contexto de e por meio de práticas sociais de leitura e de escrita, isto é, através de atividades de letramento, e este, por sua vez, só pode desenvolver-se no contexto da e por meio da aprendizagem das relações fonema-grafema, isto é, em dependência da alfabetização. (SOARES, 2004. p.14).

Vemos aqui que uma definição não exclui a outra. O sujeito letrado necessita dominar o código escrito para saber se expressar por meio dele, seja de maneira simplista ou mais elaborada. E consequentemente, o sujeito alfabetizado deve entender o fator social do instrumento que utiliza para comunicar-se.

Para Kleiman (2005) a alfabetização é uma prática do letramento, e os dois termos estão diretamente associados.

A prática da alfabetização se concretiza em eventos que se situam dentro de uma sala de aula, liderados por um especialista (o professor) que se encarrega de ensinar sistematicamente as regras de funcionamento e uso do código alfabético aos iniciantes no assunto (os alunos). Ambos - professor e aluno - têm relações sociais predeterminadas: um anima, organiza, avalia; outros respondem, realizam as atividades propostas (KLEIMAN, 2005, p.13).

A autora ainda conceitua a alfabetização como um conjunto de saberes relacionados ao código escrito da sua língua materna e como um processo de aquisição das primeiras letras. Contudo, ela deixa claro que inúmeras mudanças ocorreram ao longo da história, no que diz respeito à concepção de "ser alfabetizado" dentro das escolas, e do que seria necessário saber para poder usar a escrita ao longo da vida.

Conforme a Base Nacional Comum Curricular (BNCC), durante o processo de alfabetização é preciso que:

os estudantes conheçam o alfabeto e a mecânica da escrita/leitura processos que visam a que alguém (se) torne alfabetizado, ou seja, consiga "codificar e decodificar" os sons da língua (fonemas) em material gráfico (grafemas ou letras), o que envolve o desenvolvimento de uma consciência fonológica (dos fonemas do português do Brasil e de sua organização em segmentos sonoros maiores como sílabas e palavras) e o conhecimento do alfabeto do português do Brasil em seus vários formatos (letras imprensa e cursiva, maiúsculas e minúsculas), além do estabelecimento de relações grafofônicas entre esses dois sistemas de materialização da língua (BRASIL, 2017, p.90). 
De acordo com esse documento, nos primeiros anos do Ensino Fundamental a prática docente deve ser voltada à alfabetização, garantindo oportunidades para a apropriação do sistema da língua escrita de modo que habilidades de leitura e escrita sejam também desenvolvidas por meio de práticas letradas. A BNCC sintetiza as habilidades envolvidas na alfabetização tal como:

- Compreender diferenças entre escrita e outras formas gráficas (outros sistemas de representação);

- Dominar as convenções gráficas (letras maiúsculas e minúsculas, cursiva e script);

- Conhecer o alfabeto;

- Compreender a natureza alfabética do nosso sistema de escrita;

- Dominar as relações entre grafemas e fonemas;

- Saber decodificar palavras e textos escritos;

- Saber ler, reconhecendo globalmente as palavras;

- Ampliar a sacada do olhar para porções maiores de texto que meras palavras, desenvolvendo assim fluência e rapidez de leitura (fatiamento). (BRASIL, 2017, p. 93).

Em análise sobre os pressupostos da alfabetização apontados na BNCC, Rosi Rico (2018) - da Revista Nova Escola - explica que existem duas linhas de ensino abordadas no documento, a primeira está centrada no trabalho com práticas sociais da leitura e escrita com o uso de textos, dos quais as crianças possam refletir a respeito; a segunda linha trata sobre a compreensão do sistema de língua escrita, ou seja, aprendizagem das letras, sílabas, fonética etc. A escritora destaca ainda que essas definições geraram muitas discussões durante o processo de avaliação da BNCC. Ela ainda afirma que "Indicar a inclusão de atividades específicas sobre notação alfabética não significa desprezar a imersão no texto e sua função social nem estabelecer uma ordem de prioridade entre os dois trabalhos" (RICO, 2018, on-line).

Dessa forma, é possível perceber por meio dessas definições que a alfabetização é um processo sistemático que demanda uma consciência fonológica e estrutural. Isso precisa ocorrer mediante estratégias pedagógicas que envolvam operações cognitivas, físico-motoras, social e emocional. A criança necessita estar engajada nesse processo e o professor comprometido a apresentar-lhe todos os meios disponíveis para que a construção e aprendizagem do sistema da escrita ocorram.

No que concerne ao letramento, Kleiman (2005) afirma que sua principal característica está associada ao fato de que o letramento é determinado pelo contexto ao qual está inserido, também aos seus usos e funções. 
O letramento abrange o processo de desenvolvimento e o uso de sistemas de escrita nas sociedades, ou seja, o desenvolvimento histórico da escrita refletindo outras mudanças sociais e tecnológicas, como a alfabetização universal, a democratização do ensino, o acesso as fontes aparentemente ilimitadas de papel, o surgimento da internet. (KLEIMAN, 2005. p.22).

A autora aponta que o termo surgiu na literatura especializada para "se referir a um conjunto de práticas de uso da escrita que vinham modificando profundamente a sociedade, mais amplo do que as práticas escolares de uso da escrita, incluindo-as, porém." (KLEIMAN, 2005, p.22).

Um ponto de destaque para Kleiman (1995; 2005), em suas pesquisas remete a questão dos tipos de letramento, ela enfatiza que esta é uma prática que ocorre muito mais fora da escola do que dentro dela, pois se constitui através dos acontecimentos que cercam o aprendiz, por meio do seu envolvimento com a comunidade e, portanto as práticas de "letramento escolar" deveriam ocorrer relacionando-se a essa realidade vivida, já que ser letrado entende-se como aquele que sabe fazer o uso social da escrita, ou seja, aquele que compreende o mundo ao seu redor e utiliza das diversas linguagens, dentre elas a - escrita - para comunicar-se com ele.

A autora ressalta que o fenômeno letramento vai muito além do mundo da escrita tal qual é concebido nas instituições que são encarregadas de apresentar formalmente aos aprendizes o mundo da escrita; ela reflete que outras "agências de letramento" como família e igreja, trazem orientações totalmente diferentes quanto a este conceito. Com isso, Kleiman (2005) afirma que quanto mais a escola se aproximar das práticas sociais de outros ambientes de vivências dos alunos, mais estes poderão trazer conhecimentos relevantes das práticas que já conhecem e mais fáceis serão as adequações, adaptações e transferências que ele virá a fazer, e sendo assim melhor será a sua aprendizagem.

Para melhor esclarecer as práticas desses dois termos - Alfabetização e Letramento, Kleiman traz uma tabela apresentando os principais pontos em seu artigo "Alfabetização e Letramento: implicações para o ensino", 2002. 
Figura 1 - Ensino da Escrita

\begin{tabular}{|c|c|}
\hline Alfabetização tradicional & Letramento \\
\hline $\begin{array}{l}\text { 1. Prática individual de domínio do } \\
\text { código. }\end{array}$ & $\begin{array}{l}\text { Práticas sociais, situadas em contextos } \\
\text { especificos. culturalmente determinadas. }\end{array}$ \\
\hline $\begin{array}{l}\text { 2. Foco na capacidade individual de } \\
\text { aquisição da escrita ( portanto. } \\
\text { competitiva). }\end{array}$ & $\begin{array}{l}\text { Foco na prática coletiva, da qual cada um } \\
\text { participa segundo sua experiência, sua } \\
\text { capacidade. }\end{array}$ \\
\hline $\begin{array}{l}\text { 3. Prática homogênea. determinada } \\
\text { por poucas instituiçōes dominantes. }\end{array}$ & $\begin{array}{l}\text { Práticas diversificadas. segundo } \\
\text { instituiçōes, objetivos. identidades e papé is } \\
\text { dos participantes, etc. }\end{array}$ \\
\hline $\begin{array}{l}\text { 4. Objetivo da prática escolar: preparo. } \\
\text { para transferência a outros contextos: } \\
\text { prática circular (ler/escrever para } \\
\text { aprender a ler/escrever). }\end{array}$ & $\begin{array}{l}\text { Objetivo: realização de tarefas especificas. } \\
\text { Ler/escrever com alguma outra finalidade } \\
\text { (prazer. escape. aprendizagem. contato. } \\
\text { etc.). }\end{array}$ \\
\hline $\begin{array}{l}\text { 5. A unidade analítica de ensino } \\
\text { privilegiada é a palavra e seu } \\
\text { significado. iniciando-se na letra/sílaba. } \\
\text { culminando na frase ou na } \\
\text { seqüência/coleção de frases. }\end{array}$ & $\begin{array}{l}\text { A unidade básica privilegiada é o texto e a } \\
\text { produção de sentido. }\end{array}$ \\
\hline $\begin{array}{l}\text { 6. Gêneros privilegiados: os das } \\
\text { instituiçōes literária. acadêmica e. } \\
\text { mais recentemente. jornalística. }\end{array}$ & $\begin{array}{l}\text { Além desses, também gêneros dos } \\
\text { domínios discursivos do cotidiano familiar. } \\
\text { da publicidade. da burocracia. do } \\
\text { comércio. da política, etc. }\end{array}$ \\
\hline
\end{tabular}

Fonte: Kleiman (2002, p. 100).

Vemos aqui que um centraliza-se mais na prática individual e autônoma e o outro em atividades coletivas e no compartilhar de experiências, ampliando assim a margem de conhecimentos para tal aprendizagem. A exemplificação do segundo termo letramento -, temos inúmeras práticas letradas em instituições como a família, tais como a leitura de jornais e revistas, produções de listas de compras, receitas etc. Kleiman concorda que estas são as instituições que primeiro introduzem a criança no mundo da escrita, com práticas coletivas onde o conhecimento a respeito da escrita dáse de forma natural e por meio da colaboração, em uma relação de respeito e mediante participação de todos.

Dominar o código de linguagem escrita, as regras de gramática e ortografia são imprescindíveis para que a criança se torne um sujeito alfabetizado, porém esse processo se transforma em algo interessante e instigador do ponto de vista do aprendiz 
quando ele se sente envolvido com a prática realizada no ambiente de ensino e também, quando ele percebe o seu contexto social incluído. Sobre isso, Kleiman afirma:

$E$, vale a pena lembrar, a dificuldade para ler ou escrever algum texto está relacionada ao grau de verossimilhança da prática escolar para com a prática social situada em outras instituições; tudo é difícil quando a atividade não faz sentido, quando ela não pertence a alguma prática social conhecida, quando ela não é relevante para a vida social. (KLEIMAN, 2002, p. 108).

Para que a prática escolar atraia o aluno, como podemos observar na opinião da autora, essa criança necessita entender e associar a aprendizagem à sua realidade, e é nesse ponto que devem ser introduzidas as práticas de letramento, utilizando eventos e atividades que tem características de outras atividades e instituições da vida social do aprendiz. Feito isso, notaremos a relação profunda entre os conceitos de alfabetização e letramento e observaremos que o fator principal da aprendizagem não é o método com que se ensina, mas sim o conhecimento que é formado e o seu significado para situações específicas.

Portanto, com base nos conceitos explicitados, percebemos que a escola deve ser o principal instrumento para a formação desses sujeitos letrados - pessoas preparadas para utilizarem a escrita como ferramenta de comunicação e representação da linguagem no cotidiano, ou seja, indivíduos que saibam, de fato, fazer o uso social do código escrito -, considerando que a escola deve formar o indivíduo para a sociedade e, sendo assim, os seus conteúdos devem estar relacionados às vivências pessoais dos aprendizes.

\subsection{A prática docente no ensino da leitura e escrita}

Apresentar considerações a respeito dos conceitos de alfabetização e letramento e não refletir sobre a prática pedagógica para o ensino da leitura e escrita torna a produção deste trabalho apenas mais um dos inúmeros trabalhos que introduzem as diversas diferenciações e semelhanças entre ambos e não refletem sobre as práticas de ensino e aprendizagem.

A aquisição da língua materna de maneira consciente e as práticas de uso social dentro do ambiente escolar são temas que exigem uma maior atenção nas pesquisas da 
atualidade, pois remete a não somente avaliar como o aluno tem aprendido os conteúdos, mas também a refletir a ação docente dos professores.

Os reflexos do letramento desenvolvido (ou não) nas séries do Ensino Fundamental serão vistos nas turmas do ensino médio e universidades, quando estudantes serão mais "forçados" - no sentido de que as produções textuais nessas etapas de ensino visam o domínio dos diversos gêneros textuais para a construção dos textos solicitados em avaliações externas e processos seletivos -, a se posicionarem sobre assuntos importantes, defenderem pontos de vista e elaborar textos argumentativos, expositivos etc., e estarão ou não "qualificados" para realizarem tal atividade.

Conforme os estudos de Kleiman (2005), o ensino da leitura e escrita nas séries iniciais do Ensino Fundamental necessita acontecer de maneira consistente, a fim de introduzir os conteúdos específicos da língua, tal como o proposto nos currículos escolares, porém ainda mais para orientar o sujeito quanto a sua importância fora daquele ambiente. Um indivíduo que obteve sua formação básica de maneira bem sucedida entendeu a relevância da escrita dentro da sociedade, sabe como usá-la e tem todos os aparatos necessários para a utilização deste veículo de comunicação, dificilmente obterá fracasso em suas produções. Kleiman (1995) aponta, no entanto, que o fracasso dessa aprendizagem decorre não somente pela falha no ensino ou falhas no currículo pedagógico, mas principalmente pelo modelo de letramento escolar.

Com isso, a autora afirma que o principal problema na formação dos sujeitos letrados é o próprio letramento, a maneira como este tem sido trabalhado dentro das escolas. Em suas pesquisas, ela apresenta dois modelos de letramento e destaca aquele que tem sido introduzido erroneamente na sala de aula. São eles:

(1) O modelo autônomo de letramento - concepção que pressupõe que há apenas uma maneira de o letramento ser desenvolvido, sendo que essa forma está associada quase que causalmente com o progresso, a civilização, a mobilidade social;

(2) E o modelo ideológico de letramento - que afirma que as práticas de letramento, no plural, são social e culturalmente determinadas, e, como tal, os significados específicos que a escrita assume para um grupo social dependem dos contextos e instituições em que ela foi adquirida (KLEIMAN, 1995. p.21).

A partir das definições citadas acima, Kleiman (1995), em seus estudos, constata que o modelo que prevalece dentro das práticas escolares é o modelo autônomo de 
letramento, que muitas vezes considera a aprendizagem da leitura e escrita como um processo neutro, independente das influências externas e sociais. Ao final do processo esse modelo deve promover a capacidade de interpretar e escrever corretamente textos abstratos, e até de gêneros expositivos e argumentativos, gêneros estes que exigem muito mais uma reflexão acerca da realidade que o cerca do que apenas a aquisição de conceitos sobre "como fazer" um texto.

Para podermos visualizar melhor a maneira que tem sido abordado o ensino da leitura e escrita dentro do ambiente escolar e a partir daí refletir sobre uma prática docente idealizadora e bem sucedida, necessitamos compreender melhor quais os objetivos para a aprendizagem da leitura e escrita, bem como as habilidades e competências a serem desenvolvidas que estão propostas na BNCC, e também verificar as propostas de ensino sugeridas nos Parâmetros Curriculares Nacionais de Educação (PCN) direcionados a Língua Portuguesa.

Um dos objetivos gerais proposto nos PCN de Língua Portuguesa remete a preparação do indivíduo para a utilização e domínio das diferentes linguagens presentes no cotidiano a qual ele estiver inserido, a fim de não somente ser capaz de compreendêlas, mas de utilizá-las como meio de comunicação.

Utilizar as diferentes linguagens - verbal, matemática, gráfica, plástica e corporal - como meio para produzir, expressar e comunicar suas idéias, interpretar e usufruir das produções culturais, em contextos públicos e privados, atendendo a diferentes intenções e situações de comunicação (BRASIL, 1997, p.05).

Diante disso, os Parâmetros Curriculares Nacionais (BRASIL, 1997) afirmam que a escola deve promover condições para que, nos anos destinados ao ensino fundamental, as crianças tenham acesso aos saberes linguísticos e desenvolvam sua aprendizagem no intuito de serem capazes de fazerem uso das diversas linguagens utilizadas socialmente, e, que como cidadãos, possam expressar suas opiniões e estejam aptos a produzir textos eficazes nas mais distintas situações.

Já a Base Nacional Comum Curricular (BRASIL, 2017), em relação ao desenvolvimento das habilidades e competências na área da Linguagem e suas tecnologias, prevê que os estudantes sejam capazes de "mobilizar e articular conhecimentos desses componentes simultaneamente a dimensões socioemocionais, 
em situações de aprendizagem que Ihes sejam significativas e relevantes para sua formação integral" (BRASIL, 2017, p. 481). Além disso, quanto às competências específicas de linguagem para o Ensino Fundamental, aponta que os alunos devem ser capazes de:

- Compreender as linguagens como construção humana, histórica, social e cultural, de natureza dinâmica, reconhecendoas e valorizando-as como formas de significação da realidade e expressão de subjetividades e identidades sociais e culturais;

- Conhecer e explorar diversas práticas de linguagem (artísticas, corporais e linguísticas) em diferentes campos da atividade humana para continuar aprendendo, ampliar suas possibilidades de participação na vida social e colaborar para a construção de uma sociedade mais justa, democrática e inclusiva;

- Utilizar diferentes linguagens - verbal (oral ou visualmotora, como Libras, e escrita), corporal, visual, sonora e digital -, para se expressar e partilhar informações, experiências, ideias e sentimentos em diferentes contextos e produzir sentidos que levem ao diálogo, à resolução de conflitos e à cooperação;

- Utilizar diferentes linguagens para defender pontos de vista que respeitem o outro e promovam os direitos humanos, a consciência socioambiental e o consumo responsável em âmbito local, regional e global, atuando criticamente frente a questões do mundo contemporâneo. (BRASIL, 2017, p. 65).

Com isso, no que diz respeito à Linguagem, infere-se que as competências a serem desenvolvidas pelo aluno no contexto do Ensino Fundamental estão relacionadas a práticas de letramento, visto que implica a construção do conhecimento linguístico agregada a identidade social e cultural, possibilitando, portanto, a sua participação ativa na sociedade.

Os parâmetros curriculares relatam ser fundamental a participação dos educadores durante esse processo de aquisição da escrita, destacando que o professor deve acompanhar o desenvolvimento de cada aluno, monitorar suas produções e intervir somente nos momentos necessários no intuito de permitir que a criança seja autônoma em suas produções e peça auxílio quando, de fato, estiver necessitando de ajuda. Outro aspecto abordado pelo documento é a participação dos alunos entre si, durante as produções dentro de projetos pedagógicos, para que um aluno-escritor possa contribuir com desenvolvimento das produções do outro, favorecendo assim a troca de experiências e os conhecimentos adquiridos de cada um (BRASIL, 1997). 
Para o Primeiro Ciclo do Ensino Fundamental (do 10 ao 3o ano), os PCN's propõem que os alunos leiam e escrevam, ainda que não seja uma escrita convencional. O documento alega que esta é uma condição para que os indivíduos possam constituir sua autonomia na leitura, escrita e intelectualmente. Dentro desse período, a proposta é que os educadores construam situações de aprendizagem na qual os aprendizes possam ter o máximo de contato com a escrita alfabética. Nessas situações o educador necessita apresentar ampla quantidade de materiais didáticos durante o processo de aquisição da língua escrita, dentre eles, utilizar dos materiais e espaços disponibilizados na escola, tal como a biblioteca (BRASIL, 1997).

Na alfabetização inicial, alguns materiais podem ser de grande utilidade ao professor: alfabetos, crachás ou cartazes com os nomes dos alunos, cadernos de textos conhecidos pela classe, pastas de determinados gêneros de textos, dicionários organizados pelos alunos com suas dificuldades ortográficas mais freqüentes, jogos didáticos que proponham exercícios lingüísticos, por exemplo (BRASIL, 1997, p.62).

Ao final desse ciclo, espera-se que as crianças obtenham domínio quanto à escrita alfabética, e que tenha sido "introduzido a segmentação em frases nos seus textos, mas isso não significa que se espere que ele utilize com precisão os recursos do sistema de pontuação" (BRASIL, 1997, p. 70), ou seja, para esta etapa, é proposto que o foco da prática pedagógica seja na imersão dos aprendizes quanto formação de sujeitos autônomos, aptos para construírem frases em pequenos textos, sem muitas exigências nos quesitos pontuação e ortografia.

Se o objetivo é formar cidadãos capazes de utilizar a escrita com eficácia, que tenham condições de assumir a palavra - também por escrito - para produzir textos adequados, é preciso organizar o trabalho educativo para que experimentem e aprendam isso na escola. É necessário, portanto, ensinar os alunos a lidar tanto com a escrita da linguagem - os aspectos notacionais relacionados ao sistema alfabético e às restrições ortográficas - como com a linguagem escrita - os aspectos discursivos relacionados à linguagem que se usa para escrever. Para tanto é preciso que, tão logo o aluno chegue à escola, seja solicitado a produzir seus próprios textos, mesmo que não saiba grafá-los, a escrever como lhe for possível, mesmo que não o faça convencionalmente (BRASIL, 1997, p. 48).

O Segundo Ciclo do Ensino Fundamental (4을 ao 50 ano) tem o intuito de dar continuidade à aprendizagem que foi constituída no ciclo anterior. $\mathrm{O}$ ideal, segundo os PCN's, seria que o professor obtivesse o conhecimento de quais foram os conteúdos 
trabalhados anteriormente e que após isso fosse realizado uma análise com os alunos para descobrir o que foi aprendido e o que ficou deficiente de conhecimento, para que assim o educador possa planejar a sua prática baseando-se na realidade das crianças. "A expectativa no segundo ciclo é de que os alunos tenham um desempenho mais autônomo em relação àqueles conteúdos que já vinham sendo trabalhados sistematicamente no ciclo anterior" (BRASIL, 1997, p. 79).

Alguns dos objetivos proposto pelos Parâmetros Curriculares Nacionais (1997), direcionados para o segundo ciclo do Ensino Fundamental são:

- compreender o sentido nas mensagens orais e escritas de que é destinatário direto ou indireto, desenvolvendo sensibilidade para reconhecer a intencionalidade implícita e conteúdos discriminatórios ou persuasivos, especialmente nas mensagens veiculadas pelos meios de comunicação;

- utilizar a linguagem para expressar sentimentos, experiências e idéias, acolhendo, interpretando e considerando os das outras pessoas e respeitando os diferentes modos de falar;

- utilizar a linguagem oral com eficácia, começando a adequá-la a intenções e situações comunicativas que requeiram o domínio de registros formais, o planejamento prévio do discurso, a coerência na defesa de pontos de vista e na apresentação de argumentos e o uso de procedimentos de negociação de acordos necessários ou possíveis;

- $\quad$ produzir textos escritos, coesos e coerentes, dentro dos gêneros previstos para o ciclo, ajustados a objetivos e leitores determinados; (BRASIL, 1997, p. 80).

Podemos observar que tais objetivos sugerem que os alunos ao longo desse ciclo desenvolvam sua autonomia para a escrita alfabética, como também, que se apropriem do código linguístico a fim de não somente saber produzir corretamente, mas que possam além de tudo compreender a sua função, que adquiram segurança para comunicar-se com os outros indivíduos presente tanto na escola quanto nos outros ambientes.

Quanto à prática pedagógica, o documento enfatiza a importância de ampliar os conhecimentos já adquiridos no ciclo anterior, incluindo novos gêneros de textos, aprofundando a análise de suas características específicas, buscando a relação entre eles, e trabalhando a utilização de recursos coesivos e lexicais, ou seja, trazendo uma 
maior exploração dos aspectos ortográficos e de sistematização dos conteúdos, no entanto, sem deixar de apresentar conteúdos alinhados as necessidades e níveis de compreensão dos alunos (BRASIL, 1997).

De maneira geral, o segundo ciclo deve caracterizar-se por possibilitar ao aluno, de um lado, maior autonomia na realização de atividades que envolvam conteúdos desenvolvidos no ciclo anterior, e, de outro, por introduzir o trabalho com novos e diferentes aspectos relacionados aos usos e formas da língua. Nesse caso, o grau de autonomia na realização da atividade pode ainda ser pequeno, requerendo a colaboração de outros ou o monitoramento do professor (BRASIL, 1997, p. 80).

Ao final do segundo ciclo do Ensino Fundamental, espera-se que os alunos tenham conhecimento das regras ortográficas e saibam pesquisar outras fontes de informação para que possam utilizar como apêndice às suas produções. Busca-se que neste período as crianças estejam aptas a produzir textos próprios respeitando as características de cada gênero, e revisem suas produções, voltando a eles sempre que necessário para aprimorá-los. E por fim, espera-se que o aprendiz "desenvolva procedimentos que levem em conta as restrições que se colocam para o escritor pelo fato de o leitor de seu texto não estar presente fisicamente no momento de sua produção, quer seja esse leitor determinado (uma pessoa em específico) ou não" (BRASIL, 1997, p. 86). O documente sugere práticas orientadas pelo professor, no qual os alunos possam usar de recursos variados para o esclarecimento de dúvidas quanto à leitura e ao processo de produção escrita, a consulta a dicionários, acervos, bibliotecas, jornais, revistas, etc., a fim de obter informações e compreender os diferentes contextos apresentados. Além de "propor situações de produção de textos, em pequenos grupos, nas quais os alunos compartilhem as atividades, embora realizando diferentes tarefas: produzir propriamente, grafar e revisar" (BRASIL, 1997, p. 49).

A partir do exposto, percebemos que a proposta de ensino apresentada pelos PCN de Língua Portuguesa aproxima-se ainda mais com as práticas de letramento, pois apresenta sugestões para a utilização de textos com gêneros variados, todavia, que estejam inseridos na realidade dos alunos e alcancem as suas necessidades, para que assim, os alunos se apropriem das diversas formas de escrita e tenham mais segurança para quando lhes for solicitados suas próprias produções. 
Ainda considerando estes aspectos educacionais e refletindo a ação pedagógica em busca de melhorias para este sistema, concordamos quando Kleiman afirma que:

Quando se amplia a concepção de escrita, antes reservada para textos extraordinários - aqueles que são poucos produzidos - é possível entender melhor o impacto social da escrita: as mudanças e transformações decorrentes de novas tecnologias, os usos da escrita e seus reflexos no homem comum (KLEIMAN, 2005, p. 47).

Ademais, a autora ressalta que escola tem o papel obrigatório de tornar os seres constituintes da sociedade letrados, "fornecendo-lhes instrumental para interagir ativamente com o sistema de leitura e escrita, com o conhecimento acumulado pelas diversas disciplinas científicas e com o modo de construir conhecimento que é próprio da ciência" (KLEIMAN, 1995, p. 155).

Portanto, compreendemos que uma prática pedagógica que favorece o letramento dos aprendizes implica a integração dos preceitos do sistema da leitura e escrita, abrangendo os aspectos formais da língua materna, com práticas significativas e que atendam suas necessidades, considerando principalmente o contexto social e cultural no qual estão inseridos. Além disso, como já se tem discutido por muitos anos, é fundamental que tais práticas estejam centradas no aprendiz, colocando-o no papel ativo de leitor e produtor de textos, de modo que ele possa construir e consolidar os conhecimentos a respeito da leitura e escrita, utilizando-os efetivamente e compreendendo a sua função social.

\section{CONSIDERAÇÕES FINAIS}

Este capítulo objetivou explicitar as concepções de letramento e alfabetização, refletindo acerca da prática docente no ensino da língua portuguesa. Para isso, realizamos um estudo bibliográfico, pautado principalmente nas discussões levantadas por Vygotsky (1989), Ferreiro (1995), Soares (1995; 2004; 2009) e Kleiman (1995; 2002; 2005), além de considerar as orientações apresentadas nos documentos oficiais da Base Nacional Comum Curricular (BRASIL, 2017) e nos Parâmetros Curriculares Nacionais da Língua Portuguesa (BRASIL, 1997).

Esse estudo nos possibilitou um melhor entendimento sobre os aspectos contribuintes à aquisição da leitura e escrita, bem como a diferenciação entre alfabetização e letramento, compreendendo que esse processo de aquisição, dentro da 
escola, deve considerar o contexto social e cultural dos alunos a fim de que a aprendizagem seja significativa.

No que concerne às concepções de alfabetização e letramento, entendemos que, embora diferentes, ambos os processos são intrínsecos e interligados. E conforme a diferenciação apontada por Soares (1995; 2009), a alfabetização trata-se da ação de ensinar os aspectos formais da língua materna para que o sujeito seja capaz de ler e escrever corretamente; já letramento se refere ao uso social da escrita, refletindo diretamente no papel do aprendiz como cidadão, trazendo consequências sociais, culturais, políticas, econômicas, cognitivas e linguísticas.

Retomando as considerações de Vygotsky (1989) a respeito do processo de aprendizagem, concordamos que o principal agente deve ser aquele que aprende, e isso nos leva a refletir sobre o processo de aquisição da leitura e escrita durante a vida escolar dos alunos. Acerca disso, enfatizamos, com base nos documentos oficiais estudados, que a complexidade desse processo necessita ser acompanhada pelos profissionais docentes a fim de promover estratégias de ensino que proporcionem uma construção de sentido para a linguagem durante o seu desenvolvimento e sua utilidade no contexto do qual os indivíduos estão inseridos.

Quanto às práticas de letramento, Kleiman (1995) ressalta ser papel da escola o papel fundamental de fornecer instrumentos que permitam a interação ativa com o sistema da leitura e escrita, no entanto, ela afirma que essas práticas necessitam apresentar semelhanças com a realidade dos aprendizes, pois assim se tornará relevante para a vida social.

Portanto, considera-se que a escola precisa aproximar cada vez mais as práticas escolares das realidades vivenciadas fora da escola, para que os sujeitos $\mathrm{da}$ aprendizagem possam, então, sentir-se alocados naquele ambiente e que compreendam a relação de suas atividades com o mundo a fora. O educador, portanto, necessita desenvolver a sua prática de forma reflexiva, adaptando sempre que necessário suas ações pedagógicas para favorecer a percepção da criança acerca da função social da leitura e escrita, incentivando-a a utilizar de maneira efetiva e consciente na sociedade. 


\section{REFERÊNCIAS}

BRASIL. Ministério da Educação. Secretaria da Educação Básica. Base nacional comum curricular. Brasília: MEC, 2017.

BRASIL. Secretaria de Educação Fundamental. Parâmetros Curriculares Nacionais: língua portuguesa / Secretaria de Educação Fundamental. - Brasília: MEC/SEF, 1997.

CAMPOS JÚNIOR, Lázaro. 3 em cada 10 brasileiros não conseguem entender este texto. Todos pela Educação. 12 nov. 2018. Disponível em: https://www.todospelaeducacao.org.br/conteudo/inaf-3-em-cada-10brasileiros-nao-conseguiriam-entender-este-texto. Acesso em: 14 jul. 2020.

FERREIRO, Emília. Reflexões sobre alfabetização. Tradução Horácio Gonzales. 24. ed. São Paulo: Cortez, 1995. - (Coleção questões da nossa época; v.14).

KLEIMAN, Angela. Alfabetização e letramento: implicações para o ensino. Revista da FACED, Salvador, n.6, 2002, p.99-112. Disponível em: https://portalseer.ufba.br/index.php/entreideias/article/view/2778 Acesso em 11 jul. 2020.

KLEIMAN, Angela. Os significados do letramento: uma nova perspectiva sobre a prática social da escrita / Angela Kleiman (org.). Campinas, SP: Mercado de letras, 1995.

KLEIMAN, Angela. Preciso "ensinar" o letramento: Não basta ensinar a ler e escrever? / Angela Kleiman. UNICAMP, SP: Cefiel/IEL. 2005.

MELLO, Suely Amaral. O processo de aquisição da escrita na educação infantil: contribuições de Vigotsky. In: FARIA, Ana Lúcia Goulart e MELLO, Suely Amaral (orgs.). Linguagens infantis: outras formas de leitura. Campinas: Autores Associados, 2005, p.23-40.

PRESTES, M.L.M. A pesquisa e a construção científica: do planejamento aos textos da academia. São Paulo: Rêspel, 2008.

RICO, Rosi. O que a BNCC propõe para a Alfabetização? Revista Nova Escola [on-line]. 2018. Disponível em: https://novaescola.org.br/bncc/conteudo/40/o-que-abncc-propoe-para-a-alfabetizacao. Acesso em: 02 ago. 2020.

SOARES, Magda. Letramento e alfabetização: as muitas facetas. Rev. Bras. Educ., Rio de Janeiro , n. 25, p. 5-17, Abr. 2004 . Disponível em: http://www.scielo.br/scielo.php?script=sci_arttext\&pid=S141324782004000100002\&lng=en\&nrm=iso Acesso em 17 mai. 2020.

SOARES, Magda. Letramento: um tema em três gêneros / Magda Soares. 3. ed. Belo Horizonte: Autêntica Editora, 2009. 128p. 
SOARES, Magda. Lingua escrita, Sociedade e Cultura: Relações, Dimensões e Perspectivas. XVII Reunião Anual da Anped, Caxambu, 1995.

VYGOTSKY, L.S. A formação social da mente. Tradução José Silva. São Paulo: Martins Fontes. 1989. 


\title{
CAPÍTULO III
}

\section{A FORMAÇÃO DE PROFESSORES NUMA PERSPECTIVA CRÍTICO - DIALÉTICA NA ABORDAGEM DA PEDAGOGIA HISTÓRICO - CRÍTICA}

\author{
Wellington Alves Silva ${ }^{1}$ \\ Silvina Faria dos Santos ${ }^{2}$ \\ Elialdo Rodrigues de Oliveira ${ }^{3}$ \\ Leila Maria Camargo ${ }^{4}$ \\ Enia Maria Ferst ${ }^{5}$
}

\begin{abstract}
${ }^{1}$ Pedagogo, aluno do Programa de Pós Graduação Mestrado em Educação da Universidade Estadual de Roraima UERR.

2 Pedagoga, aluna do Programa de Pós Graduação Mestrado em Educação da Universidade Estadual de Roraima UERR.

${ }^{3}$ Pós-doutor em currículo/PUC/SP. Doutor em Educação: Currículo, pela Pontifícia Universidade Católica de São Paulo, Professor do Programa de Pós Graduação Mestrado em Educação da Universidade Estadual de Roraima - UERR.

${ }^{4}$ Doutora em Educação: Currículo, pela Pontifícia Universidade Católica de São Paulo/ PUC-SP (PUC/SP-2016). Professora do Programa de Pós Graduação Mestrado em Educação da Universidade Estadual de Roraima - UERR.

${ }^{5}$ Doutora em Educação em Ciências e Matemática do Programa da Rede Amazônica de Educação em Ciências e Matemática - REAMEC- Professora do Programa de Pós Graduação Mestrado em Educação da Universidade Estadual de Roraima - UERR.
\end{abstract}

\section{RESUMO}

O presente trabalho objetiva a discussão a respeito da formação de professores, gestores e coordenadores num viés crítico e dialético na perspectiva da pedagogia histórico-crítico. É um trabalho de caráter bibliográfico, que visa, por meio da aplicação dessa teoria, viabilizar um modelo de educação que se paute pela formação de qualidade aos professores. A base maior do referencial teórico para este trabalho concentra-se nos conceitos da Pedagogia Histórico-Crítica, de embasamento no Materialismo Histórico Dialético de Marx, concebida por Dermeval Saviani. Tal teoria proporciona práticas educativas inclusivas com viabilidades de mudanças e acessibilidades a todos, desde os mais pobres aos mais ricos.

Palavras-chave: Formação. Docentes. Educação. Pedagogia Histórico-Crítica.

\section{INTRODUÇÃO}

Vivemos em um mundo marcado por grandes transformações sociais, econômicas, políticas, morais, entre outras. E, nessa constante ebulição dos vários segmentos da sociedade, que o trabalho será desenvolvido, em que, a formação do professor crítico é substancialmente importante para o atual momento em que vivemos, é imprescindível. 
Para que se possa contribuir, no sentido de formar seres humanos percebedores da sociedade contraditória, regida pelo capitalismo, é importante que educadores, gestores, coordenadores, alunos e pais de alunos tenham conhecimentos para entender as transformações sociais. É nessa perspectiva que se busca um direcionamento da problemática da educação e a necessidade de uma formação crítica de professores que possibilite uma práxis que situe para além do capital.

A esse propósito, o presente artigo tem o objetivo de discutir a formação de professores em uma vertente crítico-dialético. Para tanto, discorrerá sobre o contexto da educação atual, profundamente dilacerada pelas exclusões. Tem-se aqui como foco a formação de professores na dialética materialista, que no atual estágio do capitalismo global estão sem direção, aderindo muitas vezes ao consenso do capital e suas teorias duvidosas. Os objetivos para a concretização do mesmo visam analisar criticamente a importância da formação do professor num viés crítico para a construção de seres humanos situados na atual crise do capitalismo e que os mesmos deverão reconhecer a importância de uma atuação crítica da realidade social, através de uma teoria que tenha na dialética materialista seu norte: A Pedagogia Histórico-Crítica.

Isto posto, pretende-se, com base na pesquisa bibliográfica, identificar se há possibilidades para a formação de professores críticos na atual regência do capital que paute pela transformação na educação, situando-a no bojo da história, buscando uma compreensão geral, na totalidade do sentido da educação, e posteriormente sintetizada, de forma a pormenorizar as várias imbricações concernentes aos meandros da história da educação, chegando a uma síntese que será postulada na Pedagogia Histórica-Crítica.

Assim sendo, serão pontuadas considerações críticas sobre a possibilidade de uma formação do professor engajada no socialismo, este com vias a uma educação sustentada na coletividade. Dessa forma, o trabalho poderá contribuir possivelmente para amenizar os males da educação.

\section{CONCEITO DE EDUCAÇÃO}

O ato de educar é fundamentalmente humano, situa-se nas relações humanas, perspectivadas no trabalho que ele exerce sobre a natureza. Não há educação sem a interferência do homem, em sua constante transformação da natureza num espaço 
social, de contradições e lutas em busca de um processo de vida - pautado na liberdade. "Em uma sociedade como a nossa, só pode ser eficaz uma educação para a mudança" (MANNHEIM apud BRANDÃO, 2005, p.79).

O ato de educar foi por muito tempo de tradição oral. Os antepassados passavam para as gerações mais novas, toda a construção cultural, através de uma raiz ancestral, essa no tocante ao acúmulo cultural, de perpetuação da espécie e seus símbolos, bens e produção diversificada. Nesse sentido, apropriando-se do conceito de educação de Brandão (2005, p.11), a qual diz que:

A educação participa do processo de produção de crenças e ideias, de qualificações e especialidades que envolvem as trocas de símbolos, bens e poderes que, em conjunto, constroem tipos de sociedades. E esta é a sua força.

Tem-se que, a educação contempla todos os espaços sociais. E, à medida que a sociedade vai ficando complexa, o ato de educar vai ganhando contornos diferentes. Essas diferenças são estabelecidas com as concepções de educação que se constituem na sociedade em processo, dividida em classes com interesses particulares

Com o surgimento da escola, o ato de educar ganhou diferentes contornos. Se antes o ato de educar estava num plano mais subjetivo, em que o aprendizado era passado de geração em geração, pelas tradições, sem uma intencionalidade estabelecida, muitas vezes, pela simples observação, com o advento da escolarização formal, houve uma mudança substancial na forma de passar os conhecimentos. Havia uma intencionalidade. Quem teria de fato o privilégio de se apropriar dos conhecimentos de uma forma sistemática e metódica? Apenas os grupos detentores da cultura dominante. As elites constituídas, aos outros (classes populares), seriam passados conhecimentos parcos, superficiais, muitas vezes com uma intenção preestabelecida: aprender para o trabalho manual.

O conhecimento passou a ser uma "arma", no sentido de dar sustentação aos grupos hegemônicos - elites e classes burguesas. O fator educação é histórico. 0 principal alvo é o homem. Uma educação que não esteja voltada para um determinado tipo de homem não tem sentido de se constituir, não é válida. Como ressalta Saviani (2004, p. 29) "a educação visa o homem; na verdade, que sentido terá a educação se ela não estiver voltada para a promoção do homem? Uma visão histórica da educação mostra como esta esteve sempre preocupada em formar determinado tipo de homem". 
Conforme citação acima, esta formação de homem, por meio dos processos educativos tem suas diferenciações historicamente constituídas. Em cada período da história humana houve determinados interesses em confluência com os grupos dominantes. Assim, a educação prima por certos valores. Situa o homem na assimilação desses valores. Ele como ser social, situado em um determinado tempo e espaço entra em contato com diversos elementos da sua cultura e toma conhecimento de suas variáveis: valores, instituições, diversidade de culturas, raças etc., e de diversas formas, tenta intervir na sua constituição, buscando transformar, comunicando-se com outros, colaborando com outros membros do seu grupo, não apenas os excluindo.

Nessa compreensão, o objetivo mais significativo da educação é de propiciar aos homens a comunicação. Essa num sentido dialético, de percepção do movimento histórico das sociedades, de privilegiar o que cada grupo social tem de maior representatividade no espaço de sua cultura, no processo, visando assim, educar para adquirir liberdade. Essa será adquirida, no momento que pautarmos por conteúdos que tenham identidade com o grupo que estamos educando, indo direto nos valores mais profundos da esfera social. Buscando um entendimento na raiz dos problemas sociais que se insere em cada agrupamento humano. Portanto, a educação se constitui como poder. Tendo possibilidades ilimitadas para pensarmos além dos limites do senso comum, numa esfericidade mais crítica e transformadora.

Se antes a educação era realizada de maneira informal, tendo com ações preliminares as trocas sociais, a convivência em um determinado espaço da sociedade, assim, desenvolvendo princípios e valores que correspondessem aos anseios de uma determinada cultura, de forma espontânea, sem uma sistematização. Quando, porém, surge a escola como instituição, a educação passa por profundas transformações. Servirá, consequentemente aos grupos dominantes, obedecendo as normas, valores e a moral voltadas para a representatividade do poder constituído, dos grupos que controlam a perpetuação dessa hegemonia. O seu ícone passa ser a luta de classes. Pois, certamente:

A classe que domina materialmente é também a que domina com a sua moral, a sua educação e as suas ideias. Nenhuma reforma pedagógica fundamentalista pode impor-se antes do triunfo da classe revolucionária que 
reclama, e se essa afirmação parece ter sido desmentida alguma vez pelo fatos é porque, frequentemente, a palavra dos teóricos oculta, conscientemente ou não, as exigências da classe que representam (PONCE, 2001, p.169).

De acordo com Saviani (2004) a escola, como instituição laica, surge na sociedade moderna, até então tinha um enraizamento clerical. A igreja preponderava influentemente no processo educativo. Como escola laica, representará os interesses da burguesia, nesse sentido, esteve, desde sua constituição como um dos pilares da sociedade de classes, a perpetuar, a firmar um projeto político de educação para reproduzir, e dar continuidade aos ideais burgueses: os donos dos meios de produção.

Saviani (1995) salienta que, propor uma educação transformadora, exigirá dos educadores seguramente um embasamento teórico de inspiração marxista. Justamente, por ser esta teoria que desvendou o mito de uma suposta neutralidade da educação. Afirmou ser a educação uma luta entre classes distintas com interesses opostos, que sintomaticamente pende para o favorecimento da elite dominante - burguesa. Partindo desse princípio, sabe-se que toda educação é política, tem uma intencionalidade. Para tanto, o ensino deverá proporcionar um fortalecimento dos conteúdos, no intuito de compreender a política capitalista. Tendo essa clareza, o educador a politizará, estabelecendo uma dinâmica entre a escola, a cultura e as representações, fazendo da mesma um espaço para possibilitar_mudanças que de alguma forma, promovam acessibilidade por parte das classes exploradas aos postos que só a burguesia tem acesso.

Nesse sentido Saviani afirma o seguinte:

A dimensão política da educação consiste em que, dirigindo-se aos antagônicos a educação os fortalece (ou enfraquece) por referência aos antagônicos e desse modo potencializa ou (des)potencializa a sua prática política (SAVIANI, 1995, p.94).

A educação foi tomada por uma gama diversificada de teorias, que retratam o ambiente da sociedade em contradição: capitalista, na qual vivemos. Principalmente com o advento da modernidade, o período do primado da razão, em que a educação tinha uma conotação de base tradicional, em que o professor era o detentor do saber. O aluno era um mero receptor dos conteúdos - educação conteudista, 
incontestavelmente. Para realizar a atividade pedagógica exigem-se abordagens, métodos e didáticas. É importante registrar que o desenvolvimento do processo ensino e aprendizagem está fundamentado em teorias que apontam tendências pedagógicas. No Brasil, segundo Saviani, as tendências pedagógicas podem ser classificadas em: Tradicional, Nova, Tecnicista, Crítico Reprodutivistas e Histórico-Crítica.

\section{PEDAGOGIA HISTÓRICO-CRÍTICA}

O processo histórico da educação determinará o surgimento da pedagogia dialética, crítico-social dos conteúdos ou histórico-crítica. Essa última defendida pelo professor Saviani. Suas bases se consubstanciam no embasamento teórico de Marx. Surge na então sociedade capitalista monopolista, na qual, o sistema liberal estava em plena ascensão. Nesse momento histórico, o sistema educacional é nitidamente tradicional, dando sinais, através das críticas recebidas, ao surgimento da escola nova. Essas duas correntes teóricas da pedagogia (Escola Nova e Tradicional) se alimentam das contradições do sistema capitalista, justamente por não veicular, de forma radical, profunda, os fatos sociais com a escola. Esta, funcionando como um dos instrumentos para a perpetuação do modelo social conservador, que não percebe o movimento, as mudanças constantes da sociedade, e das transformações que nela ocorrem (LOPES, 1999).

A Pedagogia Histórico-Crítica situa-se na perspectiva crítico-dialética. Essa teoria, conforme Saviani (1995), concebe as contradições sociais nas lutas dos homens pela apropriação dos bens materiais, mas, não fazendo apenas uma crítica, viabilizando mudanças, através da escola. Essa deixa de ser um instrumento da burguesia e passa para as classes populares uma possibilidade de mudança no estágio social que se encontram.

Os conteúdos escolares nela têm uma importância, na medida em que, é através do conhecimento que os homens poderão conquistar postos de trabalho, antes só permitidos às elites. As práticas escolares que não tenham uma ligação com a história, que não estão em consonância com a educação, com o movimento das práticas sociais, no modelo econômico que estamos emperrados, o capitalismo, tendem a continuar no sistema educacional, marcado por contradições diversas. Elas dificilmente 
desaparecerão, a menos que chegássemos a implantar um modo socialista de organização da produção e da sociedade.

Numa sociedade dividida em classes sociais, que mantém o movimento na estrutura e superestrutura no momento mesmo do capitalismo, a concepção pedagógica adquiriu feições desse momento capitalista. Portanto, a concepção da pedagogia tradicional e da pedagogia nova só será superada quando, ao mesmo tempo, for superado o próprio capitalismo (LOPES, 1999, p. 72).

O marco da pedagogia histórico-crítica é sua relação com a questão do trabalho. Sentido da existência humana, das lutas entre os homens, por uma sociedade humana mais viável. Ela tem na dicotomia das relações sociais e trabalho sua base teórica singular. Bem como, as produções humanas, e os conflitos para que eles se afirmem socialmente.

Para Saviani a pedagogia histórico-crítica: "Trata-se de uma concepção que, como o nome indica, procura se firmar sobre uma base histórica" (SAVIANI, 1995, p.119).

Saviani (1995) salienta que não há possibilidades de realizar um projeto de desenvolvimento humano, através da educação, negando a proximidade do homem com as relações contraditórias construídas na dinâmica da vida em sociedade, historicamente, furto dos próprios anseios do homem em ocupar um espaço na pirâmide social, em que a economia é o motor propulsor dessa dinâmica. Se negarmos essa diretriz, seria estarmos negando a relação dialética que está aí imbricada.

O fator trabalho, nesse ponto é prioritário, no qual está constituído o sentido de existência, e da luta na esfera social capitalista. Para superar o problema da marginalidade, é vital pautar por uma teoria mais aprofundada nos aspectos sociais, que estabeleça uma crítica radical à ingenuidade da pedagogia tradicional por ser essencialista, portanto, russoriana, com um conceito de homem como espelho da natureza; e do escolanovismo, que reforçou a exclusão social, ao privilegiar a experiência em detrimento dos conteúdos. Portanto, fragmentada, não percebendo a totalidade das contradições sociais e suas sínteses. Saviani aponta que só uma teoria crítica, com um olhar voltado para a história, poderá desenvolver um projeto de educação com viabilidades emancipadora. 
A escola é, pois, compreendida a partir do desenvolvimento histórico da sociedade; assim compreendida, torna-se possível a sua articulação com a superação da sociedade vigente em direção a uma sociedade sem classes, a uma sociedade socialista. É dessa forma que se articula a concepção Política Socialista com a concepção pedagógica Histórico-Crítica, ambas fundadas no mesmo conceito geral de realidade, que envolve a compreensão da realidade humana como sendo constituída pelos próprios homens, a partir do processo de trabalho, quer dizer, da produção das condições materiais ao longo do tempo (SAVIANI, 1995, p.119-120).

Assim sendo, a escola pode ser portadora de condições para a elevação do conhecimento e da consciência de classe dos trabalhadores, na medida em que os educadores se comprometerem e desenvolverem os conteúdos e métodos para o aprimoramento intelectual, artístico, político e cultural dos estudantes.

\section{UMA PERSPECTIVA MATERIALISTA HISTÓRICA PARA A FORMAÇÃO DE PROFESSORES CRÍTICOS NA ATUALIDADE}

Estar numa educação socialista em um cenário dominado por ideias capitalistas é no mínimo desafiador. O professor, na atual crise por que passa o capitalismo, encontra-se, também em crise. Para Lombardi tornou-se uma confusão essas "modas" pedagógicas modernas ou pós-modernas, como assim o querem os novos educadores. Instigar o profissional da educação por uma teoria que desnude as mazelas do capitalismo global poderá ser um direcionamento para minimizar os problemas por que passa, na atual vigência, a educação (LOMBARDI, 2005).

Os professores, dessa forma, para não se subjugarem, aderindo às propostas neoliberais, necessitam "armarem-se" de uma ideologia que dignifiquem a história e a coletividade. Fundamentalmente, terão que dignificar a história; terão, portanto que conhecer a história das lutas, dos embates construídos historicamente, que demarcaram a educação, que por séculos foi marcada por aqueles que dominam em detrimento dos que são dominados. Terão assim, nessa compreensão possibilidades de se apropriarem de uma teoria com viabilidade centrada na materialidade, na concretude objetiva, com vias direcionadas para o porvir de uma humanidade menos explorada. Nesse sentido, Hobsbawm, diz que: 
Quanto ao futuro previsível, teremos que defender Marx e o marxismo dentro e fora da história, contra aqueles que os atacam no terreno político e ideológico. Ao fazer isso, também estaremos defendendo a história e a capacidade do homem de compreender como o mundo veio a ser o que é hoje, e como a humanidade pode avançar para um futuro melhor (HOBSBAWM apud LOMBARDI, 2005, p. XVII).

Entende-se, assim, que a compreensão da obra de Marx, e dos atores que se inspiram no seu método dialético para compreenderem a história das lutas dos trabalhadores, é uma possibilidade para os cursos de formação de professores, para que os mesmos se apropriem de uma teoria da educação que vise à transformação e à libertação.

A proposta de educação burguesa é verticalizada. Projeta a ampliação da educação para o aniquilamento de ascensão das classes populares, em um constante processo reprodutivista. A educação dialética, ao contrário, inspirada em Marx é horizontal, situa-se no constante devir da história. Lombardi (2005, p.21) assevera que “Em primeiro lugar, está a centralidade dialética do trabalho enquanto princípio educativo e que desemboca na proposta de uma educação ominilateral, em oposição à unilateralidade da educação burguesa"

Essa educação é integral, apropria-se dos conteúdos historicamente construídos pelo conjunto dos homens. Sendo a mesma integral, sustenta-se na unicidade e não na divisibilidade do trabalho manual em oposição ao trabalho intelectual, não há uma separação, as duas formas se complementam, diferentemente do ideário burguês, que tenta a separação de ambas, e assim, concebendo a educação como algo estanque da realidade das relações de produção empreendidas pelo conjunto dos homens que vivem em sociedade. E, para derrubar essa visão circulante hegemônica, "para derrotar a burguesia; declaramos publicamente que a escola à margem da vida, à margem da política, é falsidade e hipocrisia" (LENIN apud LOMBARDI, 2005, p. 24).

A escola está no embate das contradições sociais. Ela, como instituição, ligada ao estado é apenas um reflexo dos grandes problemas da atual conjuntura global, marcada pela crise das relações de produção, que tão violentamente tem atingido os trabalhadores pelos donos da força do trabalho: material e intelectual. Assim sendo, 
propõe-se aos docentes enveredar por uma formação preponderantemente dialética, perspectivada na objetividade e no desnudamento do capitalismo.

Para tanto, deverá instruir-se nas elaborações do próprio trabalho no seio da escola, munido de uma teoria transformadora, dando sentido a uma práxis verdadeiramente socialista. Afastando, portanto, do individualismo, pois, "qualquer aproximação com as pedagogias burguesas atuais que enfatiza o individual, o subjetivo, deve ser descartada" (LOMBARDI, 2005, p.30). A sua pedagogia deverá promover unidade lutar por uma educação imbuída de um conteúdo político na busca por apropriação por parte dos alunos dos conteúdos que só as elites têm acesso, viabilizando um espaço emancipador e de possibilidade para mudanças - a escola.

O educador precisa romper com as pedagogias escolares articuladoras dos interesses da burguesia e vinculares sua concepção e sua prática e uma perspectiva revolucionária de homem e de mundo. Não se trata simplesmente de aderir a uma concepção científica de mundo e seu poder desvelador da realidade, mas de assumir, na teoria e na prática, isto é, na práxis, uma concepção transformadora da vida, do homem e do mundo (LOMBARDI, 2005, p. 33-34).

Em tempos de irracionalidade, de empobrecimento cultural, fruto de uma educação fragmentada, reprodutora das condições materiais e intelectuais, proporcionadas pela exploração burguesa, é fundamental, de acordo com Carvalho (2005) pautar-se por uma teoria crítica que revele as contradições sociais impregnadas na sociedade capitalista a qual participamos como sujeitos históricos. Entretanto, o educador não poderá, com essa formação, ser apenas um conteudista, mas, transmitir os conteúdos numa amplitude que, sintomaticamente, encaminhará os sujeitos rumo a uma transformação política e social.

Segundo Saviani (1995), a educação não é independente dos outros setores que compõem a sociedade. Submete-se à vigência econômica e política. Os educadores, na medida do possível, se querem fazer de sua práxis: teoria e prática, uma possibilidade de mudanças, deverão conscientizar-se de que o grande crescimento da elite representa sua fragilidade.

Nesse sentido, o professor marxista indubitavelmente necessitará situar-se historicamente e adentrar na concepção teórica dialético-crítica para verdadeiramente e radicalmente poderem ser sujeitos históricos não alienados e consensualistas, e, sim, 
críticos imbatíveis no que diz respeito às execrações da classe dominante. Nesse sentido, de forma provocativa, diz Carvalho (2005, p.97):

- Não é marxista o intelectual que não compreende que o ambiente social no qual vive e elabora seus "projetos" é um ambiente burguês e que, por isso mesmo, todas as melhorias realizadas no seu âmbito significam progresso e melhora da situação da minoria, proletarização e empobrecimento da maioria.

- Não é marxista o intelectual que não entende que o Estado ao qual dirige seus "projetos" de políticas públicas e/ou para todos (?) é um Estado da burguesia para apoiar e salvaguardar os opressores e aplastar os oprimidos.

- Não é marxista o intelectual que não entende que o tal "regime popular e democrático" não é antípoda do capitalismo, mas sua continuação direta, mais próxima e imediata, seu desenvolvimento e seu fortalecimento.

De acordo com Carvalho (2005), os professores, situando em uma educação crítico-dialética, contestarão permanentemente as propostas do liberalismo global. Estarão na direção oposta, contestarão no cotidiano de suas práticas as artimanhas da direita, rompendo com os ideais pequeno-burgueses e suas falsas teorias.

Logo, o desafio da educação brasileira, na perspectiva socialista, consiste em contribuir com a formação de novas gerações capazes de decifrar e frear as políticas estatais de cunho populista, tecnicista, assistencialista, demagógico eleitoreiro, tornadas agentes de transformação social capazes de efetivar a educação popular em trincheira do progresso indispensável de emancipação intelectual do proletariado (CARVALHO, 2005, pp. 109-110).

Concretizar um projeto de educação no modelo de sociedade marcado explicitamente pela exploração do capital humano em confronto ao capital financeiro é tarefa de muita luta, se pretendemos objetivar uma proposta educacional marxista. Pois, conforme Carvalho (2005, p.111), “o processo educativo só se concretiza a partir do conhecimento científico e da militância organizada".

Em desacordo com a proposta do parágrafo acima, na atualidade, surgem inúmeras concepções salvacionistas, que na verdade não fazem mais do que sustentar e fortalecer as políticas neoliberais de formação de professores; constituindo assim, um ecletismo que, segundo Carvalho (2005, p.111), torna-se uma "sopa metodológica". 
Essas concepções de cunho liberal têm como propósito negar o marxismo-leninismo, como uma alternativa viável para a educação no modelo de transformação e ascensão das classes subalternas. Entender uma teoria da educação que aprofunde numa discussão, que denuncie os males da excludente escola capitalista, só será possível com um pensamento na totalidade da educação dialética, pois, "a escola capitalista é o local onde a educação, forma elevada de apreensão da realidade, não é para todos, mas para uma pequena minoria" (CARVALHO, 2005, p.113). Tomar para si uma teoria que empenhe em direção à prática revolucionária, desnudando o mito da neutralidade e das teorias reacionárias, é o importante papel do educador que tem como sustentação teórica o marxismo-leninismo.

A educação política, pela ótica do marxismo-leminismo, deve combater de forma dura as tendências neoliberais que sobejamente usam o "método subjetivo" para negar o caráter objetivo das leis do desenvolvimento social e o papel imprescindível e decisivo dos explorados na construção da história da humanidade (CARVALHO, 2005. pp. 115116).

É necessário, portanto, uma formação crítica, nos lineamentos de uma tradição crítico-dialética. As propostas neoliberais camuflam, não denunciam as armadilhas impostas pelo capital. Uma pedagogia calçada na história é um caminho possível para uma emancipação política do professor. Entretanto, segundo Duarte (2005, p. 205):

[...] a construção de uma pedagogia marxista deve ser vista como parte de um processo de luta de superação radical do capitalismo. Não é possível superar plenamente os problemas e as limitações da educação oferecida pela sociedade capitalista, sem a superação dessa sociedade.

Lutar permanentemente, tentar derrubar o colossal projeto de cunho liberal burguês configura-se como prioridade dos educadores que têm suas vivências atreladas a práxis do projeto capitalista, pois, a convivência com as teorias liberais é uma realidade a ser enfrentada no cotidiano da sala de aula, já que elas serão superadas com a superação da sociedade capitalista. Atentos à hegemonia do capitalismo e de conviver com as suas teorias de consenso, resta para os educadores marxistas muitos desafios: insistir numa metodologia perspectivada na superação do capitalismo, em que as condições subjetivas superam as objetivas, numa tentativa de esconder as mazelas generalizadas pelo capital. 
Também, situar a pedagogia marxista nos embates sociais, políticos, tendo como norte a dinamização do socialismo, nunca à margem da sociedade, mesmo, sabendo das dificuldades para com a teoria socialista no cenário internacional. Norteando assim a teoria de Marx para aliviar os disparates do capitalismo e criticar com todas as forças as políticas educacionais que dão sustentação a sociedade de expropriação do trabalho do proletariado por parte dos capitalistas: donos dos meios de produção (DUARTE, 2005).

O dilema dos professores, em especial os brasileiros, na vigência do capital de exploração, é não está direcionando seus esforços no debate de confrontação às teorias liberais, mas, de afirmação das mesmas. Situar seus esforços em uma crítica voraz ao capitalismo e seus métodos pedagógicos concernentes ao mesmo, possivelmente ocorrerá quando estabelecer uma matriz pedagógica marxista, que prepondera na discussão da lógica dialética. Assim sendo centrada na realidade contraditória das relações sociais entre os indivíduos na ambientação da coletividade humana. E, segundo Saviani (2005, p.224), "é no entendimento da realidade humana que devemos buscar o entendimento da educação".

Conforme ressalta Carvalho (2005, p.115-116), o enfrentamento dos problemas gerados pela divisão de classes será necessariamente um compromisso do professor socialista. No espaço educativo, ele lutará, através de uma educação crítica, para oferecer, de forma sistemática aos alunos da escola pública os conteúdos da classe burguesa. Consequentemente a escola terá uma mobilização, no sentido de diminuir as disparidades possibilitadas pela apropriação dos conteúdos culturais da referida classe. Viabilizando assim, transformações sociais, uma educação perspectivada em multiplicidade, e não em estagnação. Portanto, uma educação dialética materialista Pedagogia Histórico-Crítica, que não separa a educação do espaço social, mas que une as duas esferas, buscando compreender as diferenças construídas na dinâmica das relações contraditórias da sociedade capitalista.

Nessa nova formulação a educação é entendida como mediação no seio da prática social global. A prática social se põe, portanto, como ponto de partida e o ponto de chegada da prática educativa. Daí decorrer um método pedagógico que parte da prática social em que professor e aluno se encontram igualmente inseridos ocupando, porém, posições distintas, condição para que travem uma relação fecunda na compreensão e encaminhamento da solução dos problemas postos pela prática social, 
cabendo aos momentos intermediários do método identificar as questões solicitadas pela prática social (problematização), dispor os instrumentos teóricos e práticos para sua compreensão e solução (instrumentação) e viabilizar sua incorporação como elementos integrantes da própria vida dos alunos (catarse) (SAVIANI, 2005 p.263).

Em suma, percebe-se que essa teoria pedagógica se pauta no método materialista histórico de Marx, enfim no seu método da economia política. Estabelecendo uma íntima relação com a educação, percebendo a totalidade das contradições, sintetizando-as e lutando para transformar as adversidades da sociedade capitalista, possibilitando o melhoramento da coletividade humana.

Finalmente, cabe ao profissional da educação do século XXI, agregar a teoria dialética, para assim, contribuir para a formação de uma coletividade engajada e situada nas lutas construídas pelas contradições da sociedade de classes: capitalista, na qual estamos participando como sujeitos históricos. Conduzir um processo educacional que pretende ser libertador exigirá, de acordo com Duarte (2005), uma formação críticodialética dirimida no marxismo. Na atualidade preponderar por esta via significa situarse em um caminho que aponta para além do capital, de empreender ações transformadoras, que não apenas aponte os problemas, mas, que viabilize soluções para eles.

Dessa forma Lombardi afirma que:

(...) não faz sentido afirmar que o marxismo foi ultrapassado. [...] O marxismo continua sendo uma concepção viva e suficiente, ainda na contemporaneidade, para a análise crítica da sociedade capitalista, além de ser um referencial revolucionário e transformador da ordem existente" (LOMBARDI, 2005, p. 2-3).

O cenário educacional, na esfera da formação de professores, atualmente desponta caminhos, direcionamentos numa lógica que possa contestar o capitalismo. Percebe-se que esses caminhos estão camuflados pelo consenso neoliberal, mas, alguns arautos socialistas enfrentam com bravura esse escamoteamento do capital, e partem para contestação do modelo desumano e reprodutor de inspiração liberal burguês, pelo qual está submersa a educação.

Não podemos apenas observar o que está posto pelo capital, mas adentrar numa crítica profunda das condições materiais impostas, em que o coletivo está sendo esmagado pela visão do projeto individualista imposto por setores conservadores da 
sociedade dirimida no modelo de exploração do monopólio capitalista. Assim minimizaremos a marginalidade.

Lutar contra a marginalidade através da escola significa engajar-se no esforço para garantir aos trabalhadores um ensino de melhor qualidade possível nas condições históricas atuais. O papel de uma teoria crítica da educação é dar substância concreta a essa bandeira de luta de modo a evitar que ela seja apropriada e articulada com os interesses dos dominantes (SAVIANI, 1995, p.42).

O professor terá, assim, um trabalho de percepção das contradições sociais que se manifestam na esfera da escola, ressignificando os conteúdos, e direcionando os embates na busca para formar sujeitos críticos da sociedade em que vivem, e não marginalizados pela sociedade.

\section{CONSIDERAÇÕES}

Para compreendermos os problemas gerados pelas políticas neoliberais, necessariamente, teremos que entender profundamente a lógica do capital, que visa a retirada das responsabilidades com relação à educação do estado, para colocá-la sobre o domínio de grupos privados. Aos professores, que estão mergulhados em um mundo dominado por tais propostas, de pacotes mirabolantes caberão, situarem-se em uma teoria da educação que possa visceralmente denunciar tais propostas, na prática, e tentando direcionar suas ações para uma transformação no modelo de educação vigente: neoliberal e globalizado. Isso poderá ser favorecido, se eles se empenharem em um modelo de educação socialista.

A formação do professor, no atual estágio do capitalismo monopolista, embasada na teoria pedagógica-crítico-dialética, proporcionará um novo alento aos educadores e educandos na medida em que estarão res-significando os conteúdos, situando em uma educação universalmente posta na esfera do trabalho, o sentido de existir do homem -; numa perspectiva política, crítica, de estarem se vendo como trabalhadores para direcionarem assim, para um mundo com amplas possibilidades de transformações sociais, culturais e objetivamente materiais.

Aos docentes, propõe-se, portanto, o papel de portadores de uma educação sem restrições, mais horizontal e que desviem os discentes das falsas promessas do capital, 
nesse sentido concluímos sem pretender esgotar a problemática do acesso à educação das minorias.

A luta para conquistar uma escola pública de qualidade, passa, significativamente pela formação crítica dos professores, de suas ações poderemos ter uma escola menos excludente, seletiva e discriminadora, segregadora das possibilidades da maioria em favorecimento das minorias hegemonicamente donas dos meios de produção. Minimizando assim, a deterioração de uma teoria da educação que resgate o valor histórico do homem e sua cultura para mudar esse quadro, e propor uma educação mais humanamente possível

Sugere-se ao professor, ter uma postura dialética, compreender as disparidades de uma sociedade constituída pela divisão de classes. Existe uma intencionalidade profundamente política na educação, que estará voltada para os grupos que dominam as formas de cultura hegemonicamente constituídas. Os educadores, com uma formação na pedagogia histórico-crítica serão, potencialmente, combatentes, nas lutas por uma sociedade mais justa, uma escola pública de qualidade e acesso a todos, fazendo de suas práticas, um instrumento de elevação das classes marginalizadas, numa possível ascensão social, pela apropriação dos conteúdos, nos quais as elites têm acesso, e servem como trunfo para a sustentação do poder constituído historicamente, em que uns dominam e outros são dominados.

\section{REFERÊNCIAS}

BRANDÃO, Carlos Rodrigues. O que é educação (Coleção Primeiros Passos, 20). São Paulo: Brasiliense, 2005.

CARVALHO, Máuri de. Lênin, educação e consciência socialista. In. Marxismo e Educação: debates contemporâneos. LOMBARDI, José Claudinei; SAVIANI, Dermeval (orgs.). Campinas: SP. Autores Associados, HISTEDBR, 2005, p. 1-12).

DUARTE, Newton. Por que é necessário uma análise crítica marxista do construtivismo? In.: Marxismo e Educação: debates contemporâneos. LOMBARDI, José Claudinei; SAVIANI, Dermeval (orgs.). Campinas: SP. Autores Associados. HISTEDBR, 2005. p. 1-22).

GADOTTI, Moacir. Concepção dialética da educação: um estudo introdutório. 10ạ ed. São Paulo: Cortez, 1997. 
LOMBARDI, José Claudinei. Educação, ensino e formação profissional em Marx e Engels. In.: Marxismo e Educação: debates contemporâneos. LOMBARDI, José Claudinei; SAVIANI, Dermeval (orgs.). Campinas: SP. Autores Associados, HISTEDBR, 2005. p. 5-26).

LOPES, Regina Maria G. Pereira. Concepções pedagógicas e emancipação humana: um estudo crítico. In.: Saberes pedagógicos e atividade docente. PIMENTA, Selma Garrido (org.). São Paulo: Cortez, 1999, p. 3-18)

PONCE, Aníbal. Educação e luta de classes. 18a ed. São Paulo. Cortez. 2001.

SAVIANI, Dermeval. Educação socialista, pedagogia histórico-crítica e os desafios da sociedade de classes. In: Marxismo e Educação: debates contemporâneos. LOMBARDI, José Claudinei; SAVIANI, Dermeval (orgs.). Campinas: SP. Autores Associados. HISTEDBR, 2005. p. 25-35).

SAVIANI, Dermeval. Educação: do senso comum à consciência Filosófica. (coleção educação contemporânea) 15a ed. Campinas: SP. Autores Associados, 2004.

Escola e democracia. (Coleção polêmicas do nosso tempo. Volume 5). 30 ed. Campinas: SP. Autores Associados, 1995. 


\title{
CAPÍTULO IV
}

\section{CONSTRUINDO UMA IDENTIDADE DOCENTE INCLUSIVA NO PROCESSO DE FORMAÇÃO DE PROFESSORES}

Silvina Faria dos Santos ${ }^{1}$

Wellington Alves Silva²

Alessandra de Souza Santos ${ }^{3}$

\begin{abstract}
${ }^{1}$ Aluna do Mestrado em Educação da Universidade Estadual de Roraima 2018. Especialista em Educação Profissional Inclusiva (IFMT). Professora do Instituto Federal de Roraima - IFRR.

${ }^{2}$ Aluno do Mestrado em Educação da Universidade Estadual de Roraima - UERR. Especialista em Gestão do Trabalho Pedagógico - UNINTER.

${ }^{3}$ Doutora em Linguística pela Universidade de Brasília (2012). Professora do programa de Mestrado em Educação na Universidade estadual de Roraima - UERR.
\end{abstract}

\section{RESUMO}

A Política da Educação Especial na perspectiva da Educação Inclusiva tem lançado novos desafios para a formação docente, em especial, para a formação de professores da Educação Básica no contexto das escolas públicas. Os impasses quanto a formação inicial desses professores, a falta de incentivo nas instituições de ensino superior quanto à sua formação inicial e as fragilidades pelas políticas públicas para inclusão escolar são pontos que merecem destaque. Diante disso, o presente artigo de revisão de literatura tem como objetivo analisar as contradições, impasses e desafios para a formação docente, demandados pela atual Política Nacional de Educação Especial na Perspectiva da Educação Inclusiva (BRASIL, 2007). Os resultados mostram a fragilidade do sistema educacional no Brasil frente da realidade do processo inclusivo de alunos Público alvo da Educação Especial (com deficiências, altas habilidades/superdotação e transtorno global do desenvolvimento) na rede regular de ensino. A fragilidade do sistema se expressa na desarticulação das políticas públicas de formação de professores, na escassez de oferta de serviços especializados pelo poder público, na manutenção do modelo segregado de Educação Especial, entre outros aspectos. É necessário que se avance na formação docente para a Educação Especial na perspectiva da Educação Inclusiva. É importante também que o debate sobre essa temática seja inserido nas grandes questões que têm constituído o campo da formação docente, considerando, sobretudo, o progressivo processo de proletarização que professores do ensino comum, têm sofrido no cotidiano de suas práticas.

Palavras-chave: Educação Especial. Inclusão. Formação docente. 


\section{INTRODUÇÃO}

A proposta da Educação Especial na perspectiva da Educação Inclusiva tem lançado novos desafios para a formação docente, sobretudo, quando o foco de análise recai sobre o professor do ensino regular.

Nesse contexto, as indefinições a respeito da formação inicial desse professor, a falta de incentivo nas instituições de ensino superior quanto à sua formação inicial e as fragilidades pelas políticas públicas para inclusão escolar são pontos que merecem destaque.

Diante disso, o presente artigo de revisão de literatura tem como objetivo analisar as contradições, impasses e desafios para a formação docente, demandados pela atual Política Nacional de Educação Especial na Perspectiva da Educação Inclusiva (BRASIL, 2007).

Torna-se fundamental o investimento em pesquisas sobre a formação inicial do professor da Educação Básica na Educação Especial na perspectiva da Educação Inclusiva para que este profissional venha a se constituir como colaborador efetivo na implementação da política educacional de inclusão.

\section{O QUE É A EDUCAÇÃO INCLUSIVA?}

Desde as últimas décadas do século $X X$, no Brasil, vem sendo discutida uma educação de qualidade e por direito para todos, seja o aluno com alguma deficiência ou não. Hoje em dia não podemos considerar ambientes que excluem, não respeitam o outro, não aceitam as diferenças. Essa aceitação, em específico, às Pessoas com Deficiência ${ }^{1}$, tem como base o princípio da inclusão.

A igualdade de condição surge com o princípio da inclusão pela Declaração de Salamanca (1994) a qual proclama que os alunos com necessidades educacionais especiais tenham acesso à escola regular, independentemente de suas condições físicas, intelectuais, sociais, emocionais, linguísticas ou outras. (BRASIL, 2006, p.330).

${ }^{1}$ Considera-se as Pessoas com Deficiência (PcD) aquelas com impedimentos de longo prazo de natureza física, intelectual ou sensorial que podem ter obstruída/dificultada sua participação plena e efetiva na sociedade diante de barreiras que esta lhes impõem, ao interagirem em igualdade de condições com as demais pessoas (ONU, 2006). 
O MEC, por meio do documento Diretrizes nacionais para a educação especial na educação básica (1996), define a inclusão como:

(...) Entende-se por inclusão a garantia, a todos, do acesso contínuo ao espaço comum da vida em sociedade, sociedade essa que deve estar orientada por relações de acolhimento à diversidade humana, de aceitação das diferenças individuais, de esforço coletivo na equiparação de oportunidades de desenvolvimento, com qualidade, em todas as dimensões da vida. (p.20).

Mittler a este respeito afirma que:

A inclusão não diz respeito a colocar as crianças nas escolas regulares, mas a mudar as escolas para torná-las mais responsáveis às necessidades de todas as crianças, diz respeito a ajudar todos os professores a aceitarem a responsabilidade quanto à aprendizagem de todas as crianças que estão atual e correntemente excluídas das escolas por qualquer razão. Isto se refere a todas as crianças que não estão beneficiando-se com a escolarização, e não apenas aquelas que são rotuladas com o termo "necessidades educacionais especiais". (MITTLER, 2003, p.16).

Em se tratando de acolher e aceitar as diferenças humanas entende-se que a escola é o setor principal da sociedade que se deve iniciar a prática inclusiva. O que se entende então de práticas inclusivas no ambiente escolar?

Na perspectiva inclusiva, suprime-se a subdivisão dos sistemas escolares em modalidades de ensino especial e de ensino regular. As escolas atendem às diferenças sem discriminar, sem trabalhar à parte com alguns alunos, sem estabelecer regras específicas para se planejar, para aprender, para avaliar (currículos, atividades, avaliação da aprendizagem para alunos com deficiência e com necessidades educacionais especiais). (MANTOAN, 2003, p. 16).

Suprimindo a divisão entre ensino regular e especial a inclusão não diz respeito em colocar as pessoas nos ambientes educacionais, ou seja, integrá-las, mas em mudar os estes ambientes tornando-os acessíveis, isto se refere a todas as pessoas e não apenas aquelas que são rotuladas com o termo "pessoas com deficiência".

Percebe-se então que para a educação ser inclusiva não se trata apenas de atender as necessidades educacionais especiais dos alunos com deficiência, mas de rever as práticas educacionais arraigados na educação desde o Brasil colonial.

Essa conjuntura remete-nos a uma reflexão crítica sobre como os alunos da educação básica são incluídos nesse espaço de cultura assimilacionista e conteudista 
que acaba não favorecendo não só os alunos com deficiência, mas todos que devem ter a Escola como o espaço que constrói o desenvolvimento humano de direito.

No Brasil, segundo Mendes (2011), a realidade da educação de pessoas com necessidades educacionais especiais ainda se caracteriza por três vertentes: há um forte subsistema, patrocinado por várias instâncias do poder público, que se mantém nos limites do assistencialismo filantrópico; há um sistema educacional fragilizado, que vem sendo pressionado a abrir espaço para esse público, e, por fim, um ponto alarmante: uma parcela considerável de pessoas com necessidades educacionais especiais ainda permanece à margem de qualquer tipo de escola.

Sobre isso, a autora argumenta com um dado oficial do MEC, do ano de 2008, que indica que $71 \%$ das pessoas entre zero a 18 anos, vinculadas ao "Benefício de Prestação Continuada" (destinado à idosos e pessoas com deficiência, de qualquer idade), não frequentavam qualquer tipo de escola (BRASIL, 2009a apud MENDES, 2011).

A respeito da fragilização do sistema educacional, é importante destacar que a Educação Especial, no País, ainda enfrenta problemas (MENDES, 2010), ou seja: a oferta de serviços e oportunidades educacionais é escassa; ainda prevalece um modelo de Educação Especial segregado, discriminatório e marginalizante, baseado em escolas e classes especiais; o poder público (federal, estadual e municipal) continua omisso na prestação direta de serviços educacionais especializados, além de incentivar, explicitamente, a iniciativa privada, responsável por quase metade das matrículas dessa população; por fim, as projeções para o atendimento das necessidades dos usuários em termos de evolução de professores qualificados em sala de aula.

Diante da realidade apontada, levantamos os seguintes questionamentos: Quais as implicações da política de Educação Especial na perspectiva da Educação Inclusiva para a formação docente? A formação tem garantido práticas inclusivas? Qual a identidade docente no fazer desse profissional?

É marcada de controvérsias o tema da formação de professores para a Educação Especial na perspectiva inclusiva considerando a diversidade de opiniões assumidas em realidades distintas e os vários modelos e titulações que nessa formação incidem (DENARI, 2006).

A Resolução CNE/CEB no 2, de 11 de setembro de 2001, que institui as Diretrizes Nacionais para a Educação Especial na Educação Básica (BRASIL, 2001), ao garantir o 
atendimento dos alunos com necessidades educacionais especiais nas classes comuns do ensino regular, destaca que as escolas devem organizar seus espaços com a presença de dois tipos de professores: os da classe comum, capacitados, e os de Educação Especial, especializados, os quais devem atuar de forma colaborativa.

A respeito dos professores da classe comum, o documento (BRASIL, 2001, p. 5), no parágrafo primeiro do Art. 18, define:

São considerados professores capacitados para atuar em classes comuns com alunos que apresentam necessidades educacionais especiais aqueles que comprovem que, em sua formação, de nível médio ou superior, foram incluídos conteúdos sobre educação especial $[\ldots]$

Gatti (2010) realizou um estudo que evidenciou que disciplinas relativas à Educação Especial representam apenas $3,8 \%$ do conjunto e que, nas ementas, a abordagem assume um caráter mais genérico ou descritivo, com pouca referência a práticas educativas.

Já existe um número bem significante de universidades e instituições de Ensino Superior que incluíram nos cursos de licenciaturas, conteúdos sobre Educação Especial ou Educação Inclusiva, prevalece uma grande diversidade de enfoques e os conteúdos são contemplados, predominantemente, em cursos de formação de professores para os anos iniciais (BUENO; MARIN, 2011).

Assim, não é possível afirmar que os professores da classe comum estejam efetivamente capacitados. Outro ponto é que o debate da inclusão, na maioria das vezes, limitado aos alunos com deficiência, quando integrado aos currículos de formação de professores, dá-se de forma isolada e desconectada de uma visão epistemológica de Educação, impedindo uma reflexão sobre a teoria/prática pedagógica em si (DORZIAT, 2011).

\section{FORMAÇÃO DE PROFESSORES NA PERSPECTIVA INCLUSIVA}

Uma nova postura no desenvolvimento da práxis dos docentes é uma exigência no cenário educacional atual, esta que deve estar em conformidade com as demandas socioculturais de maneira que sua prática oportunize aos educandos uma formação que 
garanta a aquisição de conhecimentos significativos para sua atuação na sociedade e no mundo do trabalho.

De acordo com Nóvoa (2011) a profissão docente encontra-se sob a influência de dois processos antagônicos sintetizado por Mark Ginsurg da seguinte maneira: primeiramente a profissionalização a qual os profissionais se auto-valorizam, e a proletarização com a degradação do estatuto, queda de rendimentos, poder e autonomia do profissional.

No entanto explica Nóvoa os professores tendem a seguir um outro caminho devido à sobrecarga de trabalho e atividades diárias passam a seguir atalhos realizando apenas o essencial, isto faz com que se apoie nos especialistas, esperando respostas sobre o que fazer, levando a depreciação do trabalho acumulado durante anos. (NÓVOA, 2011).

Em 2008, surge a Política Nacional de Educação Especial na Perspectiva da Educação Inclusiva (2008) que tem como objetivo o acesso, a participação e a aprendizagem dos alunos com deficiência, transtornos globais do desenvolvimento e altas habilidades/superdotação (público alvo da Educação Especial) nas escolas regulares, orientando os sistemas de ensino para promover respostas às necessidades educacionais especiais (BRASIL, 2008).

Essa política passa a ser o parâmetro para as ações inclusivas no país, definindo a Educação Especial como uma modalidade de ensino que perpassa por todos os níveis, etapas e modalidades, ofertando ainda o Atendimento Educacional Especializado (AEE) ${ }^{1 .}$

O cenário legal contribui para a abertura das escolas aos alunos público alvo da Educação Especial transferindo ou dividindo assim a responsabilidade do sucesso ou fracasso escolar que antes era somente da criança ou adolescente, principalmente, os pertencentes das classes menos favorecidas.

Com o objetivo de fazer cumprir a Lei, encarando o princípio da inclusão como um dever, corre-se o risco de incluir o público alvo da Educação Especial,

${ }^{1}$ O Atendimento Educacional Especializado (AEE), definido pelo Decreto 6.571/2008 tem como função identificar, elaborar e organizar recursos pedagógicos e de acessibilidade que eliminem as barreiras para a plena participação dos estudantes, considerando suas necessidades específicas. Esse atendimento é realizado nas Sala de Recursos multifuncionais (SRM's) complementa e/ou suplementa a formação dos estudantes com vistas à autonomia e independência na escola e fora dela. (SEESP/MEC, 2008). 
independentemente de suas condições, quando a escola e seus membros não estarem preparados. Esta ação pode conduzir a integração, ao fracasso e à evasão da escola.

Viabilizar a inclusão escolar, garantindo que todos os alunos possam aprender juntos em uma escola de qualidade, é uma atitude humanitária e justa, demonstrando práticas alicerçadas nos valores de respeito a diferença.

No entanto afirma Nóvoa os professores tendem a seguir um outro caminho devido à sobrecarga de trabalho e atividades passam a seguir atalhos realizando apenas o essencial, isto faz com que se apoie nos especialistas, esperando respostas sobre o que fazer, levando a depreciação do trabalho acumulado durante anos. (NÓVOA, 1992).

Entende-se que outro caminho o qual o autor se refere, é o que vem acontecendo implicitamente nas escolas públicas é a "integração" dos alunos, pois, como já foi dito anteriormente, neste contexto o aluno deve ajustar-se à escola.

Para Mantoan, $(2008$, p. 81) [...] investir na formação do professor é tarefa bastante complexa, porque, além da fundamentação teórica, envolve o desafio da reflexão sobre a prática cotidiana e, em decorrência disso, a necessidade da mudança, $[\ldots]$.

Essa mudança é a quebra dos velhos paradigmas (exclusão, segregação e integração), para que ocorra a inclusão de fato, que deve ser construída coletivamente no espaço escolar. Uma nova postura com novos conhecimentos surge por meio da formação inicial

Autores como NÓVOA e MANTOAN coadunam no sentido que o professor tem papel importante, fundamental por uma nova postura profissional para as mudanças necessárias no âmbito da escola, construindo assim uma nova cultura escolar com relação a inclusão de pessoas com deficiência.

De acordo com Barroso: "O conceito de cultura escolar tem sido utilizado para evidenciar a função da escola como transmissora de uma cultura específica no quadro do processo de socialização e integração nacional das crianças e dos jovens." Disponível em: https://docplayer.com.br/14827836-Cultura-cultura-escolar-cultura-deescola.html. Acesso em 20 de maio de 2019.

Essa afirmação no contexto inclusivo exige um redimensionamento da prática pedagógica, aderindo uma metodologia interdisciplinar, flexível e lúdica, ou seja, práticas inclusivas. A proposta só conseguirá obter sucesso dentro de uma visão de 
trabalho numa nova concepção de educação que comungue com o princípio da inclusão, já visto aqui.

Os professores enfrentam dificuldades não só em transmitir para esses alunos as disciplinas específicas em suas áreas de formação, mas falta também o próprio conhecimento "para lidar com a Língua Brasileira de Sinais (LIBRAS) e com a presença de intérpretes em suas aulas" (SILVEIRA e SOUZA, 2011, p. 38).

A exemplo, uma situação que vem se tornando bem corriqueira é um aluno surdo em sala de aula em determinada situação necessite de uma explicação mais didática, mesmo com o Tradutor-Intérprete da LIBRAS em sala de aula, então o professor precisará conhecer esta língua para que haja a comunicação entre professor ouvinte e aluno surdo como garante a Lei n. 10.436/2002. (BRASIL, 2005).

No Brasil, esse cenário vem se modificando, um grande movimento vem ocorrendo para que se passe a ofertar na formação inicial de professores com disciplinas que favoreça um respaldo teórico e prático para a inclusão escolar deste público. Com o Decreto 5.626/2005 a LIBRAS que se tornou obrigatória nos cursos de licenciatura, porém os demais componentes da Educação Especial como: Braille, Educação Física Adaptada, Legislação etc. não é comumente contemplado nas matrizes curriculares dos cursos.

\section{CONSIDERAÇÕES}

A formação docente na perspectiva inclusiva é uma questão que enfoca vários aspectos, dentre eles, a compreensão do que de fato se ensina e como ensina nas instituições de ensino formadoras de professores.

Essa afirmação leva-nos a refletir que o professor precisa não somente ter conhecimentos específicos sobre Educação Especial, Braille, a Libras para realizar adaptações de materiais didáticos e nos espaços acadêmicos de Educação Física, mas, também precisa conceber as questões organizacionais e políticas públicas para que de fato ocorra a inclusão, bem como, a aceitação da diversidade na prática docente de um currículo humanizado.

O que se tem visto até aqui é que pensar numa educação inclusiva, nos fazeres pedagógicos envolvem tornar os espaços escolares culturalmente acessíveis, isento de preconceitos, estigmas, estereótipos e discriminações, para de fato ser visto como um 
espaço educativo inclusivo, sem os entraves ocultos, pressupõe repensar a formação docente neste prisma.

Mesmo com tantas barreiras tentando impedir que as práticas inclusivas aconteçam, o que se vê é que as discussões acerca do assunto têm aumentado, até se concluir que, a inclusão, cada dia mais faz parte dos seres humanos, para que não ocorra discriminação de nenhuma forma.

Assim concordamos com Nóvoa na seguinte afirmação:

É preciso fazer um esforço de troca e de partilha de experiências de formação, realizadas pelas escolas e pelas instituições de ensino superior, criando progressivamente uma nova cultura da formação de professores. (NÓVOA, 1992, p. 19).

Acredita-se que é de fundamental importância a criação de espaços que enriqueçam o desenvolvimento da formação inicial de professores na perspectiva de mudanças e transformações na educação do país, uma educação culturalmente construída.

Acredita-se que para a visibilidade da educação inclusiva a educação precisa ser redesenhada, muitas adaptações e mudanças deverão ser realizadas, a reestruturação do espaço, do tempo e da prática pedagógica, quebrando os velhos paradigmas, inclusive, da inclusão escolar estruturada atualmente.

Com relação as mudanças entendem-se que não diz respeito somente aos serviços de apoio especializados para apenas atender às necessidades educacionais especiais dos alunos, mas, sim ofertar cursos de capacitação/qualificação aos professores do ensino regular.

\section{REFERÊNCIAS}

BARROSO, João. Cultua, cultura escolar, cultura de escola. Lisboa Disponível em: https://docplayer.com.br/14827836-Cultura-cultura-escolar-cultura-deescola.html. Acesso em 20 de mai de 2019.

BRASIL. Coordenadoria Nacional para Integração da Pessoa Portadora de Deficiência. Acessibilidade - Brasília: Secretaria Especial dos Direitos Humanos, 2005. $160 p,: 21 \mathrm{~cm}$.

Ministério da Educação. Lei de Diretrizes e Bases da Educação Nacional. LDB nº. 9.394, de 20 de dezembro de 1996. 
. Ministério da Educação. Política Pública de Educação Especial na Perspectiva da Educação Inclusiva, 2008.

- Resolução no 02/2001. Brasília: Conselho Nacional de Educação/Câmara de Educação Básica, 2001.

DENARI, Fátima. Um (novo) olhar sobre a formação do professor de educação especial: da segregação à inclusão. In: RODRIGUES, D. (Org.). Inclusão e educação: doze olhares sobre a educação inclusiva. São Paulo: Summus, 2006.

LIBÂNEO, José Carlos. Tendências pedagógicas na prática escolar. In:

Democratização da Escola Pública - a pedagogia crítico-social dos conteúdos. São Paulo.

MANTOAN, M. T. E. (Org.). (1997). A integração de pessoas com deficiência: contribuições para uma reflexão sobre o tema. São Paulo: Memnom, SENAC.

. (Organizadora) O Desafio das diferenças nas escolas. Petrópolis, RJ: Vozes, 2008.

MAZZOTA, Marcos J. S. Educação Especial no Brasil: História e Políticas Públicas. São Paulo: Cortez, 1996.

MENDES, Enicéia Gonçalves. A formação do professor e a política nacional de Educação Especial. In: CAIADO, Katia Regina Moreno; JESUS, Denise Meyrelles de; BAPTISTA, Claudio Roberto (Org.). Professores e Educação Especial: formação em foco. Porto Alegre: Mediação/CDV/FACITEC, 2011.

MENDES, Enicéia Gonçalves. Inclusão marco zero: começando pelas creches. Araraquara, SP: Junqueira\&Marin, 2010.

NÓVOA, Antonio. Formação de professores e profissão docente. Texto publicado em NÓVOA, António, coord. - "Os professores e a sua formação". Lisboa: Dom Quixote, 1992. ISBN 972-20-1008-5. pp. 13-33

António. "Concepções e práticas de formação contínua de professores". In Formação Contínua de Professores - Realidades e Perspectivas. Aveiro: Universidade de Aveiro, 1991, pp. 15-38.

SOUSA, S. F. e SILVEIRA, H. E. Terminologias químicas em Libras: a utilização de sinais na aprendizagem de alunos surdos. QNEsc, v.33, n.1, 2011. 


\title{
CAPÍTULO V
}

\section{O PAPEL DO COORDENADOR PEDAGÓGICO EM INSTITUIÇÕES DE ENSINO BÁSICO E SUPERIOR}

\author{
DOI: 10.51859/amplla.dec139.1120-5
}

Marcus Vinicius Peralva Santos ${ }^{1}$

\begin{abstract}
${ }^{1}$ Graduado em Ciências Biológicas e em Marketing, com especialização em Ecologia e Intervenções Ambientais pela UNIJORGE, mestre e doutor em Geologia pela UFBA, Especialista em Coordenação Pedagógica, Gestão da Educação, Educação Inclusiva e Educação Inclusiva Avançada. Coordenador do curso de Microempreendedor Individual (MEI) pelo Instituto Federal Goiano campus Morrinhos e professor das Faculdades Integradas de Sergipe (FISE).
\end{abstract}

\section{RESUMO}

A função de coordenador pedagógico costuma ser mal vista por outros funcionários nos ambientes escolares, no entanto, esta função não costuma ser lembrada nos ambientes universitários, sendo um profissional que passa desapercebido nas Instituições de Ensino Superior. O profissional de coordenação pedagógica deve ser o elo entre a direção, alunos e professores dos ambientes educacionais, vindo daí a necessidade de se conhecer o perfil deste profissional. Deste modo, o presente artigo consisti em um estudo quali-quantitativo, onde realizou-se um levantamento bibliográfico referente a obras com a temática "Coordenação Pedagógica" segundo o catalogo de teses da CAPES de 1999 até 2019. Os resultados obtidos mostram que a quantidade de trabalhos sobre a temática alvo do presente estudo é baixa, sendo as IES paulistas as maiores produtoras de estudos sobre esta temática. Os trabalhos já existentes são unanimes em descrever que dentre as principais funções do coordenador inclui-se atividades de cunho pedagógico e administrativo, sendo as principais funções, estimular e criar junto ao corpo docente da instituição, situações para maior integração do trabalho, desenvolvimento de aulas atreladas ao projeto político pedagógico do curso e o incentivo constante a qualificação profissional.

Palavras-chave: Coordenação pedagógica. Ensino básico. Ensino superior. Catálogo de Teses da CAPES.

\section{INTRODUÇÃO}

O coordenador pedagógico (CP) constitui-se em um dos elementos chaves para uma adequada construção do projeto político pedagógico escolar/ universitário, em parceria com outros colaboradores do ambiente acadêmico, ao qual trabalha, a exemplo da própria direção escolar e principalmente dos professores, devendo estimular o constante aperfeiçoamento pedagógico dos docentes, além de auxiliá-los em eventuais 
problemas de cunho educacional que venham a surgir no ambiente de trabalho (MOREIRA, 2016; FERREIRA, 2019).

Nas Instituições de Ensino Superior (IES), o papel do coordenador pedagógico costuma ser desconhecido por muitos dos membros que compõem esta comunidade, sendo que muitas vezes, ele se quer é lembrado pelos colaboradores das instituições de ensino superior. Diante desta situação, questiona-se: quais as principais atribuições de um coordenador pedagógico numa instituição de ensino básico e no ensino superior?

Deste modo, o presente capítulo tem como objetivo geral descrever as principais atribuições do coordenador pedagógico dentro de uma instituição de ensino básico e superior, tendo-se como objetivos específicos: (a) pontuar as principais atividades do coordenador acadêmico; (b) pontuar os principais estudos publicados sobre a função no Brasil; e (c) discutir sobre o seu papel junto as direções, coordenações de curso e professores.

A metodologia empregada na construção do presente estudo foi fundamentada na realização de uma revisão bibliográfica, constituída principalmente por livros, artigos de periódicos, teses, publicações avulsas impressas e online, os quais apresentassem em seu contexto o tema "coordenação pedagógica".

Para a busca das bibliografias foram utilizadas duas plataformas de pesquisas, 0 Google Acadêmico e o Catálogo de Teses da CAPES. Para a primeira plataforma, foram utilizados os seguintes termos descritores: coordenação pedagógica, coordenação acadêmica, coordenação pedagógica IES e coordenação pedagógica ensino superior. Após a seleção das bibliografias, foi realizada uma leitura criteriosa para a posterior classificação das obras por subtemas, os quais serviram de base para a construção dos capítulos de fundamentação teórica. Como critério de seleção, para a plataforma do Google Acadêmico optou-se por se priorizar os estudos com base em pesquisas realizadas nos últimos 20 anos (1999 até 2019).

Para a segunda plataforma de busca, o "Catálogo de Teses da CAPES" utilizou-se os mesmos termos descritores utilizados para a primeira plataforma, sendo que para ele contemplou-se todas as obras ali catalogadas como defendidas em cursos de mestrado e doutorado pelo país, quantificando-se o total de obras publicadas sobre o tema por ano. 
Os dados tabulados foram convertidos em um quadro, o qual foi gerado por meio do programa Microsoft Office Professional Plus Excell 2016.

\section{HISTÓRICO DOS ESTUDOS SOBRE COORDENAÇÃO PEDAGÓGICA}

A função de supervisor, coordenador pedagógico, ou coordenador acadêmico começou a surgir a partir da primeira Lei de Diretrizes e Bases da Educação (Lei $n^{\circ} 4.024$ de 1961), por meio do incentivo aos investimentos nos cursos de Letras, Filosofia e Ciências, os quais eram destinados a formação profissional de professores (BRASIL, 1961).

Nos cursos de Pedagogia pelo país passou-se a se formar os profissionais técnicos em educação (pedagogos), os quais seriam os responsáveis por idealizar e estruturar os processos pedagógicos que norteiam tanto os projetos políticos pedagógicos (PPP) das instituições de ensino básico, quanto as do ensino superior, tendo sido inserido, com o passar do tempo, outras funções (FERREIRA, 2019).

Em seus primórdios, a função do supervisor, futuro coordenador pedagógico/ acadêmico, se destinava não apenas a acompanhar os projetos políticos pedagógicos, mas também ao controle e fiscalização dos professores quanto as suas atividades desempenhadas, assim como na resolução de possíveis problemas que viessem a acontecer (MOREIRA, 2016; FERREIRA, 2019).

Mais para a frente, em 1971 foi publicada a Lei $n$ o 5.692 a qual passa a descrever as atividades docentes e não docente nas instituições de ensino, com destaque a função de supervisor pedagógico, o qual diante do período militar (1964-1985), que se vivia na época, apresentava este profissional como uma espécie de "dedo duro" de tudo que ocorria de errado no ambiente escolar (FERREIRA, 2019).

Na década seguinte, com o fim do período militar em 1985, pouco a pouco o país passou a ter mudanças no perfil do supervisor, o qual por exemplo, passa a ter uma nova nomenclatura, o de coordenador pedagógico, o qual deixa de ser apenas um "supervisor", passando a ser responsável por criar um ambiente favorável a mesclar a prática e a teoria pedagógica da sala de aula, articulando a realização e cumprimento dos projetos e atividades curriculares. Deste modo, a partir da década de 1990 o coordenador pedagógico então, passa não só a ter um perfil ligado ao pedagógico, mas 
também é reconhecido como um administrador de empresas (VENAS, 2012; MOREIRA, 2016).

No estado da Bahia, o supervisor escolar e o orientador educacional eram os profissionais responsáveis por atuarem na função de coordenador pedagógico, sendo que com a lei Estadual no 7.023, de 23/01/1997, regulamentada pelo Decreto no 6.471 de 01/06/1997, os cargos de supervisor e orientador foram extintos, ocorrendo a criação do cargo de coordenador acadêmico, que passou a ser responsável por desempenhar as funções antes exercidas pelos profissionais destes dois cargos, agora não mais existentes (CAMPOS, ALMEIDA e SANTOS, 2013).

Além dos cursos de graduação, a exemplo da Pedagogia, que fornecia dados básicos sobre o papel do coordenador, surge os cursos de pós-graduação lato sensu (especializações) destinados justamente a formação de coordenadores pedagógicos, inicialmente de forma presencial, e a partir da década de 2010 já disponível em versões totalmente online.

De acordo com o catálogo de teses da CAPES, os primeiros trabalhos oriundos de cursos stricto sensu produzidos por meio do auxílio financeiro da CAPES datam de 1999 (Quadro 1), sendo todos dissertações e oriundos de três Instituições de Ensino Superior (IES), sendo elas: a Pontifícia Universidade Católica de São Paulo, a Universidade de São Paulo e a Universidade de Brasília, todos eles com uma única publicação.

Com exceção do ano de 2007 (Quadro 1), percebe-se que as IES do estado de São Paulo foram as maiores produtoras de conteúdos monográficos referentes a ação do coordenador pedagógico, havendo uma tendência crescente ao aumento de publicações com o avançar dos anos, mais precisamente, de 1999 até 2018 (Quadro 1). 
Quadro 01 - Relação de trabalhos publicados por cursos de pós graduação no Brasil com a temática "Coordenação Pedagógica" segundo o catalogo de teses da CAPES de 1999 até 2019

\begin{tabular}{|c|c|c|c|}
\hline $\begin{array}{c}\text { Ano de } \\
\text { Publicação }\end{array}$ & $\begin{array}{l}\text { Quantidade } \\
\text { de trabalhos } \\
\text { publicados }\end{array}$ & IES de publicação ( )* & $\begin{array}{l}\text { Modalidade da } \\
\text { pós-graduação/ } \\
\text { quantidade de } \\
\text { publicações }\end{array}$ \\
\hline 1999 & 3 & $\begin{array}{c}\text { Pontifícia Universidade Católica de São Paulo (1) } \\
\text { Universidade de São Paulo (1) } \\
\text { Universidade de Brasília (1) }\end{array}$ & Mestrado/ 3 \\
\hline 2000 & 4 & $\begin{array}{c}\text { Pontifícia Universidade Católica de São Paulo (1) } \\
\text { Universidade de Brasília (1) } \\
\text { Pontifícia Universidade Católica de Campinas (1) } \\
\text { Universidade Federal de Amazonas (1) }\end{array}$ & Mestrado /4 \\
\hline 2001 & 6 & Universidade de São Paulo (2) & $\begin{array}{l}\text { Mestrado/4 e } \\
\text { Doutorado/2 }\end{array}$ \\
\hline 2002 & 7 & $\begin{array}{c}\text { Universidade Federal de São Carlos (1) } \\
\text { Universidade de São Paulo (1) } \\
\text { Universidade Federal de Santa Catarina (1) } \\
\text { Universidade Federal Fluminense (1) } \\
\text { Universidade Federal do Rio Grande do Sul (1) } \\
\text { Universidade de Brasília (1) } \\
\text { Universidade Estadual Paulista Júlio de Mesquita } \\
\text { Filho (1) }\end{array}$ & $\begin{array}{l}\text { Mestrado/6 e } \\
\text { Doutorado /1 }\end{array}$ \\
\hline 2003 & 5 & $\begin{array}{l}\text { Universidade do Vale do Rio dos Sinos (1) } \\
\text { Universidade do Estado do Rio de Janeiro (1) } \\
\text { Universidade Federal do Rio Grande do Sul (1) } \\
\text { Universidade Federal do Rio Grande do Norte (1) } \\
\text { Pontifícia Universidade Católica de São Paulo (1) }\end{array}$ & $\begin{array}{l}\text { Mestrado/4 e } \\
\text { Doutorado/1 }\end{array}$ \\
\hline 2004 & 8 & $\begin{array}{l}\text { Universidade Estadual Paulista Júlio de Mesquita } \\
\qquad \text { Filho (2) }\end{array}$ & $\begin{array}{l}\text { Mestrado/7 e } \\
\text { Doutorado/1 }\end{array}$ \\
\hline 2005 & 9 & $\begin{array}{c}\text { Universidade Estadual de Campinas (2) } \\
\text { Pontifícia Universidade Católica de São Paulo (2) }\end{array}$ & $\begin{array}{l}\text { Mestrado/8 e } \\
\text { Doutorado/ } 1\end{array}$ \\
\hline
\end{tabular}




\begin{tabular}{|c|c|c|c|}
\hline 2006 & 17 & Pontifícia Universidade Católica de São Paulo (2) & $\begin{array}{l}\text { Mestrado/14 e } \\
\text { Doutorado/3 }\end{array}$ \\
\hline 2007 & 19 & Universidade de Brasília (3) & $\begin{array}{l}\text { Mestrado/15 e } \\
\text { Doutorado/4 }\end{array}$ \\
\hline 2008 & 25 & Universidade Católica de Santos (3) & $\begin{array}{l}\text { Mestrado/23 e } \\
\text { Doutorado/2 }\end{array}$ \\
\hline 2009 & 13 & Universidade Federal do Rio Grande do Norte (2) & $\begin{array}{l}\text { Mestrado/9 e } \\
\text { Doutorado/4 }\end{array}$ \\
\hline 2010 & 21 & $\begin{array}{l}\text { Universidade de São Paulo (2) } \\
\text { Universidade Federal de Mato Grosso (2) }\end{array}$ & $\begin{array}{l}\text { Mestrado/19 e } \\
\text { Doutorado/2 }\end{array}$ \\
\hline 2011 & 19 & $\begin{array}{l}\text { Universidade Federal do Rio Grande do Sul (2) } \\
\text { Universidade Católica de Brasília (2) } \\
\text { Pontifícia Universidade Católica de São Paulo (2) }\end{array}$ & $\begin{array}{l}\text { Mestrado/18 e } \\
\text { Doutorado/1 }\end{array}$ \\
\hline 2012 & 27 & $\begin{array}{l}\text { Universidade de Brasília (3) } \\
\text { Universidade de São Paulo (3) }\end{array}$ & $\begin{array}{l}\text { Mestrado/21 e } \\
\text { Doutorado/6 }\end{array}$ \\
\hline 2013 & 32 & $\begin{array}{l}\text { Universidade Estadual de Ponta Grossa (3) } \\
\text { Universidade Estadual Paulista J. de Mesquita Filho } \\
\text { (3) }\end{array}$ & $\begin{array}{c}\text { Mestrado/25 e } \\
\text { Doutorado/7 }\end{array}$ \\
\hline 2014 & 37 & $\begin{array}{l}\text { Universidade do Estado do Rio de Janeiro (3) } \\
\text { Universidade Estadual Paulista J. de Mesquita Filho } \\
\text { (3) }\end{array}$ & $\begin{array}{c}\text { Mestrado/30 e } \\
\text { Doutorado/7 }\end{array}$ \\
\hline 2015 & 49 & Pontifícia Universidade Católica de São Paulo (6) & $\begin{array}{l}\text { Mestrado/32 e } \\
\text { Doutorado/17 }\end{array}$ \\
\hline 2016 & 52 & Pontifícia Universidade Católica de São Paulo (7) & $\begin{array}{l}\text { Mestrado/47 e } \\
\text { Doutorado/5 }\end{array}$ \\
\hline 2017 & 54 & $\begin{array}{l}\text { Universidade Estadual Paulista J. de Mesquita Filho } \\
\qquad \text { (5) }\end{array}$ & $\begin{array}{l}\text { Mestrado/48 e } \\
\text { Doutorado/6 }\end{array}$ \\
\hline 2018 & 59 & Pontifícia Universidade Católica de São Paulo (5) & $\begin{array}{c}\text { Mestrado/53 e } \\
\text { Doutorado/6 }\end{array}$ \\
\hline
\end{tabular}




\begin{tabular}{|l|l|l|l|}
\hline 2019 & 29 & Pontifícia Universidade Católica de São Paulo (3) & Mestrado/18 e \\
& & Doutorado/11 \\
\hline
\end{tabular}

Nota: *entre parênteses a quantidade de publicações da (s) instituição (ões) de ensino superior com maior número de publicações no ano sobre o tema "coordenação pedagógica".

\section{PRINCIPAIS ATIVIDADES DO COORDENADOR PEDAGÓGICO}

Várias nomenclaturas são dadas ao profissional de coordenação pedagógica em seu ambiente de trabalho, dentre eles, tem-se, o profissional bombeiro (que "apaga" os conflitos existentes entre docentes e discentes), bombril (responsável por resolver mil e um problemas), salvador de pátria (por responder pelo processo de aproveitamento estudantil e pelas didáticas do corpo docente), dentre outros nomes (LANGONA E GAMA, 2018).

Conforme Inoue e Amado (2012), o CP é um formador e articulador do ambiente educacional, o qual não se pode deixar engolir pelas demandas administrativas do cotidiano. Dentre as principais atividades do profissional de coordenação pedagógica pode-se citar:

(1) Manutenção da efetividade do processo pedagógico (Gestor educacional): Se refere ao processo de organização e acompanhamento do trabalho educativo. Nele se dá a busca da manutenção da qualidade das mediações pedagógicas ocorridas dentro da sala de aula e junto a sociedade, sendo normalmente definido quanto ao seu sucesso ou não, por meio de métodos quantitativos (GEGLIO, 2012; INOUE e AMADO, 2012; SARTORI e PAGLIARIN, 2016; FERREIRA, 2019).

(2) Formação dos Professores: Ocorre por meio da ação direta dos coordenadores junto aos professores, onde o primeiro busca envolver seu corpo docente por meio da realização de grupos de estudos (reuniões pedagógicas), onde refletese de forma conjunta sobre o saber educar, propondo-se, principalmente na atualidade, a aplicação de metodologias de ensino inovadoras, as quais podem ser aplicadas por meio do investimento nos professores, não só por meio destas 
reuniões, mas também pelo incentivo a realização de cursos de pós-graduação (GEGLIO, 2012; SARTORI e PAGLIARIN, 2016; LANGONA e GAMA, 2018; OLIVEIRA e SOUZA, 2019).

(3) Gerir o Projeto Político Pedagógico (PPP): Este deve ser realizado de forma conjunta com a equipe administrativa, professores, alunos, pais e a comunidade, afim de possibilitar a criação de situações de debates e ações que promovam uma boa execução do projeto ao longo dos semestres letivos (GEGLIO, 2012; CAMPOS, ALMEIDA e SANTOS, 2013; SARTORI e PAGLIARIN, 2016; LANGONA e GAMA, 2018).

(4) Atendimento aos pais: Não se caracteriza como uma função oficial do coordenador, mas acaba acontecendo muitas vezes, por falta de pessoal para realizar tal função, ocorrendo normalmente na educação básica (LANGONA e GAMA, 2018). No ensino superior normalmente os coordenadores de curso são os responsáveis por desempenhar tal função.

(5) Acompanhamento de entrada e saída de alunos: Aplicada no ensino básico, principalmente em atividades festivas, onde o fluxo de alunos tende a aumentar (LANGONA e GAMA, 2018)

(6) Atendimentos de emergências: O coordenador pedagógico muitas vezes acaba perdendo o foco principal da sua função devido aos conflitos existentes em seu ambiente de trabalho, tais como: professor/gestão, professor/aluno, professor/família e professor/professor (MADUREIRA e LIMA, 2019).

(7) Organização de espaços: Ocorre por exemplo, para a realização de reuniões pedagógicas e eventos festivos (LANGONA e GAMA, 2018).

(8) Organização de horários: Realizada normalmente em parceria com os coordenadores (no ensino superior) e professores (no ensino básico) (INOUE e AMADO, 2012).

(9) Estabelece parcerias: Com o processo de globalização e da oferta de cursos online, é comum instituições de ensino básico e principalmente de ensino superior firmarem parcerias com empresas nacionais ou internacionais a fim de maximizar seu portfólio de recursos educacionais. 
(10) Substitui professores: Normalmente ocorrendo com maior frequência na educação básica.

Percebe-se que o CP em boa parte das vezes acaba por não realizar a formação do seu corpo docente, de modo que o processo de ensino-aprendizagem acaba por ficar estagnado (OLIVEIRA e SOUZA, 2019). Além disso, quando ocorre esta formação, recomenda-se que o CP estabeleça uma relação com o corpo docente, de modo a permitir que ambos tenham humildade para dizer o que não sabem e, juntos tentarem solucionar estas incógnitas. O ideal é que aos poucos, o coordenador consiga reestruturar o andamento das suas funções, legitimando-se como parceiro e formador dos seus professores (INOUE e AMADO, 2012).

\section{PAPEL DO COORDENADOR PEDAGÓGICO JUNTO AS COORDENAÇÕES DE CURSO E PROFESSORES EM INSTITUIÇÕES DE ENSINO SUPERIOR}

Os coordenadores pedagógicos no ambiente universitário, assim como o escolar, são responsáveis por responder por emergências que ocorrerem no ambiente acadêmico (SARTORI e PAGLIARIN, 2016), na impossibilidade de resolução por coordenadores de curso, ou até mesmo pela direção da instituição.

Outra responsabilidade da função engloba oferecer subsídios para ajudar o corpo docente a desenvolver melhor sua prática profissional, além de buscar solucionar junto a estes últimos as dificuldades encontradas no dia a dia acadêmico, de modo a favorecer a reflexão constante sobre a prática docente (OLIVEIRA e G UIMARÃES, 2013).

Porto (2015) destaca que para ser um agente transformador neste tipo de ambiente, o coordenador pedagógico deve ter em mente que deve apresentar disposição pessoal para poder atuar de forma favorável para a realização de mudanças em seu ambiente de trabalho. Isto principalmente, por conta do ambiente universitário normalmente envolver em boa parte das vezes, problemas mais gritantes do que aqueles que normalmente ocorrem no ambiente escolar. Com o aumento da faixa etária de ensino, há uma tendência a um aumento no grau de complexidade dos problemas a serem solucionados pelo coordenador. 
Souza (2002, apud LANGONA E GAMA, 2018) apontam como algumas das características essenciais ao papel do $\mathrm{CP}$, o respeito ao ritmo do outro, coragem, paciência, ousadia, solidariedade e principalmente, humildade. Deste modo verifica-se que o coordenador pedagógico deve dia a pós dia buscar revigorar seu processo formativo, de modo a permitir não só a reformulação das suas ações na teoria, mas principalmente na prática, assim estimulando sua capacidade crítico-reflexiva (SARTORI e PAGLIARIN, 2016)

Dentre as principais dificuldades para a execução de suas funções, estão a presença de traços autoritários e julgadores e a fragilidade de procedimentos para a realização de trabalhos coletivos, a rotina de trabalho burocratizada, a falta de um território próprio de atuação no ambiente acadêmico, o desvio de função, a ausência de identidade e a deficiência na formação pedagógica (OLIVEIRA e GUIMARÃES, 2013).

Acrescenta-se ainda a este cenário, a pouca comunicação que os coordenadores acadêmicos possuem junto aos professores, o que costuma ocorrer de forma inversa no ambiente escolar. No ambiente universitário, por haver uma maior subdivisão dos trabalhos, normalmente o coordenador acadêmico comunica-se diretamente com os coordenadores de curso e com a direção da IES, sendo raro seu contato com os docentes, os quais podem se sentir sem rumo, nos casos em que apresentam problemas com seu (s) coordenador (es) de curso (s).

Em suma, o profissional de coordenação pedagógica é o responsável por idealizar e monitorar todas as atividades acadêmicas, sendo que o foco principal da sua ação, deve ser sempre a formação do corpo docente (PORTO, 2015), juntamente as coordenações de curso.

\section{CONSIDERAÇÕES FINAIS}

O processo de consolidação da função de coordenador pedagógico foi um caminho longo, o qual evoluiu com a própria evolução do processo de escolarização no Brasil. Dentre as principais atribuições do coordenador pedagógico dentro de uma instituição de ensino básico e superior tem-se fomentar a formação continuada sua e dos docentes, de modo a favorecer uma formação pessoal e profissional produtiva, assim como atuar no processo de construção e atualização do PPP da instituição, dentre outros afazeres. 
Em relação aos estudos sobre o tema no Brasil, vê-se que estes apresentam uma tendência de crescimento ano após ano, sendo que as instituições de ensino superior localizadas no Estado de São Paulo, são as maiores responsáveis por publicações, considerando-se as obras publicadas em cursos stricto sensu e catalogadas junto ao portal da CAPES.

Considerando-se o ambiente universitário, verifica-se que este profissional não costuma ser muito conhecido pelos colaboradores da instituição, nem mantendo contato direto junto ao corpo docente, de forma que se faz necessário uma maior presença do coordenador pedagógico junto aos docentes, a fim de conhecer seus dilemas e escutar suas considerações para um maior progresso do processo ensinoaprendizagem.

Por fim, por se tratar de uma função essencial no ambiente acadêmico, recomenda-se que os cursos de Pedagogia invistam mais nas disciplinas relacionadas ao cargo de coordenação pedagógica, focando principalmente na parte prática da função, uma vez que os estudos consultados mostram que as pessoas que exercem esta função na maior parte das vezes só apresentam vivência teórica, não tendo a vivência prática recomendada para a função.

\section{REFERÊNCIAS}

BAHIA. Lei no 7023, de 23 de janeiro de 1997. Altera dispositivos da Lei 6.677, de 26 de setembro de 1994, e dá outras providências. Governo do Estado da Bahia. Bahia, 1997. Disponível em: <http://www.jusbrasil.com.br/legislacao/85819/lei-702397-bahia-ba> Acesso em: 06 jan. 2013.

BRASIL. Lei $n^{\circ}$ 4.024, de 20 de dezembro de 1961. Fixa as Diretrizes e Bases da Educação Nacional. Diário Oficial da União - Seção 1 - 27/12/1961, Página 11429. Disponível em: <https://www2.camara.leg.br/legin/fed/lei/1960-1969/lei-402420-dezembro-1961-353722-publicacaooriginal-1-pl.html>. Acesso em: 16 mar. 2020.

CAMPOS, E. P.; ALMEIDA, F. S, de; SANTOS, C. S. Atuação do coordenador pedagógico na perspectiva docente. In.: Seminário Internacional sobre profissionalização docente - SIPD/ Cátedra UNESCO. 4, 2013, Curitiba. Anais do XI Congresso Nacional de Educação 2013. Curitiba: EDUCARE, 2013, p. 17216-17226. Disponível em: <https://educere.bruc.com.br/ANAIS2013/trabalhos_6.html>. Acesso em 16 mar. 2020. 
GEGLIO, P.C. O papel do coordenador pedagógico na formação do professor em serviço. In: PLACCO, V.N.S.; ALMEIDA, L. R. (Org.). O coordenador pedagógico e o cotidiano da escola. 9a ed. São Paulo: Loyola, 2012.

INOUE, A.; AMADO, C. Coordenador pedagógico: função, rotina e prática. Palmeiras, BA: Instituto Chapada de Educação e Pesquisa, 2012.

FERREIRA, A. C. A coordenação pedagógica nas produções acadêmicas: balanço tendencial de dissertações e teses no período de 2013 a 2018. 2019. Dissertação (Mestrado em Educação) - Pontifícia Universidade Católica de São Paulo, São Paulo.

LANGONA, N. F.; GAMA, R. P. Dimensões do trabalho do coordenador pedagógico no contexto escolar. Laplage em Revista. Sorocaba. v. 4, n.1, p. 225-237, jan.-abr. 2018.

MADUREURA, A. O.; LIMA, M. V. G. Mediação pedagógica (professor e coordenador pedagógico) junto ao aluno que apresenta dificuldade de aprendizagem na leitura e na escrita. Revista PLUS FRJ - Revista Multidisciplinar em Educação e Saúde, n. 6, p. 98-111, Jan.2019.

MOREIRA, E. F. M. Atuação do coordenador pedagógico no cotidiano escolar. Monografia (Especialização em Coordenação Pedagógica). Universidade Aberta - Universidade do Paraná, Paravavaí, 2016.

OLIVEIRA, J. da S.; GUIMARÃES, M. C. M. O papel do coordenador pedagógico no cotidiano escolar. Revista Científica do Centro de Ensino Superior Almeida Rodrigues. Ano I, 1a ed, p. 95 - 103, Jan.2013.

OLIVEIRA, J. F. de; SOUZA, A. R. de (Organizadores). Gestão pedagógica, organização curricular e qualidade da educação. Anais do XXIX Simpósio Brasileiro de Política e Administração da Educação. [Livro Eletrônico]. Brasília: ANPAE, 2019.

PEREIRA, S. E. A.; MARINHO, J. C. B.; PESSANO, E. F. C. A coordenação pedagógica e sua importância no processo educacional: um estudo de caso no município de Uruguariana - RS. Revista Exitus, Santarém, v. 8, n. 3, p. 254-279, set.-dez. 2018.

PORTO, M. R. Coordenação pedagógica e gestão escolar: uma relação democrática? 2015. Monografia (Especialização em Coordenação Pedagógica) - Centro de Formação Continuada de Professores, Universidade de Brasília, Brasília.

PRADO, G. do V. T.; PROENÇA, H. H. D. M. Práticas de formação profissional na escola: desafios na atuação da coordenadora pedagógica em parceria com os professores. Educação Unisinos. v. 22, n. 2, p. 175-184, abr.-jun. 2018. 
SANT'ANA, C. O trabalho do coordenador pedagógico no auxílio ao professor com alunos com dificuldades no processo de alfabetização. Pedagogia em Ação, Belo Horizonte, v. 11, n.1, p.29-37, 2019.

SARTORI, J.; PAGLIARIN, L. L. P. O coordenador pedagógico: limites e potencialidades ao atuar na educação básica. Revista Espaço Pedagógico. Passo Fundo, v. 23, n.1, p. 185-204, jan./jun. 2016. Disponível em: <http://seer.upf.br/index.php/rep/article/view/6364/pdf>. Acesso em: 25 nov. 2019. 


\section{CAPÍtULIO VI}

\section{A EDUCAÇÃO PERMANENTE COMO ESTRATÉGIA PARA ORGANIZAÇÃO DO PROCESSO DE TRABALHO DA EQUIPE NO CENTRO DE REFERÊNCIA EM ASSISTÊNCIA SOCIAL- CRAS ARACAPÉ-CE}

Rebeca Marques de Melo ${ }^{1}$

${ }^{1}$ Especialista em Educação Permanente: Saúde e educação em uma perspectiva integradora. Escola Nacional de Saúde
Pública Sergio Arouca- FIOCRUZ. RESUMO

Compreendendo todos os condicionantes que afetam o processo de trabalho e os atores participantes. Este artigo busca desenvolver o tema em questão, trabalhando os conceitos de gestão participativa, trabalho em equipe, educação permanente, processo de trabalho, fluxograma analisador, política de assistência social e centro de referência em assistência social. Visando analisar cada um destes conceitos pela ótica de uma construção coletiva. Com ênfase na aplicação da educação permanente dentro do Centro de Referência em Assistência Social.

Palavras-chave: Educação permanente. Processo de trabalho. Assistência social.

\section{INTRODUÇÃO}

Este trabalho tem como proposta a construção de um projeto de intervenção que visa compreender o processo de trabalho, a partir da aplicação do conceito de educação permanente através das reuniões do coletivo de educação permanente dentro do Centro de Referência em Assistência Social - CRAS-Acarapé-CE.

Partindo do objetivo principal que é organizar o processo de trabalho da equipe no Centro de referência em assistência social - CRAS Aracapé-CE. A fim de minimizar o desconhecimento por parte da equipe as especificidades do processo de trabalho no CRAS. E assim sanar o nó-critico definido através do coletivo de educação permanente.

Este projeto de intervenção surge com a intenção de trazer também o conceito de fluxograma analisador, onde este se apresenta da seguinte forma, o "fluxograma analisador" se constitui num instrumento de análise, que interroga os "para que", os 
"que" e os "como" dos processos de trabalho, e ao mesmo tempo revela a maneira de governá-lo. ${ }^{1}$ (BARBOZA e FRACOLLI, 2005)

Portanto, cabe ressaltar que, a finalidade deste é abrir uma reflexão sobre os processos autoanalíticos, ocorridos no interior de uma equipe, disparados a partir da apresentação do "fluxograma analisador", e com isso "propor" o uso desse instrumento como uma tecnologia de autogestão do trabalho. ${ }^{2}$ (BARBOZA e FRACOLLI, 2005)

A educação permanente, ainda é um tema pouco difundido dentro do trabalho da política de assistência social, seus conceitos e métodos muitas vezes são confundidos com o trabalho de educação continuada, diante disto a proposta do projeto está em inserir esses conceitos para que a equipe multiprofissional possa compreender que para o processo de trabalho se faz necessário a aplicação de tais metodologias.

A contribuição desta temática está em trabalhar o conceito de educação permanente dentro da política de assistência social ${ }^{3}$, política que tem como objetivo: realizar de forma integrada às políticas setoriais, considerando as desigualdades sociais, visando seu enfrentamento, à garantia dos direitos sociais, ao provimento de condições para atender contingências sociais e à universalização dos direitos sociais.

Este projeto tem o intuito de organizar o processo de trabalho da equipe no Centro de referência em assistência social - CRAS Aracapé-CE. Para melhoria da prestação de serviço no local e satisfação dos usuários e colaboradores.

Desse modo, o projeto pretende minimizar o nó critico apontado através do coletivo de educação permanente, que é a falta de conhecimento por parte dos profissionais sobre o funcionamento e serviços oferecidos no CRAS.

O nó critico descrito acima reflete negativamente no serviço com a falta de organização da porta de entrada do equipamento, colaborando também com a ineficácia dos demais setores, ocasionando grandes transtornos ao serviço, gerando diversos retrabalhos, encaminhamentos equivocados e insatisfação por parte dos colaboradores e usuários. Comprometendo diretamente a eficiência do serviço prestado

\footnotetext{
${ }^{1}$ http://www.scielo.br/pdf/csp/v21n4/06.pdf ${ }^{2}$ http://www.scielo.br/pdf/csp/v21n4/06.pdf

${ }^{3}$ http://www.mds.gov.br/webarquivos/publicacao/assistencia_social/Normativas/PNAS2004.pd
} 
a população usuária. Além da rotatividade constante de profissionais que ocasiona a descontinuidade do serviço prestado pelo equipamento.

Sendo assim, esse projeto, tem o objetivo de contribuir com a construção coletiva de um processo de trabalho eficaz, que desperte nos colaboradores a consciência do papel individual para transformar o coletivo, assim como o coletivo contribui para o desenvolvimento individual de cada categoria.

Essa proposta, pode contribuir para o desenvolvimento de ações coletivas e intersetoriais que colaborem para organização do equipamento. Objetivando a implantação de uma gestão coletiva como eixo central do coletivo.

Dessa maneira, este projeto pretende mostrar ao leitor a perspectiva social dos conceitos já mencionados. Compreendendo que a educação permanente atua diretamente no processo de trabalho e em suas implicações, sendo elas consideradas fragilidades ou fortalezas.

A partir do processo pensar em educação permanente podemos construir alternativas coletivas para melhoria do mesmo. Podemos então, discutir e pactuar atribuições e funções dos profissionais da equipe. Envolvendo a equipe de gestão na discussão sobre o processo de trabalho.

\title{
2. METODOLOGIA
}

Este artigo será elaborado em uma perspectiva de cunho qualitativo, com a interpretação de dados disponibilizados ao longo das reuniões de coletivo de educação permanente, visando a compreensão do processo de trabalho no CRAS. Sendo assim, conforme expressa Minayo (2007):

\begin{abstract}
A pesquisa qualitativa responde a questões muito particulares. Ela se preocupa, nas ciências sociais, com um nível de realidade que não pode ser quantificado, ou seja, ela trabalha com o universo de significados, motivos, aspirações, crenças, valores e atitudes, o que corresponde a um espaço mais profundo das relações dos processos e dos fenômenos que não podem ser reduzidos à operacionalização de variáveis. (MINAYO, 2007, pp.21-22)
\end{abstract}

Através da perspectiva qualitativa procurou-se analisar o processo de trabalho no CRAS relacionando seus objetivos com a educação permanente e a construção coletiva. Descrevendo, as particularidades do lócus de trabalho, e as subjetividades pertencentes às relações da conjuntura em questão, processo de trabalho e equipe, 
encontradas durante todos os processos de construção do projeto. Conforme expressa Minayo (2007):

[...] compreender e explicar a dinâmica das relações sociais que, por sua vez são depositárias de crenças, valores, atitudes e hábitos. Trabalham com a vivência, com a experiência, com a cotidianeidade [sic] e também com a compreensão das estruturas e instituições como resultados da ação humana objetivada. Ou seja, desse ponto de vista, a linguagem, as práticas e as coisas são inseparáveis. (MINAYO, 2007, p.24)

Considerando que a pesquisa qualitativa responde as singularidades das questões enfrentadas pela pesquisa social, sendo ela um instrumento que compreende o objeto estudado, admitindo valor as facetas do objeto em construção em seu cotidiano. Pois, quando se pesquisa nas ciências sociais, a interpretação dos dados, do material teórico e dos sujeitos, não seria tão bem apreendida se não fosse permitido considerar suas subjetividades. Conforme expressa Minayo (2007):

[...] podemos observar que o ser humano se distingue não só por agir, mas por pensar sobre o que faz e por interpretar suas ações dentro e a partir da realidade vivida e partilhada com seus semelhantes, pois o objeto da pesquisa qualitativa dificilmente pode ser traduzido em números e indicadores quantitativos. (MINAYO, 2007, p.23)

As reuniões deram início ao trabalho de construção do projeto de intervenção para que fosse possível conhecer mais profundamente a equipe e suas inquietações relacionadas ao processo de trabalho, a pesquisa bibliográfica foi utilizada para nortear os encontros, a partir da coleta de dados feita durante todas as atividades do curso procurando identificar, particularizar e demarcar assuntos com a mesma problemática, tendo como origem livros, artigos científicos ou páginas na internet. Conforme expressa Gil (2002):

A pesquisa bibliográfica é desenvolvida com base em material já elaborado, constituído principalmente de livros e artigos científicos. Embora em quase todos os estudos seja exigido algum tipo de trabalho dessa natureza, [...]. As pesquisas sobre ideologias, bem como aquelas que se propõem à análise das diversas posições acerca de um problema, também costumam ser desenvolvidas quase exclusivamente mediante fontes bibliográficas. (GIL, 2002, p.44)

Para composição da pesquisa bibliográfica, foram escolhidos textos e autores que abordassem a temática na realidade da política de assistência social, política onde está inserido o local de construção deste projeto e seus atores. Sendo assim, foram 
selecionadas literaturas de âmbito legal como a Política Nacional de Assistência Social e Política Nacional de Educação Permanente do SUAS.

Tratando da educação permanente, o autor Ceccim fala da aplicação dos conceitos da mesma no processo de trabalho definindo a mesma e suas estratégias. No que se refere ao fluxograma analisador a autora Barboza retrata o objetivo do instrumento e o seu modo de avaliação. Para definir o Centro de Referência em Assistência Social, trouxemos o autor Castilho que relata características do equipamento.

No que concerne a gestão participativa, dois autores foram abordados, sendo eles Sato e F.C Brasil, que respectivamente apresentam a participação popular como essencial para se construir a gestão participativa, e as relações comunitárias articuladas de modo a compreender o território onde será aplicado o projeto de intervenção.

Para definir o trabalho em equipe, dois autores foram elencados, Raichelis que relata as experiencias da NOB-RH sendo esta integrante da Política Nacional de Assistência Social e Silveira que trata das fragilidades da gestão no sentido de construir um trabalho amplo e participativo.

\section{REVISÃO BIBLIOGRÁFICA}

Para fazer uma análise daquilo que foi proposto para o projeto, cabe considerar categorias como educação permanente, processo de trabalho, fluxograma analisador, política de assistência social e Centro de referência em Assistência social, gestão participativa e trabalho em equipe, relacionando-os ao processo de trabalho na política de assistência social.

\subsection{Educação permanente}

O conceito de educação permanente está diretamente relacionado ao cotidiano de trabalho ou a formação, sendo estas ligadas ao trabalho coletivo, assim pautada por Ceccim (2005), [...] "em análise, que se permeabiliza pelas relações concretas que operam realidades e que possibilita construir espaços coletivos para a reflexão e avaliação de sentido dos atos produzidos no cotidiano."

O trabalho na política de assistência social, está prontamente associado a atuação conjunta e ao trabalho coletivo, as articulações são fundamentais para o fazer 
profissional e sua execução, sendo esta variável constantemente através da dinâmica diária. Dessa maneira conforme expressa Ceccim (2005):

A Educação Permanente[...], ao mesmo tempo em que disputa pela atualização cotidiana das práticas segundo os mais recentes aportes teóricos, metodológicos, científicos e tecnológicos disponíveis, insere-se em uma necessária construção de relações e processos que vão do interior das equipes em atuação conjunta, - implicando seus agentes -, às práticas organizacionais, - implicando a instituição e/ou o setor da saúde -, e às práticas interinstitucionais e/ou intersetoriais, - implicando as políticas nas quais se inscrevem [...]."(CECCIM, 2005, p. 161)

A educação permanente poderá trazer ao ambiente e ao processo de trabalho mudanças plausíveis, que serão notadas a partir da aplicação de seus conceitos no cotidiano. Conforme expressa Ceccim (2005):

A Educação Permanente em Saúde pode corresponder à Educação em Serviço, quando esta coloca a pertinência dos conteúdos, instrumentos e recursos para a formação técnica submetidos a um projeto de mudanças institucionais ou de mudança da orientação política das ações prestadas em dado tempo e lugar. (CECCIM, 2005, p. 162)

Dentro da política de assistência social, a educação permanente é um conceito ainda recente, somente no ano de 2013, o sistema único de assistência social iniciou a divulgação de tal ação junto a política, através do Capacita SUAS. Dessa maneira, conforme expressa a Política Nacional de Educação Permanente do SUAS (2013):

Educação Permanente adotada pela PNEP-SUAS diz respeito à formação de pessoas visando dotá-las das ferramentas cognitivas e operativas que as tornem capazes de construir suas próprias identidades, suas compreensões quanto aos contextos nos quais estão inseridas. (BRASIL, 2013, p.33)

\subsection{Processo de trabalho}

De modo direto o processo de trabalho está correlacionado com a educação permanente como um dos principais meios para mudança dos conceitos antes apresentados. Dessa maneira, conforme expressa a Política Nacional de Educação Permanente do SUAS (2013).

Entende-se por Educação Permanente o processo contínuo de atualização e renovação de conceitos, práticas e atitudes profissionais das equipes de trabalho e diferentes agrupamentos, a partir do movimento histórico, da afirmação de valores e princípios e do contato com novos aportes teóricos, metodológicos, científicos e tecnológicos disponíveis. Processo esse mediado pela problematização e reflexão quanto às experiências, saberes, práticas e valores pré-existentes e que 
orientam a ação desses sujeitos no contexto organizacional ou da própria vida em sociedade. (BRASIL, 2013, p.34)

A reflexão relacionada ao trabalho coletivo e aos saberes é fundamental para o reconhecimento do processo de trabalho enquanto instrumento central desta ação. Através do trabalho participativo, podemos reestruturar o ambiente de trabalho e torna-lo eficaz para população usuária e para os trabalhadores. Dessa maneira, conforme expressa a Política Nacional de Educação Permanente do SUAS (2013).

No âmbito organizacional do SUAS, a implantação da perspectiva da Educação Permanente deve partir do reconhecimento da centralidade dos processos de trabalho e das práticas profissionais relacionadas à gestão participativa e ao provimento dos serviços e benefícios socioassistenciais para a estruturação dos processos de planejamento e implementação de ações de formação e capacitação. (BRASIL, 2013, p.34)

Dessa forma essa centralidade é pautada no trabalho coletivo em benefício de todas as partes envolvidas neste, usuários, trabalhadores e gestores municipais. A concretização do trabalho depende dos serviços ofertados, e para isto, estes precisam ter sua execução de maneira eficiente e eficaz. Dessa maneira, conforme expressa a Política Nacional de Educação Permanente do SUAS (2013).

Essa centralidade resulta do papel que os processos de trabalho e as práticas profissionais desempenham como principais mediadores da gestão descentralizada e participativa do SUAS e da concretização dos serviços e benefícios ofertados. De forma que, a promoção de melhorias na qualidade dessa gestão e desse provimento exige, necessariamente, a qualificação daqueles que planejam, organizam, operam e exercem o controle social do Sistema: os gestores, os trabalhadores e os conselheiros. (BRASIL, 2013, p.35)

O trabalho na política de assistência visa uma vigilância diária, em busca de uma ruptura com os conceitos de assistencialismo na teoria e nas práticas profissionais. Deixando de lado as concepções discriminatórias de um padrão antes estabelecido, tornando as avaliações e concepções ligadas ao direito da população e ao fazer profissional ético.

Sendo este conceito ligado a interdisciplinaridade, podemos observar que a construção das reuniões do coletivo de educação permanente já se configura como a formação inicial do mesmo. Pois, a partir desse planejamento trabalhamos a 
coletividade de um modo não tradicional. Dessa maneira, conforme expressa a Política Nacional de Educação Permanente do SUAS (2013).

A Educação Permanente não se confunde com os modelos tradicionais de educar por meio da simples transmissão de conteúdo, tampouco se identifica com os modelos de formação e capacitação de pessoas, baseados na apartação dos que pensam, dirigem e planejam, dos que produzem, operam e implementam. Ela também não admite a hierarquização e a fragmentação disciplinar do conhecimento e dos saberes. Diversamente disso, se esforça por instituir um processo de ensino, aprendizagem, investigação e construção de conhecimento fundamentado na valorização da interdisciplinaridade. (BRASIL, 2013, p.36)

Diante de um trabalho multiprofissional, estamos sujeitos a diversas compreensões e contextos. Qualificar em uma perspectiva pedagógica está relacionada diretamente aos coletivos de educação permanente, espaço de discussão onde todos podem contribuir com suas perspectivas sobre o processo de trabalho. Dessa maneira, conforme expressa a Política Nacional de Educação Permanente do SUAS (2013).

Esse esforço de incorporar a interdisciplinaridade é essencial a uma perspectiva pedagógica que pretende qualificar trabalhadores que atuam no contexto de equipes multidisciplinares e que cotidianamente mobilizam processos laborais e práticas profissionais que lidam com contextos de vida experimentados por indivíduos e famílias, cuja compreensão não é possível por meio da perspectiva de disciplinas isoladas. (BRASIL, 2013, p.36)

Desse modo, segundo a Política Nacional de Educação Permanente do SUAS (2013). “A Educação Permanente no SUAS deve responder às questões, demandas, problemas e dificuldades que emergem dos processos de trabalho e das práticas profissionais desenvolvidas pelos trabalhadores". Portanto, o coletivo de educação permanente é instrumento essencial para esta prática.

A aproximação da equipe através dos coletivos e a construção do trabalho interdisciplinar gera ganhos ao processo de trabalho, pois neste ocorre a troca de experiencias e angustias perante o fazer profissional. Dessa maneira, conforme expressa a Política Nacional de Educação Permanente do SUAS (2013).

Nesse sentido, a interdisciplinaridade permite a ampliação do foco da visão profissional, favorecendo maior aproximação das equipes profissionais à integralidade das situações experimentadas por usuários e beneficiários do Sistema, podendo, por isso mesmo, contribuir na formulação de respostas às questões, demandas, problemas e dificuldades que emergem dos processos de trabalho e das práticas profissionais. (BRASIL, 2013, p.36) 


\title{
3.3. Fluxograma analisador
}

Este conceito visa nortear a equipe multiprofissional em seu fazer cotidiano. A partir de um instrumental de análise dos mesmos, construído conjuntamente nos coletivos de educação permanente. Dessa maneira, segundo Barboza (2005):

\begin{abstract}
A questão norteadora deste estudo foi testar junto aos profissionais de saúde o "fluxograma analisador", mediante a verificação dos conteúdos analíticos por ele elaborados, ao visualizarem o processo de trabalho mapeado pelo "fluxograma analisador". Pretendia-se verificar se os profissionais conseguiam identificar se com aquele processo de trabalho desenhado, e a partir disso analisar os problemas e os pontos positivos do mesmo, terminando por elaborar propostas para superação dos problemas. (BARBOZA, 2005, p.1038)
\end{abstract}

Diante do exposto, podemos apontar que o mesmo pode ser utilizado segundo Barboza (2005), com o 'objetivo de discutir e analisar, com profissionais das equipes, o uso do "fluxograma analisador" como um instrumento de autoanálise e de autogestão do processo de trabalho em saúde."

Desse modo, através dos coletivos de educação permanente, os trabalhadores serão incentivados a participar, interagir, e a analisar o processo de trabalho para a efetiva construção do produto final. Dessa maneira, segundo Barboza (2005): “estimulase os profissionais participantes do grupo a emitirem suas considerações sobre o processo de trabalho desenhado no fluxograma exposto."

Entendendo que, a construção do fluxograma é o objetivo principal deste projeto, cabe ressaltar que, segundo Barboza (2005): “o fluxograma analisador é um instrumento potente para avaliação do processo de trabalho."

\subsection{Política Nacional de Assistência Social - PNAS}

A política de assistência social surgiu na IV Conferência Nacional de Assistência Social, realizada em Brasília, em dezembro de 2003, foi aprovada por unanimidade em reunião descentralizada e participativa do Conselho Nacional de Assistência Social no ano de 2004.

A presente Política Nacional de Assistência Social - PNAS busca incorporar as demandas presentes na sociedade brasileira no que tange à responsabilidade política, 
objetivando tornar claras suas diretrizes na efetivação da assistência social como direito de cidadania e responsabilidade do Estado. ${ }^{1}$

Podemos relacionar, a política ao processo de trabalho, segundo a Política Nacional de Assistência Social (2004) “A concepção da assistência social como direito impõe aos trabalhadores da política que estes superem a atuação na vertente de viabilizadores de programas para a de viabilizadores de direitos. Isso muda substancialmente seu processo de trabalho."

\subsection{Centro de Referência em Assistência Social - CRAS}

O CRAS é equipamento base, executor da política de assistência social dentro dos territórios a ele designados, segundo Carloto, C. Castilho. C (2011) "o Centro de Referência da Assistência- CRAS é o equipamento público referência para as ações voltadas às famílias no território de sua abrangência, objetivando a prevenção do rompimento de vínculos e o fortalecimento da convivência familiar e comunitária."

De acordo com o Ministério de Desenvolvimento social (2015), O Centro de Referência de Assistência Social (CRAS) é a porta de entrada da Assistência Social. É um local público, localizado prioritariamente em áreas de maior vulnerabilidade social, onde são oferecidos os serviços de Assistência Social, com o objetivo de fortalecer a convivência com a família e com a comunidade. ${ }^{2}$

São ofertados vários serviços e o atendimento é realizado para todos aqueles que dele precisar, não sendo exigido perfil inicialmente. O trabalho no CRAS é extremamente dinâmico, portanto, é necessário organização e processo de trabalho definido para tal ação. Dessa maneira, conforme expressa a Política Nacional de Educação Permanente do SUAS (2013):

O trabalho desenvolvido no SUAS está organizado em duas funções diferentes e complementares, orientadas para o reconhecimento dos direitos socioassistenciais: a função de gestão e a função de provimento dos serviços e benefícios socioassistenciais. Cada uma delas apresenta suas particularidades relativamente a objetivos imediatos, processos de trabalho, especialidades e composição profissional, mas se unificam em torno de uma mesma finalidade e por estarem contidas em um mesmo contexto sistêmico. (BRASIL, 2013, p.29)

${ }^{1}$ http://www.mds.gov.br/webarquivos/publicacao/assistencia_social/Normativas/PNAS2004.pd

${ }^{2}$ http://mds.gov.br/assuntos/assistencia-social/unidades-de-atendimento/cras 
Naquilo que concerne o processo de trabalho no CRAS e a educação permanente, podemos apresentar de maneira objetiva, conforme expressa a Política Nacional de Educação Permanente do SUAS (2013):

O trabalho relacionado à função de provimento de serviços e benefícios é fundado essencialmente em relações sociais e intersubjetivas. Os conhecimentos teóricos, metodológicos e tecnológicos requeridos apresentam uma estreita vinculação com os contextos históricos, econômicos, políticos e socioculturais. Por isso, essa função requer constante análise, reflexão e adequação - por parte dos trabalhadores - de práticas profissionais e processos de trabalho, seja no que se refere às relações internas às equipes de trabalho, seja no que diz respeito ao trabalho dirigido diretamente aos cidadãos que demandam as proteções da Assistência Social. (BRASIL, 2013, p.30)

Podemos observar que os conceitos dependem um do outro, assim é feito o trabalho de educação permanente, através do trabalho coletivo, reuniões direcionadas, onde todos são participantes interagem em aprendizados concretos, pois a partir da escuta qualificada o grupo consegue compreender o trabalho do outro e se fazer parte do mesmo.

\subsection{Gestão participativa}

Naquilo que tange a gestão participativa, podemos apontar que a mesma representa uma habilidade de cogestão, sendo assim um modelo para tornar o processo de trabalho mais claro e eficiente, conforme expressa, Brasil (2018):

Diante disso, são fomentados a criação e a manutenção de espaços que propiciem a "reflexão crítica e a problematização das situações enfrentadas" no dia a dia do trabalho, "favorecendo o trabalho em equipe", a cogestão, "a gestão participativa e a corresponsabilização nos processos de ensinoaprendizagem para o alcance dos objetivos" institucionais (BRASIL, 2018, p. 25).

O modelo de gestão participativa estimula o trabalho de articulação, movimento este que é preconizado pelo Sistema Único de Assistência Social, onde se envolvem estruturas macro e micro através da rede socioassistencial. Dessa maneira, segundo F.C Brasil (2018):

É neste contexto que percebe-se a importância das relações comunitárias e articulação de rede, uma vez que identifica-se a existência de representação social relacional que aposta na parceria entre profissional, usuários e comunidade para possíveis processos de mudança social e política na vida destes sujeitos. ${ }^{1}$

\footnotetext{
${ }^{1}$ https://www.gesuas.com.br/blog/as-relacoes-comunitarias-e-o-trabalho-do-cras/
} 
A gestão participativa não se faz apenas com as relações profissionais, o usuário também deve ser participante deste processo, sendo estimulado a observar, a cobrar e a sugerir, se tornando protagonista enquanto representante de uma comunidade. Sendo assim, de acordo com Sato (2014):

\begin{abstract}
A participação popular, por não se apresentar inerente à cultura da população brasileira, necessita ser estimulada para que se expresse em sua concretude. Para tanto, acredita-se aqui que os serviços socioeducativos desenvolvidos no CRAS têm o potencial de serem viabilizadores e difusores da ideologia da cultura de direitos. Uma vez focados no alargamento da participação dos usuários nos espaços decisórios das políticas públicas e, ainda, das instâncias de decisões da totalidade da sociedade do qual fazem parte, estes serviços tornam-se ferramentas fundamentais à efetivação do exercício dos poderes econômicos, culturais, políticos e sociais por aqueles que são socialmente explorados. (SATO, 2017, p.11)
\end{abstract}

Assim como os profissionais tem o dever de conhecer o serviço, os usuários também tem o direito de ter posse desses saberes. A gestão participativa enquanto modelo e ferramenta, poderá proporcionar ao usuário esse entendimento, e assim a oportunidade de fortalecer essa relação. Segundo Sato (2018). "Uma estratégia de promoção do protagonismo popular consiste em fomentar a desburocratização das relações com os sujeitos que reivindicam direitos e serviços, melhorando, assim, qualidade do atendimento"

A Política Nacional de Assistência Social, conceito também citado neste trabalho, enfatiza a participação popular, "[...] de modo a torná-la uma de suas principais diretrizes, assegurando instâncias fomentadoras do controle social, como as Conferências e os Conselhos." ${ }^{1}$. Segundo Sato (2018). "O direito ao protagonismo popular é o que essa nova política traz de mais progressista, por visar o controle social, o protagonismo de seus usuários em sua construção."

Através de todos esses conceitos e ferramentas, podemos compreender que é possível tornar o processo de trabalho mais eficaz, fazendo o uso da participação de todos, sendo eles, profissionais, gestores e usuários, todos aqueles que fazem parte da política como um todo. Utilizando assim a educação permanente na construção dessa cadeia coletiva de saberes.

\footnotetext{
${ }^{1}$ https://tede2.pucsp.br/handle/handle/17696
} 


\title{
3.7. Trabalho em equipe
}

O trabalho em equipe é um dos conceitos mais importantes neste trabalho, ele representa para além da compreensão dos processos vivenciados durante toda a formação neste curso de especialização, esse conceito representa a transformação e o amadurecimento de uma equipe de trabalho através da educação permanente.

Compreender as dificuldades faz parte da formação dos coletivos de educação permanente que foram inseridos no equipamento através das atividades propostas durante o curso. Entender que para alguns problemas encontraremos alternativas coletivamente e que para outros dependemos de ações que estão além do nosso domínio, é um dos pontos que fortalece a construção coletiva. Sendo assim, segundo Silveira (2009):

As fragilidades presentes na gestão e na participação em âmbito local reforçam limitações que são constitutivas dos processos descentralizadores, revelando a tendência aos arranjos institucionais que podem banalizar o próprio Suas. Há uma tendência dos municípios e estados cumprirem requisitos mínimos para manter o financiamento sem necessariamente expressar qualidade na estruturação da rede socioassistencial e das condições institucionais de gestão. Silveira (2009, p. 343)

Os espaços sócio-ocupacionais, estão repletos de fragilidades, o serviço público não está isento dessa premissa, enfrentamos diariamente forças políticas, precarização das condições de trabalho e também dos contratos profissionais, falta de gestão e recursos, entre outros. Segundo Raichelis (2010):

\begin{abstract}
A implantação do Suas e sua rápida expansão por todo o território nacional vem ampliando consideravelmente o mercado de trabalho para os assistentes sociais e demais profissionais atuantes nessa área. Ao mesmo tempo e no mesmo processo, contraditoriamente, aprofundam a precarização das condições em que este trabalho se realiza, considerando o estatuto de trabalhador assalariado do assistente social, subordinado a processos de alienação, restrição de sua autonomia técnica e intensificação do trabalho a que estão sujeitos os trabalha- dores assalariados em seu conjunto. (RAICHELIS, 2010, p.751)
\end{abstract}

Essas condições afetam diretamente a equipe, e, portanto, o trabalho desta. Uma fragilidade em especifico reflete continuamente no trabalho do CRAS, e o nó critico encontrado através do coletivo de educação permanente formador deste projeto relata este problema. As mudanças corriqueiras dos profissionais não só afetam os mesmos, 
mas tudo aquilo que envolve o serviço prestado pelo equipamento. Como a falta de conhecimento por parte dos profissionais e a inconstância das ações e acompanhamentos. Sendo assim, segundo Raichelis (2010):

A NOB-RH/Suas prevê a formação de equipes de referência, que devem ser constituídas por servidores efetivos responsáveis pela organização e oferta de serviços, programas, projetos e benefícios de proteção social básica e especial, levando-se em consideração o número de famílias e indivíduos referência dos por porte dos municípios, tipo de atendimento e aquisições e direitos que devem ser garantidos aos usuários. (RAICHELIS, 2010, p.764)

Porém, compreendendo que muitas ações fogem a nossa competência, precisamos criar estratégias de enfretamento dessas problemáticas. E uma delas é entender cada área profissional e o fazer delas dentro do serviço, assim o trabalho em equipe se torna mais conciso e efetivo para todos que estão inseridos naquele ambiente. Segundo Raichelis (2010):

Trata-se de um processo de grande complexidade, pois cada uma das categorias profissionais envolvidas tem uma história particular de organização e de luta corporativa e sindical, com acúmulos e reivindicações específicas no que tange às condições de exercício do trabalho, aos conhecimentos e saberes construídos, aos parâmetros éticos-políticos orientadores do trabalho profissional. (RAICHELIS, 2010, p.764)

O trabalho em equipe consiste no respeito ao fazer profissional de cada um, além de representar parceria e comprometimento, entendendo que não conseguiremos construir um coletivo sem estes aspectos, partindo da premissa que o processo de trabalho depende dessa construção e somente a partir da junção de todos estes elementos será possível fortalecer o serviço.

\section{CONSIDERAÇÕES FINAIS}

Mediante o exposto podemos destacar que em uma perspectiva teleológica, o maior propósito apresentado neste projeto foi a organização do processo de trabalho de um espaço sócio ocupacional, onde atua uma equipe multiprofissional.

Porém, não podemos deixar de lado todo o esforço empreendido durante esses meses de preparação, e a formação de um coletivo de educação permanente, antes inexistente e sem nenhuma perspectiva de aplicabilidade.

Esses foram alguns dos resultados alcançados através deste projeto, podemos também levar em consideração o espaço coletivo que foi idealizado e posto em prática 
através do mesmo, como disse anteriormente era inexistente, e hoje se torna uma ferramenta capaz de propor mudanças e reforçar ações dentro do espaço de trabalho.

O projeto resultou em diversos ganhos para o processo de trabalho, por consequência para a equipe e seus colaboradores. Em sua construção o coletivo pôde ter a ciência de que é capaz de transformar o processo de trabalho a fim de melhora-lo a partir da iniciativa do grupo, e que os participantes tem muito mais a oferecer do que imaginam.

\section{REFERÊNCIAS}

BARBOZA, Tatiane Aparecida Venâncio and FRACOLLI, Lislaine Aparecida. A utilização do "fluxograma analisador" para a organização da assistência à saúde no Programa Saúde da Família. Cad. Saúde Pública [online]. 2005, vol.21, n.4, pp.1036-1044. ISSN 0102-311X. https://doi.org/10.1590/S0102-311X2005000400006.

BRASIL, Fernanda Campos, As relações comunitárias e o trabalho do CRAS. São Paulo, 2018. Disponivel em: https://www.gesuas.com.br/blog/as-relacoescomunitarias-e-o-trabalho-do-cras/. Acesso em: 31 março.2020.

BRASIL, Política Nacional de Educação Permanente do SUAS/ Ministério do Desenvolvimento Social e Combate à Fome - 1a ed. - Brasília: MDS, 2013, 57p.

(2005) Ministério da Saúde. Secretaria de Gestão do Trabalho e da Educação na Saúde. Departamento de Gestão da Educação na Saúde. A educação permanente entra na roda: pólos de educação permanente em saúde: conceitos e caminhos a percorrer. 2. ed. -Brasília: Ministério da Saúde, 2005.

(2004) Ministério da Saúde. Secretaria de Gestão do Trabalho e da Educação na

Saúde. Departamento de Gestão da Educação na Saúde. Política de educação e desenvolvimento para o SUS: caminhos para a educação permanente em saúde: pólos de educação permanente em saúde. 1. ed. Brasília: Ministério da Saúde.

(2004). Ministério de desenvolvimento social e combate à fome. Política Nacional de Assistência Social (PNAS) - Brasília, secretaria Nacional de Assistência Social.

(2005) Ministério de desenvolvimento social e combate à fome. Norma Operacional Básica de Recursos Humanos do SUAS - NOB/SUAS, Secretaria Nacional de Assistência S n ${ }^{\circ} 109$, de 11 de novembro de 2009, publicada no DOU em 25 de novembro de 2009.Brasília. 
(2008). Ministério de desenvolvimento social e combate à fome. Secretaria Nacional de Assistência Social. Cadernos CAPACITASUAS. n.1. SUAS: configurando os eixos de mudança. Brasília: MDS; São Paulo: IEE/PUC-SP.

(2018). Ministério da Saúde. Secretaria de Vigilância em Saúde. Departamento de Vigilância Epidemiológica. Educação Permanente como ferramenta estratégica de gestão de pessoas - Experiências exitosas da cooperação entre a Secretaria-Executiva do Ministério da Saúde e a Fundação Oswaldo Cruz / Ministério da Saúde, Secretaria-Executiva - Brasília : Ministério da Saúde. Disponivel em: http://bvsms.saude.gov.br/bvs/publicacoes/educacao_permanente_ferrament a_estrategica_gestao_pessoas.pdf. Acesso em: 31 março.2020.

CARLOTO, Cássia. CASTILHO Cleide. A política de assistência social no Brasil: seu modelo protetivo e a permanência da família burguesa, 2011. Disponivel em: http://www.uel.br/eventos/gpp/pages/arquivos/Cassia\%20Carloto\%20e\%20Cia .pdf>.Acesso em: 24 fev. 2020.

CECCIM, R. B. Educação permanente em saúde: desafio ambicioso e necessário. Interface - comunicação, saúde, educação, 9(16): 161-178, set. 2004-fev., 2005.

Centro de Referência da Assistência Social. Disponível em http://www.mds.gov.br/assistenciasocial/protecaobasica/cras: Acesso em: 24 fev.2019.

GIL, Antonio Carlos. Como elaborar projetos de pesquisa. São Paulo: Atlas,2002.

MINAYO, Maria Cecilia de Souza. 1994. Ciência, técnica e arte: o desafio da pesquisa social. In: Pesquisa social: teoria, método e criatividade (M.C.S. Minayo, org.). Petrópolis: Vozes.

SATO, Christiane Shoihi, 2014. A participação do usuário nos centros de referência de assistência social do município de Poços de Caldas - Minas Gerais, São Paulo, 2014.

SILVEIRA, Jucimeri I. Sistema Único de Assistência Social: institucionalidade e processos interventivos. Serviço Social \& Sociedade, São Paulo, n. 98, 2009.

RAICHELIS, Raquel. Intervenção profissional do assistente social e as condições de trabalho no Suas, Serv. Soc. Soc., São Paulo, n. 104, p. 750-772, out./dez. 2010. Disponível em: http://www.scielo.br/pdf/sssoc/n104/10.pdf. Acesso em: 31 mar. 2020. 


\title{
CAPÍTULO VII
}

\section{CONSTRUÇÃO COLETIVA DO PROJETO POLÍTICO PEDAGÓGICO NA EDUCAÇÃO DO CAMPO}

\author{
Mikael Jurandir da Silva ${ }^{1}$ \\ Verônica Resendes Santos ${ }^{2}$
}

${ }^{1}$ Pedagogo pela UNEB e especialista em Gestão Escolar pela UNIASSELVI.
2 Pedagoga pela UNEB e especialista em Administração Escolar, Supervisão e Orientação pela UNIASSELVI.

RESUMO

A discussão proposta neste artigo consiste em problematizar a participação da comunidade na (re) construção coletiva do PPP no âmbito da Educação do Campo. A metodologia de pesquisa utilizada constitui-se em abordagem qualitativa, caracterizada também como descritiva e explicativa. Para coletar os dados e informações foi utilizado o questionário aberto com a coordenadora pedagógica de uma escola do campo no município de Paulo Afonso/BA. Os principais autores que fundamentam o estudo são: Pires (2012); Souza e Bahia (2014) Veiga (2010); e Garcia (2008). Sendo assim, é possível argumentar que o PPP é de fundamental importância para a Educação do Campo e sua construção coletiva, participativa e democrática permite que as principais demandas e anseios de todos os sujeitos envolvidos no processo educativo sejam contempladas nesse documento que deve ser a referência para todo trabalho pedagógico realizado durante o ano letivo na instituição escolar.

Palavras-chave: Educação Campo. Projeto Político Pedagógico. Construção Coletiva.

\section{INTRODUÇÃO}

O Projeto Político Pedagógico (PPP) é primordial em uma instituição de ensino, configurando-se em um documento que norteia todo o processo educativo. Para sua construção é importante conhecer o contexto sociocultural dos sujeitos e da comunidade em que a escola está inserida. Segundo Vasconcellos (2006) é possível considerar que o Projeto Político Pedagógico está sempre em movimento, intervém nas realidades onde as instituições estão alocadas e também define nitidamente as propostas e a concepção de educação que pretende seguir.

As instituições de ensino, formais ou informais, em hipótese alguma estão alheias às subjetividades e intersubjetividades presentes nos contextos nos quais as 
escolas estão inseridas e dos sujeitos que participam desses processos emancipatórios e de pertencimento. Possuem autonomia e liberdade em esquematizar o PPP considerando as peculiaridades e pretensões que cada grupo social ou étnico possui.

Deste modo, o objetivo deste trabalho é analisar como é desenvolvida a construção do Projeto Político Pedagógico em uma escola do campo no município de Paulo Afonso/BA, bem como se esse PPP é construído coletivamente.

Assim, a presente investigação é de abordagem qualitativa, uma vez que lida com as subjetividades apresentadas pelos sujeitos que dão significados próprios aquilo que praticam, dizem e vivenciam. Ademais, neste tipo de paradigma de pesquisa, o pesquisador tem a grande responsabilidade de analisar e interpretar os dados, fatos e informações sem modificá-los. Nesse sentido, Minayo (2008, p. 57), afirma que a abordagem qualitativa é fruto "[...] dos produtos das interpretações que os humanos fazem durante suas vidas, da forma como constroem seus artefatos materiais e a si mesmos, sentem e pensam".

No que tange aos fins, esta investigação é caracterizada como descritiva e explicativa. A pesquisa descritiva "procura descobrir a frequência com que um fato ocorre, sua natureza, suas características, causas, relações com outros fatos" (PRODANOV; FREITAS, 2013, p. 52). Deste modo, o pesquisador expõe e realiza o registro dos fenômenos, sem, contudo, alterá-los. Já "a pesquisa explicativa apresenta como objetivo primordial a necessidade de aprofundamento da realidade" (PRODANOV; FREITAS, 2013, p. 54), buscando esclarecer a razão pela qual determinados fatos ocorrem.

No que se refere aos procedimentos é possível afirmar que esta pesquisa pode ser descrita como um estudo de caso, pois tem como local de estudo uma situação em particular, que é o processo de elaboração/atualização do PPP em uma escola do campo no município de Paulo Afonso/BA. Segundo Severino (2017, p. 112) o estudo de caso é uma "pesquisa que se concentra no estudo de um caso em particular, considerado representativo de um conjunto de casos análogos [...]"

Como instrumento para obtenção dos dados empíricos, utilizou-se o questionário com perguntas abertas, que consiste em um conjunto sistematizado de perguntas que devem ser respondidas pelo sujeito da investigação, assim como afirma 
Gressler (1983) o questionário é constituído pela seleção proposital de questões para obter dados e informações a fim de responder as problematizações propostas na pesquisa.

Deste modo, a escolha da abordagem e dos métodos da pesquisa justificam-se por proporcionar a coleta e análise subjetiva das implicações da coordenação pedagógica, na construção coletiva do Projeto Político Pedagógico, uma vez que o profissional que desempenha essa função é também o articulador do currículo nas instituições de ensino.

A coordenação pedagógica tem papel fundamental na articulação para construção coletiva do PPP e esse projeto deverá evidenciar a identidade da escola e o que a instituição escolar idealiza, quais suas finalidades, escopos e quais os caminhos que serão seguidos para atingir os objetivos. O PPP não é fixo, mas flexível o bastante para ser moldado às necessidades dos discentes e da comunidade em suas determinadas realidades.

\section{O PROJETO POLÍTICO PEDAGÓGICO DA ESCOLA DO CAMPO}

Na contemporaneidade a Educação do/no Campo está sendo problematizada, a princípio, nos espaços acadêmicos/científicos, pelos movimentos sociais populares campesinos que criam conhecimentos, vivências e fortes resistências ao modelo predatório de educação rural imposta pelas políticas públicas (ou pela falta delas) e ideologização dos grandes latifundiários, do agronegócio, das políticas neoliberais.

Diante da falta de políticas públicas e/ou ineficácia do Estado na valorização dos sujeitos do campo, a escola e os movimentos sociais populares assumiram o compromisso de (re) significar seus valores, tradições, saberes, fazeres e a educação contextualizada, ou seja, não estereotipada.

As resistências a uma escola rural homogênea e controladora que se figura como equalizadora sociocultural, estão construindo um processo educativo que respeita as subjetividades e intersubjetividades; que elabora o currículo levando em consideração as adjacências, história, reminiscências, cultura, valores, práticas pedagógicas e saberes próprios dos atores e atrizes do campo.

Para Pires (2012, p. 43) “o campo precisa ser compreendido como um modo de vida sociocultural no sentido de que sejam afirmadas as suas identidades, bem como 
suas lutas e organizações". Deste modo, a construção do Projeto Político Pedagógico (PPP) é de fundamental importância, porque nele constam as intenções pedagógicas da instituição, que pode (re) afirmar suas identidades. Contudo, sua construção deve estar pautada na coletividade e ainda deve ser reflexiva quanto a sua realidade social e educacional.

O PPP também aponta o caminho que deverá ser percorrido durante o ano letivo, e tem sempre objetivos claros a respeito de onde se pretende chegar tomando sempre como referência o ponto de partida. Para Veiga (2010, p. 4) “como espaço da atividade humana, o projeto político-pedagógico exige um compromisso ético-político de adequação intencional do real ao ideal". Exige também, uma gestão democrática, pois, a instituição escolar está a serviço da comunidade, propondo e executando trabalhos educativos de acordo com a realidade pedagógica do campo. Segundo Vasconcellos (2006, p. 169) o PPP:

Pode ser entendido como sistematização, nunca definitiva, de um processo de Planejamento Participativo, que se aperfeiçoa e se concretiza na caminhada, que define claramente o tipo de ação educativa que se quer realizar. É um instrumento teóricometodológico para a intervenção e mudança da realidade. É um elemento de organização e integração da atividade prática da instituição neste processo de transformação.

Para Veiga (2010, p. 1), o PPP é "concebido na perspectiva da sociedade, da educação e da escola, ele aponta um rumo, uma direção, um sentido específico para um compromisso estabelecido coletivamente". Assim, os PPPs das escolas precisam ser únicos, vinculados às especificidades de cada localidade. Esse documento quando construído dentro da coletividade e democraticamente, considera as especificidades dos sujeitos do campo, portanto aponta um rumo, possibilita a ideia de futuro, de recriação. Segundo Veiga (2000, p. 13) o PPP em

Sua dimensão política se vincula ao compromisso com a formação do cidadão para um tipo de sociedade. [...] Na dimensão pedagógica reside a possibilidade da efetivação da intencionalidade da escola, que é a formação do cidadão participativo, responsável, compromissado, crítico e criativo. [...] político e pedagógico têm assim uma significação indissociável. Nesse sentido é que se deve considerar o projeto político-pedagógico como um processo permanente de reflexão e 
discussão dos problemas da escola, na busca de alternativas viáveis à efetivação de sua intencionalidade. [...] Por outro lado, propicia a vivência democrática necessária para a participação de todos os membros da comunidade escolar e o exercício da cidadania. Pode parecer complicado, mas trata-se de uma relação recíproca entre a dimensão política e a dimensão pedagógica da escola.

O PPP precisa sempre ser revisto, reformulado, (re) significado, visto que mudanças políticas e pedagógicas sempre irão acontecer e a escola precisa estar atenta a isso. A legislação brasileira, em especial, a Lei 9.394/96 que estabelece a Lei de Diretrizes e Bases da Educação Nacional (LDB), em seu Art. 12, coloca que: "Os estabelecimentos de ensino, respeitadas as normas comuns e as do seu sistema de ensino, terão a incumbência de: I - elaborar e executar sua proposta pedagógica" [...] (BRASIL, 1996). Dessa forma, as instituições de ensino têm autonomia para construção, reelaboração ou atualização das suas Propostas Político Pedagógicas alinhadas às suas realidades pedagógicas específicas.

Nesse sentido, as Diretrizes Operacionais da Educação Básica das Escolas do Campo (BRASIL, 2001, p. 23) estabelecem em seu artigo $4^{\circ}$ que:

O projeto institucional das escolas do campo, expressão do trabalho compartilhado de todos os setores comprometidos com a universalização da educação escolar com qualidade social, constituirse-á num espaço público de investigação e articulação de experiências e estudos direcionados para o mundo do trabalho, bem como para o desenvolvimento social, economicamente justo e ecologicamente sustentável.

Assim, o Projeto Político Pedagógico deve ser o resultado de uma construção coletiva que interliga os saberes/fazeres dos povos do campo, frutos das relações sociais, culturais, históricas e das suas relações "ecoambientais". E por ser um documento, deve possuir um estilo formal. E também estar sempre à disposição de todos os professores, alunos, administração escolar, coordenação pedagógica e toda a comunidade do campo, para eventuais consultas.

O decreto Presidencial $n^{\circ} 7.352$ de 04 de novembro de 2010, artigo 2, inciso II, afirma que para as escolas do campo é necessário o: 
[...] II - incentivo à formulação de projetos político-pedagógicos específicos para as escolas do campo, estimulando o desenvolvimento das unidades escolares como espaços públicos de investigação e articulação de experiências e estudos direcionados para o desenvolvimento social, economicamente justo e ambientalmente sustentável, em articulação com o mundo do trabalho. (BRASIL, 2010).

É importante considerar as especificidades deste território tão rico e construir PPP a partir das experiências locais e globais, para que suas raízes culturais e históricas não sejam distorcidas ou excluídas. Corroborando com isso, Demo (1998, p. 248), afirma:

Existindo projeto pedagógico, próprio, torna-se mais fácil planejar o ano letivo, ou rever e aperfeiçoar a oferta curricular, aprimorar expedientes avaliativos, demonstrando a capacidade de evolução positiva crescente. É possível lançar desafios estratégicos, como: diminuir a repetência, introduzir índices crescentes de melhoria qualitativa, experimentar didáticas alternativas, atingir posição de excelência.

Quando o PPP é específico no que se propõe, pode trazer mudanças necessárias para alcançar a educação que os povos do campo almejam, possibilitar a inovação das práticas pedagógicas, dos processos avaliativos e promover transformações no campo.

Para Veiga (2010, p. 1), quando o PPP é construído democraticamente “[...] constitui-se como processo e, ao fazê-lo, reforça o trabalho integrado e organizado da equipe escolar, assumindo sua função de coordenar a ação educativa da escola para que ela atinja o seu objetivo político-pedagógico". Ele deve focar no desenvolvimento integral dos sujeitos, para não deixar a desejar no que se refere as suas metas para o ano letivo vigente e maleável o suficiente para, caso necessário, adaptarse as exigências e às necessidades de aprendizagem dos alunos, bem como às demandas da comunidade.

A construção do PPP precisa de uma arquitetura democrática e autônoma dos professores, coordenadores pedagógicos, gestores educacionais, funcionários, alunos e pais, assim como aponta Garcia (2008, p. 23): 
A gestão democrática, enquanto política afirmativa do campo e da cidade é requisito para a consolidação do Projeto Político Pedagógico. Pois, será a gestão democrática que possibilitará a mobilização e o envolvimento dos sujeitos sociais nas diversas etapas de construção do Projeto Político Pedagógico; elegerão as prioridades da escola e proporão as melhorias no processo ensino aprendizagem.

Portanto, o PPP não pode ficar engavetado ou ser construído de forma distorcida e distanciada da sua materialidade histórica e cultural. Esse documento deve ser "vivo" como parâmetro para problematizar as experiências e referências, na tentativa de solucionar de forma solidária e democrática os problemas que emergem no território geográfico rural. Para Pires (2012, p. 117), o Projeto Político Pedagógico deve ser articulado e construído em cinco eixos primordiais, a saber:

- As relações entre educação e trabalho, teoria e prática social;

- A ação investigativa, questionadora e criativa;

- As relações entre educação, cultura, política e economia;

- O trabalho coletivo, a construção da autonomia dos coletivos de docente e discentes; e

- A gestão democrática, dentre outros.

Organizar esse modelo de projeto é ressignificar, dar sentido próprio e valorizar a relação de pertencimento e identidade, tanto dos alunos, pais, professores, funcionários e gestores, quanto do próprio significado das relações históricas, configurando sua própria realidade. Isso só será possível se a comunidade escolar participar ativamente de todo o processo de construção do documento, caso contrário, a relação de pertencimento pode ficar distanciada daquilo que a proposta escolar almeja nas relações identitárias, quebras de estereótipos, qualidade social da educação e aprendizagens significativas. Pois, “(...) construir o projeto pedagógico de uma escola é mantê-la em constante estado de reflexão e elaboração numa esclarecida recorrência às questões relevantes de interesse comum e, historicamente, requeridos" (GADOTTI, 2000, p. 71).

$\mathrm{Na}$ Educação do/no Campo diversos outros aspectos devem ser considerados na construção da proposta do PPP, entre alguns estão as pautas das lutas sociais dos movimentos sociais populares, como reafirma Pires (2012, p. 110) quando diz que: 
Pesquisas mostram, também, que embora a realização do projeto político-pedagógico da escola do campo seja uma tarefa complexa o próprio movimento popular vem historicamente atuando na sua construção, tendo em vista que esta nova escola torna-se cada vez mais necessária como instrumento de apoio técnico, intelectual e político nas lutas que os trabalhadores (as) do campo travam diariamente.

Os movimentos sociais estão diretamente ligados e atuantes na retomada de consciência emancipatória com os agricultores (as) e todos os povos que compõem o campo, bem como na reconstrução de seus processos identitários. As suas cobranças e reivindicações provocaram transformações profundas na maneira de enxergar o campo e seus sujeitos, pois as trocas de saberes que os movimentos sociais oferecem podem ressignificar suas relações de pertencimento e sua realidade pedagógica.

Além disso, busca problematizar discussões sobre o momento (passado, presente e futuro) político, desenvolvimento ecologicamente correto e social. Corroborando com isso, Garcia (2008, p. 122) destaca que:

Com isso, a dimensão humana da educação vai se explicitando e dando corpus à natureza política e pedagógica da escola. Porém, para ser própria de humanos, de valores humanos, a gestão escolar tem que estar revestida de práticas voltadas para a participação de todos os segmentos que constitui a comunidade escolar. Ao construir o Projeto Político Pedagógico, a escola, a comunidade escolar, está exercendo sua autonomia. Autonomia que não implica em proclamar a independência em relação ao poder público.

A subjetividade das relações humanas também implica intervenções nas questões políticas e pedagógicas quando há participação nas decisões construtivas do PPP. São precisamente as individualidades que tornam os sujeitos únicos e particulares, essas características possibilitam a tomada de consciência política e pedagógica de transformar e ressignificar o PPP, consequentemente poderá representar cada sujeito e cada grupo que constitui a realidade pedagógica, social, cultural e histórica dos sujeitos do campo. 


\section{CONSTRUÇÃO COlETIVA dO PROJETO POLÍTICO PEDAGÓGICO}

Assim como já mencionado, o Projeto Político Pedagógico de uma instituição escolar, constitui-se um documento que deve nortear todas as ações desenvolvidas nesse espaço. Para Vasconcelos (2004, p. 25) o PPP

[...] deve expressar de maneira simples (o que não significa dizer simplista) as opções, os compromissos, a visão de mundo e as tarefas assumidas pelo grupo; de pouco adianta um Projeto com palavras "alusivas", chavões, citações e mais citações, quando a comunidade sequer se lembra de sua existência.

Ademais, para que seja de fato realizável, isto é, posto efetivamente em prática é necessário que seja construído com a participação da comunidade escolar e local, a fim de que nele constem os anseios de cada segmento da instituição, assim como o tipo de sujeito o qual se pretende formar.

Por esse motivo, o processo de construção de qualquer PPP deve respaldar-se em uma determinada concepção de educação, que consiste em uma referência teórica que deve orientar toda a ordenação das instâncias pedagógicas e administrativas, dos tempos e espaços no âmbito escolar; dos métodos, estratégias, práticas e do currículo (OLIVEIRA; SOUZA; BAHIA, 2014).

O PPP é um dos pontos de partida para uma educação contextualizada, democrática e emancipatória, desde que seja construído coletivamente, esse modo de construí-lo em conjunto "[...] é regido pelo intercâmbio e pela cooperação" (VEIGA, 2003, p. 278). Nesse sentido, Veiga (2003) faz uma pertinente discussão sobre a relação entre inovação e PPP, este quando construído sob uma ótica emancipatória e edificante promove rupturas com o modo no qual têm sido implementadas as propostas de melhoria da qualidade da educação.

Neste sentido, as inovações não devem ter caráter prescritivo, pois "prescrições, por si sós, são vazias ou podem ser descartadas, se não tiverem a concordância e a cooperação de todos os envolvidos" (OLIVEIRA; SOUZA; BAHIA, 2014, p. 51). Sendo assim, reafirma-se a essencialidade de se construir coletiva e dialeticamente todo o conjunto que compõe o PPP. Assim, a coordenadora pedagógica, sujeito desta investigação, afirma: 
A verdadeira função do PPP é auxiliar a gestão da escola e a prática de ensino. Mas, para isso, é preciso atualizá-lo de maneira que ele permita cumprir esta função. Há partes do PPP que não precisam de atualização anual, apenas quando há necessidade. Além disso, é preciso que a equipe pedagógica trabalhe nele antes, preparando dados para mostrar aos demais membros da equipe. Assim, facilita para que sejam decididas ações para ajudar no cotidiano escolar. (COORDENADORA PEDAGÓGICA).

Entretanto, o PPP de uma escola é mais que um auxílio para os docentes e a gestão escolar, pois ele é a referência, o norte da instituição, nele estão elencados de forma sistematizada o caminho que deve ser percorrido, o conhecimento científico que deve ser aprendido e o que deve ser realizado por todos os envolvidos, para atingir os objetivos pretendidos e por isso deve ser constantemente consultado. Ademais, a CP traz implícita na sua fala a importante atuação da equipe diretiva no que se refere à coleta e seleção de dados pertinentes da realidade escolar, para serem apresentados aos demais nos momentos de encontro para discussão e tomada de decisões no que se refere à atualização anual do documento, visando a melhoria do processo ensinoaprendizagem.

Considera-se fundamental refletir acerca das práticas educativas em um processo de autoavaliação constante para se ter certeza de que estão sendo realizados os esforços necessários para o cumprimento da proposta pedagógica da escola, mas se após esse processo percebe-se que o conjunto das práticas na instituição está se afastando do que se propôs coletiva e dialeticamente no PPP, surge a tarefa da coordenação pedagógica e da administração escolar como corresponsáveis pelo trabalho de integração da equipe, sobretudo, do corpo docente.

A esse processo dá-se o nome de gestão pedagógica que é um trabalho de coordenação dos esforços coletivos para atingir objetivos previamente estabelecidos e que "[...] envolve a articulação entre concepções, estratégias, métodos e conteúdos, assim como demanda esforços, recursos e ações, com foco nos resultados pretendidos" (LÜCK, 2009, p. 94).

A CP fala também do processo de atualização do PPP, tarefa essencial dada a dinamicidade do processo educativo e as constantes e rápidas mudanças ocorridas na 
sociedade. Sendo assim, reconhece-se a importância de considerar aquilo que já é conhecido, isto é, a trajetória da escola e dos atores e atrizes que a integram, mas é necessário dar atenção ao novo, uma vez que no mundo contemporâneo tudo se transforma radicalmente e a escola tem a responsabilidade de estar preparada frente essas mudanças, para incorporá-las, contestá-las e se necessário, discuti-las. (OLIVEIRA; SOUZA; BAHIA, 2014, p. 41).

De acordo com a CP, o espaço-tempo destinado à discussão do currículo, PPP, projetos escolares e outros temas, é "a Jornada Pedagógica e os momentos de ACs (Aulas Complementares)" (COORDENADORA PEDAGÓGICA).

É importante salientar que as discussões, construção e implementação do disposto no PPP, documento que deve orientar todas as práticas educativas desenvolvidas na escola, não pode ser centralizada em uma única pessoa, nele deve constar as pretensões, anseios, desejos e objetivos dos sujeitos do processo que por ser construído dialeticamente, reflete a identidade da escola.

Por esse motivo faz-se necessária uma mudança na forma de conceber o PPP escolar, que por vezes é visto apenas como algo burocrático, construído para cumprir as normas estabelecidas pelos sistemas de ensino, sendo assim é importante que a construção coletiva e democrática, na qual os docentes, alunos, pais, comunidade, ou seja, todos os segmentos envolvidos no processo de (re) elaborações/atualizações devem participar da tomada de decisões. Nesse sentido, segundo a CP:

As relações de trabalho no interior da escola devem estar calcadas nas atitudes de solidariedade, reciprocidade e participação coletiva, favorecendo a reflexão e diálogo para a definição das ações educativas para que assegurem um espaço necessário na democratização do ensino. (COORDENADORA PEDAGÓGICA).

A CP acrescenta que conseguiu efetivar a participação da comunidade na construção do PPP por meio de reuniões e que os docentes participam ativamente dos espaços-tempos propostos pela gestão (como currículo, PPP, projetos escolares e outros temas) e que isso acontece "através de reuniões pedagógicas/Aulas Complementares" (COORDENADORA PEDAGÓGICA). O PPP é também um mecanismo que ajuda a assegurar a gestão democrático. A respeito do tema a CP diz: 
Desenvolvemos mecanismos de conhecimento dos nossos alunos, quais as suas condições de vida, as suas aspirações, as expectativas da família e da comunidade. Realizamos levantamentos e estudos das manifestações culturais locais que, incorporadas ao currículo, estabeleçam elos significativos com o conhecimento escolar formal, fazendo emergir a identidade da comunidade que participa da nossa escola. (COORDENADORA PEDAGÓGICA).

A CP faz o relato de uma metodologia relevante para a construção/(re)elaboração do PPP que também ajuda a conhecer melhor o contexto sociocultural em que a escola e todos os seus atores e atrizes estão inseridos: pesquisar sobre a cultura e identidade local e saber o que a comunidade almeja. Para Veiga (2003, p. 274) um bom PPP “[...] procura maior comunicação e diálogo com os saberes locais e com os diferentes atores e realiza-se em um contexto que é histórico e social, porque humano".

A escola, na elaboração do planejamento das suas ações educacionais, deve considerar a gênese da visão de sociedade, comunidade e de mundo que os sujeitos do campo estão alocados, concretizando uma ação intencional e clara, firmando compromisso coletivizado construído e vivenciado historicamente e socialmente por atores e atrizes do campo e dos movimentos sociais populares, como afirma Pires (2012, p. 110) quando diz que:

\footnotetext{
Pesquisas mostram, também, que embora a realização do projeto políticopedagógico da escola do campo seja uma tarefa complexa o próprio movimento popular vem historicamente atuando-se cada vez mais necessária como instrumento de apoio técnico, intelectual e político nas lutas que os trabalhadores (as) do campo travam diariamente.
}

Os movimentos sociais também são importantes na luta por um PPP que contemple as lutas por uma Educação do/no Campo. Esse documento se tornou um instrumento teórico-metodológico, que reúne esforços intelectuais e vivências que os movimentos sociais intervêm magnificamente bem na resolução de problemas que emergem da realidade camponesa.

No que se refere as dificuldades que enfrenta na Educação do Campo no processo de construção/atualização do Projeto Político Pedagógico a CP aduz: 
A maior dificuldade é a proposta de pesquisa, que é identificar e reconhecer quais os são os desafios da escola do campo na construção e/ou na ressignificação do Projeto Político-Pedagógico com a incorporação dos saberes e os fazeres do campo com a efetiva participação da comunidade escolar. (COORDENADORA PEDAGÓGICA).

A fala da coordenadora evidencia o desconhecimento sobre as dificuldades e os desafios presentes em sua própria realidade educacional. Isso traduz-se em descontextualização da proposta política pedagógica da escola, fugindo do seu objetivo primordial que é, segundo Caldart, Arroyo e Molina (2011), criar/transformar as escolas no território geográfico rural em Escola do Campo, estas devem possuir um PPP alinhado aos anseios, desejos e realidade social, histórica e cultural dos camponeses.

A CP diz que "para solucionar/superar as dificuldades na escola do campo onde atua, tem como base o diálogo" (COORDENADORA PEDAGÓGICA). Algo importante na fala dela é que para solucionar os problemas existentes possui a dialogicidade como premissa constitutiva. Dialogar com os estudantes, professores, gestão, comunidade e os movimentos sociais além de uma ação descentralizadora torna-se democrática e participativa.

Nessa perspectiva, a concepção dialética deve ser a base de um Projeto Político Pedagógico democrático. "Essa concepção considera, por um lado, o homem como a síntese de múltiplas relações e, por outro lado, o contexto socioescolar como instância privilegiada para a compreensão dos problemas educacionais". (OLIVEIRA; SOUZA; BAHIA, 2014, p. 43).

Segundo a CP, atuar na Educação do Campo é complexo, pois:

Temos uma escola onde a participação dos pais ainda não é suficiente, pois não participam ativamente da vida escolar dos filhos, muitos deles por ser trabalhador rural ou até mesmo por não ter um grau de instrução apropriado, não se sentem preparados para tal. No entanto, a nossa escola está bastante empenhada em buscar essa participação, a fim de que eles se envolvam com a aprendizagem dos filhos, incentivando-os a melhorar o desempenho e a serem pessoas atuantes na sociedade. (COORDENADORA PEDAGÓGICA).

Essa não participação dos pais segundo a coordenadora pode estar ligada a ser trabalhador rural, mas, por trabalhar no campo implica despreparo para opinar sobre a 
vida escolar dos seus filhos? Qual o "grau" de instrução necessário para participar das atividades escolares dos seus filhos e filhas?

Essas são questões provocativas que devem ser vistas e pensadas em suas complexidades. Esse sentimento de inferiorização dos (as) agricultores (as) está alocado em todo o processo histórico-social das populações do campo e esse pensamento controlador dos grandes latifundiários e do modelo urbanocêntrico tem provocado a depreciação da cultura e conhecimento oriundos de suas experiências singulares.

Para Cuché (1999, p. 184) "também se pode ver o desenvolvimento entre eles [camponeses] dos fenômenos de desprezo por si mesmos. Estes fenômenos são frequentes entre os dominados e são levados a aceitação e à interiorização de uma imagem de si mesmos construída pelos outros". É exatamente o que a Educação do Campo vem desconstruindo com o movimento ativo de desesteriotipação e consolidação de práticas educativas valorativas dos atores e atrizes do campo.

Assim, trabalhar no campo não implica em ignorância ou em abandonar a vida escolar dos filhos, porém, a escola deve buscar o envolvimento das famílias nas atividades da instituição e no processo educativo dos seus filhos como afirma a CP, uma vez que a participação da comunidade na construção do PPP e nas decisões da escola é de extrema importância porque os sujeitos imbricados no processo educativo devem expor suas esperanças e anseios, pois isso pode proporcionar uma atuação coletiva e compartilhada e ter uma finalidade convergente: Educação do/no Campo. Ainda, o envolvimento da comunidade onde a escola está inserida sócio-culturalmente de forma direta e efetiva, está envolta na gestão participativa e, portanto, democrática.

\section{CONSIDERAÇÕES FINAIS}

As problematizações realizadas nesta investigação possibilitaram constatar que de acordo com a CP, a equipe gestora busca canalizar os esforços da comunidade escolar para promover e articular o trabalho coletivo na instituição, esses momentos se efetivam nas Atividades Complementares - ACs e demais encontros coletivos, nos quais acontecem discussões acerca do processo educativo.

Na concepção da CP o Projeto Político Pedagógico serve de auxílio para a gestão, desse modo, frisa também a corresponsabilidade da equipe gestora no que tange a 
seleção e organização de dados da realidade escolar, isto é, de um diagnóstico, para no momento de encontro com todo o grupo haver as deliberações necessárias, com vistas a superar os problemas e dificuldades encontradas, procurando estabelecer uma ruptura com práticas arraigadas.

No entanto, a escola ainda encontra dificuldades no que se refere a efetivação da participação da comunidade local na tomada de decisão, segundo a coordenadora esse é o principal obstáculo para a construção do PPP da escola do campo, pois se torna complexo identificar os anseios e aspirações de um grupo que apresenta singularidades e particularidades específicas do contexto sociocultural em que estão inseridos sem a concreta efetiva colaboração de seus atores e atrizes.

Contudo, o estudo mostra que a escola se empenha em incorporar ao seu currículo conhecimentos e saberes próprios do contexto no qual os discentes estão inseridos, na intenção de estabelecer conexões com outros conhecimentos também importantes para a formação do educando.

É importante salientar, o quanto ainda é necessário avançar no que se refere a superação de uma imagem estereotipada do campo e dos sujeitos que vivem nele. Essa visão negativa de si e do campo tem suas origens históricas calcadas na negligência a um direito básico: o direito à educação.

Por fim, pode-se constatar que os campesinos se sentem inferiorizados em nível de instrução escolar formal e, por isso, possuem dificuldades em participar da escolaridade dos seus filhos e filhas. A escola deve pensar propostas políticas pedagógicas e projetos para a superação dessa marginalização, introjetada pela elite burguesa, para efetivar a participação da comunidade nas tomadas de decisão da escola.

Há também a possibilidade de a escola buscar apoio em outras esferas da gestão municipal, estadual ou federal para trazer esses agricultores e agricultoras que não cursaram a educação básica para que tenham acesso e condições de frequentar o ensino formal na comunidade campesina. 


\section{REFERÊNCIAS}

BRASIL. Lei de Diretrizes e Bases da Educação Nacional.1996. Disponível em: <http://www.planalto.gov.br/ ccivil_03/Leis/L9394.htm>. Acesso em 18 de julho 2018.

Diretrizes Operacionais para a Educação Básica nas Escolas do Campo resolução CNE/CEB n. 1, de 3 de abril de 2002. Diário Oficial da República Federativa do Brasil, Poder Executivo, Brasília, DF. 9 de abr. 2002, seção1, p. 32.

Decreto Lei № 7.352, de 04 de novembro de 2010. Dispõe sobre a política de educação do campo e o Programa de Educação na Reforma Agrária (PRONERA).

CUCHÉ, Denys. A noção de cultura nas Ciências Sociais. Bauru: EDUSC, 1999.

DEMO, Pedro. Desafios modernos da Educação. 7 ed. Petrópolis: vozes, 1998.

GADOTTI, Moacir. Perspectivas atuais da educação. Porto Alegre: Artes Médicas Sul, 2000.

GARCIA, Rodney. Consolidação das Políticas Educacionais do Campo. Tangará da Serra: Gráfica e Editora Sanches Ltda, 2008.

MINAYO, Maria Cecília de Souza. O desafio do conhecimento. 11 ed. São Paulo: Hucitec, 2008.

OLIVEIRA, M. A. M.; SOUZA, M. I. de; BAHIA, M. G. M.; Projeto político-pedagógico: da construção à implementação. In: OLIVEIRA, M. A. M. (Org.). Gestão Educacional: Novos olhares, novas abordagens. 10 ed. Petrópolis, RJ: Vozes, 2014, p. 40-53.

PARO, Vitor H. Gestão democrática da escola pública. Ática, 2002.

PIRES, Angela Monteiro. Educação do campo como direito humano. 1 ed. São Paulo: Cortez, 2012. Coleção educação em direitos humanos; v. 4.

PRODANOV, Cleber C; FREITAS, Ernani C. de. Metodologia do trabalho científico [recurso eletrônico]: métodos e técnicas da pesquisa e do trabalho acadêmico. 2 ed. Novo Hamburgo: Feevale, 2013. Disponível em: <http://www.faatensino.com.br/wp-content/uploads/2014/11/2.1-E-bookMetodologia-do-Trabalho-Cientifico-2.pdf>. Acesso em 26 de fev. 2018.

SEVERINO, Antônio J. Metodologia do Trabalho Científico [Livro eletrônico]. 2 ed. São Paulo, Cortez, 2017.

VASCONCELLOS, C. S. Planejamento: Projeto de ensino-aprendizagem e projeto educativo. 15a Ed. São Paulo: libertd, 2006. 
VASCONCELLOS, C. S. Coordenação do Trabalho Pedagógico. São Paulo: Libertad, 5a ed. 2004.

VEIGA, Ilma Passos Alencastro. Anais do I Seminário Nacional: Currículo em Movimento - Perspectivas Atuais Belo Horizonte, novembro de 2010.

- Inovações e Projeto Político-Pedagógico: uma relação regulatória ou emancipatória? Cad. Cedes, Campinas, v. 23, n. 61, p. 267-281, dez. 2003. Disponível em: < http://www.cedes.unicamp.br>. Acesso em: 26 de fev. 2018.

. Projeto político-pedagógico da escola uma construção possível. Campinas-SP: Papirus Editora, 2000.

. Projeto Político Pedagógico: uma construção possível. Campinas: Papirus, 1995. 


\title{
CAPÍTULO VIII
}

\section{INOVAÇÃO CURRICULAR BASEADA EM PROJETOS: DESENVOLVENDO COMPETÊNCIAS COM APRENDIZAGEM ATIVA}

\author{
Blasius Silvano Debald ${ }^{1}$ \\ Raíza Brustolin de Oliveira²
}

\begin{abstract}
${ }^{1}$ Doutor em Educação. Pró-reitor e docente do Centro Universitário União das Américas - UniAmérica-PR.
${ }^{2}$ Mestre em Sociedade Cultura e Fronteiras. Coordenadora do NITE- Núcleo Integrado de Gestão e Tecnologias Educacionais e docente do Centro Universitário União das Américas - UniAmérica-PR.
\end{abstract}

\section{RESUMO}

O processo de inovação na educação superior requer esforço, formação, acompanhamento e principalmente gestão da aprendizagem. O Centro Universitário União das Américas - UniAmérica, desde 2014, vem implementando mudanças nos processos de aprendizagem, indicando a necessidade de desenvolver competências ao invés de ensinar os conteúdos. Contudo, a partir de 2019, implementou uma nova matriz curricular em todos os cursos da instituição, mas apresentaremos o case do curso de Pedagogia, com o Projeto inovação curricular baseada em projetos: desenvolvendo competências com aprendizagem ativa. A finalidade do projeto era romper com a organização curricular fragmentada, estruturado em disciplinas e com o ensino dos conteúdos. Este modelo de educação não auxilia o estudante no mundo do trabalho, pois aprende conteúdos, decora, faz provas, mas não aprende a fazer e muito menos pratica elementos da futura profissão. A matriz curricular baseada em projetos foi estruturada sem a definição da semestralidade, mas por áreas de atuação profissional e projetos que desenvolvem as competências profissionais e pessoais. Há projetos que resolvem problemas demandados das empresas e instituições, bem como os simulados que desenvolvem as competências para o exercício profissional. Os projetos integradores de extensão, demandas da sociedade, são semestrais, e os simulados, cinco semanas, das quais quatro são para o desenvolvimento do projeto e uma para avaliação, apresentação e feedback individual.

Palavras-chave: Inovação curricular. Projeto. Aprendizagem ativa. Competências. Docência.

\section{INTRODUÇÃO}

A educação superior, especialmente as licenciaturas, estão se reinventado para acompanhar os avanços tecnológicos, os novos contextos da sala de aula e as diferentes formas de aprender. Há um descompasso entre o que é ensinado na universidade, nos 
cursos de Pedagogia e a realidade do contexto enfrentado pelo professor na sala de aula da educação básica atual.

Uma matriz curricular compartimentada e dividida, voltada prioritariamente à apreensão do conteúdo teórico se propõe a trabalhar apenas um aspecto da formação do professor que é o conhecimento teórico do processo de ensino e aprendizagem, e mesmo nessa proposta ainda há lacunas, pois, os conteúdos são trabalhados de forma disciplinar e cartesiana o que dificulta a construção de uma visão de conjunto do processo educacional como um todo. Espera-se que em algum momento o estudante junte essas "partes de conhecimentos" para atuar como professor.

Muitas vezes trabalhar o conhecimento necessário se dá de forma unilateral, realizada pelo docente que transmite o conteúdo aos estudantes em aulas expositivas, não proporcionando por vezes a contestação e a crítica às práticas e teorias apresentadas na disciplina, o que torna o futuro pedagogo um reprodutor de práticas e conhecimentos vigentes na academia. O pilar da pesquisa, quando presente, na maioria dos casos está voltado a um processo puramente acadêmico como é um Trabalho de Conclusão de Curso.

Essa maneira de formar professores restringe a adoção de novas práticas frutos de pesquisa, o que por sua vez não promove a atualização e melhoria contínua da Educação Básica. E então o que parece ser algo "normal” que adiamos uma mudança há anos, pode ser interpretado como um fator crucial para o descompasso na formação de milhões de crianças e adolescentes. É claro que faltam políticas públicas, mas a academia tem sua grande parcela de responsabilidade na medida em que adia mudanças necessárias para tornar a formação de professores mais coerente com a realidade.

Nesse contexto, competências pessoais e profissionais que sempre foram relevantes, e que em detrimento da descentralização do conhecimento técnico a partir da era da informação com o advento da internet, se tornaram demandas pessoais e profissionais latentes, como a capacidade de lidar com as emoções, de liderar, e resolver problemas, não são contempladas, tornando a formação ainda mais deficitária e incompleta.

A inteligência emocional e as habilidades socioemocionais que inclusive hoje estão presentes nas políticas públicas, quando não presentes na formação do professor 
podem impactar de duas formas: a) impedindo que ele trabalhe essas habilidades em seus alunos na medida em que não vivenciou ou não compreendeu a relevância; b) expondo ele a uma vivência profissional intensa sem as devidas habilidades de lidar com as emoções. O desenvolvimento das habilidades socioemocioniais interferem na saúde mental do docente, que, pode ser agravada devido à baixa valorização e más condições de trabalho, porém, a competência de lidar com as próprias emoções pode amenizar o sofrimento desses professores na medida em que desenvolveriam estratégias de manejo, impactando, assim, positivamente a forma como promovem o aprendizado dos seus alunos.

Além disso, outro aspecto contemplado de forma desarticulada é a própria prática realizada nos estágios, que normalmente são realizados ao final do curso, pois entende-se que todo o conteúdo anterior é subsídio básico para tal, permitindo que o licenciado vivencie sua realidade profissional apenas ao final da formação, muitas vezes proporcionando uma perspectiva restrita das possibilidades de trabalho do Pedagogo. Ademais, a separação entre teoria e prática propõe uma visão binária do exercício da profissão, como se os estudos teóricos fossem desarticulados da prática docente em si, o que pode reafirmar uma cultura de que a prática docente está desarticulada de estudo e atualização constante, muito comum entre os professores. Um caso menos recorrente, mas não menos importante é o fato de só depois dessa vivência o estudante perceber que aquela profissão não está relacionada ao seu propósito de vida enquanto materialização das suas potencialidades em prol do outro e de si mesmo, percebendo que não quer seguir a carreira docente quando já cursou mais de $50 \%$ da carga horária do curso.

Desta forma, acompanhando as mudanças nas políticas educacionais brasileiras, considerando as propostas que sinalizam a rever as práticas formativas nos cursos de formação de professores desenvolvendo habilidades, vinculando a prática à teoria e promovendo a pesquisa de forma integrada, entendemos que o momento era propício para reorganizar o currículo dos cursos da instituição. O curso de Pedagogia, que é objeto de proposição do Projeto inscrito, compreendeu que era uma oportunidade para rever a formação dos licenciados, rompendo com uma cultura tradicional de formação na graduação. 


\section{CONTEXTO DA INSTITUIÇÃO E A INOVAÇÃO CURRICULAR}

O contexto institucional foi favorável para a implementação das mudanças nos cursos de graduação e, especificamente no presente projeto do curso de Pedagogia, pois a segunda década do século XXI trouxe um conjunto de inovações que encontraram espaço na educação superior. A UniAmérica, primeiro Centro Universitário Comunitário do Paraná, assumiu o compromisso com a melhoria da educação básica e superior e, portanto, os gestores e corpo docente não mediram esforços para implementar as mudanças e transformações nos processos de aprendizagem. Aproximar a formação acadêmica do campo profissional foi um passo importante para quebrar a estrutura curricular organizada em semestres e disciplinas, que priorizava a teoria em detrimento da prática experimental. Os estudantes de Pedagogia aprenderam o conteúdo, no momento em que precisavam aplicá-lo na resolução dos problemas dos projetos.

O Centro Universitário UniAmérica existe desde 2001 na cidade de Foz do Iguaçu localizada no extremo oeste do Paraná que tem aproximadamente 258.532 habitantes (estimativa de 2019). A instituição que nasceu como Faculdade União das Américas foi adquirida em 2013 por uma associação formada por um grupo de educadores e gestores que trabalharam durante muito tempo assessorando outras instituições de ensino no Brasil e países da América Latina.

O curso de Pedagogia foi criado no final de 2006 a partir da adaptação do Normal Superior que existia desde 2002. O perfil dos matriculados no curso de licenciatura de Pedagogia é composto por jovens, em sua maioria mulheres que tinham interesse em trabalhar na rede municipal de ensino, o que de fato ocorreu ao longo desses anos.

Após a mudança de 2013 o curso passou por diversas atualizações metodológicas tendo a aprendizagem ativa como norte: a) Ensino híbrido, incorporado de forma mais intensa à utilização das tecnologias aplicadas à educação, principalmente utilizando ambiente virtual de aprendizagem; b) Projeto Integrador - Projetos semestrais em que os estudantes em grupos propõem soluções a problemas reais da sociedade, sejam escolas, Ongs e instituições de forma geral - houve a superação da matriz disciplinar em uma matriz curricular modular, e em 2019 ocorreu a implementação da matriz curricular por projetos. 
O projeto foi implementado em fevereiro de 2019 até junho de 2020, embora tenha continuidade, uma vez que é a nova proposta curricular da instituição e do curso. Participaram do projeto, 67 estudantes do curso de Pedagogia, além do colegiado de docentes formado por sete profissionais que foi responsável para pensar a nova organização curricular, contando com a assessoria da Professora Norma Viapiana Golfeto.

A matriz de Pedagogia (Anexo I), foi organizada em três áreas de atuação profissional - docência, gestão e espaços não escolares, locais que foram definidos como de atuação do pedagogo e, portanto, futuro campo de atuação dos licenciados em formação. Na sequência, pensou-se em projetos que representassem o dia a dia dos professores, tanto nas questões de planejamento, aplicação de atividades, elaboração de instrumentos avaliativos, correção das avaliações e atividades e a formação continuada. Assim, foram listados vários projetos profissionais e pessoais que desenvolveram as competências do profissional da educação.

Entendemos que o Projeto inovação curricular baseada em projetos: desenvolvendo competências com aprendizagem ativa tem importância e significado para a educação superior, pois transforma a maneira de se aprender a futura profissão, muito mais interativa, participativa e sendo protagonista do processo educativo.

Concordamos com Demo (2002) ao afirmar em seu texto Professor e seu direito de estudar que: [...] A qualidade da educação depende, em primeiro lugar, da qualidade do professor (p. 72). [...] A LDB ainda é do tempo da aula.. [...] seu diploma deveria ser provisório, para que fosse renovado continuamente. Professor que não estuda não pode "dar aula" (p. 84). Na obra Inovações radicais na educação brasileira, organizado por Campos e Blikstein (2019), apresentam a experiência que serviu de base para a estruturação do projeto no curso de Pedagogia, pois os processos inovadores, ainda são raros se olharmos o número de instituições de ensino superior no país.

A aprendizagem centrada no estudante, apoiada pela aprendizagem personalizada, o desenvolvimento de competências e a educação híbrida como facilitadores foram incorporados da obra de Horn e Staker (2015). E para sustentar um planejamento inovador, bem como processos avaliativos focados no processo, a obra Planejamento para a compreensão, de Wiggins e McTighe (2019) foi o porto seguro para a base teórica do projeto desenvolvido com os licenciados de Pedagogia. 
Como a proposta apresentada tem a centralidade no desenvolvimento de competências e não no ensino dos conteúdos, a proposta de organização curricular rompeu como as disciplinas e a fragmentação dos conteúdos ensinados no curso de Pedagogia, trouxe um novo olhar para a formação dos licenciados, pois o que aprendiam na sala de aula estava relacionada ao exercício profissional. Assim, demonstraram maior interesse nos processos de aprendizagem, envolvendo-se com as atividades, projetos, tornando-se protagonistas.

Listaremos projetos da área de atuação profissional de docência e suas respectivas ementas:

Projeto de Aprendizagem e Desenvolvimento Humano. Competência: (Ser capaz de) criar roteiros de aprendizagem que explorem o desenvolvimento humano.

Projeto de Linguagem Oral e Escrita. Competência: (Ser capaz de) organizar jogos didáticos que auxiliem na aquisição da linguagem oral e escrita.

Projeto para o Desenvolvimento do Raciocínio Lógico. Competência: (Ser capaz de) criar jogos lúdicos que estimulem o desenvolvimento do raciocínio lógico, mobilizando conhecimentos, metodologias e objetos de aprendizagem.

Projeto para a Aprendizagem em Alfabetização e Letramento. Competência: (Ser capaz de) organizar atividades de alfabetização e letramento de forma significativa mobilizando conhecimentos, abordagens experiências prévias.

Projeto de Ludicidade na Educação Infantil e Anos Iniciais. Competência: (Ser capaz de) planejar e aplicar estratégias lúdicas a favor do desenvolvimento infantil nas séries iniciais.

Projeto de Elaboração de Instrumentos Avaliativos. Competência: (Ser capaz de) elaborar instrumentos avaliativos contemplando cada faceta da avaliação, considerando o processo de desenvolvimento da aprendizagem de cada estudante se valendo das mais diversas estratégias.

Projeto de Música e Teatro. Competência: (Ser capaz de) se expressar de diferentes formas para o desenvolvimento artístico por meio da música e do teatro.

Projeto de Curso de Formação Docente. Competência: (Ser capaz de) planejar um curso de formação docente considerando os pressupostos, o perfil dos professores e os objetivos de aprendizagem que se busca alcançar. 
As competências desenvolvidas nos projetos relacionam-se com o fazer docente que aplicará, após a conclusão do curso de Pedagogia, no exercício profissional. Assim, já vivenciar tais competências demonstrou que o licenciado sai mais preparado para enfrentar o mundo do trabalho, no caso específico, a sala de aula, além dos aspectos que fazem parte do ato de ensinar alguém a aprender para a vida. Em cada projeto, espera-se que o estudante desenvolva competências específicas e gerais do pedagogo. Para Zabala e Arnau (2010, p. 49) "o termo competência representa a alternativa que supera as dicotomias: memorizar e compreender; conhecimentos e habilidades; teoria e prática [...] A melhoria da competência implica a capacidade de refletir sobre sua aplicação e, para alcançá-la, é necessário o apoio do conhecimento teórico."

Para maior compreensão e entendimento, esclarecemos que cada projeto teve a duração de cinco semanas, sendo quatro de efetivo trabalho e uma para avaliação, composta de exercício de compreensão, avaliação dissertativa para verificar a autoria da solução, apresentação e discussão do projeto, e, por fim, feedback individualizado, apontando elementos da solução apresentada. Os estudantes discutiram em grupos, definiram um problema de estudo, listaram as possibilidades de solução e iniciaram o processo de aprendizagem. Caso necessitassem testar, utilizavam os laboratórios. $\mathrm{O}$ estudo é em grupos, mas cada um apresentou sua solução, considerando seu processo de reflexão, testagem e aplicação. $E$, ao final, teve a apresentação individual, além do feedback em que demonstrou se adquiriu ou não a competência.

Os estudos de fundamento são realizados no Ambiente Virtual de Aprendizagem e a instituição utiliza as Unidades de Aprendizagem produzidas pela editora de conteúdos Sagah. Além dos estudos de fundamento, que atendem os requisitos das Diretrizes Curriculares Nacionais de Pedagogia, outros materiais de apoio são utilizados como, por exemplo, vídeos, matérias jornalísticas e podcasts.

Cada projeto que é desenvolvido tem um plano de aprendizagem, no qual estão expressos os objetivos, competências, os conteúdos, metodologia, avaliação e referências (Anexo V). O plano é cadastrado no Sistema Acadêmico antes do início do projeto pelo docente responsável e é avaliado pelo coordenador que aceita ou rejeita. Em caso de aceite fica disponibilizado para a Secretaria Acadêmica fazer o arquivamento digital. Após planejamento realizado o docente elabora a Trilha de Aprendizagem, uma planilha na qual insere os principais elementos que serão partes do projeto e serão 
organizados no Ambiente Virtual de Aprendizagem como forma de conduzir o estudante para a realização do projeto. A Trilha de Aprendizagem contempla o Nome do Projeto; entregas/etapas; materiais dos conteúdos a serem trabalhados e as atividades a serem realizadas.

O documento é organizado pelo docente, que o envia ao coordenador para validação e em seguida o encaminha para o Núcleo Integrado de Tecnologias e Gestão Educacional (NITE) para postagem no Ambiente de Aprendizagem. A Trilha é uma orientação para os estudantes da instituição, pois auxilia na organização e planejamento da aprendizagem. Também é o indicador para o estudante realizar o estudo prévio, um dos pilares da inovação curricular implementada nos cursos e no curso de Pedagogia.

O docente estrutura seu planejamento a partir do projeto, com um problema (real ou simulado), define as competências que serão desenvolvidas, estabelece as atividades de aprendizagem que são meios auxiliares para pensar e criar a solução e, por último, os conteúdos de fundamento e de apoio para a base teórica. Esse material é disponibilizado no Ambiente Virtual de Aprendizagem.

O projeto é organizado em momentos assíncronos de estudo individual independente, e momentos síncronos presenciais em sala com o docente e com a turma, concretizando a sala de aula invertida, modalidade de ensino híbrido adotada. A aula, momento presencial, é utilizada para fazer a orientação, mediação e esclarecimentos de dúvidas em relação aos estudos prévios realizados pelo estudante bem como propor atividades que desenvolvam habilidades e conhecimentos e auxiliem na concretização de cada etapa do projeto. Vale ressaltar que as salas de aula são organizadas em grupos nas quais as carteiras ficam voltadas ao grupo e não ao professor, proporcionando um momento de aprendizagem por pares ainda mais efetivo.

Os processos didáticos para a realização de cada projeto estão ancorados no tripé saber, saber fazer e fazer. É assim que entendemos que ocorre a aprendizagem significativa e efetiva. Cada atividade é pensada antes dos conteúdos, pois parte do pressuposto de desenvolver as competências.

O planejamento dos procedimentos didáticos na instituição é organizado a partir de uma lógica não usual em cursos de licenciatura. Ao ofertar um projeto, o colegiado define as competências que serão desenvolvidas, planeja as atividades de aprendizagem que farão parte do processo e, por fim, seleciona os conteúdos de fundamento e 
complementares para a base teórica e de aprofundamento. Em um modelo tradicional, o professor organiza sua disciplina a partir de objetivos de ensino, lista os conteúdos que serão abordados e contempla atividades para fixação dos conteúdos. No curso de Pedagogia e demais da instituição, o conteúdo não é o pilar central da formação, mas o desenvolvimento de competências. A opção aproxima o licenciado ao campo profissional, pois aprende, verifica se sabe fazer e, por fim, faz, concretizando a aprendizagem.

Outro elemento inovador são as atividades de aprendizagem desenvolvidas pelos licenciados de Pedagogia. Não são para fixar os conteúdos, mas são meios auxiliares para que os estudantes consigam criar/desenvolver a solução do problema do projeto. Assim, se apresentar uma solução ao final do projeto, o docente poderá avaliar se desenvolveu ou não a competência esperada. A organização de tal forma torna a aprendizagem mais dinâmica, envolvente e participativa.

Ressalta-se que os licenciados são matriculados por projeto e não por turma. No currículo não há pré-requisitos, oportunizando a aprendizagem de times, equipes e pares. Essa é outra inovação na matriz curricular, tornando viável, sob o aspecto econômico o curso, pois cada turma tem no máximo 35 estudantes em sala e não menos de 25.

Para o desenvolvimento dos projetos, o curso de Pedagogia conta com um Laboratório Pedagógico, o qual disponibiliza matérias de apoio e é o local de criação e desenvolvimento de experimentos, quando é o caso. O locar fica disponível aos licenciados durante o período de aula e localiza-se anexo a sala de aula. E fora do horário de aula requer agendamento.

Os procedimentos didáticos são pensados para o desenvolvimento das competências pessoais e profissionais. É importante desenvolver competências pessoais e profissionais, pois no cotidiano profissional, requer conhecimento, habilidades e atitudes para lidar com os conflitos, situações adversas da profissão docente.

Destacamos também que cada período presencial do docente com os estudantes seguiu uma orientação institucional, na qual os seguintes passos precisam ocorrer: a) contextualização e problematização da atividade de aprendizagem (em torno de 30 minutos); b) explicação do passo a passo da atividade do dia (10 minutos); c) trabalho em equipe para realização da atividade (45 minutos); d) apresentação das soluções da 
atividade (45 minutos); e) feedback e aprofundamento do docente (30 minutos). Ao quebrar o tempo do encontro presencial, está-se priorizando a intensidade, o engajamento e a adesão dos estudantes nas tarefas e atividades.

É oportuno lembrar que o curso de Pedagogia e os demais da instituição, não trabalham com disciplinas e sim, com projetos. Assim, como já foi explicado em outro momento, os licenciados de Pedagogia fazem um Projeto Integrador de Extensão Semestral (normalmente é um problema demandado de escolas, colégios ou instituições de ensino) e quatro Projetos Mensais (duração de cinco semanas, sendo quatro para a realização do projeto (12 encontros presenciais, em três dias por semana) e uma semana dedicada para feedback do processo de aprendizagem, individual com cada estudante.

Durante as realizações do Projeto Integrador de Extensão, os licenciados de Pedagogia compõem grupos de estudos com outros cursos, estimulando a interdisciplinaridade. Durante a vigência do projeto apresentado, estudantes de Pedagogia tiveram contato com os de Psicologia e História.

A formação continuada dos docentes é realizada mediante o Programa de Apoio aos Docentes (PAD), momento em que são acompanhados nas etapas de planejamento, prática de sala de aula, elaboração de instrumentos avaliativos, feedback aos estudantes e correções de atividades. Como a gestão de aprendizagem é compreendida como um todo, a formação continuada faz parte dos procedimentos didáticos, pois ajusta e aperfeiçoa elementos que requeiram alinhamento institucional.

Com o intuito de aprimorar os procedimentos didáticos, o colegiado se reúne, ordinariamente, uma vez por mês e sempre que for necessário. Participa de formações e se envolvem com as melhorias do curso. Realizam atividades de formação complementar com os estudantes, enriquecendo a formação, e, sempre que possível, trazem profissionais que atuam em diferentes áreas para dialogar com os licenciados de Pedagogia.

\section{CONSIDERAÇÕES FINAIS}

O Projeto da nova matriz curricular foi construído pelo colegiado, com orientação da Assessoria Pedagógica e amplamente discutido nas reuniões de Colegiado de Curso e do Núcleo Docente Estruturante (NDE), bem como fóruns e debates institucionais 
foram organizados para ampliar e aprofundar a compreensão e entendimento da proposta, uma vez que era algo inovador e não tinha nada parecido no mercado. 0 pioneirismo exige empenho, dedicação e estudos, mas os resultados são alentadores. Ter estudantes e docentes motivados para aprender vale o esforço.

Por fim, além de romper com a fragmentação disciplinar, a aprendizagem por projetos proporciona experiências de aprendizagem que promovem no aprendente o desenvolvimento de habilidades socioemocionais, autonomia, auto-organização, colaboração, solução de problemas, proporcionando uma formação integral, e vivencial integrando teoria e prática aspecto inerente ao desenvolvimento de competências.

\section{REFERÊNCIAS}

CAMPOS, Flavio Rodrigues; BLIKSTEIN, Paulo (Orgs.). Inovações radicais na educação brasileira. Porto Alegre-RS: Penso, 2019. (Série Tecnologia e Inovação na Educação Superior).

DEMO, Pedro. Professor e seu direito de estudar. In: SHIGUNOV NETO, Alexandre; MACIEL, Lizete Shizue Bomura (Orgs.). Reflexões sobre a formação de professores. Campinas-SP: Papirus, 2002. (Coleção Magistério: Formação e Trabalha Pedagógico).

FERNADES, Domingos. Avaliação alternativa: perspectivas teóricas e práticas de apoio. In: Futuro Congressos e Eventos. Livro do III Congresso Internacional sobre Avaliação da Educação. Curitiba: Futuro Eventos, 2005. p. 79- 92.

HOFFMANN, Jussara Maria Lerch. Avaliação Mediadora: uma prática em construção da pré-escola à universidade. Porto Alegre: Educação \& Realidade, 2000.

HORN, Michael B.; STAKER, Heather. Blended: usando a inovação disruptiva para aprimorar a educação. Tradução de Maria Cristina Gularte Monteiro. Porto Alegre-RS: Penso, 2015.

MASETTO, Marcos T. Processo de avaliação e processo de aprendizagem. In:

Competência Pedagógica do Professor Universitário. 2. ed. p. 165-179. São Paulo: Summus, 2012.

TOSTES, Maiza Vaz; ALBUQUERQUE, Guilherme Souza Cavalcante; SILVA, Marcelo José de Souza; PETTERLE, Ricardo Rasmussen. Sofrimento mental de professores do ensino público. In: Saúde Debate. Rio de janeiro. v. 42, n. 116, p. 87-99, Jan-Mar. 2018. 
WIGGINS, Grant; MCTIGHE, Jay. Planejamento para a compreensão: alinhando currículo, avaliação e ensino por meio do planejamento reverso. Tradução de Sandra Maria Mallmann da Rosa. Porto Alegre-RS: Penso, 2019.

ZABALA, Antoni; ARNAU, Laia. Como aprender e ensinar competências. Tradução de Carlos Henrique Lucas Lima. Porto Alegre: Artmed, 2010. 


\title{
CAPÍTULO IX
}

\section{PROJETOS PEDAGÓGICOS PARA A EDUCAÇÃO INFANTIL: PRINCIPAIS DESAFIOS EM SUA FORMULAÇÃO NO SISTEMA EDUCACIONAL BRASILEIRO}

\author{
DOI: 10.51859 /amplla.dec139.1120-9
}

Marcus Vinicius Peralva Santos ${ }^{1}$

\begin{abstract}
${ }^{1}$ Graduado em Ciências Biológicas e em Marketing, com especialização em Ecologia e Intervenções Ambientais pela UNIJORGE, mestre e doutor em Geologia pela UFBA, Especialista em Coordenação Pedagógica, Gestão da Educação, Educação Inclusiva e Educação Inclusiva Avançada. Coordenador do curso de Microempreendedor Individual (MEI) pelo Instituto Federal Goiano campus Morrinhos e professor das Faculdades Integradas de Sergipe (FISE).
\end{abstract}

\section{RESUMO}

Para um adequado processo de ensino-aprendizagem da criança durante o período escolar recomenda-se que todos os membros da comunidade escolar participem de todas as etapas que norteiam a idealização, elaboração, construção e execução do projeto político pedagógico. No que se refere ao projeto pedagógico da educação infantil, recomenda-se uma atenção especial no seu processo de idealização, uma vez que ele será a base inicial para a construção do saber na criança, de modo que o presente artigo teve por objetivo descrever os principais desafios no processo de formulação de um projeto pedagógico na educação infantil. A metodologia empregada consistiu na realização de uma revisão bibliográfica descritiva quanti-qualitativa que contemplou trabalhos publicados, em especial, nos últimos 20 anos (1999 a 2019). Verificou-se que cinco grandes problemas norteiam o processo de construção dos projetos na educação infantil, mas que a pesar disso, as fontes de dados online apresentam um quantitativo de obras publicadas sobre o tema bastante expressivo, 0 que mostra a preocupação dos pesquisadores sobre o tema. Com o avançar dos estudos sobre o tema acredita-se que a construção do projeto pedagógico pouco a pouco consiga superar tais desafios, o que em parte já vem se tornando realidade, em especial, por meio da inclusão de projetos voltados a realidade das crianças com necessidades especiais.

Palavras-chave: Projeto pedagógico. ensino infantil. currículo.

\section{INTRODUÇÃO}

Conforme Santos (2018), a educação pode ser entendida como o processo de construção coletiva e permanente do conhecimento, baseada nos princípios de justiça, solidariedade, respeito, convivência e valorização da vida na diversidade. Nesse sentido é interessante que as escolas adotem uma metodologia cooperativa e participativa, que 
contribua na construção da autonomia moral e intelectual de todos os membros da comunidade escolar.

Esta ênfase na construção do conhecimento deve ser empregada desde os anos iniciais de estudo do indivíduo, período este chamado de educação infantil - dos 0 aos 6 anos de idade (SAISI, 2010; SANTOS, 2018), que de acordo com o artigo 29 da Lei de Diretrizes e Bases da Educação Brasileira (LDB - Lei no 9.394/96) se caracteriza por ser a primeira etapa da educação básica, tendo como finalidade o desenvolvimento integral das crianças das crianças até quatro anos de idade nas mais variadas vertentes, o que inclui os aspectos social, intelectual, psicológico e físico, de modo a complementar os esforços realizados pela comunidade e família do individuo em processo de estudo (BRASIL, 1996).

Um importante elemento norteador para a delimitação dos rumos a serem seguidos na educação brasileira corresponde a elaboração dos projetos políticos pedagógicos (BRASIL, 1996), os quais devem dialogar a realidade local do ambiente estudantil ao qual esta sendo inserido, a fim de assim, buscar possíveis soluções aos problemas locais enfrentados, tais como, a exigência da legislação educacional brasileira de exigir de creches/escolas autonomia pedagógica, financeira e administrativa com chances restritas de sucesso (SANTOS, 2018).

Deste modo, o presente artigo tem como objetivo geral descrever os principais desafios no processo de formulação de um projeto pedagógico na educação infantil, tendo-se como objetivos específicos: (a) caracterizar o projeto político pedagógico; (b) pontuar os principais desafios em sua elaboração; e (c) analisar a situação das publicações sobre o tema em fontes de dados online e impressa.

Ressalta-se por fim, a importância de se realizar estudos sobre os desafios da formulação de projetos pedagógicos, uma vez que estes servirão de base norteadora para a realização de ações promotoras da construção do "ser cidadão" da criança, servindo como alicerce para que esta possa se desenvolver nos campos psicológico, mental e social.

O presente artigo foi realizado por meio da realização de uma revisão bibliográfica, na qual buscou-se referências em bases de dados online (a exemplo do Google Scholar, SciELO, Speel, Portal de Periódicos da CAPES - Figura 1) e impressas (livros, revistas científicas, manchetes de jornal - ATARDE e CORREIO - Figura 1), que 
abordassem em seu contexto o tema "Projetos Pedagógicos na educação infantil", tratando-se de uma pesquisa descritiva quanti-qualitativa.

Figura 1 - Principais fontes de dados online e impressas utilizadas na pesquisa
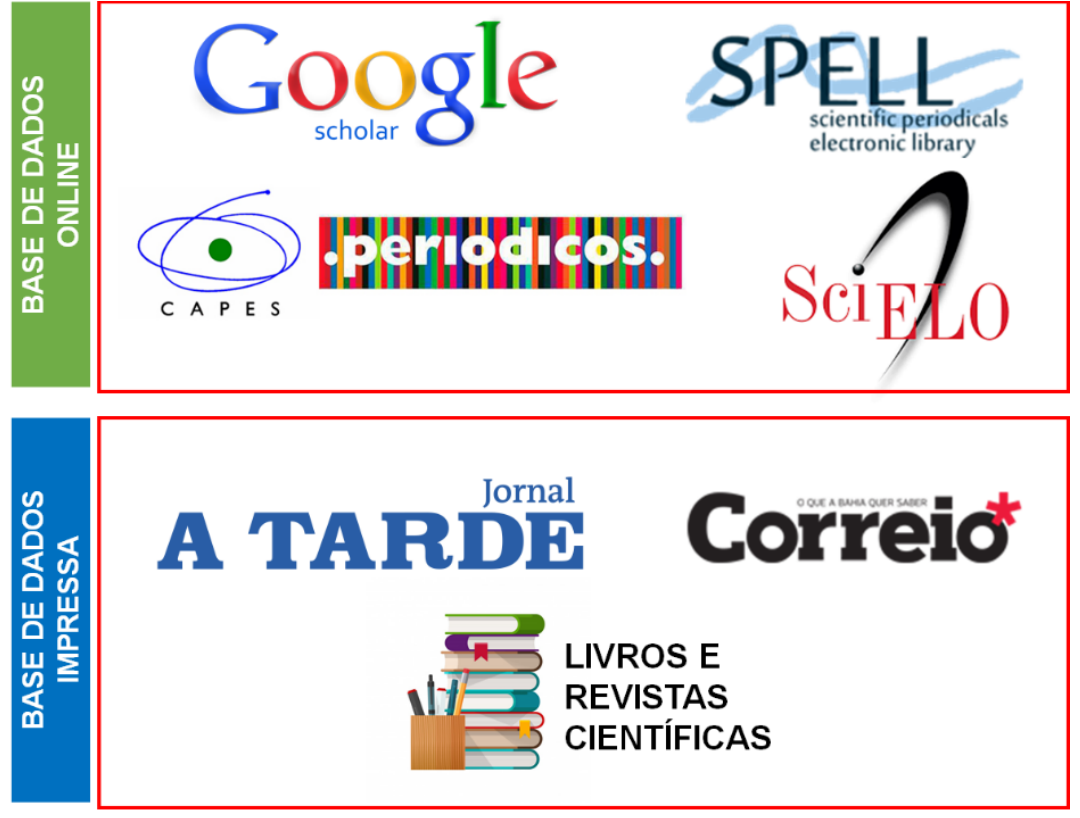

Como palavras-chaves utilizadas durante as buscas tem-se: "Projeto pedagógico", "Projeto pedagógico na educação infantil”, "desafios projeto pedagógico" e "desafios projeto pedagógico educação infantil". A realização das buscas por referências durou um período de 6 meses, compreendendo os meses de julho a dezembro de 2019. Como item balizador para a seleção das referências, optou-se por se utilizar trabalhos publicados nos últimos 20 anos (1999-2019).

Os dados tabulados foram convertidos em um quadro, o qual foi gerado por meio do programa Microsoft Office Professional Plus Excell 2016.

\section{PROJETO PEDAGÓGICO NA EDUCAÇÃO INFANTIL}

A fim de melhor descrever o papel do projeto pedagógico para a construção de um currículo de qualidade na educação infantil, o presente tópico foi subdividido em dois subtópicos, os quais são apresentados a seguir:

\subsection{0 sistema educacional brasileiro e sua legislação}

O rompimento de barreiras históricas, juntamente com a superação de limitações impostas ao exercício da cidadania constituem-se em alguns dos esforços da 
Legislação Educacional brasileira, a fim de oferecer aos cidadãos uma educação de qualidade e com características democráticas (SANTOS, 2018).

A Educação Infantil é a base para o desenvolvimento integral do ser humano, sendo que ela foi reconhecida como parte do sistema educacional de ensino brasileiro por meio da promulgação da Constituição Federal do Brasil em 1988 (BRASIL, 1988). Por isso, o professor deve se atentar aos predicativos pontuados nas diversas leis que regem a educação brasileira, além do próprio projeto pedagógico da escola, sendo que em sala de aula, ele deve ter uma atenção especial as necessidades do aluno, de modo a incentivá-lo a se desenvolver de forma pessoal e conjunta as outras crianças e com todas as condições que a lei the assegura, assim incentivando a construção do seu perfil cidadão (SANTOS, 2018).

A década 1990 foi o período em que ocorreu o maior quantitativo de legislações voltadas a preocupação com a educação Infantil. Entre as legislações produzidas neste período pode-se citar o Estatuto da Criança e do Adolescente (1990), a Política Nacional de Educação Infantil (1994), a Lei de Diretrizes e Bases da Educação Nacional (1996), o documento Subsídios para o Credenciamento e Funcionamento das Instituições de Educação Infantil (1998), as Diretrizes Curriculares Nacionais para a Educação Infantil Parecer no 022/98 (1998) e o Referencial Curricular Nacional para a Educação Infantil (1998) (SAISI, 2010).

Na década de 2000 essas legislações foram complementadas com a elaboração das Diretrizes Operacionais para a Educação Infantil (2000), pelo Plano Nacional de Educação (2001) e pela Lei no 11.274/2006, a qual ampliou o Ensino Fundamental de oito para nove anos, englobando os alunos de seis anos de idade, os quais faziam parte da educação infantil anteriormente, o que reduziu esta última de criança de zero a seis anos para agora, crianças de zero a cinco anos (SAISI, 2010).

Além disso, em 2008 foi lançado a Política Nacional de Educação Especial na Perspectiva da Educação Inclusiva (PNEEPEI) a qual veio a reforçar a necessidade de comprometimento das escolas em atender as especificidades educacionais que apresentem algum tipo de necessidade especial inclusiva (ARAÚJO, CORDEIRO e GIROTO, 2019). 
O surgimento dos projetos voltados a área educacional é produto do movimento social "Escola Nova”, que surgiu na transição do século XIX para o século XX. Eles surgem como uma estratégica educacional inovadora (favorecendo o pensamento crítico), a chamada pedagogia de projetos, a qual vem de embate ao padrão educacional da chamada "Escola Tradicional" (que inibe o pensamento crítico) (TOMAZ et al., 2018).

A palavra "projeto" provêm do latim "projectu", sendo de modo geral conceituado como algo para o futuro, que não é atual, que ainda não foi executado, pois trata-se de uma antecipação do futuro (Nogueira, 2007 apud RODRIGUES, 2013). Conforme Godotti (2000 apud TOMAZ et al., 2018), o projeto pedagógico visa desconstruir a chamada "educação fragmentada", por meio da sua superação, servindo de base para a construção de uma educação inclusiva e unificada, o que é corroborado pelos estudos de Tomaz et al., (2018).

Dentre as características de um projeto político pedagógico, está a sua essência em buscar resgatar no educando seus valores e crenças, assim servindo de base para que o mesmo possa tomar conhecimento sobre a realidade escolar e do seu meio externo, possibilitando-o de analisar as situações do contexto político-social em que se encontra inserido e assim tomar decisões (SANTOS, 2018).

A LDB assegura em seu artigo 12 a construção do Projeto Político Pedagógico dos ambientes escolares, o qual compreende um conjunto de propostas e ações a serem colocadas em prática a fim de fortalecer o processo de ensino do estudante (BRASIL, 1996; SANTOS, 2018; TOMAZ et al., 2018), sendo ele comumente elaborado pela Secretaria de Educação do Município ou pela coordenação pedagógica da escola (RODRIGUES, 2013).

A LDB ainda assegura em seu artigo 14 que os profissionais de educação devem participar na elaboração do projeto pedagógico escolar, e dando ainda mais respaldo a educação infantil, em 2006 o Ministério da Educação (BRASIL, 2006) publicou os parâmetros de Qualidade para a Educação Infantil, documento este que apresentava as escolas exemplos de atividades de qualidade que poderiam ser seguidas por elas, a fim de maximizar o projeto pedagógico infantil.

Em 2009, complementando os trabalhos de lei anteriormente citados, foi publicado as Diretrizes Curriculares Nacionais (DCNs) para a Educação Infantil, as quais 
configuram como obrigatório a elaboração deste projeto, conforme a Resolução CNE/CEB n05 de 17 de dezembro de 2009 (BUQUE e NOGUEIRA, 2014).

Deste modo, os projetos político pedagógicos precisam ser bem planejados, a fim de atender todas as demandas educacionais que a criança precisa, além de ser construído de forma conjunta por todos os membros da escola (RODRIGUES, 2013). Este projeto visa orientar as políticas públicas e os processos de planejamento, elaboração, execução e avaliação das propostas pedagógicas e curriculares, sendo de fundamental importância para o sucesso escolar (BUQUE e NOGUEIRA, 2014).

É de extrema importância que o professor se utilize do lúdico no projeto pedagógico, por meio da utilização de jogos, brinquedos e brincadeiras a fim de estimular nas crianças o desenvolvimento de habilidades, sua imaginação, além de proporcionar a elas descobrirem e aprenderem coisas novas, além de compartilharem experiências (RODRIGUES, 2013).

Um aspecto que vem sendo bastante valorizado no processo de elaboração do projeto pedagógico na educação infantil se refere a aplicação da chamada "Pedagogia de Projetos" que corresponde a uma metodologia de ensino que visa permitir que a criança participe de forma ativa de uma ação real do seu cotidiano escolar tendo objetivos focados nas experiências pessoais dos alunos, assim estimulando-os a ampliar os seus conhecimentos (RODRIGUES, 2013).

Deste modo, a Pedagogia de Projetos estrutura o processo de ensinoaprendizagem em três aspectos, sendo eles: (1) o processo de elaboração, (2) sua execução e (3) sua avaliação perante a resposta das crianças em sua aplicação em sala de aula (RODRIGUES, 2013).

Conforme Rodrigues (2013), o projeto pedagógico deve apresentar um cronograma de ações a serem executadas ao longo do semestre/ano bem delimitado, sendo logicamente também passível de alterações, de modo que permita que o processo educativo da criança ocorra da forma mais natural possível.

As DCNs deixam claro em seu texto que as propostas pedagógicas voltadas a Educação Infantil devem considerar a criança como o centro do planejamento curricular e sujeito histórico e de direitos, incentivando que o projeto pedagógico valorize as práticas cotidianas e a construção da identidade pessoal e coletiva (BRASIL, 1996). 
Dentre os estudos sobre a construção de projetos pedagógicos voltados a educação infantil no Brasil, três são abaixo exemplificados, sendo dois voltados para crianças em geral e o terceiro voltado em particular a crianças com necessidades especiais.

O primeiro estudo de caso se refere ao trabalho de Saisi (2010) que utilizou a estratégia metodológica de pesquisa-ação para analisar a interação entre as famílias e a escola no processo de construção do projeto pedagógico de uma escola infantil pública de São Paulo, no qual entrevistou funcionários, crianças e pais de alunos da educação infantil, sendo que ao final do estudo pode constatar que de modo geral, os pais mostraram-se satisfeitos com o projeto pedagógico da escola, sendo um ponto negativo da escola o fato de realizar reunião de pais no horário de aula das crianças, o que dificulta os pais de participarem deste momento de troca de experiências e conhecimento do projeto pedagógico que está sendo executado junto aos seus filhos. Quanto as professoras, estas mostraram-se conhecedoras das expectativas das famílias quanto aos seus trabalhos junto as crianças sabendo pontuar os pontos positivos e negativos da interação família $X$ escola $X$ crianças no processo de construção do projeto pedagógico infantil.

Emmel et al (2013) relataram um estudo de caso prático que tiveram com dois grupos de crianças das turmas "Jardim A" de uma creche, sobre a presença de borboletas numa praça em que eles tinham costume de caminharem sob a supervisão das professoras do colégio em que estudavam. O projeto conhecido como "Projeto Borboletas" surgiu a partir das indagações das próprias crianças sobre a vida das borboletas, compondo-se então de um tema do projeto pedagógico oficial baseado em um fato real vivenciado pelas crianças.

Deste modo, as professoras levaram para sala de aula, uma borboleta a fim de sanar as duvidas das crianças, a exemplo da quantidade de asas e de patas, do que ela se alimentava, para que serviam as antenas, o que possibilitou as professoras pesquisarem sobre o tem e ensinar as crianças que as borboletas podem ser de vários tipos, além de apresentarem cores variadas, sendo passado posteriormente atividades sobre comparar a borboleta visualizada em sala com aquelas que eles viam em seu dia a dia, e fazer desenhos das mesmas em tecido, dando origem a obra de arte denominada como "Lar das borboletas". Deste modo o projeto buscou ressignificar as diferentes 
formas de interpretar, representar e simbolizar as vivências das crianças por meio dos desenhos (EMMEL et al, 2013).

Outro trabalho, agora uma temática um pouco mais especifica quando comparado aos dois anteriores, se refere ao estudo de Tomaz et al (2018) que realizaram um estudo de caso referente a aplicação de projetos a crianças com necessidades especiais na Escola Francisco Alves Azevedo (PB) no projeto pedagógico das turmas da educação infantil. O estudo consistiu na realização de uma entrevista roteirizada com perguntas acerca do contexto educacional das crianças com necessidades especiais a professoras do ensino infantil e por meio da realização de uma pesquisa bibliográfica. Pode-se constatar que o projeto pedagógico da escola não apresenta projetos destinados aos alunos com necessidades especiais, além de não conter espaço acessível e material pedagógico especializado, o que dificulta o processo de ensino-aprendizagem deles, além de não contar com profissionais qualificados para atender aos anseios dos alunos especiais.

\section{RESULTADOS E DISCUSSÃO}

Para que o Projeto Pedagógico na Educação Infantil alcance os objetivos propostos, recomenda-se, conforme os Parâmetros Nacionais de Qualidade da Educação Infantil, que o projeto leve em consideração quatro aspectos, sendo eles (BRASIL, 2006):

1) Implementação e acompanhamento das políticas para a Educação Infantil;

2) As propostas pedagógicas das instituições de Educação infantil;

3) A infraestrutura necessária ao funcionamento da instituição; e

4) A formação continuada e regular dos professores.

Percebe-se a necessidade de que todos os membros do ambiente escolar, o que inclui-se a direção, professores, coordenação pedagógica, alunos e pais participem do processo de construção do projeto político pedagógico escolar, de modo que este documento possa retratar da forma mais fidedignamente as expectativas e concepções dos seus idealizadores, o que é bastante destacado nos estudos de Emmel et al (2013), Rodrigues (2013), Buque e Nogueira (2014) e Araújo, Cordeiro e Giroto (2019). 
Conforme observado por Emmel et al (2013), um currículo significativo na educação infantil é fruto de um processo de aprendizagem que valoriza o aprender de diferentes conhecimentos da história da humanidade articulado reconstrução do passado e o decifrar e aplicação de novas linguagens, sendo que isto só será possível por meio da aplicação de um projeto pedagógico devidamente fundamentado, que contemple tais aspectos.

$\mathrm{Na}$ atualidade o projeto pedagógico da educação infantil não deve se destinar apenas a prática do brincar, o que é importante nesta fase de aprendizagem, mas também deve contemplar a problematização, a realização de atividades a nível individual e coletivo, aspectos estes que são bem descritos nos trabalhos de TOMAZ et al., (2018) e Guilherme (2019).

De acordo com Buque e Nogueira (2014), dentre os problemas no processo de elaboração do projeto pedagógico infantil, a serem superados se tem: (1) a tomada de decisão unilateral - onde apenas um grupo, ou uma pessoa do ambiente escolar é o responsável pela elaboração do projeto pedagógico; e (2) não retratamento da realidade escolar - quando o projeto contempla aspectos que não fazem parte do cotidiano da criança, o que pode prejudicar o seu processo de assimilação da informação (neutralidade).

Os estudos de Tomaz et al., (2018) acrescentam ainda outros três problemas: (3) a falta de problematização - onde os projetos destinam-se ainda apenas a reprodução de conteúdos ou somente ao brincar ao aluno, não permitindo a ele refletir sobre a sua realidade, (4) a não inclusão dos alunos com necessidades especiais no processo de construção do saber - fato este que se dá pela inexistência de planos voltados as suas necessidades, de modo que estes ficam de fora, ou apresentam maior dificuldade no processo de questionar as questões problematizadoras que o projeto pedagógico deve conter; e (5) ausência de compromisso na educação inclusiva - ocorrendo devido à falta de ética dos governantes, das instituições e dos profissionais envolvidos na construção do currículo escolar.

Os problemas acima relatados podem ser superados por meio: (1) da tomada de decisão compartilhada - corresponde ao processo de elaboração conjunta do projeto pedagógico, uma vez que este projeto é um instrumento político que envolve de forma coletiva a tomada de decisões, permitindo que a criança usufrua dos seus direitos civis, 
social e humano (BUQUE e NOGUEIRA, 2009); (2) contemplação de aspectos vivenciados no cotidiano das crianças - o projeto pedagógico deve apresentar no processo de sua construção, aspectos relacionados as vivências cotidianas da criança, de modo que ela possa aprender e refletir sobre aquilo que ela consegue enxergar, tornando sua aprendizagem significativa, o que dificilmente ocorreria caso se utilizasse aspectos/temas não conhecidos pelas crianças.

Outro aspecto que deve ser melhor idealizado na produção do projeto pedagógico se refere (3) a idealização de questões norteadoras (problematizações) durante as aulas. Este aspecto deve levar em consideração a situação descrita no aspecto (2). Um bom exemplo de aplicação de questões problematizadoras é o trabalho de Emmel et. al., (2013) no qual os autores relatam a utilização de borboletas/mariposas avistadas no dia a dia das crianças de uma creche, para discutir questões como, porque elas possuem tal coloração? Do que elas se alimentam? Porque aparecem a noite nas residências?

Por fim, os problemas (4) e (5) poderão ser solucionados a partir do momento em que as escolas contemplem em sua estrutura e em seu projeto pedagógico estruturas que permitam a locomoção adequada das crianças com necessidades especiais, além de projetos que possibilitem que as crianças especiais possam ser atendidas por profissionais especializados que poderão acompanha-los de perto tentando solucionar os seus anseios pessoais e permitindo que estas crianças tenham oportunidade de vivenciar práticas pedagógicas inovadoras, assim como as demais crianças que compõem o grupo escolar, itens estes primorosamente discutidos e exemplificados em trabalhos como os de Tomaz et al., (2018) e nas obras do livro "contradições e desafios na educação brasileira" de Guilherme (2019).

Em relação a situação atual das publicações referentes ao processo de construção, elaboração e idealização do projeto pedagógico no Brasil, pode-se verificar que o país apresenta uma grande produção de trabalhos publicados sobre o tema, tanto no que se refere as fontes de dados online (Tabela 1), quanto em fontes impressas (em especial livros, a exemplo de Guilherme (2019)).

No que se refere as quatro fontes de dados online consultadas pode-se verificar que o Google Scholar (bastante conhecido no Brasil como Acadêmico ou Google Acadêmico), foi a fonte com maior quantitativo de trabalhos disponibilizados (1.142.000 
trabalhos) para todos os quatro tipos de termos-chaves utilizados para a realização das buscas, seguido pelo Portal de Periódicos da Capes (3.493), SciELO (275) e Speel (3) (Tabela 1).

Cabe destacar que a base de dados Google Scholar engloba uma infinidade de revistas científicas em seu portfólio, quando comparado as outras três bases pesquisadas, o que justifica o grande quantitativo de obras hospedadas online e disponíveis para consulta pela população.

No que tange as referências impressas, para os jornais utilizados, A TARDE e CORREIO, para o período de consulta dos mesmos, não foi verificado nenhuma publicação que abordasse a temática em questão aqui trabalhada, embora, eventualmente fossem publicados textos com outras temáticas educacionais. Por outro lado, os livros voltados a área de educação apresentam bastante informações sobre projetos pedagógicos e a temática da educação especial inclusiva tem se mostrado um tema que tem criado cada vez mais destaque, principalmente em publicações dos últimos dois anos, o que demonstra que os pesquisadores da área tem se atentado a necessidade de reformulação do projeto pedagógico a fim de contemplar os alunos especiais, os quais ainda enfrentam grandes desafios para serem inseridos ne educação não só infantil, mas também no fundamental, médio e superior.

Tabela 1 - Principais fontes de dados online, termos chaves, quantitativos de trabalhos encontrados e tempo se realização das buscas de julho a dezembro de 2019

\begin{tabular}{|c|c|c|c|}
\hline $\begin{array}{l}\text { Base de } \\
\text { dados }\end{array}$ & Termos-chaves utilizados & $\begin{array}{c}\text { Trabalhos } \\
\text { encontrados }\end{array}$ & $\begin{array}{c}\text { Tempo de busca } \\
\text { (s) }\end{array}$ \\
\hline \multirow{4}{*}{$\begin{array}{l}\text { Google } \\
\text { Scholar }\end{array}$} & Projetos Pedagógicos & 502.000 & \multirow{4}{*}{0,08 a 0,11} \\
\hline & $\begin{array}{l}\text { Projetos Pedagógicos na } \\
\text { educação infantil }\end{array}$ & 162.000 & \\
\hline & Desafios projeto pedagógico & 355.000 & \\
\hline & $\begin{array}{c}\text { Desafios projeto pedagógico } \\
\text { educação infantil }\end{array}$ & 123.000 & \\
\hline \multirow{3}{*}{ SciELO } & Projetos Pedagógicos & 222 & \multirow{3}{*}{0,08 a 0,11} \\
\hline & $\begin{array}{l}\text { Projetos Pedagógicos na } \\
\text { educação infantil }\end{array}$ & 4 & \\
\hline & Desafios projeto pedagógico & 48 & \\
\hline
\end{tabular}




\begin{tabular}{|c|c|c|c|}
\hline & $\begin{array}{c}\text { Desafios projeto pedagógico } \\
\text { educação infantil }\end{array}$ & 1 & \\
\hline \multirow{4}{*}{ Speel } & Projetos Pedagógicos & 3 & \multirow{4}{*}{0,08 a 0,11} \\
\hline & $\begin{array}{l}\text { Projetos Pedagógicos na } \\
\text { educação infantil }\end{array}$ & 0 & \\
\hline & Desafios projeto pedagógico & 0 & \\
\hline & $\begin{array}{c}\text { Desafios projeto pedagógico } \\
\text { educação infantil }\end{array}$ & 0 & \\
\hline \multirow{4}{*}{$\begin{array}{l}\text { Portal de } \\
\text { Periódicos da } \\
\text { CAPES }\end{array}$} & Projetos Pedagógicos & 1.678 & \multirow{4}{*}{0,08 a 0,11} \\
\hline & $\begin{array}{c}\text { Projetos Pedagógicos na } \\
\text { educação infantil }\end{array}$ & 273 & \\
\hline & Desafios projeto pedagógico & 1.244 & \\
\hline & $\begin{array}{c}\text { Desafios projeto pedagógico } \\
\text { educação infantil }\end{array}$ & 298 & \\
\hline Total & --- & 1.145 .771 & --- \\
\hline
\end{tabular}

NOTA: $s=$ segundos

\section{CONSIDERAÇÕES FINAIS}

O projeto pedagógico da educação infantil deve ser elaborado de forma conjunta por todos os membros do ambiente escolar, de modo a servir como um instrumento norteador das ações/atividades a serem desenvolvidas na escola, sendo que este deverá ter por finalidade responder as necessidades sociais do ambiente ao qual a escola encontra-se inserida.

Mais do que um instrumento norteador, o projeto pedagógico se caracteriza também por apresentar um caráter transformador, uma vez que as atividades nele contidas servirão para transformar a criança em um cidadão consciente dos seus direitos e deveres. Deste modo, ele deve ser bem elaborado e favorecer o surgimento de novas aprendizagens e significações conceituais, o que pode ser obtido com sucesso por meio da incorporação da pedagogia de projetos em seu portfólio de estratégias educacionais.

Os principais desafios encontrados no processo de elaboração do projeto pedagógico na educação infantil foram cinco, sendo eles: (1) a tomada de decisão unilateral; (2) não retratamento da realidade escolar; (3) a falta de problematização; (4) a não inclusão dos alunos com necessidades especiais no processo de construção do 
saber; e (5) ausência de compromisso na educação inclusiva, sendo que todos eles são passíveis de serem solucionados.

Por fim, no que se refere a situação das publicações online e impressas, pelo fato das fontes online serem muito mais fáceis de serem acessadas, elas obtiveram um número expressivo de trabalhos disponibilizados (1.145.771 trabalhos), quando comparado aos trabalhos impressos, os quais apresentam maior dificuldade de obtenção. De modo geral o Google Scholar mostrou-se ser a base de dados com maior quantitativo de trabalhos disponíveis para visualização e mostra que a produção de conteúdo sobre projeto pedagógico na educação infantil e seus desafios no processo de elaboração é um tema atual e com bastantes publicações.

\section{REFERÊNCIAS}

ARAÚJO, L. A. de; CORDEIRO, A. P.; GIROTO, C. R. M. Um encontro com a diversidade na educação infantil por meio do projeto "simplesmente diferente" sob a perspectiva do professor, da criança e da família. Revista Ibero-Americana de Estudos em Educação, Araraquara, v. 14, no esp. 1, p. 775-790, abr. 2019. Disponível em: $<$ https://webcache.googleusercontent.com/search?q=cache:I52vPLdhZY8J:http s://periodicos.fclar.unesp.br/iberoamericana/article/download/12206/8056+\& $c d=14 \& h l=p t-B R \& c t=c l n k \& g l=b r>$. Acesso em: $10 \mathrm{dez} .2019$.

BRASIL. Ministério da Educação e Cultura. Constituição da República Federativa do Brasil. Texto Constitucional de 05 de outubro de 1988, Brasília: Senado Federal, Subsecretaria de Edições Técnicas, 1988. Disponível em: <http://www.planalto.gov.br/ccivil_03/constituicao/constituicao.htm>. Acesso em: 07 ago. 2019.

Lei de Diretrizes e Bases da Educação Nacional. Lei no 9394, de 20 de dezembro de 1996. Dispõe sobre as Diretrizes e Bases da Educação Nacional. Brasília: MEC, 1996. Disponível em: <http://portal.mec.gov.br/seesp/arquivos/pdf/lei9394_ldbn1.pdf>. Acesso em: 03 out. 2019.

Referencial Curricular Nacional para a Educação Infantil. Brasília: MEC/SEF, 1998. Vol. 1,2 e 3. Disponível em: <http://portal.mec.gov.br/seb/arquivos/pdf/rcnei_vol1.pdf>. Acesso em: 11 jul. 2019.

Parâmetros Nacionais de Qualidade para a Educação Infantil. Brasília: MEC, $2006 . \quad$ Disponível em: 
<http://portal.mec.gov.br/seb/arquivos/pdf/Educinf/ eduinfparqualvol1.pdf>. Acesso em: 05 dez. 2019.

BUQUE, A. C,; NOGUEIRA, R. M. de S. O projeto pedagógico na educação infantil: a elaboração do projeto pedagógico do CEI- UFGD. In.: Encontro de Ensino, Pesquisa e Extensão da UFGD, 8, 2014, Grande Dourados, Anais do $8^{\circ}$ Encontro de Ensino, Pesquisa e Extensão da UFGD. Grande Dourados: UFGD, 2014. Disponível em: <http://eventos.ufgd.edu.br/enepex/anais/ arquivos/784.pdf>. Acesso em: 19 set. 2019.

EMMEL, R. et al. Projetos Pedagógicos na educação infantil: Reflexões sobre o desenvolvimento do projeto borboletas. Revista Ciência em Tela, v. 6, n.1, p. 18, 2013. Disponível em: <http://www.cienciaemtela.nutes.ufrj.br/artigos/ 0601pe01.pdf>. Acesso em: 07 nov. 2019.

GUILHERME, W. D. Contradições e desafios na educação brasileira. 3a ed. Ponta Grossa: Atena Editora, 2019.

RODRIGUES, A. C. G. Pedagogia de projetos: o lúdico na educação infantil. 2013. Monografia (Graduação em Pedagogia) - Universidade Estadual da Paraíba, Departamento de Educação, Guarabira. Disponível em: <http://dspace.bc.uepb.edu.br/jspui/bitstream/123456789/4966/1/PDF\%20\%20 Ana\%20Carla\%20Gomes\%20Rodrigues.pdf>. Acesso em: 02 ago. 2019.

SANTOS, V. S. dos. Projeto Político Pedagógico (PPP). Planaltina: Creche Magia dos Sonhos, 2018. Disponível em: <http://www.se.df.gov.br/wpconteudo/uploads/2018/07/pppplanaltinacreche-magia-dos-sonhos.pdf>. Acesso em: 01 dez. 2019.

TOMAZ, L. B. et al. A importância de projetos na educação infantil para crianças com necessidades especiais na escola Municipal Francisco Alves Azeredo. In.: Congresso Nacional de Educação. 5, 2018, Olinda, Anais do V Congresso Nacional de Educação. Olinda: CEMEP, 2018. Disponível em: <http://www.editorarealize.com.br/revistas/conedu/trabalhos/TRABALHO_EV1 17_MD1_SA10_ID9349_10092018223011.pdf>. Acesso em: 07 out. 2019. 


\section{CAPÍTULO X}

\section{EDUCAÇÃO POSTURAL NA INFÂNCIA E ADOLESCÊNCIA: UM FATOR ESSENCIAL NOS TEMPOS ATUAIS}

\section{RESUMO}

Este artigo trata sobre a importância da avaliação e principalmente da educação quanto a postura em crianças e jovens. Para tanto, foi realizada uma pesquisa bibliográfica de cunho narrativo sobre o tema. $\mathrm{O}$ estudo em questão teve como objetivo geral identificar e apresentar os métodos de avaliação postural e a importância de se avaliar constantemente os jovens, além de informar a comunidade quanto ao problema postural dos maus hábitos nas AVDs. Conclui-se então que devem ser feitas avaliações posturais na comunidade esportiva e, principalmente escolar de forma periódica afim de identificar no começo esses desnivelamentos posturais para que se possa corrigi-los o quanto antes.

Palavras-chave: Avaliação Postural; Desvios Posturais; Educação; Crianças; Adolescentes.

\section{INTRODUÇÃO}

O presente artigo de trata-se de uma revisão de bibliografia, o qual tem o intuito de revelar quais são, como tentar tratar e claro algumas evidências para tentar evitar o surgimento dos desvios posturais, um problema postural importante, que atrapalha a vida de indivíduos em todas as faixas etárias, principalmente no que tange as crianças e adolescentes.

A postura da coluna vertebral é algo de muita importância para nosso dia a dia, pois uma má postura se for mantida pode gerar quadros dolorosos, mal-estar e até mesmo dores crônicas e problemas maiores na vida do indivíduo ao longo da vida. Uma má postura pode ser fruto de um movimento errôneo, de um problema estrutural (musculatura enfraquecida) ou congênito, porém pode ser algo psicossomático, ou seja, ter relação direta com o estado emocional do indivíduo em questão, com isso o 
indivíduo retraído ou tímido, por exemplo, tende a ter uma hipercifose torácica juntamente com uma flexão de tronco, etc (KENDALL et al., 1995).

Não existe uma definição de postura, pois é algo individual que depende de fatores, hereditários, congênitos, adquiridos, culturais, mas que a postura seja confortável para o sujeito, mas se esta postura leva a um gasto energético, portanto pode ser avaliada como uma postura que pode ser melhorada, com treinamentos, reforço muscular ou casos mais extremos, com cirurgia, como cita o estudo de Kendall et al. (1995), dessa forma, a eficiência na utilização do corpo na postura ereta passou a se dar por meio de uma posição corporal que envolvesse o mínimo de sobrecarga das estruturas, com o menor gasto de energia, consistindo esse processo numa resposta neuromecânica que se relaciona com a manutenção do equilíbrio e com a estabilidade músculo-esquelética (FILIPOVIC; VISKIC-STALEC, 2006).

Acredito que um dos principais motivos dos problemas posturais seja a falta de exercício físico direcionado nas fases iniciais da nossa vida, que trariam maior mobilidade, conhecimento do próprio corpo, assim como é citado no artigo de Graup (2008), os movimentos naturais conforme vamos envelhecendo vai se perdendo e com isso a pouca mobilidade vai ficando mais evidente.

Apesar de numerosas causas e fatores de risco que estão relacionados com problemas na coluna lombar, deve-se considerar a possibilidade de ser um problema relacionado com a inatividade física, pois para alguns autores o sedentarismo está diretamente ou indiretamente relacionado com encurtamentos musculares ou ainda com dores na coluna (OLIVEIRA, 2006), e esses fatores têm se apresentado ligados ao acometimento de desvios posturais. Os déficits de mobilidade articular, principalmente no que concerne aos encurtamentos musculares, são ponto determinante na relação dos desvios posturais, pois de acordo com Denys-Struyf (1995) citado por Graup (2008), essa relação nem sempre é estabelecida, o que torna os trabalhos deficitários quando se investiga postura corporal. Essa relação é também apontada como de extrema importância por Chagas et al. (1993), que afirmam que dentre vários estudos sobre a gênese de problemas posturais, reveste-se de importância àqueles relacionados às alterações musculares. Considerando a coluna lombar, o enfraquecimento da musculatura abdominal, assim como encurtamento na musculatura da cadeia posterior do tronco (VOLPON, 1996), e anterointerna da bacia, que podem ocasionar déficits de 
mobilidade articular, têm sido apontados como os principais fatores responsáveis pelo surgimento de desvios.

Com as atividades das pessoas cada vez mais corridas, a falta de preocupação com a postura é algo que só é notado quando alguém tenta corrigir a sua postura, falando ou tocando o corpo da pessoa para que a mesma melhore a postura, em crianças e adolescentes deveria ser algo mais focado com mais ênfase em exercícios preventivos, pois nesta fase a correção e adaptação é mais eficaz.

Contudo, os avanços tecnológicos têm contribuído de forma muito expressiva para que, cada vez mais, haja alteração do padrão da postura. Isso se deve ao aumento do tempo de tela, substituição de atividades manuais por eletrônicas, redução das horas de descanso, aumento do tempo sentado, falta de atividades físicas entre outros. Diante do exposto o objetivo geral da presente pesquisa foi avaliar a postura dos atletas e principalmente com os dados obtidos e com a revisão de literatura neste trabalho exposto, enfatizar a importância de cuidar da correta postura e ergonomia nas atividades de vida diária (AVDs). O artigo busca ainda como objetivos específicos, identificar padrões de desvios posturais nos avaliados, além de trazer o foco da área para a infância e juventude, onde não somente nos clubes esportivos, mas no ambiente escolar como um todo deve-se ter avaliações e recomendações posturais sistematicamente para estes problemas diminuam consideravelmente. A relevância do estudo consiste na colaboração com as evidências existentes na área, promovendo saúde nas escolas desportivas e centros educacionais em geral.

\section{DESVIOS POSTURAIS NO PLANO CORONAL}

Os desvios posturais como já elucidado, são problemas de ordem psicológica, congênita, muscular e hereditária, no entanto podem ser corrigidos. Quanto aos desvios posturais no plano coronal (KNOPLICH, 1985; VERDERI, 2009):

a) Pé Supinado: Apresenta queda lateral do arco transversal e o tendão calcâneo torna-se varo. Pode estar associado ao pé cavo e/ou a um joelho genovaro. Devemos estabelecer equilíbrio dos músculos dorsais e plantares e os exercícios devem estar associados a outras deformidades; 
b) Pé Pronado: Apresenta queda medial do arco transversal e o tendão calcâneo torna-se valgo. Pode estar associado ao pé plano e/ou a um joelho genovalgo. Os exercícios devem seguir os mesmos princípios do pé supinado (VERDERI, 2009).

c) Genuvarum: Conhecido como "pernas curvas", consiste em angulação externa da articulação do joelho, com o eixo do fêmur e da tíbia desviando-se medialmente, pode ocasionar pé supinado;

d) Genuvalgo (joelhos em " $x$ "): Angulação medial do joelho e desvio para fora do eixo longitudinal da tíbia e do fêmur. Nos casos mais estruturados, as pontas distais do fêmur e da tíbia são rodadas para fora pela tração do bíceps femoral e tensor da fáscia femoral, e o corpo distal da tíbia desenvolve torção interna compensatória. No desequilíbrio do arco plantar, ocasiona o pé pronado e plano e hiperextensão em adução dos joelhos.

e) Escoliose: Desvio assimétrico, lateral da coluna vertebral, resultado da ação de um conjunto de forças assimétricas que incidem sobre a coluna. A escoliose é classificada por: Idiopática que é uma causa desconhecida, infantil, juvenil e adolescente. Congênita que é a falha na formação dos ossos e na segmentação. Neuromuscular: poliomielite, paralisia cerebral, distrofia muscular e outros. Traumas: fraturas, cirurgias e queimaduras. Fenômenos irritantes: tumores medulares, hérnia de disco. Posturais: má postura e falsa escoliose. A nomenclatura é sempre dada pelo lado da convexidade, com os músculos do lado côncavo encurtados, e os do convexo alongados. A escoliose pode ser em "s" (compensatória) ou em "c" (funcional).

\section{DESVIOS POSTURAIS NO PLANO SAGITAL}

No plano sagital existem outros desvios, tais como (KNOPLICH, 1985, BIENFAIT, 1995):

a) Pé cavo: aumento do arco longitudinal, sem origem definida. Podem ser provenientes de doença paralítica, desequilíbrios posturais e musculares no período de crescimento, de doenças neurológicas ou deformidades da coluna, mas não se sabe como isso ocorre;

b) Pé Plano: É a diminuição do arco plantar e está sempre associado a um talusvalgus. Provoca rotação medial dos eixos tibiais e femorais e, consequentemente, a tendência a um joelho valgo, direcionando as patelas para o sentido medial. Tipos de 
pé plano: Pé plano flexível, pé plano verdadeiro, pé plano falso - tecido adiposo, pé plano funcional - causado pela fraqueza e estiramento dos músculos, ligamentos e fáscia plantar; deve ser corrigido por exercícios, pois pode alterar a mecânica corporal.

c) Genoflexum: Ocorre uma dorsiflexão do tornozelo, retração dos flexores do quadril (quando em pé) e esforço constante do quadríceps;

d) Genurecurvatum: Ocorre uma flexão plantar do tornozelo, mudança na posição da patela e compressão da articulação do joelho.

e) Hiperlordose Lombar: Aumento da curva na região cervical ou na região lombar, acentuação da concavidade cervical e/ou lombar no plano sagital. A hiperlordose lombar está associada a uma anteversão da pelve, que não deve exceder a $20^{\circ}$. Esse desvio é comum em ginastas e mulheres que fazem uso de salto alto;

f) Hipercifose Dorsal: É o aumento da convexidade posterior no plano sagital, podendo ser flexível ou irredutível, a cintura escapular torna-se projetada para a frente, com deslocamento das escápulas para baixo e para a frente. A musculatura peitoral torna-se hipertônica e a dorsal, hipotônica. A cabeça é projetada para a frente da linha de gravidade, ocasionando a hiperlordose cervical. Toda a hipercifose, de moral geral, tem sua lordose compensadora, cervical e lombar, para dessa forma poder manter a sustentação do corpo, mesmo que de forma descompensada

g) Dorso plano ou retificação da lombar: É a diminuição da curvatura da coluna na região da lombar, a coluna lombar tem uma leve curvatura, uma lordose, e quando essa curvatura perde sua acentuação, ou seja, quando é diminuída, é porque houve uma "retificação da coluna lombar". Kunzler et al.(2014) e Graup et al. (2010), convergem em dizer que a posição errônea ao sentar e por longos períodos é um dos principais agravantes no surgimento desse quadro. "A lombalgia é um dos maiores problemas de saúde pública. Há em média um gasto com esta patologia de 30 bilhões de dólares/ano, sendo cerca de $80 \%$ dos custos referem-se a pacientes com dores crônicas nas costas" (JESUS; MARINHO, 2006).

h) Cifo-lordose, exagero da curvatura normal anteroposterior da coluna. O termo Cifolordose, que é uma combinação das duas deformidades: hipercifose e hiperlordose, é aplicado, portanto, para a convexidade dorsal e concavidade lombar. Suas causas são: congênitas, pós-traumáticas, má postura, obesidade, fraqueza de grupos musculares, movimentos repetitivos (KNOPLICH, 1985). 
i) Postura desleixada ou dorso curvo: É o aumento da cifose torácica fisiológica com o achatamento da coluna lombar, seguido da anteriorização da cabeça e inclinação pélvica posterior (retroversão).

\section{MÉTODOS DE AVALIAÇÃO DA POSTURA}

Para a realização de uma avaliação postural, podem ser feitos alguns testes, tais como:

- Fio de Prumo: Consiste em avaliar a postura e desvios de um indivíduo através de uma linha que passa lateral e posteriormente ao corpo. Nesta avaliação são marcados os pontos anatômicos específicos conforme informado a seguir (recomenda-se uso de adesivos reflexivos para facilitar a visualização com o flash da fotografia) (KENDALL, 2007). Marcação dos pontos anatômicos: Fossa anterior do maléolo externo; Centro da articulação do joelho; Acima do trocanter maior do fêmur (eixo de articulação do quadril); Acrômio (centro da articulação do ombro); Lóbulo da orelha; Calcanhares; Linha poplítea; EIPS; Ângulo inferior da escápula; Processos espinhosos de C7 a L5; EIAS; Cicatriz umbilical.

- Flexicurva: Feita de um material maleável e de baixo custo, a flexicurva possibilita a realização de um molde da coluna vertebral, sendo esse possível somente no plano sagital, a fim de verificar as lordoses e cifoses (TEIXEIRA; CARVALHO, 2007). Devem ser marcados os processos espinhosos das vértebras C7, T1, T12, L1, L5 e S1, sendo moldada a flexicurva a partir da vértebra C7 até S1. Após o molde pronto, o mesmo deverá ser desenhado em um papel milimetrado, identificando os processos espinhosos, criando posteriormente um sistema de coordenadas $\mathrm{X}$ e $\mathrm{Y}$, onde deverão ser marcados 6 (seis) pontos aleatórios entre T1 e T12 e mais 6 entre L1 e L5. Calculado os resultados, estes devem ser inseridos no software da flexicurva, para que se chegue ao resultado final. (TEIXEIRA; CARVALHO, 2007).

- Teste de força: O teste de força do músculo é utilizado para determinar a capacidade de um músculo ou de grupos musculares de atuarem no movimento e sua capacidade de gerar estabilidade e suporte à articulação. A objetividade do teste de forca está baseada na capacidade de o examinador tocar e observar a resposta muscular de músculos fracos e a sua capacidade de mover-se ao longo da sua amplitude de movimento no plano horizontal ou manter a resistência do segmento avaliado em uma 
posição antigravitacional. Os testes realizados são: Teste de força abdominal, glúteo máximo, glúteo médio, extensores do tronco e romboides (CANDIOTTI, 2015).

- Teste de amplitude de movimento e comprimento muscular (flexibilidade): O teste de comprimento do músculo consiste em afastar a distância entre a origem e inserção do músculo, utilizando movimentos passivos ou ativos assistidos para determinar a extensão de alongamento do músculo.

Este teste é utilizado para determinar se o comprimento do músculo é normal, limitado ou excessivo, afastando-se a distância entre a origem e inserção do músculo. Os testes de flexibilidade usados foram: Teste de iliopsoas, isquiotibiais, peitoral maior, rotadores externos do ombro, rotadores internos do ombro, tensor da fáscia lata, redondo maior e grande dorsal (CANDIOTTI, 2015).

- Verificação da gibosidade: Além disso ainda se verificou a gibosidade, que consiste em o indivíduo flexionar o tronco à frente e ir subindo lentamente, de modo a observar possíveis desníveis que indiquem escoliose. Níveis de avaliação do teste: se for alguma alteração de um dos lados da coluna é sinal que o indivíduo possui gibosidade, que é um indício de escoliose.

Para a avaliação dos dados obtidos, no fio de prumo usou-se o software biomec flex versão 3.0, desenvolvido pelo grupo de investigação da mecânica do movimento (UFRGS). Os testes de flexibilidade e força serão avaliados conforme planilha de resultados (Candiotti et al., 2015). Além disso, avaliou-se a dor nos atletas, por meio do Questionário McGill de Dor, adaptado por Varolli e Pedrazzi (2006).

\section{CONCLUSÃO}

Com isso então se conclui o presente estudo demonstrando a importância das atividades físicas para se evitar e para diminuir esses problemas, mesmo que com algumas divergências entre os artigos presentes na revisão bibliográfica, pode-se perceber uma aparição de desvios posturais em indivíduos ao longo de toda a vida, desde a adolescência, passando pela fase adulta, até chegar à velhice, onde são mais intensificados os quadros de lombalgia e desvios.

Portanto, levando em conta os dados do referencial bibliográfico, percebe-se que é importante a prevenção desde cedo e o olhar atento dos profissionais de Educação Física nas escolas, clubes, academias e afins, para identificar e encaminhar 
para uma devida solução de problemas de ordem postural e muscular, pois ao contrário do que se pensa, quadros de ordem postural estão cada vez mais comuns em jovens, o que é alarmante, logo o estudo em questão incita essa busca pela saúde, ou seja, a busca pela melhora postural dos indivíduos, passando ativamente pelos profissionais da área da saúde, a sugestão que fica é, devemos prestar atenção na postura, pois é melhor prevenir do que tratar.

\section{REFERÊNCIAS}

BIENFAIT, Marcel. Os desequilíbrios estáticos: fisiologia, patologia e tratamento fisioterápico. São Paulo: Summus, 1995. 149 p. ISBN 8532304532.

BRACCIALLI, Lígia Maria P.. Estudo das relações existentes entre crescimento e desvios na postura. Reabilitar, 9:19-24,2000.

CAILLIET, R. Escoliose - diagnóstico e tratamento. 2. ed. São Paulo: Manole, 1976.

CHAGAS JCM, PUERTAS EB, SCHMIDT B, LAREDO FILHO J. Estudo histoquímico dos músculos rotadores do dorso de pacientes portadores de escoliose idiopática do adolescente. Rev Bras Ortop. 1993;28(3):

CHEN YL. Vertebral centroid measurement of lumbar lordosis compared with the Cobb technique. Spine. 1999; 24: 1786.

DUARTE, Marcos.Análise estabilográficada postura ereta humana quasi-estática. 2000. Tese de Doutorado. Universidade de São Paulo.

Filipovic V, Viskic-stalec N. The mobility capabilities of persons with adolescent idiopathic scoliosis. Spine, 2006;31(19):2237-2242.

GRUNENTAL PORTUGAL S.A. Site: http://www.grunenthal.com/grtweb/Grunenthal_Portugal/Tratamento_da_Dor/Sobr_a_Dor/Os_tipos_de_do r/167000189.jsp. Acessado em 25 de novembro de 2016.

LONGO, Reginaldo Dimas Raimundo. A Postura e os hábitos de vida como fatores para consciência corporal. Curitiba: SEED/PR. 2009.

KAPANDJI, I. A. Fisiologia articular :Esquemas comentados de mecanica humana. 1. ed. São Paulo: Manole, 1980.

KENDALL, F. Músculos: provas e funções. São Paulo: Manole, 1995.RIO RP. LER - ciência e lei (lesões por esforços repetitivos). Belo Horizonte: Health, 2007.

KNOPLICH, José. Como se tratam os desvios da coluna. São Paulo: Geigy, 1985. 26 p. 
MENDES, A. R., LEITE, N. Ginástica Laboral: Princípios e aplicações práticas. $2^{\circ}$ ed. São Paulo: Manole, 2008.

MACIEL, Regina Heloisa et al. Quem se beneficia dos programas de ginástica laboral?.Cadernos de Psicologia Social do Trabalho, v. 8, p. 71-86, 2005.

MAGGE, D. J. Avaliação Musculoesquelética.4ạed. São Paulo: Manole, 2005.

MARTINEZ, J. E., GRASSI, D. C, MARQUES, L. G. Análise da aplicabilidade de três instrumentos de avaliação de dor em distintas unidades de atendimento: ambulatório, enfermaria e urgência. RevBrasReumatol, Editora ElsevierLtda, 2011.

OLIVEIRA, S.; et al. A RPG como modificador da qualidade de vida de indivíduos portadores de lombalgia: um estudo Piloto. Revista Terapia Manual Fisioterapia Manipulativa. Londrina, v.4, p.12-16, 2006.

GRAUP, Susane; SANTOS, Saray Giovana dos; MORO, Antônio Renato Pereira. Estudo descritivo de alterações posturais sagitais da coluna lombar em escolares da rede federal de ensino de Florianópolis. Revista Brasileira de Ortopedia, Florianópolis, vol.45, n.5, p.453-459, 2010.

PORTO, Flávia et al. O exercício físico influencia a postura corporal de idosas?. Motriz: Revista de Educação Física, Rio Claro, vol. 18, n. 3, p. 487 - 494, jul. - set., 2012.

GRAUP, Susane. Desvios posturais na coluna lombar e a relação com dor, mobilidade articular e atividade física em adolescentes. Dissertação (mestrado) Universidade Federal de Santa Catarina, Centro de Desportos. Programa de Pós-Graduação em Educação Física, 2008.

KUNZLER, Mateus et al. Associação entre postura sentada e alterações posturais da coluna vertebral no plano sagital de escolares de Lajeado, RS. Revista Baiana Saúde Pública, Porto Alegre, vol. 38, n. 1, p. 197-212, jan. - mar., 2014.

JESUS, Gisele Torres de; MARINHO, Ildélia de Souza fusco. Causas de lombalgia em grupos de pessoas sedentárias e praticantes de atividades físicas. Centro Universitário Toledo - UNITOLEDO, Araçatuba, 2006.

DETSCH, Cíntia. Prevalência de alterações posturais em escolares de ensino médio de São Leopoldo (RS), Brasil. Dissertação (mestrado) - Universidade do Vale do Rio dos Sinos, Programa de Pós-Graduação em Saúde Coletiva, 2005.

MARTELLI, Raquel Cristina; TRAEBERT, Jefferson. Estudo descritivo das alterações posturais de coluna vertebral em escolares de 10 a 16 anos de idade. TangaráSC, 2004. Revista Brasileira Epidemiol, vol. 9, n. 1, p. 87-93, 2006. 
DETSCH et al. Prevalência de alterações posturais em escolares do ensino médio em uma cidade no Sul do Brasil. Revista Panamericana de Salud Pública, vol. 21, n. 4, p. 231-238, 2007.

PORTO, F. Avaliação postural dos idosos de Porto Alegre-RS com o uso da Técnica de Moiré de Sombra. (2008). 108 f. tese (Doctor) - Instituto de Geriatria e Gerontologia, PUCRS, Porto Alegre-RS, 2008.

HAMMERBERG, E. M.; WOOD, K. B. Sagittal profile of the elderly. Journal of spinal disorders and techniques, Hagerstown, v. 16, n. 1, p. 44-50, Feb 2003.

PORTO, F.; GURGEL, J. L.; RUSSOMANO, T.; FARINATTI PDE, T. Moire topography: characteristics and clinical application. Gait \& Posture, Oxford, v. 32, n. 3, p. 4224, Jul 2010.

MINISTÉRIO DA SAÚDE, MINISTÉRIO DA EDUCAÇÃO E DESPORTO. Postura corporal: integração dos fatores culturais e sociais aos fatores biológicos. Brasília, 1994.

TEIXEIRA F.A.; CARVALHO G.A. Confiabilidade e validade das medidas da cifose torácica através do método flexicurva. Rev. Bras. Fisioter. 2007; 11(3): 199-204.

VANICOLA, Maria Claudia et al. Reeducação da postura corporal.Motriz, v. 13, n. 4, 2007.

VAROLI, Fernando Kurita; PEDRAZZI, Vinícius. Adapted version of the mcgill pain questionnaire to Brazilian Portuguese. Braz. Dent. J., Ribeirão Preto , v. 17, n. 4, p. 328-335, 2006.

VERDERI, Erica. A importância da avaliação postural. Lecturas: Educación física y deportes, n. 57, p. 33, 2003. , Érica.Programa de educação postural. Phorte, 2005. 


\title{
CAPÍTULO XI
}

\section{A PANDEMIA DE COVID-19 E A DISSEMINAÇÃO DE FAKE NEWS: CONSIDERAÇÕES PARA UM LETRAMENTO MIDIÁTICO}

\author{
Vinicius Villani Abrantes ${ }^{1}$
}

\begin{abstract}
${ }^{1}$ Graduando em Letras, pela Universidade Federal de Juiz de Fora. Graduando em Direito, pela Faculdade Metodista Granbery
\end{abstract}

\section{RESUMO}

O presente capítulo está inserido no cenário da Covid-19 (SARS-CoV-2) em território nacional. A pandemia instalou no Brasil incertezas em diversas searas da sociedade; além disso, intensificou um grande desafio da contemporaneidade: a disseminação de Fake News, em face de evidências cientificas. A partir desse recorte dicotômico, este estudo buscará apresentar enfrentamentos a Fake News em momentos de pandemia, levando em consideração o conturbado cenário de combate ao Covid-19 no Brasil. Nesse contexto, é objetivo geral desta pesquisa dissertar sobre o cenário de disseminação de notícias falsas sobre a pandemia no Brasil; tornando-se objetivo específico demonstrar a importância de uma educação para a efetiva e consistente na busca de informações e evidências científicas. Para cumprir com o mencionado, a presente pesquisa de caráter básico e exploratório, utiliza a metodologia qualitativa crítica, integrando elementos que advém da análise de reportagens, textos especializados, legislações e protocolos nacionais e internacionais, de maneira a construir um arcabouço teórico crítico. $\mathrm{O}$ artigo conclui a disseminação de Fake News, de certa maneira, dificultou o controle da nova doença no Brasil; além disso, que a construção de comportamentos conscientes na busca de informações deve ser incorporadas.

Palavras-chave: Covid-19. Evidências Científicas. Fake News. Desafios contemporâneos.

Há verdadeiramente duas coisas diferentes: saber e crer que se sabe.

A ciência consiste em saber; em crer que se sabe reside a ignorância"

- Hipócrates

\section{INTRODUÇÃO}

No final do ano de 2019, o mundo é surpreendido por uma nova doença de etiologia desconhecida que atava gravemente os pulmões. A cidade Wuhan ${ }^{1}$, na China,

\footnotetext{
1 De acordo com Abrantes (2020), é importante mencionar que boa parte dos avanços nas pesquisas
- que se relacionam ao Covid-19 - só foram possíveis pela rápida ação dos pesquisadores chineses, do

1 De acordo com Abrantes (2020), é importante mencionar que boa parte dos avanços nas pesquisas
médicas - que se relacionam ao Covid-19 - só foram possíveis pela rápida ação dos pesquisadores chineses, do próprio município de Wuhan, na descoberta da sequência do genoma do vírus que lá circulava.
} 
foi o primeiro epicentro dessa nova infeção - que semanas depois se transformou em uma pandemia de abrangência multilateral (SENHORAS, 2020a).

A Organização Mundial de Saúde, também conhecida pela sigla OMS, apenas notificou oficialmente o mundo sobre essa nova doença em março de 2020, quando os casos confirmados já tinham ultrapassado 200 mil em todo o mundo. De acordo com as pesquisadoras Ribeiro e Cabral (2020), as medidas implementadas pelo Governo da China não foram suficientes para que pudesse conter a propagação da nova infeção, fato que levou com que a OMS atuasse com maior veemência nesse contexto.

A pandemia do novo coronavírus vem gerando tragédias e instabilidades humanas, políticas, sociais e econômicas em todo o globo. Nesse cenário, "somos ao mesmo tempo vítimas da doença ou de suas consequências, testemunhas, observadores, analistas, torcedores e atores, com responsabilidades relacionadas à prevenção, [e] ao cuidado (...)" (HENRIQUES; VASCONCELOS, 2020, p. 25).

Nesse cenário conturbado, a população vem diariamente sendo bombardeada com informações de diferentes maneiras - muitas dessas são falsas. De acordo com o Matos (2020) e com o estudo realizado pelo INCT \& LEA (2020), as Fake News aumentaram durante a pandemia.

Fake News (notícias falsas, em português) são grandes iscas para os cliques em massa. Elas aparentam notícias jornalísticas, entretanto, na maioria dos casos são criadas e disseminadas pela internet com viés políticos ou econômicos. É válido mencionar que pesquisadores como Guess, Nyhan e Reifler (2018) definem o fenômeno das notícias faltas como "um novo tipo de desinformação política" (p. 2).

Do lado oposto as notícias falsas durante a pandemia, está as evidências cientificas e os comunicados oficiais (e sérios) das entidades internacionais e Brasileiras. A partir desse recorte dicotômico, este estudo buscará apresentar enfrentamentos a Fake News em momentos de pandemia, levando em consideração o conturbado cenário de combate ao Covid-19 no Brasil. Nesse contexto, é objetivo geral desta pesquisa dissertar sobre o cenário de disseminação de notícias falsas sobre a pandemia no Brasil; tornando-se objetivo específico demonstrar a importância de uma educação para a efetiva e consistente na busca de informações e evidências científicas.

Para cumprir os objetivos dispostos, bem como responder o problema de pesquisa, o presente estudo de caraterística exploratória - isto é, através da exploração 
de diversos materiais especializados, busca-se gerar conhecimento e novas perspectivas sobre uma temática -, utiliza a metodologia qualitativa crítica. O grande anseio desta pesquisa é que cada vez mais a sociedade seja educada para que, de maneira consistentes e critica, possa buscar informações que sejam verídicas e íntegras.

Por fim, para uma melhor sistematização deste capítulo, a primeira seção é destinada a abordar aspetos inerentes a pandemia de Covid-19 com ênfase no território nacional. Na seção subsequente é apresentado um panorama sobre Fake News e materiais científicos durante a pandemia.

\section{A PANDEMIA DE COVID-19}

A palavra "pandemia" tem origem grega e, em sentido amplo, refere-se a qualquer acontecimento que seja capaz de alcançar toda a população. De acordo com Abrantes (2020), é valido mencionar que no início da pandemia houve grande preocupação dos Estado de que a epidemia pudesse atingir grandes proporções, se transformando em uma pandemia de abrangências multilateral ${ }^{1}$ (SENHORAS, 2020) fato que realmente ocorreu.

As autoras Belasco e Fonseca (2020) afirmam que as doenças emergentes e infecciosas são grandes desafios para a saúde pública global - calha mencionar que a atual pandemia (de Covid-19) é a maior ameaça à saúde pública mundial desde a pandemia da Gripe espanhola, em meados de 1918 (FERGUSON et al., 2020).

As referidas pesquisadoras, Belasco e Fonseca (2020) ainda mencionam que a descoberta do novo Coronavírus, se deu por recorrentes pneumonias com causas desconhecidas no município de Wuhan, na China. Huang et al. (2020) apontam que os sintomas do Sars-Cov-2 são: febre, tosse seca, dispneia, mialgia ou fadiga e lonfopneia. Nesta direção de ideias, vale mencionar que as secreções respiratórias foram consideradas o principal meio de propagação deste novo vírus (BELASCO; FONSECA, 2020).

1 Neste ponto, convém mencionar o raciocínio de Flor e Bezerra (2020) “(...) percebe-se justamente que o processo da globalização gera questões que não mais podem ser solucionadas dentro dos próprios ordenamentos dos Estados nacionais, sendo necessário recorrer à proteção de direitos numa perspectiva universal" (p. 6). Isto significa que problemas globais, carecem de respostas e cooperação global para uma solução mais justa e eficaz. 
Neste contexto é importante mencionar sobre a atuação da Organização Mundial de Saúde, doravante OMS. A referida organização foi fundada como uma das agencias das Nações Unidas, por meio da Assembleia Mundial de Saúde (com sede na Suíça). Uma das principais atividades da OMS é auxiliar na cooperação técnica e científica entre os países do globo.

Apesar de muito criticada, nesse contexto de pandemia, principalmente pelo lapso temporal para declarar a pandemia, boa parte das estratégias realizadas e determinadas pela OMS só foram possíveis pela sua ágil e proativa diplomacia da saúde - produto de experiências e esforços anteriores ${ }^{1}$ (LUIGI; SENHORAS, 2020).

Para além do mencionado, ainda no mesmo contexto, a Organização Mundial de Saúde teve também um importante papel frente a países de regimes políticos mais fechados (LUIGI E SENHORAS, 2020). A supracitada organização conseguiu que países com regimes mais fechados pudessem corroborar com o compartilhamento de informações e também outras questões - por exemplo, no Irã, a OMS conseguiu enviar uma missão cientifica para que pudesse atuar conjuntamente ao governo do país (ABRANTES, 2020).

\section{ENTRE EVIDÊNCIAS CIENTIFICAS E FAKE NEWS}

De mãos atadas com a desinformação, estamos imersos em um contexto de pandemia em que foi possível observar uma intensificação do número de notícias falsas sendo espalhadas. Dentro desse contexto de compartilhamento de notícias falsas, as redes sociais e os aplicativos de mensagem contribuem veemente desenfreado da (des)informação.

No ano de 2016, o Oxford Dictionary elegeu pós-verdade como a palavra do ano. Naquele contexto, haviam ocorrido dois eventos emblemáticos: a saída do Reino Unido da União Europeia e a vitória de Donald Trump para a presidência dos Estados Unidos. Além de compartilhar o mesmo ano, os dois eventos tiveram em comum um alto índice de disseminação de notícias falsas ou, em inglês, fake news, principalmente por meio das mídias sociais (GOMES; PENNA; ARROI, 2020, p. 2).

\footnotetext{
${ }^{1}$ A referida organização atuou em seus surtos com potencial pandêmico: Ebola, H1N1, Zika, Pólio, Mets e Sars - todos de caráter de emergencial global (LUIGI; SENHORAS, 2020; SENHORAS, 2020b).
} 
Calha mencionar que "pós-verdade" não significa que ocorreu a superação de uma época em que apenas informações verdadeiras eram compartilhadas e lidas, mas sim que a notícia ganha um impulso e velocidade quando compartilhada, se tornando um grande incêndio virtual (GOMES; PENNA; ARROI, 2020, p. 3). Alguns estudiosos, como Matos (2020) apontam que o compartilhamento dessas notícias falsas, principalmente nesse contexto em que vivemos, podem ser consideradas um problema de saúde pública. Ainda em consonância com o autor mencionado, o grande ponto dentro dessa problemática consiste no desnorteamento da população ${ }^{1}$ - notícias robustas e verdadeiras, infelizmente, adquirem menor impacto em diversos núcleos sociais.

Imerso no fluxo da pandemia, muitas das notícias publicadas nos meios de comunicação em massa e consumidas por diversas pessoas foram falsas, conforma afirma Neto et al. (2020). Nessa perspectiva de sanar dúvidas sobre as suspeitas de ser ou não uma Fake News, os referidos autores apontam que o Ministério da Saúde brasileiro capturou as notícias falsas e as classificou como Fake News.

Em 2018, o Ministério da Saúde brasileiro criou um espaço em um sítio eletrônico e nas redes sociais visando a combater as Fake News, e se propôs a esclarecer os fatos com base nas evidências científicas e suas fontes. Isto foi necessário em virtude de um parecer que apontou que aplicativos de trocas de mensagens dificultavam a população de se proteger de doenças, tais como febre amarela, gripe e sarampo (NETO et al., 2020, p. 4).

Ainda em consonância com a pesquisa de Neto et al. (2020) foram originadas cinco categorias de Fake News, durante os momentos iniciais da pandemia de Covid-19, levando em consideração os dados disponibilizados pelo Ministério da Saúde: (a) informações relacionadas aos discursos de autoridades na saúde; (b) terapêutica; (c) medidas de prevenção; (e) prognósticos da doença; e (f) vacinação.

Diante do estudo realizado por Neto et al. (2020), fica evidente que o compartilhamento das Fake News foi mais rápido a partir do momento em que as

${ }^{1}$ Nesse ponto, fazendo uma conexão com a ideia de pós-verdade mencionada, “a percepção do que é ou não verídico pode ser manipulada recorrendo, por exemplo, às emoções e crenças pessoais, 'cegando' a percepção dos fatos - ou melhor, conduzindo ao mundo da pós-verdade" (GOMES; PENNA; ARROI, p. 3). 
evidências científicas passaram a serem mais questionadas no campo da política - o que expõe a população à propagação de condutas inadequadas.

Nesse sentido, traz-se à tona o debate em prol da saúde pública sobre as Fake News em tempos da pandemia da COVID-19. Em outras palavras, as informações veiculadas e identificadas pelo Ministério da Saúde desorientam a população ao produzirem efeitos que, ao serem compartilhadas, colocam em risco as condutas diretivas (NETO et al., 2020, p. 4).

Refletir sobre notícias falsas é, em certo modo, (re)pensar na maneira em que são disponibilizadas as publicações científicas e também sobre a maneira em que essas informações são consumidas pela população em geral. Com o grande avanço da pandemia de Covid-19, há de se pensar em medidas rápidas e eficientes para preservar a população desse grande problema. É necessário pensar em fortalecer as esferas cientificas e promover, cada vez mais, estratégias cientificas para a melhor compreensão do movimento de enfrentamento a pandemia de Covid-19.

\footnotetext{
Atores desonestos - incluindo governos e organizações apoiadas por doadores bem financiados e propensos a conspirações e charlatanismo - são responsáveis por injetar dúvidas [não só] sobre a ciência médica bem estabelecida e promover teorias e explicações selvagens sobre a causa e o tratamento de doenças (WAISBORD, 2020, p.7) ${ }^{1}$
}

A pandemia não só trouxe medo e tirou vidas, como também evidenciou faces problemáticas que estavam intrínsecas na sociedade brasileira - como poucas vezes foi evidenciado em planos globais.

\section{CONSIDERAÇÕES FINAIS}

Fica-se evidente que na sociedade brasileira há ausência de uma cultura crítica sobre o consumo de informações midiáticas. Levando em consideração a famosa frase de Nietzsche, não há fatos, apenas interpretações, há de se pensar em desenvolver critérios contundentes para a análise e, por conseguinte, absorção das informações.

\footnotetext{
${ }^{1}$ Grifo nosso.
} 
Nos influxos e fluxos da tecnologia e da globalização, com o grande número de informações, tópicos para uma educação voltada para a busca e análise de informações midiáticas se mostram extremamente relevante. Nos sistemas educacionais, por exemplo, os professores e professores-em-formação podem trabalhar com o atual contexto, a partir de perspectiva de desinformação e leituras críticas.

Há de se pensar em um letramento midiático, conforme já mencionado, leituras críticas das partes imagéticas e não-imagéticas de um texto; para além disso, é sempre importante a busca de informações em diversos pontos, para que assim possa-se comparar as informações dispostas. Neste ponto, fica evidente a importância de se disponibilizar conteúdos científicos de forma mais clara e acessível, com a finalidade de atrair diversos nichos sociais, facilitando uma atenuação de notícias falsas.

Um dos grandes desafios da educação na contemporaneidade é a formação de uma cultura cidadã - que, de certa maneira, implica no que foi tecido neste capítulo. Isto significa que não se pode consumir informações e conhecimento de forma passiva e ingênua, mas preciso criar instrumentos de autonomia e discursividade.

\section{REFERÊNCIAS}

ABRANTES, V. V. "Brasil E Costa Rica no Combate à Pandemia de Covid-19". Boletim de Conjuntura (BOCA), vol. 3, n. 8, 2020.

GOMES, S. F.; PENNA, J. C. B. de O.; ARROIO, A. Fake News Científicas: Percepção, Persuasão e Letramento. Ciênc. educ. (Bauru), Bauru, v. 26, e20018, 2020. Disponível em: 2020. https://doi.org/10.1590/1516731320200018. Acesso: 04 set 2020.

GUESS, A., NYHAN, B., \& REIFLER, J. Selective Exposure to Misinformation: Evidence from the consumption of fake news during the 2016 US presidential campaign. Dartmouth, 2020. Disponível em: < https://www.dartmouth.edu/ nyhan/fakenews-2016.pdf >. Acesso: 04 set 2020.

HENRIQUES, C. M. P.; VASCONCELOS, W. Crises dentro da crise: respostas, incertezas e desencontros no combate à pandemia da Covid-19 no Brasil. Estudos Avançados, v. 34, n. 99, p. 25-44, 7 ago. 2020. Acesso: 04 set 2020.

INCT; LEA. Manual de enfrentamento de fake news em tempos de covid-19. INCT; LEA: Recife, 2020. Disponível em < https://sites.ufpe.br/rpf/wpcontent/uploads/sites/43/2020/05/Manual-de-enfrentamento-a-fake-news.pdf >. Acesso: 04 set 2020. Acesso: 04 set 2020. 
MATOS, R. Fake news frente a pandemia de COVID-19. Vigilância Sanitária em Debate: Sociedade, Ciência \& Tecnologia (Health Surveillance under Debate: Society, Science \& Technology) - Visa em Debate, v. 8, 2020.

NETO, M.; GOMES, T de O.; PORTO, FR.; RAFAEL, R de MR.; FONSECA, M.H.S.; NASCIMENTO, J. Fake news no cenário da pandemia de Covid-19. Cogitare enferm. [Internet]. 2020. Disponível em: http://dx.doi.org/10.5380/ce.v25i0.72627. Acesso: 04 set 2020.

RIBEIRO, M. T. A.; CABRAL, C. H. de P. L. "A dignidade humana frente às medidas sanitárias restritivas da OMS e dos estados em tempos de pandemia". Cadernos Eletrônicos Direito Internacional sem Fronteiras, vol. 2, n. 1, junho, 2020.

SENHORAS, E. M. “Coronavírus e Educação: análise dos impactos assimétricos". Boletim de Conjuntura (BOCA), vol. 2, n. 5, 2020.

WAISBORD, S. Fake health news in the new regime of truth and (mis)information. Reciis - Revista Eletrônica de Comunicação Informação e Inovação em Saúde, v.14, n.1, p.6-11, jan.-mar. 2020. Disponível em: < https://www.reciis.icict.fiocruz.br/index. php/reciis/article/view/1953>. 


\title{
CAPÍTULO XII
}

\section{ENSAIO SOBRE OS DESAFIOS DA EDUCAÇÃO NA CONTEMPORANEIDADE: REFLEXÕES SOBRE A EDUCAÇÃO NO BRASIL}

\author{
Ricardo Marinho da Silva ${ }^{1}$
}

\begin{abstract}
${ }^{1}$ Mestrando em Psicologia. Escola de Ciências Sociais da Universidade de Évora Portugal - UÉVORA
\end{abstract}

\section{RESUMO}

A educação brasileira é fruto sócio histórico atravessada pelo viés politico-ideológico que acompanha contemporaneamente os fenômenos sociais. A partir disso, o presente ensaio teórico tem como objetivo refletir, de forma crítica, sobre a educação brasileira, sob o recorte socioeconômico, político e histórico. Identificou-se que a educação brasileira se constrói a partir de desigualdades sociais e se equilibra a reforçar lugares de exclusão social. Tais desafios, denunciam uma sobreposição do sistema econômico capitalista-neoliberal, impactando na educação democrática-universalista-equitativa. Espera-se, a partir deste ensaio, criar-se novas reflexões e que, com isso, surjam novas oportunidades de se pensar a educação de maneira universalista-equitativademocrática. Expectamos que este eclipse seja da mais curta duração e que seus rastros não sejam irreparáveis ao projeto público de educação Brasileira na contemporaneidade.

Palavras-chave: Educação pública brasileira. Contexto histórico da educação pública no brasil. Educação Universal-Equitativa-democrática. Problemáticas contemporâneas na educação. Ensaio teórico.

\section{INTRODUÇÃO}

A história da educação brasileira é preconizada pelo colonialismo europeu. Refletida das grandes navegações - época de buscas europeias por rotas comerciais marítimas, gerando eurocentrismo - dominação europeia sob as Américas e, consequentemente, colonização/civilização das populações dissidentes. Transportadas em seus navios negreiros, estilos de vida, crenças e teorias, sombreadas pela exploração, escravização e genocídio da população indígena/negra.

Com o movimento da Revolução Industrial na Inglaterra, contexto de desenvolvimento técnico-científico, marcada pela centralização do trabalho maquinizado/operacionalizado. No Brasil, essa comutação ocorre, com a mudança do 
cenário agropecuário para o incentivo ao cenário industrial-urbano, moderniza-se a economia e demanda a qualificação da emergente burguesia. A busca por educação qualificada se amplia, desloca-se da centralidade existente em torno da monarquia e volta-se a atender as necessidades da nova elite brasileira.

Os ideais "Liberté, Egalité, Fraternité", que tiveram função de revolução sociopolitica-económica- capitalista, que ensaiam a criação dos países democráticos e seus mitos de ideais de igualdade, equidade e universalidade no Brasil, consolidam-se na construção de um ideal de lógica educacional democrática, teoricamente organizada na perspectiva da igualdade de direito.

Entretanto, após três séculos, o Brasil ainda colhe os frutos da colonização (exploração), cultura eugenista (branqueamento) e democracia destinada às elites, impactando em graves problemas estruturais-institucionais e subjetivos, que fazem a educação ser direito de poucos que, atrelado ao neoliberalismo, se tornaram reducionistas às lógicas tecnocientíficas, restritas ao mercado.

A partir disso, o presente ensaio teórico reflete sobre a educação brasileira como um reflexo sócio-histórico-cultural, consequentemente, reprodutora de estruturas sociais que foram marcadas por exploração, escravização, branqueamento, silenciamento e genocídio. A educação pública brasileira se equilibra entre a arte de educar/ensinar, mas para isso ocorrer, é preciso jogar com as problemáticas que se apresentam na educação. Tais desafios denunciam que a educação contemporânea é atravessada por políticas ideológicas de viés conservador-religioso somada a sobreposição do sistema econômico, impactando na educação democráticauniversalista-equitativa. Espera-se, a partir desse ensaio, criar-se novas reflexões e, com isso, que surjam novas oportunidades de se pensar a educação pública brasileira.

\section{REVISÃO BIBLIOGRÁFICA}

\subsection{A construção da educação no Brasil}

As primeiras formas de educação no Brasil iniciam-se nas missões da Companhia de Jesus, um grupo de católicos Jesuítas exportados pelas grandes embarcações para catequizar a população indígena em 1549 (SHIGUNOV \& MACIEL, 2008). As missões tinham função de civilizar os nativos com a educação (costume) europeia. Com o 
letramento cristão, com o objetivo de catequizar a população nativa com o estilo de vida, soberania do cristianismo europeu. Em outros termos, os indígenas eram convidados a perderem aspectos da sua nacionalidade em detrimento da cultura Portuguesa. A educação, além de domesticar os comportamentos selvagens, tinha função de dominação da Igreja Católica, seguida dos interesses do governo Português (MACIEL \& SHIGUNOV, 2006; SILVA \& AMORIM, 2017).

Em 1599 é criado a diretriz curricular, pensada pela Igreja, através da metodologia eclesiástica de seminários e primeiras escolas do Brasil. Com o objetivo de letrar a elite da sociedade colonial através da alfabetização. A função desse ensino era a organização de uma sociedade hierarquizada pelo acesso à alfabetização, em que ler e escrever eram privilégios que geravam violência, exclusão e separação dos alfabetizados e não alfabetizados e o ensino da Teologia, Gramática e Filosofia eram reservados aos filhos pertencentes as burguesias Brasileiras (RIBEIRO, 1993; SILVA \& AMORIM, 2017).

Em 1750 o primeiro-ministro de Portugal Marquês do Pombal decidiu abolir a educação católica, por acreditar que representava uma ameaça ao poder absoluto do rei (MACIEL \& SHIGUNOV, 2006). Movimento que desmonta a educação cristã, retira-se o absoluto poder da igreja, dando o protagonismo da educação ao professor. Essa nova forma de educação foi restrita à elite brasileira, fazendo com que os índios catequizados perdessem espaço no sistema de ensino (AMOROSO, 1998). O objetivo desse novo modelo de educação imposto ao Brasil, era fortalecer a economia Portuguesa, através do incentivo/desenvolvimento das indústrias e das companhias de comércio, com a crença que através da remodelação do sistema de ensino brasileiro pelo absolutismo/iluminismo a formação produtiva da colónia nutriria a construção do sistema de produção pré-capitalista em Portugal. Todavia, o país colonizado que sofria com o regime de vários tipos de explorações não tinha condições económicas, mão de obra qualificada e estrutura pedagogia para suportar os avanços do modelo de educação europeia (VICENTE, 1993; PINSKY, 2010; CALIXTRE \& FILHO, 2014).

Com a chegada da família real Portuguesa no Rio de Janeiro em 1808, trazendo consigo a monarquia como forma de governo, em que a economia é baseada no latifúndio monocultor escravista e destinado à exportação. $\mathrm{O}$ desenvolvimento socioeconômico da Europa extorquia a custo da exploração no lugar de colonizador. Em 
consequência, os encaminhamentos para a construção de pobreza, vulnerabilidade e desigualdades no Brasil eram crescentes (SILVA \& DELGADO et. al., 2005; SCHULTZ, 2008; MEIRELLES, 2015).

A primeira educação formal no Brasil surge através da primeira Constituição Política do Império do Brasil, que nasceu da necessidade de legitimar o novo império, elaborada por um Conselho de Estado e outorgada pelo Imperador D. Pedro I. A constituição de 1824 é importante para a organização político-institucional do Brasil como país independente de Portugal (OLIVEIRA, 2005). É através da primeira constituição que surgem os direitos civis e políticos, tendo por base a liberdade, a segurança individual e o direito a propriedade. As leis asseguravam o estatuto de cidadão brasileiro e lhes permitiam o direito ao voto, educação, liberdade de expressão, liberdade religiosa e direito à propriedade (BRASIL, 1824). A titularidade da cidadania direitos civis, definida constitucionalmente, era restrita aos homens livres e refletia-se nos direitos civis e político. No entanto, a I. A constituição de 1824 não concernia cidadania - direito de cidadão civil para mulheres, negros escravos e indígenas. A essa população os direitos eram negados, atribuíndo-lhes o papel de exclusão e invisibilidade civil-política e social (VEIGA, 2008; PINSKY, 2010, 2012; BARROS, 2016).

Essa política de exclusão, que oblitera gravemente a população abjeta, implicava diretamente na educação: Em primeiro momento descrito na I Constituição Brasileira em 1824, que afirmava a escola como um direito de todos os cidadãos, com exceção das mulheres, negros escravos e indígenas que não eram considerados cidadãos. E lhes era proibido o acesso à Educação, não pertencentes a sociedade brasileira (BRASIL, 1824; FONSECA, 2002). Em segundo momento com a I lei da educação 1 de 14 de janeiro de 1837, que vetava o acesso de escravos, pretos africanos, ainda que fossem livres. Criando narrativas que promovem espaços de exclusão política-social a população negra/indígena na história do Brasil (MOYSÉS, 1994; VEIGA, 2008; BARROS, 2016).

Em 1850 é criada a lei no 601, que estabelecia o fim da apropriação de terras através do trabalho, restrita apenas por compra do estado (Brasil, 1850). As terras que eram ocupadas por negros/indígenas passaram a ser propriedade do estado. A lei de terras trata-se de um projeto político-constitucional que retira habitações/direito a terra a população indígena e negra pertencente. Dando o lugar de desabrigadas, vulneráveis a situação de extrema pobreza e miséria. A construção do Brasil se organizava a produzir 
escravos por via de desigualdades sociais. Segundo Silva (2015), a lei de terras beneficiava os senhores que dominavam o cenário político e econômico do Brasil imperial. Em contrapartida, a lei de terras ofereceu subsídios de terra e incentivos financeiros a trabalhadores imigrantes da Europa com o objetivo de popularem o território brasileiro. Tal fenômeno é considerado como política de embranquecimento. Trata-se de projetos políticos-ideológicos destinados a erradicar etnias africanas e indígenas da formação do Brasil (PINTO, 2014; SILVA, 2015).

Acrescido a esse contexto, o movimento capitalista - sistema económico que valorizava a moeda, consolidando política de Estado e economia de mercado, começa a germinar. O sistema económico agrário se transforma numa hierarquia burguesa sistema industrial, estabelecendo novas relações/configurações do viver, influenciando desde as características do mercado de trabalho até o funcionamento do Estado (SILVA, 2020).

Com a mudança político-social industrial específica da civilização ocidental e sua engrenagem voltada para o crescimento econômico, é implantada no país a primeira escola superior voltada para a formação de médicos, no Estado da Bahia. Posteriormente, são criadas as Escolas de Engenharia e logo depois de Direito, estas em Olinda e São Paulo, instituição historicamente influenciadas pelo contexto europeu, voltadas para dar conta das crescentes demandas que a elite e o Estado apresentavam na época (MENDONCA, 2000; MARTINS, 2002).

Estabeleceu-se no país uma sociedade pós-colonial que se esforçava por se recuperar da exploração portuguesa e seus padrões de branqueamento elitistas, escravocratas e de exclusão (SILVA \& DALTRO, 2018). Dessa forma, o Estado, a segurança e saúde pública trabalhariam para resolver a condição miserável do país, utilizando de estratégias para eliminar ou controlar o crescimento (natalidade) da raça negra. Culturalizando as mortes de pessoas negras, pobres ou pertencentes do ciclo da exclusão. Que são vistas, ou melhor, não são vistas como perda, mas sim, tendo suas mortes como naturalizadas no cotidiano da vida (SILVA, 2020).

O debate racial tornou-se relevante para a elite intelectual da época, que acreditava que a eugenia seria a higiene social em prol do progresso do país (MANSANERA \& SILVA, 2000; BARBOSA, 2016). No Brasil, Renato Kehl foi o marco responsável pelo movimento eugenista, implantando a ideia de segregação de 
deficientes, esterilização eugênica, controle matrimonial, seleção de imigrantes, castração dos anormais e criminosos e educação eugênica obrigatória nas escolas (FIUZA, 2016). Seus principais apoiantes, que representavam a elite branca brasileira, eram Júlio de Mesquita, dono do jornal O Estado de S. Paulo; Arnaldo Vieira de Carvalho, fundador da Faculdade de Medicina em São Paulo e Monteiro Lobato, escritor influente no Brasil.

A culturalização da inferioridade negra se disseminou na sociedade brasileira, junto a ideia de miscigenação como solução para evolução das mazelas do Brasil (ALMEIDA, 2018; BATISTA, 2018). A educação da época colocava a descendência africana como responsável pela situação de extrema pobreza e vulnerabilidade causada pelo colonialismo europeu. Em consequência, criavam-se políticas de embraquecimento da população (GONÇALVES, 2017). Estas políticas eugenistas propostas por Francis Galton (1822-1911), defendiam a entrada de imigrantes brancos europeus, como projeto para embranquecer a população brasileira ao longo dos anos (FORMIGA et. al., 2019). Tais ventos produziram uma educação racista, excludente e segregadora, ensinando a sociedade que a educação de qualidade era direito pertencente a poucos, nomeadamente à elite branca brasileira (ALMEIDA, 2002).

O século XIX, marcado pelos ideais de "Liberté, Egalité, Fraternité" da Revolução Francesa e seus regimes liberais de estado laico e não intervencionista no contexto europeu. À luz desse contexto histórico, a educação se consolida no Brasil como território de elites econômicas e intelectuais. Fortemente influenciada pelo projeto nacional de higienização escravocrata da época que lhes retirava o direito, violentava e criminalizava a população negra residente (CARDOSO, 2008; SILVA, 2010; COSTA, 2013; ESTEVES, 2014).

No século XX, a educação se constrói como produtora de conhecimento a serviço dos ideais de modernidade, ordem, progresso e racionalidade. A educação, portanto, torna-se teoricamente direito de todos, constitucionalmente em 1988, todavia, no plano do real acessado por poucos. Alimentado pelos contextos de extrema pobreza, vulnerabilidades e pelos processos subjetivos causados pelos discursos escravocratas coloniais. Nesse contexto, as instituições de Ensino Superior no Brasil eram restritas a burguesia elitista, buscando atender ao mercado que demandava mão de obra 
qualificada para formação do comércio nacional, ao mesmo tempo que a educação básica buscava criar sua identidade enquanto sistema de educação (STALLIVIERI, 2006).

No início na década de 1950-60, intelectuais opositores do governo e do modelo educacional vigente na Era Vargas, como Anísio Teixeira e Darcy Ribeiro, inauguram um importante movimento de democratização do ensino público (NUNES, 2000; CAVALIERE, 2010). O teórico da educação Anísio Teixeira formou-se em Ciências Jurídicas e Sociais no Rio de Janeiro, em 1922. Em 1924 foi diretor-geral de instrução do governo da Bahia, fundou o Centro Educacional Carneiro Ribeiro a atual "Escola Parque" em 1950, em Salvador e reitor da Universidade de Brasília em 1964. Anísio Teixeira foi o principal teórico da educação, importante para a universalização de uma escola pública, laica, gratuita e obrigatória. Acreditava na escola como espaço de produção democrática, instrumento de justiça social e de correção das desigualdades construídas (CORDEIRO, 2001). Darcy Ribeiro estudou Ciências Sociais com especialização em Antropologia pela Escola de Sociologia e Política de São Paulo em 1946. Participou da discussão de Lei de Diretrizes e Bases da Educação; criou a Universidade de Brasília em que foi o primeiro reitor, foi ministro da Educação e chefe da Casa Civil do Governo João Goulart. Sua relevância social foi em construir uma educação pública-social fundamentada e pensar na articulação entre a formação básica e a superior de maneira integrada (MIGLIEVICH-RIBEIRO, 2017).

Visando a promoção de novos contornos para a educação, esses intelectuais propunham uma educação democrática, territorial e configurada como importante instrumento de apoio ao crescimento social do jovem país. Construindo uma nova educação interessada no social, democratização do ensino de qualidade, pesquisa qualificada e extensão comprometida com os problemas sociais, organização a serviço da reinvenção da ciência, da cultura e da política para a construção de uma nova sociedade brasileira mais equitativa-igualitária (TEIXEIRA, 1957; NUNES, 2000; MARTINS, 2012).

Entretanto, esse ciclo de crescimento expansionista social-intelectual-cultural, que apresenta grandes avanços para a criação de uma sociedade igualitáriademocrática-universalizada, se interrompe com a chegada da ditadura, que investe na formação tecnicista e funcional (BRENNANDE \& MEDEIROS, 2018), intencionalmente 
atrelado às demandas mercadológicas em uma perspectiva que priorizava as exigências do capital em detrimento das vulnerabilidades sociais.

Após um longo período de paralisia da era moral-cívica de formação técnicamercadológica, os ventos da educação foram lentamente se redesenhando. Em 1968 ocorre o movimento da reforma universitária, acompanha a ele os ideais de eficiência administrativa indissociabilidade do ensino, pesquisa e extensão como fundamentação das instituições de Ensino Superior (STALLIVIERI, 2006). Com projetos como a Lei do Conselho Nacional de Educação-Lei no 9.131/95 e a Lei de Diretrizes e Bases da Educação- Lei n 9.394 de 20 de dezembro de 1996, articulados com o os Parâmetros Curriculares Nacionais (PCN), emergem novas possibilidades de acesso ao ensino e com isso se ensaiam novas possibilidades para se pensar numa educação com contornos democráticos (SILVA \& DALTRO, 2018). No entanto, tais iniciativas, desenhadas teoricamente no papel e transportadas para a sua execução no plano real da experiência, solucionam as problemáticas da educação na contemporaneidade?

2.2. Problemáticas político - sócio - históricas: reflexões sobre implicações na Educação contemporânea

De acordo com Krawczyk (2011), a educação democrática no Brasil, trata-se de um falho projeto de educação de qualidade acessível a toda população. Criado, teoricamente, para encobertar a falta de acesso e de igualdade de oportunidades educacionais circunspectos em altas porcentagens de estudantes, que permanecem fora da escola pela desigualdade regional, de sexo e cor/raça. Haja vista, o sistema educacional brasileiro continua a perpetuar metabolismos de desigualdades sociais/socioeconômicas nas estruturas educacionais (SAMPAIO, 2011).

Refletidas em políticas educacionais que não suprem as necessidades básicas das escolas, exemplificadas em falta de estrutura institucional-pedagógica e recursos físicos/financeiros (MARQUES, 2003). Movimentos que ensaiam o assassinato de uma democracia que assegura a educação publica de qualidade, o transformando em um projeto falido/empobrecido destinado a uma específica população carenciada. Dessa forma, identifica-se que o projeto violento de exclusão sócio histórica que constrói a educação no Brasil, continuam presentes, tornando-se cada vez mais imperceptíveis, inteligentes e evoluem acompanhando as novas configurações sociais. 
No plano do real, notamos ostensivamente por políticas de investimento à educação básica privada; em contrapartida, do movimento de contingenciamento que geram precarizações na educação publica. Criando na rede de ensino grandes disparidades que refletem na qualidade/eficiência entre os colégios de educação básica privados e públicos (SAMPAIO \& GUIMARÃES, 2009), favorável às escolas privadas (Moraes \& Belluzzo, 2014), refletidas no dimensionamento que se constituem como problema sócio-político e pedagógico. Isso reflete na qualidade de ensino ofertada que desloca a educação do território de direito - responsabilidade do Estado e a coloca como produto comercial - no campo do lucrável, destinado financeiramente a poucos (CARMEN \& ALAVARSE, 2011).

Acrescendo a esse contexto, a compreensão de que processos ideológicos acompanham as reformulações sócio-político-econômicas que formam a educação. Constatou-se, que a escola como instituição pertencente a uma estrutura social, confirma e reproduz estruturas sociais perversas. O que nos permite inferir que a universidade de qualidade é projetada para não ser acessada por todos, especialmente por grupos historicamente violentados/excluídos/invisibilizados que tiveram como única possibilidade a educação básica precária. Amparados em sucateamentos e vulnerabilidades presentes em escolas da rede pública (GOLDEMBERG, 1993; ERNICA \& BATISTA, 2012; BRUEL \& BARTHOLO, 2012).

Num ciclo em que estudantes que possuem melhores condições socioeconômicas, obtém, em consequência, melhores escores para ingresso no ensino superior de qualidade. Em outros termos, alunos que estudam todo o ciclo de ensino fundamental e básico nos melhores colégios privados, acessam de maneira facilitada, o ensino superior como as melhores universidades federais/públicas e privadas de qualidade (PILATTI \& CECHIN, 2018).

Tal projeto psicopedagógico de viés político-socioeconômico se engrena como um ciclo produtor de desigualdades, cuja função é manter estruturas/padrões como estruturas normativas para o funcionamento da sociedade. Como aponta Goldemberg: “Não é possível, hoje em dia, aumentar substancialmente a renda média de adultos sem instrução, nem se consegue educar adequadamente crianças cujas famílias vivem à beira da miséria" (GOLDEMBERG, 1993, p.65). Haja vista, a educação tornou-se um privilégio, atribuído a uma eleita elite social (SILVA \& DALTRO, 2019), preparada para 
ocupar o seu lugar, de status social (ALMEIDA, 2002), colocando a formação, de qualidade, atravessada pela ideia colonialista traduzidas por vieses elitistas, voltadas, especificamente, a classe média alta brasileira. A partir disso surge o seguinte questionamento: como solucionar os desafios da educação brasileira?

\subsection{Desafios da educação no Brasil: problemáticas política - sócio - históricas e suas implicações} na Educação moderna-contemporânea

O século XXI é marcado por grandes transformações políticas-ideológicas de descentralização de poder e investimento em programas sociais que afetam positivamente a democratização do ensino. Com criação de programas sociais que ampliavam o número de vagas nas universidades públicas e privadas, com especial ênfase na interiorização e aumento dos centros técnicos federais e universidades públicas no território brasileiro (MARTINS, 2002). Como programas como Universidade para Todos (PROUNI); Sistema de Seleção Unificada (SISU), Programa de Ações Afirmativas e o Programa de Financiamento Estudantil (FIES) que são projetos que foram criados como estratégias, auxiliando o acesso de grupos excluídos/invisibilizados, nomeadamente negro/indígenas e estudantes de escolas públicas ao acesso à universidade. Foram planeadas um conjunto de políticas públicas desenvolvidas buscando modificar a realidade histórica-social, que garantia o acesso à universidade, restrito a uma parcela específica de brasileiros. Esses programas tornam-se de grande relevância social, pois contrabalanceiam as desigualdades sociais historicamente construídas, criando novas possibilidades - realidades de vida.

Porém, ao longo desse período, tais medidas, em seu processo de execução, foram vendidas por outras ideologias de governo em incentivo neoliberal que thes retirou a responsabilidade do estado e investiu cada vez mais em privatizações, transformando o acesso a educação em um negócio com finalidades lucrativas (SILVA \& DALTRO, 2018). O que traduz que a educação publica não é considerada uma prioridade nesse atual plano político-governamental, o que torna o financiamento e gestão da educação publica produtos escassos (GOLDEMBERG, 1993).

A partir desses novos modelos neoliberais de educar, colhemos como frutos os agrotóxicos do cessamento de tais projetos político-sociais reforçando, novamente, lugares de falta de acesso e extremas desigualdades. Como o desmonte do Ministério 
da Educação e suas políticas de contigenciamento (congelamento) de verbas destinadas às esferas públicas. Afetando diretamente a Educação Básica pública, institutos técnicos federais e Universidades Públicas como o corte de verbas do Fundo Nacional de Desenvolvimento Educacional (FNDE), Coordenação de Aperfeiçoamento de Pessoal de Nível Superior (Capes), e especificamente programas que garantem acesso e permanência da população pobre-periférica-negra na educação publica de qualidade.

Refletindo, o Estado, fortalecido pelo discurso neoliberal, produz uma educação cada vez mais menos preocupada com a responsabilidade social. Trata-se de um processo social, econômico e cultural cujo o seu desenvolvimento é desigual, pois as regras do mercado baseadas em lucro capitalista controlam todas as esferas da vida humana, consequentemente, afetando o campo da educação, tornando-a responsável na produção de desigualdades cada vez mais excludentes (PIRES \& REIS, 1999; ROMAN, 1999).

Em consequência a execução dessas politicas neoliberais, pode-se observar o alarmante sucateamento da universidade pública, decorrente da crescente redução dos investimentos a ela endereçados e o crescimento do número de instituições de ensino superior pouco preocupadas com a qualidade do tripé, pesquisa-ensino-extensão e menos ainda com as dificuldades dos estudantes, ou mesmo a questão da desigualdade social aí colocada de forma pandêmica.

Em paralelo acresce políticas de educação contemporâneas como o "Escola sem partido" e "Programa future-se" que são programas do governo criados para combater a ideologia de gênero, combater a educação sexual e o chamado marxismo cultural na educação, todavia, são projetos que promovem ideologias conservadoras, munidas de enviesamentos religiosos e sucateamento/privatização do sistema público, que quando não prioriza o sistema económico, coloca em causa a laicidade do estado. Impactando em retrocessos de ordem social, econômica e cultural. Agonizadas em conflitos que retroalimentam processos de exclusão social e acentuam o individualismo, os interesses privados e logica de consumo.

Dessa forma, o presente ensaio reflete que se antes o cenário da educação pública brasileira não era o ideal, atualmente se agrava vendido a uma governabilidade hora conservadora, outra hora neoliberal, timidamente preocupada em políticas/programas sociais. Provocando cortes destinados à educação pública, que 
afeta diretamente a população indígenas, quilombolas e estudantes de baixa renda. 0 contingenciamento das verbas destinadas a educação atingem em especial alunos cotistas, oriundos de escola pública, aqueles que ingressaram em universidade federal e precisam de políticas de ações afirmativas para permanência no ensino superior ou por via dos programas sociais ingressam na educação superior privada, atravessada pela lógica produtivista do mercado, que secundariza o processo de ensino-aprendizagem sob a lógica do produzir e lucrar.

Um circuito de precarização a estruturas educacionais, metodologias de ensino, relações interpessoais entre aluno- professor, aluno-aluno, além das subjetividades que são condicionadas. Aos que não conseguem/não possuem condições a pertencer, lhes é imposto o escasso e sucateamento como única possibilidade, retirando-lhes o direito à igualdade. O sistema capitalista-neoliberal vende a educação como produto que, para ter acesso em sua integralidade, com qualidade, é preciso pertencer ao mundo mercantil. Reduzindo a educação em modelos competitivos para fins de mercado de trabalho, sob a forma de excluir os mais fracos para sobreviver -possibilidade de lucrarnum ciclo de desigualdades mascaradas sob o manto do mérito (SILVA \& DALTRO, 2018; SILVA, 2020). Dessa forma, trata-se de ventos difíceis para encarar um assertivo projeto democrático de educação pública que promova verdadeira inclusão educacional (KRAWCZYK, 2011).

Essa realidade contemporânea, se reflete numa educação que mesmo com políticas de ações afirmativas, ainda (re)produz violências históricas - sociais econômicas. Movimento que enviesa posições discriminatórias, raciais e preconceituosas dentro do universo educacional, causando impacto social e psicológico. Haja vista, modelos educacionais são dialéticos: moldados/constituídos a atenderem interesses sociais e reproduzirem lógicas de funcionamentos sociais. Isto posto, as deficiências no sistema público educacional geram desigualdade na distribuição da renda e, consequentemente, maior ciclo de pobreza e molda uma sociedade cheia de desigualdades sociais (GOLDEMBERG, 1993).

Esta realidade consolidou-se como uma cultura de exclusão, disfarçada sob o manto da inclusão, alimentando a lógica de formação das elites do país, sob a constituição democrática (PAIVA, 2010; SILVA \& DALTRO, 2018). Tal feito torna-se infirme quando atrelado aos ideais do mérito. Mantendo e ampliando diferentes formas 
e modelos de desigualdade social. Com isso, as violações de direitos vêm sendo banalizadas e sujeitos invizibilizados de diferentes formas o que promove, muitas vezes, de modo perverso, experiências de elevado sofrimento e adoecimento. Em que a educação atua como um projeto coadjuvante - responsável por produzir miserabilidades e culpabilizar os indivíduos pela sua extrema pobreza.

\section{CONSIDERAÇÕES FINAIS}

O objetivo deste trabalho não é fazer juízo de valor sobre a educação no brasil, tão pouco sobre o cenário sócio-político-económico. Espera-se que a partir da reflexão, abram-se novos horizontes nos permitindo outros olhares e, com isso, se alterem o sentido das coisas.

A história da educação brasileira ainda reproduz marcas do colonialismo europeu. Sombreadas pela exploração, escravização, cultura eugenista e democracia destinada as elites, impactando em graves problemas estruturais-institucionais e subjetivos, que fazem a educação ser direito de poucos que, atrelado ao neoliberalismo, tornaram-se reducionistas às logicas tecnocientíficas restritas ao mercado.

Dessa forma, reflete-se que a educação brasileira é um reflexo socio-históricocultural, reprodutora de modelos/normas/estruturas de funcionamentos coloniaiseugenistas baseados na exploração, cultura competitiva, hierárquica e excludente marcadas por vulnerabilidades latentes que são emergentes. Que se faz da vontade política fundamentada por interesses mercadológicos, constituídas independentemente do contexto cheio de vulnerabilidades sociais. Se formatando a ser um projeto políticosocial que reafirma estruturas de funcionamentos sociais que garantem lugares de extrema desigualdades, invisibilidade e insucessos.

Nesse contexto, refletir sobre a educação no Brasil é emergente, mais que uma problemática para o desenvolvimento de um sociedade democrática-universalequitativa-igualitária, é um paradigma que confronta estruturas/modelos de funcionamentos sociais atravessado por soberanias económica que favorecem interesses das elites brasileiras. Provocando uma precarização intencional, a educação pública brasileira enfrenta crises não é de agora. Sobrevivendo a um dia de cada vez. Se equilibrando entre assegurar materiais necessários básicos ou investimento em material 
pedagógico. Confrontados cada vez mais com risco do sucateamento-congelamentos e o plano de privatização do setor público.

A criação de programas sociais, que universalizam de forma equitativa o acesso a educação, é importante e torna a educação democrática, acessível a toda população. Porém, não erradica as desigualdades e suas frutíferas políticas de exclusão sociais construídas historicamente e que evoluem em parceria com o sistema. A situação que estamos a viver demonstra que a educação brasileira ainda é um privilégio de poucos. Receamos um mundo sem educação pública se prospectarmos passos dentro de um quadro socio-político-económico-cultural. A falta de equidade no desenvolvimento das contemporâneas leis de ampliação de acesso ao ensino, ocorrem de forma semelhante ao processo de libertação dos escravos que se configuram, em muitos casos, como um ciclo perverso que coloca a educação como um bem de direito, possível de ser adquirido, mas inalcançável no plano real da experiência.

Espera-se a partir desse ensaio crie-se novas reflexões, com isso, surjam novas oportunidades de se pensar a educação pública brasileira, e, com isso, modificar estruturas de funcionamento introjetadas como verdades absolutas na sociedade. Se viver não tem sido fácil e o horizonte começa a eclipsar cada vez mais no planeta terra. A partir dessa reflexão espera-se que possa construir futuramente consciência transformadora, equitativa, empática que valorize a educação como parte da transformação. Num mundo que mais se investe em tecnologia e consumismo é urgente o despertar para a importância de construir uma sociedade/projeto democrático de educação pública que promova verdadeira inclusão educacional. Espera-se que este eclipse seja da mais curta duração possível e que seus rastros não sejam irreparáveis a educação.

\section{REFERÊNCIAS}

AMOROSO, Marta Rosa. Mudança de hábito: Catequese e educação para índios nos aldeamentos capuchinhos. Rev. bras. Ci. Soc., São Paulo , v. 13, n. 37, p. 101114, June 1998. Available from $<$ http://www.scielo.br/scielo.php?script=sci_arttext\&pid=S010269091998000200006\&lng=en\&nrm=iso>. access on 12 Aug. 2019. http://dx.doi.org/10.1590/S0102-69091998000200006. 
ALMEIDA, Ana Maria; NOGUEIRA, Maria Alice. (Org.). A escolarização das elites: um panorama internacional da pesquisa. Petrópolis: Vozes, 2002.

BATISTA, Waleska Miguel. A inferiorização dos negros a partir do racismo estrutural. Rev. Direito Práx. , Rio de Janeiro, v. 9, n. 4, pág. 2581-2589, outubro de 2018. Disponível em $<$ http://www.scielo.br/scielo.php?script=sci_arttext\&pid=S2179896620180004 02581\&lng=en\&nrm=iso>. acesso em 12 de agosto de 2019. https://doi.org/10.1590/2179-8966/2018/36867 .

BARBOSA, Maria Rita de Jesus. A influência das teorias raciais na sociedade brasileira (1870-1930) e a materialização da Lei no 10.639/03. Revista Eletrônica de Educação, v. 10, n. 2, p. 260-272, 2016. ISSN 1982-7199. access on 17 Aug. 2020. DOI: http://dx.doi.org/10.14244/198271991525

BARROS, Surya Pombo de. Escravos, libertos, filhos de africanos livres, não livres, pretos, ingênuos: negros nas legislações educacionais do XIX. Educ. Pesqui., São Paulo, v. 42, n. 3, p. 591-605, set. 2016. Disponível em <http://www.scielo.br/scielo.php?script=sci_arttext\&pid=S1517-

97022016000300591\&lng=pt\&nrm=iso>. acessos em 12 jan. 2020. http://dx.doi.org/10.1590/S1517-9702201609141039.

BRASIL, Presidência da República. Casa Civil. Subchefia para Assuntos Jurídicos. (1824).

Disponível em: http://www.planalto.gov.br/ccivil_03/Constituicao/Constituicao24.htm>. acesso em 12 de agosto de 2020.

BRASIL, Legislação Informatizada - Lei no 5.465, de 3 de Julho de 1968 - Publicação Original. Lei no 5.465, de 3 de Julho de 1968. Disponível em: https://www2.camara.leg.br/legin/fed/lei/1960-1969/lei-5465-3-julho-1968358564-publicacaooriginal-1-pl.html>. acesso em 12 de agosto de 2020.

BRASIL, Presidência da República Casa Civil. Subchefia para Assuntos Jurídicos. LEI No 601, DE 18 DE SETEMBRO DE 1850. Dispõe sobre as terras devolutas do Império. Disponível em: http://www.planalto.gov.br/ccivil_03/LEIS/L0601-1850.htm Acessado em 17 de julho de 2020.

BRENNANDE, Edna Gusmão Góes; MEDEIROS, José Washington de Morais. A RAZÃO INVERTIDA: O TECNICISMO NA EDUCAÇÃO COMO VEÍCULO DE COLONIZAÇÃO DO MUNDO VIVIDO. P2P E INOVAÇÃO, v. 4, n. 2, p. 6-28, 21 mar. 2018.

BRUEL, Ana Lorena; BARTHOLO, Tiago Lisboa. Inequality of educational opportunities in Rio de Janeiro public school system: transition between segments of elementary school. Rev. Bras. Educ., Rio de Janeiro, v. 17, n. 50, p. 303-328, Aug. 2012. Available from <http://www.scielo.br/scielo.php?script=sci_arttext\&pid=S141324782012000200004\&lng=en\&nrm=iso>. access on 17 Aug. 2020. http://dx.doi.org/10.1590/S1413-24782012000200004. 
CARDOSO, Adalberto. Escravidão e sociabilidade capitalista: um ensaio sobre inércia social. Novos estud. - CEBRAP, São Paulo, n. 80, p. 71-88, mar. 2008 . Disponível em <http://www.scielo.br/scielo.php?script=sci_arttext\&pid=S010133002008000100006\&lng=pt\&nrm=iso>. acessos em 10 fev. 2019. http://dx.doi.org/10.1590/S0101-33002008000100006.

CAVALIERE, Ana Maria. Anísio Teixeira e a educação integral. Paidéia (Ribeirão Preto), Ribeirão Preto, v. 20, n. 46, p. 249-259, Aug. 2010 . Available from $<$ http://www.scielo.br/scielo.php?script=sci_arttext\&pid=S0103-

863X2010000200012\&Ing=en\&nrm=iso>. access on 17 Aug. 2020. https://doi.org/10.1590/S0103-863X2010000200012.

CALIXTRE, André Bojikian; FILHO Niemeyer Almeida. Cátedras para o desenvolvimento : patronos do Brasil: Rio de Janeiro: Ipea, 2014. 656 p. ISBN 978-85-7811-241-7

CORDEIRO, Célia Maria Ferreira. Anísio Teixeira, uma "visão" do futuro. Estud. av. , São Paulo, v. 15, n. 42, pág. 241-258, agosto de 2001. Disponível em <http://www.scielo.br/scielo.php?script=sci_arttext\&pid=S0103-

40142001000200012\&lng=en\&nrm=iso>. acesso em 12 de agosto de 2020. https://doi.org/10.1590/S0103-40142001000200012 .

COSTA, Jean Carlo de Carvalho. Sílvio Romero e a "idéia das três raças": uma hermenêutica do nacional a partir da categoria miscigenação. Revista Cronos, v. 7, n. 1, 9 jan. 2013.

DE ALMEIDA, Silvio Luiz. O que é racismo estrutural?. Belo Horizonte: Letramento, 2018.

ESTEVES, Cleydia. O território brasileiro e a formação nacional: algumas aproximações a partir da produção intelectual no Brasil. GOT, Porto, n. 6, p. 89-111, dez. 2014 . Disponível em <http://www.scielo.mec.pt/scielo.php?script=sci_arttext\&pid=S218212672014000200007\&lng=pt\&nrm=iso>. acessos em 17 ago. 2019. http://dx.doi.org/10.17127/got/2014.6.007.

ERNICA, Maurício; BATISTA, Antônio Augusto Gomes. A escola, a metrópole e a vizinhança vulnerável. Cad. Pesqui., São Paulo, v. 42, n. 146, p. 640-666, Aug. 2012 Available from <http://www.scielo.br/scielo.php?script=sci_arttext\&pid=S010015742012000200016\&lng=en\&nrm=iso>. access on 17 Aug. 2020. https://doi.org/10.1590/S0100-15742012000200016.

FERREIRA, Bia. Cota não é esmola. Estúdio Showlivre, 2018. Disponível em: <https://youtu.be/QcQlaoHajoM> Acesso em: 31 de agosto de 2020.

FIUZA, Denis Henrique. A Propaganda da Eugenia no Brasil: Renato Kehl e a implantação do racismo científico no brasil a partir da obra "Lições de Eugenia". ADEDOS: 
UFRGS, v. $8, \quad$ n. $19.2016 . \quad$ Disponível em: https://seer.ufrgs.br/aedos/article/view/68669. access on 17 Aug. 2019.

FORMIGA, Dayana de Oliveira; MELO, Charles Aparecido Silva; PAULA, Ana Beatriz Rodrigues. O pensamento eugênico e a imigração no Brasil (1929-1930). Intelligere, n. 7, p. 22, 11 set. 2019.

GONCALVES, Paulo Cesar. Escravos e imigrantes são o que importam: fornecimento e controle da mão de obra para a economia agroexportadora Oitocentista. Almanack, Guarulhos, n. 17, p. 307-361, Dec. 2017 . Available from <http://www.scielo.br/scielo.php?script=sci_arttext\&pid=S2236-

46332017000300307\&lng=en\&nrm=iso>. access on 17 Aug. 2020. https://doi.org/10.1590/2236-463320171710.

GOLDEMBERG, José. O repensar da educação no Brasil. Estud. av., São Paulo, v. 7, n. 18, p. 65-137, Aug. 1993 . Available from <http://www.scielo.br/scielo.php?script=sci_arttext\&pid=S010340141993000200004\&lng=en\&nrm=iso>. access on 17 Aug. 2020. https://doi.org/10.1590/S0103-40141993000200004.

KRAWCZYK, Nora. Reflexão sobre alguns desafios do ensino médio no Brasil hoje. Cad. Pesqui., São Paulo, v. 41, n. 144, p. 752-769, Dec. 2011 . Available from $<$ http://www.scielo.br/scielo.php?script=sci_arttext\&pid=S010015742011000300006\&Ing=en\&nrm=iso>. access on 24 Aug. 2020. https://doi.org/10.1590/S0100-15742011000300006.

MACIEL, Lizete Shizue Bomura; SHIGUNOV NETO, Alexandre. A educação brasileira no período pombalino: uma análise histórica das reformas pombalinas do ensino. Educ. Pesqui., São Paulo, v. 32, n. 3, p. 465-476, dez. 2006 . Disponível em $<$ http://www.scielo.br/scielo.php?script=sci_arttext\&pid=S151797022006000300003\&lng=pt\&nrm=iso>. acessos em 12 ago. 2019. https://doi.org/10.1590/S1517-97022006000300003.

MARTINS, Eliana Bolorino Canteiro. Educação e serviço social: elo para a construção da cidadania [online]. São Paulo:Editora UNESP. 2012. A polótica de educação brasileira: uma leitura sob a óptica do serviço social. pp. 75-113. ISBN 978-853930-243-7. Available from SciELO Books <http://books.scielo.org>.

MARTINS, Antonio Carlos Pereira. Ensino superior no Brasil: da descoberta aos dias atuais. Acta Cir. Bras., São Paulo, v. 17, supl. 3, p. 04-06, 2002. Available from <http://www.scielo.br/scielo.php?script=sci_arttext\&pid=S0102$86502002000900001 \& \operatorname{lng}=e n \& n r m=$ iso $>$. access on 17 Aug. 2020. https://doi.org/10.1590/S0102-86502002000900001.

MANSANERA, Adriano Rodrigues; SILVA, Lúcia Cecília da. A influência das idéias higienistas no desenvolvimento da psicologia no Brasil. Psicol. estud., Maringá , v. 5, n. 1, p. 115-137, Mar. 2000 . Available from 
<http://www.scielo.br/scielo.php?script=sci_arttext\&pid=S1413-

$73722000000100008 \&$ Ing=en\&nrm=iso>. access on 17 Aug. 2019. https://doi.org/10.1590/S1413-73722000000100008.

MARQUES, Luciana Rosa. O projeto político pedagógico e a construção da autonomia e da democracia na escola nas representações sociais dos conselheiros. Educ. Soc., Campinas, v. 24, n. 83, p. 577-597, Aug. 2003 . Available from $<$ http://www.scielo.br/scielo.php?script=sci_arttext\&pid=S0101-

73302003000200014\&lng=en\&nrm=iso>. access on 24 Aug. 2020. http://dx.doi.org/10.1590/S0101-73302003000200014.

MENDONCA, Ana Waleska P.C.. A universidade no Brasil. Rev. Bras. Educ., Rio de Janeiro n. 14, p. 131-150, Aug. 2000 . Available from $<$ http://www.scielo.br/scielo.php?script=sci_arttext\&pid=S1413-

24782000000200008\&lng=en\&nrm=iso>. access on 17 Aug. 2019.

MEIRELLES, Juliana Gesuelli. A família real no Brasil: política e cotidiano (1808-1821) [online]. São Bernardo do Campo: Editora UFABC, 2015, 91 p. ISBN: 978-8568576-96-0. https://doi.org/10.7476/9788568576960.

MIGLIEVICH-RIBEIRO, Adelia. Darcy Ribeiro e UnB: intelectuais, projeto e missão. Ensaio: aval.pol.públ.Educ., Rio de Janeiro, v. 25, n. 96, p. 585-608, set. 2017 . Disponível em <http://www.scielo.br/scielo.php?script=sci_arttext\&pid=S010440362017000300585\&lng=pt\&nrm=iso>. acessos em 12 ago. 2020. Epub 26Jun-2017. https://doi.org/10.1590/s0104-40362017002500939.

MOYSÉS. Sarita Maria Affonso. Leitura e apropriação de textos por escravos e libertos no Brasil do século XIX. In: Revista de Ciência e Educação - Educação e Sociedade. São Paulo: Papirus, n.48, agosto/1994.

MORAES, André Guerra Esteves de; BELLUZZO, Walter. O diferencial de desempenho escolar entre escolas públicas e privadas no Brasil. Nova econ., Belo Horizonte, v. 24, n. 2, p. 409-430, Aug. 2014 . Available from $<$ http://www.scielo.br/scielo.php?script=sci_arttext\&pid=S010363512014000200409\&lng=en\&nrm=iso>. access on 17 Aug. 2020. http://dx.doi.org/10.1590/0103-6351/1564.

NUNES, Clarice. Anísio Teixeira entre nós: a defesa da educação como direito de todos. Educ. Soc., Campinas, v. 21, n. 73, p. 9-40, Dec. 2000 . Available from <http://www.scielo.br/scielo.php?script=sci_arttext\&pid=S010173302000000400002\&Ing=en\&nrm=iso >. access on 17 Aug. 2019. http://dx.doi.org/10.1590/S0101-73302000000400002.

OLIVEIRA, Eduardo Romero. A idéia de império e a fundação da monarquia constitucional no Brasil (Portugal-Brasil, 1772-1824). Tempo, Niterói , v. 9, n. 18, p. 43-63, June 2005 Available from 
<http://www.scielo.br/scielo.php?script=sci_arttext\&pid=S1413-

$77042005000100003 \&$ Ing=en\&nrm=iso>. access on 17 Aug. 2020. https://doi.org/10.1590/S1413-77042005000100003

PAIVA, Angela Randolpho. (org.). Entre dados e fatos: ação afirmativa nas universidades públicas brasileiras. Rio de Janeiro: Pallas, 2010.

PINSKY, Jaime. A escravidão no Brasil. ed. São Paulo: Contexto. (2010).

PINSKY, Jaime; PINSKY, Carla Bassanezi. História da cidadania. / Jaime Pinsky, Carla Bassanezi Pinsky. 6a. ed. - São Paulo: Contexto, 2012.

PINTO, Márcia Cristina Costa; Ferreira, Ricardo Franklin. Relações Raciais No Brasil E A Construção Da Identidade Da Pessoa Negra. Revista Pesquisas e Práticas Psicossociais, 2014. v. 9, n. 2, p. 256-266.

PIRES, Marília Freitas de Campos; REIS, José Roberto Tozoni. Globalização, neoliberalismo e universidade: algumas considerações. Interface (Botucatu), Botucatu , v. 3, n. 4, p. 29-39, Feb. 1999 . Available from $<$ http://www.scielo.br/scielo.php?script=sci_arttext\&pid=S141432831999000100003\&lng=en\&nrm=iso>. access on 24 Aug. 2020. https://doi.org/10.1590/S1414-32831999000100003.

PILATTI, Luiz Alberto; CECHIN, Marizete Righi. Perfil das universidades brasileiras de e com potencial de classe mundial. Avaliação (Campinas), Sorocaba , v. 23, n. 1, p. 75-103, Apr. 2018 Available from $<$ http://www.scielo.br/scielo.php?script=sci_arttext\&pid=S141440772018000100075\&lng=en\&nrm=iso>. access on 17 Aug. 2020. http://dx.doi.org/10.1590/s1414-40772018000100006.

RIBEIRO, Paulo Rennes Marçal. História da educação escolar no Brasil: notas para uma reflexão. Paidéia (Ribeirão Preto), Ribeirão Preto, n. 4, p. 15-30, July 1993 . Available from <http://www.scielo.br/scielo.php?script=sci_arttext\&pid=S0103863X1993000100003\&lng=en\&nrm=iso>. access on 12 Aug. 2020. http://dx.doi.org/10.1590/S0103-863X1993000100003.

ROMAN, Marcelo Domingues. Neoliberalismo, política educacional e ideologia: as ilusões da neutralidade da pedagogia como técnica. Psicol. USP, São Paulo, v. 10, n. 2, p. 153-187, 1999 . Available from $<$ http://www.scielo.br/scielo.php?script=sci_arttext\&pid=S010365641999000200011\&lng=en\&nrm=iso>. access on 22 Aug. 2020. https://doi.org/10.1590/S0103-65641999000200011.

SAMPAIO, Breno; GUIMARAES, Juliana. Diferenças de eficiência entre ensino público e privado no Brasil. Econ. Apl., Ribeirão Preto , v. 13, n. 1, p. 45-68, Mar. 2009. Available from <http://www.scielo.br/scielo.php?script=sci_arttext\&pid=S1413- 

https://doi.org/10.1590/S1413-80502009000100003.

SAMPAIO, Sônia Maria Rocha., org. Entre a escola pública e a universidade: longa travessia para jovens de origem popular. In: Observatório da vida estudantil: primeiros estudos [online]. Salvador: EDUFBA, 2011, pp. 27-51. ISBN 978-85-2321211-7. Available from SciELO Books <http://books.scielo.org>.

STALLIVIERI, Luciane. O Sistema De Ensino Superior Do Brasil Características, Tendências E Perspectivas. Grupo estratégico de análise da educação superior no brasil, 2006.

Disponivel em:<http://www.ucs.br/ucs/tplPadrao/tplCooperacaoCapa/cooperacao/assess oria/artigos/imprimir/sistema_ensino_superior.pdf> Acesso: 24 de jan de 2020.

SILVA, Cristiane Maria da Costa et al . Educação em saúde: uma reflexão histórica de suas práticas. Ciênc. saúde coletiva, Rio de Janeiro, v. 15, n. 5, p. 2539-2550, Aug. $2010 \quad$ Available from $<$ http://www.scielo.br/scielo.php?script=sci_arttext\&pid=S141381232010000500028\&lng=en\&nrm=iso>. access on 24 Aug. 2019. https://doi.org/10.1590/S1413-81232010000500028.

SILVA, Ricardo Marinho; Daltro, Mônica Ramos. Experiências de sofrimento e enfrentamento no ingressar ao ensino superior: narrativa autobiográfica. Revista Psicologia, Diversidade e Saúde, (2018). 7(3), xx-xx. doi: 10.17267/23173394rpds.v7i3.1930

SILVA, Ricardo Marinho. Ensaio sobre o livro "Admirável Mundo Novo" de Aldous Huxley: uma proposta crítica contemporânea. Revista Psicologia, Diversidade e Saúde, (2020). 9(2), xx-xx. doi:10.17267/2317-3394rpds.v9i2.2811

SILVA, Gleidson; AMORIM, Simone Silveira. Apontamentos sobre a educação no Brasil Colonial (1549-1759). Interações (Campo Grande), Campo Grande, v. 18, n. 4, pág. 185-196, dezembro de 2017. Disponível em <http://www.scielo.br/scielo.php?script=sci_arttext\&pid=S151870122017000400185\&lng=en\&nrm=iso>. acesso em 12 de janeiro de 2019. https://doi.org/10.20435/inter.v18i4.1469 .

SILVA, Marcio Antônio Both da. Lei de Terras de 1850: lições sobre os efeitos e os resultados de não se condenar "uma quinta parte da atual população agrícola". Rev. Bras. Hist., São Paulo, v. 35, n. 70, p. 87-107, dez. 2015 . Disponível em $<$ http://www.scielo.br/scielo.php?script=sci_arttext\&pid=S0102-

01882015000200087\&lng=pt\&nrm=iso>. acessos em 12 jan. 2019. Epub 27Nov-2015. https://doi.org/10.1590/1806-93472015v35n70014.

SILVA, Frederico Barbosa; DELGADO, Guilherme; CASTRO, Jorge Abrahão; CARDOSO. José Celso; THEODORO, Mário \& BEGHIN, Nathalie. Questão social e políticas 
sociais no Brasil contemporâneo / Luciana Jaccoud, organizadora ; Frederico Barbosa da Silva ... [et al.]. - Brasília : IPEA, 2005. 435 p. : gráfs., tabs.

SHIGUNOV NETO, Alexandre; MACIEL, Lizete Shizue Bomura. O ensino jesuítico no período colonial brasileiro: algumas sugestões. Educ. rev. , Curitiba, n. 31, pág. 169-189, 2008.

Disponível

em $<$ http://www.scielo.br/scielo.php?script=sci_arttext\&pid=S0104$40602008000100011 \& \operatorname{lng}=e n \& n r m=i s o>$. acesso em 12 de agosto de 2020. https://doi.org/10.1590/S0104-40602008000100011 .

SCHULTZ, Kirsten. Perfeita civilização: a transferência da corte, a escravidão e o desejo de metropolizar uma capital colonial. Rio de Janeiro, 1808-1821. Tempo, Niterói , v. 12, n. 24, p. 5-27, 2008 . Available from <http://www.scielo.br/scielo.php?script=sci_arttext\&pid=S1413$77042008000100002 \&$ Ing=en\&nrm=iso>. access on 12 Aug. 2019. https://doi.org/10.1590/S1413-77042008000100002.

TEIXEIRA, Anísio. Educação não é Privilégio. São Paulo: Cia. Editora Nacional, 1957.

VICENTE, António Pedro. Política exterior de D. João VI no Brasil. Estud. av. , São Paulo, v. 7, n. 19, pág. 193-214, dezembro de 1993. Disponível em <http://www.scielo.br/scielo.php?script=sci_arttext\&pid=S010340141993000300006\&lng=en\&nrm=iso>. acesso em 10 de janeiro de 2019. https://doi.org/10.1590/S0103-40141993000300006.

VEIGA, Cynthia Greive. Escola pública para os negros e os pobres no Brasil: uma invenção imperial. Rev. Bras. Educ., Rio de Janeiro, v. 13, n. 39, p. 502-516, dez. 2008. Disponível em <http://www.scielo.br/scielo.php?script=sci_arttext\&pid=S141324782008000300007\&lng=pt\&nrm=iso>. acessos em 12 ago. 2019. https://doi.org/10.1590/S1413-24782008000300007. 


\title{
CAPÍTULO XIII
}

\section{FILOSOFIA DA CIÊNCIA E DA MODERNIDADE: BREVE ANÁLISE DE JAMAIS FOMOS MODERNOS, DE BRUNO LATOUR}

\author{
Patrícia Aurora Corrêa Mazoti ${ }^{1}$ \\ Franciele Vaz de Souza ${ }^{2}$ \\ João Barbosa ${ }^{3}$
}

\footnotetext{
1 Mestre em Ciências Sociais e graduada em Filosofia pela UNESP/Marília.

${ }^{2}$ Mestranda em Filosofia e graduada em Filosofia pela UNESP/Marília.

${ }^{3}$ Graduado em Filosofia pela UNESP/Marília.
}

\section{RESUMO}

O presente texto estabelece uma breve análise da obra "Jamais Fomos Modernos", de Bruno Latour, com o objetivo de apontar suas contribuições para a filosofia da ciência. Além disso, objetiva-se contribuir para a reflexão sobre a modernidade, uma vez que a proposta principal do livro consiste na problematização do conceito de modernidade e a proposição de um novo olhar para a sociedade que chamamos de Moderna.

Palavras-chave: Modernidade. Filosofia da Ciência; Bruno Latour.

\section{INTRODUÇÃO}

\begin{abstract}
O menor vírus da AIDS nos faz passar do sexo ao inconsciente, à África, às culturas de células, ao DNA, a São Francisco, mas os analistas, os pensadores, os jornalistas e todos os que tomam decisões irão cortar a fina rede desenhada pelo vírus em pequenos compartimentos específicos, onde encontraremos apenas ciência, apenas economia, apenas representações sociais, apenas generalidades, apenas piedade, apenas sexo. (LATOUR, 1994, p. 8)
\end{abstract}

O livro de Bruno Latour (1947 -) foi publicado originalmente com o título de Nous n'avons jamais été modernes, pela editora La Découverte, em 1991. A primeira edição traduzida para o Brasil ocorreu em 1994. A argumentação teórica é dividida através de cinco capítulos: Crise, Constituição, Revolução, Relativismo e Redistribuição. O presente texto apresenta uma abordagem concentrada nos dois primeiros capítulos da obra mencionada, dada à pertinência das questões tratadas para o debate na área da Filosofia. 
A proposta principal do livro "Jamais Fomos Modernos" consiste na problematização do conceito de modernidade e a proposição de um novo olhar para a sociedade que chamamos de Moderna. O autor oferece o conceito de rede que considera como intercalado aos elementos da política e da ciência, pois se encaixam como peças de uma nova antropologia simétrica.

O primeiro capítulo narra diversos acontecimentos que podemos visualizar nas páginas dos jornais, ora sobre avanços inimagináveis no campo das ciências e das tecnologias, ora sobre as grandes catástrofes que derivam destes avanços. Diante deste cenário, o autor discorre a respeito da sobreposição de informações híbridas que trata, ao mesmo tempo, de economia, política, ciência, cultura, religião, entre outros. Não obstante, os analistas não desejam abordar o panorama completo das informações, mas subdividem o conhecimento da seguinte forma: à direita reside o interesse, o poder e a política dos seres humanos e, à esquerda, o conhecimento da natureza. Deste modo, Latour põe em suspensão o conceito de modernidade e afirma que este se constitui de forma ambígua, pois tanto é um período em que a ordem é desejada, como também provoca a hibridização das coisas e dos sujeitos.

O segundo capítulo analisa a historicidade da Modernidade a partir da sua constituição que se dá a partir da separação do governo, da natureza e das ciências exatas, bem como dos humanos e dos não-humanos, suas propriedades, relações, competências e agrupamentos. Thomas Hobbes (1588 - 1679) e Robert Boyle (1627 1691) inventaram o mundo moderno, um mundo no qual a representação das coisas através do laboratório - resultou na dissociação da representação dos cidadãos por intermédio do contrato social. Diante deste contexto, o autor afirma que o mundo moderno jamais existiu, uma vez que nunca funcionou de acordo com as regras da sua Constituição.

\section{CRISE}

Latour principia seu processo de argumentação proporcionando uma amostra da formação de híbridos e refletindo sobre como assuntos dos campos da ciência e da política - que são tratados separadamente pela maior parte da massa crítica da modernidade - na verdade, estão diretamente relacionados e possuem implicações que 
quase nunca são pensadas. O título do capítulo - "Crise" - refere-se à constante divisão que se faz das áreas de conhecimento e das práticas científicas. Atualmente, existem situações que o conhecimento intelectual não sabe classificar. Latour exemplifica através dos diversos assuntos retratados no jornal - este que constitui a bíblia do homem moderno - pois toda cultura e natureza são reviradas em suas páginas. Essa confusão cria a mistura que tece o nosso mundo, ela cria os híbridos.

A divisão em diversas áreas do conhecimento não pretende deslumbrar o panorama completo. Para tanto, rompem o nó górdio ${ }^{1}$ e seus trabalhos tornam-se incompreensíveis porque são recortados, divididos em três categorias usuais dos críticos: a natureza, a política e o discurso - já que, de um lado, encontra-se o conhecimento das coisas e, do outro, o interesse, o poder e a política dos homens. Por isso, nossa vida intelectual seria mal construída, como se fosse distinta em sua relação com os indivíduos e a sociedade, pois:

Por falta de opções, nos autodenominamos sociólogos, historiadores, economistas, cientistas políticos, antropólogos. Mas, a estas disciplinas veneráveis, acrescentamos sempre o genitivo: das ciências e das técnicas. [...] a questão é a de reatar o nó górdio atravessando, tantas vezes quantas forem necessárias, o corte que separa os conhecimentos exatos e o exercício do poder, digamos a natureza e a cultura. Nós mesmos somos híbridos, instalados precariamente no interior das instituições científicas, meio engenheiros, meio filósofos, um terço instruídos sem o que desejássemos; optamos por descrever as tramas onde quer estas nos levem. Nosso meio de transporte é a noção de tradução ou rede. Mais flexível que a noção de sistema, mais histórica que a estrutura, mais empírica que a de complexidade, a rede é o fio de Ariadne destas histórias confusas (LATOUR, 1994, p. 9).

É dessa maneira que o autor apresenta o cenário e a mentalidade que a sociedade moderna construiu para classificar suas áreas de conhecimento. Aqui é introduzido o conceito de redes, o fio de Ariadne $^{2}$ que liga todas essas áreas até então

1 “Górdio, um pobre camponês, que foi escolhido pelo povo para rei, em obediência à profecia do oráculo, segundo a qual o futuro rei chegaria numa carroça. Enquanto o povo estava deliberando, Górdio chegou à praça pública numa carroça, com a mulher e o filho. Tornando-se rei, Górdio dedicou a carroça à divindade do oráculo, amarrando-a com um nó, o famoso nó górdio, a propósito do qual se dizia que, quem fosse capaz de desatá-lo, tornar-se-ia senhor de toda a Ásia. Muitos tentaram em vão, até que Alexandre Magno chegou à Frígia, com suas conquistas. Tentou também desatar o nó, com o mesmo insucesso dos outros, até que, impacientando-se, arrancou da espada e cortou-o. Quando, depois, conseguiu subjugar toda a Ásia, começou-se a pensar que ele cumprira os termos do oráculo em sua verdadeira significação" (BULFINCH , 2002, p. 63).

2 "Os atenienses encontravam-se, naquela época, em estado de grande aflição, devido ao tributo que eram obrigados a pagar a Minos, rei de Tebas. Esse tributo consistia em sete jovens e sete donzelas, que eram entregues todos os anos, a fim de serem devorados pelo Minotauro, monstro com corpo de 
vistas de maneira fragmentada. Segundo Latour, a noção de redes (em comparação com noções de sistema, estrutura e complexidade) é a mais adequada para explicar a visão de mundo proposta por ele. A rede é o centro de sua argumentação, pois busca justificar a sua validade e adequação para o entendimento do conhecimento e das disciplinas de maneira comparativa e complementar.

Os críticos desenvolveram três repertórios distintos para falar do mundo: naturalização, socialização e desconstrução. Cada um apresenta uma potência em si mesmo, mas não podem ser combinados com as demais teorias. A crítica entraria em crise ao tentar estabelecer essas divisões. Porém, Latour propõe uma antropologia do mundo moderno, a qual torna possível a partir da alteração da própria definição do mundo. A seguir, de forma breve, será apresentado alguns aspectos pertencentes as teorias de autores que foram eleitos como representantes das vertentes críticas.

Pierre Bourdieu (1930 - 2002), segundo Latour, teria desenvolvido uma crítica que apenas deslumbraria a socialização. Os dois autores distanciam-se em suas concepções da ciência em diversos pontos. Para Latour, os fatos científicos são construções coletivas fixadas através de alianças entre atores (humanos e não humanos) formando uma complexa rede. Já Bourdieu provém de uma tradição estruturalista, que considera os fatos sociais como produto de um meio social jamais neutro, onde a hierarquia e o poder estão sempre presentes. Ele interpreta os fatos científicos como fatos sociais, negociados dentro de um campo de lutas. Para Bourdieu, o campo científico é "o universo no qual estão inseridos os agentes e as instituições que produzem, reproduzem, ou difundem [...] a ciência" (2004, p.20).

homem e cabeça de touro, forte e feroz, que era mantido num labirinto construído por Dédalo, e tão habilmente projetado que quem se visse ali encerrado não conseguiria sair, sem ajuda. Teseu resolveu livrar seus patrícios dessa calamidade, ou morrer na tentativa. Assim, quando chegou a ocasião de enviar o tributo e os jovens foram sorteados, de acordo com o costume, ele se ofereceu para ser uma das vítimas, a despeito dos rogos de seu pai. O navio partiu, como era de hábito, com velas negras, que Teseu prometeu ao pai mudar para brancas, Etra e Teseu Página | 188 no caso de regressar vitorioso. Chegando a Creta, os jovens e donzelas foram todos exibidos diante de Minos, e Ariadne, filha do rei, que estava presente, apaixonou-se por Teseu, e este amor foi correspondido. A jovem deu-Ihe, então, uma espada, para enfrentar o Minotauro, e um novelo de linha, graças ao qual poderia encontrar o caminho. Teseu foi bem-sucedido, matando o Minotauro e saindo do labirinto. Levando, então, Ariadne, regressou a Atenas, juntamente com os companheiros salvos do monstro. Durante a viagem, pararam na llha de Naxos, onde Teseu abandonou Ariadne, deixando-a adormecida.1 A desculpa que deu para tratar com tanta ingratidão sua benfeitora foi que Minerva lhe apareceu num sonho ordenando-lhe que assim o fizesse. Ao aproximar-se do litoral da Atica, Teseu esqueceu-se da combinação que fizera com o pai e não mandou alçar as velas brancas. O velho rei, julgando que o filho tivesse morrido, suicidou-se. Teseu tornou-se, então, rei de Atenas" (BULFINCH, 2002, p. 187). 


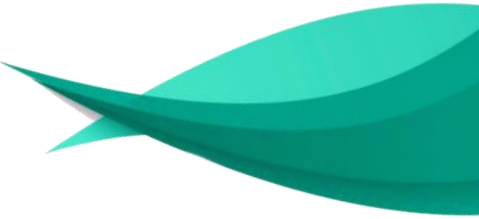

Jean-Pierre Changeux (1936 -) é um neurocientista francês - segundo Latour, um crítico da naturalização - que através de seus estudos busca a compreensão da vida e da mente humana. Afirma que pretendeu realizar uma espécie de filosofia da biologia molecular, pois primeiro procurou compreender como funciona nosso cérebro no nível molecular e, em seguida, buscou a identificação do primeiro receptor de neurotransmissor. Os elementos de seu pensamento podem ser compreendidos mais detalhadamente a partir do excerto abaixo:

Cientista extremamente criativo, de olhos postos nos mecanismos fundamentais de regulação biológica em qualquer forma de vida, Changeux logo extrapolou o modelo das proteínas alostéricas para os receptores de neurotransmissores. E foi para testar essa proposição teórica que ele terminou chegando a seu segundo feito experimental considerável, o isolamento do receptor de acetilcolina. Foi, assim, sobre uma sólida base de biologia molecular, teórica e experimental, que o tranquilo cientista francês seguiu em busca de outras decifrações do mais fascinante dos órgãos dos sistemas vivos, o cérebro humano, e aportou, entre outras investidas, nas bases materiais, biológicas e bioquímicas da consciência. Essa construção rigorosamente científica foi sendo erguida num terreno cultural fértil, densamente humanístico, filosófico, que é da própria formação de Changeux e no qual ele mantém firmemente os pés. Assim, pode estendê-lo ao leitor com grande força em seus livros de divulgação científica - incluindo o que escreveu em coautoria com o filósofo Paul Ricoeur, La nature et la règle. Ce qui nous fait penser (Odile Jacob, 1988, Paris). A ciência é tomada por Changeux sempre no interior da cultura - mas sem deixar de reivindicar jamais "uma visão fisicalista", como ele mesmo diz, fundada em mecanismos moleculares (MOURA, 2011, p. 11).

Jacques Derrida (1930 - 2004) é um dos precursores da corrente teórica denominada Desconstrução. A reflexão empreendida pelo filósofo apresenta-se como um incessante trabalho de investigação que coloca sob suspeita os discursos da Filosofia e das Ciências Humanas, da Literatura e da História, da Fenomenologia e da Psicanálise, ao questionar, inclusive, o próprio conceito clássico de ciência. A respeito do conceito de Desconstrução pode-se observar que:

Utilizado pela primeira vez por Jacques Derrida em 1967 na Gramatologia, o termo 'desconstrução' foi tomado da arquitetura. Significa a deposição, decomposição de uma estrutura. Em sua definição derridiana, remete a um trabalho do pensamento inconsciente ('isso se desconstrói'), e que consiste em desfazer, sem nunca destruir, um sistema de pensamento hegemônico e dominante. Desconstruir é de certo modo resistir à tirania do Um, do logos, da metafísica (ocidental) na própria língua em que é enunciada, com a ajuda do próprio material deslocado, movido com fins de reconstruções cambiantes (DERRIDA \& ROUDINESCO, 2004, p.9). 
Prosseguindo com a crítica, o autor ressalta a importância do acontecimento da queda do muro de Berlim para que os modernos perdessem a segurança em seus pressupostos. Teria sido melhor não tentar tornar-se mestre e dono da natureza? Teria sido melhor não tentar acabar com a exploração do ser humano sobre o ser humano? Essas dúvidas produziram efeitos diversos: levaram ao ceticismo do pós-modernismo, a uma postura antimoderna e também a indicação daqueles que não se deixaram afetar e continuaram acreditando na promessa da ciência e/ou da emancipação. Entretanto, como Latour ressalta:

\footnotetext{
Quer sejamos antimodernos, modernos ou pós-modernos, somos todos mais uma vez questionados pela dupla falência do miraculoso ano de 1989. Mas iremos retomar nossa linha de pensamento se considerarmos este ano justamente como dupla falência, como duas lições cuja admirável simetria nos permite compreender de outra forma todo nosso passado. E se jamais tivermos sido modernos? A antropologia comparada se tornaria então possível. As redes encontrariam um lar (LATOUR, 1994, p.15).
}

Depois de apresentar tal questionamento, Latour coloca seus esforços na explicação do que pode ser então algo moderno. Para ele, a modernidade vem apresentada por dois conceitos que, por serem excludentes, possuem forte capacidade de complementariedade. O primeiro deles é o de tradução, que traz misturas de gêneros e disciplinas, proporcionando a hibridização de seres em natureza e cultura. 0 segundo é o de purificação, que traz a criação de zonas completamente excludentes e divide o mundo em humanos e não-humanos. A ideia de tradução oferece a base para o conjunto de práticas que se enquadram no conceito de redes. Purificação se relaciona diretamente à crítica às redes pelos considerados modernos. O autor afirma que, enquanto estas ideias forem encaradas de maneira separada, ainda estará em vantagem à modernidade e seu conjunto de ideias fragmentárias.

O autor expõe que a sociedade ocidental desenvolveu um modelo em que torna possível que estas duas visões de mundo caminhem juntas. Nenhuma delas tornar-se-ia superior à outra, mas seriam complementares, já que não é possível tomar consciência da hibridização trazida pela tradução sem antes compreender as categorias criadas pela purificação. A tese consiste na seguinte questão: caso tomemos consciência dessa mistura de tradução e purificação deixaremos não somente de ser modernos, mas também de ter sido modernos, porque conseguiremos enxergar toda a nossa bagagem 
e, através deste fato, deslumbraremos o conhecimento com um novo olhar. Um olhar que não enxerga relações conflituosas e desconexas, pelo contrário, consegue explicar a complementaridade e enxergar valor nas diferenças.

\section{CONSTITUIÇÃO}

A modernidade considera dois lados ontológicos para explicar o fenômeno das coisas: "humano" separado do "não-humano". Com tal cisão, deixa-se Deus de lado. O que passou a importar encontra-se nos meandros daquilo que era humano, e o que não fosse, era logo delineado. É o que Latour compara com a constituição presente no direito: há o âmbito judiciário e executivo. Neste caso, há a cisão do mundo natural e o mundo social.

Assim, os assuntos foram se dividindo de modo que cada um se responsabilizasse por uma área, como se nenhuma tivesse vínculo com a outra. A constituição política, por exemplo, era da alçada dos juristas; a constituição da natureza era responsabilidade de cientistas; já aqueles que faziam um trabalho de tradução, de vinculação de um assunto a outro, era responsabilidade de quem estudava essa rede; já os coletivos estrangeiros estavam sob a responsabilidade da antropologia, já que ela era a única área capaz de delinear todos os meandros de uma sociedade: da taxonomia das plantas ao modo como a sociedade se dava.

A constituição que se dá no âmbito do direito tem o dever de traçar as nuances do poder, como ele passa de uma pessoa à outra, os cargos, as leis. A constituição da natureza, por sua vez, tem como intuito separar o humano do não-humano, isto é, como eles se relacionam ou se repelem. Latour destaca exemplos do momento do início dessa cisão - dessa constituição que segrega - a partir da abordagem das ideias de duas notáveis figuras: Thomas Hobbes e Robert Boyle.

Para embasar o argumento sobre tal dicotomia, Latour se utiliza do livro Leviatã e bomba de vácuo: Hobbes, Boyle e a vida experimental, elaborado por Steven Shapin (1943 -) e Simon Schaffer (1955 -). Logo na capa do livro é possível perceber uma mistura de elementos de estudos de Hobbes e Boyle: a figura emblemática de Leviatã que, na mão esquerda, carrega a bomba de ar - tão aclamada pela ciência de Boyle sendo que, na figura original, havia um cetro, que representava o poder absoluto do 
soberano político; e na mão direita, assim como na figura original, está uma espada representação do instrumento político de proteção, neste caso pendendo mais para a política de Hobbes.

Dessa forma, o livro de Shapin e Schaffer apresenta essa mistura, que não é puramente figurativa, já que representa o enlace estabelecido ao longo do conteúdo do livro, esse que enfatiza a postura de matemático que Hobbes teve, e a postura política de Boyle. Em ambos os casos, as respectivas tradições suprimiram e o que foi perpetuado foi o lado político de Hobbes e o científico de Boyle (como se fosse uma afronta realizar uma abordagem de outra posição que tais pensadores tomaram para além daquilo que se destacaram). Apesar das diferenças notáveis entre o pensamento dessas figuras, "ambos desejam um rei, um parlamento, uma Igreja dócil e unificada, e são adeptos fervorosos da filosofia mecanicista" (LATOUR, 1994, p. 22).

Burlando princípios filosóficos clássicos, originados desde a Antiguidade - o qual tinha como preceito básico a episteme - Boyle instituiu que o conhecimento deveria ser baseado na doxa (opinião). A princípio tem-se a impressão que as observações são constatações feitas sem rigor, porém, a proposta de Boyle baseia-se na confiabilidade das testemunhas ao redor do ato da experiência. Não é uma mera opinião o que Boyle almejava, e sim que os observadores atestassem que determinado fato realmente ocorreu e como foi realizado. A veracidade de tal fato poderia ser comprovada dentro de um espaço, seja o laboratório ou as casas de estudiosos. A inserção do homem no laboratório é essencial, já que é ele quem irá fabricar - mesmo que artificialmente - os fatos. Os fatos, ao serem presenciados, carregavam em si uma comprovação da íntegra veracidade.

Ao contrário de Boyle, Thomas Hobbes detinha um método mais lógico, baseado na confiabilidade única e exclusiva ao Estado. Acreditando que as pessoas não deveriam depositar sua fé na religião ou em um ser transcendente, elas deveriam delegar tal poder ao soberano, ou seja, à figura política máxima. Assim, o conhecimento e o poder estariam no mesmo nível e vinculados num só plano: soberano, Deus, matéria e multidão. O soberano sempre estaria no ápice; o que não significava, para Hobbes, um governo totalitário, já que sua posição inclinou-se à defesa da República, na qual as pessoas cederiam para o soberano a possibilidade de controlar o Estado. 
Com o surgimento da Royal Society - sociedade científica a qual Boyle e outros cientistas faziam parte - Hobbes viu a figura do Estado ameaçada e a iminência de uma guerra quase comprovada, já que o Estado não tinha mais o controle de tudo, pois os laboratórios extrapolavam sua vigilância: laboratórios fechados e experimentos com seletas testemunhas. Logo, tudo o que o Estado unificou encontrava-se em perigo, já que sociedades desta esfera apresentavam um forte indício de separação; tudo que englobava aspectos imateriais, de experimentos no laboratório a constatações acerca da Bíblia e Deus representavam uma ameaça à soberania do Estado.

Outros exemplos que Latour, sob a ótica de Hobbes, cita referente à divisão do Estado e o perigo que ocorreria à sociedade por ceder poder a instâncias imateriais e religiosas, compreendem o Levellers e Diggers, grupos conhecidos no contexto da Revolução Puritana, no século XVII. Eram grupos avessos às posturas de gastos em excesso, bem como cobrança de tributos exorbitantes do rei Carlos I, que recorriam à Bíblia para argumentar que Deus delegava liberdade e igualdade a todos, independentemente de sua condição racial ou econômica. O nome Levellers decorre do verbo, em inglês, to level, isto é, nivelar; que, nesse contexto, referia-se ao nivelamento jurídico das condições sociais, igualar tais condições conforme a vontade de Deus. Já os Diggers, provêm do verbo to dig, que significa cavar; já que na ocasião este grupo almejava uma reforma agrária espontânea que garantisse o acesso dos camponeses à terra; em outras palavras, planejavam uma ação direta contra o Estado e seu poder.

O que Shapin e Schaffer fazem, segundo Latour, não é uma mera comparação historiográfica acerca das semelhanças e diferenças entre Hobbes e Boyle. Eles contextualizam, colocando-os dentro de uma história, de um lugar, de um momento que influenciou diretamente em seus pensamentos. Os autores mostram fatos políticos, sobre Deus e afins, ultrapassando a noção da bomba de ar. Este instrumento integrava um todo muito mais complexo.

Eles partem do princípio que existe um macro-contexto social - a Inglaterra, a disputa dinástica, o capitalismo, a revolução, os mercadores, a Igreja - e que este contexto, de certa forma, influencia, forma, reflete, repercute e exerce uma pressão sobre as 'ideias relativas' à matéria, à elasticidade do ar, ao vácuo e aos tubos de Torricelli (LATOUR, 1994, p. 26).

Torna-se possível, então, encontrar a arqueologia do objeto. Em outras palavras, há a preocupação de fazer o levantamento de como se deu a ascensão da bomba de ar 
e demais objetos primordiais para o progresso da ciência. Os objetos ganham enfoque novamente, depois de um tempo desvalorizado pela crítica. É de suma importância que as pessoas saibam das falhas que acometiam os objetos e faziam a experiência falhar. A falha faz parte do processo. E apesar de todas as falhas, as pessoas ainda assim criavam laços entre si a partir dos objetos criados em laboratório, fortalecendo a crença na doxa, e a preferência pelas ideias práticas.

Mesmo com tantas transformações ocorrendo e o contexto histórico indicando que muito mais mudanças estavam por vir, Hobbes relutou e se indignava com descobertas como a existência de vácuo. De acordo com seus princípios filosóficos, acreditar necessariamente em asserções deste âmbito era absurdo: para Hobbes, o que existia no recipiente não era vácuo, mas algum éter invisível. E mesmo após Boyle colocar uma pena no recipiente e provar que a ausência de movimentos da pena indicaria a inexistência de ar, Hobbes considerava ultrajante rebater seus anseios filosóficos com uma pena.

Para além das críticas hobbesianas, Boyle seguiu adiante com seu método de argumentos baseados em testemunhas, essas que se colocavam como se fosse um júri. Mas não era qualquer júri. As pessoas que recebiam mais confiabilidade estavam no âmbito da fé: eram sacerdotes e juristas, pessoas da fé e da lei, respectivamente. Quanto melhor fosse a posição social, maior era sua credibilidade para testemunhar as experiências. Isto, aliás, era outro motivo pelo qual Hobbes repudiava tal prática, considerando-as improfícuas e tendenciosas.

A novidade em Boyle refere-se à forma de aplicação de sua teoria. Anteriormente a ele, as pessoas atribuíam explicações divinas ou de âmbito humano, mas nunca haviam se utilizado de questões não-humanas. É justamente essas questões que Boyle considerava mais confiável que as opiniões humanas, pois, para ele, essas poderiam enganar e/ou burlar os resultados. No caso de objetos que "falam por si", seria impossível extrair mentiras, já que a natureza e seus objetos, não mentem.

Estes não-humanos, privados de alma, mas aos quais é atribuído um sentido, chegam a ser mais confiáveis que o comum dos mortais, aos quais é atribuída uma vontade, mas que não possuem a capacidade de indicar, de forma confiável, os fenômenos. De acordo com a Constituição, em caso de dúvida, mais vale apelas aos não-humanos para refutar os humanos (LATOUR, 1994, p. 29). 
Como, então, uma lei científica pode ser dita universal, se os experimentos foram feitos num contexto determinado, dentro de um laboratório? A universalidade, portanto, não pode ser tida na esfera epistemológica, e sim, de redes. A maneira como uma lei é constituída e disseminada nos lugares é possibilitada pela expansão proporcional dos laboratórios que buscam atestar determinada teoria e contribuir para sua fundamentação em lei. Assim, a universalidade pressupõe prática, só que agora em laboratórios. A partir de então, o conhecimento não é um universal como tentou vários filósofos - a tábula rasa de John Locke ou a crença verdadeira justificada, de Platão. As práticas vão sendo repetidas e confirmadas - ou refutadas. $\mathrm{O}$ atestado de universalidade é feito através da comprovação. Não é uma verdade estabelecida e todos que se sentirem contemplados intelectual e empiricamente, aderem. Em outras palavras, não é mais um universal a priori.

Mesmo que a análise de Shapin e Schaffer penda mais para o lado de Hobbes possivelmente devido à formação social de ambos - o que os autores procuram em seu livro é uma maneira de tornar essa dicotomia natureza/homem como complementares e não díspares entre si; uma interpretação simétrica dos fatos. Ao mostrar aos leitores as posições políticas de Boyle e as considerações matemáticas de Hobbes, podemos vislumbrar que existem outras facetas do conhecimento que devemos considerar. Há muita ciência na política e muita política na ciência, pois "eles inventaram nosso mundo moderno, um mundo no qual a representação das coisas através do laboratório encontra-se para sempre dissociada da representação dos cidadãos através do contrato social" (LATOUR, 1994, p. 33).

Boyle e Hobbes, segundo Latour, criaram duas diferentes noções de representação: ao primeiro atribui-se a representação científica, dos objetos; ao segundo, a representação política, dos humanos. Latour afirma que Hobbes cria uma "política científica" onde a ciência instrumental desenvolvida no laboratório seja excluída, assim como Boyle desenvolve um "discurso político" onde a política deveria ser excluída. A partir de então, percebe-se uma cisão entre estas duas esferas, uma divisão epistemológica na qual não poderia mais haver nenhuma relação entre a representação dos não-humanos e a dos humanos, "entre o artifício dos fatos e a artificialidade do corpo político" (LATOUR, 1994, p. 33), já que a autoridade de ambos residia, justamente, em sua cisão. Portanto, ficaria a cargo da ciência representar os 
objetos, mas sem nenhuma influência da política e à política caberia representar os cidadãos, mas seria proibida sua relação com os não-humanos, relativos à ciência.

Latour considera que o Leviatã de Hobbes seria o resultado do cálculo de "cidadãos nus", um "deus mortal, esta criatura artificial" (1994, p. 34), o qual receberia a força e autorização para decidir e representar a todos. O soberano é o porta-voz, a personificação dos cidadãos, portanto são eles que o elegem e podem interditá-lo, cujo poder constitui-se por relações sociais. Para Latour, é a partir de Hobbes "que começamos a compreender o que significam as relações sociais, poderes, forças, sociedade" (1994, p.34).

Já a Boyle, Latour atribui a criação do laboratório, máquinas artificiais criadoras de fenômenos que, em suas palavras "representam a natureza como ela é" (1994, p. 34). Os cientistas são os porta-vozes dos objetos, esses que, por sua vez, são mudos, "mecanismos brutos", traduzidos pela atividade científica e pelas testemunhas no laboratório e ao redor da bomba de vácuo. Então, é a partir de Boyle que "começamos a conceber o que é uma força natural, um objeto mudo, mas que possui - ou qual foram dados - sentidos" (LATOUR, 1994, p. 35).

Acerca dessa separação nos sentidos da palavra "representação", Latour afirma que:

os descendentes de Hobbes e de Boyle nos fornecem os recursos que usamos até hoje: de um lado, a força social, o poder; do outro, a força natural, o mecanismo. De um lado o sujeito de direito; do outro, o objeto da ciência. Os porta vozes políticos irão representar a multidão implicante e calculadora dos cidadãos; os porta-vozes científicos irão de agora em diante representar a multidão muda e material dos objetos. Os primeiros traduzem aqueles que os enviam, que não saberiam como falar todos ao mesmo tempo; os segundos traduzem aqueles que representam, que são mudos de nascimento (1994, p. 35).

Segundo Latour, o fato de a constituição moderna separar estas esferas não representa uma distância entre os humanos e as coisas, pois nem Hobbes e nem Boyle colocaram uma separação brusca entre o "mecanismo social puro" e o "mecanismo natural puro"; estes autores estabeleceram apenas uma separação no que competiam as coisas e as pessoas. Para explicar esse evidente paradoxo moderno, o autor utiliza das concepções de "mediação" e "purificação". No sentido de mediação, o que existe na modernidade é um "misto de natureza e cultura" e por purificação existe uma separação total "entre natureza e cultura". Hobbes possui uma vasta gama de escritos, 
inclusive científicos, ao mesmo tempo em que Boyle também escreveu sobre política, mas cada um acabou limitado a um único domínio.

Latour afirma que a constituição moderna possui duas garantias capitais: a criação do poder natural pelos descendentes de Boyle garante que a natureza exista para além dos homens que se detém apenas a "revelar seus segredos"; e o poder político desenvolvido pelos seguidores de Hobbes garante que são os homens e apenas os homens que constituem a sociedade. Mas, no entanto, essas garantias se tomadas separadamente, ficarão incompreensíveis, pois "se a natureza não é feita pelos homens nem para eles, então ela continua a ser estrangeira, para sempre longínqua e hostil" (LATOUR, 1994, p. 36).

Por outro lado, se a sociedade é constituída apenas pelos homens, "o Leviatã, criatura artificial da qual somos ao mesmo tempo a forma e a matéria, não seria capaz de se sustentar" (LATOUR, 1994, p. 36), essa imanência do humano resultaria numa destruição do corpo político, uma luta de uns contra os outros. Portanto, as duas garantias servem de "checks and balances", segundo Latour, pois "são dois ramos do mesmo governo" (1994, p. 36). Numa visão conjunta, as garantias se invertem. De modo geral, a natureza transcende a nós, já que existe independentemente (purificação), mas ao mesmo tempo é criada pelos cientistas no laboratório (mediação), contudo também é imanente. A sociedade é imanente uma vez que é feita pelos homens (purificação), e também transcende a eles, como afirma Latour, "o Leviatã ultrapassa infinitamente o homem que o criou, pois mobiliza em seus poros, em seus vasos, em seus tecidos as coisas inumeráveis que lhe dão sua consistência e duração" (1994, p. 37) (mediação).

Para resolver este paradoxo, Latour apresenta uma terceira garantia: "a natureza e a sociedade devem permanecer absolutamente distintas; o trabalho de purificação deve permanecer absolutamente distinto do trabalho de mediação" (1994, p. 37). Há ainda uma quarta garantia que resolve a questão de Deus na modernidade: ele estará suprimido, segundo Latour. Os seguidores de Hobbes e de Boyle retiraram Deus tanto da construção social quanto da natureza, os cientistas descartaram o "julgo" divino, ao mesmo tempo em que a sociedade criava um "deus mortal", o soberano. Entretanto, se Deus fosse totalmente afastado, as duas esferas, sociedade e natureza, ficariam suspensas e uma poderia sobrepor-se a outra. Dessa maneira, da mesma forma que 
ocorreu com a natureza e sociedade, Deus será transcendente e imanente. Para elucidar este caráter de Deus dos modernos, Latour afirma:

\begin{abstract}
Sua transcendência o afastava infinitamente, de forma que ele não atrapalhava nem a ação livre da natureza, nem da sociedade, mas conservava-se, de qualquer forma, o direito de apelar a esta transcendência em caso de conflito entre as leis da natureza e as da sociedade. O homem moderno podia ser ateu e ao mesmo tempo em que permanecia religioso. Podia invadir o mundo material e recriar livremente o mundo social, sem com isso sentir-se órfão demiurgo abandonado por todos (1994, p. 39).
\end{abstract}

Assim, a modernidade é, segundo o autor, resultante de três duplas de transcendência e imanência: da natureza, da sociedade e a de Deus, pois através dessas duplas "é possível mobilizar a natureza, coisificar o social, sentir a presença espiritual de Deus defendendo ferrenhamente, ao mesmo tempo, que a natureza nos escapa, que a sociedade é nossa obra e que Deus não interfere mais" (LATOUR, 1994, p. 40).

Esta concepção dos modernos permitiu-lhes um grandioso poder crítico: puderam combater o obscurantismo das épocas anteriores e também desfazer alguns mistos mal feitos entre "necessidades sociais e realidade natural" (LATOUR, 1994, p. 40). A "potência crítica dos modernos", para Latour, se consagra a partir da capacidade de mobilização da "natureza no seio das relações sociais, ao mesmo tempo em que a mantém infinitamente distante dos homens", esses, por sua vez, "são livres para construir e destruir sua sociedade, ao mesmo tempo em que tornam suas leis inevitáveis, necessárias e absolutas" (LATOUR, 1994, p. 42).

\title{
4. REFLEXÃO SOBRE A OBRA E SUAS IMPLICAÇÕES
}

Bruno Latour questiona a modernidade como etapa histórica. Essa modernidade que surgiu no lluminismo do século XVIII é comumente definida pelo humanismo, deixando de fora as questões não-humanas. A modernidade é generalizada e todos são obrigados a entrar, ainda que nem todos sejam modernos. Os indígenas, por exemplo, não são modernos e muito menos dicotômicos no sentido de pensar a separação entre humanos e não humanos. Segundo Eduardo Viveiros de Castro em $A$ inconstância da alma selvagem (2002), para os ameríndios, não existe essa separação entre homem e natureza, tudo é humanidade; a humanidade consiste para além do humano, pois todos são humanos: a onça, as árvores, os animais e etc. 
Para os modernos, o dinheiro é o plano de imanência; para os indígenas, o plano de imanência é a terra. A divergência entre esses sustentáculos coloca esses dois mundos em choque: existe o mundo dos indígenas e o mundo dos brancoscolonizadores, um querendo subordinar o outro. Além dessa questão, Latour também ressalta as sobreposições de informações que, por exemplo, narra grandes descobertas tecnológicas, ao passo que se verifica o contraste com culturas que não aceitam a utilização de alguns desses avanços tecnológicos.

A Modernidade, portanto, é um conceito ambíguo: um período em que a ordem é desejada, mas ao mesmo tempo, provoca à hibridização das coisas e dos sujeitos, ou seja, a modernidade é e, concomitantemente, não é. Fala-se numa transformação que, na verdade, nada transformou. Alexis de Tocqueville (1997) discorreu sobre o mito da Revolução Francesa, destacando que os três conceitos fundamentais - liberdade, fraternidade e igualdade - são, na verdade, ilusórios. Este autor também questionou o conceito de liberdade na república democrática norte-americana e sua proposta de igualdade, ressaltando que essa nunca vai existir, pois a igualdade se apresenta somente como ideal (TOCQUEVILLE, 2005). Caso a igualdade se colocasse como uma realidade palpável, poderíamos dizer que os franceses e/ou norte-americanos são libertos, iguais e fraternos. Entretanto, ao contrário disso, observa-se cada vez mais a fragmentação do mundo social a partir da constituição de guetos étnicos que se localizam nas periferias da França, dos EUA e tantos outros países "modernos".

Para Latour, a revolução, na modernidade, se coloca como um esquema linear que configura o tempo como irreversível, sem retorno; o capitalismo tem um único objetivo: o lucro, o ganhar, o que move esse sistema se caracteriza linearmente. Sendo as revoluções modernas uma ilusão, a modernidade também seria uma quimera? Conforme o autor:

\footnotetext{
Não há nenhuma relação simples entre as características de um momento histórico e a questão de saber se ele é ou não moderno. A modernidade seria portanto uma ilusão? Não, é muito mais que uma ilusão, e muito menos que uma essência. E uma força acrescentada a outras, as quais por muito tempo teve o poder de representar, de acelerar ou de resumir, mas a partir de agora não mais, não completamente (LATOUR, 1994. p.45).
}

Afinal, o que é modernidade então? Para além da noção de etapa histórica, a modernidade se apresenta como um vetor, uma força. Implica um tipo de ilusão que 
encarna e que se transforma na coisa em si, a essência. Latour fala da constituição no sentido de constituir um sistema, a constituição de uma ilusão encarnada. O plano de imanência da modernidade é o capital, o dinheiro; mas e o em si, onde está? O que é o em si? Para Gilles Deleuze, tudo isso é platônico; o dinheiro, o capitalismo, é fluxo; o real é uma perspectiva; vivemos uma perspectiva cujo plano de imanência é o dinheiro. A modernidade nesse sentido é irreversível, entretanto o "mundo moderno jamais existiu, no sentido que jamais funcionou de acordo com as regras de sua Constituição, separando as três regiões do Ser das quais falei e recorrendo, separadamente, aos seis recursos da crítica" (LATOUR, 1994 p. 44).

Deus, o homem e o mundo: as três instâncias em crise. Deus morreu, mas é transcendência pura. Em outras palavras, existe um jogo entre a transcendência e a imanência e esse é o jogo da modernidade. A queda do muro de Berlim em 1989 se colocou como marco para a modernidade, pois é a partir daí que se verifica uma modernidade plenamente voltada para o progresso, na qual o dinheiro vai se constituindo como vetor, como um modo de vida. Gradativamente, o econômico passa a regular o social.

Lévi-Strauss (2006), antropólogo francês, fala que o poder simbólico é o que predomina e que dá forma ao sistema e que, por isso, a modernidade é um símbolo presente e de natureza incontestável. Roy Wagner em A invenção da Cultura (2010), pontua que os indígenas vivem, caçam, fazem artesanato, tomam banho de rio e que essas ações, para eles, são triviais ao cotidiano e não que estão "fazendo cultura" como caracterizam os antropólogos. A própria noção de cultura é artefato criado por nossa necessidade de afastamento da natureza. A palavra cultura é um conceito inventado pelos antropólogos para medir seus próprios problemas. Desta forma, não são as questões dos indígenas que são levadas em consideração. Por exemplo, a pedra não é a cultura, o macaco não é a cultura, mas constituem um delírio para demarcar o que é natureza e o que é a cultura. Essa é uma das características da modernidade, já que separa, classifica, demarca e nomeia.

Latour pontua sobre a política da natureza, essa que, para ele, consiste em destituir o que fundamenta o cartesianismo, isto é, destituir o homem de uma grandeza que ele nunca teve e nem terá; ou então para perceber a catástrofe do fim do mundo, em que a razão iluminista de tanta luz acabou nos cegando. A constituição da 
modernidade opera-se a partir da separação da natureza, das ciências exatas e dos humanos e não-humanos. A ciência iluminista se baseia no processo de purificação que dogmatiza o processo cientifico. Na purificação, as tentativas e os erros são descartados e o que importa é o resultado final, no qual predomina a verdade, o poder e a dominação.

Boyle e Hobbes inventaram um mundo moderno no qual a representação das coisas através do laboratório encontra-se dissociada da representação dos cidadãos através do contrato social. Hobbes tentou aplicar um método da ciência para a vida politica. A ciência de Hobbes é uma tentativa de racionalizar a ação humana, demonstrar que é possível "um" ser o representante de todos.

O autor propõe a mudança de paradigma e a necessidade de superar a distinção ontológica entre "humanos" e "não humanos" que é o que singulariza a modernidade. Além disso, o autor chama a atenção para o fato de que os antropólogos possuem a capacidade de unir em seus estudos elementos diversos, tratando natureza e cultura como tecidos inteiriços. Ao propor uma antropologia simétrica, busca, dessa forma, verificar a relação híbrida entre a natureza e a sociedade. Trata-se de desmistificar a dicotomia construída a partir do século XVIII entre o mundo das representações científicas e o mundo das representações políticas. Latour acredita que a ciência teria que buscar um método simétrico, uma explicação que dê conta da cultura, sociedade e natureza ao mesmo tempo.

Antropologizar este mundo implica em uma mudança de nossa própria percepção de moderno. A antropologia simétrica busca um diálogo não somente entre as áreas do conhecimento, mas também entre mundos diversos, como o mundo dos ameríndios e o mundo da ciência moderna. Em outras palavras, busca-se quebrar essa lógica binária: natureza, de um lado, e cultura, de outro, construindo um caminho contrário da ciência e do ser humano iluminista. Quando se cria o conhecimento antropológico em rede, há, portanto a diluição da ideia de autoria e também do resgate do coletivo.

'Em rede', o mundo moderno, assim como as revoluções, permite apenas prolongamentos de práticas, acelerações na circulação dos conhecimentos, uma extensão das sociedades, um crescimento do número de actantes, numerosos arranjos de antigas crenças. Quando olhamos para elas 'em rede', as inovações dos ocidentais permanecem reconhecíveis e importantes, mas 
não ha o bastante aí para se construir toda uma história, uma história de ruptura radical, de destino fatal, de tristezas ou felicidades irreversíveis (LATOUR, 1994. p. 52).

Outra preocupação de Latour consiste em superar a cisão entre o Ocidente e as demais culturas. A ciência construiu a separação entre Nós e Eles, (nós, ocidentais, os detentores do instrumental para apreender a realidade e manipulá-la por meio da técnica) e eles, as demais culturas que assimilam essa realidade.

A Grande Divisão interior explica, portanto, a Grande Divisão exterior: apenas nos diferenciamos de forma absoluta entre a natureza e a cultura, entre a ciência e a sociedade, enquanto que todos os outros, sejam eles chineses ou ameríndios, zandes ou barouyas, não podem separar de fato aquilo que e conhecimento do que e sociedade, o que é signo do que é coisa, a que vern da natureza como ela realmente e daquilo que suas culturas requerem (LATOUR, 1994, p. 99).

\section{CONSIDERAÇÕES FINAIS}

Latour utiliza o livro de Shapin e Shaffer que aborda o empate de teorias, uma polêmica entre as visões oferecidas por Boyle e Hobbes. Conforme o autor, de fato, o panorama de mundo do cientista e do cientista político se assemelha em diversos sentidos, mas divergem em questões centrais sobre a ciência.

A controversa entre as crenças destes dois cientistas revela-se como pressuposto para o que Latour apresenta como a constituição do mundo moderno. Posto isso, percebe-se a disparidade entre as ideias: de um lado Boyle, atesta o valor da experiência controlada, da reprodução de fenômenos em laboratório; de outro, Hobbes, destaca a representação política por meio de socialização e o contrato social. Por esse motivo, essas teorias possuem o poder de influenciar toda a estrutura da sociedade, da política e da natureza.

Através da compreensão da mistura entre os conceitos de tradução e purificação Latour expõe a limitação entre o que é humano e o que não é humano, entre o que é social e o que é natural, ou seja, entre a política e a ciência. A hibridização, portanto, torna possível a construção de um novo olhar, pautado na complementariedade, no movimento, nos processos, enfim, no fio de Ariadne que entrelaça toda a epistemologia humana. 


\section{REFERÊNCIAS}

BOURDIEU, Pierre. Os usos sociais da ciência: por uma sociologia clínica do campo científico. São Paulo: Unesp, 2003.

BULFINCH, Thomas. O livro de ouro da mitologia: (a idade da fábula): histórias de deuses e heróis. Tradução de David Jardim Júnior, 26a ed, Rio de janeiro, 2002. Disponível em: <http://filosofianreapucarana.pbworks.com/f/O+LIVRO+DE+OURO+DA+MITOL OGIA.pdf> Acesso em 29 nov. 2015.

CASTRO, Eduardo Viveiros de. A inconstância da alma selvagem, e outros ensaios de antropologia. São Paulo: Cosac \& Naify, 2002.

DERRIDA, Jacques; ROUDINESCO, Elizabeth. De que amanhã . . . diálogos. Trad. André Telles. Rio de Janeiro: Jorge Zahar Editor, 2004.

GORRI, Ana Paula; FILHO, Ourides Santin. Representação de tema científicos em pintura do século XVIII: Um estudo interdisciplinar entre Química, História e Arte. Disponível em: <http://qnesc.sbq.org.br/online/qnesc31_3/06-HQ-0808.pdf>. Acesso em 29 nov. 2015

HILL, Christopher. O mundo de ponta-cabeça: ideais radicais durante a revolução inglesa de 1640. Tradução, apresentação e notas de Renato Janine Ribeiro. - São Paulo: Companhia das Letras, 1987.

LÉVI-STRAUSS, Claude. A origem dos modos à mesa (Mitológicas III). São Paulo: Cosac \& Naify, 2006.

LATOUR, Bruno. Jamais fomos modernos: ensaio de antropologia simétrica. Tradução de Carlos Irineu da Costa. $1^{\circ}$ ed. Rio de janeiro: Ed. 34, 1994.

MOURA, Mariluce. PESQUISA FAPESP. Paris, 2011, p. 11-17. Disponível em: http://revistapesquisa.fapesp.br/wp-content/uploads/2011/08/010-017186.pdf?b7cde4

Acesso 27 nov. 2015.

TOCQUEVILLE, Alexis de. A democracia na América: leis e costumes de certas leis e certos costumes políticos que foram naturalmente sugeridos aos americanos por seu estado social democrático. Tradução de Eduardo Brandão. 2. ed. São Paulo: Martins Fontes, 2005.

. O antigo regime e a revolução. 4. ed. Brasília: Editora Universidade de Brasília, 1997.

WAGNER, Roy. A invenção da cultura. Tradução de Marcela Coelho de Souza e Alexandre Morales. São Paulo: Cosac Naify, 2010. 


\title{
CAPÍTULO XIV
}

\section{A RELAÇÃO ENTRE DISCURSO E PODER: UMA BREVE CONVERSA ENTRE MARX E FOUCAULT}

\author{
José Cândido Rodrigues Neto ${ }^{1}$ \\ Valmir Pereira ${ }^{2}$ \\ Maria Aparecida Silva Bezerra ${ }^{3}$
}

\begin{abstract}
${ }^{1}$ Mestre em Literatura e Interculturalidade pela Universidade Estadual da Paraíba - UEPB.
2 Doutor em Educação pela Universidade Estadual Paulista Júlio de Mesquita Filho - UNESP.

${ }^{3}$ Graduada em Filosofia pela Universidade Estadual da Paraíba - UEPB.
\end{abstract}

\section{RESUMO}

Notoriamente vivemos em uma sociedade marcada por diversas práticas discursivas, onde cada uma destas é pautada por jogos de interesses ou reivindicações de determinado grupo social. O nosso cotidiano torna-se palco de diferentes discursos, tendo uns mais respaldo e outros ficando relegados à marginalidade. Disto decorre que o discurso tanto pode ser algo usado para dominar e manter o poder, como também pode ser uma forma de resistência ao poder vigente. Destarte, buscaremos investigar as seguintes questões: Quais são os mecanismos existentes na sociedade que visam controlar as diferentes práticas discursivas e porque estes garantem mais credibilidade e respaldo à determinados tipos de discurso em detrimento de outros? Recorreremos a reflexões feitas por Foucault e Karl Marx. Esperamos apontar algumas imbricações políticas e ideológicas relacionadas a formas de discurso que surgem em nossa sociedade, tendo em vista que cada uma destas possuem intencionalidade e direcionamento, pois os discursos não surgem ao acaso. Foucault nos alerta que há uma estreita relação entre saber e poder, tendo o poder a capacidade de gerar novos saberes e novos regimes discursivos que se atrelam a estes. Partindo da concepção marxista de antagonismo de classes, podemos inferir que havendo um poder hegemônico, que seria vinculado a uma classe dominadora, este se tornaria um vigoroso mecanismo de controle ao surgimento e a difusão dos discursos.

Palavras-chave: Discurso. Poder. Saber.

\section{INTRODUÇÃO}

É patente que vivemos em uma sociedade marcada por diversas práticas discursivas que direcionam e organizam nossa percepção da realidade. Entretanto, cada uma destas atende a determinados jogos de interesses, pois elas nãos surgem ao acaso. Desta maneira, nosso cotidiano passa a estar mergulhado em diferentes formas de discurso, sendo que uns ganham mais respaldo que outros. O filósofo francês Michael 
Foucault defende que as relações de poder existentes na sociedade são responsáveis pelo surgimento de novos saberes. Estes por sua vez, se estruturam a partir das práticas discursivas que os dão sustentação. Disto decorre, que das relações de poder surgem novas formas discursivas. De posse disto, e partindo do pressuposto marxista de antagonismo de classes podemos inferir que da relação entre classe opressora e classe oprimida decorre dois tipos de discurso que estariam presentes na sociedade, a saber, o discurso de dominação dos opressores e o discurso de resistência dos oprimidos.

A partir disto, buscaremos investigar as seguintes questões: Quais são os mecanismos de controle na sociedade que garantem maior credibilidade a determinadas práticas discursivas em detrimento de outras? E como tais mecanismos se estruturam? Para discutir estas questões partiremos de uma pesquisa bibliográfica que tem por base os autores Michael Foucault e Karl Marx. Como complementação teórica também utilizaremos obras de estudiosos deste dois pensadores, com o intuito de ampliarmos nossa compreensão dos conceitos abordados neste trabalho.

De início partiremos do pressuposto foucaultiano de que um poder gera um saber, onde este é estruturado por formas discursivas a ele atreladas. Entretanto, não partiremos da abordagem foucaltiana de relações microfísicas do poder, mas sim da abordagem marxista de dualismo de classes, que defende que uma classe dominadora detém o poder e com isto visa perpetuar a condição de exploração sobre uma classe que passa a ser oprimida. Optamos pela abordagem marxista por compreender que ela é pertinente para analisarmos nosso contexto social e político, tendo em vista que o Brasil é um país onde existem inúmeras desigualdades e injustiças sociais, e que muitas delas são decorrentes da exploração de uma classe menos privilegiada por outra mais abastada. Sendo assim, por meio do binômio saber-poder foucaultiano analisaremos a relação de antagonismo de classes e as implicações que esta dicotomia tem para o surgimento de discursos que permeiam a sociedade.

Com efeito, esperamos que este trabalho possa apontar algumas implicações que a relação entre saber e poder tem dentro de um contexto de embate entre classes sociais e também apontar algumas formas em que tal relação se estrutura dentro deste contexto. Esperamos fazer isto por meio de conceitos dos filósofos Michael Foucault e Karl Marx, não pretendemos com isto traçar uma relação ou comparação entre a obra destes autores mais apenas recorrer a alguns de seus conceitos para podermos 
desenvolver nossa análise no que tange a produção e veiculação de diferentes práticas discursivas. Analisar tal aspecto da sociedade tem a relevância de nos fazer compreender algumas formas estruturais de nosso contexto social, político e cultural, tendo em vista que este se organiza por meio de diferentes formas discursivas, uma vez que estas direcionam nossa forma de percepção da realidade.

\section{FOUCAULT E O BINÔMIO SABER-PODER}

O filósofo francês Michel Foucault nos faz atentar para íntima relação que se dá entre o poder e o saber. Em sua obra, este autor defende que o poder cria novos saberes. Por sua vez, cada saber tem capacidade de gerar novos discursos, que o difundem e o dão sustentação. Com efeito, nesta perspectiva o discurso passa a ser uma forma de veiculação de poder, havendo assim uma relação patente entre o poder e discurso. A obra de Foucault é dividida em três fases, sendo que a segunda, denominada de Genealógica, se ocupa em estudar os poderes e seus dispositivos. Desse modo, a fase Genealógica da obra focaultiana pode nos ser útil para que possamos compreender como se dá a relação existente no binômio saber-poder, sobre esta fase da obra do filósofo francês são ditas as seguintes palavras:

Do ponto de vista da Genealogia, as práticas de poder são constitutivas com relação às práticas discursivas, ou seja, elas são geradoras dos saberes. Por isso, a Genealogia ocupa-se genericamente das estratégias ou relações das práticas de poder, na constituição de um determinado saber. Em suma, ela se ocupa das "práticas de poder". Ou melhor, a Genealogia dá atenção especial ao binômio saber-poder. Todos os regimes de saber contêm relações de poder, não há aquele sem este. Essa é, talvez, a proposição mais conhecida a respeito da Genealogia. (CARDOSO JUNIOR, 2006, p.145)

Com efeito, disto decorre que a produção contínua de novos discursos está intimamente ligada às relações de poder existentes. Neste sentido, podemos compreender que as diferentes práticas discursivas existentes na sociedade possuem um íntima relação com o campo político. Sendo assim, nenhum discurso surge ao acaso ou a esmo, os diferentes discursos possuem intencionalidade e funções definidas, ou seja, cada um deles está atrelado à uma relação de poder existente no seio social. 
Foucault nos mostra que a realidade muda conforme mudam os discursos, pois estes organizam nossa forma de percepção do mundo e das coisas. Em seu livro $a$ história da loucura, o filósofo francês defende que nossa percepção e a experiência que temos a respeito da loucura se altera ao longo do tempo. Assim, podemos inferir que nossa maneira de conceber a loucura se altera conforme surgem novos discursos a respeito deste tema. Sobre a mudança de discurso em relação à loucura é dito o seguinte:

Se a loucura, em nosso tempo, é uma doença e, por isso, deve ser tratada num hospital, em outra época, o louco já andou solto e, ao contrário, era visto como aquele, dentre todos os seres, que pertencia à estrada, ao ar livre, e não ao confinamento do hospício. Ele nos lembra que, se a prisão é um dispositivo correcional que visa recondicionar o indivíduo pela máxima exposição àqueles que o vigiam, já houve em outros tempos um regime de punição, a masmorra, cujo princípio de funcionamento era justamente contrário ao da prisão ou, ao menos, como esta é concebida nos tratados de Direito penal, pois a masmorra faz o corpo mergulhar na escuridão e o torna indistinto dos outros corpos submetidos ao mesmo regime. (Ibidem, p. 138)

Portanto, podemos perceber que nossa concepção a respeito das coisas se altera ao longo do tempo. Isto se dá devido a mudança de configuração na sociedade, onde surgem novas relações de poder e estas são responsáveis pelo aparecimento de novas formas discursivas que organizam e condicionam nossa forma de conceber as coisas. Se antes a loucura era praticamente ignorada e o louco era aquele que deveria viver em liberdade, hoje a loucura é tratada como caso clínico e o louco torna-se um paciente que deve viver confinado em um regime de internação. Portanto, as reflexões feitas por Foucault nos permitem perceber que poder e saber estão em íntima relação, sendo este produzido por aquele. Disto decorre, que os discursos existentes em cada sociedade são resultantes dos diversos saberes nela existentes. Além disso, é possível inferir que das relações de poder, além de surgir os diferentes discursos, surgem as formas de controle destes. Uma vez que:

[...] em toda sociedade a produção do discurso é ao mesmo tempo controlada, selecionada, organizada e redistribuída por certo número de procedimentos que têm por função conjurar seus poderes e perigos, dominar seu acontecimento aleatório, 
esquivar sua pesada e temível materialidade. (FOUCAULT, 1999, p. 8-9)

Portanto, no próprio meio social há um controle em relação ao surgimento e veiculação das formas discursivas que se desenvolvem. Pensamos que este controle se dá no plano intelectual e também que ele se estrutura a partir de interesses de um grupo que detém o domínio sobre a produção intelectual e material da sociedade. Estaríamos a partir de agora lançando mão de uma análise marxista a respeito da forma como se estruturaram as relações de poder na sociedade, onde haveria a dicotomia entre a classe opressora e a classe oprimida.

\section{O ANTAGONISMO DE CLASSE E OS DISCURSOS DE OPRESSÃO E RESISTÊNCIA}

Em sua obra Microfísica do poder, Foucault defende que o poder constitui uma realidade microfísica. Para ele o poder se dá de forma difusa, estabelecendo micro relações. Nesta concepção, o poder não se centraliza, nem se totaliza, mas se divide em focos, formando uma teia que abarca as diversas relações no âmbito da sociedade. Neste sentido, o poder emana em todas as direções e de forma difusa. A concepção foucaultiana de poder se contrapõe à concepção Marxista, que defende que o poder se concentra nas mãos de uma classe, que se torna hegemônica e opressora. Pois como é dito, Em "Todas as sociedades anteriores, como vimos, repousam no antagonismo entre classes opressoras e classes oprimidas." (ENGELS, MARX, 2007, p. 60).

Em nossa abordagem, utilizaremos a ideia foucaultiana de que um poder gera um saber, que engendra configurações discursivas atreladas a este. Entretanto, em relação a forma como o poder se dá no meio social optaremos por recorrer ao conceito marxista de antagonismo de classes. Levando-se em consideração que o nosso país é marcado por inúmeras desigualdades e injustiças sociais, parece patente que existe um dualismo na sociedade, não só no Brasil, mais em todo o mundo capitalista. De um lado, existe um grupo privilegiado que goza de inúmeros benefícios e que explora e oprime os indivíduos menos privilegiados. Por outro lado, existe uma camada da população constituída pelas classes com menor poder aquisitivo e que gozam de poucos benefícios devido à sua condição social e financeira, que muitas vezes precisam reivindicar seus 
direitos, pois este não se efetivam ou são negligenciados. O que marcaria esta cisão social seria a quantidade de capital acumulado, pois isto traça a distinção entre a classe opressora, que é a classe burguesa, e a classe oprimida, que é constituída pelos trabalhadores e pelos indivíduos de baixo poder aquisitivo.

Este dualismo de classes é responsável por inúmeras injustiças, pois as classes opressoras desejam permanecer no poder e para isto necessitam manter a condição de dominação sobre as classes oprimidas. Uma das formas de perpetuar este estado de dominação seria por meio de discursos ideológicos, que defenderiam os interesses de uma classe dominante. Partindo do pressuposto foucaultiano de que um poder gera um saber, então poderíamos inferir que o poder da classe dominante é responsável por diversos saberes que sustentam práticas discursivas pautadas na dominação, e que torna-se ideológicas para as classes oprimidas. Também decorre que do poder das classes exploradas surgem práticas discursivas, que tornam-se formas de resistência ao poder vigente. Entretanto, o discurso da classe hegemônica tende a prevalecer, pois é produto de um poder hegemônico. Como é dito:

Os pensamentos da classe dominante são também, em todas as épocas, os pensamentos dominantes; em outras palavras, a classe que é o poder material dominante numa determinada sociedade é também o poder espiritual dominante. A classe que dispõe dos meios da produção material dispõe também dos meios da produção intelectual, de tal modo que o pensamento daqueles aos quais são negados os meios de produção intelectual está submetido também à classe dominante. (MARX; ENGELS, 2007, p. 48 apud MACHADO, 2010, p.52)

A classe dominante como sendo detentora do poder material e do capital tornase também detentora de grande parte da produção intelectual, e com isto controla diversos veículos discursivos, estendendo sua dominação às inúmeras fontes de informação, como por exemplo: a televisão, os jornais, as revistas, a literatura, entre outras. Neste sentido, os discursos de resistência ficam relegados às fontes alternativas como: blogs, jornais alternativos e outros veículos de pequena projeção, uma vez que aqueles de grande circulação são em sua maioria atrelados aos discursos hegemônicos da classe dominante e por ela controlados. Desse modo, por meio da difusão de discursos que defendem interesses de uma classe exploradora os dominadores 
estendem o domínio que se dá no plano material para o plano intelectual, uma vez que fazem prevalecer as práticas que se tornam veiculação do poder dominante.

\section{CONCLUSÃO}

Diante do que foi exposto anteriormente, é possível concluir que os diferentes discursos que surgem na sociedade estão atrelados à diferentes grupos sociais, e atendem as demandas destes. Entretanto, na própria sociedade há mecanismos de controle que excluem algumas práticas discursivas. Ficam relegadas à marginalidade aquelas que atentam contra a ordem vigente ou que colocam em questão as diversas relações que se dão no âmbito social. Tendo em vista que há uma classe privilegiada que detém o capital e que controla os diversos meios intelectuais, esta cria estratégias de manutenção do poder. Uma destas estratégias é a veiculação de discursos ideológicos que visam disseminar ideias que atendem as demandas de uma classe dominante. Sendo assim, através de discursos que visam camuflar as injustiças sociais e a exploração que ocorre na sociedade os exploradores buscam alienar as classes dominadas para que haja a manutenção do sistema econômico vigente, o capitalismo.

Deste modo, o discurso que se estrutura com o intuito de fomentar e perpetuar a exploração de um grupo por outro passa a ser um discurso ideológico de dominação, e este tem mais respaldo no meio social, uma vez que há um controle dos meios de circulação por parte dos grupos a que este discurso visa atender. Sabemos que os grandes veículos de informação em sua maioria são dominados por grupos capitalistas e que estes agem para que seus interesses sejam atendidos. Disto decorre, que tais veículos passam a acolher as exigências destes grupos e passam a disseminar as ideias e a ideologia de uma classe dominante. Entretanto, também existem os discursos que visam resistir a esta situação e que põem em questão o status quo e a ordem vigentes. Tais discursos não possuem grande respaldo dentro dos veículos que são controlados pelas classes exploradoras e passam a ocupar uma posição de marginalidade. Todavia, com o surgimento da internet, surgem diversas espaços alternativos de difusão dos discursos de resistência, uma vez que a rede mundial não pode ser totalmente controlada por determinados grupos. Tal espaço pode ser fundamental para que o grito 
dos oprimidos possa ser ouvido, pois este a todo momento é encoberto pelos brados da opressão.

\section{REFERÊNCIAS}

CARDOSO JUNIOR, H. R. Foucault em voo rasante. In: CARVALHO, A. B. et al. (Orgs.). Sociologia e educação: leituras e interpretações. São Paulo: Avercamp, 2006. p. 135-159.

COSTA, C. Sociologia: Introdução à ciência da sociedade. São Paulo: Moderna, 2005.

DROIT, R-P. Marx e o mundo de cabeça para baixo. In: . Filosofia em cinco lições. Rio de Janeiro: Nova fronteira, 2012.

ENGELS, F.; MARX, K. Manifesto do partido comunista. São Paulo: Escala, 2007.

FOUCAULT, M. A ordem do discurso. São Paulo: Loyola, 1999.

JOHNSTON, D. Karl Marx: a marcha da história. In: . História concisa da Filosofia: de Sócrates a Derrida. São Paulo: Rosari, 2008.

MACHADO, S. B. A ideologia de Marx e o discurso de Foucault: convergências e distanciamentos. Sociologias, Porto Alegre, v. 12, no 23, p. 46-73, 2010. Disponível em: < http://www.scielo.br/pdf/soc/n23/04.pdf > Acesso em 10/03/2017.

MAGALHÃES, F. 10 lições sobre Marx. Petrópolis: Vozes, 2015.

MARX, K. Contribuição à crítica da filosofia do direito de Hegel: Introdução. São Paulo: Expressão popular, 2010.

SILVA, W. C.; CARVALHO, A. B. Contribuições do materialismo histórico para a educação. In: CARVALHO, A. B. et al. (Orgs.). Sociologia e educação: leituras e interpretações. São Paulo: Avercamp, 2006. p. 39-55. 


\title{
CAPÍTULO XV
}

\section{EDUCAÇÃO EM DIREITOS HUMANOS: CONQUISTAS, AVANÇOS E DESAFIOS 1}

\author{
Thaíse da Paixão Santos ${ }^{1}$ \\ Lívia Jéssica Messias de Almeida ${ }^{2}$ \\ Maria Rita Santos ${ }^{3}$
}

\begin{abstract}
1 Doutoranda do programa de Pós-Graduação em Educação, Contextos Contemporâneos e Demandas Populares (PPGEduc) pela Universidade Federal Rural do Rio de Janeiro(UFRRJ). Professora da Educação Básica no município de Ubaitaba- Bahia.

2 Professora Adjunta do Departamento de Educação (DEDI) da Universidade Federal de Sergipe (UFS).

${ }^{3}$ Doutoranda em Educação e Contemporaneidade - Universidade do Estado da Bahia (UNEB), Mestra em Educação Universidade Estadual de Feira de Santana (UEFS).
\end{abstract}

\section{RESUMO}

O presente artigo tem como objetivo dialogar sobre Educação em Direitos Humanos (EDH) seus avanços, conquistas e desafios apresentados no contexto educacional. Para tanto, partirmos do seguinte questionamento: Quais são os princípios, políticas e programas, para garantir a efetivação da EDH Tal problematização terá como aporte teórico os seguintes autores, no campo da EDH Benevides (2004), Candau (2007), Candau; Sacavino (2013), Silva (2011), Silva; Tavares (2013), Ramos (2011), e dos marcos legais da legislação brasileira e do contexto mundial. O texto se constitui em uma revisão de literatura, a partir dos teóricos supracitados. A relevância deste estudo está pautado na contribuição para ressignificação das práticas curriculares e pedagógicas, tendo o diálogo dos atores curriculantes docentes com a EDH um aspecto fundante para os processos formativos dos sujeitos.

Palavras-chave: Educação em Direitos Humanos. Direitos Humanos. Política Curricular. Programas.

\section{INTRODUÇÃO}

A Educação em suas diversas modalidades de ensino que demanda um olhar sensível às questões referentes aos Direitos Humanos, por estar intrinsecamente relacionada com a sua itinerância. Na contemporaneidade, o cenário das políticas e dos

1 Uma primeira versão deste artigo foi publicada no XI Colóquio Internacional Educação e Contemporaneidade, no ano de 2017, disponível no seguinte endereço: https://ri.ufs.br/bitstream/riufs/9488/12/11.pdf 
programas já assegura e aponta para a necessidade de inserirem esse debate na prática formativa e nas proposições curriculares dessa modalidade, na perspectiva dos Direitos Humanos. Portanto, neste artigo discorremos a respeito dessas políticas e desses programas, contextualizando-os e destacando seus princípios, suas abrangências, suas propostas e seus objetivos.

Nessa perspectiva, a existência de marcos legais que abordam e incluem dispositivos úteis à luta pelo direito à educação, ao nomear uma base legal para o Estado implementar novas ações, políticas e programas, encontram-se em coerência com o que é proposto pela EJA, ao reforçarem o debate pela universalização do direito humano fundamental à educação e a necessária observância das especificidades e diversidades nas quais essa se materializa.

Assim com o intuito de discutir sobre a temática que está presente pesquisa teve como base metodológica a pesquisa bibliográfica. De acordo com Fonseca (2002, p.32) a pesquisa bibliográfica "é feita a partir do levantamento de referências teóricas já analisadas, e publicadas por meios escritos e eletrônicos, como livros, artigos científicos, páginas de web sites." o que nos possibilitou enquanto pesquisadoras conhecer o que já se estudou sobre o assunto. Sendo assim, nesta pesquisa lançaremos mão de referenciais publicados, acerca da referida temática, analisando e discutindo as contribuições cientificas.

O primeiro tópico desse artigo se inicia com uma breve discussão sobre a EDH conceituando e fazendo algumas distinções com outros termos. No tópico seguinte, abordaremos, sobre as políticas e programas no contexto educacional que apontam a importância da EDH, procurando analisar sua realidade a partir dos referenciais teóricos aqui trabalhados. Por fim teceremos algumas considerações na tentativa de responder à problemática.

\section{EDUCAÇÃO EM DIREITOS HUMANOS: CONCEITO E DISTINÇÕES}

As raízes históricas dos Direitos Humanos, em sua permanente evolução, trazem para os mais distintos povos contemporâneos preceitos de dignidade, liberdade e igualdade entre os seres humanos em uma dimensão cultural. No decorrer da história da humanidade, essa discussão gradativamente foi se ampliando, mas "foi uma grande 
revolução no pensamento e na história da humanidade chegar à reflexão conclusiva de que todos os seres humanos detêm a mesma dignidade" (BENEVIDES, 2004, p.56).

Ainda segundo essa autora, os Direitos Humanos são universais, naturais e ao mesmo tempo históricos. Acrescenta ainda que eles são indivisíveis e interdependentes. Nas suas palavras: "são naturais e universais porque vinculados à natureza humana, mas são históricos no sentido de que mudaram ao longo do tempo num mesmo país e o seu reconhecimento é diferente em países distintos, num mesmo tempo". Em consonância com a afirmativa da indivisibilidade e interdependência, podemos citar o que considera o Plano Nacional de Educação em Direitos Humanos (PNEDH, 2006): todos os direitos estão interligados e a concretização de um direito está arrolada com a efetivação dos outros direitos.

De acordo com Arroyo (2011, p.25), "Uma das tarefas do movimento docente e do movimento cívico-democrático foi tentar trazer de volta a educação: "Educação direito de todo cidadão". Escolas, redes e coletivos docentes retomando a função da docência e dos currículos como territórios da garantia do direito à educação". Visto que passamos por um longo período de escravidão e curtos períodos democráticos, que dificultaram essa conquista, no entanto é válido ressaltar os contornos feitos para que os Direitos Humanos fossem arrolados pela dignidade, igualdade, liberdade e justiça dos movimentos sociais, processo esse marcado por lutas, conforme $\operatorname{PNEDH}(2011$, p. 3):

Os Direitos Humanos são frutos da luta pelo reconhecimento, realização e universalização da dignidade humana. Histórica e socialmente construídos, dizem respeito a um processo em constante elaboração, ampliando o reconhecimento de direitos face às transformações ocorridas nos diferentes contextos sociais, históricos e políticos.

Nesse contexto, a educação se torna componente essencial para que esses direitos sejam estabelecidos e mantidos na sociedade. Compreendendo que o acesso à educação pode assegurar o ingresso aos demais direis através do seu empoderamento, pois nesse sentido a Educação em Direitos Humanos possibilitará que os educandos se tornem sujeitos de direitos, o que coaduna com a literatura de Silva; Tavares (2013, p.50), quando afirmam que "as pessoas podem tornar-se sujeitos de direitos, 
conhecedores dos processos e construções históricas das conquistas, avanços e recuos em relação à efetividade e ampliação dos seus direitos e deveres".

Quando reportamos a alguns termos nesta discussão da Educação em Direitos Humanos, tornam-se necessárias algumas distinções entre: educação como direito humano, educação para os direitos humanos e Educação em Direitos Humanos (grifo nosso). Para compreender algumas implicações a partir do seu próprio conceito, e a conjuntura que surge. Ramos (2011, p.92) salienta:

A expressão educação como direito humano sublinha a ideia de educação como um bem universal e inalienável, o que aprofunda seu reconhecimento legal como direito social que deve ser garantido pelo Estado. Educação para os direitos humanos remete a uma finalidade da ação educativa. [...] O polo direitos humanos do binômio é privilegiado, e a educação é uma via para que se alcancem objetivos sociais mais amplos, relativos a igualdade, democracia, etc. A expressão Educação em Direitos Humanos indica a assunção dos princípios dos direitos humanos como um pressuposto, um eixo norteador das práticas educativas. Ganha centralidade o polo educação do binômio, ressaltando-se para o termo uma dimensão propriamente pedagógica.

Esses termos se tornam interligados, pois, apesar de distintos, eles se complementam, enquanto a educação como direito humano concebe a educação como um direito indispensável para nos tornar reflexivos. A educação para os direitos humanos se torna um caminho para que se possam alcançar objetivos, tais como: dignidade, liberdade, igualdade entre outros preceitos dos direitos humanos. Nesta pesquisa, assumimos a perspectiva da Educação em Direitos Humanos ao propor uma educação que entende os Direitos Humanos como um eixo norteador da prática educativa.

De acordo com Silva (2010, p.49) a EDH:

[...] não se limita à contextualização e à explicação das variáveis sociais, econômicas, políticas e culturais que interferem e orientam os processos educativos. Ela vai além da contextualização, embora esta seja imprescindível para a compreensão da sua construção. Faz parte dessa educação apreender os conteúdos que dão corpo a essa área, ou seja: a história, os processos de evolução das conquistas e das violações dos direitos, as legislações, pactos e acordos que dão sustentabilidade e garantia aos direitos são conteúdos a serem trabalhados no currículo básico. [...] os conteúdos devem ser associados ao desenvolvimento de valores, comportamentos éticos na 
perspectiva de que o ser humano é sempre incompletude enquanto ser social, datado, localizado, o ser humano tem necessidade permanentemente de conhecer, construir e reconstruir regras de convivência em sociedade.

A temática da EDH é recente na História do Brasil e segundo Silva; Tavares (2013, p.50) "é uma das exigências e urgências para que possamos ter uma formação mais humanizadora das pessoas e o fortalecimento dos regimes políticos democráticos na sociedade". Passou a existir durante o processo de redemocratização, marca essa dos anos de 1980, que tinha uma proposta ousada de "construir uma cultura de participação cidadã, por meio da qual a sociedade brasileira se reconheça como sujeitos de direitos" (VIOLA, 2010, p.15).

\section{POLÍtICAS E PROGRAMAS NO CONTEXTO EDUCACIONAL QUE APONTAM A IMPORTÂNCIA DA EDH}

Constatamos através da pesquisa das autoras Silva e Tavares (2013), que obtivemos muitos avanços em termos normativos desde a Constituição de 1988, que se tornou uma referência e elemento propulsor para a promoção dessas políticas públicas de direitos humanos e de EDH no Brasil. É valido ressaltar que, apesar da EDH ser uma prática recente e ter seu surgimento no contexto das lutas e movimentos sociais de resistência contra o autoritarismo das ditaduras, ainda nos encontramos num cenário com breves e frágeis períodos democráticos.

Disso também decorre a importância de se educar em direitos humanos, por potencializar "o respeito ao ser humano e a sua dignidade, aos valores democráticos, à tolerância e à convivência dentro das regras do estado de direito", contribuindo para que os sujeitos adquiram o papel de ator principal de sua história, "conscientes de suas responsabilidades sociais, políticas, culturais e artífices das transformações necessárias a cada realidade" (IDEM, 2013, p.53).

Além disso, justifica-se pelas políticas que apontam para a necessidade de se instaurar uma cultura de direitos humanos. Entre os marcos legais no nosso contexto, que a asseguram, podemos fazer referência a: Declaração Universal dos Direitos Humanos (ONU, 1948); Constituição Brasileira (BRASIL, 1988); Lei de Diretrizes e Bases da Educação (Lei no 9.394, de 20 de Dezembro de 1996); Programa Mundial para 
Educação em Direitos Humanos (Unesco, 2006); Plano Nacional de Educação em Direitos Humanos (BRASIL 2006); Plano Estadual de Educação em Direitos Humanos (BAHIA, SJCDH, 2009); Diretrizes Nacionais para a Educação em Direitos Humanos (BRASIL, MEC/ CNE, 2012); Diretrizes Curriculares Nacionais para a Formação Inicial e Continuada dos Profissionais do Magistério da Educação Básica (BRASIL, 2015).

O Brasil criou a primeira versão do Programa Nacional de Direitos Humanos em 1996, e a segunda em 2002. Já em 2003, ocorreu à instituição do Comitê Nacional de Educação em Direitos Humanos (CNEDH), que teve como sua primeira incumbência a elaboração do PNEDH, para orientar as políticas públicas do Estado brasileiro para a referida temática. Tais ações decorreram da mobilização da sociedade civil e em acordo com os compromissos internacionais assumidos pela efetivação da Educação em Direitos Humanos em nosso país.

O PNEDH apresentou sua versão preliminar em 2003 e a final em 2006. Constituise num instrumento normativo, pois estabelece ações programáticas a serem alcançadas em cinco grandes áreas abrangentes: educação básica, ensino superior, educação não formal, mídia e formação dos profissionais dos sistemas de justiça e de segurança pública. Produzindo uma maior visibilidade no contexto nacional da EDH, o Plano se instituiu como um marco importante na construção de políticas públicas nessa área, uma vez que tem fomentado a elaboração de vários Programas e Planos Estaduais e Municipais de Educação em Direitos Humanos.

Em 2012, através da Resolução № 01, do Ministério da Educação-Conselho Nacional de Educação (CNE), foram estabelecidas as Diretrizes Nacionais para a Educação em Direitos Humanos, a serem observadas pelos sistemas de ensino e por suas instituições. O seu Art.3ำ aborda os princípios que fundamentam a EDH com a finalidade de promover a educação para a mudança e a transformação social, a saber:

I-dignidade humana;

II-igualdade de direitos;

III-reconhecimento e valorização das diferenças e das diversidades;

IV-laicidade do Estado;

V-democracia na educação;

VI-transversalidade, vivência e globalidade; e

VII-sustentabilidade socioambiental. 
Ainda em conformidade com as diretrizes (BRASIL, 2012, p.2-3), nos artigos 60 e 70ำ são estabelecidas as orientações para a inclusão da EDH no planejamento da educação, apresentando diversas possibilidades para a sua implantação. Assim, como sugestão, o documento apresenta as seguintes modalidades:

Art. 60 A Educação em Direitos Humanos, de modo transversal, deverá ser considerada na construção dos Projetos Político-Pedagógicos (PPP); dos Regimentos Escolares; dos Planos de Desenvolvimento Institucionais (PDI); dos Programas Pedagógicos de Curso (PPC) das Instituições de Educação Superior; dos materiais didáticos e pedagógicos; do modelo de ensino, pesquisa e extensão; de gestão, bem como dos diferentes processos de avaliação.

Art. 70 $\mathrm{A}$ inserção dos conhecimentos concernentes à Educação em Direitos Humanos na organização dos currículos da Educação Básica e da Educação Superior poderá ocorrer das seguintes formas:

I pela transversalidade, por meio de temas relacionados aos Direitos Humanos e tratados interdisciplinarmente; Ministério da Educação.

II como um conteúdo específico de uma das disciplinas já existentes no currículo escolar;

II de maneira mista, ou seja, combinando transversalidade e disciplinaridade.

Parágrafo único. Outras formas de inserção da Educação em Direitos Humanos poderão ainda ser admitidas na organização curricular das instituições educativas, desde que observadas as especificidades dos níveis e modalidades da Educação Nacional.

Diante desses programas e políticas, fica evidente que do ponto de vista normativo o Brasil está bem sedimentado, mas é eminente que ainda precisa avançar no sentido de inseri-lo efetivamente no currículo e consequentemente nas práticas formativas, e não somente em momentos pontuais, pois de acordo Silva (2011, p.6-8) “[...] na educação básica, observa-se a inserção dos conteúdos de direitos humanos nas escolas, ainda que, na maioria dos Estados, eles sejam trabalhados em forma de projetos e ações pontuais, sem estar articulado com o currículo".

Ao pensarmos a educação na perspectiva da EDH estamos falando em superar a visão de uma educação bancária (com a ideia de que os sujeitos são depósito do conhecimento e o educador um mero transmissor de informações, não havendo espaço 
para reflexão e diálogo). Para tanto, propiciar uma educação pautada nos preceitos da educação libertadora (problematizadora), que considera a realidade onde esses sujeitos estão inseridos, levando-os a refletir criticamente sobre ela, além de estimular a busca pela superação das situações de violações de direitos.

Desse modo, não podemos desconsiderar que vivenciamos ainda um contexto que vê o direito à educação apenas no viés do acesso (expansão de vagas), e não da sua permanência com qualidade, principalmente quando reportamos aos sujeitos da EJA, que fazem parte de um complexo contexto de negação de direitos. Nessa perspectiva, se sujeitos acessarem a escola, tendem a sentirem-se frustrados, pois a escolarização não é garantia de que irão sair da condição de "subcidadania", ou seja, que os direitos básicos serão assegurados a todos. Como afirma Arroyo (2011, p.340), essa é a motivação de muitos:

O acesso à escola não pode ser reduzido a uma política de vagas, de ampliação de escolas por parte dos governos. Adquire um senso político mais radical se vermos esse ir de milhões de crianças e adolescentes populares à escola básica ou de jovens e adultos da EJA como uma tentativa de passagens do lado de lá, dos não lugares, para o lado de cá, os lugares sempre negados.

Diante dessa afirmação, necessita-se contextualizar o cenário contemporâneo. Vivemos em um mundo globalizado com políticas neoliberais ${ }^{1}$, que têm acentuado as desigualdades e principalmente a violação de Direitos Humanos. Entretanto, tais violações não recaem igualmente sobre os diversos grupos sociais e culturais, mas sobre aqueles que ocupam um lugar social de desvantagens nas oportunidades de acesso à educação escolar, certamente como afirma Candau em concordância com os escritos de Hanna Arendt (1997), por não se adequarem a uma sociedade cada vez mais competitiva, pois a escola, ao tempo em que forma para atender o mercado, descarta os sujeitos e lhes nega o "direito a ter direitos" (CANDAU, 2007, p.127).

Nesse sentido, ter os princípios dos direitos humanos como um eixo norteador das práticas educativas com os alunos e professores da EJA implica pensarmos que tal educação pode possibilitar-Ihes difundir o seu caráter crítico e transformador, como nas palavras de Freire (2001, p. 99):

1 Cf. GENTILI, A.A.P.; SILVA, T. T. (Orgs.). Neoliberalismo, qualidade total e educação: Visões críticas. 11 ed. Petrópolis: Vozes, 2002. 
[...] na perspectiva da justiça, é exatamente aquela educação que desperta os dominados para a necessidade da briga, da organização, da mobilização crítica, justa, democrática, séria, rigorosa, disciplinada, sem manipulações, com vista à reinvenção do mundo, à reinvenção do poder tomado, o que vale dizer que essa educação tem a ver com uma compreensão diferente do desenvolvimento, que implica uma participação, cada vez maior, crescente, crítica, afetiva, dos grupos populares.

Segundo Arroyo (2016, p.24) a tensa visão que se tenta vincular é a de que, como sujeito não escolarizado, ele não pode ser visto como cidadão "Essas formas tão segregadoras de pensá-los e de inferiorizá-los que ainda persistem tem agido em nossa história, até pedagógica e especificamente da EJA para resistir a vincular a sua ed ucação como direito humano". Compreendemos, assim, a carência de se promover uma prática pedagógica docente que valorize as subjetividades dos jovens e adultos e, ao mesmo tempo, promova uma cultura dos direitos humanos. Nesse sentido, é valido ressaltar como as Diretrizes da Educação em Direitos Humanos afirmam que:

[...] a educação vem sendo entendida como uma das mediações fundamentais, tanto para o acesso ao legado histórico dos Direitos Humanos, quanto para a compreensão de que a cultura dos Direitos Humanos é um dos alicerces para a mudança social. Assim sendo, a educação é reconhecida como um dos Direitos Humanos e a Educação em Direitos Humanos é parte fundamental do conjunto desses direitos, inclusive do próprio direito à educação (BRASIL, 2012, p.2).

Assim, outro aspecto que merece destaque, fazendo referência à pesquisa de Silva; Tavares (2013), e que se torna pertinente para essa discussão, é quando, ao se reportarem aos espaços em que se tem realizado ações em defesa dos Direitos Humanos, a educação não formal continua sendo predominante. Nesse ínterim, ponderam que:

Ao mesmo tempo, as perspectivas de avançar nesse campo, notadamente no âmbito da educação formal, ampliam-se com a elaboração das Diretrizes Nacionais para a Educação em Direitos Humanos na Educação Básica e Educação Superior, sob a coordenação do Conselho Nacional de Educação com a participação da SECADI/ MEC, SDH e do Comitê Nacional de EDH. (IDEM p. 52).

Existem fortes indícios dos significativos avanços referentes à legislação nessa área, mas, para que a EDH crie materialidade, necessita da cooperação de uma ampla 
variedade de sujeitos, ou seja, todos os autores do ambiente educacional devem estar envolvidos, buscando a efetivação dos seus princípios e fundamentos. Nesse contexto é indispensável que se crie um ambiente propício a processos formativos ${ }^{[2]}$, que fomentem uma cultura de Direitos Humanos. De acordo com Candau; Sacavino (2013, p.66):

É, também, de especial importância desenvolver processos formativos que permitam articular diferentes dimensões - cognitiva, afetiva, artística e sócio-política - fundamentais para a educação em Direitos Humanos, assim como utilizar estratégias pedagógicas ativas, participativas e de construção coletiva que favoreçam educar-nos em Direitos Humanos.

O contexto educacional atual precisa estar atento aos novos desafios e perspectivas que continuam surgindo no que concerne à EDH, para cumprir a finalidade que lhe foi designada. Nessa perspectiva, deve ser sensível à necessidade dos segmentos sociais que participam desse processo formativo, que com ela dialogam, de modo a concorrer para a melhoria dos mesmos e buscar neles elementos que possam contribuir para a formação dos sujeitos.

\section{CONSIDERAÇÕES FINAIS}

Com este estudo compreendemos que ressignificar o currículo é imprescindível através de diálogos possíveis entre os atores curriculantes e a EDH se constitui como uma possibilidade concreta de refletirmos e pautarmos discussões acerca de um currículo que possa possibilitar uma formação pautada em princípios que dê conta do reconhecimento das diferenças e diversidade dos sujeitos, dignidade humana, igualdade de direitos, laicidade do Estado, entre outros.

Portanto considerando o cenário brasileiro, onde ainda se encontra muitos sujeitos sem acesso à educação na idade adequada, como também o processo de formação inicial e continuada de professores, muitas vezes incipiente no que tange a Educação em Direitos Humanos estamos frente a uma demanda urgente que precisa ser enfrentada. Tal enfrentamento pode ser iniciado com a implementação da Educação em Direitos Humanos na proposta curricular. Ao tempo em que se busca essa implementação, nada impede que realizemos propostas interventivas na área de formação de professores, visando a inserção da Educação em Direitos Humanos na 
perspectiva de fomentar o conhecimento dos direitos dos educandos, possibilitando-os algumas transformações, como: buscar respostas para os seus questionamentos; enfrentamentos da negação de direitos e inconformismos da situação de opressão que permitiu mantê-los a margem dos direitos humanos .

\section{REFERÊNCIAS}

ARENDT, Hannah. Origens do Totalitarismo - Anti-semitismo, imperialismo e totalitarismo. São Paulo: Companhia das Letras, 1997.

ARROYO, Miguel. A educação de Jovens e Adultos em tempos de exclusão: alfabetização e cidadania. São Paulo: Rede de Apoio à Ação Alfabetizadora do Brasil (RAAB), n.11, abril, 2011a.

. Novos passos na Educação de Jovens - Adultos In: SILVA, M.M. Aida. COSTA, Graça.dos S., LIMA, Isabel. M.O. Diálogos sobre educação em direitos humanos e a formação de jovens e adultos. Salvador: EDUFBA, 2016.

BAHIA. Secretaria da Justiça, Cidadania e Direitos Humanos. Comitê Estadual de Educação em Direitos Humanos. Plano Estadual de Educação em Direitos Humanos. 2009. Salvador.

BARROS, Rosanna. Genealogia dos conceitos em Educação de Adultos: da educação permanente à aprendizagem ao longo da vida. Um estudo sobre os fundamentos políticos- pedagógicos da prática educacional. Chiado Editora. Lisboa: 2011.

BENEVIDES, . Cidadania e Direitos Humanos. In: CARVALHO, Jose Sérgio (Org.). Educação, Cidadania e Direitos Humanos. Petrópolis, RJ: Vozes, 2004.

BRASIL. LDBEN- Lei de Diretrizes e Bases da Educação Nacional. 5a ed. Centro de Documentos e Informação Edições Câmara Brasília- 1996.

Plano Nacional de Educação em Direitos Humanos. Secretaria Especial de Direitos Humanos. Brasília, 2006.

Ministério da Educação. Conselho Nacional de Educação. Conselho Pleno. Parecer n. 08/2012 - Princípios da Educação em Direitos Humanos (EDH). Texto orientador para a elaboração das Diretrizes Nacionais da Educação em Direitos Humanos. Brasília, Pleno do Conselho Nacional de Educação, 2012, p. 1-18. Disponível em: . Acesso em 19, nov. de 2014.

Ministério da Educação. Conselho Nacional de Educação. Resolução № 1, de 30 de maio de 2012. Dispõe sobre as Diretrizes Nacionais para a Educação em Direitos Humanos. Disponível em: http://portal.mec.gov.br/index. 
phpoption=com_docman \&view=download \&alias=10889-rcp001-

12\&category_slug=maio-2012-pdf\&Itemid=30192. Acesso em: nov. de 2014.

. Ministério da Educação. Conselho Nacional de Educação. Resolução no 2 de 10 de julho de 2015. Define as diretrizes curriculares nacionais para formação inicial em nível superior ( cursos de licenciatura, cursos de formação pedagógica para graduados e cursos de segunda licenciatura) e para a formação continuada. Diário Oficial [da] República Federativa do Brasil, Brasília, 2 jul. de 2015.

.Constituição (1988). Constituição da República Federativa do Brasil de 1988.Disponível em: Acesso em: 07, jan., 2014.

BRASIL. Ministério da Educação. Diretrizes Curriculares Nacionais Gerais da Educação Básica. Disponível em: http://portal.mec.gov.br/index. phpoption=com_docman\&view=download\&alias=15548-d-c-n-educacaobasica-nova-pdf\&Itemid=30192 Acesso em: nov. 2014.

CANDAU, Vera M. Educação em direitos humanos: desafios atuais. In: SILVEIRA, Rosa M. G., et al. Educação em direitos humanos: fundamentos teóricometodológicos. João Pessoa: Editora Universitária, 2007.

CANDAU. Vera M.; SACAVINO, Susana. Educação em direitos humanos e formação de educadores. Educação (Porto Alegre, impresso), v. 36, n. 1, p. 59-66, jan./abr. 2013.

FREIRE, P. Pedagogia dos sonhos possíveis. Ana Maria Araújo Freire (org.). São Paulo: Editora Unesp, 2001.

NAÇÕES UNIDAS. Assembléia Geral (1948). Declaração Universal dos Direitos Humanos. Rio de Janeiro, 2000. Disponível em: .Acesso: set, 2015

RAMOS, Aura H. O lugar da diferença no currículo de educação em direitos humanos. Rio de Janeiro: Quartet: FAPERJ, 2011.

SILVA, Aida. Direitos Humanos na Educação Básica: qual o significado In: SILVA, Aída M. M.; TAVARES, Celma. (Orgs.). Políticas e Fundamentos da Educação em Direitos Humanos. São Paulo: Cortez, 2010.

SILVA, Aida M. M.. TAVARES, Celma. Educação em direitos humanos no Brasil: contexto, processo de desenvolvimento, conquistas e limites. Educação. Porto Alegre. 2013. Disponível em: http://revistaseletronicas.pucrs.br/ojs/index.php/faced/article/viewFile/12315 /8740. Acesso em: nov. 2015.

VIOLA, Solon Eduardo Annes. Políticas de Educação em Direitos Humanos. In: SILVA, Aída M. M.; TAVARES, Celma. (Orgs.). Políticas e Fundamentos da Educação em Direitos Humanos. São Paulo: Cortez, 2010. 


\section{CAPÍTULO XVI}

\section{TECNOLOGIAS COMO PRÁTICAS DE UMA EDUCAÇÃO INOVADORA NO SÉCULO XXI}

Walmir Fernandes Pereira ${ }^{1}$

${ }^{1}$ Mestrando em Tecnologias Emergentes em Educação - MUST University Flórida - EUA.

\section{RESUMO}

Este artigo tem como objetivo central discutir a partir de revisões bibliográficas a temática do uso de ferramentas e recursos tecnológicos dentro do espaço escolar. E a partir dessas discussões, fazer uma reflexão de que não é mais possível ensinar e entender o processo de ensino-aprendizagem distante das TIC. Portanto, precisa-se pensar em procedimentos pedagógicos eficazes e em um planejamento educacional alinhado ao uso de Tecnologias em sala de aula.

Palavras-chave: Tecnologias de Informação e Comunicação TIC. Prática docente. Educação Inovadora.

\section{INTRODUÇÃO}

Vivemos em meio a Era Digital, onde a inserção das tecnologias está em todo espaço e em todos os setores da sociedade. Para Coutinho e Lisboa (2011) essa é uma sociedade inserida num processo de mudança, fruto dos avanços na Ciência e Tecnologia.

Como bem salientado, estamos inseridos em um processo de mudança contínua, onde nós educadores devemos enxergar mudanças concretas no cenário educacional. Porém, sabemos que o processo de ensino-aprendizagem é algo cada vez mais complexo, pois todos os setores vêm evoluindo com o uso das TIC, Tecnologias da Informação e comunicação e exigindo novas competências.

Cabe agora, analisar criticamente a prática pedagógica que devemos adotar frente à promoção de uma Educação que vê a tecnologia e o processo de aprendizagem como aliados para o sucesso de ensino de nossos alunos.

A proposta de uma Educação Inovadora no século XXI visa focar na aprendizagem, preparar os alunos para que assumam papéis de empreendedores, de 
inovadores e de criativos, que ajude a desenvolver um bom conhecimento de si mesmos, uma boa autoestima e que desenvolvam o perfil de um cidadão com comportamento ético e preocupação social.

Visando a inserção de tecnologias junto às práticas de ensino conseguiremos atingir objetivos diferentes e fazermos mudanças no âmbito educacional.

Temos vários recursos tecnológicos como: internet, as redes, o celular, a multimídia que estão modificando a nossa vida no cotidiano. Resolvemos quase todas as atividades diárias e problemas conectados, a distância.

No setor Educacional, encontramos dentro de várias discussões a dificuldade de inserção de TIC em nossas práticas diárias de ensino-aprendizagem, vemos mudanças nos equipamentos, nos diversos recursos dentro nas escolas, mas não vemos mudança no procedimento das aulas, na metodologia usada pelos docentes.

De acordo com Perrenoud (2000, p. 139) "As novas tecnologias podem reforçar a contribuição dos trabalhos pedagógicos e didáticos contemporâneo.".

Ainda existem docentes que veem o uso de tecnologia e de atividades na modalidade EAD como ferramentas que prejudicam o nível de ensino. E quanto a isso, temos que ter cuidado com a forma que será conduzido o processo de ensinoaprendizagem para que realmente aconteça uma aprendizagem significativa para o aluno.

Há no meio docente a crença de que a qualidade do processo de ensino deva acontecer prioritariamente na modalidade presencial, criando assim uma resistência da maioria quanto ao uso da modalidade EAD, que prevista nas leis educacionais para algumas etapas de ensino de nossa Educação. Acreditam que a qualidade acontece quando estamos unidos no mesmo ambiente, mas sabemos e estudos apontam que o que determina o sucesso ou fracasso da aprendizagem é a interação entre professor conteúdo- aluno.

O espaço escolar continua sendo o local mais favorável para que o educando se desenvolva como sujeito ativo de um mundo cada vez mais complexo, aprenda a conviver. E nossa missão é fazer desse local algo mais próximo das mudanças contemporâneas, onde alunos e professores não vejam a escola como espaço retrógrado e pouco estimulante. 
A inserção de Tecnologias junto à prática docente, o uso de metodologias ativas, ajudará na construção de uma escola inovadora que acompanha os avanços de uma sociedade pós-industrial.

Este é o objetivo da discussão feita por este artigo, reflexionar junto a bases de pesquisas feitas por diferentes fontes publicadas em periódicos científicos que se faz necessário entender os impactos da tecnologia, de seu uso consciente dentro das unidades educacionais.

\section{METODOLOGIA}

Para a elaboração deste artigo, foi feita uma pesquisa bibliográfica em artigos (periódicos científicos), realizando uma revisão bibliográfica dos temas em comum, buscando responder indagações que nortearam a construção do trabalho acadêmico.

A partir dessa revisão de artigo, chegamos a construção desses argumentos onde são explanadas visões de diferentes especialista sobre o uso da tecnologia dentro de sala, promovendo assim, uma escola inovadora.

Ao analisarmos essas referências de especialistas feitas pela revisão de obras científicas, podemos dizer que há necessidade de mudança em procedimentos pedagógicos para que de fato aconteça uma educação que caminhe junto com as mudanças de um mundo totalmente digital.

\section{DESENVOLVIMENTO}

Escola inovadora é uma proposta que pressupõe elementos que devam se integrar, se completar e se combinar. Todos esses elementos estão alinhados em grandes eixos que precisam primeiramente focar na aprendizagem de nossos alunos, além de prover outros benefícios como: desenvolvimento da autoestima/autoconhecimento, na formação do aluno-empreendedor e aluno-cidadão.

A promoção dessa educação começa pela motivação de alunos, desenvolvendo um perfil de aluno proativo, que tem iniciativa e enxerga novas possibilidades no mundo em que o cerca. 
Sabemos que para a educação precisa acompanhar as mudanças complexas que o mundo nos propõe, ela precisa se aliar às Tecnologias, suas ferramentas e seus recursos.

Estamos vivendo a Sociedade pós-industrial caracterizada pelo uso da informação como base na determinação valores que forma esta geração contemporânea.

De acordo com Hargreaves (2004), a sociedade do conhecimento se caracteriza pela capacidade das pessoas e organizações desenvolverem habilidades para constante aprendizagem e mudanças, fazendo uso da inteligência coletiva para acelerar esse processo.

A partir dessa concepção de sociedade do conhecimento, como professores, precisamos entender o quão crucial é aprender conviver com as transformações tecnológicas dentro do campo educacional, em todas as etapas de ensino, desde a educação básica a educação superior.

Para Stieler (2007, p. 71), na escola ainda persiste a resistência ao inovador, visto que o tempo destinado a criação, a interpretação, a reflexão e a descoberta de novas tecnologias são escassas e nem sempre aproveitadas de maneira racional.

Quando pensamos em aliar tecnologia com procedimentos pedagógicos que terão êxito para a aprendizagem do aluno, estamos buscando desenvolver no educando o pensamento crítico, a criatividade, a capacidade de inovar e aprender continuamente diante do uso de recursos e ferramentas disponibilizados na por esta era digital em que vivemos.

São muitos desafios para a promoção de uma educação que inove o espaço e metodologia escolar, pois há barreiras como questões metodológicas e até a configuração dos espaços físicos de sala de aulas. A organização da sala de aula influencia muito no procedimento que o professor adotará para ensinar os seus alunos, se formato da sala sempre será de fileiras ou círculo, semicírculo.

De acordo com Ramal (2008, p. 89), “a sala de aula do futuro será um lugar comunicativo, sendo o espaço da polifonia, da diversidade das vozes, onde todos poderão se comunicar, se posicionar, e aonde, desse diálogo, vai se produzir conhecimento". 
Outro desafio a ser superado é o manuseio de ferramentas tecnológicas, é importante ter o conhecimento desses recursos, porém o que determina o sucesso da aprendizagem é o planejamento pedagógico das ações que serão desenvolvidas dentro de sala de aula, visando uma formação integral de um sujeito ativo e consciente de seu papel dentro do processo de ensino-aprendizagem.

Podemos dizer que o primeiro passo para desenvolver o princípio de uma educação inovadora é esclarecer aos docentes que o foco da aprendizagem é o aluno, ele não é um ser passivo neste processo, ele se tornou o centro. O papel do professor é gerenciar e integrar o espaço e processos de aprendizagem. Segundo passo seria configurar a sala de aula como um novo espaço, fazendo atividades diversificadas, com idas a laboratórios de informática ou trazendo os recursos para dentro de sala configurando um espaço diferente do tradicional, propondo atividades de pesquisas que podem iniciar em sala de aula e se estenderem por plataformas virtuais.

Para DEMO (2002, p. 127) “O conhecimento não deixa nada de pé. Seu ímpeto é descontruir (...). Depois reconstrói, mas sempre sob o signo da provisoriedade, para poder continuar desconstruindo".

Conforme salienta o autor acima, o papel do professor é provocar a desconstrução, tirar o aluno da zona de conforto, desinstalar, desorganizar para que o aluno comece a pensar e desenvolver competências que o tornarão ativo no processo de aprendizagem.

O foco desse processo de aprender vai além do conteúdo e propõe a construção de conhecimento e de interatividade, por isso, pensamos numa educação colaborativa que contrapõe uma educação bancária, tradicional na qual ainda estamos inseridos em espaços educacionais. O importante é a participação ativa, o envolvimento, a descoberta e a resolução de problemas.

A prática pedagógica é um dos principais eixos a ser explorado e modificado dentro da proposta de uma educação inovadora, pois ela deve acompanhar o contexto de evolução tecnológica, novas visões estão sendo inseridas em todo o processo de ensino e aprendizagem. Porém, sabemos que há resistência por parte do docente. Muitos acreditam que só de levar um slide, uma apresentação, ou irem ao laboratório de informática com os alunos, estão inovando suas práticas. 
Para Stieler (2007), os recursos tecnológicos servem para explorar novas possibilidades

pedagógicas e contribuem para a melhoria do trabalho docente em sala de aula, valorizando o aluno como sujeito do processo educativo. O autor defende a tese de que o computador pode e deve ser utilizado como um catalisador de mudança do paradigma educacional.

Cabe nessa situação refletir que para acontecer mudanças as instituições precisam se comprometer em auxiliar nas formações pedagógicas, mudar procedimentos é de fundamental importância, pois só inserir tecnologias sem mudar a forma que ensina e aborda conteúdos não trarão sucesso para a aprendizagem do aluno.

Exige-se das escolas e de suas equipes diretivas capacitações de ferramentas e recursos tecnológicos para assim trazerem segurança para os professores quando forem executar atividades em sala de aula usando as TIC. Muitos desconhecem aplicativos, ferramentas que podem trazer benefício para a interação no processo de aprender.

Podemos dizer que a tecnologia em sala de aula não é vista mais por especialistas como diferencial de docente e instituição que faz o uso, ela representa que há um acompanhamento de mudanças aliada a escola e tecnologia, pois estamos inseridos numa mesma sociedade, cheia de mudanças complexas.

O docente tem assumido novos papéis dentro de uma educação mais tecnológica, interativa e colaborativa como curadores e desenvolvedores de percursos de aprendizagem, auxiliando os alunos no que pesquisar, a questionar e em práticas de investigação.

De acordo com Ramal (2008, p. 89) Os professores do futuro devem ser vistos como arquitetos cognitivos do saber. Aquele que planeja a cada dia sua forma de ensinar, que dá ênfase a pesquisa e à mediação.

Para Moran, Masetto e Behrens (2010) o papel do docente no cenário de uso de tecnologias na educação assumem estas quatro atuações: orientador e mediador intelectual, orientador e mediador emocional, orientador e mediador gerencial e comunicador e orientador ético.

Portanto, podemos dizer que não é mais possível excluir das práticas de ensino e aprendizagem o uso da tecnologia, seus recursos e ferramentas, é necessário sim, uma reflexão, a práxis, de sua prática pedagógica no contexto educacional. 


\section{CONCLUSÃO}

A partir das discussões feitas acerca do tema Educação inovadora com o uso de Tecnologia, de suas ferramentas e recursos em sala de aula, podemos inferir que é de fundamental importância buscarmos aperfeiçoar os procedimentos utilizados dentro das escolas.

O processo de ensino-aprendizagem não é o mesmo do século passado, mesmo sabendo que dentro de currículos de Formação Docente há um atraso quanto ao ensino procedimental de recursos tecnológicos.

Temos que pensar e agir como professores que estão inseridos na era digital, que os avanços tecnológicos estão em nosso meio e precisamos usá-los a nosso favor, dentro de nossa metodologia.

Como pesquisado e estudado, não é levar um computador para sala ou marcar atividades de pesquisa em laboratório de informática, mas sim, mudar as estratégias de ensino, desenvolver atividades que orientem o aluno a ter pensamento crítico, a se sentir ativo na aprendizagem, a perceber que ele é o centro das ações de ensinoaprendizagem.

Portanto, ao adotarmos ações como essas em nosso ambiente escolar, teremos assim êxito em nossas práticas docentes e não nos sentiremos mais isolados de uma sociedade totalmente tecnológica, a sociedade do século XXI.

\section{REFERÊNCIAS}

BACICH, L.; MORAN, J. Metodologias ativas para uma educação inovadora: uma abordagem teórico-prática. Porto Alegre: Penso, 2017.

COUTINHO, C. P.; LISBÔA, E. S. Sociedade da informação, do conhecimento e da aprendizagem: desafios para educação no século XXI. Revista de Educação, v. 18, n. 1, p. 5-22, 2011.

DEMO, P. Complexidade e aprendizagem: a dinâmica não linear do conhecimento. São Paulo: Atlas, 2002.

MORAN, J. M.; MASETTO, M. T.; BEHRENS, M. Novas tecnologias e mediação pedagógica. Campinas: Papirus, 2010.

PERRENOUD, P. Dez novas competências para ensinar. Porto Alegre: Artmed, 2000. 
RAMAL, A. C. Ler e Escrever na cultura digital. Revista Pátio, ano 4, no14. p.89-118,2000.

STIELER, E. C. FERREIRA, M. V. Um estudo da aplicação da planilha do Excel no ensino de matemática financeira. Disponível em: <http://www.limc.ufrj.br/htem4/papers/71.p df> Acesso em 24 set. 2009. 


\title{
CAPÍTULO XVII
}

\section{UTILIZAÇÃO DE MÍDIAS SOCIAS COMO INSTRUMENTOS DE DIVULGAÇÃO CIENTÍFICA, INSTITUCIONAL E DE CONSTRUÇÃO DO CONHECIMENTO POR ALUNOS DOS CURSOS DE SAÚDE DE UMA FACULDADE PARTICULAR DO MUNICÍPIO DE LAURO DE FREITAS - BAHIA}

\author{
DOI: 10.51859/amplla.dec139.1120-17
}

Marcus Vinicius Peralva Santos ${ }^{1}$

\begin{abstract}
${ }^{1}$ Graduado em Ciências Biológicas e em Marketing, com especialização em Ecologia e Intervenções Ambientais pela UNIJORGE, mestre e doutor em Geologia pela UFBA, Especialista em Coordenação Pedagógica, Gestão da Educação, Educação Inclusiva e Educação Inclusiva Avançada. Coordenador do curso de Microempreendedor Individual (MEI) pelo Instituto Federal Goiano campus Morrinhos e professor das Faculdades Integradas de Sergipe (FISE).
\end{abstract}

\section{RESUMO}

O presente capítulo visou analisar o uso das mídias sociais por alunos de uma instituição de ensino superior particular do município de Lauro de Freitas - BA, verificando se as mídias sociais ofertadas pela IES atendiam aos anseios dos alunos e consequentemente da própria instituição. Deste modo, foi aplicado de um questionário com 12 perguntas, para alunos de 6 cursos de saúde distintos, englobando semestres variados. Ao todo participaram do estudo 136 alunos, os quais demonstraram fazer maior uso do aplicativo WhatsApp (>50,0\%), sendo o blog a mídia de menor uso $(>90,0 \%)$. Deste modo verificou-se que o WhatsApp atende aos anseios da comunidade universitária, seja para a comunicação, lazer, dentre outros aspectos, enquanto o blog não atende à demanda dos alunos, e sendo atualizado apenas por mera formalidade dos coordenadores da instituição.

Palavras-chave: WhatsApp. Blog. Mídias sociais. Tecnologias da Informação. Metodologias ativas.

\section{INTRODUÇÃO}

Em meio as transformações da atualidade, a universidade se configura num ambiente de grande fertilidade científica, sendo as suas práticas docentes, principalmente no que concerne ao ambiente de sala de aula, altamente discutidas quanto ao seu real valor e significado, não só para o aluno, mas para a sociedade como um todo (UNIJORGE, 2017). A partir de tal perspectiva que os métodos de ensino são colocados como alvo principal de análise. Com isso, surgem discussões de como a escolha dos materiais didáticos e a abordagem metodológica influenciam o modo de 
pensar dos alunos e como estes podem contribuir com a obtenção de conhecimentos pela sociedade (SANTOS, 2008; ROCHA JÚNIOR et al, 2014).

Móran (2015), em seu trabalho intitulado "Mudando a educação com metodologias ativas" destaca como as instituições educacionais têm se atentado as abordagens metodológicas aplicadas em sala de aula e procurado caminhos a fim de tornar as aulas mais atrativas ao seu alunado. Busca-se então a aplicação de metodologias ativas de ensino, as quais priorizam um maior engajamento do aluno no processo de construção do conhecimento. Dentre as metodologias ativas discutidas pode-se citar o ensino híbrido (ou blended), a sala de aula invertida e a realização de projetos interdisciplinares.

Pode-se destacar ainda o uso do blog (BARBOSA e SERRANO, 2005; GONÇALVES, 2011), do WhatsApp (HONORATO e REIS, 2014; ARAÚJO e BOTTENTUIT JUNIOR, 2015) e de jogos virtuais (G1 BAHIA, 2016) como metodologias ativas de ensino da atual década em que vivemos. Pode-se pensar nestas duas primeiras mídias sociais apenas como fonte de informações, ou como fonte de transmissão e de divulgação de dados, mas elas servem também como aliadas do processo de ensino-aprendizagem tanto na educação fundamental (HONORATO e REIS, 2014; G1 BAHIA, 2016), como no ensino superior (ARAÚJO e BOTTENTUIT JUNIOR, 2015).

Segundo Rocha Júnior et al. (2014), estas mídias sociais, dentre outras tem um importante papel e influenciam no contexto educacional dos estudantes de ensino superior, uma vez que estes tendem a acessar estes meios frequentemente. Destaca-se que além de procurarem se informar sobre a instituição da qual fazem parte, esses estudantes buscam por notícias, tecnologias, vídeos, dentre outras fontes de informações, constituindo-se, portanto, em fontes de pesquisa e de dados importantes ao alunado.

Com base em tais aspectos, o presente artigo apresenta como questão norteadora: Como têm sido utilizadas as mídias sociais a fim de informar e permitir a construção do conhecimento a alunos dos cursos de saúde de uma instituição de ensino superior do município de Lauro de Freitas - BA?

O objetivo geral é identificar como tem sido utilizadas as principais mídias sociais pelos alunos dos cursos de saúde de uma IES do município de Lauro de Freitas, tendose como objetivos específicos: (a) identificar quais as principais mídias sociais utilizadas 
pelos alunos dos cursos de saúde; (b) pontuar as principais características das mídias identificadas como mais utilizadas; e (c) verificar as principais formas de utilização de tais mídias pelos alunos.

A metodologia aqui empregada consistiu na realização de uma pesquisa descritiva e quanti-qualitativa, a qual teve como público alvo os alunos dos cursos de saúde de uma IES particular no município de Lauro de Freitas, sendo a amostra constituída pelos alunos dos cursos de Biomedicina, Enfermagem, Nutrição, Farmácia e Estética e Cosmética. Aplicou-se, durante dois dias consecutivos (a fim de se alcançar um maior quantitativo de entrevistados) no semestre de 2018.2, um questionário com 12 questões de natureza mista (objetiva e subjetiva), o qual contemplou questões referentes ao uso das mídias sociais em seu dia-a-dia no contexto da faculdade em que estudavam.

Os dados tabulados foram convertidos em tabelas e gráficos, os quais foram gerados por meio do programa Microsoft Office Professional Plus Excell 2016.

\section{MÍDIAS SOCIAIS E SUA UTILIZAÇÃO COMO METODOLOGIAS DE ENSINO ATIVAS}

O uso de ferramentas tecnológicas na educação de ensino fundamental médio e superior já é uma realidade, uma vez que a tecnologia está nos mais variados ambientes em que circulamos dia a dia e sendo seu avanço rápido e contínuo. Portanto, de difícil acompanhamento (HONORATO e REIS, 2014).

Os objetivos pretendidos pelas instituições educacionais devem ser acompanhados por metodologias adequadas que motivem os alunos e os incentivem a participarem do processo de construção do saber, estimulando a criatividade e experimentando novas possibilidades de aprendizagem (MORAN, 2015).

\subsection{WhatsApp Messenger}

Dentre as novas possibilidades de aprendizagem, pode-se citar o uso do WhatsApp Messenger. Ele corresponde a um aplicativo de mensagens disponível para download gratuitamente para BlackBerry, Android, iPhone, Windows Phone, dentre outros, que permite o envio de mensagens ilimitadas, a criação de grupos e o envio de imagens, vídeos e áudio (HONORATO e REIS, 2014; ORSOLI, 2015). 
Em relação a este aplicativo, Honorato e Reis (2014) ainda ressaltam que este recurso apresenta valor educacional, uma vez que no mesmo é possível a criação de grupos para a tiragem de dúvidas referentes a uma ou mais disciplinas. Um exemplo destacado neste trabalho, corresponde ao fato de que em um grupo de alunos que responderam a um questionário, relatarem o uso dos grupos do WhatsApp para envio de fotos de exercícios de livros distintos, a fim de estudar para as disciplinas do colégio. Este discurso é reforçado por outros estudos, a exemplo de Araújo e Bottentuit Junior (2015), desta vez voltado ao ensino de Filosofia no ensino superior.

Mercado, Gomes e Silva (2018) publicaram o artigo “Metodologia do Ensino Superior com Tecnologias da Informação e Comunicação: Estratégias de ensino experienciadas", no qual abordam o uso de metodologias educacionais com o uso das tecnologias da informação e comunicação (TIC) como instrumentos norteadores da promoção e inovação da qualidade do ensino superior. Durante a realização da disciplina "Metodologia do Ensino Superior com TIC" esta foi ministrada de forma hibrida (presencial e online), havendo o uso das ferramentas WhatsApp a fim de promover o debate de vídeos analisados durante as aulas, Facebook, construção de blog coletivo, dentre outras. Os resultados obtidos ao longo da disciplina deram origem a produção de livros digitais, artigos científicos, mapas conceituais e circulares, dentre outros produtos, constituindo-se em experiências didáticas inovadoras conforme preconizado pelo Ministério da Educação (MEC) do Brasil.

\subsection{Edulify.com}

Lopes, Silva e Oliveira (2014) relatam em seu estudo sobre a utilização de uma plataforma virtual denominada Edulify.com com o intuito de promover o ensino bLearning por meio da gamificação e colaboração participativa e premiação dos alunos de uma faculdade particular. No trabalho os autores destacam a importância da Cultura Digital ou "Cibercultura" sobre os processos educacionais na atualidade e neste contexto foi criado a ferramenta Edulify.com que consiste em uma rede social universitária de uso de docentes e discentes, não sendo uma ferramenta de Educação à Distância (Ead), mas tendo como foco a interatividade entre os usuários.

Os autores destacam que os alunos que tiveram acesso ao Edulify.com fizeram um bom uso do mesmo, havendo um quantitativo de comentários superior a 200, 
evidenciando-se a valorização deste ambiente pelos alunos. Por outro lado, destaca-se a importância dos docentes participarem desta rede social, uma vez que a participação destes foi baixa, sendo requerido que estes incorporarem as ferramentas online em seu dia-a-dia, assim assegurando a melhoria do processo ensino-aprendizagem (LOPES, SILVA e OLIVEIRA, 2014).

\subsection{Instagram}

Brigido e Veloso (2018) descrevem o uso do Instagram como recurso didático no ensino superior em seus trabalhos de mestrado com base em 15 trabalhos publicados no período de 2013 a 2017 no Brasil e no exterior. Dentre os trabalhos destacou-se os termos interação, colaboração, participação e engajamento como possibilidades de uso ou objetivos do uso do Instagram para o Ensino Superior. Os trabalhos foram agrupados em seis grandes grupos, sendo eles: (1) Fotografia, leitura e escrita, (2) Fotografia, (3) vídeos, leitura e escrita. (4) Fotografia e memes; (5) Memes; (6) Desenhos de estruturas. Os dados iniciais do estudo deixam claro como o Instagram encontra-se em acessível pelos brasileiros, em especial a população universitária, a qual utiliza-se desta mídia para compartilhar experiências em sala de aula e em eventos externos, a exemplo de estágios e visitas técnicas.

Seu uso tem tudo para potencializar o debate acadêmico sobre o uso das mídias sociais no ensino superior, uma vez que, além de permitir o compartilhamento de fotos e textos, possibilita compartilhar vídeos de curto tempo, os quais até certo modo podem contribuir para que o universitário seja o mais sucinto possível ao gravar seus vídeos.

\section{USO DAS MÍDIAS SOCIAIS PELOS ALUNOS DOS CURSOS DE SAÚDE DE UMA IES DO MUNICÍPIO DE LAURO DE FREITAS - BA}

Ao todo 136 alunos responderam ao questionário alvo de estudo do presente capítulo, sendo que estes alunos puderam ser agrupados como pertencentes a seis cursos, sendo eles: Farmácia (36,76\%), Nutrição (17,65\%), Enfermagem (16,18\%), Fisioterapia (13,97\%), Estética e Cosméticos (12,50\%) e Biomedicina (2,94\%). 
Item 01 - Qual o curso e semestre que você encontra-se matriculado em 2018.2?

Para uma melhor análise dos resultados obtidos, o quantitativo de respostas dadas pelos entrevistados foram classificados quanto ao curso em que se encontravam matriculados e em relação ao semestre que se encontravam cursando (Pergunta 1 do questionário), de modo que o maior quantitativo de alunos participantes foi da turma do 7 o semestre de Farmácia (22,79\%), seguido pelas turmas do 5으 semestre de Farmácia e do 3 o semestre de Fisioterapia, ambos com 13,97\% (Figura 1a).

Figura 1 - Frequência relativa dos alunos dos cursos de saúde de uma IES de acordo (a) com o curso e semestre que se encontram matriculados em 2018.2 e em (b) seu gênero

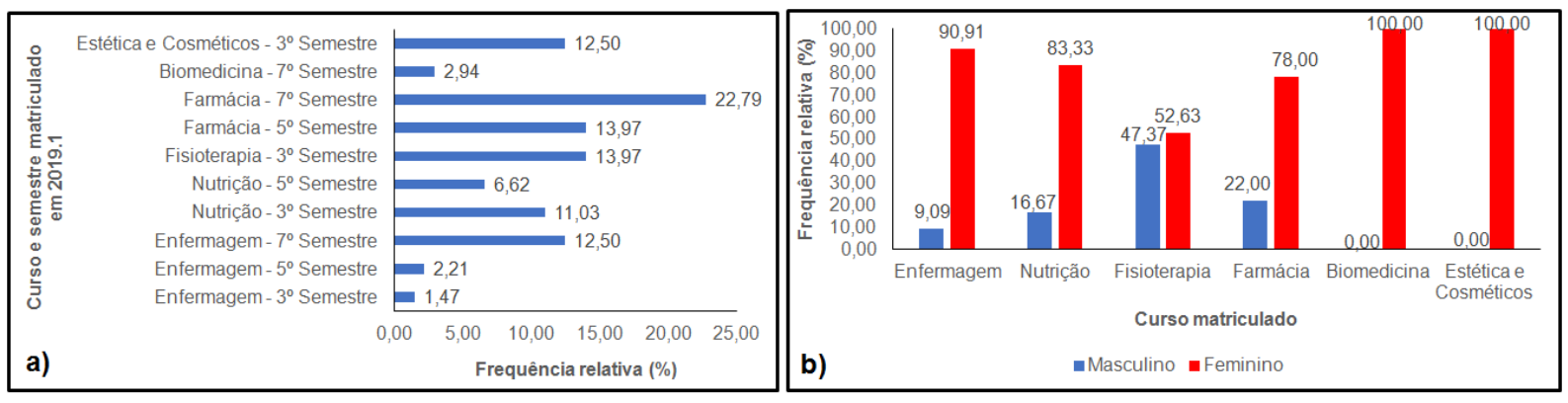

\section{Item 02 - Qual o seu gênero?}

Respondendo a segunda pergunta do questionário, 19,00\% dos alunos se enquadraram como pertencentes ao sexo masculino e $81,00 \%$ ao sexo feminino. Aplicando-se esta mesma questão, agora com base no curso em que os alunos encontram-se matriculados, temos que para os seis cursos analisados a representatividade de mulheres participantes foi maior do que a masculina, sendo a nível de comparação, a menor diferença dentro do curso de Fisioterapia (5,26\%) e a maior dentro dos cursos de Biomedicina e de Estética e Cosméticos (100,00\% em ambos os cursos), onde nestes dois últimos cursos não houve participação masculina no preenchimento do questionário (Figura 1b).

\section{Item 03 - Quais as mídias sociais que você utiliza no seu dia a dia?}

Quanto ao terceiro questionamento, foi comum entre os entrevistados dos seis cursos, o uso do Instagram, Facebook, WhatsApp e Twitter (Figura 2). Analisando-se por curso, o aplicativo WhatsApp é o mais utilizado pelos estudantes de Fisioterapia 
$(43,90 \%)$ e de Farmácia (43,80\%). Para o curso de Nutrição o Instagram (41,40\%) foi o mais utilizado, sendo que no curso de Biomedicina este aplicativo também constitui-se em um dos mais usados com 30,80\% de adesão entre os estudantes (Figura 2).

Figura 2 - Frequência relativa das respostas dos alunos de saúde em relação ao uso das mídias sociais em seu dia-a-dia no semestre 2018.2.

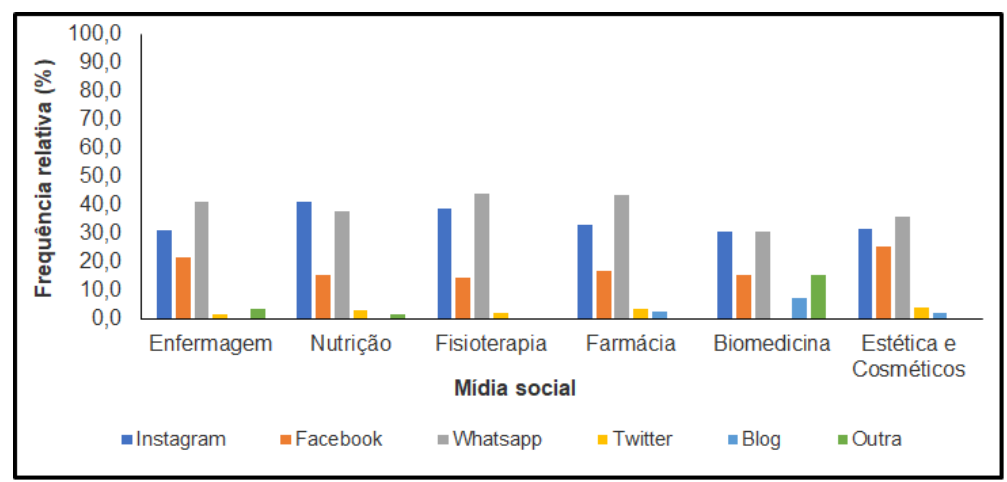

Item 04 - Para qual finalidade você utiliza as mídias sociais mencionadas?

Neste item, as finalidades lazer, estudo, trabalho e comunicação foram comuns a todos os cursos (Figura 3). Os valores percentuais obtidos entre as opções de finalidade de uso foram relativamente próximos entre si, com exceção da opção "outros", mas de modo geral, os maiores percentuais ficaram para a utilização para comunicação, em especial nos cursos de Fisioterapia $(29,40 \%)$ e de Biomedicina (28,60\%) (Figura 3).

Figura 3 - Frequência relativa das respostas dos alunos em relação a finalidade de uso das mídias sociais no semestre 2018.2.

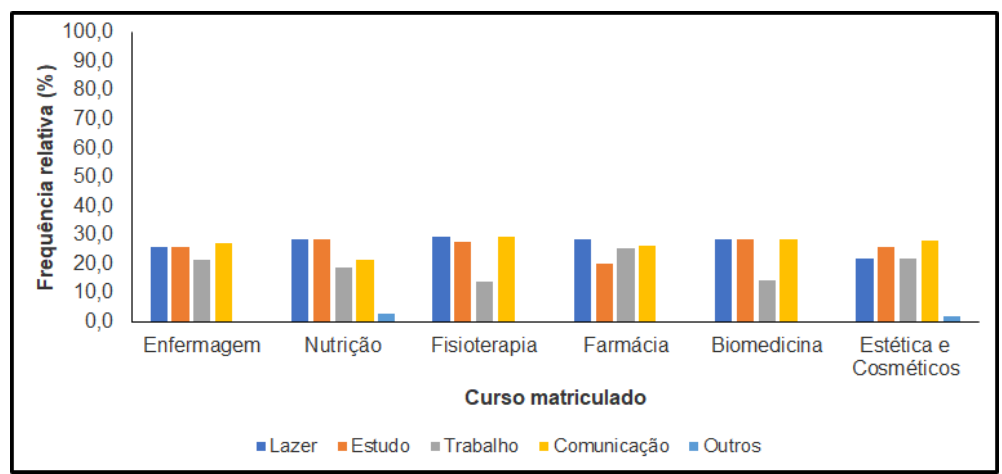

\section{Item 05 - Você já ouviu falar/sabe dizer se o seu curso de graduação possui blog?}

Quanto ao quinto questionamento, "Você já ouviu falar/sabe dizer se o seu curso de graduação possui blog?", o curso de Biomedicina foi o único curso em que se 
constatou que todos os alunos entrevistados desconhecem totalmente a existência do blog do curso (Figura 4), o que não ocorreu com tamanha expressão nos demais cursos.

Quanto ao conhecimento, os cursos com maior quantitativo de alunos que já ouviram falar ou sabem dizer que o curso em que se encontram matriculados tem blog destaca-se Nutrição $(50,0 \%)$. No entanto, é uma realidade perante todos os cursos que a maior parte dos alunos não conhecem o blog do seu curso, sendo os maiores percentuais obtidos em Biomedicina (100\%), Fisioterapia (84,2\%) e Farmácia (66,0\%) (Figura 4).

Figura 4 - Frequência relativa das respostas dos alunos em relação ao conhecimento da existência ou não de blog em seu curso, no semestre 2018.2

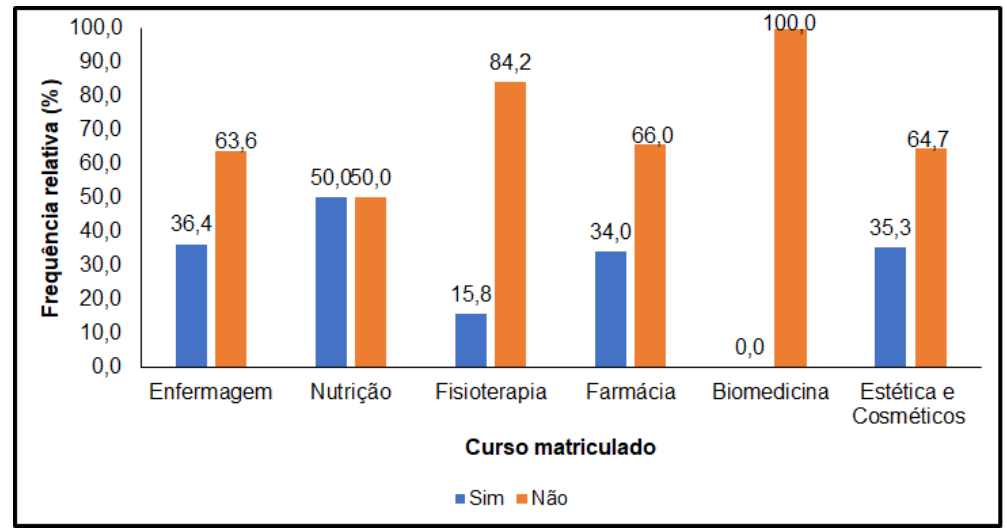

Item 06 - Caso conheça o blog do seu curso, quem Ihe apresentou o mesmo?

Neste item, as respostas oscilaram muito entre os participantes, sendo que para o curso de Enfermagem prevaleceu a opção coordenador do seu curso $(40,0 \%)$, para os cursos de Nutrição $(46,7 \%)$ e Biomedicina (100\%) o "docente do seu curso" e para os demais a opção colega de sua sala de aula (Figura 5). 
Figura 5 - Frequência relativa das respostas dos alunos em relação a quem the apresentou o blog, no semestre 2018.2.

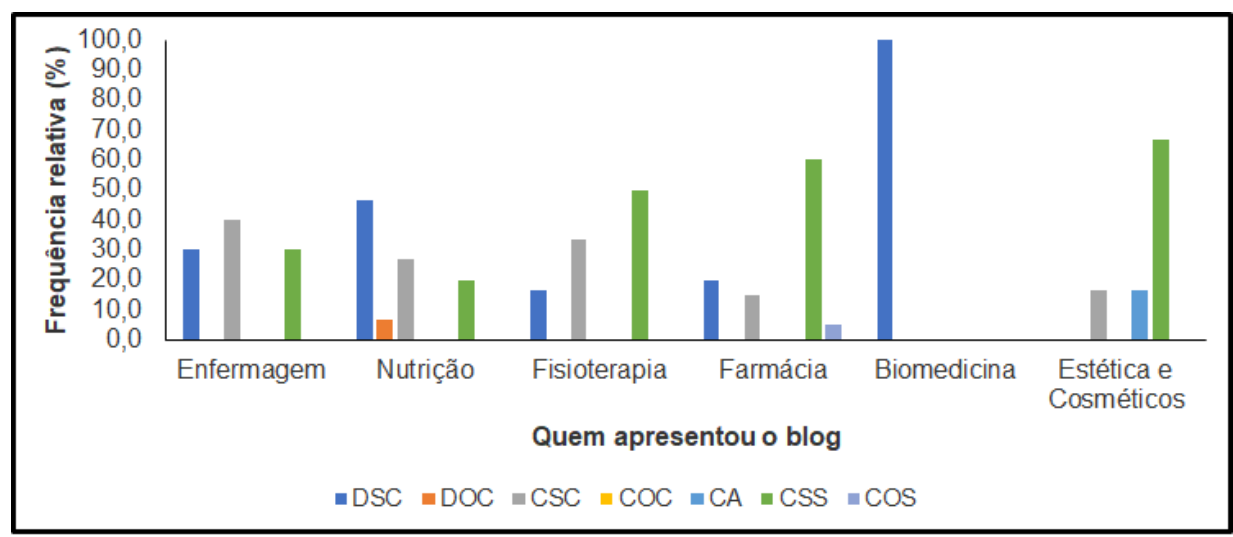

Nota: DSC =Docente do seu curso $/$ DOC= Docente de outro curso $/ \mathrm{CSC}=$ Coordenador de seu curso $/ \mathrm{COC}=$ Coordenador de outro curso/ CA= Coordenadora Acadêmica/ CSS = Colega de sua sala/ COS= Colega de outra sala/ NR = Não respondeu

\section{Item 07 - Você sabe qual a finalidade do Blog do seu curso?}

Quanto ao sétimo questionamento, "Você sabe qual a finalidade do Blog do seu curso?", mais uma vez o total desconhecimento dos alunos sobre esta mídia alcançou valores elevados. Os maiores percentuais da resposta "Não conheço a finalidade do Blog do meu curso" foram aos cursos de Biomedicina (100\%) e de Enfermagem $(90,9 \%)$ (Figura 6).

Figura 6 - Frequência relativa das respostas dos alunos em relação ao conhecimento sobre a finalidade do blog, no semestre 2018.2

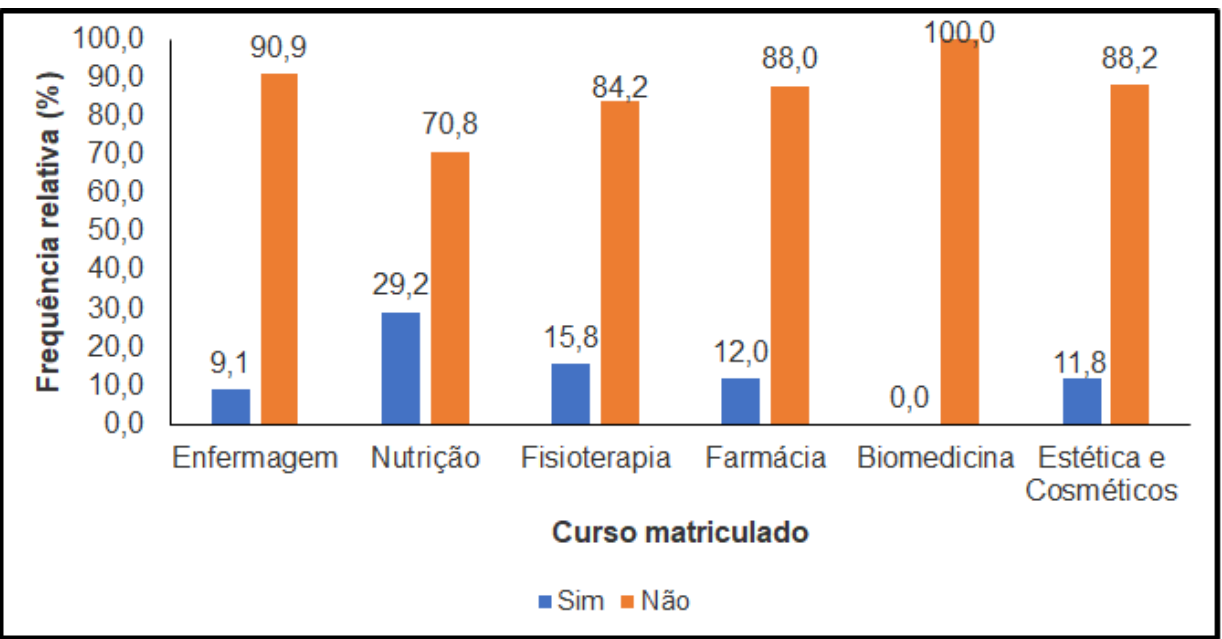

WWW.AMPLLAEDITORA.COM.BR (7) 
Item 08 - Você sabe como chegar até a homepage do Blog do seu curso?

Para esta pergunta mais uma vez o nível de desconhecimento dos alunos foi elevado. Os maiores percentuais da resposta "Não sei chegar até a homepage do blog do meu curso" foram para os cursos de Biomedicina (100\%) e Estética e Cosméticos (88,2\%) (Figura 7).

Figura 7 - Frequência relativa das respostas dos alunos em relação ao conhecimento sobre como chegar a homepage do blog, no semestre 2018.2

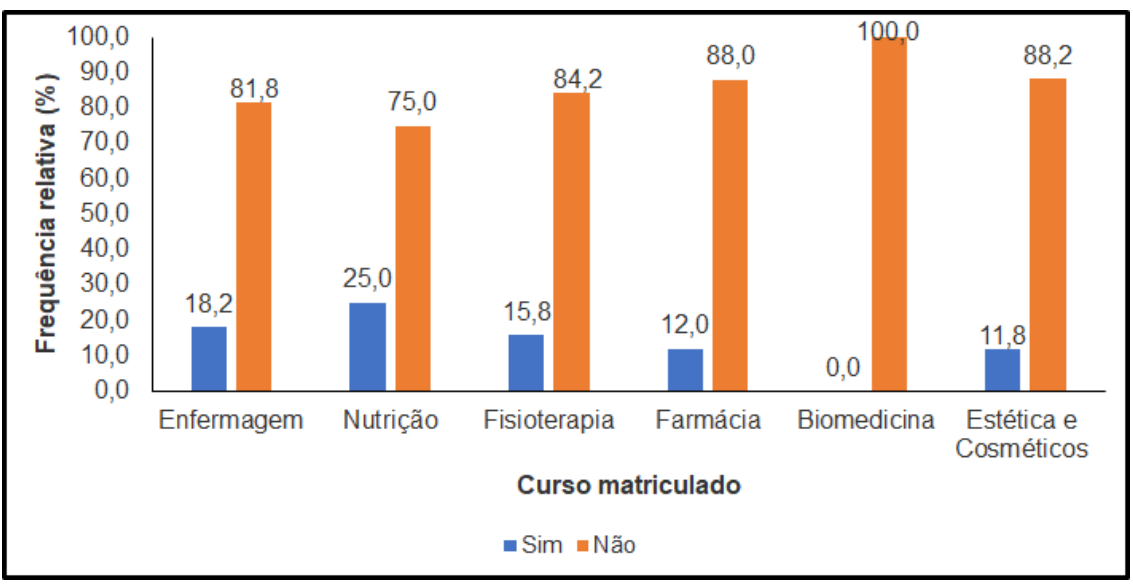

Item 09 - Qual das mídias sociais abaixo a coordenação do seu curso utiliza para entrar em contato com você?

Quanto ao nono questionamento, o uso do aplicativo WhatsApp foi unânime entre a maioria dos entrevistados, sendo os maiores valores obtidos entre os alunos dos cursos de Biomedicina (100\%) e Estética e Cosméticos (88,9\%) (Figura 8).

Item 10 - Qual das mídias sociais abaixo os professores do seu curso utilizam para entrar em contato com você?

Assim como o item anterior, o aplicativo WhatsApp foi o mais votado pelos entrevistados, sendo os maiores percentuais obtidos para o curso de Estética e Cosméticos (100\%) e Fisioterapia (90,5\%) (Figura 9).

Figura 8 - Frequência relativa das respostas dos alunos em relação as mídias sociais utilizadas pela coordenação para entrar em contato com o aluno, no semestre 2018.2 


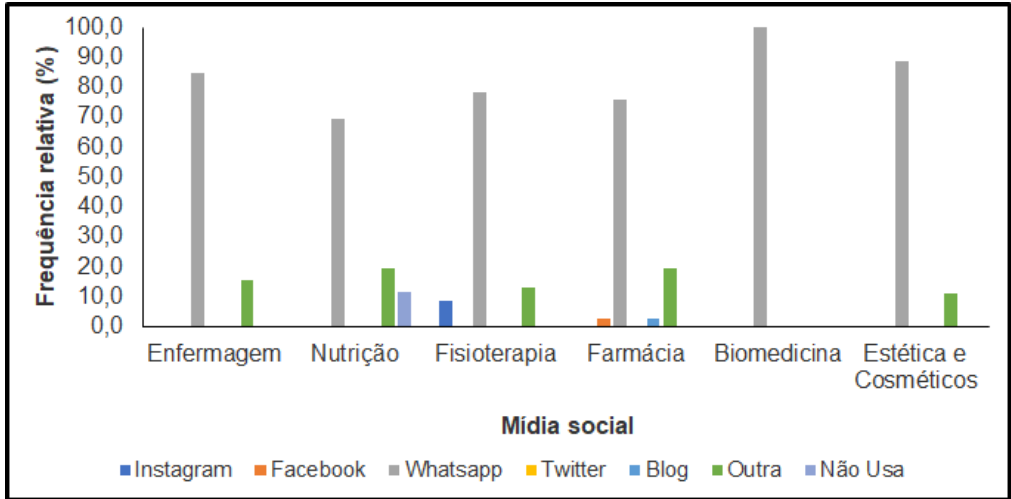

Figura 9 - Frequência relativa das respostas dos alunos em relação as mídias sociais utilizadas pelos professores para entrar em contato com o aluno, no semestre 2018.2

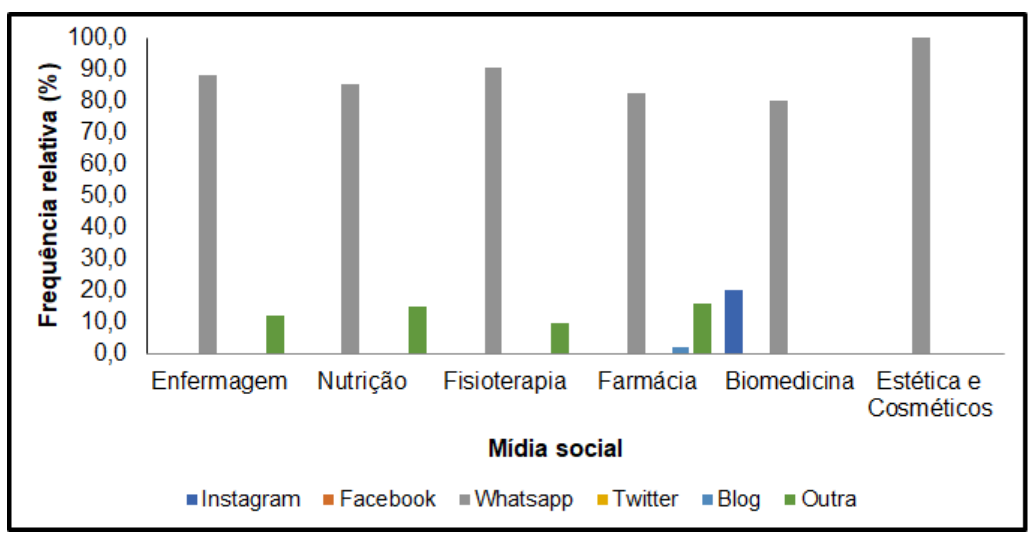

Figura 10 - Frequência relativa das respostas dos alunos em relação a eficiência das mídias sociais utilizadas pela faculdade, no semestre 2018.2

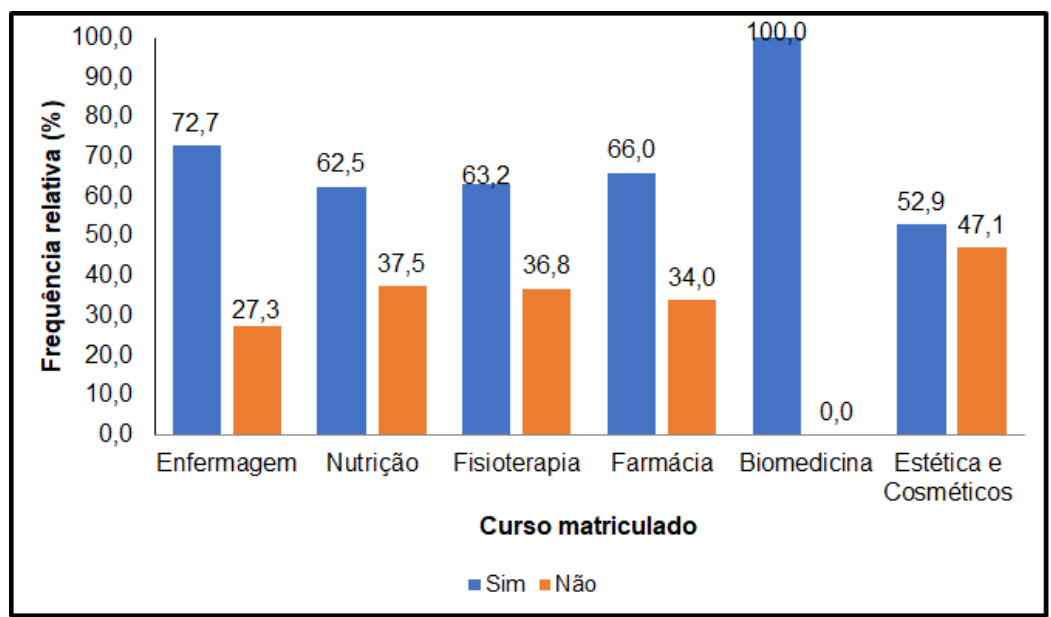

WWW.AMPLLAEDITORA.COM.BR (9) 
Item 11 - Você considera eficiente as mídias sociais utilizadas em sua faculdade?

A décima primeira pergunta do questionário perguntava aos entrevistados se “Você considera eficiente as mídias sociais utilizadas em sua faculdade?". Para todos os seis cursos a opção "Sim. Considero eficientes as mídias sociais utilizadas em minha faculdade" foi a opção mais votada, sendo as maiores representatividades alcançadas junto aos cursos de Biomedicina (100\%) e Enfermagem (72,7\%) (Figura 10).

\section{Item 12 - Você sugeriria que sua coordenação/professores utilizassem outra mídia social para interagir com você?}

A décima segunda e última pergunta do questionário consistiu em uma pergunta subjetiva, a qual questionava os participantes quanto ao seguinte aspecto: "Você sugeriria que sua coordenação/professores utilizassem outra mídia social para interagir com você?". Dos 136 participantes do presente estudo, apenas 6 responderam a questão, de modo que só se pode contabilizar o resultado de três cursos, Enfermagem, Nutrição e Biomedicina, os quais em sua maioria optaram por não sugerir a utilização de outras mídias sociais (Figura 11).

Figura 11 - Frequência relativa das respostas dos alunos em relação a sugestão de melhorias no uso das mídias sociais pela coordenação e professores no semestre

2018.2

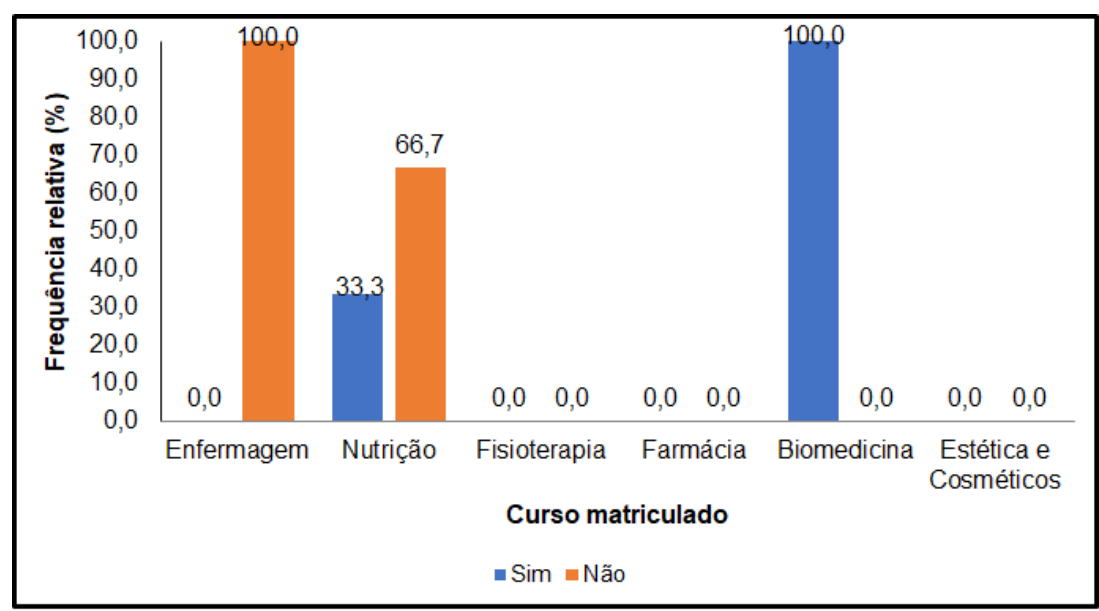

WWW.AMPLLAEDITORA.COM.BR (2) 


\section{IMPORTÂNCIA DAS MÍDIAS SOCIAIS NO PROCESSO DE COMUNICAÇÃO E}

\section{CONSTRUÇÃO DO SABER PELOS ALUNOS}

De um modo geral, o curso de Farmácia da IES analisada foi o que apresentou maior quantitativo de alunos para participação no questionário (Figura 1a), uma vez que este é o curso com maior quantitativo de turmas e de número de alunos por sala, isso quando comparado a turmas de mesmo semestre de outros cursos de saúde da faculdade. Por outro lado, a baixa adesão dos alunos do curso de Biomedicina é explicada pelo fato da IES só possuir uma única turma deste curso, a qual tem um quantitativo de alunos bem baixa, não ultrapassando 20 alunos (Figura 1a).

As turmas de 10 semestre não foram selecionadas para participar do presente estudo, visto que no período da aplicação dos questionários, estas turmas encontravamse em sua primeira semana de aula, de modo que optou-se por analisar as turmas do segundo semestre em diante, visto que as turmas iniciais não iriam saber responder sobre o uso das mídias sociais na faculdade, problema este que já não aconteceria com as turmas dos semestres posteriores, por já terem vivenciado o uso das mídias dentro do ambiente universitário.

Conforme a análise do gênero dos participantes pode-se verificar que para todos os cursos o gênero feminino é predominante (Figura 1b), com destaque aos cursos de Biomedicina (100\%) e Estética e Cosméticos (100\%) (Figura 1b). Conforme a literatura, a exemplo dos trabalhos de Pastore, Rosa e Homem (2008), este perfil com predominância do sexo feminino, é historicamente característico de cursos de saúde, uma vez que naturalmente é atribuído ao público feminino à prática do "cuidar", estando ai envolvido o próprio processo de construção cultural da sociedade em que os participantes encontram-se envolvidos.

Dentre as mídias sociais utilizadas no dia a dia dos participantes (Figura 2) se destacaram quatro mídias, as quais diferem entre si entre vários aspectos, sendo estas: (1) WhatsApp; (2) Facebook; (3) Twitter e (4) Instagram. Quanto a utilização do WhatsApp Honorato e Reis (2014) e Orsoli, (2015) destacam o fato deste ser um aplicativo gratuito, o qual permite a seus usuários a comunicação e troca de materiais de forma prática e fácil, concordando com os resultados aqui encontrados tanto para os 
estudantes (Figura 2 e 3), quanto para o uso da coordenação (Figura 8) e dos professores (Figura 9).

A segunda mídia mais utilizada pelos estudantes, após o WhatsApp é o Instagram (Figura 2), o qual conforme selecionado pelos participantes do presente estudo permite a eles se comunicarem entre si e com seus professores, além de publicação de materiais em formato de foto e vídeo, mas tendo uma desvantagem perante o WhatsApp, sendo esta não ser possível fazer o download do material compartilhado, exceto, caso a pessoa apresente um outro aplicativo instalado em seu celular, o qual permita fazer o download da foto ou vídeo, a exemplo do aplicativo "Inst downloader".

A IES apresenta como mídias de informação aos alunos o Blog e o Instagram, sendo que o Blog é considerado pela direção nacional da Faculdade, a principal mídia utilizada para informar aos alunos sobre eventos e operações cotidianas da IES, sendo inclusive um dos elementos analisados nas auditorias internas que todos os cursos da faculdade passam de tempos em tempos, a fim de verificar o andamento e a qualidade dos serviços prestados da coordenação ao seu corpo de alunos.

Apesar do que é descrito acima, o Blog quase não foi mencionado pelos estudantes (Figura 2 e 6 ) e isto se explica em parte, por ele ser uma das mais antigas mídias sociais da atualidade, quase não sendo mais utilizado, quando comparado a outras mídias recentes, a exemplo do Twitter e do Instagram.

Apesar de ser organizado por categorias e datas, contendo post recentes localizados no topo da página e os antigos em páginas posteriores, sendo mais simples de manuseio, quando comparado a um site convencional (BARBOSA e SERRANO, 2005; GONÇALVES, 2011), o layout dos blogs acaba não sendo muito convidativo a nova geração de universitários. Ainda em relação ao Blog do curso, embora seja um recurso bastante utilizado pelas coordenações, o alto desconhecimento dos alunos sobre o mesmo se dá por diversos motivos, dentre eles: (1) o blog só é mencionado aos alunos na primeira semana de aula; (2) o blog não apresenta um layout convidativo; (3) muitos blogs não são atualizados com frequência, o que afasta seus visualizadores.

Quanto a finalidade do uso das mídias sociais (Figura 3) a opção mais selecionada entre os participantes foi a de uso para comunicação, em particular o WhatsApp, visto que este é um aplicativo gratuito e permite a comunicação e compartilhamento de materiais por várias vias, conforme destacado em trabalhos como os de Honorato e Reis 
(2014) e Mercado, Gomes e Silva (2019). Este último destaca seu uso em ambientes universitários como ferramenta de comunicação entre os alunos para a realização de atividades, o que é uma realidade na IES estudada no presente artigo. Este recurso segundo os alunos, também é o mais utilizado pela coordenação e docentes para se comunicarem com os mesmos. Os maiores divulgadores desta mídia social (Figura 5) são os docentes e os colegas de sala de aula, devendo-se destacar neste último item a ação dos líderes de sala, que tem a responsabilidade de divulgar este e demais recursos junto aos colegas de sala.

Por ser um elemento que só é citado no início de semestre e por boa parte dos coordenadores não usarem cotidianamente o blog, mais uma vez os alunos também demonstraram total desconhecimento sobre a existência (Figura 4) e finalidade do blog (Figura 6), uma vez que o que não é visto, ou não é citado acaba caindo no esquecimento dos alunos ao longo do semestre. Um item a ser aqui considerado é o fato, conforme destacado no trabalho de Senra e Batista (2011), do blog utilizar textos como base de sua construção. Isto contribui mais ainda para afugentar os alunos, visto que boa parte da clientela dos alunos da IES são de alunos das classes C e D, sendo muitos os primeiros da família a adentrarem em uma instituição de ensino superior.

Logicamente, uma vez que os alunos só escutam falar desta mídia social uma única vez no curso, e visto que o mesmo não é atualizado pelo setor responsável, outro quesito do questionário que foi "Você sabe como chegar até a homepage do Blog do seu curso?" também apresentou valores altíssimos de desconhecimento pelos alunos (Figura 7). Alguns dos alunos que responderam ao questionário, inclusive responderam oralmente que já tinham ouvido falar do blog, mas que ninguém tinha ensinado a como chegar no blog, o que acaba sendo um grave erro de comunicação da IES, uma vez que oferecem aos alunos um produto, mas estes não são ensinados a como chegar ao mesmo.

Quando se analisa o item "Você considera eficiente as mídias sociais utilizadas em sua faculdade?" (Figura 10), cabe destacar que os alunos dão bastante ênfase no uso da mídia WhatsApp, sendo que o blog não foi se quer uma única vez mencionado pelos alunos. O último item de questionamento foi "Você sugeriria que sua coordenação/professores utilizassem outra mídia social para interagir com você?", e embora o resultado para a opção "Não" tenha sido alta, esta elevada representatividade 
se deu pelo fato de apenas 6 alunos dos 136 participantes terem respondido, Deste modo, o resultado obtido para esta pergunta mostra não condizer com a realidade de fato da opinião dos alunos.

\section{CONSIDERAÇÕES FINAIS}

Portanto, podemos afirmar que as principais mídias sociais utilizadas pelos alunos dos cursos de saúde de uma IES do município de Lauro de Freitas em seu dia-adia são o WhatsApp (> 35,0\%), seguido do Instagram (> 30,0\%), sendo estas mídias utilizadas principalmente com a finalidade de permitir a comunicação entre alunos/docentes/coordenação.

O WhatsApp foi a mídia mais selecionada pelos alunos talvez pelo fato de ser um aplicativo gratuito, de fácil manuseio, que permite a realização de conversas individuais e coletivas, além de permitir uma série de outras funcionalidades, a exemplo de web conferências e produção de gifs que saltam ao olhar dos alunos.

Respondendo a questão norteadora do presente artigo "Como têm sido utilizadas as mídias sociais a fim de informar e permitir a construção do conhecimento a alunos dos cursos de saúde?", verificou-se que as mídias sociais são utilizadas principalmente para atividades de lazer $(26,0 \%)$ e para a realização de comunicação por professores e pela coordenação, ambos com percentuais acima dos $80,0 \%$.

Recomenda-se que coordenações e professores utilizem as mídias socias de maior prestigio pelos alunos (WhatsApp e Instagram), o que permitirá a estes uma maior construção do conhecimento dos alunos, além de informa-los sobre as demandas cotidianas da instituição, visto que, segundo relato oral dos alunos, dificilmente os docentes e a coordenação encaminham a eles materiais de aulas e/ou eventos pelo WhatsApp.

Diante da baixa visualização do Blog pelos alunos, há de se considerar que a instituição possa com o passar dos próximos semestre diminuir a utilização do blog, uma vez que a grande maioria dos alunos foram enfáticos em questionar se existia blog do curso e onde ele ficava, mostrando que o investimento da IES neste tipo de mídia não contribui em nada ao seu alunado e consequentemente para a própria IES, devendo-se investir um novo tipo de mídia social, em especial o WhatsApp e o Instagram. 


\section{REFERÊNCIAS}

ARAÚJO, P. C.; BOTTENTUIT JUNIOR, J. B. O aplicativo de comunicação Whatsapp como estratégia no ensino de Filosofia. Revista Temática. Ano XI, n. 2, 2015. Disponível em: <http://periodicos.ufpb.br/index.php/tematica/article /view/22939>. Acesso em: 05 set. 2017.

BARBOSA, C. A. P.; SERRANO, C. A. O blog como ferramenta para construção do conhecimento e aprendizagem colaborativa. UFC, 2005. Disponível em: <http://www.virtual.ufc.br/cursouca/modulo_web2/parada01_cid2/para_sabe r_mais/011tcc3.pdf>. Acesso em: 07 out. 2017.

BRIGIDO, J. de A. V.; VELOSO, J. M. M. Uso do Instagram como recurso didático e tecnológico no Ensino Superior. In.: WORKSHOP EM CRIATIVIDADE, INOVAÇÃO E INTELIGÊNCIA ARTIFICIAL, 1, 2018, Belém. Anais do I Workshop em Criatividade, Inovação e Inteligência artificial. Belém: UFPA, 2018. Disponível em: <https://www.aedi.ufpa.br/criar/docs/pdf11.pdf>. Acesso em: 04 mar. 2019.

G1 BAHIA. Pontos turísticos de Salvador viram ginásios do jogo 'Pokémon Go'. 2016. Disponível em: <http://g1.globo.com/bahia/noticia/2016/08/pontos-turisticosde-salvador-viram-ginasios-do-jogo-pokemon-go.html> Acesso em: 03. Out. 2016.

GONÇALVES, F. G. Blog - O que é? Como funciona? E por que "blogar"?. Revista Brasileira de radiologia, v.44, n.3, mai./jun. 2011. Disponível em: <http://www.scielo.br/pdf/rb/v44n3/02.pdf>. Acesso em: 11 out. 2017.

HONORATO, W. de A. M.; REIS, R. S. F. Whatsapp - Uma nova ferramenta para o ensino. In.: SIMPÓSIO DE DESENVOLVIMENTO, TECNOLOGIAS E SOCIEDADE, 4, 2014, Itajubá. Anais. Itajubá: Universidade Federal de Itajubá, 2014. p. 1-6.

LOPES; V. M. S.; SILVA, L. V. C. da; OLIVEIRA, S. R. de. Redes sociais e metodologias ativas no apoio ao ensino presencial. In: FÓRUM NACIONAL DE METODOLOGIAS ATIVAS DE ENSINO-APRENDIZAGEM NA FORMAÇÃO EM SAÚDE. 7, 2014, Curitiba. Anais do VII Fórum Nacional de Metodologias Ativas de Ensino-Aprendizagem na Formação em Saúde. Curitiba: INESCO, 2014. Disponível em: <http://repositorio.asces.edu.br/handle/123456789/151>. Acesso em: 04 mar. 2019.

MERCADO, L. P. L.; GOMES, M. G. da S.; SILVA, C. G. D. da. Metodologia do Ensino Superior com Tecnologias da Informação e Comunicação: Estratégias de ensino experenciadas. Revista Educação em Perspectiva. Viçosa, v.9, n.2, p.453-478, mai./ago. 2018. Disponível em: <https://www.researchgate.net/publication/330336113_Metodologia_do_ensi no_superior_com_tecnologias_da_informacao_e_comunicacao_estrategias_de _ensino_experienciadas>. Acesso em: 07 jul. 2019. 
MÓRAN, J. Mudando a educação com metodologias ativas. In.: SOUZA, C. A. de S.; MORALES, O. E. T. (orgs.). Coleção Mídias contemporâneas. Convergências midiáticas, educação e cidadania: aproximações jovens. v. 3. Ponta Grossa: UEPG/ PROEX, 2015.

ORSOLI, F. Introdução às mídias sociais. SEBRAE, 2015.

PASTORE, E.; ROSA, L. D.; HOMEM, I. D. Relações de gênero e poder entre trabalhadores da área da saúde. In: SEMINÁRIO INTERNACIONAL FAZENDO GÊNERO. 8, 2008, Florianópolis. Anais do 8o Seminário Internacional Fazendo Gênero. Florianópolis: UFSC, 2008. Disponível em: <http://www.fazendogenero.ufsc.br/8/sts/ST25/Pastore-RosaHomem_25.pdf>. Acesso em 07 jul. 2019.

ROCHA JÚNIOR, V.; SARQUIS, A. B.; SECHNEM, S.; DIAS, T. Uso de mídias sociais no setor de ensino superior, Revista Brasileira de Gestão e Inovação, Caxias do Sul, v.1, n.2, jan./abr. 2014.

SANTOS, N. D. de O. Metodologia Científica. Curitiba: Aymará, 2008. (Série EAD - FJA).

SENRA, M. L. B.; BATISTA, H. A. Uso do blog como ferramenta pedagógica nas aulas de Língua Portuguesa. Revista Diálogo e Interação. v. 5, n. 1, 2011. Disponível em: <http://www.pucrs.br/ciencias/viali/tic_literatura/artigos/ blogs/diartigos69.pdf>. Acesso em: 08 jul. 2019.

UNIJORGE. Metodologia científica. Ambiente Virtual de Aprendizagem CANVAS. Rio de Janeiro: UVA, 2017. 


\section{CAPÍTULO XVIII}

\section{ENSINO REMOTO EMERGENCIAL UMA NOVA REALIDADE PARA EDUCAÇÃO SUPERIOR}

DOI: 10.51859 /amplla.dec139.1 120-18

Maria Nádia Alencar Lima ${ }^{1}$

${ }^{1}$ Pedagoga. Universidade Federal Rural da Amazônia - UFRA.

\section{RESUMO}

O ensino remoto ou a EaD estão sendo lançados mãos pelas universidades federais em medida emergencial por causa da pandemia provocada pelo COVID-19 e que resultou no distanciamento social em todas as redes de ensino pública e privada do país, com isso surgiu a necessidade não menos urgente da ressignificação da prática pedagógica dos professores para o extrapolar da sala de aula rumo as plataformas educacionais digitais como ferramentas mobilizadoras do processo de ensino e aprendizagem. Neste sentido para o presente estudo foi aplicada a pesquisa bibliográfica e utilizada a abordagem qualitativa que foi realizada através da revisão de literatura com a finalidade de trazer a luz conhecimentos disponíveis e reflexões sobre o assunto em pauta, no que refletiu o marco conceitual do estudo que foi estruturado ao se fazer o entrelaçamento entre adaptação dos professores as tecnologias digitais como mediadoras do ensino remoto e as dificuldades de acesso dos alunos as estas tecnologias. Indispensável nas bibliografias revisitadas foi o levantamento do campo teórico para identificar e sustentar os principais desafios encontrados tanto pelos professores quanto pelos alunos para o desenvolvimento da dinâmica propulsora da ensinagem por transmissão de dispositivos digitais capazes de promover conceitos significativos de aprendizagem no ensino superior.

Palavras-chave: Ensino remoto. Acesso. Adaptação. Tecnologia digital.

\section{INTRODUÇÃO}

O mundo globalizado está interligado pelas redes sociais, e o trabalho remoto desde a década de 1990 faz parte da rede de comunicação via plataforma digital, e da difusão das informações meio a sociedade contemporânea, porém no sistema de ensino público ele surge como uma novidade enquanto metodologia pedagógica a ser implementada por força do distanciamento social que se deu por causa da pandemia por COVID-19, sendo um desafio a ser vencido no contexto das universidades federais. 
O ensino remoto na educação superior pode ter vantagens, mas certamente que os fatores negativos se sobressaem em tempos de adaptação dessa metodologia adotada abruptamente no contexto da rotina da prática pedagógica no ensino superior da educação pública, pois com a suspensão das atividades de ensino, pesquisa e extensão por causa da pandemia os professores se viram diante de uma realidade até então pouco provável na graduação de cursos que obrigatoriamente precisam das aulas presenciais para desenvolverem as pesquisas e/ou estudos de campo que levam a difusão dessas pesquisas.

Para o professor o trabalho remoto tem a concepção diferente da visão do mercado capitalista de produção/mão de obra superfaturada, de gerar menos despesas para a empresa que não precisa se ocupar em comprar utensílios como mesas, computadores, impressoras, além de ter a diminuição de despesas com aluguéis para fixar escritório, não disponibiliza vale transportes e alimentação, e ainda tem redução de impostos, etc. Essas vantagens econômicas comerciais não se aplicam a rotina da docência praticada através do trabalho remoto, a partir das residências dos próprios professores.

Ministrar aulas a partir da própria casa exige despesas extras para o servidor como estrutura de tecnologias digitais, estrutura de canais de comunicação via internet com muita qualidade, acréscimo de despesas financeiras provenientes do uso estendido de energia elétrica para manusear as ferramentas tecnológicas, administrar o espaço e o tempo sem ficar sobrecarregado ou sem ser a todo instante interrompido por situações relativas à casa, se ocupar em fazer planejamento capaz de alcançar o aluno que tem acesso a tecnologia digital, mas não tem em casa orientações sobre os procedimentos adequados para o bom uso do conteúdo compartilhado pelo professor, entre tantos outros desafios.

O processo de ensino e aprendizagem no formato remoto tem muitos desafios a serem vencidos, o primeiro deles é o preconceito estabelecido sobre a ideia distorcida de que quem trabalha em casa estar sempre disponível, essa premissa não procede e não deve ser ignorada nem subestimada sob o vício das argumentações que tem o único intuito de diminuir ou desqualificar o trabalho docente via plataforma digital. O segundo diz respeito as ferramentas as próprias plataformas digitais e as ferramentas que permitem a interação e transmitem a comunicação entre os sujeitos do processo. 0 
terceiro ponto negativo e talvez o mais complexo se reflete no isolamento do trabalho pedagógico do professor pela falta do contato humano, das relações sociais que a internet por mais que crie espaços interativos não tem a capacidade de substituir a presença física do professor em sala de aula.

\section{REVISÃO BIBLIOGRÁFICA}

Com a suspensão das aulas presenciais, muito tem se falado em capacitar professores e alunos para a dinâmica inerente ao trabalho remoto e para a educação à distância (EaD), mas é preciso que dê visibilidade antes de mais nada a questões como as condições que os alunos vivem e se tem restrições de acesso as tecnologias digitais que passaram a ser a "sala de aula" virtual em tempos de pandemia, além disso não se pode excluir do processo as pessoas com alguma deficiência ou limitação que seja impeditivo para o acesso a metodologia remota ou ao EaD. A grande questão é que é preciso repensar a prática pedagógica e garantir o ensino de qualidade mediado pelas plataformas digitais que tem por hora tomado o lugar de destaque no processo de ensino e aprendizagem.

A estrutura organizacional do sistema educativo que se forma para atender demandas imediatistas estão na contramão dos métodos de ensino de aprendizagem que coloca o aluno como protagonista do processo, pois tem se dado mais importância a cumprir o calendário escolar, ainda que atropelado pela falta de capacitação dos professores para mobilizar o ano letivo do que prezar pela qualidade do produto que está sendo oferecido, que no caso em pauta trata-se do ensino.

De acordo com Zabala (1998, p. 144) "Historicamente os métodos globalizados nascem quando o aluno se transforma no protagonista do ensino; quer dizer, quando se produz um deslocamento do fio condutor da educação das matérias ou disciplinas como articuladoras do ensino para o aluno e, portanto, para suas capacidades, interesses e motivações. "Para poder estabelecer uma conexão entre a nova forma de adquirir saberes sem uma prévia adaptação quem vai protagonizar o processo de ensino e aprendizagem é a plataforma digital mediada pela ação docente, não mais o aluno.

Os alunos se posicionam e percebem de formas diferentes o universo acadêmico e a dinâmica que configura a importância e a significância dos conteúdos e as especificidades atreladas a tríade ensino, pesquisa e extensão, um conjunto de estudos 
que só podem ser realizados de modo correlacionado, se, presencialmente, além de compreenderem o caminho de construção do conhecimento de modo muito específico, pois o método que pode funcionar para um aluno, pode inviabilizar completamente a compreensão e a aprendizagem do outro tirando do aluno o papel de protagonista porque implementar o ensino pelas plataformas digitais de qualquer jeito elimina uma da características do protagonismo estudantil que é a manutenção da autonomia do aluno, pois sem aparato pedagógico pelas dificuldades de acessibilidade as tecnologias e ao uso delas fica a aquisição de conhecimento do aluno comprometida e entregue a própria sorte.

O ensino remoto ou a EaD não podem ser impostos, devem ser opções para não correrem o risco de se transformar em uma metodologia mediada pelo professor através de uma ferramenta de modo aleatório e colocar a prática docente no centro da desconfiança de sua eficácia e eficiência. Segundo Zabala (1998, p. 159) “O nexo comum dos métodos globalizados, também o é a necessidade de criar as condições que permitam que o aluno esteja motivado para a aprendizagem e que seja capaz de compreender e aplicar os conhecimentos adquiridos. ", para isso é preciso também políticas públicas capazes de garantir o acesso de todos os alunos e professores da rede pública as tecnologias e aos conhecimentos que movem essas tecnologias no espaço extra universidade.

Para Zabala (1998, p. 159) “As estratégias globalizadoras pretendem que aquilo que se aprende parta de uma necessidade sentida e não de conhecimentos impostos. " A ideia de sentimentos se sobreporem as imposições quando a discussão é o processo de ensino e aprendizagem vale apena experimentar e buscar alternativas para atender a expectativa advinda do aprender a aprender.

Sem dúvida nenhuma a tecnologia é um elemento essencial a qualquer instituição universitária moderna que produz ciência, além disso ela faz parte das boas práticas, por isso o que se questiona na atualidade está para além do convívio diário com as tecnologias no ambiente universitário. A problemática está para quem ela vai servir, se a realidade do Brasil mostra o descompasso de acesso e restrição entre os alunos universitários e que o assunto passou a ganhar uma notória dimensão com a suspensão das aulas presenciais tendo o professor de uma hora para outra ter que desenvolver seu 
plano de aula $100 \%$ via plataforma digital para o programa de graduação integralmente presencial das universidades federais.

Certamente que todos os saberes ou forma de adquirir os saberes são indispensáveis para a atividade docente, mas é antes preciso que se viabilizem os mecanismos que tornem legítimas as ações que levam a difusão dessas multiplicidades de saberes através do ensino via plataforma digital, pois segundo Freire (1918, p. 92) “O ensino dos conteúdos implica o testemunho ético do professor. ", e isso implica dizer que não deve ser a prática docente reduzida há uma mera transmissão de informação sem o compromisso de que as aprendizagens sejam significativas.

Não é possível ignorar as dificuldades de acessos de professores e alunos aos meios digitais de comunicação no período de pandemia, que inviabilizou as aulas presenciais e abriu a discussão para o ensino remoto ou Ead em algumas universidades públicas, porém é preciso um entendimento conjunto entre os sujeitos do processo sobre a importância da autonomia tanto do professor quanto do aluno para construírem de modo responsável e consciente os saberes que ainda não sabem como se lê em Freire (1918, p. 92) "Sei que ignoro e sei que sei. Por isso, tanto posso saber o que ainda não sei como posso saber melhor o que ainda não sei como posso saber melhor o que já sei. E saberei tão melhor e mais autenticamente quanto mais eficazmente construa minha autonomia em respeito à dos outros. "

Importante dizer que embora na literatura educacional não se encontre referências sobre o "ensino remoto", mas como já foram ditas anteriormente não se trata de um tema novo, mas de uma nova metodologia de ensino que passou a ser discutida por causa da pandemia por COVID-19, portanto não fazia parte da realidade da educação superior das universidades federias que ofertam por exemplo os cursos de graduação das agrarias de modo presencial e de repente aquelas aulas de campo não podem mais serem desenvolvidas e a alternativa do ensino remoto vincula o contraste deste modelo de ensino que não tem viabilidade na aula prática inerente ao currículo da graduação em pauta.

Uma análise sobre viabilidade tanto do ensino remoto e a EaD pode ser encontrada nos discursos de muitos autores que defendem esses modelos de ensino como se lê no fragmento seguinte de Farias, (2013, p.18) que afirma que “[...] esse novo método de ensino faz com que o professor/tutor passe a ser considerado um mediador da 
aprendizagem, tornando-se necessário o domínio das ferramentas informacionais, além da capacidade de formar alunos críticos, participativos e, sobretudo, autônomos no processo ensino-aprendizagem." Percebe-se que a autora é confiante nos bons resultados provenientes desse modelo de ensino e aprendizagem.

Com algumas ressalvas para o desenvolvimento de algumas atividades pedagógicas, mas com cunho ideológico a favor da manutenção do uso das tecnologias mediadas pelos professores, encontra-se sobre essa discussão a redação onde Veiga, et al $(1998$, p. 01) pontua que "a realização de pesquisas pela Internet é uma alternativa promissora, mas requer cuidados especiais na escolha de editores de texto, controle de vírus e manutenção de listas de endereços eletrônicos atualizadas. " Entretanto, este ficaria na conta de mais um trabalho que teria o professor que organizar para orientar os alunos nas aulas remotas, afim de estabelecer a interação na nova forma de mediar o processo de ensino e aprendizagem.

Acrescente-se que no contexto do ensino regular da educação superior o professor empreende muitas ações pedagógicas interligadas e dependentes das interaçõ es sociais presenciais, pois conforme Pimenta e Anastasiou (2014, p. 218) “A ensinagem na universidade exige considerações sobre a ciência, o conhecimento e o saber escolar, determinantes do trabalho de alunos e professores. "Essa abordagem é importante porque leva a reflexão de que por mais que muitos professores tenham se formado mediante uma visão moderna de ensino, ainda assim o ofício da docência via plataformas digitais ou seja ensino remoto é atualidade um desafio real a ser enfrentado.

\subsection{Diferenças entre EaD e ensino remoto}

O conceito de Ensino Remoto não aparece nas literaturas pedagógicas por ter entrado no universo docente em condições de distanciamento social em medida emergencial, por causa da pandemia por COVID - 19. Entretanto está sendo viabilizada por algumas universidades federais através das plataformas educacionais de maneira interativa diária com transmissão em tempo real, sendo uma metodologia adotada excepcionalmente para atender a este momento de suspensão das aulas presenciais.

No que se refere a EAD, esta modalidade de ensino se dá através de aulas gravadas e encontra definições legais no artigo 80, inciso 40 da Lei de Diretrizes e Bases da 
Educação Nacional (9.394/96) e também no Decreto no 9.057, de 25 de maio de 2017. “Art. 10 Para os fins deste Decreto, considera-se educação a distância a modalidade educacional na qual a mediação didático-pedagógica nos processos de ensino e aprendizagem ocorra com a utilização de meios e tecnologias de informação e comunicação [...]", nesses termos as diferenças entre ensino remoto e educação a distância são claras.

Tabela 1 - Diferenças entre ensino remoto e educação a distância

\begin{tabular}{|c|c|}
\hline ENSINO REMOTO & EDUCAÇÃO A DISTÂNCIA \\
\hline $\begin{array}{l}\text { As aulas são em tempo real, com o } \\
\text { mesmo professor e disciplina das } \\
\text { aulas presenciais. }\end{array}$ & $\begin{array}{l}\text { As aulas são gravadas para todas as } \\
\text { disciplinas }\end{array}$ \\
\hline $\begin{array}{l}\text { Há a interação diária entre o professor e } \\
\text { o aluno, deixando a relação mais } \\
\text { próxima possível. }\end{array}$ & $\begin{array}{l}\text { Há um tutor para tirar as dúvidas dos } \\
\text { alunos. }\end{array}$ \\
\hline $\begin{array}{c}\text { Material personalizado, desenvolvido } \\
\text { pelo professor da disciplina. }\end{array}$ & Atividades e materiais padronizados \\
\hline $\begin{array}{l}\text { Cronograma e calendário próprios, } \\
\text { alinhado com o Plano de Ensino, } \\
\text { mas adaptado ao momento que } \\
\text { estamos vivendo. }\end{array}$ & $\begin{array}{l}\text { Cronograma e calendário padronizados e } \\
\text { unificados. }\end{array}$ \\
\hline $\begin{array}{l}\text { Material Didático e avaliações produzidas } \\
\text { de acordo com os assuntos } \\
\text { aplicados em aulas remotas. }\end{array}$ & $\begin{array}{l}\text { Avaliações e testes padronizados, } \\
\text { produzidos e corrigidos em massa. }\end{array}$ \\
\hline
\end{tabular}

Fonte: https://www.fsa.br/diferenca-ead-ensino-remoto

A relação, a associação ou mesmo a confusão que vem sendo feito entre ensino remoto e educação a distância tem várias hipóteses, e uma delas é a falta de intimidade que os professores descobriram que não tinham com os dois modelos mobilizados através de tecnologias digitais, mas com dinâmicas que se diferem como a forma de interação com aluno, a organização e distribuição de conteúdo em tempos adversos, 
etc., Vale destacar que até alguns poucos meses atrás as aulas eram essencialmente presenciais nas universidades federais.

Considerando que o Ministério da Educação (MEC) autorizou a prorrogação do ensino remoto até 31 de dezembro pelas instituições de educação superior, a discussão que cabe é em quais condições os professores e os alunos vão compartilhar informações e conhecimentos específicos de cada disciplina e o que fazer com os alunos que não tem acesso a computadores, nem a internet? Cabe a discussão porque não existe opções de metodologias de grande alcance neste momento, de uma ferramenta educativa capaz de atender a demanda dos alunos sem exclusão de muitos deles.

As transformações na educação escolar, historicamente tem ocorrido meio a longos debates, conferências, reuniões, congressos nacionais e internacionais, entre outras vias de dialogicidade, e não se trata nesta abordagem de discutir apenas as dificuldades de um número significativo de alunos em estabelecer conexão com as tecnologias que devem ser mediadas pelos professores, a questão é mais profunda, porque ainda não se tem a conta exata de quantos alunos do ensino superior ficarão fora do processo de ensino e aprendizagem pela também falta de igualdade de oportunidade de acesso as plataformas digitais.

Certamente que todo o estardalhaço se encontra pela falta de capacitação dos professores para atuar fora do espaço físico da sala de aula em plataformas educacionais digitais e pelas condições econômico-social de uma grande parcela de alunos que estão na universidade pública, somadas as incertezas do nosso tempo. Morin (2007, p. 16) afirma que "A educação deveria incluir o ensino das incertezas que surgem nas ciências [...]" certamente que a inclusão do estudo das incertezas enquanto pressupostos do currículo moderno não avaliza a facilidade de adaptação ao novo, mas possibilitaria ensinar a compreensão que de acordo com Morin (2007, p. 31) "o conhecimento permanece como uma aventura para a qual a educação deve fornecer o apoio indispensável. "Isso implicar a superação dos professores a antigos hábitos e velhas práticas pedagógicas, a fim de adaptarem-se as necessidades do momento.

\subsection{As universidades federais e o retorno as aulas através do ensino remoto ou a EaD}

Em condições especiais por causa da pandemia por COVID-19, o MEC publicou no dia 17 de junho de 2020, no Diário Oficial da União a Portaria n. 544, de 16 de junho de 2020, que 
“Dispõe sobre a substituição das aulas presenciais por aulas em meios digitais, enquanto durar a situação de pandemia do novo Coronavírus - Covid-19, e revoga as Portarias MEC no 343, de 17 de março de 2020, no 345, de 19 de março de 2020, e no 473, de 12 de maio de 2020. " O documento tem valor legal até 31 de dezembro de 2020 e nele é dada também a autonomia para as instituições de ensino para se apropriarem das tecnologias a fim de darem continuidade no ano letivo como se lê na redação que compõe o Artigo 1ㅇ, § 1ㅇ:

\begin{abstract}
Autorizar, em caráter excepcional, a substituição das disciplinas presenciais, em cursos regularmente autorizados, por atividades letivas que utilizem recursos educacionais digitais, tecnologias de informação e comunicação ou outros meios convencionais, por instituição de educação superior integrante do sistema federal de ensino, de que trata o art. 20 do Decreto $n=9.235$, de 15 de dezembro de 2017. § 10 O período de autorização de que trata o caput se estende até 31 de dezembro de 2020. (PORTARIA $N^{\circ} .544 / 20202$ )
\end{abstract}

Após cinco meses das aulas presenciais terem sido suspensas em todo o Brasil o Portal do Ministério da Educação (MEC) voltou a atualizar os dados sobre o retorno das atividades acadêmicas das universidades onde retrata o quadro geral correspondente ao retorno das aulas na modalidade EaD ou Remota, onde até 10 de julho de 2020, contava com 27 das 69 universidades federais do país já tinham iniciado as aulas à distância ou já estão com data marcada para o retorno remoto, conforme orientações definidas pela portaria $n^{\circ} .544 / 2020$.

Certamente que todos esses meses foram cercados de incertezas e improvisos até que se chegasse ao consenso da viabilidade ou simplesmente continuidade do ano letivo completamente mediado pelas tecnologias educacionais digitais, tendo sido esta uma medida autorizada pelo ministério da Educação desde o início do mês de junho. A demora da implementação do ensino remoto emergencial se deu também pela dificuldade não só dos professores em se adaptarem ao novo modelo de difusão dos conteúdos, mas principalmente pela falta de acesso as tecnologias digitais por parte dos alunos do ensino superior das universidades federais tendo sido um ponto que refletiu as desigualdades na educação pública do país.

Freire (2018, p. 76) escreveu que "Ensinar exige apreensão da realidade" ou seja o professor até então precisa muito conhecer e ter mais do que a posse de um 
computador e da rede de internet para desenvolver a prática pedagógica, ele precisa sobretudo estabelecer vínculos com a nova forma de realizar a docência "conhecer as dimensões que caracterizam a essência da prática. " (Idem, p. 67), essas dimensões dizem respeito as especificidades gerais do processo de ensino e aprendizagem que incluem desde as condições de organização de tempo/espaço, planejamento e execução da ação pedagógica até as condições de receptação do produto final pelos alunos universitários.

Nas circunstancias atuais são muitas as questões que precisam ser repensadas para esta nova forma de atuar e produzir para compartilhar conhecimentos menos excludentes, entre elas repercute o planejamento participativo (o que o professor tem condições de desenvolver através do ensino remoto e o que o aluno tem capacidade de assimilar mediatizados pela ação dialógica) e em que contexto motivacional o aluno vai participar das aulas, pois no processo de ensino e aprendizagem:

[...] há necessidade de que os que se envolverem estejam suficientemente incentivados, a fim de que se sintam motivados para a participação [...] é imprescindível que tenham consciência de que, como participantes do processo, são sujeitos e, por isso mesmo, em condições de comprometer-se e assumir. Embora o planejamento participativo seja, na realidade, um movimento de "dentro para fora", acredita-se que um impulso externo inicial se faz necessário. (DALMÁS, 2008, P. 43).

O impulso externo pode ser ativado pela oportunidade de intervenção experimental provocada justamente pela necessidade de mudança da prática pedagógica e seus elementos didáticos que incluem o planejamento diário, a fim de atender as expectativas dos alunos em decorrência da mudança de comportamento interativo do espaço físico da universidade para o espaço das plataformas educacionais digitais vislumbrando a significância adaptativa que é fundamental para a preservação da singularidade da comunicação entre professor e aluno, conforme anuncia Gandin $(1983$, p. 100) "[...] um processo de planejamento exige, quando se pretende o bem de todos, que a participação aconteça em cada momento e em cada ação", isto é, buscando maneiras de relacionar o conteúdo a realidade individual e coletiva dos alunos. 


\section{CONSIDERAÇÕES FINAIS}

Este estudo possibilitou entender como os professores e alunos das universidades federais estão se integrando e se adaptando ao ensino remoto ou a EaD mesmo com todas as dificuldades que foram levantadas neste estudo e que refletiu as desigualdades na educação superior pública do país e que isto conforme os argumentos apresentados dizem respeito a modificar estratégias e procedimentos de ensino para atender uma nova demanda didático-pedagógica.

Conclui-se que o binômio ensino e aprendizagem está em processo de ressignificação do próprio ambiente acadêmico e pode acontecer por vários canais de comunicação, por vias interativas presenciais e não presenciais como as que estão acontecendo pelas plataformas educativas digitais por medida de emergencial estabelecida pelo ministério da educação nas universidades federais.

Negar, portanto, a importância da utilidade das tecnologias digitais para a difusão dos conteúdos escolares não elimina a necessidade de revisão da prática pedagógica antes desenvolvida apenas no espaço físico da sala de aula, também não se pode negar as dificuldades de estabelecer a rede educativa de conhecimento específico de cada curso da graduação exige, principalmente quando trata-se de um professor que atua em diferentes cursos com disciplinas distintas, então, para a continuidade do ano letivo é imprescindível que haja uma conscientização dos envolvidos ao enfrentamento do desafio que perpassa pela mudança de postura do professor e pela garantia dos recursos tecnológicos básicos possíveis principalmente para os alunos.

\section{REFERÊNCIAS}

BRASIL. Lei de Diretrizes e Bases da Educação Nacional (9.394/96) Brasília: Senado Federal, Coordenação de Edições Técnicas, 2017.

BRASIL. Decreto no 9.057, de 25 de maio de 2017. Regulamenta o artigo 80 da Lei $\mathbf{n}^{\circ}$ 9394, de 20 de dezembro de 1996, que estabelece as diretrizes e bases da educação nacional. Publicado no DOU de 26 de maio de 2017 e retificado em 30 de maio de 2017. 
DALMÁS, Ângelo. Planejamento participativo na escola: educação, acompanhamento e avaliação. 14a ed. Petrópolis, RJ: Vozes, 2008.

\section{DIÁRIO OFICIAL DA UNIÃO. PORTARIA № 544, DE 16 DE JUNHO DE 2020. DISPONÍVEL}

EM: https://www.in.gov.br/en/web/dou/- Acessado em: 28 de agosto de 2020.

FREIRE, Paulo. Pedagogia da autonomia: saberes necessários à prática educativa. 56ạ . ed . Rio de Janeiro / São Paulo: Paz e Terra, 2018.

FARIAS, Suelen Conceição. Os Benefícios das Tecnologias da Informação e comunicação (TIC) no Processo de Educação a 49 Distância (EAD). São Paulo: Revista RDBC, 2013. Disponível em . Acessado em 17 de dezembro de 2016.

GANDIN, Danilo. Planejamento como prática educativa. São Paulo: Loyola, 1983.

MORIN, Edgar. Saberes necessários à educação do futuro. Tradução de Catarina Eleonora F. da Silva e Jeanne Sawaya; revisão técnica de Edgard de Assis Carvalho. 12a . ed. São Paulo: Cortez; Brasília, DF: UNESCO, 2007.

PIMENSTA, ANASTASIOU. Docência no ensino superior. 5a ed. São Paulo: Cortez, 2014.

VEIGA, Ricardo Teixeira; MOURA, Alexandre Inácio de; GONÇALVES, Carlos Alberto; BARBOSA, Francisco Vidal. O Ensino à Distância pela Internet: Conceito e Proposta de Avaliação. Disponível em. Acessado em 15 de dezembro de 2016.

ZABALA, Antoni. A prática educativa: como ensinar. Tradução Ernani F. da F. Rosa. Porto Alegre: Artmed, 1998. 


\title{
CAPÍTULO XIX
}

\section{ENSINO REMOTO EMERGENCIAL: DESAFIOS EDUCACIONAIS EM TEMPOS DE COVID-19}

\author{
Julyana Rodrigues Maciel ${ }^{1}$ \\ Fernanda Gomes da Silva ${ }^{2}$ \\ Júlia Diana Pereira Gomes ${ }^{3}$ \\ Líbne Lidianne da Rocha e Nóbrega ${ }^{4}$ \\ Sabrina Gomes da Silva ${ }^{5}$ \\ Wesley Queiroz Peixoto ${ }^{6}$
}

\begin{abstract}
1 Professora da Escola de Enfermagem Thereza Néo
2 Pós- graduanda em Atenção Básica. Programa de Residência Multiprofissional em Atenção Básica, Saúde da Família e Comunidade. Universidade do Estado do Rio Grande do Norte - UFRN

${ }^{3}$ Mestranda em Enfermagem. Programa de Pós-Graduação da Universidade da Integração Internacional da Lusofonia Afro-brasileira - UNILAB

${ }^{4}$ Doutoras em Ciências da Saúde. Programa de Pós-Graduação em Enfermagem da Universidade Federal do Rio Grande do Norte - UFRN

${ }^{5}$ Graduandas em Nutrição. Faculdade Nova Esperança - FACENE

6 Pós-graduando em Saúde Materno-Infantil. Programa de Residência Multiprofissional em Saúde Materno-infantil UFRN
\end{abstract}

\section{RESUMO}

Diante da propagação do novo vírus, causador da doença COVID-19, atividades sociais, culturais e econômicas necessitaram ser reajustadas. Assim como, instituições educacionais foram fechadas e o ensino foi transferido para o Ensino Remoto Emergencial. O presente estudo trata-se de um relato de experiência de estudantes e professores dos cursos de Enfermagem e Nutrição, acerca das vivências no processo de ensino-aprendizagem diante do cenário em tempos de COVID-19. Dentre as ferramentas para o Ensino Remoto Emergencial, foram utilizadas Plataformas Digitais. Os resultados foram organizados em duas categorias: INTERRELAÇÃO PROFESSORALUNO e APLICAÇÃO DAS TECNOLOGIAS DIGITAIS NO ENSINO REMOTO. A primeira, traz a relevância do professor na formação do aluno e as condições para realizar de modo efetivo e eficaz. Já a segunda, retrata as tecnologias digitais como mediadoras nos processos de ensino-aprendizagem dos alunos durante a atual crise na Saúde Pública e seus principais desafios. Portanto, a aplicação de ferramentas avaliativas que mensurem a qualidade do ensino e o nível de rendimento do discente e do docente faz-se necessário, visto que tal modalidade implica no perfil do aluno a ser formado e na sua capacidade crítica e reflexiva, enquanto profissional e sujeito da sociedade. Neste interim, os recursos tecnológicos devem além de superar as limitações pela doença COVID-19 na educação, criar possibilidades para que os alunos sejam alcançados de forma eficaz e eficiente.

Palavras-chave: Educação. Tecnologia de Informação. Competência Profissional. Infecções por coronavírus. 


\section{INTRODUÇÃO}

No contexto atual, o mundo encontra-se em uma grave crise de Saúde Pública, em decorrência da propagação do novo vírus, denominado SARS-CoV-2 que significa Síndrome Respiratória Aguda Grave por coronavírus 2, causador da doença COVID-19, que foi detectada em 31 de dezembro de 2019 em Wuhan, na China. Logo, em janeiro de 2020 a Organização Mundial de Saúde (OMS) informou a circulação do vírus em outras regiões, se expandindo para outros países, sendo em 30 de janeiro declarado estado de Emergência de Saúde Pública de Importância Internacional (ESPII) (LANA, et al.,2020).

Diante deste cenário, a Organização Mundial de Saúde decretou adoção de medidas excepcionais de proteção, afim de prevenir e reduzir a disseminação da infecção pela COVID-19 e dentre tais ações, estão presentes a vigilância ativa, detecção precoce, gerenciamento de casos, rastreamento de contato e o isolamento social, que trouxe maior impacto sobre a rotina cotidiana e as relações pessoais entre a população (WHO, 2020).

$\mathrm{Na}$ conjuntura emergencial que a propagação do vírus ocasionou, as atividades sociais, culturais e econômicas necessitaram ser reajustadas, afim de suprir as demandas da sociedade e prosseguir suas tarefas. De modo não diferente, o sistema educacional também foi alvo de tais modificações e precisou se adaptar ao modelo de ensino para responder às demandas atuais.

Os agravos provocados pelo novo coronavírus retratam as instituições de ensino como um dos espaços de risco de transmissão, visto que a multiplicidade e heterogeneidade do seu público possibilita a propensão de casos desde assintomáticos a gravemente fatais, havendo assim, a necessidade de reavaliação do processo de ensino-aprendizagem (ARRUDA, 2020).

No Brasil, em fevereiro, havia casos em investigação, mas sem registros confirmados. Mesmo assim, como medida de prevenção ao aumento de casos, o Ministério da Educação (MEC) lançou a Portaria № 343, de 17 de março de 2020, que dispõe sobre a substituição das aulas presenciais por aulas em meios digitais, enquanto a situação de pandemia da COVID-19 permanecer (BRASIL, 2020). 
Em 16 de junho de 2020, o MEC publica a Portaria № 544, autorizando a substituição de estágio e práticas por aulas remotas. Assim sendo, instituições educacionais, públicas e privadas foram fechadas e o Ensino Presencial necessitou ser transferido para o Ensino Remoto Emergencial (ERE) (BEHAR, 2020).

Torna-se necessário portanto, evidenciar que ERE não se configura como Educação à Distância (EAD), visto que esta possui um planejamento pedagógico próprio, dotado de aspectos organizacionais, conteúdos, metodologias, tecnologias e estratégias pedagógicas a serem empregadas (BEHAR, 2020).

O termo "Remoto", segundo o dicionário Priberam (2020), configura-se ao que é realizado de modo distante do espaço. Deste modo, professores e alunos tiveram que se adequar a tal modalidade de ensino diante do decreto que os impede de frequentar os espaços físicos, como forma de diminuir a disseminação do vírus.

"Emergencial", remete as modificações que foram necessárias ao planejamento pedagógico para o ano de 2020 (BEHAR, 2020), o qual careceu de adequações, sendo preciso o uso das Tecnologias de Informação e Comunicação (TIC), como está exposto no Art.1 da Portaria № 343/2020: “autorizar, em caráter excepcional, a substituição das disciplinas presenciais, em andamento, por aulas que utilizem meios e tecnologias de informação e comunicação".

As TIC são consideradas toda e qualquer tipo de ferramenta tecnológica que viabilize a informação e auxilie na comunicação, como hardware, software, rede ou telemóveis em geral (SENAI, 2019). Todos sendo utilizados como métodos de ensino para evitar que os alunos e professores tivessem maiores prejuízos no ano letivo em curso.

Nesse sentido, em meio ao confinamento domiciliar e na presença das relações familiares, os professores buscaram se reinventar com utilização da internet e com os meios tecnológicos disponíveis para darem cobertura educacional aos seus estudantes.

No caráter de inovação, faz-se necessário mencionar que o cenário atual possui opções e possibilidades diferentes de emergências pandêmicas passadas, visto o grande avanço tecnológico vivenciado. Entretanto, a maioria dos docentes não estava preparada e capacitada para atuar nesta nova modalidade de ensino, apresentando dificuldades em manter os alunos atentos e concentrados, bem como a realizar leituras 
corporais, avaliar de modo preciso o rendimento do aluno e manter um ambiente mais interativo, o que tornam a educação online ainda mais desafiadora (ARRUDA, 2020).

Portanto, diante do novo contexto vivenciado e os impactos ocasionados pela COVID-19, de modo especial, na educação, torna-se relevante evidenciar aspectos importantes na conjuntura do processo de ensino-aprendizagem de professores e alunos das instituições de ensino.

Assim sendo, o presente estudo traz o relato dos desafios vivenciados por profissionais e graduandos da área da saúde através do Ensino Remoto e suas repercussões nos níveis de aprendizagem e comunicação professor-aluno-instituição.

\section{METODOLOGIA}

Trata-se de um relato de experiência de estudantes e professores dos cursos de Enfermagem e Nutrição, acerca das vivências no processo de ensino-aprendizagem diante do cenário em tempos de COVID-19.

O relato de experiência consiste em um texto desenvolvido através de uma dada experiência, o qual é capaz de contribuir de forma relevante para sua área de atuação, configurando-se como uma "descrição que um autor ou uma equipe faz, por meio de uma vivência profissional tida como exitosa ou não, mas que possibilite a discussão, a troca e a proposição de ideias para a melhoria do cuidado na saúde" (UFJF, 2016, p.1).

O presente estudo contém os relatos sobre o Ensino Remoto de discentes, sendo 1 de nutrição e 3 de pós-graduação em enfermagem, contando ainda, com as vivências de 2 docentes de enfermagem, que integram o corpo de uma Instituição de Ensino Técnico e outra de Ensino Superior.

As aulas relatadas dizem respeito ao primeiro semestre do ano de 2020 , que iniciou de forma presencial e necessitou ser transferido para o modo de Ensino Remoto Emergencial no mês de abril. Estas ocorreram diariamente, no mesmo período em que antes eram realizadas no modo presencial: matutino, vespertino ou noturno.

Dentre as ferramentas, foram utilizados Plataformas Digitais, como Google meet e Hangouts meet, auxiliando na criação de salas de aulas virtuais e para o acesso destes meios foi necessário o login no computador ou em um dispositivo móvel (Android, Iphone ou Iped) com acesso a rede de internet. 
As atividades e avaliações acadêmicas ocorreram através das Plataformas Google Classroom, Ambiente Virtual de Aprendizagem (AVA), Google Forms, Socrative e Rave, sendo este último, um aplicativo utilizado para a apresentação de vídeos e filmes.

A metodologia planejada para a realização das aulas tratou-se de apresentações por vídeo conferência e com a utilização de slides construídos pelo programa Power Point do Microsoft Word, tratando-se dos assuntos referentes as disciplinas elencadas para o ensino nesta modalidade.

Ao final de algumas aulas foi utilizou-se também o Software Mintemeter que é usado em tempo real como ferramenta de interação entre os participantes, sem a necessidade de downloads ou criação de contas. Tem uso fácil e autoexplicativo e auxilia no processo de feedback sobre a satisfação e nível de aprendizagem obtidos nas aulas.

A frequência dos alunos foi contabilizada ao final de cada aula, em que cada um destes ficava responsável por deixar registrado seu nome no chat do aplicativo utilizado em que estavam formadas as salas de aula ou através de formulários digitais nos quais o aluno preenchia seu nome e e-mail.

\section{RESULTADOS E DISCUSSÕES}

\subsection{Interrelação professor-aluno}

No processo de formação do aluno, o professor possui papel relevante e para que isso seja possível é necessário o domínio e aprimoramento nas metodologias de ensino que facilitem a aquisição do conhecimento pelos estudantes, conhecimento sobre o perfil de aprendizagem de cada aluno, domínio sobre o conteúdo a ser ministrado e tais circunstâncias possibilitam uma boa aula e facilitam a produção de conhecimento do aluno (SIDI, 2017).

Para obter condições de realizar esse papel de forma efetiva e eficaz, o professor que faz uso de tais ferramentas precisa garantir que sua 'mensagem' seja recebida com sucesso, para tanto, dispõe de "um conjunto de funcionalidades como a troca de mensagens, arquivos e imagens, incluindo recursos de som e de desenho. Quão maior é a existência de recursos, melhor é feita a comunicação entre professor e aluno" (SILVA, FRANCO; AVELINO, 2006, p.3). 
Mesmo o ambiente sendo modificado, o professor ainda precisa planejar aulas, conhecer seus alunos, traçar estratégias de ensino e elaborar avaliações e atividades que sejam condizentes com a realidade atual, mas que despertem no discente a sua corresponsabilidade nesse trajeto rumo à aquisição de novos conhecimentos.

Nesse sentido, o ensino através de tecnologias digitais, promove maiores desafios para a realização da interação aluno-professor, mas não impede que essa ação ocorra. Para isso, faz-se necessário que o professor configure seu plano de aula, de modo que valorize os pensamentos dos alunos e promova o debate através dos recursos disponíveis nas plataformas digitais, assim como estimule a pesquisa, avaliação e o feedback dos seus alunos.

\subsection{Aplicação das tecnologias digitais no ensino remoto}

As tecnologias digitais têm sido reconhecidas como mediadoras importantes nos processos de ensino-aprendizagem dos alunos durante o contexto atual de crise na Saúde Pública, de modo que, viabilizaram a continuidade da realização das atividades escolares, universitárias e de ensino.

Diante das emergentes necessidades educacionais, os agentes desse processo se veem em uma posição de precisarem de constante atualização, em especial, os docentes que identificam a carência em sua qualificação profissional e buscam uma obtenção de melhoria da qualidade dos serviços ofertados e do ensino produzido nesse ambiente.

As capacitações visam a construção de competências, que aliadas a capacidade de saber-fazer que fomentam o processo ensino-aprendizagem e perpassam pelo saberaprender, o que envolve distintas construções, desconstruções e reconstruções de saberes e práticas (TONHOM et al., 2014).

Mesmo assim, apesar de muitos docentes demonstrarem interesse em si capacitarem, não houve tempo hábil nem iniciativa das instituições a priori, para lhes fornecerem ambiente de estudo e/ou meios de qualificação profissional para a nova modalidade de ERE. Portanto, muitos destes, tiveram que buscar por conta própria, cursos, palestras, vídeos e por vezes, ajuda de familiares e amigos mais jovens para conseguirem formar uma base sólida de saberes sobre as tecnologias atuais.

Essa realidade foi ainda mais dificultada para aqueles docentes com mais de 20 anos de formação, pois não tiveram acesso a esse tipo de modalidade educacional em 
seu período de graduação, isso demonstra que existe uma carência de ações e atividades voltadas para a Educação Permanente.

Para Almeida et al (2016) a Educação Permanente é "uma estratégia para refletir sobre o processo de trabalho político-pedagógica que favorece, aos trabalhadores, um processo de ensino-aprendizagem dentro do seu cotidiano laboral". Corroborando com essa ideia, esse trabalho reforça a necessidade de políticas e programas de incentivo à capacitação docente que Ihes deem a oportunidade de buscarem melhorias em seu modo de ensinar-aprender.

Além disso, os próprios alunos apresentaram dificuldades com o Ensino Remoto Emergencial, nem sempre atreladas à falta de domínio tecnológico, mas sim, pela facilidade de distração e mudança de foco que dispositivos oferecem, em especial, pelo uso das redes sociais.

Sem mencionar o fato de que, o próprio acesso à rede de internet é dificultado em algumas localidades e diversos alunos dependem da rede de vizinhos, parentes e em alguns casos, utilizam os dados móveis dos telefones celulares.

Outro aspecto relevante que dificultou a aprendizagem foi a discrepância no padrão econômico dos alunos, pois alguns, não tinham sequer a possiblidade de uso desses dispositivos (aparelho celular, notebook, computador, tablet, entre outros) o que gerou desigualdade no acesso e culminou na evasão escolar de alguns destes.

\section{CONSIDERAÇÕES FINAIS}

Neste interim, compreende-se que na conjuntura atual pensar nas atividades educacionais por meio dos recursos tecnológicos, deve ir além da continuidade como forma de superar as limitações ocasionadas pela COVID-19, mas criar possibilidades para que todos os alunos sejam alcançados e que o ensino se dê de forma eficaz e eficiente.

Assim como, torna-se relevante a aplicação de ferramentas avaliativas que mensurem a qualidade desse ensino e o nível de rendimento tanto do discente quanto do docente nesse novo modelo de sala de aula. Essa ferramenta deve observar o material didático disponível, postura dos professores, estratégias de aprendizagem com tecnologias e ludicidade, comportamento e feedback dos estudantes e a comunicação entre eles. 
Tudo isso pode e vai implicar diretamente no perfil do aluno a ser formado e na sua capacidade crítica e reflexiva, não somente enquanto profissional, mas também enquanto sujeito ativo dentro da sociedade como um todo.

\section{REFERÊNCIAS}

ALMEIDA, J.R.S et al. Educação Permanente em Saúde: uma estratégia para refletir sobre o processo de trabalho. Revista da ABENO, v.16, n. 2, p. 7-15, 2016. Disponível em: https://revabeno.emnuvens.com.br/revabeno/article/view/248. Acesso em: 25 de ago. 2020.

ARRUDA, E.P. EDUCAÇÃO REMOTA EMERGENCIAL: elementos para políticas públicas na educação brasileira em tempos de Covid-19. EmRede, v. 7, n. 1, p. 257-275. 2020. Disponível em: https://www.aunirede.org.br/revista/index.php/emrede/\%20article/view/621. Acesso em:28 de ago. 2020.

BEHAR, P.A. O Ensino Remoto Emergencial e a Educação a Distância. Universidade Federal do Rio Grande do Sul. 2020. Disponível em: https://www.ufrgs.br/coronavirus/base/artigo-o-ensino-remoto-emergenciale-a-educacao-a-distancia/. Acesso em: 25 de ago. 2020.

BRASIL. Portaria no 343, de 17 de março de 2020. Dispõe sobre a substituição das aulas presenciais por aulas em meios digitais enquanto durar a situação de pandemia do Novo Coronavírus - COVID-19. Disponível em: https://www.in.gov.br/en/web/dou/-/portaria-n-343-de-17-de-marco-de-2020248564376. Acesso em: 26 de ago. 2020.

BRASIL. Portaria no 544, de 16 de junho de 2020. Dispõe sobre a substituição das aulas presenciais por aulas em meios digitais, enquanto durar a situação de pandemia do novo coronavírus - Covid-19, e revoga as Portarias MEC no 343, de 17 de março de 2020, no 345, de 19 de março de 2020, e no 473, de 12 de maio de 2020. Disponível em: https://www.in.gov.br/en/web/dou/-/portaria-n-544-de16-de-junho-de-2020-261924872. Acesso em: 26 de ago.2020.

LANA R.M.et al. Emergência do novo coronavírus (SARS-CoV-2) e o papel de uma vigilância nacional em saúde oportuna e efetiva. Cad Saúde Pública 2020.v.36, n.3:e00019620. Disponível em: https://pesquisa.bvsalud.org/controlecancer/resource/pt/mdl-32187288. Acesso em: 26 de ago. 2020.

PRIBERAM. Dicionário Priberam da Língua Portuguesa. Disponível em: https://dicionario.priberam.org/. Acesso em: 26 de ago.2020. 
SIDI, P.M. O papel do professor nas relações de ensino e aprendizagem: interfaces educacionais. Seminário Gepráxis. Bahia, v. 6, n. 6, p 3254-3264, 2017. Disponível em: http://anais.uesb.br/index.php/semgepraxis/article/viewFile/7431/7204. Acesso em: 27 de ago.2020.

SILVA, D; FRANCO, C. E.C; AVELINO, D. F. Aplicação da tecnologia de acesso remoto no ensino à distância. Associação Educacional Dom Bosco. FCEACDB. Resende, RJ, Brasil. Disponível em: https://www.aedb.br/seget/arquivos/artigos06/342_Artigo_SeGET_EAD.pdf. Acesso em: 26 de ago. 2020.

TONHOM, S.R. et al. A formação de enfermagem por área de competência: limites e possibilidades. Rev. esc. enferm. USP. São Paulo, v. 48, n. espe2, p. 213-220. 2014. Disponível em: https://www.scielo.br/scielo.php?pid=S0080$62342014000800213 \&$ script=sci_arttext\&tlng=pt. Acesso em: 25 de ago.2020.

UFJF. Instrutivo para elaboração de relato de experiência. Estágio em Nutrição em Saúde Coletiva. Universidade Federal de Juiz de Fora. Campus Governador Valadares. Instituto de Ciências da Vida. Departamento de Nutrição. 2016.p.1-2. Disponível em: https://www.ufjf.br/nutricaogv/files/2016/03/Orienta\%C3\%A7\%C3\%B5esElabora\%C3\%A7\%C3\%A3o-de-Relato-de-Experi\%C3\%AAncia.pdf. Acesso em: 27 de ago. 2020.

WHO. World Health Organization. Statement on the second meeting of the International Health Regulations (2005) Emergency Committee regarding the outbreak of novel coronavirus (2019- nCoV). Genebra. 2020. Disponível em: https://www.who.int/news-room/detail/23-01-2020-statementon-themeeting-of-the-international-health-regulations-(2005)-emergency-committeeregarding-theoutbreak-of-novel-coronavirus-(2019-ncov). Acesso em 26 de ago. 2020. 


\title{
CAPÍTULO XX
}

\section{EDUCAÇÃO NO CONTEXTO DA PANDEMIA DE COVID-19: UMA ANÁLISE DO PROCESSO ENSINO-APRENDIZAGEM NA UFERSA-CMPF}

\author{
Fabíola Luana Maia Rocha ${ }^{1}$ \\ Kaelly de Freitas Silva ${ }^{2}$ \\ José Henrique Maciel de Queiroz ${ }^{3}$
}

\begin{abstract}
${ }^{1}$ Mestre pelo Programa de Pós-Graduação em Ensino - PPGE da Universidade Estadual do Rio Grande do Norte UERN e graduada em Engenharia Civil e Bacharelado em Ciência e Tecnologia, pela Universidade Federal Rural do Semi-Árido - UFERSA, Pau dos Ferros/RN, Brasil

${ }^{2}$ Graduanda em Ciência e Tecnologia pela Universidade Federal Rural do Semi-Árido - UFERSA, Pau dos Ferros/RN, Brasil

${ }^{3}$ Especialista em Engenharia de Estruturas de Concreto Armado pela Faculdade Única de Ipatinga - FUNIP e Engenheiro Civil pela Universidade Federal Rural do Semi-Árido - UFERSA, Pau dos Ferros/RN, Brasil
\end{abstract}

\section{RESUMO}

Em 2020, com a chegada do novo coronavírus no Brasil e o cenário de pandemia desencadeado, uma série de atividades passaram a ser realizadas com adaptações, como ocorreu com a educação no geral. Diante disso, o objetivo deste trabalho é analisar os resultados obtidos com os novos procedimentos e modelos adotados para o processo de ensino-aprendizagem na UFERSA durante o semestre suplementar 2020.3. Para isso, utilizou se de uma metodologia aplicada, com abordagem quantitativa e qualitativa, onde a ferramenta de coleta de dados foi o questionário, direcionado aos discentes que efetuaram matrícula no semestre em questão. Observou-se que a maioria dos discentes consideraram as aulas remotas como uma alternativa viável para este período no qual as aulas presenciais estão impossibilitadas e que apesar de enfrentarem certas dificuldades para acesso e cumprimento das atividades propostas, se matriculariam novamente nesta modalidade de ensino, no caso de uma nova oferta.

Palavras-chave: Ensino-aprendizagem. Pandemia. Covid-19. Ensino a distância. Período suplementar.

\section{INTRODUÇÃO}

Diante do cenário pandêmico o processo de ensino-aprendizagem presencial sofreu mudanças em todo o mundo. Frente a isso, há a necessidade de adaptação do sistema educacional a práticas pedagógicas que estejam presentes além das salas de aula. Nesse sentido, surge em meio ao panorama atual a modalidade de Ensino à Distância como alternativa para refrear os possíveis atrasos causados no meio acadêmico. 
Nessa perspectiva, apesar de ser amplamente utilizada no ambiente acadêmico, a internet e sua facilidade de acesso à informação tornam-se uma ferramenta questionável quando posta como via principal de mediação de conhecimentos. Tal fato se dá, provavelmente, porque o contato da maioria dos discentes e docentes, em cursos de graduação, de forma on-line está apenas ligado ao envio/repasse rápido de materiais, atividades, notas, avisos, estudos extras, escrita acadêmica, entre outros; ou seja, formas de complementação do ensino presencial.

Dessarte objetivou-se analisar a influência no ensino-aprendizagem e a perspectiva dos discentes acerca da realização de aulas remotas na Universidade Federal Rural do Semi-Árido durante o Período Suplementar Excepcional 2020.3. De forma mais específica buscou-se verificar o grau de relevância que os discentes conferem ao ensino remoto, seu rendimento no(s) componente(s) curricular(es) estudado(s) e grau de aprendizagem nas aulas remotas. Foram evidenciadas também, as dificuldades no processo de ensino-aprendizagem efrentadas durante a pandemia de covid-19. Para isso, tomou-se como metodologia a pesquisa aplicada, visto que a análise dos efeitos da pandemia no ensino-aprendizagem pode possibilitar a adoção de práticas para melhor gerenciar eventuais dificuldades denotadas pelo corpo discente.

\section{REVISÃO BIBLIOGRÁFICA}

\subsection{A influência da pandemia na contemporaneidade}

Coronavírus é o nome dado à uma família de vírus e, dentre estes, está o Covid19, uma doença infectocontagiosa que pode causar febre, dor de cabeça, perda do paladar e olfato e até mesmo problemas respiratórios graves, segundo a Organização Mundial da Saúde (2020). Por ser uma doença de fácil transmissão - assim como a gripe ou outras de sua família patogênica - e a fácil mobilidade herdada com a globalização, este vírus se espalhou rapidamente em escala global.

Os impactos da pandemia de Covid-19 no ano de 2020, indiscutivelmente, refletem hoje e irão refletir em um período considerável da história contemporânea. Arbix (2020) argumenta que, apesar dos grandes avanços na pesquisa tecnológica e científica mundial, a preocupação frente ao surgimento de epidemias que assolaram os 
últimos anos parece esfriar, não sendo recorrente o preparo e desenvolvimento em saúde para que o aparecimento de novas doenças sejam contidas.

Em virtude disso, observam-se devastadores efeitos econômico-político-sociais com o período pandêmico do novo coronavírus. De acordo com Arbix (2020, p. 65), temse que:

\begin{abstract}
"a atual crise gerada pela Covid-19 já deixou [...] três grandes marcas: a primeira está cravada no alto custo em vidas e sequelas que feriram populações imensas em um curto espaço de tempo; a segunda responde pela aguda recessão e consequente diminuição do emprego, de salários e de renda, fechamento de empresas e desorganização da economia, com aumento das desigualdades e da pobreza; a terceira está ligada à corrosão institucional e à disseminação do medo e da perplexidade na sociedade."
\end{abstract}

Na educação, segundo a UNESCO (2020), cerca de 70\% dos estudantes de todo o mundo estão vivenciando os efeitos da suspenção de atividades presenciais. Em virtude disso, é evidente também, que muitas dessas instituições de ensino não teriam suporte profissional e tecnológico para retomar as atividades de forma remota. Muitos docentes e discentes sofreram abrupta mudança na forma de ensino-aprendizagem, causando déficit a este último.

\title{
2.2. A alternativa de ensino-aprendizagem em tempos de Covid-19
}

Como consequência da pandemia, escolas, universidades e demais instituições de ensino precisaram suspender as aulas presenciais em virtude da necessidade de manter o isolamento social da comunidade acadêmica. O recurso pedagógico agora utilizado para minimizar os prejuízos causados pela suspensão de atividades presenciais é a modalidade de ensino à distância (EaD). O EaD é um modelo que advém da cibercultura, que se inicia com os avanços tecnológicos ao final do século XX. (LÉVY, 1999).

Apesar da modalidade EaD estar sendo mais amplamente utilizada agora, ela está presente na contemporaneidade a bastante tempo e, mesmo que não utilizada exclusivamente, está presente na vida de discentes e docentes cotidianamente. A facilidade que se tem ao disponibilizar materiais e conseguir acessá-los faz com que plataformas de ensino sejam presentes na vida estudantes, desde a educação básica até o nível superior. 
Apesar disso, a modalidade $\mathrm{EaD}$ ainda possui precariedades decorrentes, principalmente, das desigualdades sociais, culturais e/ou até mesmo psicológicas. Nesse sentido, é de extrema importância que sua adoção seja amplamente debatida e que não vise substituir totalmente o ensino presencial, já que não há garantia de que todos possuem acesso à internet, local e material adequado para os estudos, dificultando o aprendizado de milhares de estudantes. Ainda nesse aspecto, entram docentes e demais responsáveis pelo ensino em escolas e universidades que não tiveram contato profissional com as tecnologias, desfavorecendo o repasse (2016, SOUZA; FRANCO; COSTA apud DIAS; PINTO, 2020).

Para conter os atrasos no ensino e facilitar a dinamicidade na abordagem pedagógica, docentes buscam utilizar ferramentas nas diversas plataformas existentes na internet. Dentre elas, pode-se citar aplicativos de videoconferência como Youtube, Google Meet, Zoom, Skype e Microsoft Teams. Estes aplicativos atuam como ambientes de sala de aula, conectando toda turma ao conteúdo abordado pelo docente através da exposição de slides e demais recursos audiovisuais, como a tradicional aula com lousa.

Para os métodos avaliativos, podem ser utilizadas ferramentas como Google Forms ou a própria plataforma online adotada pela instituição de ensino, como o do Sistema Integrado de Gestão de Atividades Acadêmicas (SIGAA), na UFERSA. Nesta última, há a possibilidade de envio e recebimento de arquivos de aula, materiais de estudo e atividades, e ainda produção de questionários, fóruns e tarefas. Com esses recursos, as notas são lançadas automaticamente pela plataforma, no caso de questionários, ou quando houver a correção do docente, no caso das atividades, tarefas e fóruns.

Recursos como os citados acima constituem a maior fonte de ensino, porém, no ensino presencial, materiais como esses já poderiam ser usados para complementarem atividades presenciais. Isto evidencia que a adaptação decorrente da pandemia tornou os conhecimentos no mundo tecnológico algo necessário e obrigatório, cujas práticas serão posteriormente inseridas no contexto pós-pandêmico.

Segundo Atié (2020), ao observar a situação de inúmeros docentes de todo o Brasil, ela nota o envolvimento e esforço de cada um em obter experiência sobre métodos antes não utilizados com tanta frequência, como também em manter o aprendizado de seus discentes. Para isso, a adequação à modalidade de ensino a 
distância trouxe para docentes, diretores e coordenadores grandes desafios e dedicação extra para o próprio aprendizado on-line.

\section{METODOLOGIA}

De forma clássica, a pesquisa em questão pode ser classificada de acordo com sua natureza, seus objetivos, procedimentos adotados e sua abordagem da problemática. Quanto a sua natureza, ela se classifica como aplicada, já que busca atribuir conhecimentos que possam ser posteriormente incorporados a essa realidade local (PRODANOV; FREITAS, 2013). Nesse tocante, analisar o desempenho e satisfação do corpo discente em relação à nova realidade trará consequentes contribuições para amenizar determinados impasses ocorridos com a modalidade de ensino já existente no mundo moderno, mas que se tornou novidade para maioria docentes e discentes.

Acerca dos objetivos, esta pesquisa pode ser classificada como descritiva com a aplicação de um questionário que encontra-se anexo. Nesse modelo de pesquisa, a análise é feita sem que haja interferência no campo estudado, "tal pesquisa observa, registra, analisa e ordena dados, sem manipulá-los, isto é, sem interferência do pesquisador" (PRODANOV; FREITAS, 2013, p. 52). Dessa forma, pôde-se, através de um formulário disponibilizado aos discentes pela plataforma Google Forms, consultá-los para elucidar questões pertinentes a essa nova modalidade para a instituição, buscando ainda entender variáveis que possam estar relacionadas para ocorrência de tal resultado.

O campo de estudo da pesquisa, foi a UFERSA Centro Multidisciplinar de Pau dos Ferros (CMPF), localizado no município de Pau dos Ferros, Rio Grande do Norte, na região do Alto Oeste, distante a cerca de 389 km da capital do Estado, Natal. A UFERSACMPF conta com 7 cursos de graduação e iniciou suas atividades no ano de 2012. Durante a pandemia do novo coronavírus no Brasil a instituição suspendeu suas atividades presenciais de ensino e entre os meses de junho e julho promoveu a oferta de alguns componentes curriculares de graduação de forma não presencial durante o chamado semestre suplementar excepcional 2020.3, onde cada docente ofertou opcionalmente um componente, e os discentes puderam se matricular em até 2 componentes. Tais discentes, que se matricularam nesta oferta, são a população desta pesquisa. 
No que tange aos procedimentos técnicos adotados para realização deste estudo, destaca-se inicialmente a pesquisa bibliográfica que embasou o entendimento do processo de ensino-aprendizagem e seu estado durante o período pandêmico. Para isso, buscaram-se livros, artigos científicos, revistas, dissertações entre outros. Segundo Lakatos e Marconi (2003), a pesquisa bibliográfica é de fundamental importância para o pesquisador, pois o coloca em contato com diversos pensamentos, opiniões e novos conhecimentos acerca do tema estudando, dando-o mais propriedade, autonomia para entender como o trabalho será feito e quais os efeitos dos resultados obtidos.

Já em relação à abordagem do problema, a pesquisa foi quantitativa, analisando graficamente e em percentual as respostas dos discentes; e também pesquisa qualitativa, pois o questionário já citado atua como ponte para que os estudantes expressem questões acerca do Semestre Excepcional Suplementar da UFERSA feito de forma remota. Na pesquisa qualitativa, os resultados são analisados para que o pesquisador entenda e crie hipóteses frente aos resultados obtidos, caracterizando os impactos de acordo com os percentuais encontrados e as ligações entre os resultados de cada variável.

\section{RESULTADOS E DISCUSSÕES}

A seguir serão apresentados os resultados com base nas respostas dos 98 discentes que participaram da pesquisa acerca do Semestre Suplementar Excepcional 2020.3 da UFERSA. Para os questionamentos mais pertinentes ao trabalho, propõe-se a exibição de gráficos para facilitar a visualização. Inicialmente, obtiveram-se, dados socioeconômicos: $62,7 \%$ dos participantes se declararam do sexo masculino e $37,3 \%$ do sexo feminino; ainda verificou-se que a maioria possui até dois salários mínimos em sua renda mensal familiar.

Um dos primeiros itens analisados faz referência ao trancamento de disciplinas, cuja maioria dos discentes relataram não ter realizado este procedimento $(87,8 \%)$, como é visto no gráfico 1 . Dos 12 discentes que trancaram algum componente curricular foi questionado o porquê deste trancamento, cuja maioria selecionou as opções: dificuldades na compreensão, carga horária elevada e problemas com acesso à internet. 
Gráfico 1 - Trancamento de disciplinas.

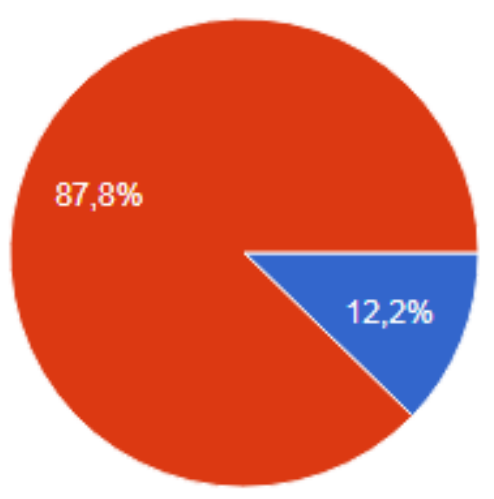

Fonte: Próprios autores (2020)

Diante da afirmativa de que aulas remotas seriam alternativas viáveis para o ensino-aprendizagem na UFERSA em tempos de pandemia, os discentes demonstraram em maioria concordarem parcialmente ou totalmente $(72,4 \%)$, como é mostrado no gráfico 2. Nesse sentido, como ainda abordam outras três perguntas sobre satisfação frente à experiência, obtenção de conhecimentos e rendimento pessoal nas disciplinas, as respostas variaram entre regular e ótimo, com baixa insatisfação.

Gráfico 2 - Aulas remotas como alternativas para o ensino-aprendizagem.

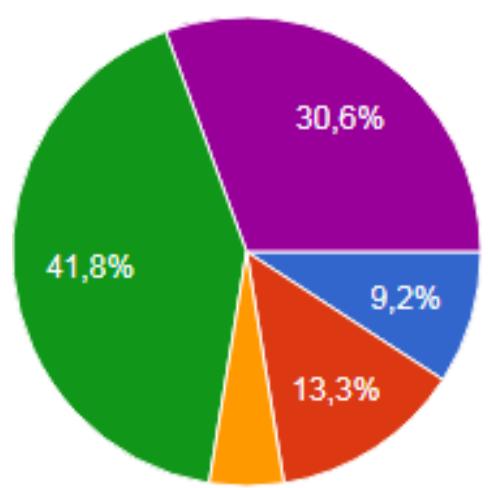

\section{Discordo totalmente \\ Discordo parcialmente \\ Não sei \\ Concordo parcialmente \\ Concordo plenamente}

Fonte: Autoria própria.

Quando questionados sobre a ocorrência de dificuldades para estudar em casa, a maioria dos estudantes $(63,3 \%)$ relataram ter enfrentado em alguns momentos (ver gráfico 3). Dentre as causas mais citadas, em ordem decrescente, estava o barulho, aparecimento de afazeres domésticos, problemas de leitura no computador/notebook/celular, dificuldades no uso dos recursos tecnológicos e carga horária semanal elevada. 
Gráfico 3 - Dificuldades para estudar em casa.

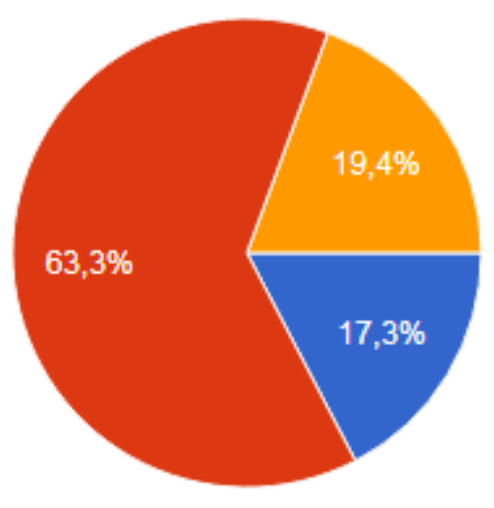

Sim, sempre

Em alguns momentos

Não

Fonte: Próprios autores (2020)

Adversidades ocorridas com quedas de internet ou lentidão no acesso de materiais e atividades também foram colocadas como fatores limitantes no processo de ensino-aprendizagem. Como descrito no gráfico 4, 50\% dos discentes responderam que a internet foi um fator limitante em pelo menos alguns momentos. A dependência total no envio de atividades, presença em aulas e realização de provas traz ao discente e docente a passividade frente a falhas e imprevistos.

Gráfico 4 - Internet como fator limitante.

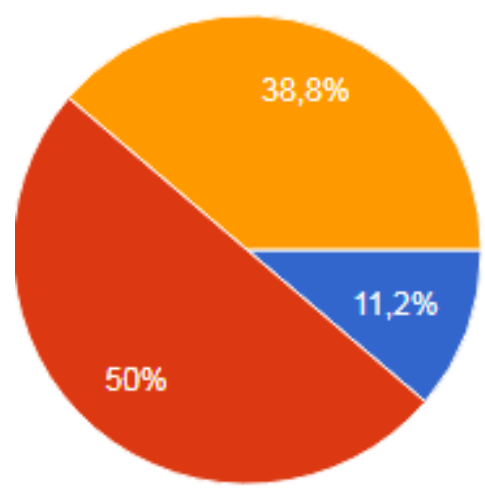

Sim, sempre

Em alguns momentos

Não

Fonte: Próprios autores (2020)

Ainda referente às dificuldades enfrentadas pelos discentes ao dependerem totalmente do espaço doméstico para seus estudos foi colocado como fator limitante a falta de espaço apropriado para os estudos, como ilustrado no gráfico 5 com 46,9\% em alguns momentos e $15,3 \%$ sempre. Relacionando com o fato de que a maioria dos entrevistados se classificou com renda máxima de até dois salários mínimos, pode-se levantar uma grande questão restritiva que ainda é correlacionada com os problemas citados de barulho, aparição de afazeres domésticos, fatores estes que diminuem a 
concentração dos discentes em aulas, horas de estudos extras e realização de atividades avaliativas.

Gráfico 5 - Falta de espaço apropriado para estudar como fator limitante.

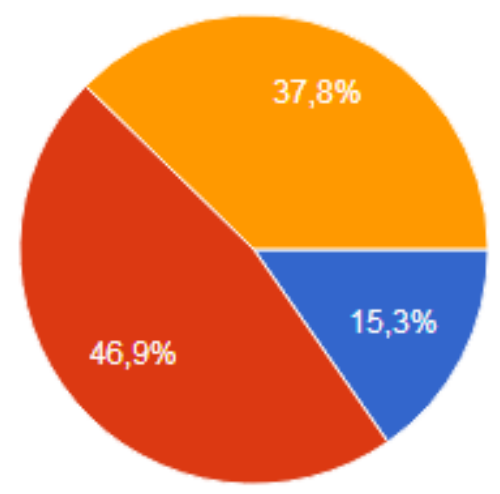

Sim, sempre

Em alguns momentos

Não

Fonte: Próprios autores (2020)

O gráfico 6 abaixo mostra a posição dos discentes diante da afirmativa de que a interação entre docente e discente ser a mesma que em semestres presenciais, cuja maioria das respostas variaram entre "discordo parcialmente" e "discordo totalmente" (51\% quando somados). Além disso, tal óbice pode ser também ligado ao questionamento posterior, onde $60,2 \%$ dos discentes afirmaram ter tido dificuldade para tirar dúvidas com o docente em pelo menos alguns momentos.

Gráfico 6 - Interação docente discente.

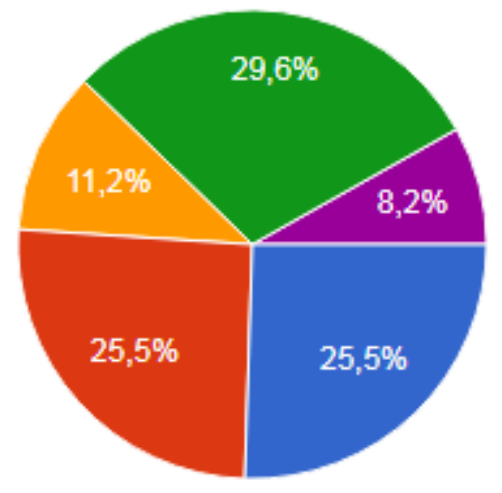

Discordo totalmente

Discordo parcialmente

Não sei

Concordo parcialmente

Concordo plenamente

Fonte: Próprios autores (2020)

Outro fator pertinente ao qual os discentes demonstraram suas opiniões foi acerca das exigências nas avaliações e atividades na modalidade EaD serem as mesmas que de forma presencial. Apesar das respostas variarem bastante, apenas uma pequena parcela de $18,4 \%$ concordou totalmente com a afirmação. Uma consequência desse modelo de ensino adotado pela universidade provisoriamente é a facilidade de acesso 
de discentes a consulta durante as avaliações e atividades, o que pode, evidentemente ter influenciado nesse tipo de resposta.

Há de se considerar ainda o fato de que muitos docentes readaptaram suas metodologias avaliativas de forma inesperada e rápida, fazendo com que o Semestre Suplementar Excepcional da UFERSA tenha sido também uma espécie de "teste" frente à necessidade futura de um novo semestre on-line durante a pandemia de covid-19.

Gráfico 7 - Exigências nas avaliações e atividades na modalidade EaD.

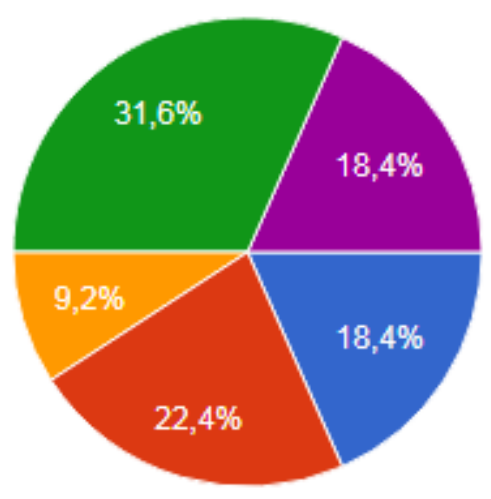

Discordo totalmente

Discordo parcialmente

Não sei

Concordo parcialmente

Concordo plenamente

Fonte: Próprios autores (2020)

Por fim, o questionário foi finalizado com a seguinte pergunta: você se matricularia novamente em um componente curricular com aulas remotas? Cujos resultados mostrados no gráfico 8 destacam que 83 discentes $(84,7 \%)$ matriculariam-se novamente caso a UFERSA adote novo semestre de Ensino a Distância. Apenas 15,3\% dos participantes, não realizariam nova matrícula em uma nova oferta de componentes curriculares no modelo adotado no semestre avaliado, resultado satisfatório, considerando as contraposições existentes.

Gráfico 8 - Possibilidade de matrícula em um novo semestre com aulas remotas.

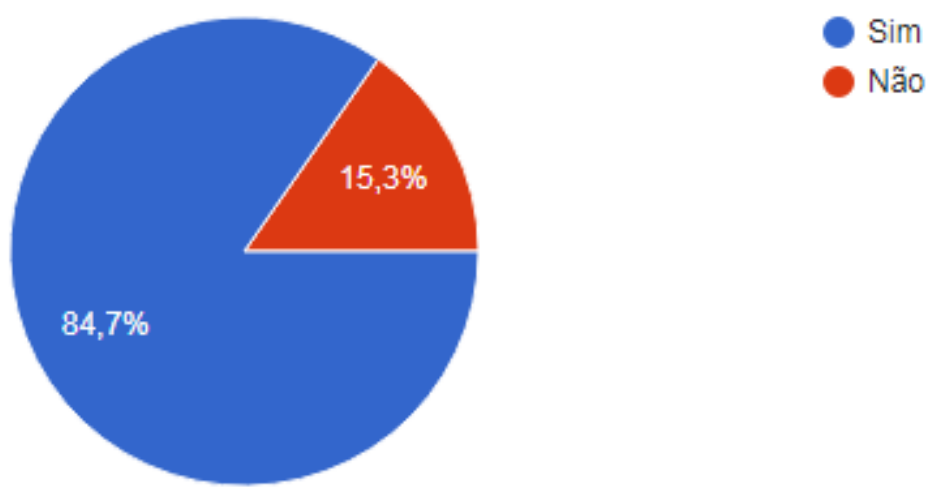

Fonte: Próprios autores (2020) 
Isso mostra que, apesar das adversidades de se cursar um semestre com aulas remotas para muitos tenha sido novidade, de forma inesperada e com alguns impasses a serem melhorados, ainda há presunção positiva sobre a modalidade que se tornou única opção diante da atual situação.

\section{CONSIDERAÇÕES FINAIS}

Levando-se em consideração os resultados obtidos com a pesquisa em questão, evidenciou-se que a modalidade de Ensino a Distância (EaD) contribuiu para a continuidade do ensino no país, freando os atrasos das instituições educacionais que não possuíam outra opção diante da impossibilidade de aulas presenciais.

Porém, uma consequência de se adotar metodologias com pouco tempo de planejamento para discentes, docentes e demais colaboradores da instiuição, bem como sem atender de forma satisfatória todo público universitário está no esperado aparecimento de adversidades e falhas previsíveis e outras imprevisíveis.

O Semestre Suplementar Excepcional da UFERSA, serviu também como experiência, visto que, por não ser obrigatório e sendo também um semestre extra, foi tido como teste para o semestre 2020.1 que ocorrerá também de forma remota. Frente a isso, este estudo alcançou os objetivos propostos e é capaz de motivar mudanças e questionamentos para que esta modalidade possa suprir as necessidades dos discentes e docentes que participarem novamente um semestre com aulas a distância de maneira mais eficaz.

\section{REFERÊNCIAS}

ARBIX, GLAUCO. Ciência e Tecnologia em um mundo de ponta-cabeça. Estud. av., São Paulo, v. 34, n. 99, pág. 65-76, ago. de 2020. Disponível em: http://www.scielo.br/scielo.php?script=sci_arttext\&pid=S0103$40142020000200065 \&$ lng=en\&nrm=iso. Acesso em 12 de ago. de 2020.

ATIÉ, Lourdes. Prática docente: 30 depoimentos sobre como a escola foi recebida em casa. Desafios da Educação. Mai. de 2020. Disponível em: https://desafiosdaeducacao.grupoa.com.br/depoimentos-sobre-escola-emcasa/. Acesso em: 17 de ago. de 2020.

DIAS, Érika; PINTO, Fátima Cunha Ferreira. A Educação e a Covid-19. Ensaio: aval.pol.públ.Educ., Rio de Janeiro, v. 28, n. 108, pág. 545-554, set. de 2020. 
Disponível em: http://www.scielo.br/scielo.php?script=sci_arttext\&pid=S010440362020000300545\&lng=en\&nrm=iso. Acesso em: 10 de ago. de 2020.

FRANCO, Maria Amélia do Rosario Santoro. Prática pedagógica e docência: um olhar a partir da epistemologia do conceito. Rev. Bras. Estud. Pedagog., Brasília, v. 97, n. 247, p. 534-551, dez. de 2016 . Disponível em: http://www.scielo.br/scielo.php?script=sci_arttext\&pid=S217666812016000300534\&lng=pt\&nrm=iso. Acesso em: em 13 de ago. de 2020.

LAKATOS, E. M.; MARCONI, M. A. Fundamentos de metodologia científica. 5. ed. São Paulo: Atlas, 2003.

LÉVY, Pierre. Cibercultura. São Paulo: Editora 34, 1999.

LIMA, Claudio Márcio Amaral de Oliveira. Informações sobre o novo coronavírus (COVID-19). Radiol Bras, São Paulo, v. 53, n. 2, pág. 5-6, abril de 2020. Disponível em: $\quad$ http://www.scielo.br/scielo.php?script=sci_arttext\&pid=S0100$39842020000200001 \&$ Ing=en\&nrm=iso. Acesso em: 13 de ago. de 2020.

PRODANOV, C. C.; FREITAS, E. C. Metodologia do Trabalho Científico: Métodos e Técnicas da Pesquisa e do Trabalho Acadêmico. 2. ed. Novo Hamburgo: Feevale, 2013.

UNESCO. A Comissão Futuros da Educação da UNESCO apela ao planejamento antecipado contra o aumento das desigualdades após a COVID-19. Paris: UNESCO, 16 abr. de 2020. Disponível em: https://pt.unesco.org/news/comissao-futuros-da-educacao-da-unescoapela-ao-planejamento- antecipado-o-aumento-das. Acesso em: 4 ago. de 2020.

OMS. Perguntas e Respostas sobre coronavírus (COVID-19). Brasil: OMS, 17 de abr. de 2020. Disponível em: https://www.who.int/emergencies/diseases/novelcoronavirus-2019/question-and-answers-hub/q-a-detail/q-acoronaviruses\#: :text=symptoms. Acesso em: 7 de ago. de 2020. 
ANEXO - QUESTIONÁRIO PARA DISCENTES DA UNIVERSIDADE FEDERAL RURAL DO SEMI-ÁRIDO QUE CURSARAM O SEMESTRE SUPLEMENTAR EXCEPCIONAL 2020.3

1. Qual seu gênero?

( ) Feminino ( ) Masculino ( ) Prefiro não dizer ( ) Outro. Qual?

2. Selecione sua renda mensal familiar:

( ) Até um salário mínino

( ) De um a dois salários mínimos

( ) De dois a três salários mínimos

( ) De quatro a cinco salários mínimos

( ) Mais de cinco salários mínimos

3. Você participou de aulas na modalidade EaD (Ensino a distância) na Universidade Federal Rural do Semi-Árido - Centro Multidisciplinar de Pau dos Ferros/RN, no semestre 2020.3?

( ) Sim ( ) Não

4. Você se matriculou em quantos componentes curriculares no semestre 2020.3 da UFERSA - CMPDF?

( ) 1 ( ) 2

5. Você fez trancamento de algum componente curricular? (Se sim, responder a questão 6, se não, seguir para a questão 7).

( ) $\operatorname{Sim}($ ) Não

6. Se trancou alguma disciplina, qual(is) motivo(s) influenciou(aram) o trancamento?

( ) Problemas com acesso à internet

( ) Dificuldade na compreensão

( ) Sobrecarga

( ) Outro. Qual(is)?

7. Você concorda que as aulas a distância são uma alternativa viável para o ensinoaprendizagem na UFERSA em tempos de pandemia?

( ) Concordo totalmente

( ) Concordo parcialmente

( ) Não sei

( ) Discordo parcialmente

( ) Discordo plenamente

8. Qual seu nível de satisfação com as aulas realizadas de forma remota?

( ) Ótimo

( ) Bom

( ) Regular

( ) Ruim

( ) Péssimo

9. Você concorda que as aulas à distância conseguiram trazer conhecimentos relevantes para o seu aprendizado?

( ) Concordo totalmente

( ) Concordo parcialmente

( ) Não sei

( ) Discordo parcialmente

( ) Discordo plenamente 
10. Qual seu rendimento no(s) componente(s) curricular(es) estudado(s) no período 2020.3?
( ) Ótimo
( ) Bom
( ) Regular
( ) Ruim
( ) Péssimo

11. Você teve dificuldades para estudar em casa no período 2020.3?

( ) Sim, sempre ( ) Em alguns momentos ( )Não

12. Qual(is) dificuldade(s) você mais encontrou ao estudar em casa nesse período suplementar?

( ) Barulho

( ) Aparecimento de afazeres domésticos

( ) Dificuldade em ler na tela do computador/celular

( ) Dificuldade com os recursos tecnológicos

( ) Carga horária semanal elevada

( ) Outro. Qual(is)?

13. A internet foi um fator limitante para o estudo, realização de provas e/ou assistir aulas?

( ) Sim, sempre ( ) Em alguns momentos ( )Não

14. A falta de espaço apropriado para estudar foi um fator limitante para o seu rendimento acadêmico no período remoto?

( ) Sim, sempre ( ) Em alguns momentos ( )Não

15. Você concorda que a interação docente-discente foi a mesma que em semestres presenciais?

( ) Concordo totalmente

( ) Concordo parcialmente

( ) Não sei

( ) Discordo parcialmente

( ) Discordo plenamente

16. Na sua concepção foi mais difícil tirar dúvidas com o(s) docente(es) de forma remota?

( ) Sim, sempre ( ) Em alguns momentos ( )Não

17. Você concorda que a exigência nas avaliações e atividades na modalidade EaD é igual à presencial?

( ) Concordo totalmente

( ) Concordo parcialmente

( ) Não sei

( ) Discordo parcialmente

( ) Discordo plenamente

18. Você se matricularia novamente em um componente curricular com aulas remotas?

( ) $\operatorname{Sim}($ ) Não 


\section{CAPÍTULO XXI}

\section{EDUCAÇÃO A DISTÂNCIA: QUAL O PAPEL DO TUTOR NESSE CENÁRIO?}

Walmir Fernandes Pereira'

${ }^{1}$ Mestrando em Tecnologias Emergentes em Educação - MUST University Flórida - EUA.

\section{RESUMO}

Este artigo propõe uma discussão acerca do papel da tutoria, na figura do tutor, identificando suas principais funções dentro da modalidade de cursos a distância. Aborda como acontece a mediação pedagógica online com o foco na aprendizagem do aluno. A partir dessa temática, foi realizado um estudo bibliográfico elencando os principais conceitos abordados e analisando pesquisas feitas no campo de atuação do tutor dentro do ciberespaço de aprendizagem.

Palavras-chave: Educação a distância, Tutoria, Mediação Pedagógica.

\section{INTRODUÇÃO}

O presente trabalho tem como tema a prática da tutoria, tendo com foco a importância do papel do tutor para cursos a distância $E$ frente a este assunto, trataremos da discussão de como se dá o papel do tutor, identificando quais são as suas principais funções dentro desta modalidade de ensino EAD. Abordaremos a temática e a importância da mediação pedagógica online.

Nesta perspectiva de pesquisa, estas são as questões que nortearam o trabalho:

- Qual o papel do Tutor dentro de um curso de modalidade EAD?

- Como deve ser a mediação pedagógica online com o aluno desta modalidade garantindo o foco na aprendizagem?

Primeiramente, pode-se dizer que a Educação a Distância (EAD) vem conquistando e recebendo destaque em nossa sociedade contemporânea, isso porque com o advento das tecnologias da informação e comunicação, podemos buscar atender às necessidades que antes dificultavam alguns setores. Um desses setores é o educacional, aonde a TIC vem auxiliando no processo de aprendizagem e formação de vários alunos, principalmente, dos que estudando em cursos a distância. 
As tecnologias, usadas no processo de ensino-aprendizagem, sozinhas, não vão garantir o sucesso necessário para as demandas as quais são destinadas. Precisamos da figura do Tutor, pessoa que auxiliará mediando o foco de aprendizagem dos alunos.

A figura do tutor é de fundamental importância, pois ele é um mediador do processo de aprendizagem dos alunos e é também, fundamental para criar situações que favoreçam à construção do conhecimento. Ele contribui com a sua boa atuação impulsionando um aluno a não desanimar no caminho dos estudos, atingindo os objetivos traçados pelo curso, mesmo em meio às dificuldades encontradas.

A mediação pedagógica surgiu no contexto da "Pedagogia Progressista", caracterizada por uma nova relação professor-aluno e pela formação de cidadãos participativos e preocupados com a transformação e o aperfeiçoamento da sociedade. $\mathrm{Na}$ década de 70, o sistema educacional brasileiro tinha uma abordagem de ensino conhecida como "Pedagogia Tecnicista", na qual cabia ao aluno assimilar passivamente os conteúdos transmitidos pelo professor.

Então podemos dizer que a mediação pedagógica está associada à atitude e ao comportamento do professor que se coloca como um facilitador, incentivador ou motivador da aprendizagem, de forma ativa colaborando para que o aprendiz chegue aos seus objetivos.

\section{METODOLOGIA}

Para a elaboração deste artigo foi feita uma pesquisa bibliográfica, numa abordagem qualitativa, com o objetivo de descrever seu processo e sua importância, bem como trazer uma revisão bibliográfica sobre a temática da prática com foco na importância do papel do tutor para cursos a distância.

Este trabalho visa olhar para o esclarecimento e a busca por uma definição clara sobre o tema, como deve ser o papel do tutor suas principais funções e como deve acontecer a mediação pedagógica on-line com o foco na aprendizagem do aluno de um curso EAD, estas questões buscam responder por meio de pesquisas qualitativas realizadas em bibliografias que tratam sobre o tema. 


\section{DESENVOLVIMENTO}

Vivemos, na Era digital, influenciados pelos aparatos tecnológicos e telemáticos dentro de vários setores de nossa sociedade, em especial no campo educacional. Hoje a tecnologia estabelece a base de nosso sistema social. Com a criação de recursos cada vez mais sofisticados, mexendo com as estruturas culturais do mundo todo, intervindo em práticas de ensino e aprendizagem.

Por meio dos avanços tecnológicos, a Educação a Distância (EAD) tem conquistado cada vez mais espaço no ambiente educacional, mas a EAD ainda é concebida como um assunto mais complexo no campo Educacional, pois como salienta Moraes (2003, p. 111) a educação a distância é uma questão bastante complexa, pois trata-se de analisar e avaliar a qualidade das relações sociais nos ambientes de aprendizagem mediados por alguma técnica.

Compreendendo uma essas complexidades, é importante ressaltar que na modalidade da Educação a Distância (EAD), há a distinção entre papéis de agentes fundamentais no processo educacional, figuras de professor e tutor. O tutor atua diretamente com os alunos, seja de modo presencial ou a distância, sanando suas dúvidas, avaliando-os, tentando identificar suas dificuldades e mediando o processo de ensino-aprendizagem.

De acordo com Nunes (2011) 'o tutor é visto como um professor, mas com características peculiares às necessidades da EaD'.

A tarefa do tutor é mais complexa dentro da EAD, pois dar uma explicação de forma presencial não vai requerer as mesmas habilidades que fazer isso por meio das TIC. Ele precisa conhecer outros recursos para interagir e mediar (texto, som, vídeo, fórum, chat, videoconferência etc.) para se fazer compreender pelos alunos.

Analisando o fazer do Tutor, sua função em meio aos cursos de educação a distância, se faz na mediação de todo o processo de aprendizagem do aluno.

Como salienta Pimentel (2003) “Ele deve promover a realização de atividades e apoiar sua resolução e não apenas mostrar a resposta certa; deve oferecer novas fontes de informação; deve entender o assunto ensinado e a organização do conteúdo; deve guiar orientar e apoiar". 
É importante entender que o papel do tutor é fundamental, pois o mesmo participa de forma ativa da prática pedagógica, do desenvolvimento dos processos de ensino e de aprendizagem para o acompanhamento e a avaliação do projeto pedagógico do curso no qual está inserido.

Dentre as funções de um tutor, temos a sua atuação como mediador, facilitador e incentivador no processo de aprendizagem individual e em grupo. Exige uma participação ativa na construção do conhecimento do aluno. E segundo PERRENOUD (2000) "é mais do que ensinar, trata-se de fazer aprender, concentrando-se na criação, na gestão e na regulação das situações de aprendizagem".

No contexto virtual de aprendizagem, faz-se necessário o papel do tutor que será o responsável por garantir a comunicação bidirecional entre tutor-aluno e alunoprofessor, comunicação que será importante para promover a construção de conhecimento. É necessário que o tutor faça o acompanhamento do desenvolvimento do aluno e possua habilidade e agilidade nas respostas e retornos de mensagens, dúvidas e esclarecimentos, interagindo assim, com os alunos.

De acordo com Silva (2001), interatividade é um conceito de comunicação, e não de informática, podendo ser empregado para significar a comunicação entre interlocutores humanos, entre humanos e máquinas entre usuário e serviço.

A interatividade dentro de um ambiente educacional depende mais da sensibilidade e interferência humana do que das ferramentas tecnológicas, por isso, o princípio da dialogicidade deve prevalecer nas ações do tutor de cursos de modalidade a distância.

A mediação pedagógica on-line tem o papel fundamental dentro desse contexto educacional de Educação 4.0 (TIC), Tecnologias de Informação e Comunicação, que como salienta Schnitman (2001) a incorporação dessas tecnologias aos modelos de EAD agregaram agilidade à emissão, à recepção e à distribuição de conteúdos e promoveram a interação entre os sujeitos envolvidos no processo de ensino e aprendizagem.

Podemos dizer que o entendimento que temos sobre mediação pedagógica online está associado ao processo comunicativo (a interatividade/ dialogicidade que o tutor exerce) proporcionado pelas TIC ou ao papel de mediador do professor/tutor do curso. 
Segundo Behrens (2000), o papel de mediador pedagógico pode ser desempenhado por qualquer participante de um curso online, vez que essa atitude e esse comportamento voltado para a facilitação e motivação podem ser desencadeados na relação entre os próprios alunos. Concordamos também com a ideia defendida por Mallman (2008) que a mediação pedagógica online perpassa pelos materiais didáticos produzidos no interior de uma equipe multidisciplinar, pelas interações entre os envolvidos na aprendizagem e também pela infraestrutura tecnológica e condições operacionais.

A mediação pedagógica pode ser vista através de uma ação de intervenção no aprendizado do sujeito, seja presencial ou online. Ação concretizada essencialmente pelo professor, por meio de signos e de instrumentos auxiliares que ajudaram na condução de alunos e professores na prática educativa.

A interação e mediação desse processo de ensino aprendizagem acontecem através dos AVA, ambiente virtual de aprendizagem, uma espécie de sala de aula virtual, que para Costa e Oliveira (2004, p. 118) são espaços das relações do saber, ambientes que favorecem a construção do conhecimento.

Esse espaço virtual auxiliará toda a mediação do tutor junto ao aluno, atendendo assim às necessidades, promovendo novas formas de diálogos e desenvolvendo o conhecimento.

Para Kensky (2003) o professor na sala de aula presencial tem o poder da "fala", enquanto no espaço virtual essa "fala" é substituída pelo diálogo e colaboração entre os membros do grupo.

Pode-se fundamentar também a mediação na visão sócio- interacionista de Vygotsky (2007) a aprendizagem e o desenvolvimento baseado não mais na ação direta do sujeito sobre o objeto (S-R), mas em uma ação mediada pelo outro, a qual ele intitula "elo intermediário".

Portanto, podemos dizer que na perspectiva de Vygotsky a mediação é um processo. Sabemos que o aprendizado vem de processos cognitivos, emocionais que são auxiliados, mediados e facilitados pelo papel do docente, seja na figura de professor/ tutor dentro de um ambiente de aprendizagem. 
E de acordo com Palloff e Pratt (2004) "Os alunos precisam entender sua responsabilidade na criação de uma comunidade de aprendizagem e a importância de sua interação".

\section{CONCLUSÃO}

Este artigo buscou mostrar através de uma pesquisa bibliográfica como se dá no meio virtual de aprendizagem o papel do tutor e suas principais atribuições, e como visto no desenvolvimento, faz-se muito necessário a figura do tutor, que mediará o aluno durante todo o processo de aprendizagem dentro de um curso na modalidade EAD.

Portanto, ao ler as bibliográficas já publicadas no meio acadêmico, por meio de artigos, livros e Tese de doutorado, podemos dizer que a mediação pedagógica online é a maior atribuição que um profissional de educação, no figura de um tutor, deve exercer em meio ao ambiente virtual de aprendizagem de um curso a distância. Ela auxiliará, ajudará a sanar as dificuldades, a motivar e fazer com que o processo de ensino e aprendizagem realmente se efetive.

\section{REFERÊNCIAS}

ANDRADE, Jaqueline B. F. de. A mediação da tutoria online: $O$ enlace que confere significado à aprendizagem. Dissertação (Mestrado) - UFC/UNOPAR, Salvador, 2007.

BEHRENS, Marilda Aparecida. O paradigma emergente e a prática pedagógica. Petrópolis - RJ: Vozes, 2005

BRASIL. Lei no 9.394, de 20 de dezembro de 1996. Disponível em: <http://portal.mec.gov.br/seed/arquivos/pdf/legislacao/refead1.pdf>. Acesso em: 24 ago. 2017. BRASIL. Presidência da República. Decreto n. 5.622, de 19 dezembro de 2005.2 Disponível em: $<$ http://www.planalto.gov.br/ccivil_03/_ato2004-

2006/2005/Decreto/D5622.htm>. Acesso em: 21 ago. 2017. BRASIL. Presidência da República. Decreto n. 5.800, de 08 de junho de 2006. Disponível em: < http://www.planalto.gov.br/ccivil_03/_ato2004-

2006/2006/decreto/d5800.htm>. Acesso em: 21 ago. 2017.

BRASIL. Ministério da Educação. Referenciais de Qualidade da Educação Superior a Distância de $2007 . \quad$ Disponível em: <http://portal.mec.gov.br/seed/arquivos/pdf/legislacao/refead1.pdf>. Acesso em: 24 ago. 2017. BRASIL. Presidência da República. Decreto no 9.057, de 25 de maio de 2017. Disponível em: < 
https://www.planalto.gov.br/ccivil_03/_Ato2015-

2018/2017/Decreto/D9057.htm\#art24>. Acesso em: 21 ago. 2017.

COSTA, J. W. da; OLIVEIRA, M. A. M. (Orgs). Novas linguagens e novas tecnologias educação e sociabilidade. Petrópolis, RJ: Vozes, 2004.

KENSKI, V. Tecnologias e Ensino Presencial e a Distância . Campinas, SP: Papirus, 2003.

MALLMANN, E. M. Mediação pedagógica em educação a distância: cartografia da performance docente no processo de elaboração de materiais didáticos. Tese de doutorado. Florianópolis: UFSC/CED/PPGE, 2008.

MEC/SEED - Ministério da Educação / Secretaria de Educação a Distância. Referenciais de qualidade para a educação superior a distância. Brasília, 2007. Disponível em: . Acesso em: 05 set. 2009.

MORAES, R. A. Educação a Distância: aspectos histórico-filosóficos . In: Linguagens e interatividade em Educação a Distância ed. Rio de Janeiro: DP\&A, 2003.

MOREIRA, M. Manual do Tutor - CEFOR. Belo Horizonte: PUC Minas Virtual, 2005.

NUNES, Vanessa Battestin. Avaliação da Tutoria na EAD. In: Tecnologias Computacionais e Práticas Educativas Inclusivas: perspectivas de trabalho em escolas e instituições acadêmicas. 1a ed. Curitiba: Editora CRV, 2011.

PALLOFF, R. M.; PRATT, K. O aluno virtual: um guia para trabalhar com estudantes on-line. Porto Alegre: Artmed, 2004.

PERRENOUD, P. Construindo Competências. Revista Fala Mestre!, 2000.

PIMENTEL, Nara Maria. Educação a distância. Florianópolis: SEAD/UFSC, 2003.

SILVA, M. Sala de aula interativa: a educação presencial e a distância em sintonia com a era digital e com a cidadania. In: Boletim Técnico do Senac, v. 27, n. 2, maio/ago. 2001. Disponível em:

SCHNITMAN, I. M. A mediação pedagógica e o sucesso de uma experiência educacional on- line. ETD - Educ. Tem. Dig., Campinas, v.12, n.esp., p.287-314, mar.

2011 - ISSN: 1676- 2592.

VYGOTSKY, L. S. A formação social da mente . 7. ed. São Paulo: Martins Fontes, 2007. 


\section{CAPÍTULO XXII}

\section{E-LEARNING E MOODLE: CONTRIBUIÇÕES PARA O PROCESSO DE ENSINO E APRENDIZAGEM}

Walmir Fernandes Pereira ${ }^{1}$

${ }^{1}$ Mestrando em Tecnologias Emergente em Educação - MUST University - Flórida - EUA

\section{RESUMO}

O presente artigo vai abordar a temática do E-learning, que é uma das várias formas de Formação a Distância. É um processo de aprendizagem que implica a separação de tempo e/ou local entre o formador e formando e é efetuada por meio do uso da internet ou intranet. Apresentará o Moodle, ambiente virtual de aprendizagem, que é um sistema de administração de atividades educativas destinado à criação de comunidades de aprendizagem online. Ressalta as características do Software livre e gratuito, Moodle, como as ferramentas e recursos promovem a interatividade entre professores e alunos e um exemplo de Instituição de Ensino Superior que utiliza o Moodle para viabilizar o e-learning em seus três cursos de pós-graduação oferecidos pelo Sistema UAB, Universidade Aberta do Brasil. Fez-se uso de uma pesquisa bibliográfica para a construção deste trabalho, utilizando o embasamento de artigos publicados em periódicos científicos. Concluindo assim que há muitas contribuições para o processo de ensino-aprendizagem a adoção do uso da metodologia do E-learning em conjunto com as ferramentas do Moodle.

Palavras-chave: E-learning. MOODLE. Ferramentas e Recursos Tecnológicos. Instituição de Ensino.

\section{INTRODUÇÃO}

O presente trabalho visa trazer contribuições para a discussão acerca do cenário do ensino a distância, onde é crucial repensar o papel dos docentes e das instituições de ensino. A adoção das Tecnologias como apoio no processo de ensino e aprendizagem é um recurso que não pode mais negar dentro das metodologias inseridas em cursos online e presenciais. O E-learning e o Moodle, um Software livre com suas ferramentas, recursos tecnológicos e um exemplo de uma Instituição de Ensino Superior que o adota em suas práticas de Ensino e aprendizagem são temáticas que este artigo vai discutir.

O E-learning é considerado uma poderosa ferramenta no processo de aprendizagem porque evoca novas tecnologias, considera os ritmos diferentes de aprendizagem de cada aluno e oportuniza nossos aprendizes com visões diferenciadas. 
Ele também está inserido no mercado de trabalho como uma ferramenta de treinamento, podendo transmitir um conteúdo específico para cada área da empresa, pois tem o custo reduzido.

O uso do E-learning aplica o potencial das tecnologias de informação e comunicação ao desenvolvimento da aprendizagem e da formação. É um processo personalizado, pois permite a flexibilidade nos termos de tempo e ação, formador e aluno não se encontram fisicamente no mesmo locas, porém estão ligados através da rede. A internet é o veículo que transmite os conteúdos educativos e é feito o acompanhamento pelo formador. A adoção dessa metodologia permite ao formando aprender no seu ritmo, desenvolver as competências individuais de que necessita, no tempo possível.

De acordo com Amaral e Leal (2006) o e-learning é um processo pelo qual, o aluno aprende através de conteúdos colocados no computador e, ou, Internet e em que o professor, se existir, está à distância utilizando a Internet como meio de comunicação (síncrono ou assíncrono), podendo existir sessões presenciais intermédias, sendo de cinco tipos diferentes de e-learning" ensino on-line assíncrono, ensino online com momentos assíncronos, ensino on-line misto (on-line e presencial), ensino on-line e ensino baseado em computador.

Há uma ferramenta, um recurso muito utilizado pelas Instituições de Ensino Superior na modalidade de Educação a Distância principalmente, e Presencial, que é o Moodle (Modular object-Oriented Dynamie Learning Environment) um ambiente virtual de aprendizagem (AVA) a distância que é regido pela GLP e desenvolvido inicialmente pelo australiano Martin Douglas no ano de 1999.

Este ambiente virtual de aprendizagem é um Software Livre, traduzindo é um programa gratuito que poder baixado, utilizado e modificado por qualquer pessoa no mundo todo. Ele foi desenvolvido sobre a perspectiva da teoria Construtivista Social, que defende a construção de ideias e conhecimentos coletivos de forma colaborativa, uns para os outros, criando assim uma cultura de compartilhamento de significados dentro das instituições de aprendizagem.

Para a construção deste trabalho foi utilizada a pesquisa bibliográfica, numa abordagem de uma revisão bibliográfica de livros, artigos de periódicos, revistas eletrônicas que abordam as temáticas de E-learning e do Moodle. Sendo que com essas 
pesquisas, busca-se esclarecer definições, características e a adoção de instituições que fazem o uso dessa metodologia e desse software no processo de ensino-aprendizagem de seus alunos.

\section{DESENVOLVIMENTO}

Como salienta Almeida (2003, p. 29) "ambiente virtuais de aprendizagem são sistemas computacionais disponíveis na internet que permitem integrar diferentes mídias, linguagens e recursos, apresentar informações, desenvolver interações, produzir e socializar produções, independente do tempo e do espaço de cada participante". Assim, como definido pelo autor é o Moodle, uma ferramenta didática online, que disponibiliza ao professor a escolha de recursos e ferramentas como: fóruns, chats, diários, dentre outras que se enquadram com os objetivos de aprendizagem pretendidos pelo professor durante a disciplina.

O espaço destinado a aprendizagem dentro deste software é colaborativo e dinâmico, pois promove o cooperativismo, a troca e compartilhamento de materiais, pesquisas, coletas, revisão de avaliações e tarefas entre colegas, a visualização do registro de notas no ensino a distância, parcialmente presencial e presencial.

Dentro de um ambiente virtual de aprendizagem é necessária a promoção da interação entre alunos e seus professores, segundo Silva (2006), valorizam-se a interação e troca de informações entre professor e aluno, no lugar da reprodução passiva de conteúdos utilizando a oratória.

Segundo Moran (2006, p. 41) "definir educação com uso da tecnologia on-line como conjunto de ações de ensino-aprendizagem desenvolvidas por meios telemáticos, como a internet."

Como o autor acima salienta o Moodle é a sala de aula on-line com suas interfaces, ferramentas e estruturas decisivas para a promoção da interatividade e da aprendizagem dos alunos.

O uso da internet é de fundamental importância dentro das instituições educacionais, sejam elas a distância, parcialmente presencial ou presencial, pois como Resende (2005) a internet é a ferramenta de potencial mediação do processo de ensino aprendizagem. Ela possibilita uma interatividade entre professor, aluno e tecnologia. 
O Moodle promove atividades exigem interações dialógico-problematizadoras, potencializando a aprendizagem no âmbito da formação pessoal e profissional. Parafraseando Freire (1997) a colaboração, a união e a organização são umas das principais características da ação dialógica. Há também nesse processo dialógico o desenvolvimento do senso colaborativo, que agrega valor e enriquece o grupo gerando a aprendizagem.

Uma característica do Moodle de precisa-se ressaltar é o papel da aprendizagem ativa, onde o aluno passa a ser responsável pela aquisição de seu conhecimento, desenvolve a autonomia, perseverança, domínio de leitura e interpretação, ou seja, formando-se numa autodidata.

Alguns recursos que podem ser encontrados no Moodle, sendo AVA, Ambiente Virtual de Aprendizagem: chat, fórum, mensagem, workshop (oficina de trabalho) e Wiki (Coleção de documentos em hipertexto). Ele cria comunidades on-line, sua proposta é "aprender em colaboração", usando o ambiente virtual. É um espaço livre, aberto, gratuito, que pode ser distribuído e seus usuários também podem ser seus construtores, contribuindo para a sua melhoria.

A criação do Moodle nasceu do propósito de ajudar educadores a criar cursos on-line, tendo o foco na interação e na construção colaborativa de conteúdos. Seu ambiente virtual é um espaço para além de publicações de materiais, e sim com ferramentas e recursos que auxiliarão a aprendizagem.

Várias Instituições de Ensino Superior fazem o uso do Moodle, como por exemplo, a Unifesp, Universidade Federal de São Paulo, pelo Sistema UAB, Universidade Aberta do Brasil, nos cursos de Especialização a distância. Primeiramente, essas Universidades pesquisam as ferramentas e recursos que o ambiente virtual de aprendizagem pode disponibilizar para assim traçar os objetivos de aprendizagem que serão ofertados em seus cursos e utilizados por seus docentes.

A Universidade Federal de São Paulo adotou em três de seus cursos de pósgraduação: Especialização em Informática em Saúde (EIS), Especialização em Cuidado Pré-natal (CECPN) e em seu Mestrado Profissional em Ensino em Ciências da Saúde para a Região Norte do Brasil (Morte) a utilização do Moodle como ferramenta didática .

A Instituição de Ensino Superior, Unifesp, fez um estudo da classificação das ferramentas presentes por padrão no Moodle e estabeleceu seus objetivos 
pedagógicos, dividindo assim: para a Avaliação de Aprendizagem nos cursos escolheu estas ferramentas do ambiente virtual de aprendizagem: bancos de dados, enquete, exercícios, lição interativa, Hot Potatoes, pesquisa de avaliação, questionários, tarefa arquivo único, tarefa- arquivos múltiplos, tarefa- atividade off-line, tarefa- texto online, Workshop; para a Comunicação e Interação, as ferramentas: Chat, fórum; para a Criação de Conteúdo em Colaboração: Diário, Glossário, Lams, Wiki e para a transferência de Dados: Link para diretório, link para arquivo, Link para HTML, Link para TXT, Rótulo e Scorm.

O Moodle foi utilizado por estes cursos de pós-graduação da Unifesp como repositórios de materiais e transferências de informações por serem cursos na modalidade a distância. A Comunicação e interação ocorreram segundo a universidade, através das ferramentas citadas de interatividade entre alunos e professores.

A partir do uso do AVA como recurso para a promoção desses cursos na modalidade EAD, a pesquisa feita pela instituição de Ensino Superior que adotou suas ferramentas tecnológicas chegou a conclusão que o Moodle tem como foco a interação e a construção colaborativa de conhecimento, que suas propostas pedagógicas são Construtivistas, que disponibiliza ferramentas para a implantação de cursos e processos de formação baseados na pedagogia construtivista e voltados para a interação e que seus processos de ensino-aprendizagem estão alinhados com a proposta pedagógica que o curso desenvolver.

\section{CONSIDERAÇÕES FINAIS}

A educação virtual está cada vez mais próxima das escolas e das universidades, e o professor não pode mais estar alheio a mudanças tecnológicas. Precisa conhecer os suportes e as várias ferramentas do ensino on-line. $\mathrm{O}$ ambiente virtual de aprendizagem, AVA, com seus registros servem para oferecer referenciais de reflexão docente. $O$ uso das tecnologias no ensino on-line usada pelo professor tem como objetivo tornar a aprendizagem mais significativa.

O papel do docente no E-learning é de mediação da aprendizagem, de todo o processo de ensino. Ele analisa a postura do aluno, como aprende, e o que realmente tem aprendido no curso de modalidade EAD, através dos recursos e ferramentas do 
Moodle, a interatividade acontece de forma dialógica, mantendo o aluno como a tivo frente ao conteúdo da disciplina ofertada pela plataforma de ensino.

Pode-se observar com essa pesquisa que o Moodle é uma ferramenta didática largamente utilizada e que pode trazer muitas contribuições para as Instituições Acadêmicas que o adotam em seus projetos de ensino, ofertados através de curso presencial, parcialmente presencial e a distância. Ele contribui para o desenvolvimento acadêmico de seus usuários.

Como relatado no desenvolvimento do trabalho, Instituição que utilizam o software livre e gratuito, conhece ferramentas que proporcionam a facilidade de acesso à informação e à interação entre os usuários que fazem uso.

Portanto, conclui-se que o Moodle é sim uma ferramenta que deve ser adotada pelas Instituições de ensino e aprendizado, porque traz muitos benefícios para a comunidade acadêmica e deve ser disseminado pelo centros acadêmicos de Graduação e Pós-graduação com a finalidade de melhorar e facilitar o acesso à informação para um número maior de usuários.

\section{REFERÊNCIAS}

ALMEIDA, M. E. B. de. Educação a distância na internet: abordagens e contribuições dos ambientes digitais de aprendizagem, São Paulo, Educação e Pesquisa, 2003.

AMARAL, L. \& LEAL, D. «From Classroom Teaching to elearning: The way for a strong definition», C.a.I. WMSCI - World MultiConference on Systemics, 2006.

FREIRE, P. Pedagogia da Autonomia: Saberes necessário à prática educativa. São Paulo, Paz e Terra, 1997.

LUCENA, C. J. P., \& Fuks H. Professores e Aprendizes na Web: A Educação na Era da Internet, Rio de Janeiro, Editora Clube do Futuro, 2000.

MORAN, J. M(1994). Novos Caminhos no Ensino a Distância. Centro de Educação a Distância (CEAD), Rio de Janeiro, SENAI.

RESENDE, R. S.(2005). Fundamentos teórico-pedagógicos para EAD. In: Congresso Internacional de Educação a Distância, 12. Florianópolis: Anais eletrônicos do Congresso Internacional de Educação a Distância.

SAMPAIO, M. N.; LEITE, L. S (1999). Alfabetização tecnológica do professor. Petrópolis, Vozes. 
SILVA, M(2006). Criar e professorar um curso on-line: relato de experiência. In: SILVA, M. (Org.). Educação on-line: teorias, práticas, legislação e formação corporativa. 2.ed. São Paulo, Loyola.

VALENTE, J. A (2005). Pesquisa, comunicação e aprendizagem com o computador: o papel do computador no processo ensino aprendizagem. In: ALMEIDA, M. E. B. de; MORAN, J. M. (Org.). Integração das tecnologias na educação: salto para o futuro. Brasília, Ministério da Educação, p.22-31. 


\title{
CAPÍTULO XXIII
}

\section{MULTICULTURALISMO PEDAGÓGICO NA ESCOLA: RE-SIGNIFICAÇÃO PARA UMA NÃO HOMOGENEIZAÇÃO}

\author{
Maria Aparecida Silva Bezerra ${ }^{1}$ \\ José Cândido Rodrigues Neto ${ }^{2}$
}

${ }^{1}$ Graduada em Filosofia - UEPB.

${ }^{2}$ Mestre em Literatura e Interculturalidade pela Universidade Estadual da Paraíba - UEPB.

\section{RESUMO}

Há muito têm se falado de diversidade e da importância de sua valorização, respeito e etc. Mas até que ponto o diálogo do multiculturalismo consegue adentrar nas diferenças? O multiculturalismo cumpre mesmo um papel de discussão dentro das culturas ou se sobressai na superfície de suas problemáticas? As escolas têm proporcionado debates ou têm apenas tratado das diferenças como "folclóricas" e "exóticas"? Vale destacar que o presente artigo não se envereda pela via da moralidade, mas trata antes de discutir a forma como o multiculturalismo têm sido abordado nas escolas, através de revisão de literatura de autores que se debruçaram ao tema. 0 presente estudo visa então trazer a tona uma problematização acerca do diálogo proposto através do tema multiculturalismo, bem como possibilitar uma reflexão a fim de possibilitar um outro olhar ao tema e consequentemente uma ressignificação de práticas pedagógicas.

Palavras-chave: Multiculturalismo. Escola. Ressignificação.

\section{INTRODUÇÃO}

O currículo escolar, em suas últimas atualizações, vem abrindo espaço para conhecimentos e temáticas que até então pareciam ser "eletivas" ao ensino. O ensino de história e cultura afro e indígena, por exemplo, foi incluído no currículo há muito pouco tempo, tendo em vista que tais culturas são inerentes da história do Brasil. Mesmo assim, são temáticas e estudos que encontram ainda muitas resistências quando se trata de respeito, aceitação e problematização.

O ponto alto dessas resistências se tratam de metodologias, estudos e préconceitos que ainda sondam o imaginário das pessoas, acerca do que viria a ser um estudo mais demorado dessas culturas. Não obstante, o tema que engloba essas culturas, carrega já em si uma gama de problemáticas que foram sendo agregadas a ele, 
a partir de metodologias desfalcadas e não problematizadas, que acabaram gerando uma imagem superficial daquilo que têm grande potencial de ser um aliado a desmistificação dessas culturas: o multiculturalismo.

O tema do multiculturalismo possui terrenos nas quais deve-se ter o cuidado ao pisar. Falar em multiculturalismo é falar não só em culturas, mas também em costumes, tradições, modos de viver, e suas respectivas relações e conflitos, na qual é intrínseco a vidas que comungam dessas culturas, não podendo assim separar tema de vidas envolvidas em tais discussões.

Por isso, o tema do multiculturalismo torna-se delicado, pois, em uma abordagem honesta, o assunto se aprofunda nas problematizações que ocorrem nos interiores dessas culturas. No entanto, muitas vezes, o tema é tratado como mero componente curricular e de forma superficial, tornando-o, assim, mais um tema que atravessa apenas o currículo e que é desenvolvido sob uma ótica normatizadora, técnica e homogênea.

Falar em outras culturas é delicado no tocante aos diversos "lugares de fala" que são intrínsecos às próprias culturas, ou seja, falar de fora dessas culturas já traz aqui um olhar alheio das dinâmicas internas dos grupos, culturas, sociedades.

O presente estudo não objetiva, no entanto, falar "por" outras culturas, mas sim falar "sobre", em um apanhado mais teórico do que pragmático. Na verdade, a discussão que se segue se propõe não só a falar sobre, mas, mais do que isso, se presta ao que não é dito, o que é silenciado, dessas culturas, em campos externos, em especial aqui: ao campo da escola.

\section{O QUE É MULTICULTURALISMO}

Multiculturalismo se apresenta de forma polissêmica e com nomes polissêmicos, como afirma Candau (2008). O tema do multiculturalismo se relaciona com uma gama de interligações nas quais um artigo não consegue dar conta de sua complexidade. 0 multiculturalismo é polissêmico também porque se guia entre várias vertentes e teorias, sendo alvo constante de debates e muitas vezes da fala destes.

O multiculturalismo surgiu decorrente de movimentos de lutas e resistência de povos que sofreram tentativas de silenciamento de suas culturas, bem como a imposição de padrões culturais dominantes a serem seguidos. Dentre os objetivos do 
multiculturalismo, o respeito a raça e aos costumes, ou seja, a diversidade étnica, foi o estopim de toda a mobilização em prol do respeito às diversas culturas discriminadas e marginalizadas.

Grande parte dos teóricos que se dedicaram ao estudo da cultura afirma que a iniciação do multiculturalismo tenha se dado nos Estados Unidos, mediante reivindicações, em grande parte, da cultura negra.

Os movimentos ocorridos a partir daí contam com a contribuição de professores, estudantes, teóricos, entre outros, que passaram a trazer à luz estudos e reflexões sobre racismo, homogeneização guiada pela cultura branca e consequentemente o silenciamento da cultura negra, em seus costumes, tradições, e etc. A partir de um apanhado histórico, Vieira (2011) reflete:

\begin{abstract}
A partir dos anos 70 , há um relativo avanço nas lutas multiculturalistas, à proporção que os Estados Unidos instituem, à custa das pressões populares, políticas públicas em todas as esferas de poder público, visando garantir igualdade de oportunidades educacionais, de integração e justiça social a grupos culturais diversos, tais como os não-brancos, do sexo feminino, deficientes, alunos(as) de baixa renda etc. Nos anos 80 e, especialmente, nos anos 90, são fortalecidos os estudos sobre o multiculturalismo em decorrência da ampliação da influência dos estudos sobre as diferentes culturas no discurso curricular, que valoriza o hibridismo, a pluralidade e as diferenças culturais. (VIEIRA, 2011)
\end{abstract}

A partir da citação acima é evidente que os estudos do tema foram de mister importância para que os movimentos e o debate acertam do multiculturalismo pudessem ocorrer. Através do debruçamento sobre o tema, estudantes, ouvintes, entre outros, puderam ter mais clareza sobre as teias invisíveis que perpassavam o tema e consequentemente se mobilizarem para uma reivindicação de seus direitos, que muitas vezes foram tidos como "não - direito" aos negros, pobres e marginalizados. Foi a partir de um olhar demorado para as questões que segregavam pessoas e propiciavam privilégio de outras, que as primeiras manifestações puderam ocorrer.

O multiculturalismo chega ao Brasil também nas primeiras décadas do século XX e causa repercussão na esfera do poder público, na medida em que exige, direta ou indiretamente, medidas e políticas públicas que possam garantir, em maior parte aos negros e afrodescendentes, a valorização e o respeito às culturas. A luta de início foi travada, em sua maior parte, pela comunidade negra. Porém, com o passar dos anos e o debate emergente sobre as muitas culturas e a importância de um rompimento com 
práticas homogeneizadoras, outras minorias passaram também a fazer parte das reivindicações: mulheres, pobres, etc.

Em suma, é notória a importância das minorias que passam a se mobilizar e reivindicar por direitos fundamentais na sociedade. A constituição parece não alcançar esta parcela da sociedade que vive a mercê de uma constituição frequentemente ignorada. As vozes das minorias serviram não só para dar relevância as urgências de direitos, como também suscitaram por um discurso que fosse capaz de dialogar com todos, sem distinção.

Toda essa urgência por um discurso que pudesse abarcar a dimensão e a complexidade de vários modos de vida deram oportunidade de fazer com que o que conhecemos hoje por multiculturalismo pudesse então fincar suas raízes em terrenos mais férteis. O debate do multiculturalismo surge não só como consequência da reivindicação por direitos e respeito às culturas, mas parece estar imbricado também em uma urgência de se dialogar com essas culturas e entender como ocorre os processos pelas quais as culturas se definem e se apresentam como tais.

Porém o Multiculturalismo não se firmou em apenas um modo de ser. Devido a sua abrangência, complexidade e também movido por interesses e individualidades de diversos grupos, o multiculturalismo se divide então em vertentes, nas quais dialogam sob viés e campos de atuação específicos. É o que será tratado a seguir.

\section{VERTENTES DO MULTICULTURALISMO}

Sendo o multiculturalismo polissêmico em seu objeto de estudo, a cultura, múltiplas são também as vertentes pelas quais, durante seu percurso, muitas abordagens se enveredaram. Para tratar das vertentes do multiculturalismo será aqui de grande ajuda a revisão de literatura de autores/pesquisadores do tema em questão.

Peter McLaren (1997) traz quatro vertentes fundamentais para entender o multiculturalismo e suas nuances, sendo elas: multiculturalismo conservador ou empresarial, multiculturalismo humanista liberal, multiculturalismo liberal de esquerda, multiculturalismo crítico e de resistência.

Através leitura de McLaren (1997), Vieira traz uma explanação sobre as vertentes multiculturais anteriormente citadas. A partir deste autor e do estudo realizado por Vieira (2011) apresenta-se então a característica destas. 


\subsection{Multiculturalismo conservador ou empresarial}

O multiculturalismo conservador ou empresarial reconhece a existência da polissemia cultural, em suas diversas culturas, grupos e etnias, porém não as legitima, utilizando-se então de prestigio em relação aos grupos mais favorecidos, inviabilizando a voz das minorias que estão ao seu redor. Consequentemente esta vertente produz uma ideia de objetificação de culturas, na medida em que as vê apenas pelo viés de sua utilidade, como foram vistas, por exemplo, afro-americanas, que "são representadas como escravos e escravas, como serviçais e como aqueles que divertem outros, visões que estiveram fundamentadas nas atitudes profundamente auto-elogiosas, autojustificatórias e profundamente imperialistas dos europeus e norte americanos" (McLaren: 1997, p. 111)

Sendo assim, na visão conservadora liberal/empresarial têm-se já uma instrumentalização da cultura, na medida em que seu rigor cultural é eliminado, se valendo apenas do teor laboral e técnico dessas culturas. Aqui, a identidade é silenciada para dar vez apenas ao utilitarismo.

\subsection{Multiculturalismo humanista liberal}

A vertente humanista liberal por sua vez trata todas as culturas e grupos como iguais, seja em suas potencialidades assim como nas chances de ascender no meio social. Nesta perspectiva, a cultura é tratada como um detalhe que pode ser ignorado, na medida em que se iguala todos os grupos, fazendo-se crer que as diferenças podem ser superadas (e eliminadas) em prol de um objetivo em comum: a inserção no mercado.

Claramente a vertente se envereda por caminhos liberais, consequentemente coloca as culturas e minorias em posição da meritocracia: há espaço para quem se esforçar. Desconsidera as dificuldades e conflitos existentes nos cernes das culturas e consequentemente a falta de oportunidades para estes grupos menos favorecidos.

\subsection{Multiculturalismo liberal de esquerda}

O multiculturalismo liberal de esquerda difere do de direita apenas no quesito do objeto de diferenciação. Aqui, a característica que será valorizada será a diferença. Nesta vertente, a diferença é o ponto alto da discussão, onde se deve dar as devidas relevâncias. 
A vertente em questão acaba caindo também no discurso falacioso da valorização cultural, pois apenas evidencia as diferenças, não as trabalhando em seus conflitos e suas consequências. A diferença aqui ganha um papel apassivador, da qual nada influenciaria em outros processos sociais.

\subsection{Multiculturalismo crítico e de resistência}

A vertente crítico e de resistência vê a cultura em sua multiplicidade e seus campos de conflitos e debates. Aqui a cultura não é homogeneizada, pois há um reconhecimento não só das diferenças que apassiva, mas também das diferenças que são conflituosas, bem como a importância das formações de identidade e diferença no seio das culturas. Na vertente em questão, as culturas não são apenas constituídas por suas diferenças meramente culturais, mas são também constituídas por todos os percalços e lutas que lhe são necessárias, bem como os diferentes grupos, minorias, raças, entre outras, que lhe constituem.

Aqui também a diversidade étnico-racial é abraçada e levada em diante, a fim de ser considerada em políticas públicas, sejam elas educacionais e para a sociedade em geral. Ao reconhecer as culturas, seus conflitos e desfavorecimentos a vertente crítico e de resistência possibilita a inserção de garantias necessárias às minorias e reforça o caráter, propriamente dito, de resistência à forças antagônicas de homogeneização.

\section{MULTICULTURALISMO NA ESCOLA}

Apesar da escola ser terreno privilegiado de formação e de discussões, a mesma parece ainda trabalhar sob o viés de uma homogeneização, reflexo da herança do ensino tradicional (ainda perceptível em algumas didáticas) e um currículo mecânico, voltado para as atividades técnicas. As escolas tendem a lidar com as diferenças de forma superficial e também padronizada; semana da pessoa com deficiência, semana do índio, dia da consciência negra, etc. Ao incluir tais temas no currículo e em dias específicos para tratar desses grupos étnicos e raciais, a escola acredita estar trabalhando bem as diferenças, quando, na verdade, está segregando e reforçando ainda mais o teor "exótico" e "folclórico" dessas minorias.

Muitas vezes as diferenças são interpretadas apenas como físicas e externas aos indivíduos. Candau (2011) traz à tona a importância das psicologias da educação no 
processo de aceitação e reconhecimento das diferenças, pois com as abordagens das teorias psicogenéticas na educação os diferentes ritmos de aprendizagem passaram a serem considerados, levando em consideração as potencialidades e as formas diferentes de desenvolvê-las. Porém, as teorias da psicologia na educação não abraçam ao todo a diversidade, em específico o conceito de diferença.

O conceito de diferença é bastante caro ao multiculturalismo pois é a partir do debate acerca de identidade e diferença que as imbricações do multiculturalismo passam a germinar de forma frutífera, ou seja, é na abordagem das significações do que viria a ser identidade e diferença que a temática em questão poderá se enveredar pelo caminho da criticidade e ressignificação. Porém, ainda em se tratando das teorias da psicologia trabalhadas na educação, é possível identificar uma limitação ao tema da diferença, pois O conceito de diferença "Nesta perspectiva, o termo diferença está em geral referido às características físicas, sensoriais, cognitivas e emocionais que particularizam e definem cada indivíduo." (CANDAU, 2011, P.4). ou seja, diferença aqui se trata de uma análise restrita do campo psicológico de cada indivíduo. Ainda sob a ótica de Candau (2011), pode-se constatar que:

\footnotetext{
Certamente estas tendências apresentam contribuições significativas para o desenvolvimento de processos de ensino-aprendizagem mais sensíveis às características peculiares de cada aluno/a. No entanto, a fato de se centrarem exclusivamente nos aspectos individuais de caráter psicoafetivo e, em algumas vertentes como na baseada no behaviorismo, de modo muito redutivo, têm como base uma concepção de sujeito da aprendizagem muito limitada, não considerando dimensões como a sócio-histórica e cultural, que são praticamente ignoradas. (CANDAU, 2011, P. 4)
}

Dessa forma, as teorias psicogenéticas abordam a diferença de modo isolado, dentro de sua área de estudo, dando relevância apenas as formas com as quais o cérebro aprende e apreende conteúdo. Não se trata de apontar a psicologia como uma área menos importante, mas sim de entender suas limitações enquanto área que dialoga diretamente com a educação. Ou seja, como já citado por Candau, a psicologia não possibilita o diálogo ao multiculturalismo na medida em que não adentra nas construções históricas dos indivíduos; sua origem, seus conflitos, o meio em que vive e como isso resulta na educação e/ou até mesmo na não-educação. 
Diante de toda a discussão acerca das vertentes do multiculturalismo e das tentativas deste chegar a escola, como diálogo embasado em pressupostos consideráveis, se tem percebido que a escola ainda está longe de ser este lugar de abertura ao multicultural. Apesar de todos os passos relevantes que foram dados, seja em políticas públicas de inclusão, leis e emendas, currículos etc. Parece ainda haver uma resistência da educação de trabalhar, de fato, as imbricações multiculturais.

Trabalhar em uma perspectiva multicultural é hoje os desafios enfrentados pela escola, pois na medida em que a globalização segue em ritmo frenético, as culturas e suas simbioses também sofrem e provocam alterações. O horizonte educacional, em particular a escola, torna-se assim ambiente propício para que os indivíduos possam terem uma visão mais ampla do que os cerca, inclusive o que permanece em invisibilidades e silenciamentos.

A escola, enquanto formadora de indivíduos, assume grande responsabilidade não só de iniciar novos conhecimentos, mas também de romper com tradições que não permitem problematizar o lugar do outro.

Como bem aponta Canen (2007)

os problemas que se apresentam, particularmente na área educacional, no mundo complexo e contemporâneo, não podem reduzir-se a olhares que se fecham em campos disciplinares de fronteiras rígidas, mas, ao contrário, exigem respostas elas próprias complexas, mestiças, híbridas, que atravessam tais fronteiras, construindo redes que desafiam noções essencialistas de cientificidade. No caso do multiculturalismo, em que o objeto por excelência é o desafio a preconceitos, a visões essencializadas e homogeneizadas das identidades e das diferenças e a discursos que as constroem, no âmbito das relações sociais e educacionais, certamente sínteses criativas a partir de olhares plurais só têm a contribuir no caminho da construção de alternativas educacionais propiciadoras da formação de gerações abertas à diversidade cultural, e desafiadoras de congelamentos identitários e preconceitos. (CANEN, 2007, P.101)

Cabe a escola não só reconhecer as identidades e diferenças das quais the são constituintes, é preciso, em se tratado de lidar com o multicultural, que as fronteiras sejam ultrapassadas, pois se manter fixo em lugares privilegiados para adentrar outras culturas é também se manter no superficial e na identidade engessada de categorias 
eternizadas pelo ensino tradicional. É preciso romper com a ideia de índio folclórico, negro escravizado, etc.

O multiculturalismo tem se tornado um discurso ineficiente por consequência de modos e interpretações e tentativas defasadas de trabalhar o multicultural.

É de suma importância que as escolas passem a descongelar essas identidades de seu aspecto "exótico", pois só a partir de uma discussão que leve em conta não só as identidades aparentes, mas também as diferenças e principalmente os conflitos, diálogos, linguagens, das quais as culturas são constituintes, para que se possa, de fato, falar em multiculturalismo.

\section{CONSIDERAÇÕES FINAIS}

Perante a discussão acima elencada, conclui-se que o multiculturalismo, apesar de toda sua herança defasada, é ainda uma oportunidade de problematizar e dialogar a respeito do lugar do ouro, em especial, sua cultura. $O$ trabalho em questão não se ateve a tomar lugar de fala, mas sim, se propôs a um diálogo entre uma abordagem multicultural, suas vertentes que o identificam e o lugar deste nas instituições de ensino. Adentrar no terreno do multiculturalismo não é tarefa fácil, pois seria preciso muito mais estudos e comprovações para lidar com sua complexidade. Diante de toda a discussão acerca das vertentes do multiculturalismo e das tentativas deste chegar a escola, como diálogo embasado em pressupostos consideráveis, se tem percebido que a escola ainda está longe de ser este lugar de abertura ao multicultural. Porém, se faz de suma importância que o diálogo continue em aberto para que as tendências superficiais possam serem superadas e darem lugar a ressignificações, sejam elas no cultural, social, e em especial, na escola. É de suma importância que as escolas passem a descongelar essas identidades de seu aspecto "exótico", pois só a partir de uma discussão que leve em conta não só as identidades aparentes, mas também as diferenças e principalmente os conflitos, diálogos, linguagens, das quais as culturas são constituintes, para que se possa, de fato, falar em multiculturalismo. 


\section{REFERÊNCIAS}

CANDAU, V.M.F. Sociedade, educação e cultura(s): Questões e propostas. 2 ed. Petrópolis, RJ: Vozes, 2008a.

CANDAU, Vera M.F. Diferenças culturais, cotidiano escolar e práticas pedagógicas. Currículo sem fronteiras. v.11, n.2, p 240-255, Jul/Dez 2011.

CANEN, Ana. O multiculturalismo e seus dilemas: implicações na educação. Comunicação\&política. Rio de Janeiro, v.n.25 p.96-107, Jan, 2007.

CANEN, Ana. Sentidos e dilemas do multiculturalismo: desafios curriculares para o novo milênio. In: MACEDO, Elizabeth, LOPES, Alice Casimiro. Currículo: debates contemporâneos. São Paulo: Cortez, 2010.

HALL, S. A Identidade Cultural na Pós-modernidade. 11a ed. Rio de Janeiro: DP\&A, 2006.

MCLAREN, P. Multiculturalismo Crítico. São Paulo: Cortez, 1997

MOREIRA, A.F.; CÂMARA, M. J. Reflexões sobre o currículo e identidade: implicações para a prática pedagógica. In: Moreira, A. F. e Candau, V.M.F. (org.). Multiculturalismo: diferenças culturais e práticas pedagógicas. Petrópolis-RJ: Vozes, 2008. P. 38-66

PEREZ GÓMEZ, A.I. A cultura escolar na sociedade neoliberal. Porto Alegre: Artes Médicas, 2001.

VIEIRA, Diana. Educação de Jovens e Adultos e Pluralidade Cultural: a realidade de um Colégio Supletivo de Ensino Médio. 2011. 147 p. (Mestrado em Educação) Pontifícia Universidade Católica do Rio de Janeiro,2011. 


\title{
CAPÍTULO XXIV
}

\section{O PAPEL LIBERTADOR DA EDUCAÇÃO FRENTE A CRIMINALIZAÇÃO DA CULTURA PERIFÉRICA}

\author{
Felipe de Araujo Chersoni ${ }^{1}$ \\ Giovanna Botini Zortea ${ }^{2}$ \\ Elcio João Gonçalves Moreira ${ }^{3}$
}

\begin{abstract}
${ }^{1}$ Pós-graduando em Direitos Humanos pela Faculdade Cidade Verde - UniFCV. Pós-graduando em Direito Penal pela Universidade Leonardo da Vinci - Uniasselvi. Graduado em Direito pelo Centro Universitário de Maringá UniCesumar. Advogado.

2 Pós-graduanda em Direitos Humanos pela Faculdade Cidade Verde - UniFCV. Pós graduanda em Psicoterapia e Orientação Psicanalítica pelo Centro Universitário de Maringá - UniCesumar. Graduada em Psicologia pelo Centro Universitário de Maringá - UniCesumar. Psicóloga clínica e social.

${ }^{3}$ Mestrando do Programa de Pós-Graduação em Ciências Jurídicas no Centro Universitário de Maringá - UniCesumar. Bolsista do Programa de Suporte à Pós-Graduação de Instituições de Ensino Particulares (PROSUP/Capes). Graduado em Direito pelo Centro Universitário de Maringá - UniCesumar. Graduado em Ciências Sociais pela Universidade Estadual de Maringá - UEM. Membro do Grupo de Pesquisa Reconhecimento e Garantia dos Direitos da Personalidade. Professor da Rede Pública do Estado do Paraná.
\end{abstract}

\section{RESUMO}

Este trabalho procura demonstrar como o Estado, em toda sua construção histórica, articulou políticas para segregar as populações que fogem dos padrões eurocêntricos, em especial os povos africanos. Como metodologia, parte-se de uma investigação bibliográfica que elucida os processos de criminalização da cultura e juventude periférica. Revelou-se que diversos mecanismos legais foram utilizados como meio de otimizar tal segregação, como é o caso da criminalização da capoeira, maconha e até mesmo de algumas vertentes musicais. Sendo assim, observa-se que a subjetividade de tais sujeitos é extremamente desprezada pelo aparato punitivo e, neste viés, busca-se resgatar o papel libertador da educação e da arte, como agentes de acolhimento e valorização cultural.

Palavras-chave: Punição. Periferia. Arte. Educação reflexiva.

\section{INTRODUÇÃO}

Fazendo um resgate histórico da construção de políticas públicas voltadas para pessoas libertas da escravidão, trazemos um recorte sobre os aspectos culturais, sociais e subjetivos que nortearam este processo, buscando compreender como se deu o direito ao lazer e à expressão cultural. Neste viés, portanto, observa-se que além de não existirem políticas públicas eficientes para acolher determinados grupos sociais, o 
estado, utilizando-se de aparatos legais, como é o exemplo de legislações e normativas vigentes, produziu um efeito contrário, pois passou a segregar ainda mais estes grupos.

Uma forte imposição cultural se deu desde quando as pessoas escravizadas chegaram do continente africano como, por exemplo, a proibição de falarem sua própria língua e os dialetos advindos de seus ancestrais, bem como, a proibição ao exercício da religião, dentre outras medidas.

Embora estas questões pareçam ser arcaicas ou pertencerem a um momento histórico remoto, seus efeitos estão a todo momento presentes na sociedade, tendo em vista que há hoje um superencarceramento da população negra e uma política de segurança, que usa de uma ordem adversa daquela que seria a coerente em um estado democrático, que é o uso da violência e do poder, ambos problemas estruturais.

Tendo em vista que a Educação tem como função o desenvolvimento intelectual e também afetivo de cidadãos éticos, criativos e socialmente comprometidos, levantase a hipótese de que uma formação escolar efetivamente emancipadora, pautada na valorização cultural, pode ser uma aliada no enfrentamento a este sistema penal que há muito tempo vem punindo o lazer periférico.

Assim, o presente artigo teve como objetivo analisar as questões acima pontuadas, bem como analisar como o estado atua diante destas questões. Para tanto, a pesquisa utilizou o método hipotético-dedutivo, fundamentado em pesquisa e revisão bibliográfica de obras, artigos, legislação, doutrina e jurisprudência aplicáveis ao caso.

\section{REVISÃO BIBLIOGRÁFICA}

\subsection{Criminalização da Capoeira}

A capoeira é considerada uma expressão cultural brasileira que carrega consigo parte da história de um país. Contudo, ela nem sempre foi vista como uma expressão cultural, haja vista que, para Netto $(2018$, p. 1) a capoeira passou por um processo de criminalização, pois está ligada a um determinado público, que não era bem visto socialmente. Esse processo também ocorre com a cultura de periferia, mas diante da importância que a capoeira possui, no ano de 2008 ela veio a ser reconhecida como patrimônio imaterial da cultura brasileira. 
Para compreender como se deu estes acontecimentos, é imprescindível resgatar a própria construção histórica do Brasil. Com a chegada das caravanas portuguesas, que fora nomeada de "descobrimento do Brasil", ocorreu um processo de escravização indígena, estes que eram os habitantes nativos dessas terras.

Após este acontecimento, os povos trazidos da África também passaram a ser escravizados, ou seja, tais pessoas foram separadas de suas famílias, retiradas de suas terras, e sob força, obrigadas a trabalharem como se fossem objetos de desejo do grande capital. Ainda nesse cenário, a opressão desses povos causou diversas revoltas populares, e assim sendo, a população escrava constitui consigo diversas formas de resistência, organizando fugas e se rebelando com os opressores. E aqui a capoeira começa a dar seus primeiros passos, nascida como uma forma de resistir e lutar. (NETTO, 2018, p. 2).

Braga e Saldanha (2014, p. 119) apontam que além de todos os castigos corporais, agressões e punições em praças livres, os dominadores imputavam-lhes uma segregação cultural, como, obriga-los a falar a língua portuguesa, e impor os "bons modos" e a crença católica, além de uma proibição desenvolverem suas tradições e culturas nas senzalas. A capoeira então passou a ser uma forma de resistir, criada por herdeiros da cultura africana, onde carregam todo o sofrimento e espírito de resistência de tal época.

Ferreira (2011, p. 148) problematiza os processos de criminalização desta época, compreendendo que o jus puniendi estatal, quando se trata de escravizados, eram intensamente maiores do que homens brancos. Ressalta-se que o número de pessoas escravizadas presas era inclusive maior do que os próprios processos penais, evidenciando uma segregação e um projeto estatal de higienização.

Soares (1998, p. 51) denuncia que no dia 10 de setembro de 1810 foi um dia marcado na história, pois foi presa uma pessoa escravizada de nome Felipe, nação Angola, de propriedade de Francisco José Alves. Nesta época, prisões de africanos eram comuns, porém, este deu início ao aprisionamento de pessoas presas por capoeiragem, delito este tipificado no Código Penal da época:

Art. 402. Fazer nas ruas e praças publicas exercícios de agilidade e destreza corporal conhecidos pela denominação capoeiragem; andar 
em correrias, com armas ou instrumentos capazes de produzir uma lesão corporal, provocando tumultos ou desordens, ameaçando pessoa certa ou incerta, ou incutindo temor de algum mal:

Pena - de prisão celular por dois a seis meses.

Parágrafo único. E' considerado circunstância agravante pertencer a capoeira a alguma banda ou malta. Aos chefes, ou cabeças, se imporá a pena em dobro. (BRASIL, 1980).

Serafim e Azevedo (2011, p. 9) denunciam que a capoeira era mais do que uma simples expressão cultural, era o símbolo máximo de resistência de corpos de pessoas escravizadas, simbolizada como a única arma contra a tirania das elites sobre seus corpos, que sempre fora alvo do controle estatal, realidade que perdura até os dias atuais. Sendo assim, a representação que os membros da classe dominante tinham a respeito da capoeira foi exemplificada pelo chefe da polícia do Rio de Janeiro em 1878, ao considerar os capoeiristas doentes mentais. O que deixa explicito os projetos excludentes e de higienização cultural.

\subsection{Criminalização cultural da maconha}

Carlini (2006, p. 315) relaciona a maconha com a cultura trazida pelos Africanos, uma vez que em algumas religiões o fumo era considerado sagrado, e passou a ser cultivado pelas pessoas escravizadas quando chegaram no Brasil.

Barros e Peres (2011, p. 4) apontam que em 1809 foi criada a Guarda Real da Polícia, como forma de manter o patrulhamento das cidades e, na medida em que seus atos foram se manifestando, observou-se desenvolver uma segurança pública pautada na violência, e assim a referida guarda logo passou a substituir os antigos capitães do mato. O principal alvo desse policiamento eram as festas de guetos, com o cunho proibicionista, pois passou-se a se punir aqueles que bebiam cachaça, ouviam músicas africanas e consequentemente os que faziam o uso da maconha.

Saad (2013, p. 5) aponta que neste contexto, as práticas e costumes dos negros, que eram tão presentes na sociedade recém-saída da escravidão, representavam um entrave para o lema "ordem e progresso" pretendidos pelas elites intelectuais, política e religiosa da época. Assim como o candomblé e a capoeira, a maconha estava associada aos africanos, bem como, seus ancestrais e seu uso acabava que por prejudicar a formação da república, que tinham como ideal construir uma nação pautada na moral religiosa. 
Boiteux (2019) acredita que é necessário compreender as funções ocultas da política de drogas, que age de forma a ocultar seu verdadeiro caráter com um maquiado discurso de proteção à saúde. Tal política age como forma de reprimir e controlar certos grupos indesejáveis ao sistema.

Neste sentido, muito embora consumir psicoativos não seja um hábito apenas das classes dominadas, observou-se nas propagandas proibiconistas americanas os estereótipos dos indesejáveis estampados nas capas de jornais, sendo estes, negros, mexicanos, chineses, que normalmente relacionavam tais grupos com o uso da maconha e com atos como estupros. Entre os anos de 1901 e 1902 ocorreu o chamado pânico racista, onde propagandas associavam homens negros com o consumo de cocaína, onde uma campanha aduzia a ideia de que tais homens faziam o uso de tais substâncias para estuprarem mulheres brancas. (BOITEUX, 2011).

Batista (2003, p. 20-21) aponta que o mercado ilícito de drogas concentrou um grande investimento nas politicas de segurança pública, pois para combater tal mercado era necessário um grande investimento, porém, para além disso, tal investida contra as drogas foi usada para segregar e aprisionar a população negra, assim como sua cultura, como uma segunda fase de imposição do eurocentrismo.

Neste viés, o fato da proibição da maconha se originou, portanto, na necessidade de o Brasil construir uma sociedade pautada nos mandamentos das classes dominantes. A elite trazia consigo a ideação de dominar certas camadas sociais e após o período de liberdade das pessoas escravizadas, além de não ter sido construída políticas públicas voltadas ao acolhimento dessas pessoas, em contrapartida foram criados mecanismos de criminalização das mesmas. (MACRAE; SIMÕES, 2018, p. 2).

\subsection{Criminalização da juventude periférica}

Gomes (2018, p. 94-99) aponta o desamparo social na qual os jovens contemporâneos estão submetidos. Nas sociedades primitivas, a passagem da infância para a vida adulta, era permeada por rituais que ofereciam ao sujeito segurança e uma espécie respaldo de significados que auxiliavam nesta travessia. No cenário contemporâneo, por sua vez, os jovens se veem à deriva, pois não encontram amparo na cultura que se constitui como um campo de construção da identidade, de tal modo que os auxiliam na passagem da adolescência. 
Imersos em uma cultura ambivalente, que ora vê os adolescentes como os prodígios que realizarão os ideais apregoados na cultura, ora os percebe como um risco para o meio social, a subjetividade dos jovens acaba ficando vulnerável diante das projeções da sociedade e da mídia. Sendo assim, os jovens procuram por si próprios manifestações que lhe ofereçam amparo e construção de laços sociais. (GOMES, 2018, p. 94-99).

\begin{abstract}
Mesmo não encontrando esses dispositivos coletivos de maneira estruturada e bem estabelecida, muitos adolescentes não deixam de buscar no corpo social referências disponíveis, a partir das quais eles possam produzir significantes para os elementos estranhos com os quais se deparam. Assim sendo, os jovens acabam por criar seus próprios ritos, símbolos, modas e linguagens peculiares, visando marcar sua identidade distintiva de outros grupos etários, nos quais estabelecem a linha entre os "caretas" e os "entendidos". (GOMES, 2018, p. 97).
\end{abstract}

Dentre tais amparos, portanto, revela-se que os jovens se reúnem em grupos de iguais, por exemplo efetuando os chamados "rolezinhos", aderem a expressões artísticas, adotam determinados estilos de moda, cortes de cabelo, gírias, etc. (GOMES, 2018, p. 99). (CALLIGARIS, 2000, p. 33-53).

Neste sentido, a cultura e o lazer, por representarem uma instrução popular, podem se apresentar ao jovem como uma válvula de escape e representar um amparo subjetivo, haja vista que o lazer se constitui de três funções essenciais, sendo estas a função do descanso, do divertimento e do desenvolvimento pessoal. (DUMAZEDIER, 2014, p. 29-32).

Tendo visto isso, destaca-se o fenômeno dos "rolezinhos" que ganhou destaque na mídia de 2014, e se caracterizavam como um ritual de lazer arquitetado por jovens periféricos que combinavam encontros coletivos nos chamados "templos do consumo", os shopping centers. Tais jovens denunciavam o contraste social entre sujeitos que ocupavam um espaço para simplesmente compartilhar momentos com amigos, e pessoas que estavam ali para atender à demanda do mercado, isto é, consumir. Porém, os adolescentes "rolezeiros", diferente do que se costuma pensar, não estavam ali para criticar o apelo ao consumismo, mas, pelo contrário, manifestavam o desejo de se enquadrar nos padrões do sistema. Contudo, os jovens causaram alvoroço e um 
evidente incômodo nos lojistas e consumidores, tendo ocupado a centralidade de debates calorosos na mídia e na internet por um bom tempo. Nas palavras de Gomes (2018, p. 100) "ninguém procura ouvir o que esses jovens pensam, mas todos parecem saber o que deveriam pensar".

Dirigentes dos shoppings entraram com liminar na justiça solicitando o impedimento dos "rolezinhos", e reforçaram a mão de obra de agentes de segurança nas entradas dos estabelecimentos. Haja vista que os encontros eram convocados de maneira online, por intermédio de determinadas páginas do Facebook, houve o apelo de alguns comerciantes para que a rede social bloqueasse estas páginas, representando assim, a manifesta negação do direito à livre expressão. Neste viés, observa-se que "a polícia se comporta, na maioria das vezes, com base na força bruta, como uma força de "segurança preventiva", reprimindo pessoas, que no caso dos rolês, não cometeram nenhum crime". (GOMES, 2018, p. 101).

Todavia, Gomes (2018, p. 100) assevera que as motivações dos encontros denominados rolês eram bem mais despretensiosas do que era retratado pela mídia, e se expressavam, suscintamente, pelo desejo de "juntar a galera", fazer novas amizades, exibir o uso de suas marcar preferidas e estilos visuais, e compartilhar sonhos. Tal como explicita Beguoci (2014 apud Gomes, 2018, p. 102):

\footnotetext{
Os rolezinhos são grandes festas em espaços privados empreendidas por jovens pobres e de periferia que não possuem acesso fácil a espaços de lazer e cultura e são penalizados pela ausência de serviços públicos, o que favorece ainda mais o desamparo e a já mencionada "entrega" destes jovens à cultura da TV e da Internet, espaços nos quais serão induzidos ao consumo. Diante do esvaziamento do espaço público, em especial em áreas violentas e pobres, os shoppings se apresentam como espaços bem organizados e "seguros" para esses encontros, cujo objetivo é a diversão.
}

Questiona-se, pois, o paradoxo que é colocado a jovens periféricos que ocupam um lugar social de invisibilidade e anonimato justamente em uma cultura contemporânea que clama pela hiper-valorização da imagem, caracterizando a chamada "sociedade do espetáculo". (GOMES, 2018, p. 103).

Esse fato gera, por si só, vários questionamentos. Jovens negros e periféricos não podem ocupar os espaços centrais? Essa é a lógica que foi criada e institucionalizada 
pela sociedade, que não aceita que centro e periferia estejam no mesmo espaço, tanto que quando um negro ou alguém da periferia passa a ocupar um espaço comercial, como é o caso dos shopping centers, eles são fiscalizados a todo momento pela segurança local, pois representam um "risco" eminente.

Observa-se que há uma construção social que afasta determinados grupos de pessoas de acessar alguns espaços, pois essa lógica que foi criada e integrada em sociedade mostra que o jovem periférico não pode ocupar o espaço central, que foi "construído" para as pessoas de classe alta. Assim, quando ele passa a tentar ocupar esses espaços, este ato gera um movimento repressor e racista.

\subsection{Criminalização artística: música como elemento de representatividade}

Freud (1927, p. 232-245) destaca que para viver em civilização, é necessário empreender a repressão de alguns impulsos que nos são naturais e, tais renúncias nos causam desgosto. Sendo assim, algumas satisfações substitutas oferecem a regalia de nos reconciliar com os esforços para renunciar a tais instintos e, neste viés, a arte reconhecidamente promove tal reconciliação. Freud ainda enuncia que as manifestações artísticas "elevam os sentimentos de identificação, de que todo grupo cultural necessita". (FREUD, 1927, p. 154).

Partindo deste viés, Facina (2009, p. 1) denuncia que nas periferias das grandes cidades, algumas vertentes musicais se destacam e se transforam em verdadeiros instrumentos de representatividade da juventude, como é o caso do funk, do rap. e outros. O grito da favela, a voz dos morros e a liberdade, o som das grandes massas. Algumas pessoas afirmam que tais estilos musicais são formados por pessoas que não fazem arte, alegando que são desafinados e despertam um sentimento de ódio, além de trazerem pornografia em suas letras. E sendo assim, tais seguimentos foram sendo associados à criminalidade e ao tráfico de drogas, ensejando, portanto, diversos projetos de lei que criminalizavam tal cultura.

Cymrot (2010, p. 10) elenca que apesar de nenhum projeto de lei de criminalização do funk ter sido aprovado até aqui, em legislações estaduais e municipais observa-se diversos mecanismos que dificultam os chamados "bailes funk" de acontecer, ainda mais quando os mesmos acontecem em regiões periféricas, e é notório 
o aparato de repressão estatal que os mesmos sofrem, com violentas intervenções policiais em tais festividades.

Kehl (1999, p. 95-96) pontua que todo jovem almeja o reconhecimento social, mas os jovens periféricos precisam empreender ainda mais esforços para alcançar este ideal. Neste sentido, a autora analisa a legião de fãs do grupo de rap Racionais $M C^{\prime}$ s, composto em sua maioria, por jovens negros e pobres. Para Kehl, existe um elo especial entre estes artistas e seus fãs, haja vista que as músicas do referido grupo representam, no mundo psíquico de tais jovens, o ideal de reconhecimento de seus discursos, e enaltecem o orgulho da raça negra, favorecendo a autoestima destes jovens que se encontram às margens da sociedade.

A autora demonstra que o grupo propõe fazer uma revolução não com armas, mas com palavras, e sugere que a inclusão dos "irmãos de etnia e de pobreza" se dê pela valorização de si e de sua história, e não pelo esforço para se enquadrar na lógica do mercado. Neste sentido, a mensagem que o grupo apregoa poderia ser sintetizada em: "fique esperto, fique consciente - não faça o que eles esperam de você, não seja o "negro limitado" (título de uma das músicas de Brown) que o sistema quer, não justifique o preconceito dos "racistas otários" (título de outra música)". (KEHL, 1999, p. 96).

No entendimento de Kehl (1999, p. 97), Mano Brown e seus companheiros de banda não objetivam agradar às classes altas, tampouco disseminar o discurso meritocrata que atribui unicamente ao sujeito a responsabilidade pelas suas condições sociais. Pelo contrário, o grupo almeja enaltecer a autoestima de jovens negros e periféricos, e assim, produz impactos na subjetividade destes jovens, suscitando a identificação grupal, a força da união, e o enaltecimento de seus discursos. Em suas palavras, "quando os Racionais apelam a que os manos se identifiquem com a causa dos negros, estarão propondo um campo identificatório". (KEHL, 1999, p. 102).

Neste viés, observa-se um elo de representatividade de tais estilos musicais com o cotidiano desses jovens periféricos, que pouco eram vistos nas mídias e a partir da disseminação desta cultura passaram a pertencerem a um grupo social específico e que denunciavam suas vulnerabilidades. 


\subsection{0 papel da educação frente às culturas de periferia: educação para a liberdade}

Pela lógica social-capitalista aquilo que é produzido no centro possui um caráter democrático, pois representa o desejo de todos, mas não é bem isso que ocorre. 0 centro representa um espaço de grande distanciamento social, e abarca a essência das instituições, uma vez que não é, de fato, um espaço democrático.

A periferia ainda não ganhou seu espaço diante da centralidade, há a um movimento contrário que insiste em não convergir ambos os espaços. Assim, cria-se a lógica de que a periferia produz as suas próprias manifestações artísticas e possui os seus próprios problemas sociais, que devem estar distantes do centro.

Visando romper com essa lógica, os debates frente a essa questão têm de intensificado, de tal modo que, mesmo a passos curtos, o centro está sendo ocupado e sendo palco de vários movimentos de resistência.

Uma das grandes ferramentas que se tem para romper com lógicas que foram sistematizadas e institucionalizadas em sociedade é a educação, por meio dela pode-se haver a promoção da liberdade, tanto que a periferia é o grande palco dos movimentos educacionais de transgressão.

Nesse sentido, Michael Apple (1995, p. 6-7) elenca que:

"[...] o mundo da fuga de capital, do desemprego, da degradação do trabalho, da desintegração das cidades e comunidades, tudo isso não diz respeito à educação, afinal de contas. Um mundo no qual o racismo está novamente em ascensão, no qual estamos tentando empurrar, tanto ideológica quanto economicamente, as mulheres de volta para o trabalho não remunerado do lar, no qual colocamos nossos idosos em depósitos, esse também tem pouco a ver com a educação. Afinal de contas, a educação é um processo psicológico, um processo inteiramente compreendido através do discurso da aprendizagem."

A educação representa o caminho para um processo emancipatório da periferia, pois ela passou a valorizar aquilo que era produzido pelas pessoas que não tinham acesso ao centro, de tal maneira que suas vidas e expressões culturais ganharam forma, e espaço dentro dos centros.

Nesse processo de transgressão por meio da educação, Paulo Freire construiu importantes diálogos, de tal modo que ele se mostra como o principal libertador social por meio de uma educação reflexiva. Para ele, uma sociedade estruturada por uma 
lógica de distanciamento social de classes o diálogo nem sempre ocorre, ele pode se estabelecer em outros espaços dentro da periferia, mas não no centro. (FREIRE, 1985, p. 12).

\section{CONSIDERAÇÕES FINAIS}

Constata-se, portanto, que a cultura e expressão artística dos povos da periferia há muito tempo vem sendo depreciada e até mesmo criminalizada pelo sistema penal aliado ao sistema econômico excludente. Desde o início da escravidão no Brasil, os povos negros são punidos por suas expressões culturais. Tendo em vista que a cultura e a arte constituem a subjetividade do ser humano, amparando os sujeitos nos seus modos de existir no mundo, constata-se que a criminalização da cultura periférica, além de produzir segregação social, afeta também a saúde mental.

A partir desta perspectiva, evidenciamos que a educação pode resgatar a expressão artística dos sujeitos periféricos, compreendendo-a como parte essencial do processo de subjetivação e, portanto, apontar o caminho para desconstrução de preconceitos que consequentemente geram a criminalização da arte popular.

A construção de uma educação voltada a liberdade, não representa apenas dar voz a uma parcela da sociedade, mas romper com uma construção pautada na centralidade das relações, onde a voz está na boca daqueles que tem poder. Logo, educar é dar voz a aqueles que são marginalizados, estes que possuem suas culturas abafadas, mas que as vezes são jogadas nos grandes centros, quando caem nos gostos daqueles que estão no poder das relações.

\section{REFERÊNCIAS}

APPLE, Michael W. Trabalho docente e textos: economia política das relações de classe e de gênero em educação. Porto Alegre: Artes Médicas, 1995.

BARROS, André; PERES, Marta. Proibição da maconha no Brasil e suas raízes históricas escravocratas. Rio de Janeiro: UERJ, 2011.

BATISTA, Vera Malaguti. O medo na cidade do Rio de Janeiro: dois tempos de uma história. Rio de Janeiro: Revan, 2003.

BOITEUX, Luciana. A proibição como estratégia racista de controle social e a guerra às drogas. São Paulo: Diplomatique, 2019. Disponível em: 
https://diplomatique.org.br/a-proibicao-como-estrategia-racista-de-controlesocial-e-a-guerra-as-drogas/. Acesso em: 11 jun. 2020.

BRAGA, Janine de Carvalho; SALDANHA, Bianca de Souza. Capoeira: da criminalização no Código Penal de 1890 ao reconhecimento como esporte nacional e legislação aplicada. Paraíba: Conpedi, 2015.

BRASIL. Código Penal dos Estados Unidos do Brasil. Governo Provisório, 1890. Disponível em: http://www.planalto.gov.br/ccivil_03/decreto/18511899/D847.htmimpressao.htm. Acesso em: 18 jul. 2020.

CALLIGARIS, Contardo. A adolescência. São Paulo: Publifolha, 2000.

CARLINI, Elisaldo Araújo. A história da maconha no Brasil. São Paulo: Revista de Literatura, 2006.

CYMROT, Danilo. A criminalização do funk sob a perspectiva da teoria crítica. 2011. 200 f. Tese (Mestrando) - Universidade de São Paulo-USP, São Paulo, 2011.

DUMAZEDIER, Joffre. Lazer e cultura popular. São Paulo: Perspectiva, 2014.

FACINA, Adriana. "Não me bate doutor": funk e criminalização da pobreza. V ENECULT - Encontro de Estudos Multidisciplinares em Cultura, Salvador, 2009.

FERREIRA, Ricardo Alexandre. Crimes em Comum: escravidão e liberdade sob a pena do Estado imperial brasileiro (1930-1988). São Paulo: Unesp, 2011.

FREIRE, Paulo. Educação e mudança. Rio de Janeiro: Paz e Terra, 1985.

FREUD, Sigmund. O futuro de uma ilusão (1927). São Paulo: Companhia das Letras, 2014.

GOMES, Vinicius Romagnolli Rodrigues. Adolescentes na contemporaneidade: desamparo e laços fragilizados em meio aos "ideais" da sociedade de consumo. Rio de Janeiro: Gramma, 2018.

KEHL, Maria Rita. Radicais, Raciais, Racionais: a grande fratria do rap na periferia de São Paulo. São Paulo: Perspectiva, 1999.

MACRAE, Edward; SIMÕES, Júlio Assis. A subcultura da maconha, seus valores e rituais entre setores socialmente integrados. Bahia: Neip, 2019.

NETTO, Nilo Silva Pereira. Capoeira: de manifestação marginal à expressão da cultura brasileira. Curitiba: CE PAPA JOÃO PAULO I, 2018.

SAAD, Luísa Gonçalves. "Fumo de negro": a criminalização da maconha no Brasil (c. 1890-1932). Salvador, 2013. 
SERAFIM, Jhonata Goulart; AZEREDO, Jeferson Luiz de. (Des) criminalização da cultura negra nos Códigos de 1890 e 1940. Amicus Curiae, Unesc, v. 6, ed. 6, 2011.

SOARES, Carlos Eugênio Líbano. A capoeira escrava no Rio de Janeiro 1808-1850. São Paulo: USP, 1998. 


\title{
CAPÍTULO XXV
}

\section{A EDUCAÇÃO DAS RELAÇÕES ÉTNICO-RACIAIS NA SEGUNDA VERSÃO DA BASE NACIONAL COMUM CURRICULAR'}

\author{
Lívia Jéssica Messias de Almeida ${ }^{1}$ \\ Maria Rita Santos ${ }^{2}$ \\ Thaíse da Paixão Santos ${ }^{3}$
}

\begin{abstract}
1 Professora Adjunta do Departamento de Educação (DEDI) da Universidade Federal de Sergipe - UFS.
2 Doutoranda em Educação do Programa de Pós-graduação em Educação da Universidade do Estado da Bahia - UNEB. ${ }^{3}$ Doutoranda em Educação do Programa de Pós-graduação em Educação da Universidade Federal Rural do Rio de Janeiro- UFRRJ.
\end{abstract}

\section{RESUMO}

Este artigo realiza uma análise discursiva das abordagens sobre as relações étnico-raciais na Base Nacional Comum Curricular (BNCC), investigando se as determinações das leis no 10.639/03 e no 11.645/08 constituem-se como eixos direcionadores do documento. Para concretizar essa análise, realizamos uma análise documental a partir da segunda versão do texto revisada e publicada, em abril de 2016, no sítio do Ministério da Educação, e para o tratamento dos dados utilizamos a análise do discurso. Assim, concluímos que a BNCC não contempla as determinações previstas nas leis federais e nas Diretrizes Curriculares Nacionais para a Educação das Relações Étnico-raciais e para - Ensino de História e Cultura Afro-brasileira e Africana, pois observamos uma abordagem mínima e pouco referenciada sobre a temática, demonstrando um alinhamento com a matriz político-social da cultura escolar dominante.

Palavras-chave: Educação das relações étnico-raciais. Base Nacional Comum Curricular. Currículo.

\section{INTRODUÇÃO}

A construção do presente artigo emerge dos estudos realizados na disciplina Currículo e Construção do Conhecimento ofertada pelo Programa de Pós-Graduação em Educação da Universidade Federal de Sergipe (UFS) e, principalmente, pela necessidade de discussão das abordagens referentes às relações étnico-raciais no texto da Base Nacional Comum Curricular (BNCC). A opção por discutir esse tema se deu por duas

1 Uma primeira versão deste artigo foi publicada no XI Colóquio Internacional Educação e Contemporaneidade, no ano de 2017. No seguinte endereço: https://ri.ufs.br/bitstream/riufs/9327/8/A_base_nacional_comum_curricular_e_a_educacao_para_as_r elacoes.pdf 
demandas: primeiro, pela BNCC tentar estabelecer e orientar uma organização nacional dos currículos dos sistemas de ensino da educação básica; e, segundo, pela necessidade de uma análise que observe se os direcionamentos curriculares estão de acordo com as determinações das leis no 10.639/03 e no 11.645/08 que instituem o a obrigatoriedade do ensino da história e cultura afro-brasileira, africana e indígena nas escolas brasileiras.

Este artigo foi desenvolvido a partir dos pressupostos da metodologia de análise documental tomando como fonte primária o texto da segunda versão revista e publicada pelo Ministério da educação, em abril de 2016. Para o tratamento dos dados utilizamos a análise do discurso, pois consideramos, da mesma forma que Silva (2011), que o currículo é texto, discurso, documento, ou seja, o currículo é documento de identidade. Nesse sentido, trabalhamos com sequências discursivas (SD), ou seja, "unidades cujo tamanho é igual ou superior a uma frase, extraída da continuidade dos textos de acordo com as regularidades enunciativas" que apontam para o funcionamento das formações discursivas na qual se insere o corpus a ser analisado. Desse modo, as SDs foram agrupadas e selecionadas a partir do objeto de análise, sendo que essa forma de recorte do corpus não influencia no entendimento das formações discursivas, devido ao discurso se fazer presente "em cada uma de suas enunciações, por mais ínfimo que pudesse ser seu objeto, isto é, o discurso investe tudo", pois tratase de "um espaço de regularidades enunciativas" (MAINGUENEAU, 1998, p. 128).

Em suma, buscando analisar os discursos referentes às relações étnico-raciais presentes na BNCC com o objetivo de investigar se as determinações das leis no 10.639/03 e no 11.645/08 constituem-se como eixos direcionadores do documento, dividimos o texto em duas partes, a saber: na primeira, pensamos as relações étnicoraciais na educação apresentando os direcionamentos dos movimentos sociais negros compreendendo-os como condições de produções discursivas, por conceber a ideia de que os discursos são produtos de uma anterioridade histórica e imediata; e, na segunda parte, realizamos uma discussão especificamente sobre o texto da BNCC analisando as sequências discursivas em consonância com as ideias defendidas no tópico anterior. 


\section{A DEFESA DOS MOVIMENTOS POR UMA EDUCAÇÃO ANTIRRACISTA: PRINCÍPIOS, CONCEPÇÕES E SIGNIFICADOS}

O campo educacional já se mostra como um dos precursores a transformações para contemplar as relações étnico-raciais, pois é possível visualizar ações operadas pelo governo no sentido de implementar políticas públicas de ações afirmativas. Isso ocorre devido às pressões dos movimentos negros da sociedade civil com o objetivo de corrigir as desigualdades e as injustiças históricas entre negros e brancos, bem como eliminar discriminações e promover a inclusão social.

O desenvolvimento dessas políticas afirmativas educacionais emerge da compreensão, de acordo com Santos (2005), de que a escola tem uma grande parcela na responsabilidade na perpetuação das desigualdades raciais. Historicamente, o sistema de ensino brasileiro pregou, e ainda prega, uma educação formal de embranquecimento cultural em sentido amplo. A educação formal não era só eurocentrista e de ostentação dos Estados Unidos da América, como também desqualificava o continente africano e inferiorizava racialmente os/as negros/as, quer brasileiros/as, quer africanos/as ou estadunidenses.

Tais abordagens excludentes aconteciam na educação mesmo com a Lei de Diretrizes e Bases da Educação Nacional - LDB (nª 9.394/96) assegurando a igualdade de condições de vida e de cidadania, o direito às histórias e culturas dos diversos povos que compõem a nação brasileira, bem como, o acesso às diferentes fontes da cultura nacional a todos os brasileiros. Mesmo com esse direcionamento legal, a cultura e história afro-brasileira e africana continuam sendo renegadas e marginalizadas, negando a democracia, e, consequentemente, uma educação para a liberdade.

Compreendendo e atendendo a antigas reivindicações do movimento social negro no que diz respeito à educação, foi aprovada a Lei no 10.639/03 que institui o ensino da História e Cultura Afro-Brasileira e Africana nos estabelecimentos de Educação Básica com o intuito de resgatar a contribuição do povo negro nas áreas social, econômica e política, pertinentes à História do Brasil, visando desconstruir práticas educativas com perspectivas eurocêntricas que veiculam e perpetuam a ideologia dominante. Para Gomes (2010), a lei se insere em um processo de luta pela superação do racismo na sociedade brasileira e tem como protagonistas o Movimento Negro e os 
demais grupos e organizações partícipes da luta antirracista. Revela também uma inflexão na postura do Estado, ao pôr em prática iniciativas e práticas de ações afirmativas na educação básica brasileira, entendidas como uma forma de correção de desigualdades históricas que incidem sobre a população negra em nosso país.

Sendo assim, a lei surge no sentido de promover uma reflexão sobre as relações étnico-raciais, pois a carência no planejamento escolar, na própria concepção de currículo e de construção da identidade dos sujeitos tem dificultado a promoção de relações interpessoais democráticas e igualitárias entre os agentes que integram o ambiente escolar (CAVALLEIRO, 2005). Ao passo que o silêncio sobre o racismo, o preconceito e a discriminação raciais nas diversas instituições educacionais contribui para que as diferenças de fenótipo entre negros e brancos sejam entendidas como desigualdades naturais. Mais do que isso, reproduzem ou constroem os negros como sinônimos de seres inferiores (Ibidem).

O silêncio escolar sobre o racismo cotidiano não só impede o florescimento do potencial intelectual de milhares de mentes brilhantes nas escolas brasileiras, tanto de alunos negros quanto de brancos, como também nos embrutece ao longo de nossas vidas, impedindo-nos de sermos seres realmente livres "para ser o que for e ser tudo" livres dos preconceitos, dos estereótipos, dos estigmas, entre outros males (CAVALLEIRO, 2005, p.11).

Para romper com esse silêncio, a implementação das Leis no 10.639/03 e no 11.645/08 se configuram como um grande passo na tentativa discutir, refletir e problematizar as relações étnico-raciais no Brasil. Uma vez que a educação tem a possibilidade de se constituir como um campo mais promissor do espaço social de questionamento e desconstrução da hierarquia entre grupos humanos incutida por uma ideologia racista. Nesse sentido, Gomes (2010) aponta que uma das formas de interferir pedagogicamente na construção de uma pedagogia da diversidade e garantir o direito à educação é conhecer a história e a cultura africanas e afro-brasileiras. Esse entendimento poderá nos ajudar a superar opiniões preconceituosas sobre os negros, a África, a diáspora; a denunciar o racismo e a discriminação racial e a implementar ações afirmativas, rompendo com o mito da democracia racial.

Nesse horizonte, foram elaboradas as Diretrizes Curriculares Nacionais para a Educação das Relações Étnico-raciais e para o Ensino de História e Cultura Afro-brasileira 
e Africana, orientações que visam à construção de uma prática pautada no reconhecimento e na valorização do povo negro no espaço escolar. Essas orientações surgem quando reeducar para as relações étnico-raciais impõe "aprendizagens entre brancos e negros, trocas de conhecimentos, quebra de desconfiança e um projeto conjunto para construção de uma sociedade justa, igual e equânime" (BRASIL, 2004, p.14).

As diretrizes trazem para o debate a consciência política e histórica da diversidade, considerando à igualdade básica da pessoa humana como sujeito de direitos, pautando-se na compreensão de que a sociedade é formada por pessoas pertencentes a grupos étnico-raciais distintos, os quais possuem cultura e história próprias, igualmente valiosas e que em conjunto constroem, na nação brasileira, sua história. Ao mesmo tempo em que colocam, como necessidade para a promoção de um ensino diverso, à superação da indiferença, injustiça e desqualificação com que os/as negros/as, os povos indígenas e também as classes populares às quais os negros, no geral, pertencem, são comumente tratados (BRASIL, 2004).

A efetivação das políticas de ações afirmativas dentro do espaço escolar depende, necessariamente, de medidas que garantam condições físicas, materiais, intelectuais e afetivas para o desenvolvimento de ações coerentes, a fim de produzirem resultados significativos no combate ao preconceito, ao racismo e a discriminação. É consenso que a escola não é o lugar de origem da desigualdade racial, entreta nto é vista como um espaço mais perverso e avassalador em sua perpetuação.

Nesse sentido, não são os objetivos de tais políticas trocar a concentração de um currículo etnocêntrico europeu por um de foco africano, mas de ampliar as concepções abordadas nos currículos para a imensa diversidade que compõe a nação brasileira. Nessa perspectiva, cabe às escolas incluir, no contexto dos estudos e atividades que proporciona diariamente, também as contribuições histórico-culturais dos povos indígenas e dos descendentes de asiáticos, além das de raiz africana e europeia. Pois, a relevância do estudo de temas dessas culturas e povos não se restringe a determinadas populações, ao contrário, diz respeito a todos/as os/as brasileiros/as, uma vez que devem educar-se enquanto cidadãos atuantes no seio de uma sociedade multicultural e pluriétnica, capazes de construir uma nação democrática (BRASIL, 2004). 
Assim, isso se trata de um esforço que significa construir um projeto de sociedade que age na perspectiva do fim das desigualdades raciais, na qual a escola se configura em um lugar democrático de (re)produção e publicização de conhecimentos e posturas que nos encaminhem à sociedade justa. Portanto, com um desafio dessa natureza, seria revolucionário pensar em um novo princípio educativo e social de respeito à diversidade, com vistas a romper com a ideia monoculturalista-essencialista de um contexto educativo homogeneizado e uniformizado.

\section{AS RELAÇÕES ÉTNICO-RACIAIS NA SEGUNDA VERSÃO DA BASE NACIONAL COMUM CURRICULAR}

Pensar numa base nacional comum curricular para o Estado brasileiro requer um trabalho árduo e intenso devido aos complexos problemas que envolvem a sociedade e consequentemente o campo educacional. Segundo o texto da BNCC, a base objetiva orientar a construção de propostas curriculares para as diferentes etapas de escolarização, com o intuito de estabelecer os direitos e princípios de aprendizagem, além de afirmar que não trata de uma demanda nacional nova para educação. Elizabeth Macedo (2015) aborda um pequeno resumo desse histórico, em seu artigo "Base nacional comum para currículos: direitos de aprendizagem e desenvolvimento para quem", desse modo,

o debate atual teria se iniciado com a Constituição de 1988, seguindo com a LDB (BRASIL,1996), a elaboração de Parâmetros Curriculares Nacionais (MEC, 1998a) e culminando com a promulgação das Diretrizes Curriculares Nacionais Gerais para a Educação Básica e do Plano |Nacional de Educação (PNE). (BRASIL, 2010) Há, certamente, ausências nessa linha do tempo que muito poderiam auxiliar e ampliar a discussão atual. As críticas da academia e dos movimentos de trabalhadores da educação aos Parâmetros Curriculares Nacionais (PCN) (ANPED, 1996; CANEN, 2000; CUNHA, 1996; MOREIRA, 1997; SANTOS, 2002; SILVA; GENTILI, 1999) é uma delas. No âmbito das instâncias vinculadas ao Estado, as diretrizes curriculares elaboradas pelo Conselho Nacional de Educação (CNE), em 1998 (BRASIL, 1998a), como resposta à tentativa do Governo Fernando Henrique Cardoso de ler as bases comuns nacionais previstas na LDB como parâmetros curriculares nacionais. Dizia o CNE à época: "[...] embora os Parâmetros Curriculares propostos e encaminhados às escolas pelo MEC sejam nacionais, não têm, no entanto, caráter obrigatório, respeitando o princípio federativo de colaboração nacional [...]". (BRASIL, 1998, p. 7) Ou seja, o órgão entendia, e isso mostra que se 
trata de um entendimento possível, que as bases curriculares comuns se configuravam em diretrizes para a educação e não numa proposta curricular ou listagem de conteúdos [...](MACEDO, 2015; p. 01-02).

Ainda segundo a autora, o movimento mais recente se justifica pelas legislações de então: Constituição e LDB, como também pela Lei no 13.005 (BRASIL, 2014) que institui o Plano Nacional de Educação. O Plano tem 20 metas para a melhoria da qualidade da Educação Básica e quatro delas fariam referência à Base Nacional Comum Curricular (BNC), de modo que a Lei criaria o arcabouço legal que exige a elaboração de bases nacionais comuns curriculares para os ensinos fundamental e médio (MACEDO, 2015).

Ao estabelecer esse objetivo e o histórico aos quais a BNCC se pauta, diversos posicionamentos são postos em discussão, em que dois se destacam: de um lado, observa-se o anseio por uma padronização do ensino que consiga abarcar as necessidades de uma educação mercadológica com orientações para uniformização dos currículos, estabelecendo como conteúdos necessários aqueles que estão dentro da lógica de avaliação dos organismos internacionais para cada etapa para que o Brasil possa avançar como país desenvolvido. De outro, consegue-se visualizar um movimento crescente de que essa proposta curricular, da maneira como está formatada e pelos agentes que a direcionam, não consegue abarcar as demandas identitárias, políticas, históricas, sociais e culturais de um país diverso e desigual como o nosso Ao ler esse documento observamos que se trata de um produto de negociações e conflitos entre múltiplos agentes com diferentes projetos de sociedade e de educação.

Entretanto, percebemos que os movimentos contra-hegemônicos ainda são minoria quando se fala desse jogo de disputa, principalmente aqueles que pautam uma educação antirracista e contra a desigualdade social. Afirmamos essa ideia na medida em que observamos, em consonância com diversos autores e autoras que estão atualmente teorizando sobre o currículo, a participação ativa de diversos agentes privados na construção das orientações curriculares da base, como exemplo das Fundações vinculadas a grupos financeiros como Roberto Marinho, Victor Civita, Airton Senna e Grupo Lemann, bem como Empresas como Natura, Gerdau e Volkswagen, grupos educacionais como CENPEC e "movimentos" como Todos pela Educação são alguns dos exemplos mais explícitos. 
Tal percepção nos conduz a uma perspectiva de currículo amparada em Sacristán (2008) em que se configura como a expressão do equilíbrio de interesses e forças que gravitam sobre o sistema educativo num dado momento. Considera que o currículo, em seu conteúdo e nas formas através das quais nos apresenta e se apresenta aos professores e alunos, é uma opção historicamente configurada que se sedimentou dentro de uma determinada trama cultural, política, social e escolar. De par com essa ideia, resguardadas as suas diferenças, Apple (1999) argumenta que o currículo nunca é apenas um conjunto neutro de conhecimentos que, de algum modo, aparece nos textos e nas salas de aula de uma nação. É sempre parte de uma tradição seletiva, da seleção de alguém, da visão de algum grupo do conhecimento legítimo. Para ele, o currículo é produto das tensões, conflitos e compromissos culturais, políticos e econômicos que organizam e desorganizam um povo. (...) a decisão de definir o conhecimento de determinados grupos como o mais legítimo, como conhecimento oficial, enquanto o conhecimento de outros grupos raramente consegue ver a luz do dia, revela algo de extremamente importante sobre quem tem o poder na sociedade.

Nessa perspectiva de currículo, como um lugar de disputa e relações de poder, e percebendo a participação desses grupos no direcionamento da BNCC, o documento posto em análise revela a conservação e reprodução das estruturas sociais de poder. Desse modo, pautar uma efetiva educação para as relações étnico-raciais que questiona a meritocracia e a desigualdade torna-se dissonante com sua concepção de sociedade e educação, uma vez que esse sistema lucra contínua e reiteradamente com racialização e etnização para exploração da força de trabalho. Em nossa compreensão, a educação pode se configurar como um espaço de tentativa de superação do racismo, do preconceito e da discriminação. Desse modo, se mostra como possibilidade de deslocamento das estruturas vigentes tanto nas relações raciais quanto na organização de classes, uma vez que os negros compõem a grande maioria da classe trabalhadora superexplorada.

Pensar desse modo indica uma das principais dificuldades na formulação e implementação das políticas públicas de ações afirmativas para essa população específica em todas as áreas, principalmente na educação que se configura como um instrumento crucial de organização da luta contra o racismo. Por pensar a importante função da educação e considerar a BNCC como uma ação de política pública analisamos 
as sequências discursivas que tratam das relações étnico-raciais no texto. Como primeira análise, observamos que a temática é pouco mencionada e tratada ao longo das suas 652 páginas do documento, ressaltamos no tópico "Estrutura dos componentes da área no Ensino Fundamental", nada é comentado sobre a necessidade de trabalho com os conteúdos relacionados às relações étnico-raciais e nem com os valores civilizatórios dos povos afro-brasileiro, africanos e indígenas.

Ao longo do documento, encontramos apenas oito sequências discursivas que abordam a temática, vale destacar que a maioria são citações que não desenvolvem o significado, a importância do trabalho e os direcionamentos curriculares necessários para desenvolver uma educação para as relações étnico-raciais de base antirracista. Desse modo, nos questionamos: Por que a BNCC não aborda orientações específicas e aprofundadas de combate ao racismo, à discriminação e ao preconceito. Essa pergunta não possui resposta casual, pois o silêncio traz consigo algo que significa, inscrevendo-o em uma dada formação discursiva e que reflete posicionamentos de uma determinada ideologia. A opção por não obter de forma adequada orientações específicas e condizentes com as determinações legais previstas nas Leis no 10.639/03 e № 11.645/08, trata-se de uma escolha condizente com a estruturação e fortalecimento do racismo na sociedade brasileira, evidenciando a marginalização histórica das populações negra e indígena nas políticas públicas.

Das poucas sequências que encontramos no texto trazemos o primeiro recorte para o debate, integrado aos "Princípios da base nacional comum curricular e direitos de aprendizagem e desenvolvimento", no eixo "A BNCC e as modalidades da educação básica":

SD01: A Educação para as Relações Étnico-Raciais, prevista no art. 26A da Lei no 9.394/1996 (LDB), objetiva a ampliação de conhecimentos acerca da educação para as relações étnico-raciais e, consequentemente, para a eliminação do racismo e do etnocentrismo no ambiente escolar e na sociedade brasileira. $\mathrm{O}$ estudo de História e Cultura Afro-Brasileira e Indígena (Leis no 10.639/2003 e no $11.645 / 2008$ ) é ministrado no âmbito de todo o currículo escolar, em especial nas áreas de educação artística e de literatura e história brasileiras, em todas as etapas da Educação Básica, compreendendo a história e a cultura que caracterizam a formação da população brasileira (p.37). 
Desse modo, cabe destacar que a educação das relações étnico-raciais não se trata de uma modalidade da educação básica, mas de propor uma nova organização curricular a partir da produção de conhecimento africano, afro-brasileiro e indígena desconsiderando o etnocentrismo europeu e marginalização dos diversos povos que compõem a nação brasileira. Outra questão que vale ressaltar, é que não se trata de uma ampliação de conhecimento conforme destacado na SD01, trazendo um entendimento de uma perspectiva adicional ou apêndice como essa construção discursiva pode indicar, mas de um conhecimento necessário e fundante que descoloniza os currículos e, dessa forma, contribui para uma sociedade antirracista, justa e igualitária.

Nos tópicos "Etapa da educação infantil", na sequência discursiva 02, e "A relação da BNCC com as diretrizes curriculares da educação infantil", na sequência discursiva 03, que teorizam sobre a etapa da Educação Infantil, observamos que as relações étnico-raciais foram citadas a partir do princípio de combate ao preconceito e discriminação culturais e da orientação sobre a necessidade dos projetos educacionais incluírem em seus currículos da educação infantil a diversidade.

SD02: Conforme já anunciado nas DCNEI, esse trabalho deve se pautar pela constante reflexão e intervenção, por parte do/a professor/a, no combate ao preconceito e às discriminações culturais, de gênero, étnico-raciais, de classe social (p. 56).

SD03: Centralidade das crianças-A atitude de acolhimento das singularidades dos bebês e das crianças e a criação de espaço para a constituição de culturas infantis definem a centralidade da criança. As diversidades culturais, sociais, etárias, étnico-raciais, econômicas e políticas de suas famílias e comunidades, presentes em sua vida, precisam ser contempladas nos projetos educacionais (DCNEI, Art.4) (p.59).

No tópico "A estrutura do componente na educação básica (ensino médio)", especificamente no subitem "História fundamentos do componente", bem como no tópico "A área das ciências humanas no ensino médio" as relações étnico-raciais são apresentadas a partir do princípio do respeito às singularidades étnico-raciais e dentro do estranhamento as diversas formas de desigualdade. 
SD04: O estudo da História contribui para os processos formativos de crianças, adolescentes, jovens e adultos inseridos na Educação Básica ao ampliar suas vivências e significados sociais com reflexões sobre os nexos históricos que os constituem. Esse estudo favorecerá o exercício da cidadania na medida em que, comprometido com o caráter complexo e plural desses nexos, estimule e promova o respeito às singularidades étnico-raciais e culturais, e à liberdade de pensamento, de ação, de credo religioso, e de opções políticas (p.155).

SD05:(a) a desnaturalização da cultura e da organização social e, em decorrência, a sensibilização e o estranhamento com diversas formas de desigualdade (socioeconômica, racial, de gênero) e identidades (culturais, religiosas, étnico-raciais, geográficas)(p. 628).

Apesar de aparecer em alguns momentos a temática das relações étnico-raciais e do mesmo modo outras identidades marginalizadas, enfatizamos que estas não podem somente ser citadas na BNCC com algumas indicações contemplando poucos princípios como acontece nas SD 02,03, 04,05; pois são resultados de contexto de excludentes e desse modo necessitam ser teorizadas e demonstradas em direcionamentos obrigatórios de inserção nos currículos.

Nos “Objetivos de aprendizagem e desenvolvimento de educação física para os anos finais do ensino fundamental" e no tópico "As unidades curriculares da sociologia para o ensino médio" as relações étnico-raciais também apareceram, conforme sequências discursivas 06, 07 e 08:

SD006: Enfrentar, com autonomia, situações de injustiça e preconceito geradas e/ou presentes no contexto das lutas e produzir alternativas para sua superação, com especial atenção às questões étnico-raciais e indígenas.[DCH] (p. 389).

SD07: Identificar, compreender e recriar coletivamente os valores atribuídos às danças de salão e de rua, com especial atenção às questões étnico-raciais e indígenas (p. 391).

SD08: Identificar como marcadores sociais as dimensões étnicoraciais, religiosa, regional, entre outras (p.648).

Observamos nas regularidades discursivas das sequências que as relações étnicoraciais fazem parte dos objetivos para o desenvolvimento da educação física e da sociologia, mas não compõem os objetivos para outras áreas, principalmente, de linguagens e matemática, nas etapas do Ensino Fundamental Anos Finais e do Ensino Médio. Tratando a questão de maneira restrita e recortada demonstrando uma superficialidade e não uma abordagem que contemple todo o currículo. Essas 
negligências pressupõem pouca consideração aos temas referentes às relações étnicoraciais na construção desse documento orientador das escolas brasileiras.

Assim, mencionar as relações étnico-raciais de maneira pontual nesse documento que objetiva ser referência curricular para o país, significa não assumir o compromisso de combate ao racismo e construção de uma educação igualitária. Devemos enfatizar que o tratamento de não considerar ou considerar de forma precária também se trata de uma política, que deve ser problematizada e desconstruída, o Estado brasileiro historicamente se valeu da omissão na reprodução das desigualdades e do racismo, desse modo a BNCC deveria propor de modo explícito os direcionamentos previstos para uma educação para as relações étnico-raciais.

\section{CONSIDERAÇÕES FINAIS}

As discussões sobre a necessidade de políticas públicas de ações afirmativas sempre foram alvo de muitos conflitos por parte de pesquisadores e pesquisadoras, bem como da população brasileira em geral, devido à justificativa de que a adoção de políticas universalistas seria insuficiente para abranger toda e qualquer população. Desse modo, ao longo tempo o abismo entre brancos, negros e indígenas, principalmente na educação, aumentou o que demanda do Estado brasileiro propostas e ações de políticas públicas que contemplem essas populações discriminadas.

Nesse sentido, a BNCC se constitui como uma ação educacional que diante das aprovações das Leis no 10.639/03 e no 11.645/08 deveria pautar a construção de um currículo que contemple o ensino da história e cultura africana, afro-brasileira e indígena. Entretanto, a segunda versão publicada deste documento de orientação curricular não considera em sua plenitude as determinações previstas nas leis e nas Diretrizes Curriculares Nacionais para a Educação das Relações Étnico-raciais e para o Ensino da História e Cultura Africana e Afro-brasileira, pois observamos uma abordagem mínima e pouco referenciada sobre a temática, além de compor a parte de modalidades de ensino quando deveria reordenar e construir novas perspectivas curriculares.

Isso nos traz as seguintes reflexões: "Que grupos sociais têm o poder de se representar e quais podem apenas ser representados nos currículos Que grupos sociais e étnico/raciais têm sido historicamente representados de forma estereotipada e distorcida" (GOMES, 2007; p.26). Tais questionamentos podem ser feitos depois de 
nossas conclusões e nos demonstram que a formatação/direcionamento curricular parte da cultura dominante, pois, segundo Silva (2011, p. 147), o conhecimento corporificado no currículo carrega as marcas indeléveis das relações sociais de poder, em suma, o currículo é território político. Em síntese, negligenciar ou tratar as relações étnico-raciais de maneira pontual configura-se como mais um incentivo a reprodução e legitimação de preconceitos e discriminações. Abordar uma educação antirracista nos currículos significa uma ação afirmativa que ajude a reparar a exclusão cultural, histórica, política, social e econômica da população negra e indígena, a fim de combater os efeitos cumulativos das discriminações ocorridas ao longo do tempo.

\section{REFERÊNCIAS}

BRASIL. Lei no 9394 de 24 de dezembro de 1996. Estabelece as diretrizes e bases da educação nacional. Brasília: Ministério da Educação, 1996.

BRASIL. Ministério da Educação. Lei no 10.639 de 09 de janeiro de 2003 . Altera a Lei $n^{\circ}$ 9.394, de 20 de dezembro de 1996, que estabelece as diretrizes e bases da educação nacional, para incluir no currículo oficial da Rede de Ensino a obrigatoriedade da temática "História e Cultura Afro-Brasileira", e dá outras providências.

BRASIL. Parecer 003/2004 - Diretrizes Curriculares Nacionais para a Educação das Relações Étnico-Raciais e para o Ensino de História e Cultura Afro-Brasileira e Africana. Relatora: Profa. Dra. Petronilha B. Gonçalves e Silva. Brasília, DF: MEC CNE/CP. 10 de mar. de 2004.

BRASIL. Lei da obrigatoriedade da temática da História e Cultura Afro-Brasileira e Indígena: Lei № 11.645/08, Brasília. 2008. Disponível em < https://www2.camara.leg.br/legin/fed/lei/2008/lei-11645-10-marco-2008572787-publicacaooriginal-96087-pl.html> Acesso em 11 de ago 2020.

CAVALLEIRO, Eliane. Introdução. In: BRASIL. Educação anti-racista: caminhos abertos pela Lei Federal no 10.639/03 / Secretaria de Educação Continuada, Alfabetização e Diversidade. - Brasília: Ministério da Educação, Secretaria de Educação Continuada, Alfabetização e Diversidade, 2005.

Racismo e anti-racismo na educação: repensando nossa escola. São Paulo: Sumus, 2001.

GOMES, Nilma Lino. Educação, relações étnico-raciais e a Lei 10.639/03. Disponível em http://www.acordacultura.org.br/artigo-25-08-2011. Acesso 03 de mar de 2010. 
Indagações sobre currículo : diversidade e currículo / [Nilma Lino Gomes] ; organização do documento Jeanete Beauchamp, Sandra Denise Pagel, Aricélia Ribeiro do Nascimento. - Brasília : Ministério da Educação, Secretaria de Educação Básica, 2007.

GUIMARÃES, Antônio Sergio Alfredo. Racismo e anti-racismo no Brasil. 2. ed São Paulo, SP: Ed. 34, FUSP, 2005.

MACEDO, Elizabeth. Base nacional comum para currículos: direitos de aprendizagem e desenvolvimento para quem. Revista Educ. Soc., Campinas, v. 36, no. 133, p. 891908, out.-dez., 2015.

MAINGUENEAU, Dominique. Novas tendências da análise do discurso. Pontes: Editora da Universidade Estadual de Campinas- SP, 3. ed., 1997. SILVA, Tomas Tadeu. Documentos de identidade: uma introdução as teorias do currículo. -3. ed. Belo Horizonte: Autêntica, 2011. 156 p. 


\title{
CAPÍTULO XXVI
}

\section{AS "MANEIRAS DE FAZER" DO PRÉ-UNIVERSITÁRIO PARA AFRODESCENDENTES EM ITABUNA-BAHIA ${ }^{1}$}

\author{
Lívia Jéssica M. de Almeida ${ }^{1}$ \\ Maria Rita Santos ${ }^{2}$ \\ Thaíse da Paixão Santos ${ }^{3}$
}

\begin{abstract}
Professora Adjunta do Departamento de Educação (DEDI)Universidade Federal de Sergipe (UFS).
${ }^{2}$ Doutoranda pelo Programa de Pós-graduação em Educação e Contemporaneidade da Universidade do Estado da Bahia (UNEB). Bolsista Capes.

${ }^{3}$ Doutoranda do programa de Pós-Graduação em Educação, Contextos Contemporâneos e Demandas Populares (PPGEduc) pela Universidade Federal Rural do Rio de Janeiro(UFRRJ).
\end{abstract}

\section{RESUMO}

Neste artigo, propomos investigar as narrativas das experiências de acesso à universidade de educadores negros do Pré-universitário para Afrodescendentes (PREAFRO) em Itabuna-Bahia, entre os anos de 2005 a 2011, com o objetivo compreender os processos de construção da identidade racial e suas implicações com as experiências de acesso à universidade. Metodologicamente, esta pesquisa se pautou na realização de entrevistas narrativas com quatro educadores que estudaram no PREAFRO, todos moradores de bairros periféricos e aprovados (as) nos processos seletivos da UESC e retornaram como educadores (as) voluntários (as), para colaborar com o acesso de outros estudantes do cursinho. Na tentativa de compreender essas experiências apresentamos: a organização, os objetivos, o público alvo, as táticas de resistência e os princípios que visam orientar todas as decisões coletivas tomadas nas reuniões do PREAFRO com a finalidade: promover o acesso à universidade da população negra; manter discussões sobre cidadania, discriminação racial e exclusão; incentivar leituras para reinterpretar os conhecimentos sobre a História do Negro no Brasil, com enfoque na História Regional e possibilitar aos estudantes outros olhares sobre as questões negras. Nesse sentido, organizar por conta própria ações voltadas para o acesso quer dizer intervir para provocar mudanças para um grupo que, na maioria das vezes, não teve oportunidades de conhecer possibilidades de formação e transformação.

Palavras-chave: Acesso. Universidade. Estudantes Negros.

${ }^{1}$ Este artigo foi produzido a partir da dissertação de mestrado intitulada "Quantos além de mim"? Narrativas das experiências de acesso à universidade de educadores negros do PREAFRO em ItabunaBahia", defendida em 2014 no Programa de Pós-graduação em Educação da Universidade Estadual de Feira de Santana. 


\section{INTRODUÇÃO}

A partir de 2005, o PREAFRO uma iniciativa do Grupo Encantarte ${ }^{1}$, se organiza em caráter voluntário, formato que permanece atualmente, para promover o acesso de estudantes negros a universidade. Egnaldo, um dos idealizadores desse grupo narra o início das atividades do cursinho:

Entramos em contato com outros militantes de movimentos populares, com a proposta de retornar ao formato inicial, com caráter voluntário, sem nenhuma parceria com o poder público. Dessa vez vieram outros movimentos, como o grupo Ação negra, o Grupo Quilombo, a Conlutas, então, decidimos criar um novo Pré-universitário, fizemos uma reunião, buscamos as lideranças, procuramos os professores e as escolas que pudessem ceder 0 espaço para a realização das aulas. Fizemos o trabalho de divulgação, reuniões com os primeiros estudantes e criamos o primeiro núcleo no Maria Pinheiro. No ano seguinte um grupo do bairro Califórnia se organizou e nos procurou dizendo 'somos um grupo de estudantes e precisamos de professores. Assim, começaram as atividades do PREAFRO, que seguiu na base da resistência e decidimos seguir como no início com o trabalho voluntário, inclusive com professores que foram estudantes aprovados na época do PRUNE, que já retornavam para colaborar com o acesso de outros (Egnaldo França, Entrevista Narrativa, 2013).

Essa narrativa traz dois elementos significativos, quais sejam: o retorno de exestudantes para contribuir voluntariamente com o acesso de outros e a noção de resistência ${ }^{2}$, como um instrumento de luta contra a exclusão racial. Para tornar possível a execução das suas "táticas", o PREAFRO conta com algumas parcerias, uma vez que, não possui espaço físico próprio, nem equipamentos de informática, Data show etc. Concernente, ao espaço para o funcionamento dos dois núcleos as parcerias são com a direção de duas escolas municipais: Escola Municipal Dom Ceslau Stanula no bairro Pedro Jerônimo, e o outro na Escola Ubaldo Dantas, no bairro da Califórnia que disponibilizam duas salas no turno noturno, possibilitando as aulas diárias e as

${ }^{1}$ Grupo Encantarte, um movimento de resistência negra que idealizou e organizou o PREAFRO em Itabuna-Bahia.

${ }^{2}$ Movimentos de luta contra os processos de exclusão racial, nesse caso, do acesso ao ensino superior. 
atividades nos finais de semana. Essa parceria com as escolas é o único vínculo do cursinho com o poder público.

O corpo docente é formado por 24 professores voluntários, sendo 12 por núcleo, e parceiros do projeto, alguns desses ex-estudantes do PREAFRO que ingressaram na universidade e retornam como professores, ao mesmo tempo em que estudam nos cursos de graduação da UESC. Por se tratar de uma ação com caráter voluntário, nenhum dos colaboradores possui vínculo funcional ou empregatício, a distribuição das aulas se dá a partir da disponibilidade dos professores em ministrá-las com horários duplos no período noturno, uma vez por semana, durante os meses de março a dezembro, compondo dez meses de atividades distribuídas nos seis dias da semana, das 19 às 22 horas, totalizando três horas diárias.

\section{OS "SUJEITOS DA EXPERIÊNCIA" E SUAS TÁTICAS}

O caráter voluntário dessa iniciativa exige um esforço por parte da coordenação do curso, dos professores e dos estudantes, no sentido de manter o quadro de professores ao longo do ano e garantir que as aulas aconteçam. Compreendemos, que a falta de recursos gera a maior dificuldade enfrentada pelo cursinho, qual seja: a falta de professores. Por tratar-se de uma atividade voluntária, muitas vezes esbarra na necessidade desse profissional ingressar no mercado de trabalho, e assim não ter condição de conciliar as aulas no PREAFRO, com os seus horários remunerados.

Esse é um problema revelador, que dá indícios para começar a entender outro, a saber: a evasão, pois os horários vagos por falta de professores têm um efeito negativo para os estudantes que "às vezes param de frequentar o curso". Assim, a evasão fica em "aproximadamente $10 \%$ de estudantes, tomando como base o número de inscritos no início do ano letivo" (Documento de princípios, p.4). Entretanto, entendemos esse como sendo um dos motivos da evasão, já que se faz necessário um estudo sobre esse problema, para identificar outras questões que devem contribuir com essa evasão.

Egnaldo, do lugar de coordenador do cursinho, menciona o retorno de Gilvan, professor de Matemática e um dos protagonistas ${ }^{1}$ desta pesquisa, como um

\footnotetext{
${ }^{1}$ Nomeados assim por e tratar de pessoas que conquistaram algo novo com relevância social para o seu grupo.
} 
acontecimento significativo, posto que, desde então, o PREAFRO não teve mais dificuldade nessa área. Consideramos esse retorno como uma alternativa para atenuar essa dificuldade, uma preocupação que faz parte das táticas de resistência do cursinho para continuar com aulas semanais todos os anos desde 2005. Egnaldo organiza a sua narrativa sobre como essa ideia do estudante retornar, após o seu acesso na universidade, dizendo:

A gente tem uma prática de cada sala ter uma liderança, quando um estudante se destaca no papel de líder, naturalmente, perante os colegas, no sentido de solidariedade mútua, sabe? [...]. Assim, vai se construindo a ideia de retornar, assim que acessar a universidade, porque tem consciência que muitos não foram aprovados. Então, isso faz a gente olhar pra trás, basta esse gesto de olhar pra trás para muitos voltarem (Egnaldo França, Entrevista Narrativa, 2013).

Apreendemos que essa ideia de retornar está relacionada com a movimentação, no sentido de continuar contornando as estratégias dos processos seletivos, cujas regras excluem a maioria ou do ponto de vista do "sujeito da experiência" (LARROSA, 2011). Significa também movimentar-se dentro do estabelecido e recuperar a capacidade de indignar-se, buscando questionamentos que ainda precisam ser respondidos. Então, utilizamos esse "olhar para trás" como uma metáfora para designar as inquietações dos estudantes que durante as aulas no PREAFRO insistiram "na solidariedade concreta, nos laços de ajuda mútua que ligam os indivíduos uns aos outros e sem os quais a vida individual, e não apenas a coletiva, não seria possível" (KROPOTKIN, 1955, apud SOUSA SANTOS, 2010, p.335).

Consideramos a ausência de recursos financeiros como uma das principais dificuldades enfrentadas pelo PREAFRO, pois existem também outras despesas fixas para a manutenção das atividades, tais como: cópias dos textos usados nas aulas, transporte dos professores que moram distantes das escolas onde funciona o cursinho, aquisição de obras da literatura brasileira exigidos para as provas do vestibular da UESC, locação de transporte para aula de campo, pincéis e apagadores. Diante desta necessidade, buscam parcerias com o comércio local para patrocinar alguns custos, que se somam a outra fonte de recursos advinda de uma taxa mensal, não obrigatória, no 
valor de $\mathrm{R} \$ 10,00$ reais, solicitada aos estudantes a título de colaboração para manutenção dessas despesas.

Vale enfatizar, que a ausência de políticas públicas, sobretudo, no Sul da Bahia, voltadas para o público-alvo das ações do PREAFRO leva o cursinho a tentar diminuir as lacunas educacionais e assim assumir parte da responsabilidade que caberia ao poder público. Nesse sentido, organizar táticas de resistência possibilita caminhos ainda inéditos para os estudantes da comunidade, bem como não permite que os representantes pela gestão pública se acomodem, enquanto esse grupo assume todas as consequências da negação de direitos, principalmente no que tange ao acesso ao sistema educacional.

Não obstante essas dificuldades, o PREAFRO matrícula no início de cada ano 120 estudantes. Os interessados fazem a inscrição presencial, por meio do preenchimento de uma ficha-diagnóstico, onde são respondidas algumas questões. Baseados nessas informações disponibilizadas para esta pesquisa, traçamos um perfil desses estudantes, a saber: a maioria deles se autodeclaram negros ${ }^{1}$, são mulheres, com renda familiar em torno de um salário mínimo ${ }^{2}$ e que terminaram o ensino médio há mais de cinco anos, e a escolaridade da maioria dos pais se restringe ao ensino fundamental. Inclusive, uma característica comum entre eles é o fato de a maioria serem os primeiros de toda a sua geração familiar a tentar ingressar numa universidade. Esse ineditismo aparece no conjunto das narrativas dos protagonistas, destacado nesses excertos:

A minha maior angústia é saber que meu irmão e eu somos os primeiros e ainda os únicos da nossa família (Adriana Silva, Entrevista Narrativa, 2013).

Eu desconheço outra pessoa além de mim que tenha conseguido entrar na universidade, da minha família eu sou o único dos meus irmãos (Egnaldo França, Entrevista Narrativa, 2013).

Tanto que da minha família eu fui o primeiro a entrar na UESC (Gilvan Nascimento, Entrevista Narrativa, 2013).

\footnotetext{
${ }^{1}$ Utilizamos o termo, conforme o IBGE, englobando pretos e pardos, na categoria, negros.
}

${ }^{2}$ Valor atual do Salário Mínimo no Brasil: $\mathrm{R} \$$ 724,00 a partir de 01.01.2014 
Somos, minha irmã e eu, os primeiros de todas as gerações da nossa família, e talvez por algum tempo, seremos os únicos a ingressar na universidade (Wilton Macedo, Entrevista Narrativa, 2013).

Compreendemos esses fragmentos como indícios importantes, que apontam que os meios necessários para promover o acesso ainda não estão disponíveis para esse grupo. Então, ainda "há uma diferença" interpretada socialmente como inferioridade e transformada em desigualdade, que talvez explique os motivos que impedem e/ou retardam os estudantes dessa localidade, de concluírem o ensino fundamental e/ou médio, demonstrando desigualdades educacionais acumuladas, revelando a produção da "não existência", com o propósito de tornar a diferença insuperável (SOUSA SANTOS, 2004). Neste caso, associamos a ausência desse grupo do ensino superior a um processo hierárquico tido como natural, onde uma minoria pode ser considerada aprovada para essa modalidade de ensino.

Apreendemos que as "táticas" de resistências organizadas pelo PREAFRO confrontam essa lógica ao transformar as suas experiências ditas como ausentes em presenças possíveis. Tanto que os protagonistas desta pesquisa, junto com outros 32 estudantes, conseguiram contornar essas barreiras e ingressaram na universidade no período entre 2006 e $2011^{1}$ - 36 estudantes, sendo 22 mulheres, 14 homens, nos diversos cursos de graduação, assim distribuídos: 14 nos cursos de bacharelado e 22 nos de licenciatura, entre os quais, dois foram selecionados a partir da avaliação do ENEM, como bolsistas do Programa Universidade para Todos (PROUNI) para os cursos de Pedagogia e Engenharia Ambiental na Faculdade de Tecnologia e Ciências (FTC)-Itabuna.

Chamou atenção o número reduzido de estudantes nos cursos diurnos, outro fator que tende a excluir, impedir ou dificultar o acesso dos estudantes do PREAFRO a alguns cursos, como Agronomia, Ciências Biológicas, Ciências da Computação e Educação Física, todos disponíveis, apenas diurnamente, ou seja, as aulas acontecem tanto no turno matutino como vespertino. Assim, para estudar nesses cursos, faz-se necessário ter disponibilidade durante o dia, condição esta distante da realidade dos estudantes do PREAFRO, uma vez que a maioria deles ou trabalham e tem disponível o

\footnotetext{
${ }^{1}$ Escolhemos esse período em virtude das ações do PREAFRO terem se iniciado nesse formato, em 2005, e os estudantes terem participado do vestibular em 2006.
} 
turno noturno ou estão desempregados, tornando inviável a permanência nesses cursos que exigem mais recursos financeiros para dar conta das despesas com livros, alimentação, transporte e etc. Tanto que "uma instituição cujos cursos têm funcionamento predominantemente diurno já representa uma interdição para estudantes que necessitam, desde muito cedo, assumir a responsabilidade com a própria sobrevivência e, em muitos casos, com a sobrevivência da família" (SANTOS E QUEIROZ, 2005, p.21).

Restando, portanto, a "opção" dos cursos que funcionam no período noturno, aqueles com "menor prestígio social, como os de licenciatura" ${ }^{1}$, indicando novamente uma ausência produzida com a intenção de manter a universidade como um espaço hierarquizado, ou como em Queiroz (2001, p.5), obedecendo "a gradações de prestígio em que a 'cor' é contaminada por outros discriminadores, tais como renda, origem familiar, educação, que atuam empurrando o indivíduo para um ou outro polo da dicotomia branco/preto". E o mais grave encontra-se na negação de que esse é um mecanismo do sistema educacional para continuar mantendo esse grupo distante dos lugares socialmente prestigiados, visto que não há uma proibição expressa que impede os negros de ingressar na universidade, levando a ideia falaciosa de que todos têm a mesma possibilidade de acesso. Nesses casos, muitos já internalizaram essa ideia ou defendem que "alguns estudantes excepcionais possuiriam" as condições intelectuais para tal façanha. Ora, não se trata da excepcionalidade conferida a alguns em detrimento de outros, pois,

Sabemos que os estudantes das escolas públicas cumprem sua escolarização em condições extremamente precárias, e que para os estudantes negros, a essas condições se soma a discriminação racial. Desse modo, podemos concluir que a aprovação no vestibular, de estudantes negros, oriundos de escolas públicas, em cursos altamente prestigiados, não poderia ser considerada um caso de simples seleção, porque esses estudantes enfrentaram a concorrência desigual de estudantes oriundos de escolas privadas de excelência, e demonstraram desempenho satisfatório (QUEIROZ, 2001 p.18).

1 Cf. escala de prestígio apresentada por Delcele Mascarenhas Queiroz In O Negro e a Universidade Brasileira. 2004. Disponível em Historia Actual Online 2004.Disponível em: dialnet.unirioja.es/descarga/articulo/829437.pdf 
Ainda que haja diferenças entre o contexto da Universidade Federal da Bahia (UFBA), uma universidade da esfera federal, localizada na capital do estado da Bahia, onde foi realizado esse estudo de Queiroz e a Universidade Estadual de Santa Cruz(UESC), universidade estadual do interior baiano, encontramos proximidades importantes entre os dados dos estudos de Queiroz (2004) e aqueles dos estudantes do PREAFRO aprovados nos vestibulares da UESC, que não são selecionados para os cursos de alto prestígio, como Medicina, Enfermagem, Direito e outros.

Os cursos com alto prestígio social mencionados por Queiroz evidenciam que as universidades federais são marcadas pela desigualdade racial.

\footnotetext{
Esses resultados apresentam as universidades federais brasileiras investigadas, com espaços fortemente seletivos, particularmente marcados pela desigualdade racial. Embora tenha ficado bastante evidente a posição de desvantagem em que se encontram os estudantes negros, é oportuno lembrar, mesmo assim, que se está diante de um segmento da população negra já bastante selecionado, porque bem-sucedido na disputa por uma oportunidade na universidade pública brasileira, portanto, pouco representativo do conjunto dos estudantes negros brasileiros.[...] Os dados da distribuição por cor, dos estudantes situados em cursos de alto prestígio, evidenciam a posição privilegiada dos brancos com relação ao acesso a cursos de elevado prestígio social, em todas as universidades investigadas (QUEIROZ,2004,p.7) (grifo nosso).
}

Chamamos atenção para os trechos em destaque, pois, consideramos que eles dão pistas sobre o cenário de desvantagens que também compõe as experiências dos estudantes do PREAFRO: são muitas as condições adversas, desde a ausência de escola nas comunidades onde vivem, a discriminação racial que reforça os estereótipos que inferiorizam o negro, afetando negativamente a sua autoestima, afastando-o da escola, a pobreza material que reflete na trajetória escolar, a violência urbana que recai com mais força sobre os moradores da periferia, a falta de serviços públicos básicos, como: saneamento, água, iluminação, saúde e etc.

Esses estudantes do PREAFRO que acessam a universidade fazem parte de um grupo de negros bem-sucedidos, "na disputa por uma oportunidade na universidade 
pública brasileira" (QUEIROZ, 2004, p.7), pois, a pesquisa que resultou nas ações do PREAFRO constatou uma desigualdade educacional que atinge a maioria dos negros, desde o ensino fundamental, passando pelo ensino médio e a universidade.

Portanto, consideramos as ações desse cursinho positivas no sentido de que tenta reverter esse cenário desfavorável e, sobretudo, porque adota uma concepção de educação que orienta para a formação de indignados, inconformados e com "sujeitos da experiência" que vão ao encontro dos acontecimentos e podem ser transformados por eles, ao tempo em que também se formam e se transformam. Essa é uma proposta de educação "corajosa, curiosa, despertadora da curiosidade, mantenedora da curiosidade" (FREIRE, 2001, p.101).

\subsection{As "Maneiras de fazer" do PREAFRO}

A partir de Certeau (2004) e Larrosa (2011), consideramos que a tática é a arte do "sujeito da experiência", aquele que pode ser transformado no transcurso do tempo, mas também rejeita, subverte, transforma e modifica os acontecimentos, sem deixá-los. Nesse caso, permanecem outros, dentro da universidade que também é transformada por eles, num movimento de ida e volta.

Nessa perspectiva, as outras "maneiras de fazer" têm alcançado um dos objetivos do cursinho, tanto que na Pesquisa de Amostragem Étnico-racial realizada junto aos estudantes da UESC, envolvendo a frequência ou não de cursinhos, revelou que a necessidade do "cursinho se faz presente, com altos percentuais, mesmo nos cursos de menor prestígio social, com porcentagens ora muito próximas, ora superiores a $50 \% "$.

Interpretamos essa necessidade como sendo um dos elementos que geram inquietações, sobretudo nos movimentos de resistência negra, entre os quais está inserido o PREAFRO, levando-o a organizar ações para promover o acesso a esses cursos. E essa pesquisa feita na UESC revelou que os cursinhos têm conseguido:

Fazer com que os jovens das camadas menos privilegiadas consigam ter acesso à universidade pública. Importante observar que na categoria daqueles que fizeram o cursinho "popular" ocorre porcentagem em todos os cursos do conjunto e em alguns casos elas são muito significativas, como na Química (30,3\%), nas Físicas (licenciatura 25,0\% e bacharelado 15,4\%), Economia (21,1\%), Letras (22,3\%) e Ciências Biológicas (16,3\%). Ocorrem 
também na Matemática, no Direito e na Administração, em porcentagens em torno de $11 \%$. Nos demais cursos do conjunto aparecem em percentuais pequenos, com exceção da Medicina, explicado pela grande competição que marca o vestibular do curso (FIAMINGUE, et.al.2007, p.43).

Competição essa que pré-seleciona os candidatos a tais cursos, assim, os movimentos populares tecem "ações reais" para tentar diminuir "o fosso entre estudantes negros e oriundos do sistema público de ensino e os estudantes oriundos do sistema privado" (SANTOS, 2005, p.14). Sobre essas ações reais, os escritos de Oliveira (2005, p. 44) trazem algumas pistas: Michel de Certeau estuda essa produção cotidiana de saberes e de formas de sobrevivência dos grupos sociais subalternizados buscando evidenciar os processos pelos quais os 'participantes da vida cotidiana' burlam e usam de modo 'não-autorizado' as regras e produtos que os poderosos lhes impõem.

É com esses grupos subalternizados que vamos identificar nossos educadores e educadoras que estão sendo criticados e desvalorizados, tanto pela maior parte dos acadêmicos e pesquisadores quanto pelas chamadas autoridades educacionais'. Criando 'maneiras de fazer' (caminhar, ler, produzir, falar), 'maneiras de utilizar', tecendo redes de ações reais, que não são e não poderiam ser meras repetições de uma ordem social/de uma proposta curricular. Os educadores e educadoras tecem redes de práticas pedagógicas que, através de 'usos e táticas' de participantes que são, inserem, na estrutura social/curricular, criatividade e pluralidade, modificadores das regras e as relações entre o poder instituído e a vida dos que a ele estão, supostamente, submetidos.

Nessa perspectiva, propomos compreender o diferencial das "maneiras de fazer" do PREAFRO ou as "táticas" de resistências organizadas para rejeitar, transformar e modificar os "acontecimentos exteriores", para que os estudantes continuem outros. Do ponto de vista do "sujeito da experiência" que também pode ser transformado, ao perceber outras abordagens para as "muitas formas de conhecimento" e a possibilidade de aspirar "à construção de uma nova subjectividade. Não basta criar um novo conhecimento, é preciso que alguém se reconheça nele. De nada valerá inventar alternativas de realização pessoal e coletiva se elas não são apropriáveis por aqueles que as destinam" (SOUSA SANTOS, 2011, p.333). 
Para discutir as táticas concernentes "a abordagem diferenciada para os conhecimentos específicos", tomamos como referência as narrativas das experiências dos protagonistas desta pesquisa buscando interagir com a perspectiva de Larrosa (2011, p.15), que pensa "a experiência desde um ponto de vista da formação e da transformação", enfatizando a dimensão subjetividade, que envolve os princípios da subjetividade, da reflexividade e da transformação. Então, abordamos essa experiência do ponto de vista de quem a vivenciou, ou seja, do "sujeito da experiência". Sobre esse diferencial, Egnaldo constrói esse excerto:

A proposta é reconstruir a forma como eles percebem a si e a sua comunidade. O trabalho feito no cursinho incorpora as aulas de Estudos Afros, Atualidades, História Regional, é uma abordagem diferenciada para os conteúdos específicos exigidos pelas provas do vestibular, buscando discutir a realidade local a partir dos próprios estudantes (Egnaldo França, Entrevista Narrativa, 2013).

Egnaldo evoca um elemento revelador para o exercício de apreender sobre o acesso desse grupo: o diferencial do cursinho se encontra na abordagem dada aos "conhecimentos específicos". Considerando não apenas o que os estudantes sabem, do ponto de vista do exigido pelas provas do vestibular, mas, sobretudo, o que eles são ou podem vir a ser. Trata-se de uma perspectiva da ordem do estranhamento das condições vividas até ali e inquietar-se frente ao acúmulo de desvantagens a que estão submetidos, revelado pela ausência de direitos básicos, como: escola, saúde e esporte etc. ou "a partir do mais profundo de si, buscar a inteligibilidade do mais amplo e também mais profundo da vida coletiva" (SOUSA SANTOS, 2011, p.334).

Esse olhar para si ajuda a desvelar os mecanismos das desigualdades impostas na comunidade e aponta como viável o até então considerado impossível, dando início a inconformismos, inquietações e resistências, que fortalecem os estudantes para o enfrentamento do processo seletivo para ingressar na universidade. Assim, pensar os temas a serem discutidos "como algo que tem a ver com aquilo que nos faz ser o que somos e nos constitui ou nos põe em questão naquilo que somos" (LARROSA, 2011, p.9).

Trata-se de uma proposta de resistência que supõe "cancelar essa fronteira entre o que sabemos e o que somos, entre o que passa (e o que podemos conhecer) e o que nos passa (como algo a que devemos atribuir um sentido em relação com nós mesmos" 
(IDEM, p.10). Não significa, portanto, ensinar técnicas/modos de apropriação desses conhecimentos, mas de modificar as "maneiras de fazer", inserindo práticas cotidianas que deem abertura ao estudante para questionar as formas como a sociedade, da qual a educação escolar faz parte e ainda está organizada, legitimando alguns conhecimentos em detrimento de outros, numa perspectiva de certo e errado, periferia e centro, belo e feio, alto e baixo prestígio.

Certeau (2004, p.100) apresenta uma discussão para compreender as práticas cotidianas, envolvendo estratégias e táticas. A estratégia é conceituada, como o cálculo ou a manipulação de relações de força que se torna possível a partir do momento em que um sujeito de querer e poder, quer seja uma empresa, um exército, uma cidade, uma instituição científica, podendo ser isolado. Mas, reconhece-se nessas "estratégias" um tipo específico de saber, aquele que sustenta e determina o poder de conquistar para si um lugar.

Enquanto que tática não tem por lugar senão o outro, aproveita as "ocasiões" e depende delas, não possui base para estocar benefícios e prever saídas, por isso não conserva aquilo que ganha. Este não lugar, sem dúvida, lhe permite mobilidade, mas numa sujeição aos azares do tempo, para captar no voo as possibilidades oferecidas por um instante. Tem que utilizar, vigilante, as falhas que as conjunturas particulares vão abrindo na vigilância do poder proprietário. Aí vai caçar. Cria ali surpresas. Consegue estar onde ninguém espera. É astúcia. Em suma, a tática é a arte do fraco [...] é movimento "dentro do campo de visão do inimigo", e no espaço por ele controlado, assim o sujeito fraco joga com as forças do outro, mas não o manipula (CERTEAU, 2004, p.102).

Em se tratando do PREAFRO, essas táticas são engendradas como dito por De Certeau (2004), num cotidiano marcado pelas relações de poder entre os fortes e os fracos, nominados por ele de usuários ou consumidores. Nesse caso, não somente de bens materiais, mas também de bens culturais, regras e imposições das instituições etc. Tal dominação não é aceita de forma passiva, mas pode ser modificada pelas "táticas" dos praticantes do cotidiano. Portanto, os consumidores/usuários não são apenas receptores inertes dos bens/produtos a eles destinados, pois podem utilizar de modo diferente os bens produzidos para dado fim. Nesse sentido, os produtores de bens e 
produtos fazem uso das "estratégias", ao passo que os consumidores/usuários, das "táticas"1.

No que diz respeito as "táticas" cotidianas que possibilitam movimentar-se nos espaços controlados pelo "inimigo", o PREAFRO organiza uma composição curricular buscando romper com a visão que transforma diferenças em desigualdades e produz ausências tratadas como naturais. Trata-se de outros modos de atender os conteúdos exigidos para o vestibular da UESC (matemática, física, química, biologia, história, geografia, literatura, redação, língua portuguesa, língua estrangeira) e para as provas do Enem, distribuídas nas áreas de exatas, humanas, biológicas, linguagens, e passa a incluir também Atualidades, História Regional e Estudos Afros, envolvendo a história dos negros na sociedade brasileira, com enfoque nas questões locais. Consideramos que essa é uma proposta para:

\begin{abstract}
Revalorizar os conhecimentos e as práticas não hegemônicas que são afinal a esmagadora maioria das práticas de vida e de conhecimento. [...] Propõe que aprendamos com o Sul, sendo neste caso o Sul uma metáfora para designar os oprimidos pelas diferentes formas de poder. [...] Esta opção pelos conhecimentos e práticas oprimidas, marginalizadas, subordinadas não tem qualquer objetivo museológico. Pelo contrário, é crucial conhecer o Sul para conhecer o Sul em seus próprios termos, mas também para conhecer o Norte. É nas margens que se faz o centro (SOUSA SANTOS, 2011, p.329).
\end{abstract}

Para integrar as diversas áreas, os assuntos são coletivamente ${ }^{2}$ planejados e organizados por temas semanais, que devem ser tratados em todas as áreas. Assim, a diversidade aparece como um eixo que norteia essa experiência curricular, não se tratando apenas de transversalidade dos conhecimentos ${ }^{3}$. Nesse sentido, adota-se a noção de que a diversidade decorre de um processo histórico e discursivo de construção da diferença, por meio de um vínculo entre conhecimento, identidade e poder que os

${ }^{1}$ Certeau em sua pesquisa pretende "exumar os modelos de ação característicos dos usuários, dos quais se esconde, sob o pudico nome de consumidores, o estatuto de dominados (o que não quer dizer, passivos ou dóceis)" (p. 38). O cotidiano se inventa de mil maneiras de caça não autorizadas.

${ }^{2}$ Os professores e a coordenação se reúnem uma vez por mês para organizar o planejamento dos trabalhos para o período de 30 dias.

3 Transversalidade, conforme considerada nos Parâmetros Curriculares Nacionais (1997).

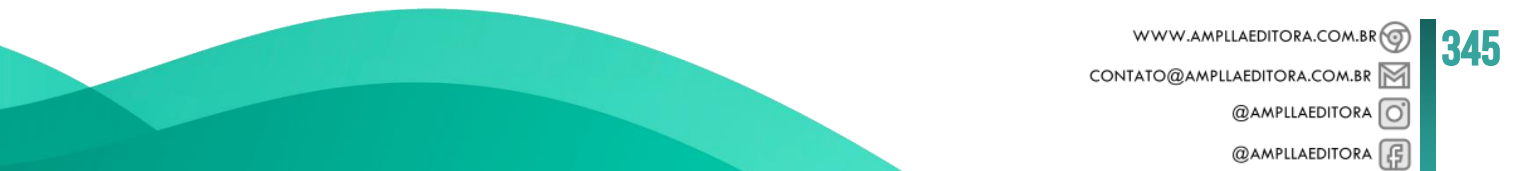


temas envolvendo raça e etnia ganham espaço na teoria curricular (SILVA, 2012). Assim, podem emergir outras formas de enfrentamento das práticas discriminatórias que implica na mudança de olhar sobre si e o outro, resgatando:

A memória coletiva e da história da comunidade negra não interessa apenas aos alunos de ascendência negra. Interessa também aos alunos de outras ascendências étnicas, principalmente branca, pois ao receber uma educação envenenada pelos preconceitos, eles também tiveram suas estruturas psíquicas afetadas. Além disso, essa memória não pertence somente aos negros. Ela pertence a todos, tendo em vista que os segmentos étnicos que, apesar das condições desiguais nas quais se desenvolvem, contribuíram cada um de seu modo na formação da riqueza econômica e social e da identidade nacional (MUNANGA, 2012, p. 12).

Uma educação preconceituosa contamina a formação e fomenta injustiça racial, especialmente de grupos submetidos à discriminação. Decorre daí, o PREAFRO adotar uma proposta que possibilita o enfrentamento de preconceitos, formulação de questionamentos e desconstrução da ideia que entende "o legado africano como saberes do mal, saberes de culturas atrasadas e pré-lógicas, repercutindo nos currículos escolares com uma carga preconceituosa que gera as discriminações" (Santana, 2006, p.39). Nesse sentido, empregar formas de resistência, para estreitar a distância entre a comunidade e a universidade, tentando modificar uma realidade imposta e pode levar o sujeito ao lugar de protagonista (Souza Santos, 2010). Dito aqui, como aqueles que conquistam algo novo com relevância social para o seu grupo, esse é o caso do primeiro morador dessa comunidade aprovado no processo seletivo da universidade pública, posto que o seu protagonismo fortaleceu a autoestima do grupo.

Trata-se, portanto, de uma abordagem curricular visando reconstruir uma história positiva sobre a "identidade coletiva Negra" e, para tanto, entre os conteúdos de História Regional estão algumas aulas de campo realizadas na região, como por exemplo, numa localidade no município de Ilhéus, denominada "Engenho de Santana", onde aconteceu uma das principais Revoltas de Escravos (1789-1791), insatisfeitos com o tratamento que recebiam ${ }^{1}$. Esse engenho foi considerado um centro econômico da

${ }^{1}$ Para ampliar os conhecimentos, consultar REIS, João José e SILVA, Eduardo. Negociações e Conflito; a resistência negra no Brasil escravista. São Paulo: Companhia das Letras, 1989, que propõe uma 
Capitania durante séculos, um modelo para os fazendeiros da região sul da Bahia. Sobre essa reconstrução da história, Munanga (2012, p.10) diz que:

\begin{abstract}
A identidade vista do ponto de vista da comunidade negra através do seu movimento social e de suas entidades políticas. O primeiro fator constitutivo desta identidade é a história. No entanto, essa história, mal a conhecemos, pois ela foi contada do ponto de vista do "outro", de maneira depreciativa e negativa. O essencial é reencontrar o fio condutor da verdadeira história do Negro que o liga à África sem distorções e falsificações [...]. Daí a necessidade e importância de ensinar a história da África e a história do negro no Brasil a partir de novas abordagens e posturas epistemológicas, rompendo com a visão depreciativa do negro.
\end{abstract}

Desconstruir uma memória negativa para reconstruir uma positiva, esse é o objetivo desse componente do currículo para atender tanto às exigências do processo seletivo da UESC, já que entre os conteúdos abordados estão as questões regionais, como um dos objetivos do cursinho, pois possibilita aos estudantes interpretar o conhecimento, a partir de uma perspectiva positiva do negro.

Essas aulas de campo são planejadas por Egnaldo, estudante do último semestre do curso de História/UESC e vice-coordenador do PREAFRO e professor responsável por essa disciplina, com a participação de professores convidados, na maioria das vezes, exestudantes do cursinho ou professores do Curso de História da UESC que atuam nessas aulas como colaboradores. Egnaldo, em sua narrativa, diz que: "A maioria dos estudantes não conhece a história dessa população escravizada, eles ficam surpresos, quando percebem que aqueles escravos sabiam ler e escreveram uma carta de reivindicações".

Sobre tais distorções, Schwartz (2001) critica: durante longo tempo, a historiografia brasileira se acostumou a ver o escravo, sobretudo, como um objeto de seus atos e vontades, de seus impulsos e desejos e, por fim, objeto da própria disciplina que o privilegiava enquanto tema de reflexão. Esse novo olhar sobre a História Regional desmistifica algumas ideias, permitindo outras perspectivas sobre o passado da população negra, especialmente nessa região, onde uma quantidade expressiva de

nova abordagem sobre escravidão negra no Brasil, resgatando as conquistas daqueles que, ao contrário do que até hoje se supôs, resistiam a tornarem-se apenas engrenagens do sistema que os escravizara. 
trabalhadores escravos manteve o cultivo e a produtividade do cacau em ritmo acelerado (CRUZ, 2011). Trata-se, portanto, de uma experiência de releituras do passado para possibilitar aos indivíduos perceberem-se no mundo, por meio de suas leituras, como atuantes da história, e não meros expectadores.

Do ponto de vista da experiência, defendida por Larrosa (2002), o texto funciona como um acontecimento, quer dizer o que importa "não é qual o livro, mas o que nos passa com sua leitura" (p.6). Assim, cabe ao leitor colocar-se no que lê, relacionando o texto com a sua subjetividade, caso contrário, pode compreender e responder perguntas sobre o texto, mas num movimento "só de ida", sem abertura para reflexão. Se nessa leitura não houver subjetividade, reflexividade, tampouco haverá transformação, porque se limitou apenas à compreensão do texto. Interessa, sobretudo, como a leitura pode ajudar a formar, de-formar ou transformar a linguagem, o pensamento do leitor, levando-o a falar, a escrever e a pensar por si mesmo, com suas próprias ideias.

Entendemos que para relacionar o texto com a sua subjetividade, um dos aspectos fundamentais é o leitor reconhecer-se no texto. Em outras palavras, a leitura deve ser o lugar do encontro com as inquietações, com o desconhecido, com a sua história e exige proximidade entre o texto e a subjetividade. Caso contrário, não resulta em formação, porque a leitura não afetou o leitor. Essa perspectiva ajuda a compreender o que faz efeito nas "maneiras de fazer" do PREAFRO, ao propor também reconstruir a percepção que os estudantes "têm de si e da comunidade", a "partir do mais profundo de si".

Ao abordar os conteúdos a partir das inquietações dos próprios estudantes, eles se reconhecem nas questões locais indo ao encontro do texto, num processo que o leitor não só adquire um novo conhecimento. Dito de outro modo, não se trata de saber algo que não sabia antes, mas de ter sido transformado pela leitura, posto que os assuntos não estão distantes deles. Assim, textos e subjetividades estão próximos, ou "a leitura como formação, seria tentar pensar essa misteriosa atividade que é a leitura como algo que tem a ver com aquilo que nos faz ser o que somos" (LARROSA, 2011, p.9).

Trata-se, portanto, de atender às demandas do grupo, rediscutindo, revalorizando para reconhecer a sua história a partir dos seus "próprios termos" e experiências. Esse novo olhar dá abertura ao possível, leva a recusas, ao inconformismo, 
a outros "fazeres", "pensares" e "sentires", fundamentais para a formação e a transformação, aquela dita por Larrosa (2011, p.10), que, entre outros, supõe "condição reflexiva, volta para dentro, subjetiva, que me implica no que sou, que tem uma dimensão transformadora, que me faz outro do que sou. Por isso [...], eu já não sou o mesmo de antes, já não posso olhar-me impávido no espelho [...] porque algo tem lugar em mim". Esse tipo de experiência exige uma ação educativa que tenha os educandos no centro, em um movimento de questionar os contextos das suas histórias, colocandoos em dúvida para pensá-los de outros modos.

Assim, há uma percepção de que existem temas que foram negados e até então eles eram homens e mulheres que não se sabiam negros; apesar dessa condição ser visível ao olhar do outro, a autoafirmação, o saber-se negro não é um processo fácil. Compreendo como uma construção coletiva da identidade com a participação de todo o grupo com suas singularidades e diferenças.

Segundo Munanga (2012, p.10), nesse processo de construção da identidade coletiva negra, faz-se necessário resgatar história, desconstruindo a memória de negativa que se encontra ainda presente em "nosso" imaginário. Desse modo, reconstruir uma verdadeira história positiva capaz de resgatar autoestima destruída por essa abordagem. Daí a necessidade e importância de ensinar a história da África e a história do negro no Brasil a partir de novas abordagens e posturas epistemológicas, rompendo com a visão depreciativa do negro.

\section{CONSIDERAÇÕES FINAIS}

Então, consideramos que o retorno desses estudantes ao PREAFRO está relacionado com essa mudança de percepção, com essa transformação de si que os tornam inconformados e prontos para intervirem para mudar o seu entorno. Intervenção essa, que não pode ser tomada como uma iniciativa para encobrir as lacunas do sistema educacional ainda presentes para esse grupo, sobretudo aquelas que envolvem medidas para atenuar os baixos níveis de escolaridade encontrados nas comunidades onde esse cursinho atua. Partimos desse pressuposto, para dizer que a experiência do retorno significa, sobretudo, recontar a história de outros estudantes de forma diferente, apesar do contexto desfavorável, que ainda mantém a universidade como um espaço para a minoria. 
Nesse sentido, organizar por conta própria ações voltadas para o acesso quer dizer intervir para provocar mudanças para um grupo que, na maioria das vezes, não teve oportunidades de conhecer possibilidades de formar e transformar. Não queremos dizer com isso que se trata de uma perspectiva fácil e comum a todos, até porque, do ponto de vista que assumo neste texto, a experiência não é a mesma em todas as ocorrências, por isso irrepetível. Entretanto, não equivale a um acontecimento da ordem do impossível, do esmorecimento, mas da resistência, da abertura, da inquietude, de produzir as condições para tornar viável que esses estudantes ultrapassem as estratégias organizadas.

Entendemos que essas são experiências vividas por cada um, a partir das singularidades concernentes a cada protagonista, mas todas tiveram o cursinho como parte do cenário, que nesse caso, promoveu encontros de estudos com o mesmo propósito: acessar a universidade.

\section{REFERÊNCIAS}

CERTEAU, Michel de A Invenção do Cotidiano: 1. Artes de Fazer. Rio de Janeiro: Vozes, 2004.

CRUZ, Ronaldo. L. Conflitos e Tensões: Análise do Pós - Abolição no Sul da Bahia, 18801910. (Dissertação de Mestrado). UNESP. Franca São Paulo. 2011.

FIAMENGUE, Elis. C.; JOSE, D. Wagner; PEREIRA; ALMEIDA, Carlos. J. A UESC em preto \& branco: pesquisa de amostragem étnico-racial. Brasília: MEC/SECAD, 2007.

FREIRE, Paulo. Pedagogia do Oprimido. Rio de janeiro: Paz e Terra, 2001.

LARROSA BONDÍA, Jorge Notas sobre a experiência e o saber de Experiência Trad. de João Wanderley Geraldi UNICAMP Rev. Bras. Educ. [online]. 2002, n.19, pp. 2028. ISSN 1413-2478. 2002.

. Experiência e alteridade em educação. In: Revista Reflexão e Ação, Santa Cruz do Sul, v.19, n2, p.04-27, jul./dez. 2011.

MUNANGA Kabengele. Negritude e identidade negra ou afrodescendente: um racismo ao avesso? Revista da ABPN. v. 4, n. 8 jul. -out. 2012.

OLIVEIRA, Ivone. de L. Novo sentido da comunicação organizacional, construção de um espaço estratégico. Anais do 26. Congresso Brasileiro de Ciências da Comunicação, Belo Horizonte - MG, setembro de 2003. São Paulo: Intercom, 2005. [cd-rom] 
QUEIROZ, Delcele. M. (Org.). O negro na universidade. Salvador: UFBA, 2001.

Desigualdade no ensino superior: cor, status e desempenho. GE: Grupo de Estudos Afro-brasileiros e Educação /n.21. 2004.

SANTOS. Jocélio.T. Vestibular com cotas: análise em uma instituição pública federal. In: Revista USP, São Paulo, n.68, p. 58-75, dezembro/fevereiro 20052006.

SANTANA, Marise. O legado ancestral africano na diáspora e a formação docente. In: Currículo, relações raciais e cultura afro-brasileira. Salto para o futuro. Ministério da Educação. Brasil.2006.

SANTOS, Flávio. G. dos. História e Cultura Afro-Brasileira na Educação Básica: Origens e implicações da Lei 10.639/2003. In: Cadernos do CEAS. $N^{\circ} 225$. Salvador: centro de Estudos e Ação Social. 2003.

SCHWARTZ, Stuart B. Escravos, Roceiros e Rebeldes. Trad. Jussara Simões. Bauru (SP): Edusc, 2001.

SOUSA SANTOS, B. Um discurso sobre as ciências. 3. ed. São Paulo, SP: Cortez Ed., 2005.

Pela mão de Alice: o social e o político na pós-modernidade. 13 ed. São Paulo: Cortez. 2010.

SILVA, Tomaz. T. da. Identidade e diferença: a perspectiva dos estudos culturais/Tomaz Tadeu da Silva (org.) Stuart Hall, Kathryn Woodward.12 ed. Petrópolis, RJ: Vozes, 2012. 


\section{CAPÍTULO XXVII}

\section{AFRICANOS DE ONDE? A NEO-COLONIZAÇÃO INGLESA E O IMPERIALISMO NA ÁFRICA EM CHIMAMANDA NGOZIE ADICHIE

\author{
Raissa Gouveia de Melo Efrem ${ }^{1}$
} \\ Rodrigo Sousa da Silva ${ }^{2}$}

${ }^{1}$ Graduada em Licenciatura Plena em História pela UFRPE

${ }^{2}$ Graduado em Licenciatura Plena em História pela UFRPE

\section{RESUMO}

O presente artigo tem como objeto de estudo obras escritas por Chimamanda Adichie, a fim de utilizá-las para captar o olhar não eurocêntrico da autora sobre a história da Nigéria e de personagens nigerianos. Foi escolhido o seu discurso $O$ perigo de uma história única, adaptado em livro pela Companhia das Letras, em 2019; além de dois de seus contos: A historiadora obstinada e Jumping Morning Hill, ambos presentes na coletânea No seu pescoço (2017). Serão abordadas discussões acerca de Ensino de História, Literatura e História da África. Dividido em 4 tópicos, o artigo identifica o contexto histórico em que Chimamanda escreve e aborda a importância da literatura de origem africana; resume e resenha sua já citada palestra; desdobra o Imperialismo na África e aponta as suas consequências nos dias atuais; e, por fim, aponta como utilizar a literatura de Chimamanda nas aulas de História da África.

Palavras-chave: Ensino de História. Chimamanda Adichie. História da África. Literatura. Imperialismo.

\section{INTRODUÇÃO}

Os escritos de Chimamanda Adichie são como um mapa que nos guia para fora da caverna e abre os nossos olhos para questionamentos anteriormente escondidos sob as sombras do eurocentrismo acadêmico e social.

O presente artigo tem como objeto de estudo obras escritas por Chimamanda Adichie, a fim de utilizá-las para captar o olhar não eurocêntrico da autora sobre a história da Nigéria e de personagens nigerianos. Foi escolhido o seu discurso $O$ perigo de uma história única, adaptado em livro pela Companhia das Letras, em 2019; além de dois de seus contos: Uma experiência privada e Jumping Morning Hill, ambos presentes na coletânea No seu pescoço (2017). 
O objetivo geral desta pesquisa é apontar como é possível compreender a história da Nigéria a partir dos contos de Chimamanda Adichie. Para isso, será introduzido brevemente a história de vida da escritora, a fim de atingir dois dos quatro objetivos específicos: identificar o contexto em que ela escreve e abordar a importância da literatura de origem africana para que, em seguida, a pesquisa possa focar não só no Imperialismo na África; como também em identificar a problemática de reunir todos os nascidos no continente sob o termo "africanos", como se possuíssem os mesmos costumes e culturas. A metodologia de caráter qualitativo se constitui em leitura teórica acerca de ensino de história; interdisciplinaridade entre História e Literatura; e História da África.

Desse modo, o primeiro tópico, intitulado "A importância de Chimamanda Adichie para a literatura africana" visa falar sobre Endereçamento - conceito trazido por Elizabeth Ellswoth para falar sobre representatividade no cinema, mas que aqui será discutido em âmbito literário; além de abordar o contexto de escrita de Chimamanda e a literatura de testemunho.

"O perigo de uma história única", a sessão dois, resume e resenha a palestra homônima de Chimamanda Adichie, trazendo o que está escrito nas entrelinhas de sua fala e mostrando a importância desse discurso não só para o presente trabalho; mas para o mundo.

"As influências do Imperialismo em A historiadora obstinada", a sessão de número três, traz a definição de Imperialismo e sua abordagem em sala de aula de acordo com a BNCC e o PCN. Ademais trata do desdobramento desse período histórico em diversos problemas atuais no continente africano e como esses problemas são retratados pela autora. Soma-se a esse debate a abordagem ocidental aos africanos como oriundos de um único lugar, sem especificidades, e como isso é consequência, dentre outros fatores, de suas independências muito recentes.

A quarta e última sessão, "A contribuição da literatura de Chimamanda nas aulas de História da África" é um complemento do tópico anterior, pois traz a parte prática de ensinar o tema Imperialismo a partir da obra de Chimamanda: objetivo geral do presente trabalho. Para isso, fala sobre a lei 11.645/08 e se debruça sobre o Ensino de História a partir da empatia e da literacia histórica de Peter Lee, ou seja, como utilizar a literatura para auxiliar a transmissão do conteúdo historiográfico. 
O artigo se justifica por buscar não só incentivar a leitura das literaturas de origem africana; como também apontar a visão eurocêntrica que existe sobre o continente, além de falar sobre o uso da literatura no ensino de história.

\section{A IMPORTÂNCIA DE CHIMAMANDA ADICHIE PARA A LITERATURA AFRICANA}

Chimamanda é uma escritora nigeriana que nos conta sobre a importância de conhecermos nossas próprias origens, para que paremos de reproduzir o cotidiano do outro como se fosse o nosso. A autora nos conta isso tudo, dado que ela própria não se enxergava nas histórias que lia, onde todos os personagens "eram brancos de olhos azuis, brincavam na neve, comiam maçãs e falavam muito sobre o tempo e sobre como era bom o sol ter saído" (ADICHIE, 2019, P. 12) e findava por reproduzi-los fielmente em suas próprias narrativas.

Devido a isso, é de suma importância salientar o conceito de Endereçamento, trazido por Elizabeth Ellswoth, visto que apesar de autora se referir ao cinema, é perfeitamente aplicável a qualquer uma das sete artes, uma vez que ela afirma que o ser humano precisa enxergar-se naquilo que ele está consumindo para que haja uma identificação e uma atenção maior no conhecimento a ser constituído. E foi ao se enxergar em histórias oriundas de seu continente que Chimamanda começou a se sentir pertencente, de fato, ao mundo da literatura.

Quando descobriu autores africanos, como Chinua Achebe e Camara Laye, sua percepção da literatura passou por uma mudança e ela percebeu que meninas com a pele de chocolate e cabelo crespo também poderiam ser protagonistas de grandes histórias literárias. Ela se sentiu representada e, por isso, começou a representar o próximo. Então Chimamanda Adichie começou a escrever sobre aquilo que ela conhecia e reconhecia, começou a representar os seus traços, sua família, seus amigos e suas próprias experiências. "O que a descoberta de escritores africanos fez por mim foi isto: salvou-me de ter uma história única sobre o que são os livros" (ADICHIE, 2019, P. 12).

É ao chegar aos Estados Unidos que Chimamanda Adichie experimenta a experiência de ser estrangeira e de ser vista como o outro. É quando o seu eu-individual se percebe, de fato, diferente. E ela estranha quando começa a enxergar a Nigéria e o 
México pelos olhos dos estadunidenses, visto que eles distorcem a imagem do que não conhecem.

Se eu não tivesse crescido na Nigéria e se tudo o que eu soubesse sobre a África viesse das imagens populares, também ia achar que se tratava de um lugar com paisagens maravilhosas, animais lindos e pessoas incompreensíveis travando guerras sem sentido, morrendo de pobreza e de aids, incapazes de falar por si e esperando para serem salvas por um estrangeiro branco e bondoso". (ADICHIE, 2019, p. 18-19).

Num dos contos de Chimamanda, é possível notar as dificuldades pelas quais ela passou para ser aceita no meio literário. Jumping Morning Hill é a sexta narrativa da coletânea No seu Pescoço (2017), e fala sobre uma escritora participando de um Workshop para escritores africanos e que é questionada ao escrever sobre problemas de gênero e por sua protagonista andar de carro, dado que de acordo com o professor responsável, não se trata de um conto verdadeiramente africano. "Está muito ocidental", ele diz, e afirma que quer ler uma história sobre a África de verdade. A própria Chimamanda passou por algo parecido com um de seus professores nos Estados Unidos, porquanto ele afirmou que seus "personagens pareciam demais com ele próprio, um homem instruído de classe média: eles dirigem carros, não estavam passando fome; portanto, não eram autenticamente africanos" (ADICHIE, 2019, p. 2021).

A narrativa de Chimamanda faz de seu relato um espaço para a conversação sobre diversos assuntos polêmicos do cotidiano de maneira leve, como religião, cultura, a saudade de casa e o mito do sonho americano. A nigeriana dedica suas obras literárias à investigação da diferença e em como ela pode ser usada para constituir personagens e mensagens fortes.

\section{O PERIGO DE UMA HISTÓRIA ÚNICA}

"Mostre um povo como uma coisa, uma coisa só, sem parar, e é isso que esse povo se torna" (ADICHIE, 2019, p. 22). É isso que Chimamanda tem por história única. Qual a primeira coisa que vem à sua cabeça quando pensa em África? Um safari, fome, aids? O perigo de uma história única fala sobre o que criamos em nossa cabeça a respeito do que não conhecemos baseado na cultura de massa que consumimos, seja em livros, telejornais ou literatura e desmonta o discurso eurocêntrico que é construído 
em nossa cabeça desde a escola, além de seguir falando sobre a influência dos estereótipos construídos em cima de determinados povos e quais os objetivos da propagação dessas histórias.

Ao longo do discurso, Chimamanda conta histórias vividas por ela e que podem ser presenciadas por quem já teve acesso às personagens de seus contos e romances, além de mencionar a presença da história única em suas experiências pessoais, como no caso da sua colega de quarto na universidade dos Estados Unidos, que ficou surpresa pelo fato de Chimamanda saber falar inglês, visto que é comum entre os estadunidenses simplesmente ignorar a história da África e acreditar que todos lá ainda se comunicam exclusivamente com os dialetos locais, como se não tivessem sofrido uma colonização genocida e absorvido o idioma do colonizador - no caso da Nigéria, a Grã-Bretanha. “Minha colega de quarto tinha uma história única da África: uma história única de catástrofe" (ADICHIE, 2019, p. 17).

No decorrer da leitura, eu pensei várias vezes no que Home Bhabha (1998) chama de discurso do colonizador, o qual busca legitimação para as suas estratégias através de conhecimentos do colonizador e do colonizado e se trata de uma série de diferenças e discriminações que se baseiam nas práticas discursivas e políticas da hierarquização racial e cultural. Sua tática é apresentar o colonizado como uma população de tipos degenerados com base na origem racial de modo a justificar a conquista e estabelecer sistemas de administração e instrução.

Esse discurso do colonizador pode ser equiparado à história única trazida por Chimamanda, visto que ambos tratam do poder e da influência de determinados povos. Poder. "É impossível falar sobre história única sem falar sobre poder" afirma a nigeriana, pois "como elas são contadas, quem as conta, quando são contadas e quantas são contadas depende muito de poder". E segue dizendo que o poder é "a habilidade não apenas de contar a história de outra pessoa, mas de fazer que ela seja sua história definitiva" (ADICHIE, 2019, p. 22-23).

O que a autora quer dizer é que países economicamente mais influentes criam uma imagem a respeito de seus diferentes e esse estereótipo é reproduzido incessantemente através de todos os meios que eles tenham acesso: mídia, literatura, música, telenovelas etc. As pessoas que consomem esse conteúdo não questionam de onde eles são provenientes, mas os reproduzem mesmo assim. E é desse modo que 
tantos sujeitos acreditam, assim como o professor de Chimamanda que aparecerá mais na frente, que africanos não podem ser intelectuais e, menos ainda, financeiramente independentes.

Quem conta uma história, conta com determinado propósito. E, normalmente, a história dos vencedores se sobressai à dos vencidos, uma vez que eles adquirem os meios necessários para a difusão de sua narrativa. "Comece a história com a flecha dos índios americanos", Adichie afirma, "e não com a chegada dos britânicos, e a história será completamente diferente" (ADICHIE, 2019, p. 23). Como alguns grupos de indígenas americanos constituíam sociedades ágrafas, não temos registros escritos documentados de sua visão dos acontecimentos, cabendo aos arqueólogos desvendarem outros resquícios. O que temos, na maioria, é aquilo que os invasores falaram a respeito deles. E o mesmo se aplica a determinados povos originários na África - com exceção dos egípcios e outras comunidades não-ágrafas.

Bell hooks em seu livro E eu não sou uma mulher? traz uma fala semelhante à de Chimamanda que muito acrescenta, com ressalvas para o extremismo de sua fala, à presente discussão, uma vez que ela afirma que

Ninguém falava sobre a África como o berço da civilização, sobre as pessoas africanas e as asiáticas que vieram para a América antes de Colombo. Ninguém mencionou os assassinatos em massa de nativos americanos como genocídio ou os estupros de mulheres nativas americanas ou africanas como terrorismo. Ninguém discutia escravidão como o alicerce para o crescimento do capitalismo. Ninguém descreveu a reprodução forçada de mulheres brancas para aumentar a população branca como opressão sexista (HOOKS, 2020, p. 194).

Foi solicitado ressalvas, pois ela não pode afirmar que "ninguém" disse ou que "ninguém" fez. Apesar de ínfimas exceções, houve pessoas como o Frei Bartolomeu de las Casas que fizeram, à sua época, denúncias. Mas, de modo geral, o que ambas as escritoras defendem, por conseguinte, é que devemos prestar atenção ao discurso que escutamos e que reproduzimos, pois ele tem um objetivo. E se queremos estudar determinada população, é fundamental que procuremos a versão daquela população a respeito dos acontecimentos, e não os escritos de terceiros. A fala das duas, somadas à de Bhabha, justificam e mostram que é possível que se cumpra o objetivo dessa 
pesquisa. Utilizar as obras de uma nigeriana para contar a história da Nigéria e do continente africano, em vez de concentrar toda a informação passada aos docentes em relatos europeus, é fundamental para que não propaguemos mais a história única que a Europa tem da África e de todos aqueles que Ihes são diferentes.

\section{AS INFLUÊNCIAS DO IMPERIALISMO EM A HISTORIADORA OBSTINADA}

Imperialismo na Ásia, África e Oceania é um conteúdo histórico abordado no primeiro bimestre do primeiro ano do ensino médio, de acordo com o PCN do Governo do Estado de Pernambuco, previsto para ser estudado dentro do contexto político, econômico e social mundial no século XIX. É importante mencionar a primeira competência das Ciências Humanas trazida pela BNCC, porquanto ela afirma que é necessário aos alunos

Analisar processos políticos, econômicos, sociais, ambientais e culturais nos âmbitos local, regional, nacional e mundial em diferentes tempos, a partir da pluralidade de procedimentos epistemológicos, científicos e tecnológicos, de modo a compreender e posicionar-se criticamente em relação a eles, considerando diferentes pontos de vista e tomando decisões baseadas em argumentos e fontes de natureza científica (BNCC, 2017).

Aqui vamos falar especificamente do Imperialismo no continente africano, processo que se intensificou com a invasão da Argélia pela França entre 1830 e 1857. A partir daí foi desencadeado uma intensa fase de exploração da África, marcada pela concorrência política e econômica entre diversas potências europeias que estavam em busca de matérias primas e de mercados consumidores fora de seus territórios devido à intensidade da Revolução Industrial. Consequentemente foi gerada uma dominação não só político-ideológica; como também econômica, cultural e social. "O desenvolvimento desse drama foi verdadeiramente espantoso" afirma Albert Boahen, "pois até 1880 apenas algumas áreas bastante restritas da África estavam sob a dominação direta de europeus" (BOAHEN, 2010, p. 2).

Muitos desses países se basearam não só no conceito de darwinismo social para justificar suas atitudes - afirmando que uma vez que a Europa era o continente mais 
desenvolvido, todas as outras regiões eram inferiores a ela, de modo que estavam passíveis de serem invadidas e dominadas; como também no que conhecemos por eugenia e acreditavam na ideia de carregarem o fardo de levar a civilização para todos os outros povos.

Foram aplicados, pelos países invasores, diversos tipos de dominação na tentativa de neocolonizar as regiões da África, como, por exemplo, o Protetorado, que trata-se de uma dominação através de um líder local, ou seja, o país colonizador define um líder local na colônia para atuar como um subalterno; e a Colônia, definida por uma dominação direta marcada pela presença de um governo do país colonizador em seu território.

Em 1914, com a única exceção da Etiópia e da Libéria, a África inteira vê -se submetida à dominação de potências europeias e dividida em colônias de dimensões diversas, mas de modo geral, muito mais extensas do que as formações políticas preexistentes e, muitas vezes, com pouca ou nenhuma relação com elas. Nessa época, aliás, a África não é assaltada apenas na sua soberania e na sua independência, mas também em seus valores culturais (BOAHEN, 2010, p. 3).

Antes de entrarmos no que diz respeito à divisão do continente, é importante citar o que Henri Brunschwing traz em seu livro A partilha da África Negra a respeito do assunto, uma vez que ele declara que "A partilha de um país ocorre quando várias potências estrangeiras se põem de acordo para colocá-lo, inteira ou parcialmente, sob sua soberania. Isso supõe, portanto, rivalidades e negociações entre os partilhantes e incapacidade de resistir por parte do dividido" (BRUNSCHWING, 2004, p. 13).

Dito isto, vale registrar que em 1891 foi assinado pelos países colonizadores o Tratado de Berlim, proposto pelo Chanceler alemão Otto von Bismarck, a fim de estabelecer não só o domínio europeu das rotas fluviais na bacia do Congo e no rio Níger, as quais eram áreas de grande fluxo comercial e de suma importância para a manutenção financeira dessas potências; como também a proibição da escravidão e do tráfico de seres humanos. Também foram realizados acordos com chefes tribais, a fim de estabelecer suas áreas de dominação, resultando no que conhecemos por Partilha da África. 
Também fizeram parte do acordo países que não possuíam colônias na África, mas que tinham interesse seja em obter uma fatia do continente africano, seja em garantir tratados de comércio, como foi o caso dos ainda Império Alemão e TurcoOtomano e dos Estados Unidos da América.

A atual Nigéria, país de onde veio Chimamanda Adichie, foi colonizada pela Inglaterra, assim como o Egito, Sudão, Uganda, Quênia, Zanzibar, Somália, Gâmbia, Serra Leoa e Costa do Ouro. O oeste africano é composto majoritariamente por excolônias francesas, com exceção de Tânger e Rio do Ouro, que são espanholas. Há também a presença, no continente, de ex-colônias alemãs, belgas, italianas e portuguesas, como é mostrado no mapa abaixo.

Figura 1 - A colonização africana.

\section{A colonização africana}

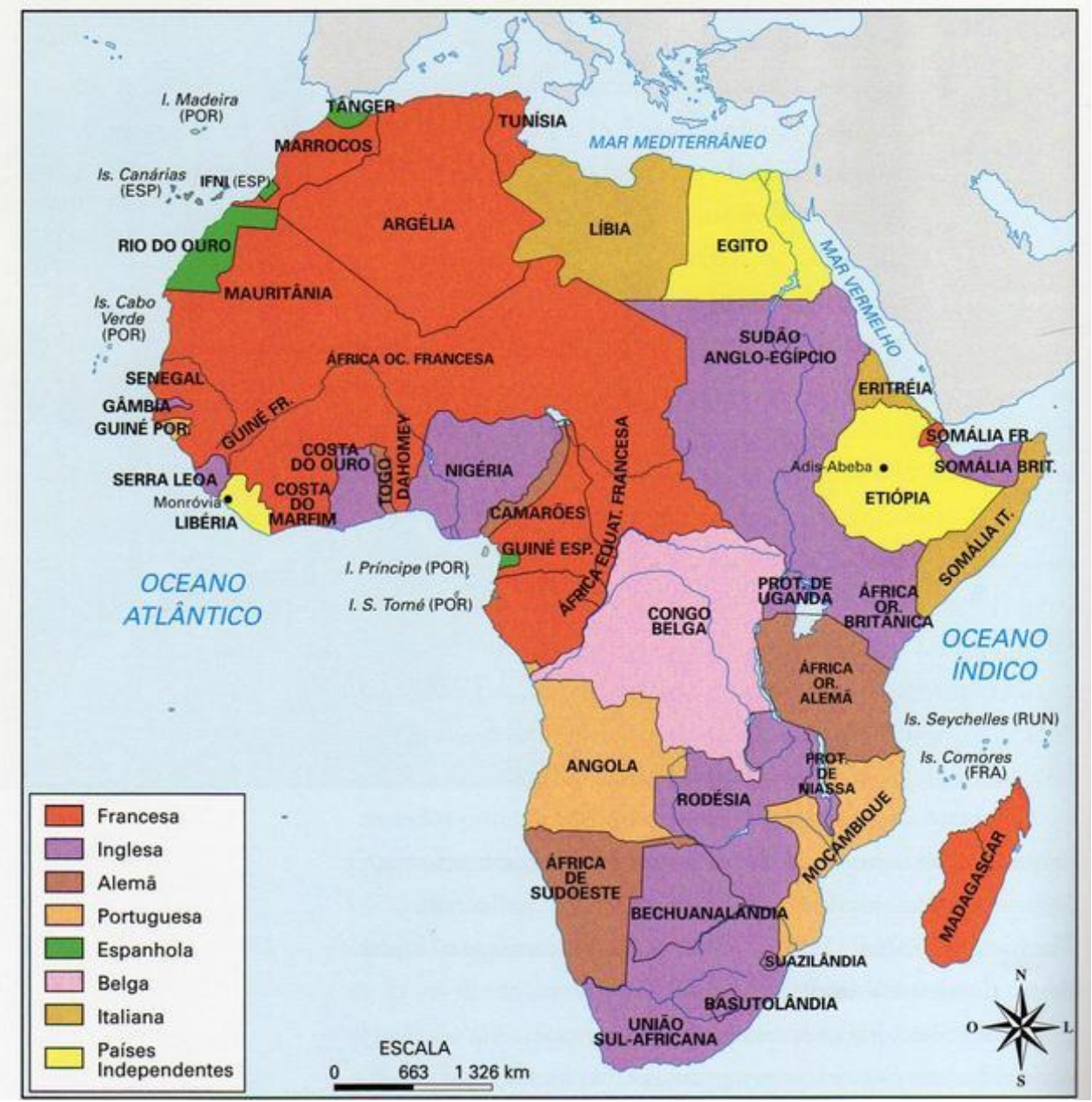

Fonte: https://www.todoestudo.com.br/historia/conferencia-de-berlim 
Essa partilha do continente foi realizada, dentre outras maneiras, de modo que os povos locais fossem divididos e que etnias distintas ocupassem o mesmo território, brigassem entre si e não interferissem nos negócios europeus. Não significa que não existiam conflitos internos antes da chegada dessas potências, mas essas brigas eram, algumas vezes, instigadas pelo europeus. A consequência dessa partilha pode ser vista nos conflitos até hoje existentes no continente africano e perfeitamente retratado por Chimamanda em um de seus contos.

A historiadora obstinada é o último conto de No seu pescoço e traz a violência tanto simbólica quanto material da colonização inglesa na África através da história de Nwamgba. A protagonista escolhe se casar com Obierika, cuja família carrega uma maldição, a qual é argumento de seus pais para ficarem contra o matrimônio. Após sofrer diversos abortos espontâneos, Nwamgba finalmente dá a luz à Anikwenwa, o primeiro e único filho do casal, pois seu marido morre pouco tempo depois, deixando-a no meio de uma disputa familiar em que os primos de seu falecido esposo exigem as posses deixadas em nome de Nwamgba.

A fim de conseguir lutar em pé de igualdade pelos seus direitos, Nwamgba manda Anikwenwa estudar com os missionários católicos ingleses, para que ele aprendesse o idioma e falasse diante do recém-estabelecido tribunal dos colonizadores. No entanto o menino muda o seu nome para Michael, um nome inglês, é batizado como cristão e se entrega de corpo e alma à cultura do colonizador.

Os mencionados missionários chegam à Onicha em 1885 e deixam a protagonista curiosa a respeito das armas que eles tinham utilizado para destruir o povo de Agueke, sua amiga, ao que o soldado respondeu que eles eram "soldados do governo britânico e os mercadores do Royal Niger Company [é] que destruíam aldeias; já eles traziam boas novas" (ADICHIE, 2017, p. 219). Podemos ver, aqui, os mais de um tipo de dominação mostrados no início dessa sessão. Nem todos os grupos agiam da mesma maneira em sua tentativa de adentrar o continente. A vila de Agueke foi dizimada, enquanto a de Nwamgba recebeu uma escola, uma igreja e a tentativa dos missionários de levar a fé cristã para outros povos.

Dado os devidos cuidados, vale salientar que os grupos africanos nunca perderam totalmente o domínio de seu território. Países como Portugal, por exemplo, negociavam com as elites locais e eram autorizados a permanecer. Essa ressalva não 
tem o intuito de relativizar os danos causados pelos invasores como faz o discurso de extrema-direita ao afirmar que na África também havia escravidão. Seu propósito é, no entanto, mostrar como o eurocentrismo é trazido até nos pequenos detalhes, pois negar a participação das elites africanas é trazer "esse favorecimento do polo dominante na relação entre colonizador e colonizado, como se os interesses do colonizador europeu constituíssem explicação suficiente para se entender o que se passou". Como continua mostrando Nicholas Davies em seu artigo As camadas populares nos livros de História do Brasil, é como se o polo dominado obedecesse "fielmente, passivamente, às instruções do polo dominante" (DAVIES, 2018, p. 129).

Voltando ao conto de Chimamanda, quanto mais Anikwenwa - ou Michael - era introduzido na cultura do colonizador, mais ele abandonava os próprios costumes. Chegou, inclusive, a se recusar a participar de sua cerimônia ima mmuo, "pois era um costume pagão iniciar os meninos no mundo dos espíritos, um costume que o padre Shanahn dissera que deveria acabar" ao que sua mãe respondeu que "um albino estrangeiro não podia determinar quando seus costumes iriam mudar" (ADICHIE, 2017, p. 226).

Ao longo do conto, Anikwenwa toma diversas outras atitudes que assustam a sua mãe. O agora assumidamente Michael, que usava um rosário em volta do pescoço e calça jeans, chega, inclusive, a questionar por que Nwamgba anda com os seios de fora, sendo que ele nunca havia notado a sua nudez antes. $O$ jovem recebeu o posto de catequista na nova missão, não comia nada que a mãe preparasse e vivia dizendo que iria salvar as almas do clã. Michael não consultou ninguém a respeito de sua noiva, Agnes - anteriormente chamada de Mgbeke. Seu casamento, é claro, não seguiu nenhum dos rituais do clã. E seus dois filhos - um menino e uma menina - receberam nomes ingleses, mas Nwamgba os chamava de outra maneira.

Michael não respeitou nem o leito de morte da mãe, implorando para que ela se deixasse ser batizada para receber a extrema-unção pois ele não poderia participar de uma cerimônia pagã. É aqui que Grace (Afamefuna), a historiadora obstinada que dá nome ao conto, aparece. Filha de Michael, criada em um internato envolto de costumes católicos. Inicialmente ela lia sobre os costumes curiosos de seu povo sem se sentir pertencida a ele, sem conectá-los a si mesma. 
O momento que desata Grace de Afamefuna é quando a sua professora tentou proibi-la de se referir aos escritos de sua avó como poesia, pois povos primitivos não eram capazes de produzir poesia. A partir daí, a neta de Nwamgba se dedica a estudar as suas origens, desenvolve um ressentimento pelo pai e pelo irmão, troca a química pela história e escreve um livro intitulado Pacificando com balas: uma história recuperada do sul da Nigéria. Alguns anos depois ela troca o seu nome, em cartório, para o escolhido por sua avó.

Tudo o que vimos nesse tópico nos leva ao que defende Ana Mônica Lopes. A historiadora nos traz em seu artigo Neocolonialismo na África que após as independências dos países africanos (em torno da década de 1950)

observamos em vários espaços a dificuldade de instauração do Estado democrático de direito e de organização de políticas econômicas que reduzissem o impacto do colonialismo e integrassem suas populações na nova ordem nacional. As fendas abertas pela necessidade de reajuste constituíram-se em veios para a penetração de sistemas de dominação econômica que pelo jogo da culpa encobrem políticas internacionais e práticas locais (LOPES, 2011, p. 12).

Somando-se sua discussão às falas de Boahen e de Brunschwing, é possível considerar que, em suma, os danos carregados pelos atuais Estados da África são fruto, para além da retirada de sua mão-de-obra jovem durante a escravização na América, da partilha do continente entre diversas potências mundiais. Tiveram independências consideradas tardias em comparação a outras colônias ocidentais porque sua própria neocolonização foi recente em paralelo a esses mesmos países. O nosso imaginário carrega a história única reproduzida pelas mídias e instituições de nossos respectivos contextos de vivências, mas os povos africanos nada tem a ver com os estereótipos que são reproduzidos sobre eles por terceiros.

Dito isto, veremos a seguir como utilizar a literatura de uma africana da Nigéria para contar a história e as revoluções de seu povo, em vez de, mais uma vez, narrarmos os relatos dos invasores. 
5. A CONTRIBUIÇÃO DE CHIMAMANDA NAS AULAS DE HISTÓRIA DA ÁFRICA

É necessário que nos aprofundemos a respeito do ensino de História no Brasil antes de mencionarmos o uso da literatura para seu auxílio. Para isso, é válido mencionar que a História "como disciplina escolar autônoma surgiu nos fins do séc. XIX, na Europa, imbricada nos movimentos de laicização da sociedade e de constituição das nações modernas" (NADAI, 2018, p. 27).

Elza Nadai menciona, ainda, em seu artigo $O$ ensino de História e a "pedagogia do cidadão" que o ensino de História se consolidou no Brasil através de um discurso laicizado que fez da organização escolar "um espaço importante das disputas então travadas entre o poder religioso e o avanço do poder laico, civil" (NADAl, 2018, p. 28). Foi ao se perguntar quem deveriam ser os agentes sociais privilegiados formadores da nação, que Nadai se debruçou na questão da identidade nacional e da memória oficial como fundamentais para consolidação da Nação.

O campo da História se transformou, assim como os temas e a metodologia. $\mathrm{O}$ historiador também saiu de um "sujeito separado e independente do objeto de estudo [e] descobriu que também constrói o seu objeto de investigação, superando a ideia tradicional e ingênua que 'os fatos falam por si só'”' (NADAI, 2018, p. 31).

O livro em que o artigo de Nadai foi hospedado, também acolheu os questionamentos de Paulo Miceli a respeito do papel do professor responsável pelo ensino de História em seu artigo Uma pedagogia da História?. Miceli começa a mostrar que o docente "deve partir da experiência cotidiana dos estudantes oferecendo elementos que lhes permitam ultrapassar as sempre lembradas formas tradicionais de ensino da História" (MICELI, 2018, p. 37) a fim de desempenharem de modo satisfatório a sua missão de ensinar.

O autor se preocupa em falar sobre as bases trazidas pelos estudantes e em como podemos nos aprofundar nelas a partir das nossas próprias experiências, para que a História não se sustente "numa sucessão de mortos-famosos, acontecimentos distantes e sem relação com a vida do estudante" (MICELI, 2018, p. 44).

É considerando, como afirma, ainda, Miceli, que o aluno deve ser incentivado a desenvolver uma espécie de sentido histórico para atuar no mundo em que vive que eu 
me preocupo em escrever a respeito de elementos que possam estimular a curiosidade e auxiliar a desenvolver esse processo de conscientização. Afinal de contas, o conhecimento histórico não pode ser visto como uma aquisição de fatos objetivos. Deve haver uma maneira que ajude o estudante a relacionar aquele determinado conteúdo com a sua realidade de vida. Algo próximo e palpável. É preciso haver empatia.

O conceito de empatia histórica, abordado por Peter Lee, assume a história como um compromisso com a indagação, dado que "tal conhecimento não deve ser inerte, não obstante deve agir como uma parte da vida do aprendiz" (LEE, 2006, p. 135). A História não é - como acredita o meu pai e tantos outros genitores - decoreba, tampouco um fato imutável tal qual vem escrito no livro didático. É essa dificuldade em correlacionar os conteúdos que impede os estudantes de desenvolverem um quadro mais organizado e útil do passado. Eles costumam dividir os conteúdos por capítulos e deixar que morram ali - separados em páginas e tópicos distintos, como se os acontecimentos se dessem de maneira isolada.

Unir os conteúdos do livro didático como dependentes entre si parece uma missão impossível. Soma-se a essa dificuldade, a custosa tarefa de fazer com que uma criança compreenda que algo que aconteceu trezentos anos atrás ainda influencia na sociedade atual, mostrando-Ihes que o racismo institucional que temos hoje ecoa a sociedade escravagista de ontem, por exemplo.

E é pensando nesse conteúdo que foi escolhido o conto de Chimamanda. Tratar a África não como o continente de sedentários e adaptáveis de Gilberto Freyre, mas como um conjunto de países independentes que ainda sofrem as consequências da invasão europeia no século XIX. A historiadora obstinada não substituirá o livro didático, no entanto oferecerá outra versão para uma narrativa considerada como já consolidada, visto que é composto por uma linguagem mais simples e acessível do que os livros técnicos.

Deixar que os estudantes conheçam a história de Ngwamba para, em seguida, desdobrar o cenário historiográfico por detrás da narrativa. Permitir que debatam sobre as atitudes de Anikwenwa, sobre o arrependimento da mãe de convencê-lo a aprender a inglês, sobre a influência do padre, sobre Afamefuna - dentre tantas outras possibilidades de discussão que a obra permite falar. Uma vez já familiarizados com a trama e com os acontecimentos, será menos árduo introduzir o conteúdo técnico. 
Utilizar a literatura torna visível a diferença entre compreender e decorar, uma vez que o interesse por ela somado à experiência individual de cada um, abre espaço para diálogos e debates. Associá-la ao ensino de História pode gerar um estímulo ao hábito de leitura dos estudantes que, a partir daí, poderão se interessar por outras leituras mais complexas e com outras temáticas.

A historiadora obstinada entrará como material de apoio, podendo o docente solicitar a leitura antecipada, em casa, para que o discente leve suas observações; ou em dupla, já na sala de aula, para que fique mais recente e mais espontâneo. Depende do tipo de dinâmica que se pretende propor.

Ter a oportunidade de apresentar contos escritos por uma autora nigeriana é poder ter outra visão acerca desses grupos sociais. É enxergar protagonistas autônomos e não estereotipados.

O ensino de história e cultura afro-brasileira e africana no ensino fundamental e médio é obrigatório em escolas públicas e privadas do Brasil desde que a lei 11.645/08 foi sancionada. Desse modo a mulher e o homem pretos devem ser apontados como sujeitos históricos formadores da sociedade brasileira, valorizando-se seus pensamentos, ideias e religiões.

Muitos dos contos presentes em No seu Pescoço, ocorreram durante o governo do ditador muçulmano general Sani Abacha, o qual governou a Nigéria de 1993 a 1998 - quando faleceu de infarto no miocárdio. Chimamanda Adichie nasceu em 1977, portanto tinha 16 anos quando Abacha assumiu o poder.

É nítido em suas narrativas a influência desse governo. Chimamanda descreve o sofrimento do povo, a violência do Estado, a resistência da mídia e de intelectuais e a humilhação passada por pessoas que imploram por abrigo nas terras do tio Sam. A autora fala da Guerra Civil da Nigéria (1967) e nos leva a questionar o porquê de sabermos tanto sobre as amplamente mencionadas Guerra Civil estadunidense e espanhola, mas nada vemos nos filmes e livros de massa a respeito do 6 de julho de 1967.

\section{CONSIDERAÇÕES FINAIS}

O intuito dessa pesquisa foi o de mostrar a urgente necessidade em valorizar a narrativa dos vencidos, não mais a dos vencedores. Contar a história da África a partir 
das experiências de uma africana, e não de um europeu. Chimamanda Adichie foi escolhida por ser, atualmente, referência mundial em literatura africana e por ser uma mulher que carrega em seus textos traços muito fortes de suas origens, possíveis de serem analisados por uma perspectiva historiográfica que nos leva a caminhar pelo caminho que ela percorreu.

Os quatro tópicos trazidos aqui são de fundamental importância para que possamos cada vez mais não só compreender histórias que vão para além do nosso euindividual; como também sair da nossa zona de conforto e criticar os estereótipos que criamos acerca daquilo que não conhecemos ainda.

Chimamanda Adichie nos possibilita pensar criticamente a respeito de culturas e de reprodução da história única ou, como chama Bhabha, do discurso do colonizador. Soma-se a sua discussão as palavras de bell hooks sobre identidade e sobre racismo, fundamentais para nossa compreensão sobre o assunto.

Os cientistas e escritores escolhidos para compor a argumentação dessa pesquisa transitam entre a África, a América e a Europa. É necessário conhecer todos os discursos para que se possa compreender o objetivo da propagação ou da ocultação de cada um. Para que se possa re e treplicar. Para que se possa, enfim, apresentar teses em vez de simples opiniões.

\section{REFERÊNCIAS}

ADICHIE, Chimamanda Ngozi. O perigo de uma história única. Tradução: Julia Romeu. $1^{\circ}$ ed. São Paulo: Companhia das Letras, 2019.

ADICHIE, Chimamanda Ngozi. Jumping Morning Hill. In: ADICHIE, Chimamanda Ngozi. No seu Pescoço. Tradução: Júlia Romeu. $1^{\circ}$ edição. São Paulo: Companhia das Letras, 2017.

ADICHIE, Chimamanda Ngozi. A historiadora obstinada. In: ADICHIE, Chimamanda Ngozi. No seu Pescoço. Tradução: Júlia Romeu. $1^{\circ}$ edição. São Paulo: Companhia das Letras, 2017.

BHABHA, Homi. O local da cultura. Belo Horizonte: EDUFMG, 1998.

BOAHEN, Albert. A África diante do desafio colonial. In: BOAHEN, Albert (Org.) História geral da África, VII: África sob dominação colonial, 1880-1935. $2^{\circ}$ edição. Brasília: UNESCO, 2010. 
BRASIL. Base Nacional Comum Curricular: Ensino Médio. Brasília: MEC/Secretaria de Educação Básica, 2017. Disponível em < http://basenacionalcomum.mec.gov.br/ >. Acesso em 29/06/2020.

BRASIL. Lei no 11.645, de 10 de março de 2008. Inclui no currículo oficial da rede de ensino a obrigatoriedade da temática "História e Cultura Afro-brasileira e Indígena". Diário Oficial da União, Brasília, 11 de março de 2008. Disponível em: < http://www.planalto.gov.br/ccivil_03/_ato2007-2010/2008/lei/l11645.htm >. Acesso em 29/06/2020.

BRUNSCHWING, Henri. A partilha da África Negra. Tradução Joel J. da Silva. São Paulo: Perspectiva, 2004.

DAVIES, Nicholas. As camadas populares nos livros de História do Brasil. In: PINSKY, Jaime (Org.). 0 ensino de História e a criação do fato. $14^{\circ}$ ed. São Paulo: Contexto, 2018.

ELLSWOTH, Elizabeth. Modos de Endereçamento: uma coisa de cinema; uma coisa de educação também. In: SILVA, Tomaz Tadeu. Nunca fomos humanos: nos rastros do sujeito. Autêntica Editora: São Paulo, 2001.

HOOKS, bell. E eu não sou uma mulher?: mulheres negras e feminismo. Tradução: Bhuvi Libanio. $3^{\circ}$ edição. Rio de Janeiro: Rosa dos Tempos, 2020.

LEE, Peter. Em direção a um conceito de literacia histórica. Tradução: Elizabeth Moreira dos Santos Schmidt, Luciana Braga Garcia, Maria Auxiliadora Schimidt e Tânia Braga Garcia. Educar, Curitiba, Especial, p. 131-150. Editora UFPR: Curitiba, 2006.

LOPES, Ana Mônica. Neocolonialismo na África. Sankofa (São Paulo), v. 4, n. 8, p. 12-21, 6 dez. 2011.

MICELI, Paulo. Uma pedagogia da História? In: PINSKY, Jaime (Org.). O ensino de História e a criação do fato. $14^{\circ}$ ed. São Paulo: Contexto, 2018.

NADAI, Elza. O ensino de História e a "pedagogia do cidadão". In: PINSKY, Jaime (Org.). O ensino de História e a criação do fato. $14^{\circ}$ ed. São Paulo: Contexto, 2018. 


\section{CAPÍTULO XXVIII}

\section{A APRENDIZAGEM DO SURDOCEGO PÓS-LINGUÍSTICO: AÇÕES PEDAGÓGICAS PARA O ATENDIMENTO EDUCACIONAL ESPECIALIZADO}

Luciana de Jesus Botelho Sodré dos Santos ${ }^{1}$

${ }^{1}$ Mestranda em Educação. Universidade Estadual do Maranhão - UEMA.

\section{RESUMO}

Este artigo tem como objetivo direcionar ações pedagógicas para fomento ao desenvolvimento e apoio à aprendizagem do aluno surdocego pós-linguístico, no Atendimento Educacional Especializado - AEE. Por meio de uma pesquisa exploratória, com uso de uma Revisão Sistemática de Literatura, apresenta a evolução dos estudos sobre a Surdocegueira, atualmente entendida como uma condição única e desvinculada do conceito de deficiência múltipla e, a partir de estudos de casos de alunos surdocegos pós-linguísticos apresenta caminhos para refletir e ressignificar práticas pedagógicas direcionadas para esses aluno no contexto do AEE. Os resultados obtidos após a análise da pesquisa evidenciam que os desafios são diversos, mas quando se trata do atendimento ao aluno surdocego, a insegurança e a dúvida são evidentes, principalmente quanto ao planejamento de ações pedagógicas que coadunem com a necessidade e possiblidade do respectivo alunado. Questão que precisa de amplas discussões, redes de apoio e metodologias para impulsionar o desenvolvimento da aprendizagem do aluno, bem como a formação do professor. Chega-se à conclusão de que o planejamento de atividades para o aluno surdocego pós-linguístico variam de aluno para aluno, e dependem do engajamento e in (formação) do professor, pois o AEE é uma ponte, no sentido de contribuir para a emancipação e autonomia acadêmica e social dos alunos público-alvo da Educação Especial, notadamente do aluno surdocego também.

Palavras-chave: Aprendizagem. Surdocego Pós-linguístico. Ações Pedagógicas. Atendimento Educacional Especializado.

\section{INTRODUÇÃO}

"Conviver com a surdocegueira é se defrontar com um mundo totalmente diferente e muito rico de experiências, exigindo conhecimento e técnicas específicas para que se possa desbravá-lo com mais habilidade e eficiência" (GRUPO BRASIL ..., 2005). A surdocegueira é um déficit sensorial com perda total ou parcial, e/ou ambos, da visão e audição. 
Assim, atuar como mediador para proporcionar apoio na aprendizagem e desenvolvimento de alunos com necessidades educacionais especiais, demanda para o professor do Atendimento Educacional Especializado - AEE a compreensão de uma complexidade de condições e déficits dos alunos público alvo da Educação Especial ${ }^{1}$, bem como a proposição de metodologias para garantir que a inclusão destes alunos aconteça, tanto na escola como na sociedade. Isto é, compreende identificar e conhecer as necessidades educacionais dos seus alunos, para a partir desse contexto, elaborar recursos e estratégias que os apoiem, tanto nos aspectos adaptativos como funcionais.

Ao se tratar da Surdocegueira, esse caminho vai requerer o conhecimento da própria condição e a observação da predominância da forma de comunicação do aluno surdocego para o mundo. E, a partir desse contexto, planejar ações educativas que dialoguem com essa realidade. Ao se pensar em atividades para mediação de conteúdos de fomento à aprendizagem a aprendizagem do aluno surdocego, faz-se necessário explorar a adequação à condição da Surdocegueira (pré ou pós aquisição de uma linguagem) e, sobretudo agir reconhecendo a deficiência como uma característica pessoal muito importante, bem como explorar situações que possam romper com obstáculos no momento da aprendizagem.

Dessa forma, a organização deste texto surgiu da necessidade de apresentar ações pedagógicas para o desenvolvimento da aprendizagem do aluno surdocego póslinguístico no AEE, no intuito de fazer com que a distância da inclusão o aluno e a escola. Além disso, objetiva analisar os percursos trilhados para se chegar ao entendimento da Surdocegueira como uma condição singular, que não mais integra a classificação de deficiência múltipla.

Essa questão se torna interessante à luz da revisão sistemática de literatura explorada nesse artigo, pois apesar de estudos e pesquisas desenvolvidos e divulgados sobre a Surdocegueira, ainda são escassas as iniciativas (materiais e humanas) para o devido atendimento para auxiliar o aluno surdocego nesse processo.

A demanda de alunos surdocegos nas para escolas regulares ainda não é muito significativa, alguns fatores como: a condição do aluno surdocego em relação aos fatores

${ }^{1}$ Compreendem os alunos com deficiência (física, intelectual, visual, surdocegueira, múltipla e auditiva), Transtornos Globais do Desenvolvimento (TGD) e altas habilidades/superdotação (BRASIL, 2008). 
pré e pós-linguísticos, a não acessibilidade da escola (material e arquitetônica), a desin (formação) do professor especializado e do professor da sala comum e a esporádica ausência da família para ampliar as discussões e possiblidades de apoio, são vistos como barreiras e, por isso devem ser rompidas ao se trabalhar no atendimento especializado, no sentido de pensar em metodologias que possibilitem a esse aluno, público alvo da Educação Especial, a sua devida inclusão no contexto escolar e, sobretudo o desenvolvimento de sua aprendizagem, a fim de superar esses obstáculos.

Portanto, precisa-se de ações pedagógicas significativas que vão de encontro com a evolução dos estudos sobre a Surdocegueira, bem como as realizações e feitos concretizados sobre esta condição. Dentre essas realizações estão a instituição a data comemorativa (27 de junho) do surdocego, em razão da comemoração ao aniversário da norte-americana surdocega Helen Keller (1880-1968), e a criação de associações de apoio e estudo da Surdocegueira pelo país como: o Núcleo de Atendimento Educacional à Pessoa com Surdocegueira (NAEPS) do Instituto Benjamin Constant (IBC), a Associação Educacional para Múltipla Deficiência (AHIMSA), Associação Brasileira de Apoio ao Surdocego (ABRASC), entre outros. E mundo afora como: na Espanha, a Asociación Española de Padres de Sordociegos (APASCIDE); na França, Centre d'éducation spécialisée pour enfants sourds-aveugles et sourds-malvoyants (CESSA); nos Estados Unidos, o Helen Keller National justify for Deaf-Blind Youths and Adults entre outros.

\section{CONHECENDO A SURDOCEGUEIRA}

A terminologia Surdocegueira foi sendo construída por intermédio de estudos e entendimentos desta condição, no decorrer dos anos após a sua descoberta. Sofreu muitas alterações desde que surgiu o primeiro atendimento ao surdocego por volta de 1800 (MAIA, 2004).

Com a apresentação feita no Curso da CENTRAU (Centro de Reabilitação da Audição do Paraná) em 1996, por profissionais da Sense Internacional - Inglaterra, as seguintes denominações foram usadas: Dificuldade de Aprendizagem Profunda e Múltipla (DAPM), Múltipla Deficiência Severa, Surdo com Múltipla Deficiência, Cego com Deficiência Adicional, Múltipla Privação Sensorial (MPS), Dupla Deficiência Sensorial até chegar a Surdocegueira. A aceitação do termo surdocego e surdocegueira sem hífen em 1991, foi indicada por Salvatore Lagati, que defendeu na IX Conferência Mundial de 
Orebrö - Suécia, a necessidade do reconhecimento da surdocegueira como deficiência única (MAIA, 2004).

O termo e sua representatividade confere ao surdocego o conceito de que não trata de um surdo que não enxerga, ou de um cego que não ouve. A surdocegueira é uma condição única, onde o surdocego apresenta necessidades específicas e funcionais para sua vida (MCLETHIE, 2002).

A surdocegueira é uma deficiência singular que apresenta perdas auditivas e visuais, concomitantemente, em diferentes graus levando a pessoa surdocega a desenvolver distintas formas de comunicação para entender, interagir com as pessoas e o meio ambiente, proporcionando-Ihes o acesso a informações, uma vida social com qualidade, orientação, mobilidade, educação e trabalho (GRUPO BRASIL ..., 2005).

A condição conferida pela surdocegueira não é meramente a somatória de duas deficiências, e sim uma dificuldade com particularidades únicas, que deve ser abordada de modo especial, em função das dificuldades que os indivíduos surdocegos apresentam para contatar o mundo e poder se inserir a ele.

Em 1995, a extinta Secretaria de Educação Especial (SEESP) do Ministério da Educação e Cultura (MEC) definiu objetivos e orientações, caracterizando a surdocegueira como uma subcategoria da deficiência múltipla, a qual abrange as deficiências visuais e auditivas. Com as Diretrizes Nacionais para a Educação Especial na Educação Básica formulada em 2001, o termo surdocegueira passou a ser utilizado, porém não trouxe nenhuma especificidade quanto a deficiência de forma particular (GALVÃO, 2010).

A presença da surdocegueira em documentos oficiais brasileiros tem início de forma pouco explorada em 2002, por meio da publicação pelo MEC da coleção Estratégias e Orientações Pedagógicas para a Educação de Crianças com Necessidades Educacionais Especiais. Entretanto, foi somente em 2005 quando o Censo Escolar Nacional solicitou dados sobre os alunos surdocegos inseridos na rede regular de ensino, que algumas cobranças e discussões sobre alunos com surdocegueira começaram a despontar (GALVÃO, 2010; ALMEIDA, C., 2008).

Na classificação das pessoas surdocegas não importa o tipo e a intensidade das perdas, mas sim a funcionalidade das mesmas. Esta condição é um comprometimento, em diferentes graus, dos sentidos receptores à distância (audição e visão). A 
combinação desses comprometimentos pode ocasionar problemas de mobilidade, comunicação e como consequências, a necessidade de intervenções em atendimentos específicos (CADER-NASCIMENTO; COSTA, 2010).

Os estudos do Grupo Brasil (2005), da Associação Educacional para Múltipla Deficiência (AHIMSA) (2018) e Maia (2004) apontam que a surdocegueira é classificada quanto ao período de surgimento e aquisição de uma linguagem para comunicação e entendimento do mundo, apresentando as seguintes delimitações: surdocegueira prélinguística e pós-linguística.

$\mathrm{Na}$ surdocegueira pré-linguística, o indivíduo nasce surdocego ou adquire a surdocegueira nos primeiros anos de vida antes da aquisição de uma linguagem. A pessoa nessa condição vai ter uma forma de comunicação bastante diferenciada para adquirir a sua informação do mundo.

A surdocegueira pós-linguística, é aquela em que a pessoa acometida por alguma patologia ou acidente, ficou surdocega após a aquisição de uma língua, seja oral, sinalizada ou o Sistema Braille. Nessa nova condição ele vai se apropriar de uma forma de linguagem que atenda as suas necessidades comunicacionais e informacionais, geralmente fazendo uso quase que exclusivamente das adequações das linguagens ou símbolos já dominantes para o modo tátil (Libras Tátil ou Braille Tátil) e entre outras formas (GODOY, 2011).

Dessa maneira, as formas, recursos ou sistemas de comunicação desenvolvidos e utilizados por surdocegos classificam-se em sistemas alfabéticos e não alfabéticos, baseados em códigos orais ou de escrita. Os sistemas alfabéticos se desenvolvem como referência de signo, a linguagem alfabética, empregando para a transmissão de mensagens, as informações letra a letra. Têm-se o traço de preservar a estrutura da língua oral. Nessas condições, é comum que o uso seja feito por surdocegos que já tenham conhecimento de uma estrutura linguística (oral ou da língua de sinais) (CERTEZA, 2010; CADER-NASCIMENTO; COSTA, 2010; MARRA, 2012; GALVÃO, 2010; ALMEIDA, W., 2015; RACHED, 2011; ALMEIDA, C., 2008).

Assim, compreendem o Braille tátil ou digital, a Escrita Alfabética na Palma da Mão, o Método Malossi, o Alfabeto Manual Tátil, o Alfabeto Dactilológico ou Alfabeto Digital. Já quanto aos sistemas não alfabéticos, o surdocego emprega o canal tátil ou visual para estabelecer a comunicação, não mais a partir da transcrição de palavras em 
letras, mas as palavras inteiras passam a ser representadas por signos já estabelecidos. Correspondem ao Método Tadoma ou Método de Vibração e a Libras Tátil (CERTEZA, 2010; CADER-NASCIMENTO; COSTA, 2010; MARRA, 2012; GALVÃO, 2010; ALMEIDA, W., 2015; RACHED, 2011; ALMEIDA, C., 2008).

Os canais de informação e recepção do surdocego são individualizados. Cada sujeito nesta condição exibe características específicas, bem como possibilidades diversas de se comunicar. O meio e a forma de comunicação vai depender da particularidade de cada surdocego, a partir da necessidade em constituir linguagem e interação entre outros sujeitos.

A partir da consciência do papel da comunicação no ambiente, as pessoas surdocegas poderão utilizar vários recursos de comunicação, entre os quais: gestos, sinais, leitura tátil das vibrações produzidas durante a emissão verbal (Tadoma), sistema Braille, alfabeto Dactilológico, objetos de referência para atividades e situações, escrita ampliada, entre outros. Considerando todos esses recursos, o tato constitui-se a via mais promissora no desenvolvimento da comunicação receptiva e expressiva do surdocego com o ambiente. Aliados a esse aspecto, todos os recursos de comunicação precisam ser adaptados à singularidade das pessoas com surdocegueira (CADERNASCIMENTO; COSTA, 2010, p. 57).

Em suma, o surdocego utiliza alguns recursos que os cegos e os surdos utilizam na sua comunicação, mas as necessidades especiais básicas são outras, principalmente na comunicação e na orientação e modalidade. É nesse ponto se compreende a surdocegueira como deficiência única.

\section{CONSIDERAÇÕES SOBRE O APRENDER PARA O ALUNO SURDOCEGO}

A aprendizagem do aluno surdocego, vai exigir não apenas propostas metodologicamente prontas de ensino e as devidas adaptações, mas entender como este aluno constroi e adquiri conhecimento, e como ele prefere que a essas informações e trocas sejam mediadas para ele, pois "[...] qualquer assunto pode ser ensinado com eficiência, de alguma forma intelectualmente honesta, a qualquer criança, em qualquer estágio de desenvolvimento [...]" (BRUNER, 1998, p. 31).

Desse modo, a aprendizagem compreende um processo de assimilação de informações e modos de ação física e mental, que serão organizados e orientados para 
o processo de construção do conhecimento. Esse processo é contínuo e acontece durante toda a vida do indivíduo.

[...] o aprendizado não é desenvolvimento; entretanto, o aprendizado adequadamente organizado resulta em desenvolvimento mental e põe em movimento vários processos de desenvolvimento que, de outra forma, seriam impossíveis de acontecer. Assim, o aprendizado é um aspecto necessário e universal do processo de desenvolvimento das funções psicológicas, culturalmente organizadas e especificamente humanas (VIGOTSKI, 2003, p. 101).

Assim, para o surdocego pós-linguístico essa aprendizagem pode ser intensificada, pois estes alunos já adquiriram determinado nível de pensamento simbólico e tendem a manterem a língua ou sistema de codificação de escrita adquiridas no curso de suas vidas, apenas fazendo as adequações necessárias para a forma tátil, que é a base do processo comunicativo do surdocego.

O professor precisa saber como a comunicação e a interação se desenvolvem tipicamente nos alunos. Esta base de conhecimento do desenvolvimento típico informará o estabelecimento de metas adequadas para a aprendizagem dos alunos surdocegos (FARRELL, 2008, p. 68).

Outro destaque que potencializa a aprendizagem desses alunos é a utilização dos resíduos sensoriais existentes. Um surdo com poucos resíduos visuais ou um cego com poucos resíduos auditivos, os resquícios (visual e auditivo) existentes podem ser aproveitados para a sua orientação e mobilidade contribuindo inclusive no processo de escolarização com apoio das Tecnologias Assistivas ${ }^{1}$.

De acordo com Bersch (2006), é necessário ir em busca de formas alternativas para utilização da Tecnologia Assistiva (TA), notadamente que coadunem com as necessidades e possiblidades do surdocego, pois:

Fazer TA na escola é buscar, com criatividade, uma alternativa para que o aluno realize o que deseja ou precisa. É encontrar uma estratégia para que ele possa 'fazer' de outro jeito. É valorizar o seu jeito de fazer e aumentar suas capacidades de ação e interação, a partir de suas habilidades. É conhecer e criar novas alternativas para a comunicação, escrita, mobilidade, leitura, brincadeiras e artes, com a utilização de materiais escolares e pedagógicos especiais. É a utilização do computador como alternativa de escrita, fala e acesso ao texto. É prover meios para que o aluno possa desfiar-se a experimentar e

${ }^{1}$ É uma área do conhecimento, de característica interdisciplinar, que engloba produtos, recursos, metodologias, estratégias, práticas e serviços que objetivam promover a funcionalidade, relacionada à atividade e participação de pessoas com deficiência, incapacidades ou mobilidade reduzida, visando sua autonomia, independência, qualidade de vida e inclusão social (BRASIL, 2007). 
conhecer, permitindo assim que construa individual e coletivamente novos conhecimentos. É retirar do aluno o papel de espectador e atribuir-lhe a função de ator (BERSCH, 2006, p. 89).

Deste modo, as habilidades cognitivas podem ser estimuladas com os recursos e estratégias pautados na abordagem das Tecnologias Assistivas, desde que o professor observe e questione o seu aluno, quanto ao modo que ele se sente predisposto para a aprendizagem. Todas as questões pontuadas pela respectiva autora são passíveis de utilização, como a escrita e leitura em Braille e letras em relevo; a expressão em Libras; brincadeiras adaptadas; artes com apoio de materiais diversos e a mobilidade com apoio de estrutura arquitetônica e medição docente.

O desenvolvimento da aprendizagem demanda a existência de propostas de ensino que visem estimular a participação ativa do aluno surdocego, promovendo também a interação deste com os colegas de sala comum, de Atendimento Educacional Especializado, com o professor e com o próprio ambiente educativo, respeitando seu tempo, necessidades e habilidades. Para Masini (2002, p. 79):

É necessário ao educador [...] engenho para propiciar práticas aos alunos, para explorar o meio circundante e comunicar-se com as pessoas, utilizando para isso os sentidos e os recursos que dispõe. Quando a situação oferece condições e o educador (tatilmente, visualmente, ou auditivamente) confirma-a, reconhecendo aquilo que ela está manifestando, ele [o aluno] se sente à vontade e espontânea, no uso de seus sentidos e dos próprios recursos.

Portanto, para que a aprendizagem do aluno surdocego ocorra ou seja estimulada, o professor precisa conhecer as suas especificidades comunicativas, na busca por compreender que existem aproximações, do que propriamente divergências entre os alunos surdocegos e os não surdocegos. Haja vista, a aprendizagem compreendo um processo complexo, que se constroi na correlação entre as representações e condições internas e externas do sujeito (MEIRA, 1998).

\subsection{Ações pedagógicas para o surdocego pós-linguístico: 0 AEE como ponte!}

Antes de propor atividades educativas para o surdocego pós-linguístico, pontuase que estes alunos não são iguais, ou seja, cada um, mesmo na condição de surdocego, apresenta necessidades e particularidades específicas. Então, reafirma-se que o objetivo do Atendimento Educacional Especializado - AEE, compreende em "[...] prover condições de acesso, participação e aprendizagem no ensino regular e garantir serviços 
de apoio especializados de acordo com as necessidades individuais dos estudantes" (BRASIL, 2011) público alvo da Educação Especial.

Para Noronha (2016, p. 70) “[...] O AEE não é reforço escolar [...] é um conjunto de atividades que envolve toda a rede de ensino e a comunidade. É desenvolvido na Sala de Recursos Multifuncionais que são "[...] ambientes dotados de equipamentos, mobiliários e materiais didáticos e pedagógicos para a oferta do atendimento educacional especializado" (BRASIL, 2011).

Nas Salas de Recursos Multifuncionais, o educando receberá atendimento específico que não irá reproduzir, nem reforçar ou ensinar os temas trabalhados em sala de aula. Sua função não é reproduzir a dinâmica da sala de aula regular, mas buscar formas diferentes de aperfeiçoar e desenvolver habilidades que permitam maior autonomia do educando no processo de ensino-aprendizagem. Evidentemente, ao contribuir para a autonomia do educando, as atividades e apoios oferecidos através da SRM contribuem também para seu melhor aproveitamento em sala de aula, ainda que este não seja seu foco (NORONHA, 2016, p. 71).

Assim, a ideia não é fragmentar as ações pedagógicas do Atendimento Educacional Especializado ao se propor atividades para surdocegos pós-linguísticos, mas indicar pequenos passos, para que mais adiante passos maiores sejam trilhados, no intuito de que se compreenda que a Surdocegueira é uma condição única que demanda múltiplos olhares e intensificação de redes de apoio, estudos e pesquisas que venham a somar com a formação e trabalho do professor do AEE e, principalmente o desenvolvimento, aprendizagem e, consequentemente a inclusão escolar e social do aluno surdocego.

Diante do expresso, foram selecionados dois estudos de caso de alunos surdocegos pós-linguísticos extraídos da tese de Galvão (2010). Convém pontuar que foram realizadas algumas adaptações nos respectivos casos como a substituição da identificação do aluno e a ocultação de dados familiares. As ações propostas foram baseadas na análise de cada caso. A partir deles serão propostas estratégias para o professor do AEE desenvolver, conforme a necessidade do aluno surdocego, na Sala de Recursos Multifuncionais.

Os casos foram selecionados em virtude de serem ocorrências mais preponderantes no ensino regular, pois geralmente surdocegos pré-linguísticos são 
atendidos em centros de reabilitação levando em consideração acesso, recursos, profissionais e, essencialmente a natureza do caso.

a) Caso 1: perda auditiva e visual adquirida

K. C. S. é uma jovem de 18 anos que atualmente cursa o 1o ano do Ensino Médio em uma escola da rede pública estadual no turno matutino. O apoio especializado da escola consta de uma intérprete de Libras que atua na sala comum de ensino. K. C. S. A respectiva jovem teve seu diagnóstico de Deficiência Auditiva ainda na infância. Quanto ao diagnóstico da Deficiência Visual, este foi determinado após constatações de dificuldades nas avaliações escolares, informadas pelos professores aos responsáveis de K. C. S., além de relatarem que a jovem esbarrava frequentemente em móveis na sala de aula, apresentando uma dificuldade de percebê-los no espaço. O diagnóstico médico foi de Síndrome Usher de grau I, com deficiência auditiva profunda bilateral, e visual do tipo retinose pigmentar, se manifestando na adolescência. No momento, faz uso do seu resíduo visual, funcionando como uma pessoa com baixa visão, mas o seu prognóstico é de perda visual total. A jovem se comunica por meio da Língua Brasileira de Sinais Libras adaptada ao seu campo de visão. De acordo com Reyes (2004) o perfil desta aluna está incluso no grupo II de surdocegos, ou seja, compreendem indivíduos que nascem com Deficiência Auditiva e adquirem a Deficiência Visual ao longo da sua vida. K.C.S. apresenta perda pós-linguística, tendo a Libras como sua língua de referência, mesmo a utilizando com pouca fluência, mas apoia-se em outras formas de comunicação, como gestos e sons.

b) Caso 2: perda visual e auditiva adquirida

F. D. M. é um jovem de 12 anos de idade que cursa o 5o ano do Ensino Fundamental em uma escola da rede pública municipal no turno vespertino. No turno oposto, o aluno recebe apoio individualizado no Centro de Apoio a Pessoa com Deficiência Visual (CAP/DV). F. D. M. nasceu prematuro, desenvolvendo retinopatia da prematuridade, o que trouxe a cegueira como sequela. Aos 6 anos de idade começaram a aparecer os primeiros sintomas relativos a uma baixa auditiva, com consequente perda profunda bilateral. Com 10 anos foi submetido à cirurgia para implante coclear em um dos ouvidos, e aos 12 anos no segundo ouvido. Desde os seus primeiros meses de vida é acompanhado por profissionais especializados em técnicas de intervenção precoce. Iniciou o processo escolar ainda na Educação Infantil, sempre em escolas regulares. 
Quando se deu a perda auditiva, passou a desenvolver o Tadoma e ter acompanhamento sistemático em sala de aula por tutores, estagiários etc. mediando a sua comunicação. Foi alfabetizado em Braille na escola e com o suporte, em sua casa, de professor especializado, foi usado durante este processo a máquina braille. É oralizado. Na classificação descrita por Reyes (2004), ele pertence ao grupo III, que engloba indivíduos com Deficiência Visual congênita e Deficiência Auditiva adquirida. No que se refere à sua comunicação, é um surdocego pós-linguístico, tendo a língua oral como a sua língua de referência e o Sistema Braille, a sua modalidade de leitura e escrita, ambos são utilizados com fluência.

Diante dos casos expostos, serão traçadas atividades que podem auxiliar o docente do atendimento especializado para o desenvolvimento da aprendizagem desse perfil de alunos, bem como servir como um direcionamento para suas ações na Sala de Recursos, pois condições precisam ser formuladas para que a aprendizagem seja realmente compartilhada e significativa para o aluno Surdocego. Para Farrell (2008, p. 68), "[...] o professor e a escola precisam criar oportunidades naturais de interação no contexto de atividades que tenham significado para o aluno".

\subsection{Propostas educativas: mãos à obra, professores!}

Os casos apresentados, apresentam duas situações onde uma aluna, K.C. S. e um aluno F. D. M. são surdocegos pós-linguísticos. Quando se recebe alunos surdocegos com esse perfil, a primeira ação a ser realizada é a observação do aluno, a coleta de dados dos mesmos com os professores da sala comum, em fichas e relatórios da escola, com a família e, notadamente com o próprio aluno. A ideia é estruturar o seu perfil para que o planejamento didático para fomento de ações de aprendizagem e apoio ao ensino regular seja proporcionado de forma significativa.

Seguidamente, o Plano de Atendimento Educacional Especializado é estruturado com atividades, objetivos e recursos que irão atuar, no sentido de possibilitar ou mesmo potencializar o desenvolvimento desses alunos, tanto na esfera educativa quanto social. Visto que, uma das principais linhas de base do AEE é possibilitar além da aprendizagem, a autonomia do aluno público alvo da Educação Especial e sua devida inclusão.

Dessa forma, foi analisado que a aluna K. C. S. utiliza a Libras adaptada, no caso a Libras Tátil, pois seu campo de visão está limitado. Entretanto, como descrito no caso 
ela faz uso de outros apoios para se comunicar e aprender, que podem ser ampliação

da fonte das letras em tarefas e sinalização da Libras bem próxima ao seu campo visual

e emissão de sons a curtas distâncias. Assim, recomenda-se as seguintes ações

pedagógicas para esta aluna, conforme quadro abaixo:

Quadro 1 - Ações para o AEE da aluna K. C. S.

\begin{tabular}{|c|c|c|c|}
\hline Áreas & Objetivos & $\begin{array}{l}\text { Procedimentos } \\
\text { metodológicos }\end{array}$ & $\begin{array}{c}\text { Recursos, } \\
\text { equipamentos etc. }\end{array}$ \\
\hline $\begin{array}{c}\text { Linguagem } \\
\text { (exposição a alguns } \\
\text { meios de } \\
\text { comunicação } \\
\text { alternativa, } \\
\text { priorizando } \\
\text { utilização do } \\
\text { Sistema de } \\
\text { comunicação } \\
\text { escolhido pela } \\
\text { aluna) }\end{array}$ & $\begin{array}{l}\text { Potencializar a } \\
\text { utilização da Libras } \\
\text { Tátil e da Libras em } \\
\text { campo de visão } \\
\text { reduzido para } \\
\text { ampliação do } \\
\text { repertório de sinais e } \\
\text { estímulos à } \\
\text { modalidade tátil. }\end{array}$ & $\begin{array}{l}\text { Será realizada com as } \\
\text { adaptações necessárias } \\
\text { junto a aluna, a partir de } \\
\text { textos (poemas, textos } \\
\text { argumentativos etc.) para } \\
\text { compreensão, } \\
\text { interpretação e instrução } \\
\text { de novos sinais, tanto para } \\
\text { a Libras Tátil quanto para a } \\
\text { Libras em campo reduzido, } \\
\text { além de dinâmicas com } \\
\text { interpretação de letras de } \\
\text { músicas para memorização } \\
\text { de sinais. }\end{array}$ & $\begin{array}{l}\text { Dicionário de Libras } \\
\text { Letras de músicas e } \\
\text { textos impressos em } \\
\text { fonte ampliada. }\end{array}$ \\
\hline $\begin{array}{c}\text { Orientação e } \\
\text { mobilidade } \\
\text { (explanação na } \\
\text { área da } \\
\text { motricidade, treino } \\
\text { para baixa visão } \\
\text { com apoio) }\end{array}$ & $\begin{array}{l}\text { Compreender o uso da } \\
\text { bengala como auxílio } \\
\text { sinalizador efetivo e } \\
\text { eficiente de locomoção } \\
\text { independente, } \\
\text { proteção, orientação e } \\
\text { detecção das } \\
\text { informações } \\
\text { ambientais; } \\
\\
\text { Proporcionar a } \\
\text { locomoção e } \\
\text { movimento no espaço } \\
\text { escolar e social com } \\
\text { segurança e } \\
\text { autonomia. }\end{array}$ & $\begin{array}{l}\text { Elaborar um circuito na } \\
\text { escola utilizando pontos } \\
\text { de referência para a aluna } \\
\text { se desviar e se proteger. } \\
\text { As atividades neste } \\
\text { circuito num primeiro } \\
\text { momento serão guiadas } \\
\text { pelo professor para } \\
\text { captação de informações } \\
\text { com a bengala. Em } \\
\text { seguida, a aluna realizará } \\
\text { de forma autônoma com o } \\
\text { respetivo instrumento. } \\
\text { Posteriormente, será } \\
\text { realizada uma visita } \\
\text { guiada, acompanhada de } \\
\text { um familiar, fora da escola } \\
\text { para a aluna realizar a } \\
\text { interpretação do local } \\
\text { (supermercado, museu } \\
\text { etc.) }\end{array}$ & $\begin{array}{c}\text { Espaço escolar, } \\
\text { degraus, assentos, } \\
\text { corredores e demais } \\
\text { dependências; } \\
\text { Assim como cones, } \\
\text { caixas de papelão, } \\
\text { cordas etc. na quadra } \\
\text { da escola e a própria } \\
\text { bengala para um pré- } \\
\text { treino do recurso. }\end{array}$ \\
\hline $\begin{array}{l}\text { Cognição (ênfase } \\
\text { em atividades } \\
\text { envolvendo } \\
\text { conceito de leitura } \\
\text { e escrita, } \\
\text { dactilologia, }\end{array}$ & $\begin{array}{c}\text { Realizar atividades } \\
\text { para estímulos a } \\
\text { memória, } \\
\text { concentração e } \\
\text { abstração de conceitos } \\
\text { subjetivos para }\end{array}$ & $\begin{array}{l}\text { Confecção de jogos da } \\
\text { memória com fonte } \\
\text { ampliada. } \\
\text { Uso do computador para } \\
\text { potencialização da escrita }\end{array}$ & $\begin{array}{l}\text { Caixas de papelão, } \\
\text { papel A4, pincel, } \\
\text { cartolinas, EVA, cola, } \\
\text { computador e filme. }\end{array}$ \\
\hline
\end{tabular}




\begin{tabular}{|c|c|c|c|}
\hline $\begin{array}{c}\text { orientação espacial } \\
\text { e temporal e } \\
\text { descrição tátil). }\end{array}$ & $\begin{array}{l}\text { exercitar os resíduos } \\
\text { visuais e potencializar } \\
\text { o tato. }\end{array}$ & $\begin{array}{l}\text { e por meio de recursos de } \\
\text { acessibilidade do Windows } \\
\text { como a Lupa, Teclado } \\
\text { Virtual, entre outros. } \\
\text { Atividades [guia- } \\
\text { interpretado em Libras } \\
\text { tátil] com um filme } \\
\text { escolhido } \\
\text { preferencialmente pela } \\
\text { aluna ou indicado pelo } \\
\text { professor. } \\
\text { E, ditado dactilológico, } \\
\text { onde o professor realiza o } \\
\text { sinal tátil e a aluna deve } \\
\text { registrar a palavra ou fazer } \\
\text { a leitura do registro por } \\
\text { meio do sinal tátil, ou } \\
\text { dactilologia. }\end{array}$ & \\
\hline $\begin{array}{c}\text { Socialização } \\
\text { (ampliação dos } \\
\text { contatos com } \\
\text { ambientes e } \\
\text { pessoas, afirmação } \\
\text { da identidade, } \\
\text { autogestão e } \\
\text { empoderamento } \\
\text { da pessoa } \\
\text { surdocego) }\end{array}$ & $\begin{array}{c}\text { Incentivar a } \\
\text { autoafirmação do } \\
\text { aluno com relação a } \\
\text { condição de } \\
\text { surdocego. }\end{array}$ & $\begin{array}{l}\text { Organização de uma Roda } \\
\text { de Conversa na Sala de } \\
\text { Recursos entre a aluna e } \\
\text { os colegas da sala comum. } \\
\text { A dinâmica começa com } \\
\text { perguntas que os colegas } \\
\text { querem saber sobre a } \\
\text { surdocegueira, a condição } \\
\text { da colega, etc. o professor } \\
\text { nesse contexto atua como } \\
\text { moderador, pois as } \\
\text { perguntas devem ser } \\
\text { respondidas por K. C. S. e } \\
\text { complementadas pelo } \\
\text { professor quando } \\
\text { necessário. }\end{array}$ & $\begin{array}{l}\text { Roteiro de perguntas } \\
\text { ampliado. }\end{array}$ \\
\hline
\end{tabular}

Fonte: Produção da autora com base em Hoffmann e Seewald (2003) e Cader-Nascimento e Costa (2003).

Ressalta-se que a Libras Tátil apresenta-se como uma modalidade tátilproprioceptiva diferenciada da Libras (modalidade visuoespacial), pois concebe uma sequência de movimentos nas mãos. Movimentos estes, que são recebidos pelos canais tátil e proprioceptivo. É importante que se conservem os mesmos parâmetros da Libras, tais como: posição e articulação das mãos, a configuração, a locação, a orientação e a velocidade das mãos (CORMEDI, 2011).

Demandará adequações nos aspectos linguísticos, visto que, o espaço de sinalização dos sinais fica reduzido. Dependerá do resíduo visual do surdocego podendo 
ser periférico, isto é, do seu lado direito ou esquerdo; centralizado ou corporal, como a palma da mão.

Para o estabelecimento dessa forma de comunicação, a pessoa surdocega mantém uma de suas mãos ou ambas sob as mãos do mediador, de maneira que a informação possa ser compreendida pelo tato, ou seja, percebendo a articulação, o movimento, o local e a orientação da mão no espaço de sinalização.

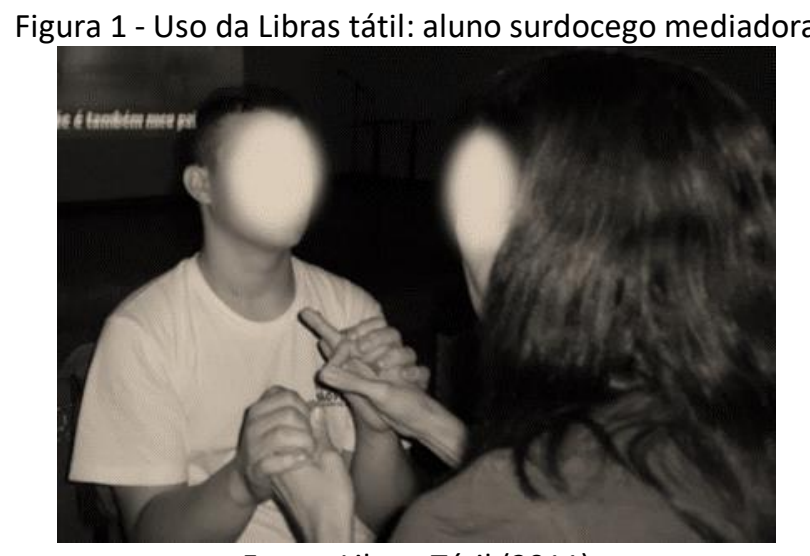

Fonte: Libras Tátil (2011)

Cader-Nascimento e Costa (2010, p. 60) chamam a atenção, quando se trata de Libras Tátil, para "[...] a importância do mediador usar roupas cujas cores contrastem com seu tom de pele, de modo a otimizar a percepção dos sinais pelo surdocego."

Quanto ao aluno F. D. M., ao contrário da aluna K. C. S., a perda auditiva foi posterior a visual, porém desde cedo ele foi acompanhado por especialistas, pois as perdas visuais e auditivas foram sendo progressivas, por isso F. D. M. faz uso do Tadoma que compreende, conforme Galvão (2010, p. 81):

[...] a uma forma de comunicação que consiste na percepção da linguagem oral pela vibração e articulação das palavras. É realizada pela mão do surdocego junto ao aparelho fonoarticulatório do falante. A pessoa surdocega, através da percepção táctil, pode sentir a vibração no rosto de quem está falando, no momento em que a pessoa está falando. Normalmente, acontece com surdocegos póslinguísticos.

Além do Tadoma, F. D. M. é oralizado e possui pleno domínio do Sistema Braille, pois foi alfabetizado também neste sistema de leitura e escrita. É um aluno com múltiplas possiblidades de comunicação para desenvolver o aprender. Com o Sistema Braille, ele pode realizar a escrita de tarefas e atividades da escola, testes etc. No quadro abaixo estão possiblidades: 
Quadro 2 - Ações para o AEE do aluno F. D. M.

\begin{tabular}{|c|c|c|c|}
\hline Áreas & Objetivos & $\begin{array}{l}\text { Procedimentos } \\
\text { metodológicos }\end{array}$ & $\begin{array}{c}\text { Recursos, } \\
\text { equipamentos etc. }\end{array}$ \\
\hline $\begin{array}{l}\text { Linguagem (exposição } \\
\text { a alguns meios de } \\
\text { comunicação } \\
\text { alternativa, priorizando } \\
\text { a utilização do Sistema } \\
\text { de comunicação } \\
\text { escolhido pelo aluno) }\end{array}$ & $\begin{array}{c}\text { Potencializar a } \\
\text { comunicação e } \\
\text { expressão de } \\
\text { informações por meio } \\
\text { do Sistema Braille, } \\
\text { Braille Tátil e Tadoma. }\end{array}$ & $\begin{array}{c}\text { Elaboração de } \\
\text { adaptações } \\
\text { necessárias junto ao } \\
\text { aluno, a partir de } \\
\text { textos (poemas, textos } \\
\text { argumentativos etc.) } \\
\text { para compreensão, } \\
\text { interpretação e } \\
\text { instrução de novos } \\
\text { pontos e combinação } \\
\text { para o Braille Tátil, } \\
\text { Sistema Braille e } \\
\text { dinâmicas com uso do } \\
\text { Tadoma na } \\
\text { interpretação de letras } \\
\text { de músicas. }\end{array}$ & $\begin{array}{l}\text { Textos transcritos para } \\
\text { o braile, reglete e } \\
\text { punção, máquina } \\
\text { braile e letras de } \\
\text { músicas transcritas } \\
\text { para o braile e o som. }\end{array}$ \\
\hline $\begin{array}{c}\text { Orientação e } \\
\text { mobilidade }\end{array}$ & $\begin{array}{c}\text { Proporcionar um } \\
\text { deslocamento seguro } \\
\text { com uso da bengala, } \\
\text { para percepção e } \\
\text { antecipação daquilo } \\
\text { que está no trajeto do } \\
\text { aluno; } \\
\text { Utilizar } \\
\text { adequadamente a } \\
\text { informação sensorial, } \\
\text { para orientar-se de } \\
\text { maneira eficaz no } \\
\text { espaço. }\end{array}$ & $\begin{array}{l}\text { Elaborar um circuito na } \\
\text { escola utilizando } \\
\text { pontos de referência } \\
\text { para o aluno que } \\
\text { deverá, com a bengala, } \\
\text { desviar e se proteger. } \\
\text { As atividades neste } \\
\text { circuito serão guiadas } \\
\text { em um primeiro } \\
\text { momento para } \\
\text { captação de } \\
\text { informações. Em } \\
\text { seguida, o aluno } \\
\text { realizará de forma } \\
\text { autônoma. E } \\
\text { posteriormente, em } \\
\text { momento oportuno } \\
\text { junto a um familiar do } \\
\text { aluno, será realizada } \\
\text { uma visita guiada fora } \\
\text { da escola para o aluno } \\
\text { realizar a interpretação } \\
\text { do local } \\
\text { (supermercado, } \\
\text { museu, biblioteca } \\
\text { pública etc.) }\end{array}$ & $\begin{array}{l}\text { Espaço escolar e suas } \\
\text { dependências; quadra } \\
\text { de esportes com } \\
\text { cones, caixas de } \\
\text { papelão, cordas etc. }\end{array}$ \\
\hline $\begin{array}{l}\text { Cognição (ênfase em } \\
\text { atividades envolvendo } \\
\text { leitura e escrita, }\end{array}$ & $\begin{array}{l}\text { Realizar atividades } \\
\text { para estímulos a } \\
\text { memória, }\end{array}$ & $\begin{array}{l}\text { Serão utilizados jogos } \\
\text { da memória em braille. } \\
\text { E confecção de alguns }\end{array}$ & $\begin{array}{l}\text { Caixas de papelão, } \\
\text { papel A4, pincel, } \\
\text { cartolinas, }\end{array}$ \\
\hline
\end{tabular}




\begin{tabular}{|c|c|c|c|}
\hline $\begin{array}{l}\text { áudiodescrição, } \\
\text { raciocínio lógico, } \\
\text { orientação espacial e } \\
\text { temporal e descrição } \\
\text { tátil). }\end{array}$ & $\begin{array}{l}\text { concentração, } \\
\text { raciocínio lógico e } \\
\text { abstração de conceitos } \\
\text { subjetivos } \\
\text { potencializando o uso } \\
\text { do tato. }\end{array}$ & $\begin{array}{c}\text { desafios como: Trilha } \\
\text { dos contos clássicos da } \\
\text { literatura infanto- } \\
\text { juvenil. } \\
\text { Uso do computador } \\
\text { com programa } \\
\text { adaptado (produção de } \\
\text { etiquetas para colar } \\
\text { nas teclas do teclado) } \\
\text { para realizar a escrita } \\
\text { de pequenos textos. } \\
\text { Realização de } \\
\text { atividades [guia- } \\
\text { interpretada no Braille } \\
\text { tátil] com um filme } \\
\text { escolhido } \\
\text { preferencialmente } \\
\text { pelo aluno ou indicado } \\
\text { pelo professor. }\end{array}$ & $\begin{array}{l}\text { computador, jogos, } \\
\text { filme e computador, } \\
\text { clássicos da literatura } \\
\text { infanto-juvenil } \\
\text { adaptados em braille. }\end{array}$ \\
\hline & $\begin{array}{l}\text { Desenvolver a escrita e } \\
\text { leitura Braille para } \\
\text { aprendizagem de sinais } \\
\text { e combinações mais } \\
\text { complexas, bem como } \\
\text { ampliação do } \\
\text { vocabulário e } \\
\text { potencialização do } \\
\text { Tadoma. }\end{array}$ & $\begin{array}{l}\text { Execução de ditado } \\
\text { oro-tátil (o professor } \\
\text { fala uma palavra e o } \\
\text { aluno deve realizar a } \\
\text { leitura oro-tátil - } \\
\text { Tadoma) para } \\
\text { identificar. O registro } \\
\text { escrito será pelo } \\
\text { Sistema Braille no } \\
\text { Brailex, uma Prancheta } \\
\text { de madeira perfurada, } \\
\text { com pinos produzindo } \\
\text { as celas braille. }\end{array}$ & $\begin{array}{c}\text { Brailex } \\
\text { Palavras transcritas em } \\
\text { braille }\end{array}$ \\
\hline $\begin{array}{c}\text { Socialização } \\
\text { (ampliação dos } \\
\text { contatos com } \\
\text { ambientes e pessoas e } \\
\text { afirmação da } \\
\text { Identidade, autogestão } \\
\text { e empoderamento da } \\
\text { pessoa surdocego) }\end{array}$ & $\begin{array}{c}\text { Incentivar a } \\
\text { autoafirmação do } \\
\text { aluno com relação a } \\
\text { condição de surdocego }\end{array}$ & $\begin{array}{l}\text { Organização de uma } \\
\text { Roda de Conversa na } \\
\text { Sala de Recursos com a } \\
\text { turma do aluno da sala } \\
\text { comum de ensino. A } \\
\text { dinâmica começa com } \\
\text { perguntas que os } \\
\text { colegas querem saber } \\
\text { sobre a surdocegueira, } \\
\text { a condição da colega, } \\
\text { sua rotina no dia a dia, } \\
\text { etc. o professor nesse } \\
\text { contexto atua como } \\
\text { moderador, pois as } \\
\text { perguntas devem ser } \\
\text { respondidas por F.D.M. } \\
\text { e complementadas } \\
\text { pelo professor quando } \\
\text { necessário. }\end{array}$ & $\begin{array}{l}\text { Roteiro de perguntas } \\
\text { em tinta e em braille. }\end{array}$ \\
\hline
\end{tabular}


Fonte: Produção da autora com base em Hoffmann e Seewald (2003) e Cader-Nascimento e Costa (2003).

Convém pontuar que o Braille Tátil também denominado de Braille Digital compreende uma adaptação para surdocegos pós-linguísticos que possuem o conhecimento do sistema de escrita e leitura Braille, o mesmo poderá ser digitado nos dedos indicador e médio da pessoa surdocega, e funcionarão como a cela braile, sendo cada falange o lugar da marcação do ponto (GALVÃO, 2010).

Figura 2 - Determinação do Braille Tátil com os dedos

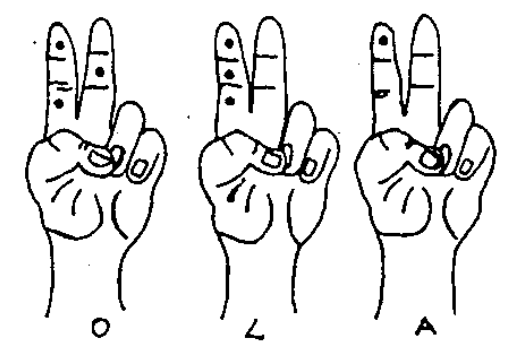

Fonte: Certeza (2010)

Outra maneira de realizar o Braile Tátil é fazendo uso das duas mãos da pessoa surdocega, onde os três dedos de cada lado (direito e esquerdo) seriam o teclado da máquina braile (GALVÃO, 2010).

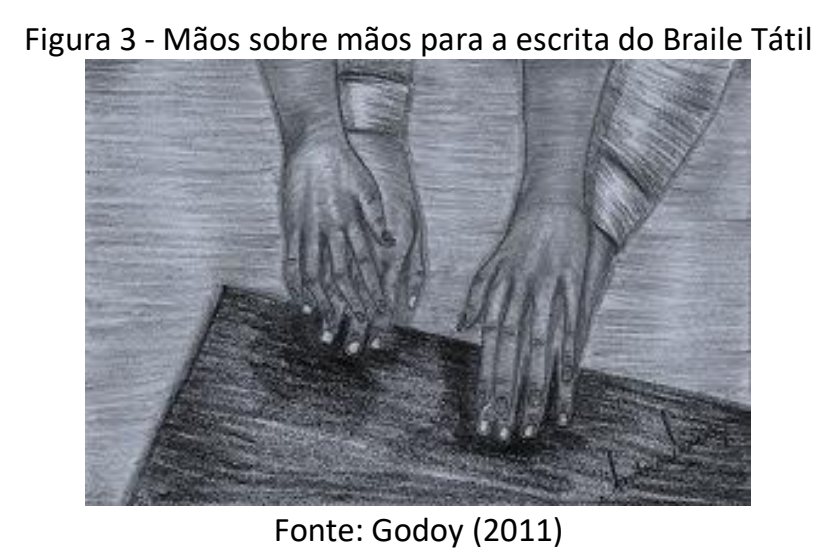

Deste modo, nos casos apresentados, serão estimulados os resíduos auditivos, visuais, táteis e cinestésico desses alunos nas ações propostas. E, principalmente a socialização por meio da necessidade de se identificarem como surdocegos e como pessoas iguais as demais com uma condição única.

Pontua-se que o tato tem particular relevância para a comunicação e aprendizagem do surdocego, pois permite o início da compreensão dos significados das 
coisas e como funcionam, fato que posteriormente vai lhes proporcionar dar sentido ao mundo e a se localizar nesse contexto.

Por conseguinte, as ações pedagógicas para os dois alunos são semelhantes, no sentido de estimular os sentidos remanescentes o que cada aluno já possui, porém cada ação apresenta particularidades.

Destaca-se que as ações foram pensadas estruturadas por áreas, conforme os quadros 1 e 2 expõem. Cada área apresenta objetivos, percursos metodológicos e os recursos a serem adotados pelo professor para utilização com o aluno surdocego. Uma vez que, o AEE é um serviço da Educação Especial que "[...] identifica, elabora, e organiza recursos pedagógicos e de acessibilidade, que eliminem as barreiras para a plena participação dos alunos, considerando suas necessidades específicas" (BRASIL, 2008).

Deste modo, o atendimento especializado não tem como designío o reforço escolar, mas sim o apoio para o desenvolvimento e estímulos a aprendizagem dos alunos que recebem este atendimento. Ao se propor atividades no contexto deste serviço da Educação Especial com as devidas adequações, é possível incluir o aluno surdocego nas situações de aprendizagem que os demais alunos estão vivendo.

Essa possibilidade de personalizar o ensino, respeitando as dificuldades e os talentos dos alunos, a partir do uso de estratégias pedagógicas diferenciadas, pode ampliar consideravelmente a inclusão com desenvolvimento acadêmico e social do sujeito com deficiências (PLETSCH, SOUZA E ORLEAN, 2017, p. 273).

Portanto, no contexto escolar o apoio individualizado do AEE aos alunos surdocegos, sobretudo em atividades mais complexas que ampliem a autonomia criam condições pedagógicas adequadas para sua participação e atuação no meio educacional e social.

\section{CONSIDERAÇÕES FINAIS}

Ao longo das presentes reflexões organizadas neste estudo que se concretizaram por meio de uma revisão sistemática de literatura destaca-se o contexto de surgimento da surdocegueira e posterior singularidade, além de ações pedagógicas a serem desenvolvidas no Atendimento Educacional Especializado - AEE. O trabalho pedagógico do professor do AEE em busca da utilização de metodologias adequadas possibilita 
melhorar a qualidade do ensino e promover o desenvolvimento do aluno surdocego póslinguístico.

Entende-se que existem diversos desafios postos aos professores, mas espera-se que esta pesquisa com a proposição de caminhos para o AEE do aluno surdocego póslinguístico represente um estímulo para que se busquem mais práticas pedagógicas. No tocante as ações propostas, a partir dos dois diferentes casos analisados de alunos surdocegos pós-linguísticos foi priorizado a ampla exploração do tato, assim como dos resíduos dos outros sentidos em prejuízo (visão e audição). Questão que pode contribuir para que esses alunos vivenciem conceitos práticos, incentivando-os a adquirirem novas habilidades e vencerem seus desafios, principalmente de acesso e preconceito.

Outro ponto importante frisado na tessitura deste texto, trata de que não basta apenas que o professor do AEE aplique metodologias adequadas, mas também que estabeleça metas que priorizem as necessidades educacionais de seus alunos, notadamente aliando a teoria à prática, pois foi percebido na análise da literatura que a efetiva inclusão de alunos surdocegos tem sido modelado por um processo de apropriação, porém os esforços de muitos professores do AEE sido incessantes.

Deste modo, com engajamento e compromisso, os professores podem contribuir com a aprendizagem e o desenvolvimento do surdocego. Tendo em vista que as possibilidades de atendimento são diversas e os materiais produzidos e discussões traçadas pelas instituições, cuja natureza é o apoio e estudo à Surdocegueira tem sido referenciais consistentes para a Educação Especial.

Enfim, diante de tudo que foi apresentado e analisado neste texto, a aprendizagem inclusiva de surdocegos demanda e depende de vários fatores, dentre eles a formação do docente do atendimento especializado e o estabelecimento de uma rede apoios. Ao mesmo tempo se caracteriza desafiadora, mas possível a partir de professores cuidadosos e sensíveis ao processo de inclusão escolar.

\section{REFERÊNCIAS}

AHIMSA - Associação Educacional para Múltipla Deficiência. São Paulo, 2018. Disponível em: http://www.ahimsa.org.br/. Acesso em: 21 jan. 2020. 
ALMEIDA, C. A. F. A aquisição da linguagem por uma surdocega pré-linguística numa perspectiva sociocognitivo-interacionista. 2008. $337 \mathrm{f}$. Tese (Doutorado em Linguística) - Universidade de Brasília, Brasília, 2008.

ALMEIDA, W. G. O guia-intérprete e a inclusão da pessoa com surdocegueira. 2015. Tese (Doutorado em Educação) - Programa de Pesquisa e Pós-graduação em Educação, Faculdade de Educação, Universidade Federal da Bahia. Salvador, 2015.

BERSCH, R. Recursos pedagógicos acessíveis: Tecnologia Assistiva (TA) e processo de avaliação nas escolas. 2006. Disponível em: $<$ http://www.assistiva.com.br/Recursos_ Ped_Acessiveis_Avaliacao_ABR2013.pdf>. Acesso em: 20 maio 2020.

BRASIL. Decreto n. 7.611, de 17 de novembro de 2011. Dispõe sobre a educação especial, o atendimento educacional especializado e dá outras providências. Diário Oficial da União, Brasília, DF, Seção 1, 18 de novembro de 2011.

BRASIL. Ministério da Educação. Secretaria de Educação Continuada, Alfabetização, Diversidade e Inclusão. Política Nacional de Educação Especial na Perspectiva da Educação Inclusiva. Brasília, DF: MEC; SECADI, 2008.

BRASIL. Presidência da República. Secretaria Especial dos Direitos Humanos. Coordenadoria Nacional para Integração da Pessoa Portadora de Deficiência. Ata da VII Reunião do Comitê de Ajudas Técnicas. Brasília, DF: CAT, CORDE, SEDH, PR, dez. 2007.

BRUNER, J. S. O Processo da Educação. Portugal: Edições 70, 1998.

CADER-NASCIMENTO, F. A. A. A.; COSTA, M. da P. R. da. Descobrindo a surdocegueira: educação e comunicação. São Carlos, SP: EdUFSCar, 2010.

CERTEZA, L. M. Cláudia Sofia. Revista Ciranda da Inclusão, Jandira, SP, ano 1, n. 11, p. 08-10, out. 2010.

CORMEDI, M. A. Alicerces de significados e sentidos: aquisição de linguagem na surdocegueira congênita. 2011. 402 f. Tese (Doutorado em Educação) Faculdade de Educação, Universidade de São Paulo, São Paulo, 2011.

FARRELL, M. Deficiências sensoriais e incapacidades físicas: guia do professor. Porto Alegre: Artmed, 2008.

GALVÃO, N. de C. S. S. A comunicação do aluno surdocego no cotidiano da escola inclusiva. 2010. Tese (Doutorado) - Universidade Federal da Bahia. Faculdade de Educação. Salvador, 2010. 
GODOY, S. A. Convivendo e aprendendo com o surdocego. Produção DidáticoPedagógica. Londrina, PR: Secretaria de Educação do Estado do Paraná; Secretaria de Tecnologia e Desenvolvimento no Programa de Desenvolvimento Educacional, 2011.

GRUPO BRASIL de Apoio ao Surdocego. ed. 34 jul./ago., 2005. Disponível em: http://www.ame-sp.org.br/noticias/tejornal.shtml. Acesso em: 22 jan. 2020.

HOFFMANN, S. B.; SEEWALD, R. Caminhar sem medo e sem mito: orientação e mobilidade. Rio de Janeiro, 2003. Disponível em: http://www.bengalalegal.com/orienta. Acesso em: 22 maio 2020.

LIBRAS Tátil. Surdo HK, Blog da Escola Municipal de Educação Bilíngue para Surdos Helen Keller, São Paulo, 2011. Disponível em: https://surdohk.blogspot.com/2011/07/libras-tatil.html. Acesso em 25 jan. 2020.

MAIA, S. R. A educação do surdocego: diretrizes básicas para pessoas não especializadas. 2004. 81 f. Dissertação (Mestrado em Distúrbios do Desenvolvimento) - Universidade Presbiteriana Mackenzie, São Paulo, 2004.

MARRA, S. Surdocegueira. In: FERREIRA, J. M.; DECHICHI, C.; SILVA, L. C. (orgs.) Curso básico: Educação Especial e Atendimento Educacional Especializado. Uberlândia, MG: EdUFU, 2012.

MASINI, E. F. S. Do sentido, pelos sentidos, para o sentido. Niterói: Intertexto, 2002.

MCLETHIE, B. Desenvolvendo conceitos através de atividades: comunicando com alunos surdocegos. Palestra apresentada no curso de Formação de Educadores com Múltiplas Deficiências Sensoriais e Múltiplas Deficiências na Universidade Presbiteriana Mackenzie, São Paulo, 2002.

MEIRA, M. E. M. Desenvolvimento e aprendizagem: reflexões sobre suas relações e implicações sobre a prática docente. Revista Ciência e Educação. Bauru, SP. v.5, n.2, p.61-70. 1998.

NORONHA, G. C. de. Da forma à ação inclusiva: curso de formação de professores para atuar em Salas de Recursos Multifuncionais. Jundiaí, SP: Paco Editorial, 2016.

PLETSCH, M. D.; SOUZA, F. F.; ORLEANS, L. F. A diferenciação curricular e o desenho universal na aprendizagem como princípios para a inclusão escolar. Revista Educação e Cultura Contemporânea, São Paulo, v. 14, n. 35, 2017.

RACHED, S. Ver e ouvir a surdocegueira: o emergir da comunicação. Recife. $177 \mathrm{f}$. Dissertação (Mestrado em Ciências da Linguagem) - Universidade Católica de Pernambuco. Recife, 2011. 
REYES, D. A. La sordoceguera: uma discapacidad singular. In: . La sordoceguera: um análisis multidisciplinar. Madrid: ONCE, 2004. p. 135-159.

VIGOTSKI, L. S. A formação social da mente. São Paulo: Martins Fontes, 2003. 


\title{
CAPÍTULO XXIX
}

\section{A IMPORTÂNCIA DO INCENTIVO AO ENSINO DA MATEMÁTICA PARA OS ALUNOS SURDOS DA EDUCAÇÃO BÁSICA ${ }^{1}$}

Ivete Loula Vasconcelos ${ }^{1}$

\begin{abstract}
${ }^{1}$ Mestre em Educação pela UTIC/PY. Vinculação institucional: Professora de Matemática da Educação Básica do Colégio Luiz Viana Filho Irecê/Ba
\end{abstract}

\section{RESUMO}

O presente artigo é um recorte da dissertação do mestrado em ciências da educação no qual foi realizado um estudo sobre as estratégias utilizadas no ensino da matemática para alunos surdos na cidade de Irecê/BA na educação básica no ano 2019; neste trabalho apresento uma visão geral acerca do incentivo no ensino da matemática para os alunos surdos, com proposito de melhorar o envolvimento dos estudantes surdos nas atividades acadêmicas desenvolvidas em sala de aula regular. Participaram deste estudo nove professores de matemática e cinco coordenadores pedagógicos que atuaram com alunos surdos, no referido município em 2019. Trata-se de uma pesquisa quantitativa, de base descritiva e se debruça sobre a investigação da prática pedagógica. Os procedimentos e os instrumentos para coleta e análise de dados envolveram: a observação das aulas de matemática e a aplicação de questionário tricotômico fechado. Os resultados da pesquisa indicam que o incentivo ao ensino da matemática para o aluno surdo deve considerar as particularidades dos discentes surdos, e atentar para a boa relação professor-aluno surdo adjacente a presença do intérprete de Libras na classe, além da sinergia positiva na sala de aula e o uso pedagógico de recursos tecnológicos para contribuir na sua aprendizagem; com intenção de que os estudantes surdos possam participar de maneira efetiva das atividades acadêmicas desenvolvidas em sala de aula regular, por conta da adversidade da comunicação, fator factual ao aprendizado durante as aulas.

Palavras-chave: Incentivo. Aluno Surdo. Ensino. Matemática.

\section{INTRODUÇÃO}

O presente artigo é um recorte de minha dissertação de mestrado defendido em janeiro de 2020, cujo objeto de estudo foi o ensino da matemática para alunos surdos

${ }^{1}$ A dissertação se intitulou "Estratégias metodológicas utilizadas no ensino da matemática para aluno surdos." e foi defendida em janeiro de 2020 no programa de Postgrado da Faculdade de Ciências Humanas e Exactas da Universidad Tecnológica Intercontinental em Assunção no Paraguai. A mesma foi produzida sob orientação do professor doutor Anibal Barrios Fretes. 
na cidade de Irecê em 2019. No presente texto volto minha atenção à perspectiva do incentivo ao ensino da matemática para estes discentes.

O incentivo ao ensino da matemática para o estudante surdo é uma forma eficaz de estimular neste, o desejo de aprender para conseguir bons resultados no processo de aprendizagem. Estes estímulos podem ser determinantes para o aluno alcançar o desempenho escolar almejado. Entretanto, é preciso respeitar as individualidades, pois cada aluno responde de uma forma diferente a esses motivos.

Portanto, para que aconteça incentivo no ensino da matemática do aluno surdo, é imprescindível o engajamento dos professores; Em vista disso, Posamentier e Krulik, (2014, p.17) afirma que "os professores precisam de algumas atividades interessantes e incomuns para começar uma aula e incentivar os alunos".

O interesse por essa temática surgiu a partir do trabalho desenvolvido em uma escola regular de educação básica, lecionando para alunos surdos. O que provocou o desejo de compreender as singularidades do ensino da matemática para estes estudantes.

O objetivo deste artigo é provocar reflexões acerca do Incentivo ao ensino da matemática para alunos surdos, de forma a repensar as práticas pedagógicas capazes de promoverem uma experiência educativa mais condizente com a realidade dos alunos surdos. Visto ser inegável que o aluno surdo percebe o mundo de maneira diferente e necessita deste incentivo. Segundo Ribas e Martins (2018), "com estudantes surdos, há de se buscar sentir o mundo pela visão, percebendo como seria assistir uma aula expositiva sem utilizar a audição, para assim propor metodologias que os incentivem e os incluam efetivamente" (p.435).

O enquadramento metodológico desta pesquisa foi pautado em uma revisão da literatura, pesquisa bibliográfica e investigação da ação pedagógica dos professores de matemática e coordenadores pedagógicos que atuaram com alunos surdos em escolas da cidade de Irecê/BA, no ano 2019. Os instrumentos e procedimentos de coleta dos dados foram feitos através de observações de aulas e aplicação de questionários com vistas a entender melhor o ensino da matemática para os estudantes surdos, bem como analisar a realidade que vivenciaram os educadores destes alunos em Irecê/BA, no a no de 2019. 
A justificativa para esta pesquisa se deu pela necessidade de novas descobertas e por provocar transformações numa seara carente de novos saberes como a matemática na educação especial e inclusiva, considerando que se trata de uma temática, ainda pouco pesquisada e discutida no meio acadêmico.

Para incentivar o ensino da matemática para alunos surdos, além de professores especialistas, é preciso contar com intérpretes de Libras. Neste sentido, Gesser (2015) entende que "os intérpretes deveriam se envolver nas práticas educacionais, de modo que dúvidas, sugestões e preparo das aulas em parceria com professores seriam fortemente incentivados" (p.543).

$\mathrm{Na}$ estrutura deste artigo primeiramente há uma apresentação dos aportes teóricos que fundamentam meu olhar sobre esta discussão. Em sequência, busco analisar algumas questões selecionadas para este trabalho que foram respondidas pelos professores e coordenadores pedagógicos e observadas nas aulas, para melhor perceber a influência do incentivo no processo de ensino no momento em que a pesquisa foi realizada.

Este trabalho tem a intenção de contribuir com a sociedade, principalmente na área da educação, ao propor melhores condições de inclusão dos alunos surdos na escola regular, para que os alunos surdos tenham acesso ao conhecimento matemático, promovendo o desenvolvimento da consciência crítica para analisar informações, na compreensão dos conceitos matemáticos, auxiliando a inclusão e o acolhimento dos alunos com deficiência auditiva na sala de aula regular.

\subsection{Relação do professor de matemática $x$ aluno surdo na sala de aula regular}

Na pesquisa supracitada, averiguou-se no tocante ao incentivo ao ensino da matemática para o aluno surdo, que este abrange à relação professor-aluno. Desta maneira, Dos Santos e Castellanos (2018) entende que "uma boa relação professoraluno é primordial para se alcançar bons resultados para ambos os envolvidos no processo educacional" (p.280).

Neste entendimento, percebemos que a relação professor-aluno surdo, conta com a mediação do interprete de Libras que atua na intermediação do conhecimento para o estudante surdo, como comenta Menezes e Santos, (2019) "a tríade professoraluno-saber ganha um novo personagem, o Intérprete de Língua de Sinais, que revela 
sua importância na relação didática" (p.778). estes mesmos autores na afirmativa abaixo, ratificam essa ideia:

um processo de ensino e aprendizagem adequado às necessidades de um surdo inclui o intérprete de Libras como sujeito desse processo, pois seu papel intermedia as ações do professor em relação aos seus alunos, bem como em relação aos alunos surdos (MENEZES; SANTOS, 2019, p.780).

Também é importante considerar que a boa relação do aluno surdo com professor de matemática, possibilita interações fundamentais na construção do seu conhecimento. De Menezes e Santos (2019) afirmam que "o processo de ensino de um saber matemático pode apresentar dificuldades no estabelecimento de suas relações com alunos surdos" (p.778).

Em consonância com estas reflexões, salienta-se que a condição individual de cada estudante surdo, com suas especificidades, reflete na sua relação pedagógica com o professor de matemática. Sobre esta questão, Almeida (2015) diz que "em um ensino inclusivo que vise a atender as necessidades dos alunos surdos, faz-se necessário que os professores tenham conhecimento sobre as particularidades das pessoas que não ouvem" (p.44).

Assim, estas especificidades dos alunos surdos devem ser levadas em consideração no momento de preparação das aulas, facilitando os caminhos para que este estudante alcance os conhecimentos. Almeida (2015) explica que "essas particularidades na sala de aula tem preocupado educadores matemáticos nos vários níveis de ensino, pois constituem um processo fundamental da atividade matemática em que estão envolvidos professores e alunos" (p.141).

\subsection{Sinergia no ensino da matemática para alunos surdos}

Um outro aspecto na incentivação do ensino a ser ressaltado, diz respeito a sinergia da aula, que é um tema muito discutido atualmente, mas pouco entendido. Sinergia é uma palavra da origem grega synergia, que significa cooperação, esforço de pessoas, que se unem para realizar uma tarefa de forma produtiva e mobiliza competências para atingirem um objetivo comum. Conforme dito por Bergue (2019): 
A sinergia é uma das características das equipes, capaz de gerar um resultado superior ao somatório das entregas individuais. $\mathrm{A}$ interação sinérgica produz isso na medida em que as pessoas, no exercício das suas atividades, compartilham saberes, e ao mobilizarem as suas competências podem influenciar 0 pensamento e a ação dos demais. (BERGUE, 2019, p.41).

Ressalta-se que a sinergia corresponde à soma dos esforços para atingir um objetivo, por exemplo, quando em sala de aula o professor forma grupos, coloca em equilíbrio as energias dos mesmos, para que determinada tarefa seja mais eficaz. Segundo Araújo (2019 “a sinergia dos fatores motivadores do docente e os fatores motivadores do discente, contribui significativamente para a estruturação de um ambiente estimulante" (p.222).

Na matemática, a sinergia se apresenta como convergência de partes de um todo para chegar a um mesmo resultado (teoria de sistemas). Entende-se também sinergia como harmonia e consenso.

Enfim, a colaboração entre educadores e educandos produz sinergia para produção de novos conhecimentos e prática pedagógica compartilhada. Larrín e Hernández (2003), afirma que "criar uma sinergia que permita não apenas a aprendizagem, mas também a geração de um conhecimento novo, na medida em que é nutrida de vozes e de posições diferenciadas, contribuem para a melhoria da prática" (p.45).

\subsection{Uso de ferramentas tecnológicas no ensino da matemática para alunos surdos}

Outra vertente no incentivo a instrução do aluno surdo, diz respeito ao uso das ferramentas tecnológicas que podem auxiliar o ensino da matemática para este estudante, pois estimula a criação de novas estratégias de ensino. Conforme Souza, (2013), explica: "sua contribuição perante a sociedade está crescendo rapidamente, bem como sua utilização no processo ensino-aprendizagem" (p.28). Ou seja, as tecnologias ampliam as possibilidades das aulas, tornam o ensino mais significativo e cria condições favoráveis à aprendizagem dos alunos surdos.

Para Dante (2016), "a utilização de todos esses recursos digitais no ensino é cada vez mais frequente e facilita a comunicação entre os agentes do processo didático, além 
de ampliar as possibilidades pedagógicas" (p.308). Da mesma forma, o livro de Chavante (2016) reitera este aspecto:

As novas tecnologias oferecem oportunidades para a criação de ambientes de aprendizagem que ampliam as possibilidades das tecnologias mais clássicas, como a lousa, o giz e o livro. Com relação as tecnologias digitais, o desafio tem sido a implementação do ensino para proporcionar condições mais favorável à aprendizagem dos estudantes (CHAVANTE, 2016, p.251).

Souza (2013) afirma que "o computador se torna um grande aliado do desenvolvimento cognitivo dos alunos. Além disso, possibilita um enfoque experimental voltado à facilidade de geração de gráficos, tabelas e expressões" (p.29), de modo que o computador possibilita explorar os conteúdos matemáticos, independente das deficiências.

Deste modo, com o uso das ferramentas tecnológicas o professor pode realizar experiências e manipulação de dados, de uma maneira que manualmente não seria possível, o que amplia as oportunidades e contribui no ensino da matemática para o estudante surdo. Nessa perspectiva, Pereira (2015) afirma que "a tecnologia aplicada à matemática pode ampliar as possibilidades e superar o ensino tradicional da matemática" (p.33).

Atualmente, a inserção de ferramentas tecnológicas no ensino é uma exigência da sociedade, que enxerga como moderna a escola que possui recursos tecnológicos. Todavia não basta que a escola tenha recursos tecnológicos, o fundamental é que o professor aplique essas tecnologias em suas aulas, o que contribuiria para o ensino da matemática, conforme explica Dante (2016):

As vantagens e prejuízos dos recursos digitais são causados pelo uso que se faz deles, ou seja, devemos evitar a noção ilusória de que a simples presença do recurso digital garante melhores resultados de aprendizagem. Em contrapartida, o uso planejado e apropriado tem se mostrado eficiente em melhorar o ensino (DANTE, 2016, p.309).

Dessa forma, fica evidente que os recursos tecnológicos não devem ser deixados de fora da sala de aula, visto que eles tornam o processo de aprendizagem matemática mais próximo das informações relevantes da vida, além de ser um importante 
incentivador no ensino para os alunos com deficiência auditiva. Balestri (2016) explica que "o uso de recursos tecnológicos [...] torna o processo de aprendizagem da Matemática mais experimental e vinculado ao conhecimento útil na vida das pessoas" (p.251).

\section{PRINCIPAIS CARACTERÍSTICAS METODOLÓGICAS}

O presente trabalho teve como base uma gama de leituras prévias sobre o tema em questão que se configuraram na revisão bibliográfica desta pesquisa, através da análise de sites, legislação, livros, artigos e revistas cientificas, com intuito de reunir informações para desenhar as particularidades no incentivo ao ensino da matemática para alunos surdos, na educação básica, na cidade de Irecê/Bahia, no ano 2019. Desta forma, reproduziram-se fundamentos teóricos que compuseram os alicerces da pesquisa.

Neste estudo, optou-se pelo enfoque quantitativo, no qual os dados coletados foram mensurados numericamente, por meio de procedimentos e operações estatísticas.

O nível de pesquisa abordado neste trabalho foi de profundidade descritiva, onde se buscou especificar as características e tópicos mais importantes que afetaram o incentivo ao ensino da matemática para o discente surdo. Assim, a coleta de dados foi direcionada a determinar como são e como se manifestou a variável nesta situação.

Quanto ao desenho da Pesquisa, foi de caráter não experimental, caracterizado pelo fato de que a pesquisadora não manipulou as variáveis envolvidas na investigação, o que significa que a pesquisadora levantou as informações tal como elas acontecem, focando na situação, suas causas e consequências, na perspectiva de temporalidade seccional, tendo em vista que foi feita a coleta de dados num determinado momento.

No método não experimental, as relações foram estudadas por meio de mensuração das variáveis de interesse, ou seja, como ocorre naturalmente. Isso foi feito pelos professores de matemática e coordenadores pedagógicos ao responderem o questionário e através da observação das aulas registradas em fichas de observação.

A população desta pesquisa contou com nove professores de matemática e cinco coordenadores pedagógicos que atuam com alunos surdos, nas escolas: Escola Estadual Luís Viana Filho, Colégios Municipais ACM, Joel Americano Lopes, Odete Nunes Dourado 
e Colégio Persona da cidade de Irecê no ano 2019; por se tratar de um universo reduzido de sujeitos envolvidos na pesquisa, não foi necessária amostra, ou seja, todos os professores de matemática e coordenadores pedagógicos de alunos surdos da educação básica do município de Irecê/BA no ano de 2019, foram abordados na pesquisa.

Na técnica de coleta de dados, esta pesquisa, utilizou a observação e a enquete com aplicação de questionário tricotômico fechado para professores de matemática e coordenadores pedagógicos que atuaram com alunos surdos, cuja análise foi apresentada em tabelas e gráficos.

As questões fechadas foram numa escala de medição de três níveis de resposta (Sempre - Às vezes - Nunca) apresentando três resultados possíveis. As fichas de observação das aulas continham duas opções de respostas para os itens observados (SIM - NÃO) apresentando dois possíveis resultados. Foram observadas três aulas de cada aluno surdo, num total de vinte e sete aulas observadas e, em seguida, adotado o seguinte critério: Se nenhum sim foi observado, o critério adotado foi NUNCA, se observado um sim, o critério adotado foi ÀS VEZES, e caso dois ou três sim observado, considerou-se o critério SEMPRE.

\section{RESULTADOS E DISCUSSÕES}

Nesta apreciação, foram explorados os questionários respondidos e as fichas de observação das aulas. Os resultantes foram obtidos a partir das respostas acerca do incentivo ao ensino da matemática para alunos surdos. No presente estudo, foram selecionadas as seguintes questões: 1) A boa relação professor-aluno incentiva o ensino da matemática para o aluno surdo? 2) A sinergia positiva da sala de aula coopera no ensino da matemática para alunos surdos na escola? 3) As ferramentas tecnológicas contribuem no ensino da matemática para alunos surdos?

\subsection{Analise dos questionários}

\section{I.I. Incentivo ao ensino da matematica para alunos surdos}


Figura 1: Distribuição numérica relativa aos questionários do incentivo ao ensino da matemática para alunos surdos

Questionários Professores de Matemática

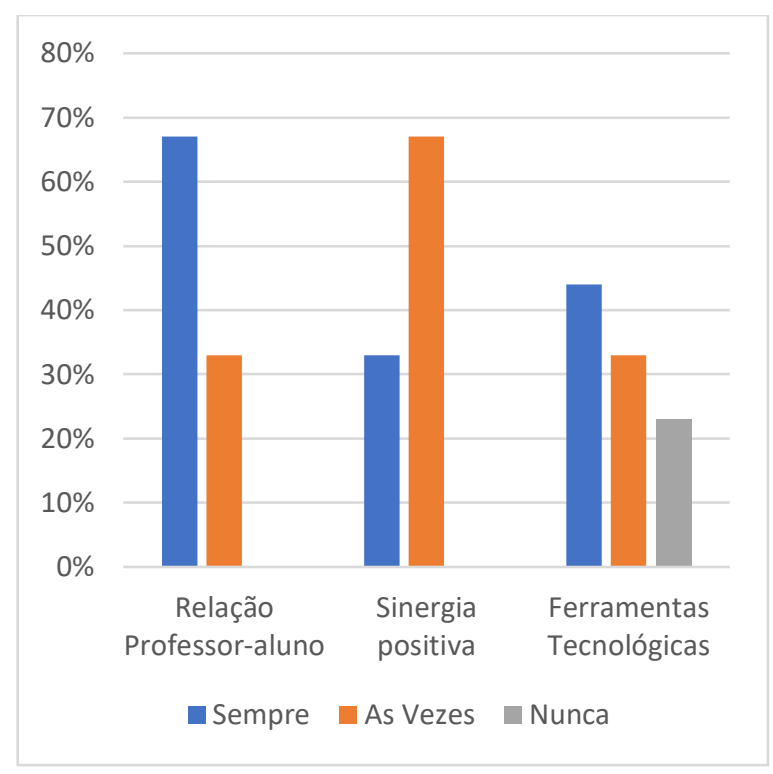

Questionários Coordenadores Pedagógicos

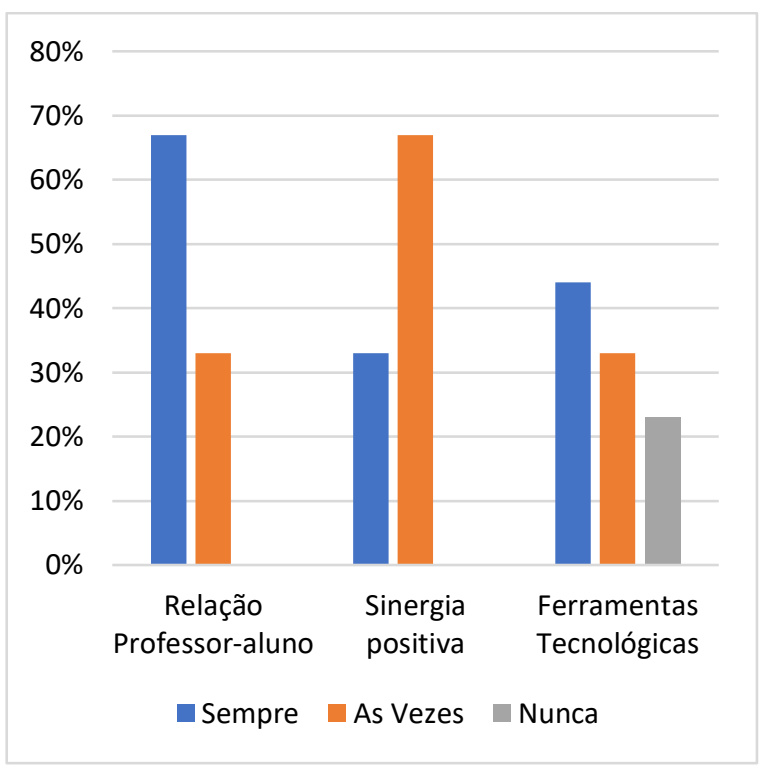

Fonte: Elaboração da autora, 2019.

Conforme evidenciado na Figura acima, relativo ao incentivo no ensino da matemática para alunos surdos constata-se, referente à pergunta 1 "A boa relação professor-aluno incentiva o ensino da matemática para o aluno surdo?", as respostas dos professores de matemática foram: (67\%) sempre, Já os coordenadores pedagógicos (60\%) sempre. Pelas respostas, percebe-se que os pesquisados consideram que a boa relação professor aluno-surdo incentiva o ensino da matemática para o aluno surdo, 
resultado importante, conforme explica Costa (2018) "quanto mais próxima a relação entre o professor e seus alunos, maior será o interesse, o envolvimento e consequentemente, o rendimento escolar dos estudantes" (p.11).

Quanto à pergunta 2 "A sinergia positiva da sala de aula coopera no ensino da matemática para alunos surdos na escola?", obteve-se como respostas: (33\%) dos professores de matemática responderam sempre e (67\%) às vezes. Já os coordenadores pedagógicos responderam (40\%) sempre e (60\%) às vezes, evidenciado que a sinergia positiva na sala de aula, sempre ou quase sempre coopera no modo de aprender matemática dos alunos surdos, opinião atestada por Goncalves (2018), que acredita que "a cooperação envolve sinergia e assume que, de alguma maneira, o todo é maior do que a soma das partes individuais, de modo que aprender, desenvolvendo um trabalho cooperativamente" (p.30).

Pertinente à questão 3 "As ferramentas tecnológicas contribuem no ensino da matemática para alunos surdos?", as respostas dos professores de matemática foram: (44\%) sempre, (33\%) as vezes e (23\%) nunca. E as respostas dos coordenadores pedagógicos (40\%) sempre, (20\%) às vezes e (40\%) nunca, decorrente de as escolas oferecerem poucos recursos nesta área, o que contribuiria para o ensino da matemática para os alunos surdos. Entretanto, de acordo com Diaz (2009) "se esses alunos tivessem acesso aos recursos tecnológicos que estão disponíveis na sociedade teriam, com certeza, uma melhor qualidade de seu processo de aprendizagem e consequente seriam inclusão no meio acadêmico em que circulam" (p.36).

Averiguou-se baixa porcentagem de uso de novas ferramentas tecnológicas e, considerando sua importância para a educação do aluno surdo, esta reputa em prejuízo ao ensino da matemática para estes estudantes.

Dessa forma, pelas respostas dos questionários no incentivo ao ensino da matemática para o aluno surdo, nota-se que a maioria dos pesquisados considera que houve boa relação professor-aluno, assim como sinergia positiva no ensino da disciplina. Entretanto, o pouco uso de ferramentas tecnológicas dificultou a instrução dos alunos surdos. 


\subsection{Analise das fichas de observação das aulas}

\subsection{Incentivo ao ensino da matemática para alunos surdos}

Figura 2: Distribuição numérica relativa das fichas de observação das aulas no incentivo ao ensino da matemática para alunos surdos

Fichas de observação das aulas

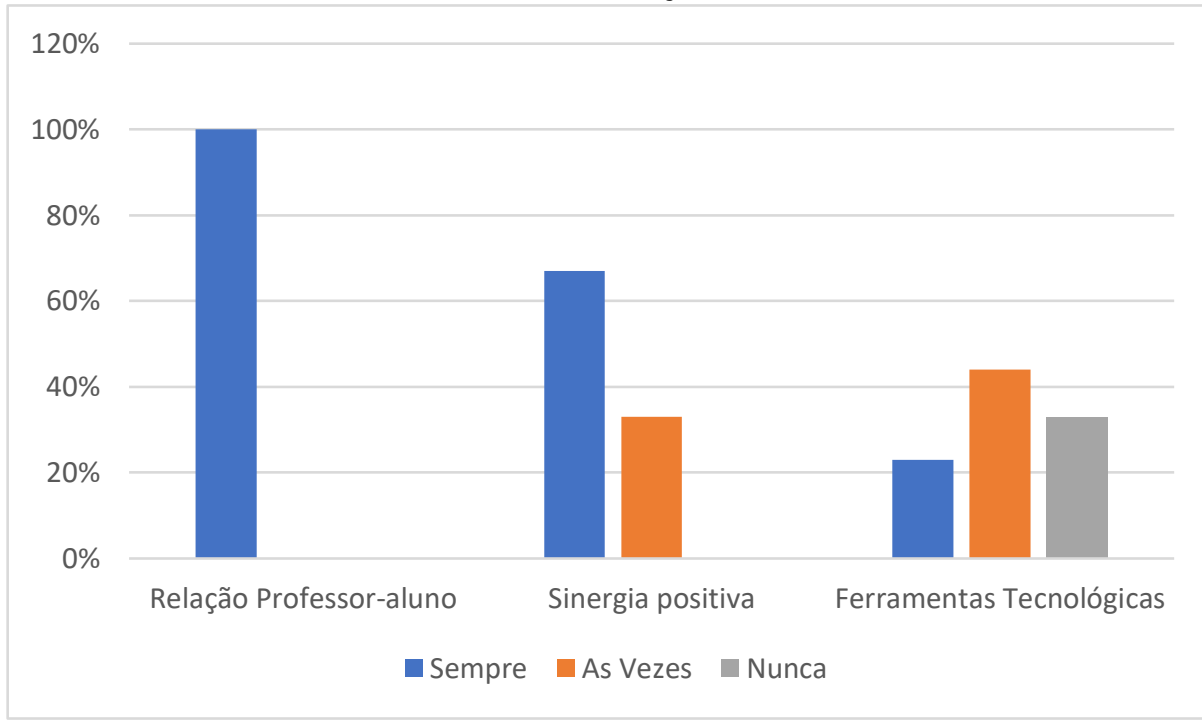

Fonte: Elaboração da autora, 2019.

No tocante à Figura 2, referente à observação das aulas no incentivo ao ensino da matemática para alunos surdos, em (100\%) das aulas observadas, houve boa relação professor aluno-surdo, resultado expressivo, como Santos e Castellanos (2018)) admite: "o professor contribui bastante no processo de aprendizagem e desenvolvimento da criança" (p.277). Esta é uma boa tática para o aprendizado do aluno surdo.

Com relação à sinergia positiva em sala de aula com o aluno surdo, foi observado (67\%) sempre e (33\%) às vezes. Isso demostrou uma boa sinergia no ensino do discente surdo e representa um item considerável. O Ministério da Educação, no caderno mais educação cita a importância dessa sinergia:

O desafio atual é a construção da sinergia, ou seja, a reunião dos esforços numa mesma direção: a conquista do sucesso escolar para todos os estudantes brasileiros das escolas públicas. Tratase, sem dúvida, de um tema amplo, com muitas experiências acumuladas e outras ainda em processo de desenvolvimento, sobre o qual nós educadores somos desafiados (BRASIL, 2009, p. 16). 
Em alusão ao uso de ferramentas tecnológicas nas aulas de matemática, foi observado (23\%) sempre, (44\%) às vezes e (33\%) nunca. Esses dados expõe que é preocupante o pouco uso das tecnologias na educação, numa sociedade com grande apelo tecnológico, o que compromete o ensino da matemática para alunos surdos; segundo Gama, (2018) “quando se trata de tecnologia e sala de aula, os professores já pensam no que poderia acontecer se todos os alunos tivessem acesso à internet, que não seria apenas essa ferramenta para o aprendizado nas aulas" (p.21).

No que concerne ao incentivo no ensino da matemática para alunos surdos, inferiu-se que houve boa relação entre professor e aluno surdo, assim como sinergia positiva na classe deste aluno, mas observou-se pouco uso das ferramentas tecnológicas nas aulas, onde seu uso poderia contribuir no ensino da matemática para o estudante surdo.

\subsection{Correlações entre os questionários e as fichas de observação das aulas}

É certo que houve boa relação professor de matemática - aluno surdo, fato que os dados mostraram pelas respostas dos questionários em que (67\%) dos professores de matemática responderam sempre, os coordenadores pedagógicos em (60\%) responderam sempre, e foi observado em (100\%) das aulas, bons índices, o que é relevante.

No que tange à sinergia positiva da sala de aula, os índices dos questionários dos professores de matemática registraram (33\%) sempre, (67\%) às vezes. Já os coordenadores pedagógicos responderam (40\%) sempre, (60\%) às vezes. Foi observado nas aulas (67\%) de ocorrências para sempre e (33\%) para às vezes, deixando claro que, sucedeu sinergia positiva regular. Para Mendes et al (2011) a sinergia positiva propicia

oportunidades educacionais para alunos com necessidades educacionais especiais na sala de aula regular e a necessidade de avançar o conhecimento sobre as alternativas mais eficazes para a preparação de profissionais envolvidos na construção de sistemas inclusivos (p.85).

Relativo ao uso de ferramentas tecnológicas no ensino da matemática para alunos surdos, as respostas dos professores de matemática foram (44\%) sempre, (33\%) às vezes e $(23 \%)$ nunca; e as os coordenadores pedagógicos (40\%) sempre, $(20 \%)$ às 
vezes e (40\%) nunca. Também foi observado nas aulas (23\%) sempre, (44\%) às vezes e (33\%) nunca.

As ferramentas tecnológicas foram pouco percebidas, tanto nos questionários como nas observações das aulas o que configura um entrave ao ensino da matemática para o estudante surdo. Nozi e Vitalino (2018) citam que "o uso das tecnologias no processo de ensino deve estar associado ao conteúdo e aos objetivos da aula, pois, dependendo do que se pretende ensinar" (p.411).

Andersen (2019) afirma que "para que o professor garanta a aprendizagem de seus alunos não basta saber o assunto. Ele precisa utilizar algum método que estimule o interesse, provoque a curiosidade e desperte a criatividade" (p.123). destarte o incentivo ao ensino da matemática para o aluno surdo é prejudicado, pois "muitas vezes o professor não tem condição de atender adequadamente o aluno surdo que se encontra em uma sala de aula junto a aproximadamente 40 alunos ouvintes" (Silva, 2017, p.20).

Assim, verificou-se por meio das informações obtidas pelos instrumentos de coleta de dados, os conceitos e referenciais teóricos acerca da pertinência do incentivo no ensino da matemática para estudantes surdos. Nesta perspectiva, Otaviano et al (2012) sintetiza: "em uma aprendizagem eficaz, é fundamental levantar possíveis fatores que possam influenciar positivamente essa aprendizagem, entre eles o interesse pelo conteúdo e a motivação do aluno" (p.62).

\section{CONSIDERAÇÕES FINAIS}

Esta pesquisa demonstrou através das respostas dos professores de matemática e dos coordenadores pedagógicos, e pela observação das aulas dos discentes surdos nesta disciplina, que ocorreu no município em questão, afável incentivo ao ensino da matemática para alunos surdos inclusos em sala de aula regular na educação básica.

É relevante ressaltar, referente ao incentivo no ensino do aluno surdo, que ocorreu um bom resultado. Por meio da boa relação professor-aluno surdo, e da sinergia positiva, apesar do pouco uso das ferramentas tecnológicas na instrução do discente surdo. Um ponto de destaque foi a presença do intérprete de Libras nas salas de aula das escolas que possuem alunos surdos inseridos. 
Em contraponto, evidenciou-se pouco uso de recursos tecnológicos pelos alunos surdos ou pela não existência destes nas escolas, ou devido ao pouco reconhecimento da sua importância, sendo que sua utilização contribuiria muito para a aprendizagem dos discentes surdos, uma sentida inquietude para as escolas que deveriam utilizá-los, mas não o utilizam.

Enfim, este trabalho analisou a promoção do ensino da matemática com intenção de que os estudantes surdos conseguissem participar de maneira efetiva das atividades acadêmicas desenvolvidas em sala de aula regular, por conta da adversidade da comunicação, fator factual ao aprendizado durante as aulas.

Diante do exposto, este trabalho tem intenção de suscitar reflexões acerca do encorajamento ao ensino da matemática para os estudantes surdos, através do emprego de novas tecnologias para o desenvolvimento de conteúdos matemáticos, a fim de alcançar as metas que considerem as particularidades dos discentes surdos.

Tendo em vista a importância do incentivo no ensino da matemática para o aluno surdo, recomenda-se investir cada vez mais na boa relação professor de matemáticaaluno surdo, para colaborar com a sinergia positiva da sala de aula e ampliar o uso pedagógico das novas ferramentas tecnológicas para o discente surdo.

\section{REFERENCIAS}

ALMEIDA, Educação de surdos: formação, estratégias e prática docente [online]. Editus. Ilhéus, BA: 2015, 197 p. ISBN 978-85-7455-445-7. Disponível em http://books.scielo.org/id/m6fcj. Acesso em 20/11/2019.

ANDERSEN, Roberto. Estudo sobre educação: inclusão responsável. Allprint editora. São Paulo: 2019.

ARAÚJO, George; SILVA, Tifany; PAULA JR, Eugenio. A motivação escolar de alunos préadolescentes. Vitrine de produção acadêmica produção de alunos do centro universitário Dom Bosco, v. 6, n. 1, 2019.

BALESTRI, Rodrigo. Matemática: interação e tecnologia, volume 2. Leya. São Paulo: 2016.

BERGUE, Sandro Castro. Gestão de pessoas: liderança e competências para o setor público. ENAP. Brasília:2019. 
BRASIL, Rede de saberes mais educação : pressupostos para projetos pedagógicos de educação integral : caderno para professores e diretores de escolas. - 1. ed. Brasília : Ministério da Educação, 2009.

CHAVANTE, Eduardo, Quadrante Matemática / Eduardo Chavante, Diego Prestes - 1 ed. - São Paulo: Edições SM. 2016 - Coleção Quadrante Matemática

COSTA, Jeane Rodrigues Resende et al. Relação professor-aluno e o desempenho escolar dos estudantes. 2018.

DANTE, Luiz Roberto. Matemática: contexto e aplicações/ Ensino Médio. 3.ed. Ática. São Paulo: 2017.

DIAZ, F., et al., orgs. Educação inclusiva, deficiência e contexto social: questões contemporâneas [online]. Salvador: EDUFBA, 2009. 354 p. ISBN: 978-85-2320651-2.Disponível em http://books.scielo.org/. Acesso em 14/10/2019.

GAMA, Sonia Menezes da. Educação e tecnologia como a tecnologia pode ajudar nas series iniciais. 2018.

GESSER, Audrei. Interpretar ensinando e ensinar interpretando: posições assumidas no ato interpretativo em contexto de inclusão para surdos. Cadernos de Tradução, v. 35, n. 2, p. 534-556, 2015.

GONÇALVES, Ângelo Manuel Marques. Cooperação, responsabilidade e autonomia na Educação em Ciências: um estudo com alunos do 10ㅇano de escolaridade. 2018. Tese de Doutorado.

LARRÍN, V.; HERNÁNDEZ, F. O desafio do trabalho multidisciplinar na construção de significados compartilhados. Pátio, Porto Alegre, Ano 7, n.26, mai/jul. 2003.

MENDES, Eniceia Gonçalves; ALMEIDA, Maria Amélia; TOYODA, Cristina Yoshie. Inclusão escolar pela via da colaboração entre educação especial e educação regular. Educar em Revista, p. 80-93, 2011.

MENEZES, Marcus Bessa; DOS SANTOS, Wuallisson Firmino. As Modificações do Saber Efetivamente Ensinado em uma Sala de Aula Inclusiva para Alunos Surdos: o caso do conjunto dos números naturais. Perspectivas da Educação Matemática, v. 11, n. 27, 2019.

NOZI, Gislaine Semcovici; VITALIANO, Celia Regina. Saberes conceituais necessários aos professores para a educação inclusiva. Revista Cocar, v. 11, n. 22, p. 394-412, 2018.

OTAVIANO, Alessandra Barbosa Nunes; ALENCAR, Eunice Maria Lima Soriano de; FUKUDA, Cláudia Cristina. Estímulo à criatividade por professores de Matemática e motivação do aluno. Psicologia Escolar e Educacional, v. 16, n. 1, p. 61-69, 2012. 
PEREIRA, Ana Carolina Costa; Cedro, Wellington Lima (orgs). Educação matemática: diferentes contextos, diferentes abordagens. EdUECE. Fortaleza: 2015.

POSAMENTIER, Alfred S.; KRULIK, Stephen. A arte de motivar os estudantes do ensino médio para a matemática. AMGH Editora, 2014.

SAMPIERI, R. H.; COLLADO, C. F.; LUCIO, M. P. B. Metodologia de pesquisa. 5 ed. Penso, Porto Alegre: 2013.

SANTOS, Gabriela; CASTELLANOS, Samuel Luís. Educação inclusiva e a pratica docente: desafios e avanços com crianças surdas. Litteraonline, v. 9, n. Esp., 2018.

SILVA, José Samuel Ferreira da (2017) O processo de ensino de matemática para alunos surdos: uma investigação com professores de escolas públicas do município de Sertânia $\quad-\quad$ PE, disponível em http://dspace.bc.uepb.edu.br/jspui/handle/123456789/15976

SOUZA, Joamir Roberto de, Novo Olhar Matemática. 2 ed. FTD. São Paulo. 2013.

RIBAS, Marcia Cristina; MARTINS, Marcio André. Contribuições da Modelagem Matemática como método de ensino para alunos surdos. Revista de Educação Matemática, v. 15, n. 20, p. 432-444, 2018. 


\title{
CAPÍTULO XXX
}

\section{USO DE RECURSOS DIDÁTICOS ALTERNATIVOS PARA O ENSINO DE ASTRONOMIA}

\author{
Jefferson Rodrigo Bezerra ${ }^{1}$ \\ Natália de Oliveira Melo ${ }^{2}$
}

${ }^{1}$ Graduando do curso de Física. Universidade Federal de Pernambuco - UFPE
${ }^{2}$ Professora orientadora. Graduada em Pedagogia - UFPE. Mestra em Direitos Humanos - PPGDH-UFPB. Especialista
em Educação em Direitos Humanos, Diversidade e Questões Étnico-Sociais ou Raciais - UCAM

\section{RESUMO}

Sabendo que a aprendizagem é um objetivo a ser alcançado no processo de ensino, uma mediação docente que ocorra de forma eficaz é fundamental para que efetive essa construção do conhecimento da forma mais eficaz possível. Para isso, o professor como mediador deve buscar outras formas de prática pedagógica que facilite esse aprendizado. Assim, a presente pesquisa teve como objetivo discutir como o uso dos recursos didáticos alternativos influenciam no desenvolvimento da aprendizagem em astronomia, driblando dessa forma, a escassez de conteúdos que os livros didáticos apresentam, aliado com a falta de formação nessa área por parte dos docentes. Para execução do proposto, efetuou-se uma pesquisa qualitativa na modalidade de entrevista, com três professores do ensino fundamental de escolas distintas em Caruaru e Bezerros, ambas cidades de Pernambuco. A entrevista que serviu como coleta de dados, se deu por um questionário estruturado para levantamento das dificuldades, vantagens, observações e resultados no uso dos recursos didáticos alternativos no ensino de astronomia. Ao fim, constatou-se que há uma grande deficiência para o ensino de astronomia, na utilização apenas dos livros e estrutura escolar, e que o uso de tais métodos de ensino cooperou para uma melhora substancial nas aulas e no processo ensino-aprendizagem.

Palavras-chave: Recursos didáticos. Astronomia. Ensino.

\section{INTRODUÇÃO}

A astronomia faz parte da ciência que inspirou a toda sociedade, na busca de conhecer e entender tudo a nossa volta. Mesmo sendo algo que está em constante ascensão, nos materiais didáticos comumentemente usados para o ensinoaprendizagem nas escolas, a astronomia tem um conteúdo abordado de forma superficial e abstrato que, aliado a uma falta de formação docente na área, compromete a eficácia do ensino. 
"O livro didático constitui um elo importante na corrente do discurso da competência: é o lugar do saber definido, pronto, acabado, correto e, dessa forma, fonte única de referência e contrapartida dos erros das experiências de vida." (VESENTINI, p.166, apud OLIVEIRA, p.1). Essa colocação dispõe o livro didático como centro principal de conteúdo, completo e acabado, fechando para possiblidades de discussões e problematizações, no qual oferece assim, uma necessidade maior para a utilização de recursos de ensino extras, que complementem as aulas e tragam diálogos não promovidos pelos livros.

Pesquisadores na área do ensino de ciências como Nardi, Bastos, Diniz e Caldeira (2009, apud TRIVELATO, 2013, p. 8) alvitra-nos sobre a necessidade de usarmos alternativas derivadas para o ensino e a aprendizagem. A utilização de recursos didáticos alternativos a métodos habituais abre um leque de possibilidades em debates, discussões e problematização de situações, e assim como nos afirma Camargo (2007, apud RIBAS et al., 2013, p 4),

Apesar de astronomia ser um assunto bastante difundido em filmes, desenhos e até noticiários mundiais, é bastante escasso em sala de aula seu debate. Tal escassez deve-se principalmente a alguns fatores, como a má formação inicial dos docentes, a pouca ou quase nenhuma formação continuada, escassez de material didático de qualidade e livros didáticos que apresentam erros conceituais (LANGHI, 2009, apud DAMASCENO, 2016, p. 25).

Partindo dessa lógica, a utilização de tais métodos alternativos vem como agente facilitador na construção do conhecimento, auxiliando o docente em sua atividade escolar. Modelos alternativos de ensino são capazes de envolver os estudantes em investigações científicas, fortalecer as capacidades de resolver problemas, despertar e manter o interesse do aluno.

O objetivo geral desse artigo é compreender como o uso de recursos alternativos de ensino auxiliam no desenvolvimento da aprendizagem em astronomia, com objetivos específicos: apontar a necessidade de usar recursos didáticos alternativos, e discutir seus impactos na construção do conhecimento. 


\section{METODOLOGIA}

Como procedimentos metodológicos para realização dessa pesquisa, foi realizado primeiramente um estudo bibliográfico, no intuito de buscar entender a problematização e realidade do ensino de astronomia nas escolas. O estudo bibliográfico, assim como afirma LIMA e MIOTO (2007) sempre é realizada para fundamentar teoricamente o objeto de estudo, contribuindo com elementos que subsidiam a análise futura dos dados obtidos.

Por se tratar de um assunto abrangente, é necessária uma base epistemológica para criar assim uma ponte entre a teoria e a prática observada. ALVES e SILVA (1992) nos alerta sobre a necessidade de obter contato com a realidade pesquisada, associado aos pressupostos teóricos que sustentam seu projeto. Nos diz ainda LIMA e MIOTO (2007, p.42) que o levantamento bibliográfico "contribui tanto para a melhor definição do objeto de estudo - uma vez que as informações são obtidas provisoriamente, permitindo voltar ao material para se obter informações adicionais".

Por se querer observar resultados e pontos de vistas pontuais e práticos, realizou-se assim uma pesquisa exploratória, com a coleta e análise dos dados realizada de forma qualitativa, esta que segundo ALVES e SILVA (1992, p. 1) se caracteriza por ser um "processo indutivo e que tem como foco a fidelidade ao universo de vida cotidiano dos sujeitos, para assim analisar de forma detalhada os pontos de vistas dos entrevistados."

Tais coletas de informações se deram em forma de entrevista contendo cinco perguntas, e aplicada a três professores do ensino fundamental e médio, averiguando como na prática acontece a construção do conhecimento utilizando os meios didáticos alternativos de ensino, como modelos de baixo custo construídos de forma artesanal, utilização de laboratórios, observações do céu em telescópios...Trazendo dessa forma, uma ponte entre os resultados observados na prática, e toda teoria já pesquisada.

Para a escolha dos entrevistados, fora considerado docentes que atuassem no ensino fundamental II e médio nas áreas de Física ou Ciências, e que já utilizaram os recursos didáticos alternativos em suas aulas, $\mathrm{O}$ professor enumerado no presente artigo como Professor 1 é docente na Escola Reunidas Casa do Trabalhador, localizado em Caruaru-PE, onde ensinou astronomia no 9 ano; o Professor 2 exerce sua atividade 
no EREM, em Bezerros/PE, em turmas do segundo e terceiro ano do ensino médio; e por fim, o Professor 3 lecionava até o ano de 2019 na Escola Municipal Professor José Laurentino Santos, também em Caruaru/PE, em turmas do sexto e sétimo ano do ensino fundamental.

\section{RESULTADOS E DISCUSSÃO}

Nesse tópico abordaremos sobre a discussão que objetivou essa pesquisa, e seus respectivos resultados obtidos. Discorreremos ainda sobre o papel do livro didático, e como o uso dos recursos didáticos alternativos de ensino auxiliam o processo de ensinoaprendizagem e contribuem para uma construção eficaz do conhecimento. Também discutiremos as entrevistas realizadas com os três docentes, discutindo suas respostas e confrontando com a base teórica utilizando os autores citados.

\subsection{A astronomia: interdisciplinaridade e o papel do educador}

A astronomia engloba conteúdos como Sistema solar, fases da lua, marés, estrelas, eclipses... assuntos esses que, segundo Pinto, Silva e Silva (2008) são responsáveis pelos estudos mais básicos de geografia e ciências na escola. Sua metodologia precisa ser observada, para que seja atingida um nível satisfatório de aprendizado, desconstruindo a concepção fantasiosa do aluno ou incrementando-a, dependendo da base de conhecimento que ele possui.

Um indivíduo no decorrer de sua vida, enriquece-se de conhecimentos empíricos adquiridos com as experiências e observações. Segundo Langhi e Nardi (2005, p 4), "concepção alternativa faz referência a uma ideia sobre determinado fenômeno natural previamente concebida por alunos e/ou professores e que é posteriormente trazida para a sala de aula". Tais concepções citadas pelos autores estão presentes na astronomia, pois os alunos trazem consigo conhecimentos adquiridos pela vivência e pelo senso comum, muitas vezes míticos ou incompletos.

Os professores como educadores, que teriam o papel de desmitificar tais pensamentos na aula de astronomia não as fazem, trazendo assim um conceito errôneo e desacertado, que segundo Pinto, Silva e Silva $(2008$, p. 3) ocorre por "má formação profissional, ou por conta de uma falta de interesse e preparo para essas aulas". 
3.2. Livros didáticos: erros conceituais, concepções alternativas e a utilização de métodos de

\section{ensino alternativos}

Como nos diz Oliveira (2014, p. 6), "o livro didático vem se apresentar como um auxílio do ensino-aprendizagem para professor e aluno, cabendo ao docente a responsabilidade de apresentá-lo como fonte de pesquisa, descoberta, e vínculo com a vida social do aluno". Porém o professor não pode ter esse instrumento didático como única fonte de conteúdo, pois assim como nos diz Oliveira (2014), dessa forma o livro torna-se única fonte de saber, sem que o mesmo esteja aberto ao diálogo e debates relacionados às problemáticas apresentadas por ele.

Os livros não são detentores do saber completo e acabado e, como consequência não se é aconselhável tê-lo como única fonte de conteúdo. Amaral e Oliveira (2008) nos alertam quando dizem que neles, existem informações imprecisas e/ou desatualizadas, além de inadequações de caráter conceitual e pedagógico, que podem prejudicar o processo de ensino-aprendizagem.

Os erros conceituais contidos em livros didáticos contribuem para uma visão distorcida do assunto em si, dando espaço para uma visão incompleta e/ou errada do conteúdo, o que segundo Pinto, Silva e Silva (2008) dá brechas para a moldura de ideias claudicantes por parte destes alunos ou do professor.

Dessa forma, Oliveira (2014) sugere o uso de outros recursos didáticos para facilitar a aprendizagem dos alunos, como também, novas metodologias de uso dos livros didáticos. A utilização de recursos didáticos alternativos a métodos habituais abre um leque de possibilidades em debates, discussões e problematização de situações, ou seja:

[...]são interessantes e desafiadoras para o aluno e suficiente para suprir as necessidades básicas na formação de jovens, permitindo relacionar os fatos às soluções de problemas, dando-lhes oportunidades de identificar questões para investigação, elaborarem hipóteses e planejar experimentos testando-as, organizando-as e interpretando dados e, a partir deles, fazer generalizações e inferências (SANTOLIN e BRANDENBURG, 2013, p. 11).

Partindo dessa abordagem, e após realizada as entrevistas com os três professores, é visto que todos têm visão, opiniões e resultados similares quando a tudo 
que relaciona o uso dos métodos alternativos de ensino. As questões utilizadas para as entrevistas estão contidas no Apêndice 1.

No primeiro questionamento sobre a suficiência dos livros didáticos, o Professor 3 (2020) respondeu: "Não, porque a maioria dos livros de ciências tem assuntos bem sintetizados no que se refere aos assuntos que abordam a astronomia". Por ter conteúdos diluídos e básicos em outras matérias como Geografia e Ciências, como nos afirma Pinto, Silva e Silva (2008), os livros não tratam tais assuntos com a completude e complexidade que estes são. Assim, para uma complementação eficaz dos livros, Oliveira (2014, p. 4) sugere que "os professores os utilizem como um apoio e não como um guia de suas práticas didático-pedagógicas". O professor 1 (2020) afirma que "o assunto é muito superficial". De fato, os livros têm em si um conhecimento raso e pronto, que não permite a abertura de discussões aprofundadas e observações reais sobre os fenômenos astronômicos.

Na segunda indagação, o Professor 1 (2020) responde que utilizou: "em algumas aulas o planetário, porque ficou melhor de explicar como funciona o movimento de rotação e translação da terra, como funcionava também a questão dos outros planetas, a posição que os outros planetas se encontram, fases da lua", é interessante perceber que um objeto, utilizado e produzido até de baixo custo, pode ser usado para diversas aulas, e ser aplicadas em vários conceitos que são interligados. o Professor 2 (2020) diz: “Optei por levar cartazes, com as fotos dos planetas, das estrelas, porque no livro não abrange muito essa parte, e fazer maquetes em relação aos planetas, em fazer as estrelas, montar o sistema solar numa maquete", afirmando ainda que "quando o aluno está mexendo, botando as mãos, colocando aquilo em prática, é mais fácil dele entender, vai criar mais interesse, vai ficar mais atento e mais interessado na aula.". o uso dos recursos didáticos alternativos é interessante pois traz consigo um leque de possibilidades, como softwares de computador, recursos audiovisual, maquetes e objetos construídos com materiais de baixo custo. Materiais estes que podem ser reaproveitados em outras aulas e oferecem um melhor aprendizado, e assim como afirma Andrade (2003, p. 58, apud MERCADO, 2016, p.4), a apropriação das tecnologias na educação possibilita o acesso "mais rápido e atualizado das informações".

Quando questionados sobre como observaram a aprendizagem na terceira indagação da entrevista, o Professor 2 (2020) informa que: "foi bem melhor, [...] eles se 
interessam mais pela coisa quando você traz coisas diferentes.". De fato, ao levar os recursos alternativos, os alunos apresentam uma atenção movida pela curiosidade de ver como funciona os objetos astronômicos e celestiais e, como alega Arcanjo et al. (2009), criam possibilidades para o professor, evitando que o cotidiano escolar não seja engolido pela mesmice do dia-a-dia. O Professor 3 (2020) informa que:

A partir do momento que eles ficaram instigados a buscar, ficaram instigados em pesquisar, a entender aquilo, para eles poderem levar pra sala de aula, pra mostrar aos amiguinhos deles, como aquilo ali funcionava, como aqueles fenômenos aconteciam, eu acredito que a evolução foi positiva, pelo fato deles terem consciência daquilo que eles estavam vendo. [...] por exemplo, se eu pedisse pra eles pesquisarem alguma coisa relacionado as fases da lua, eles voltavam com outros questionamentos, então isso significa que só aquilo que eu pedia não era suficiente pra eles descobrirem, eles precisaram descobrir outros temas relacionados a astronomia.

O professor mediador do uso de tais métodos deve observar e orientar o debate na sala, pois assim como ressalta Krasilchik (2004, apud Marasini, 2010), os recursos didáticos alternativos possuem o grande potencial para gerar um ponto de partida de uma discussão, construindo uma base e estabelecendo novos conceitos e facilitando seu conhecimento.

$\mathrm{Na}$ pergunta 4, foi observado dificuldades diversas em cada professor para aplicar os modelos alternativos que utilizaram. O professor 1 (2020) disse que sua maior dificuldade para aplicar os recursos foi de " não ter formação nessa área, os livros também não vem preparando bem o professor para esse tipo de aula", trazendo assim a ideia de que o professor deve buscar ideias e formação em outros meios, nessa questão a internet se torna a fonte mais acessível de novas ideias e capacitações. A internet permite assim, novas perspectivas no processo ensino-aprendizagem (Jonassen,1993; Cardosos, 1997; apud MERCADO, 1999). O Professor 2 (2020) diz que:

Geralmente as principais dificuldades é em relação ao incentivo que a escola não dá, e as vezes como você tem que seguir um cronograma fica difícil. Em relação ao governo ele não dá um lugar planejado para você fazer esse tipo de coisa, não tem um espaço adequado, não tem as coisas adequadas, tem que levar de casa, pedir para os alunos levarem.

As escolas públicas muitas vezes não têm, ou burocratiza o acesso a infraestrutura dela, seja laboratórios ou equipamentos que podem ser usados para o 
ensino. Kimura (2008, apud Monteiro e Silva, 2015) afirma que a existência e o acesso a infraestrutura escolar são considerados pelos próprios professores das escolas como um aspecto dotado de importância fundamental para o desenvolvimento de seu trabalho, assim como afirmou os entrevistados, essa ausência de recursos patrimoniais na unidade educacional faz com que, o professor na intenção de melhorar sua metodologia de ensino, recorra a utilização de materiais que podem ser de baixo custo, porém que não diminui sua qualidade e aplicabilidade.

Respondendo à questão cinco, sobre o nível de compreensão dos alunos, todos os três professores afirmaram que o desempenho de aprendizagem foi sim satisfatório, onde o Professor 2 (2020) diz que: "eles ficam mais interessados, mais empolgados, querem saber como faz, e como não faz". Astronomia pode ser um assunto que aguça o interesse e a curiosidade dos alunos e atesta-nos Moraes, Schwingel e Júnior (2016) que a utilização de recursos didáticos, alternativos nas aulas são meios que estimulam o aluno a se interessar pela disciplina. A partir disso podemos perceber que existem diversos meios que podem ser usados como recursos didáticos, como exposições, modelos construídos de baixo custo, jogos lúdicos... todos que possam ser usados no intuito de gerar uma discussão didática, tendo o professor como mediador de tal discussão e orientador. Entretanto, como comenta Santomé (1998, apud Marasini, 2010):

Embora a maioria das legislações sobre educação ressaltem há anos a necessidade de um ensino mais ativo, as vantagens do trabalho em grupo e cooperativo, a utilidade e função de uma maior variedade de recursos didáticos, a avaliação contínua, etc., o modelo de escola tradicional de caráter dogmático ainda não foi desterrado. Sem dúvida este modelo de escolarização encontra no livrotexto um dos seus mais firmes aliados. Daí a urgência de novos recursos didáticos que sirvam de apoio às estratégias e, em geral, a vida nas salas de aula e instituições escolares. (p. 10).

Diante disso, é sabido que a utilização consciente dos meios alternativos de ensino auxiliam de fato ao aprendizado do aluno, mas não tirando o papel do professor mediador em dominar o assunto, assim como diz Langhi e Nardi (2005) em relação aos conteúdos apresentados, no qual é necessário conhecer bem esses conteúdos e ser trabalhados adequadamente, o que pode ser conseguido por uma transposição didática e metodologias de ensino apropriadas para cada realidade. 


\section{CONSIDERAÇÕES FINAIS}

Ao término da pesquisa, constatou-se que há uma grande deficiência na formação dos professores para ensinar astronomia, na estrutura da escola, que não oferece em sua maioria, uma estrutura e/ou materiais que auxiliem o ensino, e na superficialidade com que os livros tratam o conteúdo em si. Por outro lado, verificou-se também a importância dos usos de métodos alternativos que mostraram serem proveitosos para ensinar astronomia em salas de aula, deixando todo o conteúdo menos imaginativo e mais realista de como realmente é. Importante observar que o uso de métodos didáticos extras não significa que deve-se ignorar por completo o livro, utilizando-o como um apoio que necessita de complemento. A eficácia mostrou-se acontecer em pontos gerais observados nas respostas dos entrevistados, tais como:

- Os alunos demonstraram interesse no conteúdo, deixando-os mais participativos nas aulas, trazendo questionamentos que se tornavam mais aprofundados;

- As aulas passaram a ter um entrosamento maior entre alunos e docentes;

- O aprendizado na maioria dos casos teve um grau de aproveitamento satisfatório para os três professores.

O uso dos recursos didáticos não deve ser unicamente usado, e nem elaborados com a intenção de construir uma aula divertida e diversificada, mas planejada primeiramente com o propósito de facilitar o processo de ensino-aprendizagem, aumentando assim o nível de conhecimento adquirido dentre os alunos.

\section{AGRADECIMENTOS}

Agradeço de forma especial a Natália de Oliveira Melo, que apoiou e me acompanhou por toda escrita do artigo, sempre auxiliando e disponível com paciência e todo cuidado. Também agradeço a Thaize de Lima por ter dado um suporte imensurável. E por último, mas não menos importante, agradeço aos professores entrevistados que, com disponibilidade e entendimento, ajudaram a construir esse artigo com suas ideias e experiências. 


\section{REFERÊNCIAS}

LAHERA, J.; FORTALEZA, A. Ciências Físicas nos ensinos fundamental e médio: modelos e exemplos. Porto Alegre: Artmed, 2006

TRIVELATO, S. F.; FERREIRA SILVA, R. L. Ensino de ciências: coleção ideias em ação. São Paulo: Cengage Learning, 2013.

DAMASCENO, Julio Cesar Gonçalves. 0 ensino de astronomia como facilitador nos processos de ensino e aprendizagem. 2016. 129 p. FURG, Rio Grande, 2016

OLIVEIRA, J. P. T.; A eficiência e/ou ineficiência do livro didático no processo de ensinoaprendizagem. 2014

RIBAS, Cláudio Pereira et al. Materiais alternativos para alunos cegos no ensino de Ciências. Anais do VI Encontro Regional Sul de Ensino de Biologia. Universidade Regional Integrada do Alto Uruguai e das Missões. Rio Grande do Sul, 2013.

LANGHI, Rodolfo; NARDI, Roberto. Dificuldades de professores dos anos iniciais do ensino fundamental em relação ao ensino da Astronomia. Revista LatinoAmericana de Educação em Astronomia, n. 2, p. 75-91, 2005.

MERCADO, Luis Paulo Leopoldo. Formação continuada de professores e novas tecnologias. Ufal, 1999.

LIMA, Telma Cristiane Sasso de; MIOTO, Regina Célia Tamaso. Procedimentos metodológicos na construção do conhecimento científico: a pesquisa bibliográfica. Revista Katálysis, v. 10, n. SPE, p. 37-45, 2007.

ALVES, Zélia Mana Mendes Biasoli; SILVA, Maria Helena GF. Análise qualitativa de dados de entrevista: uma proposta. Paidéia (Ribeirão Preto), n. 2, p. 61-69, 1992.

AMARAL, Patrícia; DE OLIVEIRA, Carlos Eduardo Quintanilha Vaz. Astronomia nos livros didáticos de ciências: uma análise do PNLD 2008. Revista Latino-Americana de Educação em Astronomia, n. 12, p. 31-55, 2011.

ARCANJO, Jacineide Gabriel et al. Recursos didáticos e o processo de ensino aprendizagem. SEMANA NACIONAL DE CIÊNCIAS E TECNOLOGIA, v. 6, 2009.

BELTRAME, Mauria Bontorin; MOURA, Graziella Ribeiro Soares. Edificações escolares: infra-estrutura necessária ao processo de ensino e aprendizagem escolar. Travessias, v. 3, n. 2, 2009.

DE SOUSA MONTEIRO, Jéssica; DA SILVA, Diego Pereira. A influência da estrutura escolar no processo de ensino-aprendizagem: uma análise baseada nas experiências do estágio supervisionado em Geografia. Geografia Ensino \& Pesquisa, v. 19, n. 3, p. 19-28, 2015. 
MORAES, Gleidially Nayara Bezerra; SCHWINGEL, Paulo Adriano; JÚNIOR, Edivaldo Xavier Silva. Uso de roteiros didáticos e modelos anatômicos, alternativos, no ensino-aprendizagem nas aulas práticas de anatomia humana. Revista IberoAmericana de estudos em educação, v. 11, n. 1, p. 223-230, 2016.

MARASINI, Alessandra Brochier. A utilização de recursos didático-pedagógicos no ensino de biologia. 2010.

PINTO, Cíntia Maria da Silva Ferreira; DA SILVA, João Paulo Gomes. Dificuldades no ensino de astronomia em sala de aula: um relato de caso. Revista Vivências, $3^{a}$ a ed., p. 65-75, 2018.

\section{APÊNDICE 1}

\section{Questionário}

1. Você acha que os livros didáticos são suficientes para ensinar astronomia?

2. Quais métodos alternativos você já utilizou em suas aulas, e por que optou por eles em algum momento?

3. Como você observou a evolução da aprendizagem dos alunos? O que the chamou atenção em comparação a uma aula tradicional?

4. Quais dificuldades encontrou em planejar, produzir e ministrar tais formas de ensino?

5. Na sua concepção geral, o nível de compreensão dos alunos foi satisfatório? 


\title{
CAPÍTULO XXXI
}

\section{ESTÁGIO DOCENTE EM HISTÓRIA: RELATO DE EXPERIÊNCIA NO ENSINO MÉDIO E CONSIDERAÇÕES SOBRE SUAS NOVAS DEMANDAS}

\author{
Roberto Ramon Queiroz de Assis ${ }^{1}$
}

\begin{abstract}
${ }^{1}$ Atualmente é graduando em licenciatura plena em História na Universidade Federal de Campina Grande no Centro Formador de Professores (UFCG-CFP). Foi bolsista do Conselho Nacional de Desenvolvimento Científico e Tecnológico CNPq-Brasil nos anos de (2014 a 2015 e 2016 a 2017).
\end{abstract}

\section{RESUMO}

O presente artigo busca fazer uma reflexão das novas demandas do ensino médio tecendo reflexões sobre a ótica neoliberalista que está, cada vez mais, sendo inserida no campo educacional. As discussões aqui apresentadas foram feitas a partir da observação direta, do espaço escolar e salada de aula, durante a realização de estagio supervisionado do curso de licenciatura em história no ensino médio em uma escola do alto sertão paraibano. Utilizou-se de uma bibliografia básica que verse sobre a escola pública brasileira: (LOMBARDI; SAVIANI; NASCIMENTO, 2005); educação e capitalismo: (Mészáros, 2005) e sobre aulas de história: (ROCHA, 2015).

Palavras-chave: Estágio docente; Ensino médio; Novas demandas.

\section{INTRODUÇÃO}

\subsection{Pensando no futuro: a educação para a vida ou para 0 capital?}

Inicio o relatório de estágio observacional trazendo uma crítica e reflexão ao futuro da educação básica no Brasil. Onde o ensino, cada vez mais, está sendo inserido em uma perspectiva neoliberal e a todo o momento ameaçado de tornar-se um mecanismo de formação de um contingente de mão de obra para atender "caprichos" do mercado de trabalho, desse modo à escola apresenta-se como um meio que pode sustentar um projeto de estado desenvolvido, que compreende a formação escolar com o fim da empregabilidade e inserção no mercado de trabalho.

A escola contemporânea apresenta esta dualidade que nos faz indagar: é uma formação para a vida ou uma formação para o capital? Responder essa questão muitas vezes é complexo por não poder desassociar esses dois pontos, pois são elementos que se complementam no processo de escolarização de qualquer indivíduo. Basta nos 
questionarmos sobre o que nos traz a sala de aula, várias respostas podem surgir, porém elas irão seguir dois eixos, um mais particular (desejo egoísta) ligado a sua formação pessoal enquanto indivíduo singular que faz escolhas a partir do que o atrai; a outra resposta pode seguir uma linha mais ampla, que seria uma formação mais voltada para seu espaço e atuação profissional, ou seja, corresponde a sua inserção no sistema capitalista .

Isso também não significa dizer que necessariamente essas duas linhas devem ser seguidas pelo mesmo eixo, porém por mais que eu opte por outra formação para minha atuação no capital eu não deixo de aprender e me formar enquanto sujeito. Não se estuda apenas para aprender, mais também para usar o seu conhecimento em um determinado espaço que você almeja ocupar no futuro.

A escola ela assume um caráter de intervencionismo social, que muitas vezes responde as necessidades de uma ideologia dominante. Os países que possuem instituições políticas e econômicas inclusivas como os Estados Unidos e Coreia do Sul, que se caracterizar por ter força na propriedade privada e por proporcionam uma maior inserção e participação coletiva em atividades econômicas, que por consequência dependem do uso de tecnologias, e são mais abertos à participação de uma parcela da sociedade no mundo capitalista buscando fazer o melhor dos seus talentos, e para esse dinamismo funcionar dependem diretamente das instituições que preparem esse indivíduos para atuarem nesses espaços, ou seja, a escola. (ACEMOGLU; ROBINSON, 2012, p. 58).

O Autor ainda acrescenta que essa sociedade dinâmica e desenvolvida, depende muito de tecnologias e, para elas funcionarem requer uma mão de obra qualificada, pois o desenvolvimento social está diretamente relacionado à educação como ele acrescenta dizendo que "Nem toda a tecnologia do mundo seria de grande utilidade sem profissionais que soubessem como operá-la" (ACEMOGLU; ROBINSON, 2012, p. 61).

Contudo, as habilidades e competências implicam mais que a mera capacidade de fazer funcionar equipamentos; são a educação e as competências da força do trabalho que geram o conhecimento científico sobre o qual se ergue a nossa progresso e que permite adaptações e a adoção dessas tecnologias nas mais diversas linhas de negócios (ACEMOGLU; ROBINSON, 2012, p.61). 
Nesses aspectos notamos que tecnologia, competências e as habilidades como meio para o desenvolvimento social possui uma estreita relação com a educação, pois as competências necessárias para atuar nesse mercado serão adquiridas, de início, nas escolas, por serem essas instituições que trazem em suas características os elementos de intervir na realidade social e inseri o individuo dentro dela, que em muitos países essa sociedade corresponde ao capitalismo onde as demandas de mercado estão exigindo cada vez mais da população uma formação mais específica voltada para atuar em seus seguimentos.

A problemática da educação neoliberal que atende a uma ótica capitalista recai quando, alguns dos dois elementos citados anteriormente (formação para a vida e para o capital) querem se sobrepor. Essa é a ameaça que estamos tendo, uma formação egoísta, pensada para o mercado de trabalho é que ela e posta de modo que o corpo social que segue esta linha consegue o seu sucesso, esquece-se da coletividade.

Segundo Mészáros (2005, p. 48), devemos fazer o controle desses dois elementos, a nossa formação e sermos conscientes nesse processo pra discernir o que nos aprendemos para o nosso crescimento e em que medida ele esta posto para a perpetuação de uma ideologia dominante:

A aprendizagem é, verdadeiramente, a nossa própria vida. E como tanta coisa é decidida dessa forma, para o bem e para o mal, o êxito depende de se tornar consciente esse processo de aprendizagem, no sentido amplo e "paracelsiano" do termo de forma a maximizar o melhor e a minimizar o pior (MÉSZÁROS, 2015, p. 48).

A preocupação que recai sobre esse projeto de educação brasileira é: de que modo se dará a formação dos jovens para além do capitalismo? Tendo em vista que a formação crítica de uma parcela de jovens será prejudicada por um projeto de ensino que exclui ou reduz a ciências humanas do currículo escolar, onde a sua formação será prejudicada.

Para sairmos desse quadro, não basta apenas mudar o ensino, tem de mudar o sistema a qual a escola prepara os alunos, pois matem uma estreita relação e pensar essa mudança é um pouco utópica, até então segundo Mészáros (2005) uma reforma não é possível sem a alteração da outra.

Uma reformulação significativa da educação é inconcebível sem a correspondente transformação do quadro social no qual as práticas educacionais da sociedade devem cumprir as suas vitais e 
historicamente importantes funções de mudanças (MÉSZÁROS, 2005, p. 25).

Pois a escola sempre estará atendendo demandas de sua sociedade.

\section{ORGANIZAÇÃO DA EDUCAÇÃO BÁSICA NO BRASIL}

A atual organização da educação básica brasileira está dividida em três fases: A Educação infantil: que compreende desde a creche até a pré-escola atendendo crianças de 3 a 5 anos; O Ensino fundamental: de 6 a 14 anos dividido em Alfabetização: $1^{\circ}$ ao $3^{\circ}$ Ano, Anos iniciais: $1^{\circ}$ ao $5^{\circ}$ Ano e Anos finais: $6^{\circ}$ ao $9^{\circ}$ Ano; o Ensino médio: do $1^{\circ}$ ao $3^{\circ}$ Ano para jovens com idade entre 15 a 17 anos que conta com a modalidade da Educação de jovens e adultos(EJA) a partir dos 18 anos. O ciclo que correspondente ao ensino médio é a que está na mira das reformas do ensino.

Para a construção do presente relatório de estágio observacional buscou-se detalhar os aspectos que permeiam o espaço escolar e as relações bem como sociabilidades que os sujeitos mantêm dentre da escola e seus espaços como o processo de ensino aprendizagem e a relação professor aluno, bem como suas adequações para as novas demandas do ensino médio. Percebendo o estágio enquanto o momento que propicia a pesquisa, e observando que o ciclo final da educação básica, que atende uma parcela de jovens que se prepararam para uma vida profissional ou acadêmica no ensino superior, este relatório traz reflexões sobre as perspectivas para o futuro que esses alunos têm e de que modo sua formação no ensino médio os prepara para esses novos espaços.

\section{O ESPAÇO ESCOLAR E SUA ADAPTAÇÃO ÀS DEMANDAS DO ENSINO MÉDIO}

O espaço escolar é constituído por um conjunto de ambientes que estão articulados entre si e que se tornam lugares que comportam sociabilidades. É o lugar onde é praticada a burocracia de gerir a instituição e também espaço de aprendizagem é o local onde são perpassadas as relações sociais entre os sujeitos que atuam na instituição escolar que, em seu fazer, esta alicerçada por leis e normas que norteiam suas ações e funções que devem ser de caráter intervencionista da realidade social. 
Devemos entender o espaço escolar como um ambiente que está sofrendo constantes mudanças, e suas funções bem como as políticas educacionais, também mudam para tender necessidades da sociedade. Esse fluxo de mudanças é continuo e nos ajudam a (re) significar o espaço escolar passando a compreendê-lo como local de sociabilidades mais amplas que vai além da relação ensino-aprendizagem, mas perpassa também como um espaço de amparo e proteção as jovens e adultos que ela frequenta ${ }^{1}$.

E. E. E. F. M Bonifácio Saraiva de Moura (BSM) esta localizada na cidade de Monte Horebe Paraíba foi criada por meio do decreto n¹1.871 de 10 de Março de 1987. Desde então se caracteriza por ser uma instituição de ensino que oferta educação básica nas modalidades fundamental dois e médio, atendendo tanto a população urbana quanto rural, na cidade é a única escola que comporta o ensino médio atendendo todos os alunos egressos do ensino fundamental dois do município tem a capacidade atender mais de quatrocentos e cinquenta alunos (Projeto Político Pedagógico, 2018).

A escola está divida em oito salas de aulas, possui uma ampla estrutura com quadra poliesportiva e espaço de recreação. O espaço pedagógico além das salas de aulas, que também não deixam de ser um lugar onde ocorre aprendizagem, pode citar também, a biblioteca que apesar do espaço pequeno que impossibilitando realizar leituras no local, os professores utilizam como espaço onde os alunos podem encontrara leituras complementares aos assuntos vistos em sala, o incentivo a leitura na escola e permanente e reforçada por cada professor, sendo que a procura por parte dos alunos não existe, durante os meus dias de estágio pouco vi alunos se direcionar a biblioteca atrás de leituras, em relação à quantidade de alunos no laboratório de informática que é superior àqueles que frequentam a biblioteca.

O laboratório de informática que dispõe de 12 computadores, é o espaço mais procurado pelos alunos, podemos atribuir o desinteresse a biblioteca por parte alunos pelo fato de encontrem na sala de informática um ambiente interativo que produz respostas mais rápidas a suas demandas de pesquisa. O laboratório também dispõe de e um Datashow que é utilizado por todos os professores, sendo necessário, para fazer o

${ }^{1}$ Para uma maior reflexão acerca do espaço escolar e as constantes mudanças que estão ocorrendo na escola pública brasileira nos últimos séculos, ver o livro: LOMBARDI, José C.; SAVIANI, Dermeval; NASCIMENTO, Maria Isabel Moura. A escola pública no Brasil: história e historiografia. Autores Associados, 2005. 
uso, reservar com antecedência; que tanto pode ser utilizado em sala de aula ou então dentro do laboratório de informática.

A escola BSM é uma unidade articuladora do ProEMI (Programa Ensino Médio Inovador) dentro das ações busca desenvolver educação, bem como o alcance das metas do Plano Nacional de Educação (PNE), dentro dos objetivos do ProEMI destacase por

[...] apoiar e fortalecer o desenvolvimento de propostas curriculares inovadoras nas escolas de ensino médio, ampliando o tempo dos estudantes na escola e buscando garantir a formação integral com a inserção de atividades que tornem o currículo mais dinâmico, atendendo também as expectativas dos estudantes do Ensino Médio e às demandas da sociedade contemporânea (PROEMI,2019) ${ }^{1}$.

A participação neste programa, ao menos, implica dizer que a referida escola proporciona aos alunos, nela matriculada, uma experiência extracurricular que pode abordar temas e proporcionar momentos que no dia a dia escolar não seria contemplada.

A análise in locos da sala de aula, que esta inserida dentro do espaço contextualizado, foi observada que a turma do $8^{\circ}$ anos tarde é constituída por 32 alunos regularmente matriculados, com idade variada de 16 a 18 anos onde as aulas de história estão dispostas no cronograma dos escolares duas vezes por semana com duração de $45 \mathrm{~min}$. A professora que acompanha os alunos é formada em geografia, porém, atua na área de história no ensino médio.

Durante as observações realizadas, pouco se viu os alunos usarem dos espaços pedagógicos que a escola dispõe. As aulas tem um caráter tradicional com o uso do livro didático, quadro e pincel. A turma em si é muito numerosa e não dispõe de livro didático para todos os alunos. Os poucos que tem são compartilhados e fotografados para os alunos estudarem em casa. Essa minha primeira observação na escola revelou uma preocupação, o quanto está precário o ensino público ofertado para os jovens da cidade de Monte Horebe-Pb.

1 ProEMI - Ministério da Educação - Portal do MEC disponível em: http://portal.mec.gov.br/index.php?option=com_content\&view=article\&id=13439\&Ite mid $=10$. 
Essa realidade não é isolada no cenário nacional, onde este princípio de “igualdade" que é preconizada nas políticas educacionais por si só já expressa à desigualdade, quando na realidade deveríamos utilizar do conceito de equidade para que possa haver uma distribuição equânime da educação promovendo desse modo o acesso e permanência dos jovens na escola. Bem como oferta qualidade e condições para que possa haver um ato de ensinar que seja efetivo para os alunos. Porem pensar nestes aspectos estar mais próximo de um sonho do que realidade, como nos mostra Paiva (2005, p. 182) que nossa sociedade é marcada por grandes e profundas desigualdades, onde esta se tornando cada vez mais difícil assegurar tais diretos, como o acesso e qualidade do conhecimento a todos que o sistema educacional logra acesso.

Nota-se ainda que a escola Bonifácio ainda não aderiu ao programa escola cidadã integral que:

Trata-se de um novo modelo de escola pública implantado na Paraíba, com a proposta de organização e funcionamento em tempo único (integral). É uma política pública e está inserida no Plano Nacional de Educação (Meta 6: "Oferecer educação em tempo integral em, no mínimo, 50\% (cinquenta por cento) das escolas públicas, de forma a atender, pelo menos, $25 \%$ (vinte e cinco por cento) dos (as) alunos (as) da educação básica) e também no Plano Estadual de Educação. 0 programa tem como foco a formação dos jovens por meio de um desenho curricular diferenciado e com metodologias específicas, que apresentam aos estudantes do Ensino Médio possibilidades de se sentirem integrantes do seu projeto de vida (PROJETO ESCOLA CIDADÃ INTEGRAM GOVERNO DO ESTADO DA PARAÍBA) ${ }^{1}$.

A escola a qual o estagio foi realizado não é uma escola técnica e dentro do seu projeto político pedagógico não se observa aspectos que tragam aspectos de uma formação conservadora, na instituição são transparecidos os valores Freiriano de uma pedagogia critica.

\subsection{Protagonismo estudantil no espaço escolar}

Pensar o protagonismo estudantil perpassa por questões metodológicas e formação do professor. Que sai da sua postura, dono do conhecimento e torna-se mediador dos assuntos, e os alunos não mais bancários, tornam-se corresponsável do

1 Projeto Escola Cidadã Integral Técnica do Governo do Estado da Paraíba. Disponível em: http://paraiba.pb.gov.br/educacao/escolas-cidadas-integrais/o-que-e-a-escola-integral/ 
seu aprendizado. Aceitando a s competências individuais de cada sujeito como partida para discussão.

Para que esse processo ocorra é necessário o interesse do alunado e por parte do corpo de profissionais da escola, professores, coordenadores, gestor, merendeiras (o) e guarda escola. Para estes estarem dispostos e integrar os alunos dentro de suas atividades de planejamento e organização do espaço escolar. Tornado o aluno um sujeito ativo na tomada de decisões de questões que tocam os alunos.

A realidade da turma que pude acompanha durante todo o estágio docente, devido suas peculiaridades, não demonstrou interesse para as atividades que sejam voltadas ao protagonismo juvenil. Muitos não se relacionam ou mantém um contato efetivo com o espaço escolar e atividades de gestão e organização, em sua grande maioria estão nela para cumpri uma fase de sua vida que foi interrompida por algum motivo, a volta a escola é tida como uma fase que deve ser cumprida, não se preocupando com outras questão que sejam voltadas a sua atuação dentro das escola, o dia de trabalho, família, atividade domestica e crianças é a realidade cotidiana dos alunos do EJA.

$\mathrm{Na}$ escola observamos ações pontuais que são voltadas para o protagonismo estudantil, no conselho da escola existe membros do corpo estudantil que participam das reuniões e tomadas de decisão da escola, Ainda contam com o grêmio estudantil eventos onde os alunos se envolvem na organização da Semana Estudantil Esportiva de Arte e Cultura (SEEPAC).

\subsection{Aulas de História no Ensino Médio: práticas e expectativas}

Mais uma vez encontramos um dilema dentro da sala de aula: professor sem formação especifica na área ministrando disciplinas de outra área do conhecimento. No Terceiro ano do ensino médio me deparei com uma professora formada em geografia dando aulas de história. Por mais que seja disciplina da mesma área, ciências humanas, elas apenas se complementam e não significa dizer que um geógrafo, necessariamente, possa dominar um conhecimento histórico, ao menos que possua alguma formação que o possibilite estar na sala de aula ministrando tal disciplina.

Durante as observações a professora em questão não dominou nenhuma aula de forma didática é completa. Todos os conteúdos foram apresentados em sala de aula 
por meio de vídeos baixados do YouTube, logo após era aplicado questionários em sala. A professora estava com uma estagiaria em sala que se produzia a responder as atividades juntos com os alunos os explicando e auxiliando nas correções.

A aula ela deixa a desejar, sentimos um vazio na hora do ensino, esperasse a todo o momento o posicionamento da professora ele não existe. Um ensino tem que ser significativo para o aluno e para o professor explicar os conceitos chaves para os alunos apreender o conteúdo, a aula deve possuir uma mediação e aproximação dos assuntos a realidade do aluno, dessa forma eu vejo que o conteúdos tomam maior sentido e torna a vida escola mais prazerosa.

O que me preocupa é o distanciamento dos conteúdos para a fase que o aluno se entra, a professora estava debatendo Brasil colônia e processo de ocupação dos sertões pelo Rio São Francisco a criação de gado e a busca do ouro no estado de Minas Gerais. Enquanto no programa para o ensino meio em especial ao $3^{\circ}$ ano estão previstos temáticas para estudar conjuntura política, econômica e social do início do século XX até os dias atuais bem como o papel das ideologias e dos movimentos sociais que permitem entender as guerras mundiais e a Guerra Fria, a formação dos regimes nazifascistas, do populismo e das ditaduras militares na América Latina, a descolonização, a contestação cultural, a luta pelos direitos civis e os processos de redemocratização e, por fim, a globalização e as características do mundo atual

\section{RELAÇÃO PROFESSOR - ALUNO}

Um dos grandes desafios na docência, em tempos líquidos, onde tudo é digital, online é estabelecer um ensino que seja significativo para os sujeitos que dele participa. Ou seja, o professor e aluno, enquanto elementos que devem interagir de forma significativa no contexto educativo, pois são essas interações que promovem um ensino/aprendizagem bem sucedidas como nos mostra Vilella e Uchoa (2008) que:

Os processos de significação no contexto educativo enfocam as interações sociais na busca da compreensão de situações nas quais se desenvolve um processo ensino-aprendizagem bem sucedido, relacionando isto a processos de significação do conhecimento por parte do aluno, exige que sejam analisados os aspectos motivacionais que permitem perceber se o aluno está disposto a dar atenção e se empenhar nas atividades propostas pelo professor (VILELLA; UCHOA, 2008 p, 41). 
Esta afetividade, que é abordada pelos autores anteriormente citadas, refere-se ao conjunto de interações estabelecidas em sala no momento do ensino, ou seja, é a motivação do aluno em prestar atenção ao que o professor fala e ter foco no conteúdo bem como o professor chamar atenção do aluno para as explicações. Estas relações são consideradas afetivas, pois existe ou ao menos dede existir uma sintonia entre os sujeitos, aluno/professor, deve ocorre de forma efetiva, desse modo possibilitando uma aprendizagem que seja significativa para ambos e possibilitando a construção do conhecimento no aluno que se sente motivado a aprender.

Desse modo o dialogo entre os sujeitos em sala de aula, como parte das interações dentro da sala é um mecanismo essencial para o ensino, pois desse modo o professor pode saber como o conteúdo esta sendo processado pelos alunos; já uma aula sem dialogo não é possível ter esse feedback, portanto considero essas interações como essenciais.

A relação professor aluno dentro da educação de jovens e adultos e de extrema importância, pois é através dela que o aluno pode que ocorre o processo de aprendizagem. Que quando pensada dentro do contexto do EJA deve levar e consideração que uma grande parte dos alunos vem de uma rotina diária longa e cansativa e passaram por um longo período sem frequentar a escola e o professor dentro deste contexto deve utilizar de um método que faça os alunos sentirem-se motivados a permanecer nos estudos e frequentar a escola.

O professor é o mediador e incentivador de cada aluno, e o bom relacionamento, preocupação e carinho com os alunos ajudam no seu desenvolvimento intelectual, incentivando-os a continuar frequentando as aulas. Criatividade, solidariedade e confiança são essenciais na relação entre o professor e o aluno de EJA. A autoestima elevada influencia na capacidade de todos de aprender e ensinar.

\section{AVALIAÇÃO NO ENSINO DE HISTÓRIA}

A avaliação, dentre os métodos que são aplicados para conhecer o nível de conhecimento que o aluno adquiriu, deve ser de caráter contínuo e não restrito a momentos específicos do planejamento.

Na grande maioria dos casos de avaliação como nos aponta Rocha (2015), ao fazer uma reflexão sobre o processo avaliativo nos mostra que ele assume uma 
característica particular que é a de medir o conhecimento do aluno, sendo esperando que os alunos exteriorizem um conjunto de informações adquiridos ao longo das aulas "Nesse caso, se almeja na avaliação que os alunos sejam capazes de replicar o que thes foi transmitido, como conjunto de informações" (ROCHA, 2015 p. 90).

Porém a autora ao fazer estes apontamentos sobre a multiplicidade de objetivos que uma avaliação comporta, mostra que para alcançar todos os objetivos do processo avaliativo devemos adotar métodos diferenciados bem como a própria exposição do conteúdo também deve mudar:

Se desejarmos que o domínio de informações habilite os alunos a fazer sua crítica, já estaremos em um terreno cognitivo de maior complexidade, que exigirá, seja pela interação verbal ou qualquer outra, que os alunos exercitem sua capacidade analítica e de julgamento. Se almejarmos que os alunos, a partir do domínio do conteúdo factual, sejam implicados, recolham para si elementos identitários da narrativa apresentada, precisaremos propiciar atividades em aula em que eles exercitem tais ações de subjetivação do conhecimento, em sua objetividade. E esse conjunto de atividades deverá fazer parte do planejamento das aulas, que pode se organizar de diferentes formas, contemplando rotinas diárias, sequências didáticas e projetos (ROCHA, 2015 p. 90).

A partir dessas colocações compreendo que o método avaliativo deve variar conforme o objetivo pretendido. Aulas e objetivos diferentes exige também uma avaliação diferenciada.

Ainda como nos mostra Gatti (2003):

O exercício da docência com propósitos claros e consensuais alimenta um processo de avaliação mais consistente e mais integrado na direção de uma perspectiva formativa, voltada para o desenvolvimento dos alunos e não para cumprir uma formalidade burocrática - passa/não passa - ou mesmo para satisfazer o exercício de autoritarismos ou autoafirmações pessoais. Nesta perspectiva, a avaliação do aluno é continuada, variada, com instrumentos e elementos diversificados, criativos e utilizada no próprio processo de ensino, como parte deste, na direção de aprendizagens cognitivosociais valiosas para os participantes desse processo (GATTI, 2003 p. 111).

Desse posicionamento sobre a avaliação, podemos observamos que o processo avaliativo deve romper com os valores tradicionais que a avaliação carrega, um deles é 
o de medir conhecimento através de nota, a autora nos mostra que a avaliação deve estar comprometida com o desenvolvimento educacional do aluno e deve ser vista para além de um requisito burocrático.

As avaliações são continuas em forma de estudo dirigido aplicado através de vídeos. A professora me relata que avaliações marcadas não surtem efeitos positivos e muitos dos alunos não passam nas provas, por esse motivo ela opta por fazer provas continuas logo após as explicações. Esses momentos avaliativos são momentos burocráticos onde não estão preocupados com a aprendizagem e sim em apenas cumpri um requisito que é por nota no diário e fechar nas datas certas.

As avaliações são flexíveis, a professora opta pelo modelo de estudo dirigido, justifica sua escolha dizendo que em "avaliações tradicionais" os alunos não conseguem um bom desempenho. As atividades contínuas favorecem a aprovação dos alunos, relata a professora.

\section{CONSIDERAÇÕES FINAIS SOBRE O ESTÁGIO}

A experiência de estágio docente é importante na medida em que o aluno fica imerso no contexto de sua futura atuação. É no estágio onde entramos em contato com o nosso fazer profissional é neste momento que nos deparamos com os problemas e vantagens da área que pretende futuramente atuar. No nosso caso especifico, no campo da história é no estágio onde buscamos entender os espaços teorizados em sala de aula e vivenciamos na prática, desse modo podendo fazer o balanço entre teoria e pratica, percebendo os distanciamentos e proximidades que envolvem essas duas faces do ensino: a teoria e a pratica docente.

O estágio supervisionado revelasse como um importante instrumento de integração entre universidade, escola e comunidade, importante para o crescimento pessoal e profissional dos discentes estagiário (FILHO, 2010). O estágio supervisionado é ainda o momento em que as teorias aprendidas são aliadas à prática bem como o momento em que o futuro profissional experimenta e atua efetivamente em seu campo de formação.

O ensino de história especificamente no ensino médio apresentasse como uma possibilidade de propor a reflexão e compreensão dos movimentos socia is e políticos do final do século $X X$, pelos conteúdos preconizados úteis as reflexões sobre atual 
conjuntura em que vivemos de modo a situar os alunos no tempo e espaço e compreender a organização geopolítica e econômica do mundo hoje e como essas relações ditam modos de vida e de que modo essas relações interferem no nosso cotidiano.

Observamos desse modo que o ensino de História deve estar integrado com a realidade social em que o aluno mantem suas relações, propiciando uma integração com a sociedade possibilitando o crescimento e desenvolvimento do aluno. Desse modo observamos que a incorporação de novas linguagens e tecnologias no ensino da História, como análise de filmes e uso da informática, por exemplo, contribuem para a aproximação do aluno com as mudanças da sociedade, em relação à cultura, política e integração social (NEU, 2014).

\section{REFERÊNCIAS}

ACEMOGLU, Daron; ROBINSON, James. Por que as nações fracassam. Rio de Janeiro, 2012.

MÉZAROS, István. A educação para além do capital. Boitempo editorial, 2015.

LOMBARDI, José C.; SAVIANI, Dermeval; NASCIMENTO, Maria Isabel Moura. A escola pública no Brasil: história e historiografia. Autores Associados, 2005.

VILLELA ROSA TACCA, Maria Carmen; UCHOA DE ABREU BRANCO, Ângela Maria Cristina. Processos de significação na relação professor-alunos: uma perspectiva sociocultural construtivista. Estudos de Psicologia, v. 13, n. 1, 2008. Disponível em: <http://www.redalyc.org/articulo.oa?id=26113105> ISSN: 1413-294X

GATTI, Bernardete A. O professor e a avaliação em sala de aula. Estudos em Avaliação Educacional, [s.I.], n. 27, p.97-114, 30 jun. 2003. Fundação Carlos Chagas. http://dx.doi.org/10.18222/eae02720032179.

ROCHA, Helenice Aparecida Bastos. Aula de história: evento, ideia e escrita. História \& Ensino, v. 21, n. 2, p. 83-103, 2015. DOI: 10.5433/2238-3018.2015v21n2p83.

PAIVA, Vanilda A Escola Pública Brasileira no Início do Século XXI. Lições da História. In: LOMBARDI, José Claudinei; SAVIANI, Dermeval; NASCIMENTO, Maria Isabel Moura (Org.). A Escola Pública no Brasil. História e Historiografia. Campinas: Autores Associados, 2005. P. 161-191. 
FILHO, A. P. O Estágio Supervisionado e sua importância na formação docente. Revista P@rtes. 2010.

Disponível

em: http://www.partes.com.br/educacao/estagiosupervisionado.as

NEU, Simone. A disciplina de história no ensino médio: preparação para a cidadania ou para o vestibular? Revista de educação Don Alberto, 2014. 


\section{TEDITORA \\ LAMPLLA}

DESAFIOS DAEDUCAÇÃO

NACONTEMPORANEIDADE

DISCURSOS EMERGENTES

E CONCEPÇÕES DE ENSINO

ORGANIZADORES

Jessica Kelly Sousa Ferreira

Leonardo Pereira Tavares

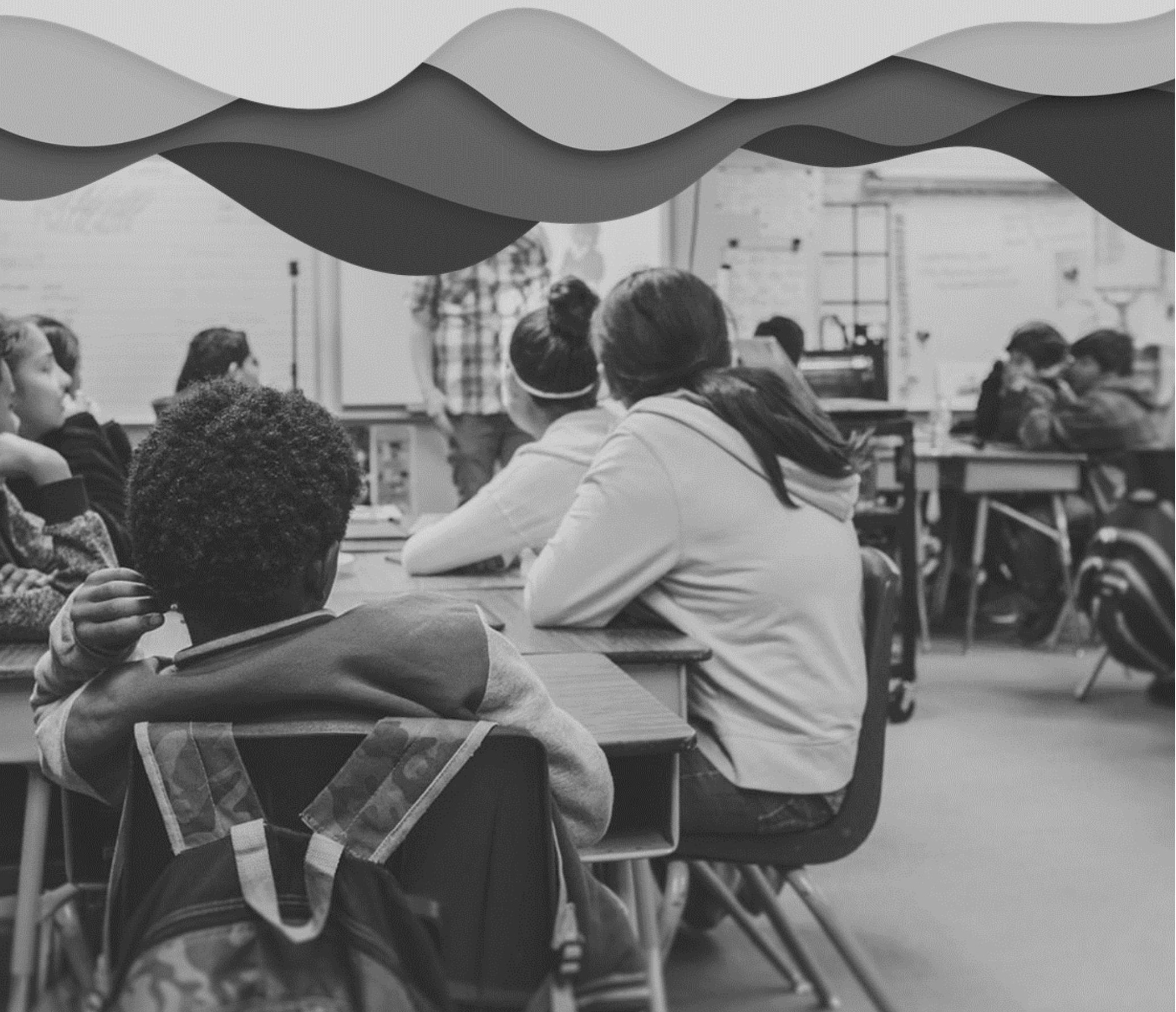


